SB 221

.W67

Copy 1

IRTMENT OF AGRICULTURE.

DIVISION OF CHEMISTRY.

BULLETIN

No. 27.

\title{
THE SUGAR-BEET INDUSTRY.
}

CULTURE OF THE SUGAR-BEET

A N D

MANUFACTURE OF BEET' SUGAR.

13)

H. W. WILEY,

CHEMIST.

PUBLISHED BY AUTHORLTY OF THE SECRETARY OF AGRICUYTURE.

WA SHINGTON:

GOVERNMENT PRINTING OFFICE.

1890. 


$$
\text { \% }
$$








\section{U.S. DEPARTMENT OF AGRICULTURE. DIVISION OF CHEALSTRY.}

\section{BULLETIN}

No. 27.

\section{TIIE SUGAR-BEET INDUSTRY.}

\section{CULTURE OF THE SUGAR-BEHT}

AND

MANUF AOTURE OF BEET SUGAR.

B Y

H. W. WITLEY,

CHEMIST.

PUBISHED BY AUTHORITY OF THE SLCRETALY OF AGRICULTUR

$$
\vdots \vdots
$$

WASHINGTON:

GOVERIMANT PRINTING OFFIOE.

1890.

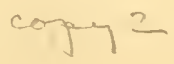





\section{PREF A T O R Y NOTE.}

Washinfton, D. C., May 12, 1890.

SIR: I have the honor to submit herewith, for your inspection and approval, the mannseript of Bulletin No. 27 of the chemical division, entitled "The Sugar-Beet Industry."

Respectfully,

Hon. J. M. Rusk,

H. W. Wiley,

Chemist.

Secretary. 



\section{N TROD U C T IO N.}

During the past year the Department of Agriculture has receired many hundreds of iuquiries from all parts of the United States relating to the culture of the sugar-beet and the production of sugar therefrom. This growing interest in beet enlture, together with the fact that all the prerious publications of the Department concerning the sugar-beet are ont of print, has led to the preparation of the present bulletin.

The object of this bulletin is to give, as nearly as possible, the present condition of the beet sugar industry of the Unitel States; to locate, approximately, those portions of the country which are best suited for the production of the sugar-beet, and to indicate the line of work uecessary to the suecessful introduction and extension of the beet sugar industry in this country.

In connection with the elaboration of the above plan, a résumé will be given of the publications of the Department on this subject, above referred to, and which are no longer aecessible to the jublic. The principal publications, omitting the brief acconnts published in Annual Reports which have been issued by the Department, are as follows:

(1) "Report on the Culture of the Sugar-beet and the Mannfacture of Sugar therefrom in France and the United States," by Dr. IVm. McMurtrie; Government Printing Office, 18s0, pages 294.

(2) "The Beet Sugar Industry of the United States," Bulletin No. 3, of the Chemieal Dirision, pages 24 to 27 with 12 mean temperature charts.

(3) Bulletin No. 5 of the Chemical Division, Part Second, "Beet Sugar," pages 37 to 137 , inclusive, with 12 plates.

In addition to the above publications, numerous articles, mostly ab. stracts of the above, have appeared in the Annual Reports, and a few pages of the bulletin entitled "Encouragement to the Sorghum aud Beet Sugar Industry," issuel in 1883 by the Department, were devoted to the sngar. beet.

It is evident that a work of this kind for the United States must be chiefly a compilation of the results obtained in other conntries, since the industry here is so yourig that little is known of it from onr own investigations. Nevertheless, a large quantity of material has been gathered during the past year relating to beet sugar in rarious parts of the United States, and this matter will also be incorporated in this bnl- 
letin. It must be understood that the object of this bulletin is not to gire a complete treatise npon the culture of the sugar-beet and the manufacture of sugar therefiom, but simply to indicate in a general way, for the information of those interested, the general prineiples of this industry. One especial object which will be kept in view will be to prevent those intending to engage in this industry from going wrong in the begimning, and squandering their money and time in battling with problems which seience has already met and orercome. it is further hoped that the careful perusal of the data which will be presented will prevent any mistakes from being made which would end in fiuancial clisaster and which are so apt to attend the early history of every iudustry.

There will probably be found for many years to come in the United States more enthusiasm than knowledge connected with the sugar-beet, and the result of this will be, unless great care be taken, that many rentures will be made which may result in financial disaster, disaster which conld have been avoided by a thorough comprehension of the fundamental principles of the inclustry.

In so far as the manufacture of sugar from the matured beet is concerned we are able to start at the present time with the aceumulated knowledge and experience of three-quarters of a century of investigation. So perfect have the processes of manufacture become that nearly all of the sugar which is stored in the beet can be secured in merchantable form and by comparatively inexpensive methods. By the term inexpensive, howerer, it must be nuderstood that the actual processes of mannfacture are denoted and not the cost of the machinery. The various processes for the extraction of the sugar from the beet, the best methods of clarifying the juice and of evaporating it and for separating the sugar from the molasses, are thoronghly well understood and are no longer legitimate subjects for public experiment. The great problem in this country is the agrienltural one. The selection of suitable soil, the finding of the proper climatic conditions, and instruction in the method of planting, cultivating, and harvesting the beets, are all matters of vital importance. Withont a careful study of these subjects, and withont the proper knowlerge thereof, it will be a hopeless task to introdnee successfully the beet sugar industry into this country.

One of the great dangers to be aroided is the formation of hasty conclusions in regard to the proper localities for the prodnction of the sugar-beet. Often without any study whaterer of the climatic conditions or of the character of the soil, efforts are made to build large and expensive factories, which as often have to be abandoned on account of having beeu wrongly located. The studies which have been made heretofore in regard to climatie conditions have been of such a nature as to locate, in a general way, the areas in the United States suitable for the eulture of the sugar-beet.

It has been fomel in general that the coast valleys of California, 
and probably large areas near the coast in Oregon and Vashington, certain parts of the Dakotas and Nebraska, localities in Minnesota, Iowa, Wiseonsin, and Michigan, parts of northern Illinois, Indiana, Ohio, and New York present farorable conditions for sugar-beet culture, but in the localities thus broadly intimated there are certain restricted areas most suitable to the sugar-beet, and it is only these restrieted areas to which we must look for success. The fact that in one locality, for instance in Nebraska, good sugar-beets ean be produced would be no warrant whatever for assuming that all parts of that State were equally suitable for this purpose, and this remark may be applied to every one of the States mentioned abore.

Sugar-beets have also been raised in other localities in the United States, notably in New England, New Jersey, Delaware, and Kansas, and while there may be areas in the New England States where beets ean be successfully grown, it must be admitted that the States last named stand in the secoud rank of beet sugar producing localities. In Kansas, during the last year, as will be shown in the body of this re port, sugar-beets were grown aud a considerable quantity of sugar manufactured therefrom. This, howerer, does not show that Kansas will be able to compete with more farorable localities in the prorluction of beet sugar.

In general it may be said that the summers in Kansas are too hot to expect the produetion of a sugar-beet uniform in its nature and containing a high pereentage of sugar.

If the sugar-beet industry is to succeed in this country this success must eome from sharp competition with the same industry in older comntries, where its conditions are better understood and where the localities suited to it hare been selected by long and often costly experience. It must also compete with the sugar-eane industry, both of this eountry aud of tropical countries, and for this reason we ean only expect it to surrive in those loealities where soil and climatic condi. tions, proximity of fuel, cheapness of labor, and other farorable envi. ronments are found.

It is to be hoped that the mistakes which have so long threatened the sorghum sugar industry with destruction may be aroided with the sugar-beet. Calm judgment and sober reason must not gire way to enthusiasm and extraragant expectations. All eouditions of success must be earefully studied, all the diffieulties in the way of suecess must be intimately inrestigated and allowed for, and ample capital, coupled with judicious perseverance, must be enlisted in its behalf.

Many attempts have been made for the past twenty-five years to in. trodnce the beet-sugar industry in to the United States. Factories have been located in the New England States, notably in Maine and Massaehusetts, also in Delaware, in Illinois, and in California. With two exceptions all of these rentures have brought with them financial disaster. The factories in New Englanl, Delaware, and Illinois, and some of those 
started in California have been abandoned. One faetory in California has been very suecessfully operated for a number of years, viz, the one at Alvarado. Another one, viz, at Watsonville, has been in successful operation for two years. From the success of these $t$ wo it is reasonable to infer that others must also suceed when the proper conditions are supplied. It is well, however, that just now, when there seems to be such an awakening in regard to beet sugar, a few words of waruing should be spoken. Auy further tinancial disasters would exercise a most depressing effect upon the advancement of the industry. These disasters are sure to come if attempts are made to erect factories in a short time in localities where the capabilities of the soil and climate are untried, with capital insufficient in amount, and under the direction of those unskilled in all the branches of the industry itself.

For the proper erection aud completion of a beet sugar factory not jess than twelve months shonld be allowed, and eren in this time it can only be properly accomplished under experiencerl technical control. During the present month, March, 1890, letters have heen received at this Department from persons who contemplate the erection of a factory during the present season to be ready for operation by October 1. The orders for the machinery for these factories have not even yet been placed nor the contracts for the building let nor arrangements made for growing the beets.

It is easy to see that if such a work as this is pushed forward it ean only end in failure. In contrast with this I may cite the instance of another factory, which is now in course of erection, which was locatel after a whole year spent in studying the conditions of soil and climate and in the actual growth of numerons plots of beets, and for which the machinery was ordered fully a year in atvance of the time when it was to be userl. The suecess of sueh a factory is almost a foregone conchusion. It is to be hoped that all persons intending to invest in the beet sugar industry may follow the latter and not the former example. 


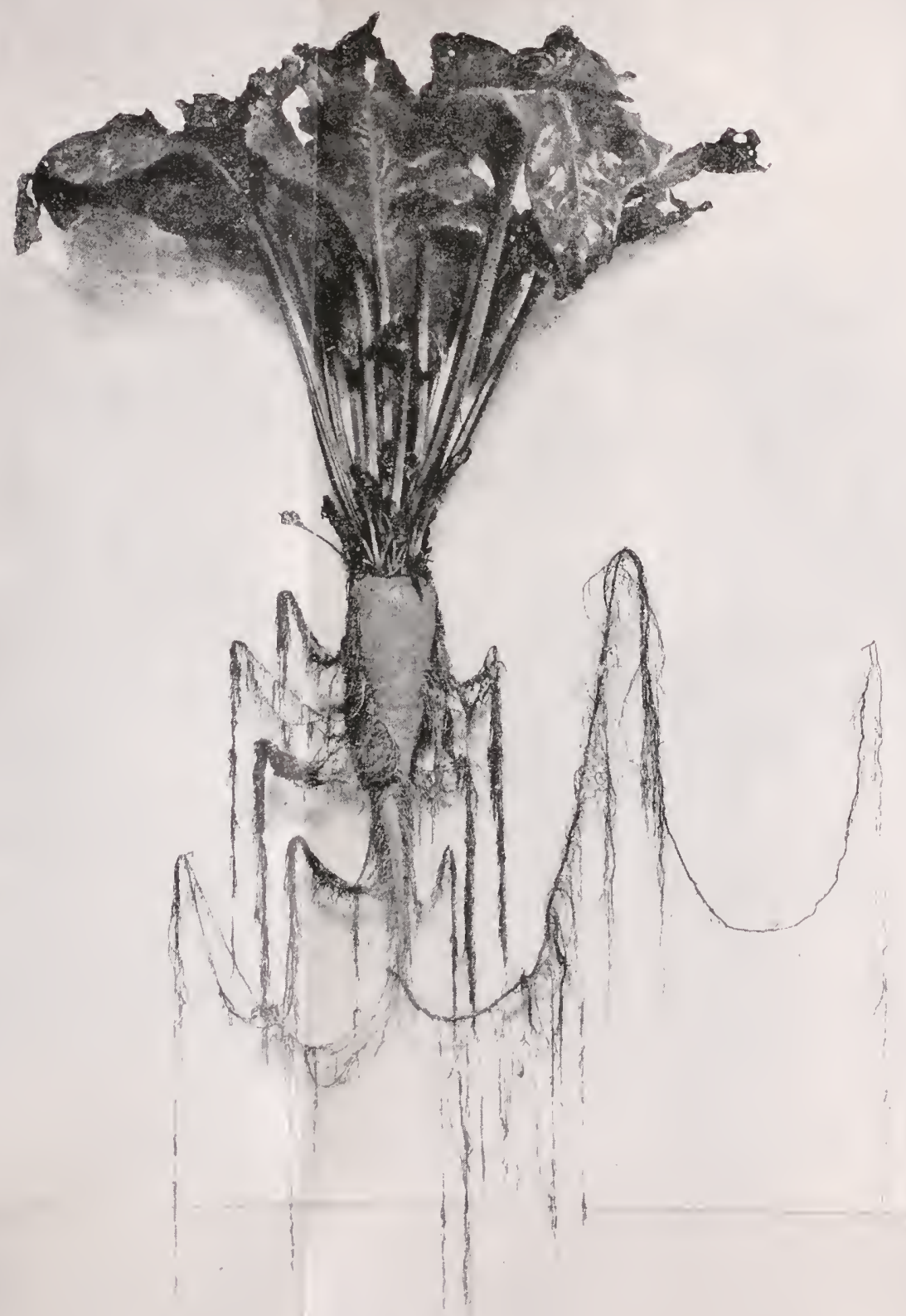

THE MATURE SUGAR-BEET. 

זE. 


\section{THE SUGAR-BEET INDUSTRY.}

\section{HISTORICAL.}

THE EARLY HISTORY OF THE SUGAR-BEET AND TIE MANUFAC'TURE OF SUGAR THEREFROM.*

"It is diffienlt to trace the exact origin of this plant, which has beene of so much interest and value in Enrope, and is not only of national but also of continental importauee to the people of the other side of tho Atlantic. Its antiquity finds eridenee in the fact that Theophrastus described two varieties: the deep-red, and the white beet. Olivier do Serres, in his writings in 1590, makes mention only of the red beet, and states that it had not long been introduced into Europe, and says that "the juice yielded on boiling is similar to sugar sirup." "This variety was introduced in England in 1518, but the white variety was not linown until 1570 .

"According to the Abbé Rosier, four varieties were already known in 1782, the small and large rel, the yellow, and the white. The variety lnowu as disette, and which is still grown in France for feeding purposes, was believed to have originated in Germany. It was brought into notiee by Vilmorin, the ancestor of the present hear of the great seerl house of Vilmorin. Andrienx \& Co., who died in 1804, and was introAnced by Perkins into Eugland in 17S6.

"The root does not seem to have been considered as having an indus. trial value, aud was cultivated only for the table or for cattle food nutil 1747, when Margraft; a member of the Berlin Academy of Sciences, beliering sugar to be a regular coustituent of plants other than the sngar-cane, male examination of different varieties of regetables, and succeeled in separating from several kinds varying quantities of crystallizable sugar. His method of researeh consisted in cuttiug the material to be examined into thin slices, rapidly drying it, reducing to fine powler, and exhansting with diluted alcohol. The results of his researches were announced iu a memoir read before the Berlin Acadeny of Sciences, in the year above mentionerl. Of all the plauts examinerl, he found the beet to be the richest in sugar, and believing that Europe would find in this root the basis of an immense industry, he urged the importance of his diseovery upon the Academy, hoping to see valuable

* Culture of the Sugar-Beet. U. S. Department of Agriculture. Special report No. 28. By Dr. Williau McMurtrie. 1880. 
and practical results follow it ; hut he' was not destined to sce his hopes fulfillel. His methols of work, which were at best imperfect, were of a nature to sneceed only in the lahoratory, and the prices of colonial sugars were so low as to render competition by the products from a new and untried source ont of the question.

"This important discovery, therefore, remained dormantfor nearly half a century, when one of Margrafi's pupils, Karl Franz Achard, son of a French refugee in Prussia after the revocation of the celebrated edict of Nantes, and director of the Academy of Sciences of Berlin, again took uj) the line of research started by his preceptor, and finalls succeeded in extracting sugar from the root on a comparatively large seale. The process he employed was peeuliarly his own, and gave results which were at the time of an astonishing character. He annomced his results in 1797 , published his mode of operation, and in the latter part of 1799 presented a sample of his product, with a description of his method, to the Institute of France, stating that the cost of ploduction of muscovado of good quality should not exceed 6 cents per pound. Achard's statements were as much the subject of doubt and even of serere ridicule by the people of his time as are the statements made by the Department of Agriculture in relation to sugar produced at the present time from sorghnm and maize, and were even accepted with reserve by the members of the Institute of France, notwithstauding the high repute he enjoyed among his scientific confires. The interest of the French Institute was so aroused, lowerer, that a commission was appointed by that body to make an examination of the work of Achard and to repeat his experiments. The commission consisted of Cels, Chaptal, Darcet, Fourcros, Guyton, Parmentier, Tessier, Vamquelin, and Deyenx. In their report they stated that Bermond had made unsuccessful experiments in the introduction of the culture of the sugar.cane in France, and the same was the result with the sugar-maple, for though the latter might possibly be grown it could never compete with the sugar.eane. Other plants had been experimented with; the turnip, carrot, parsnip; chestnut, stalks of maize, and many other plants were submitted to experiment, but, notwithstanding the assertions of certain enthusiasts, it was proren that uone of these plants could supplant the cane, and that in spite of the sugar they were presumed to contain the experiments were uusuccessful. Such was the state of things when Achard made the announcement of his experiments and results.

"The commission then proceed to state that they had repeated the experiments of Margaff to determine the value of their roots, fincling them to contain a little over 6 per cent. of sugar. They applied the methon of Achard for extraction on a larger scale, repeated serrial times, and succeeded in obtaining only a muscovalo of very brown color and disagreeable to the taste. This muscoralo, howerer, was realily purified by means of alcohol, and in this way a sugar candy was obtained dit: fering in no particular from that wiven ly cane sugar. 
"The eonclusions arrived at were to the effect that if with Achard's process sugar may be extracted from the beet, the quantity was much less than that given by the alcohol process indicated by Margraff.

"They then modified the experiments by working on the jnice of uncooked beets and obtained 25 per cent. more of muscovado; and as a final result of all their experinents they adopt as the cost of refined sugar abont 18 cents per pound, but think this figure may be rednced by improved methods.

The report conchudes as follows :

It resuits from what precedes:

(1) That it is certain that the beet which grows in Franee, and which may bo recognized by its white flesh, traversed hy red hands or rays, contains sugar as well as the same speeies grown at Berlin that Achard worked upon.

(2) That the sugar may he extracted by varions processes, and aequire by aid of rejeated purifications all the qualities of cane sugar.

(3) That the quantity of sugar which this root contains is so great that atteution should be given to its extraction.

(4) If, as wo are assured by Achard, we may, as it were, render this root richer in sngar at will by caring for its culture, it is desirable that experiments be unade upon this subject.

(5) That independently of these experiments it wonld be of xalue to determine if, among the several varieties, some do not exist more rich in sugar than those pointed ont by Achard.

(6) That, adnittiug the results of these experiments, it remains to be demonstrated that the beet may np to a certain point supplant the sugar-cane.

(7) That it is true to say that the cost of sugar can not be determined with rigorous exactness without knowing the results of operations made on a large scale. However, at the present time it may be presumed that this price would not be higher than that of cane sugar in ordinary times.

(8) Finally, if Margraff shonld justly be cited as being the anthor of the discovery of sugar in the beet, it must also be admitted that Achard is the first to have made fortunate application of this discorery, not only in anmonncing the farorable quantity that may be extracted, but also in pointing ont the processes to which we could resort for success.

"Achard's appreciation of the action and conclusions of this commission may be gleaned from the following letter addressed to Citizen ron Mons, and dated Berlin, November 16, 1800 (Ann. de Chem. 39, 223):

I thank you sincerely for sending me the interesting report of the Institute. I have noted with infinite pleasure that the researches made by the celebrated French chemists confirm my discovery. The differences found in the products as tu the quantities aul qualities result either from the culture of the beet or the variety chosen for the tests. Notwithstanding the objections of the commission, I am still of the opinion that the best method consists in boiling the roots before expressing the jnice, the clarification then taking place within the cells themselves by the coagulation of the allumen, so that we obtain the juice eutirely clarified, or better clarified than it is possible to attain from raw beets by the addition of blood or other coagulable substinces.

"But the report of the French commission had the effect to dampen any enthusiasm that may have been aroused in France by the publication of Achard's annotucement, and for the few years that immediately 
followed it no interest seems to hare been manifested there on the sub. ject.

"It was, however, otherwise in Germany. Achard's letter proves that his zeal was in no way abated, and other workers were eagerly following the new line of investigation and experiment now made so attractive by Achard; and Lampadius, professor of chemistry and metallurgy at the School of Mines at Fre,yburg, took it up, repeated the experiments of his eminent predecessor in the work, improved upon his methods, from the arerage results of which he estimated the cost of refined sugar would not exceed 18 cents per Euglish pound, about the same limit es. tablished by the commission of the Institute. Hermbstaedt also, modifsing the method of Achard, succeeded in extracting from 125 pounds of roots of Beta vulgaris $5 \frac{1}{3}$ pounds of brown sugar and $1 \frac{7}{8}$ pounds of sirup), which drained off. The Baron de Koppy, having interest and confidence in the methods and results of Achard, erected in 1S05 upon his estate at Krayn, near the town of Strehlen, in Lower Silesia, works capable of the annual extraction of the sugar contained in about 525 tons of roots, besides the manufacture of the rum and vineginr resulting from the utilization of the wastes of mannfacture, viz, the pulp and molasses. These works of Koppy were constructed after the designs furnished by Achand, and carried on accorling to the methods he had determined. Achard also erected a factory on his own estate at Cunern, near Steinau, on the Oder. The results obtained by these two enterprising pioneer's in the beet-sugar industry were followed by the estab. lishment of other works at Athaldsleben and near Augsburg, and the interest which had thus been aroused in Germany bid fair to be again communicated to the French. This was hastened by a letter of Achard to the editor of the Moniteur, and published in that journal of October 2, 180S. This so thoroughly explains his position, the character of his work, and the progress he had made since the report upon his former results, that we deem it of value to reproduce it here:

SiR: The manufacture of sugar in Europe being, in all its relations, and principally nnder existing eircumstances, a very important object, I believe that you will not refuse to grive publicity, in the Moniteur, to an exposé of the resnlts of my researehes upon the mannfacture of sngar from the beet root, and the alvantages which this new kind of Enropeau industry assures to all nations for which sugar is an exotie staple.

It was decided by the report given by the celebrated chemists, Cels, Chaptal, Fonrcroy, Guytou, Parmentier, Tessier, Vauquelin, and Deyeux, under date of January 25,1800 , to the class of mathematical and physical sciences of the National Institute of Franee, upon the examination they made of my researches tending to the profitable extriction of sugar from beets-

A. That the beet contains sugar.

13. That the sugar may be extracted by different processes, and acquire by sufficient purifieation all the properties of eane sugar.

C. That even hy following my first methods, which were still very imperfect at the time the celebrated lieneh ehemists were oceupied with their varitication, it was to be presumed that the price of beet-root sugar would not be higher than that of the cane in orlinary times. 
D. That all dloubts of the existence of sugar in the heet root and the possibility of extracting it being dissipated, it only remains to be llesired that the experiments misle on a larger scale may gire to my work upou this object the degree of anthenticity it merits.

Encouraged by the suffrage of so illustrious savants, I have labored during eight years to perfect the mannfacture of sugar from beets by experimental researches made on a large scale in a factory I have established on an estate called Cunern, which I own near Steinan, in Lower Silesia. My labors have led to the rletermination of a much more profitable method for extracting the sugar from beet roots, so that by my new processes 25,000 kilograms (55,000 pounds) of these roots furnished 2,309 French pounds (2,098 English ponnds) of unclayerl muscovarlo, richer in pure crystalline sugar, in the relation of $66^{\circ} 2$ to 591 than the brown muscovado of Jamaica, or 1,923 French pounds (1,748 English pounds) of a clayed muscovado richer in pure sugar in the relation of 666 to 664 than the white muscovarlo of Martinique, while by following my first imperfect methods the commission appointed by the Institnte of France to repeat my experiments extracted and was able to oxtract from 25,000 kilograms (55,000 pounds) of roots, the product of 1 arpent of land (about 1 acre), only 782 pounds of muscovado (711 English ponnds), containing 448 French ponuds (407 Euglish pounds) of puresugar; that is, about one-third the quantity that may be extracted by aid of my new processes. The cost of production of muscovado from beet root accorling to uy new processes, provided the extraction is carried on in a well established factory, and the manufacturer secures his roots at the modera te price by growing them himself, as those in the colonies almost exclusively cnltivate the cane, is compensated for as much by the leaves of the beets, which serve as food for cattle, as by the rum, other spirits, and vinegar extracted from the wastes of mannfictnring the muscovado; that is, the pulp of the root exhausted of the juice which the press can remove, and the molasses.

The same being the case with the cane, it follows that sugar may be extracted with the same pecuniary advantage from the beet in Enrope as from the eane in the islands. An arpent yielding, according to the basis determined by the French commission charged with repeating $11 y$ first experiments, 25,000 kilograms of beets, from which is extracted by mp perfected methods 2,309 and 1,923 pounds of mnscovado, according to the quality given it, it follows that to prorluce $10,000,000$ ponuds of muscovarlo, it is necessary to set apart during the summer months only letween 4,330 and 5,200 arpents of land to the culture of the beet. An area of this extent is too small to canse its ise in the production of indigenons sugar to be followed by the restriction of other important cultures, and this is all the more true since it is necessary to set apart for the culture of the beet, as it is practiced in this proviuce, ouly fields which bave been nsed two years for the culture of spring and winter wheats and remain a third year in fallow without furnishing other products than the pasturage of eattle that are allowed to range upou it, and which is more than compensated for by the leaves of beets. The facts $I$ have established in the preceding article are based-

A. Upon the report which the commission appointed to repeat my first essays in the extraction of sugar from the beet made in 1800 to the class of mathematical and physical sciences of the Institute of Sciences of France.

B. Upon the later official examinations of nıy manufacture of sugar at Cunern by my newly perfected methods aud the results they have given, made by a commission appointed by the Prussian Govermment.

C. Upon the results furnished by a beet-root sugar factory established in this province aceording to my instructions by M. le Baron de Koply on hisplace called Krayn, near the town of Strehlen. This establishment is adapted to the annual extraction of the sugar contained in 10,000 Silesian quintals or $577,500^{*}$ kilograms of beets, besides the manficture of the rum and vinegar which is obtained from the wastes of preparing muscovalo, viz, the pulp of pressed beets and molasses. 
The constant success with which tho manufacture of unseovado established at Krayn has worked during three years, and the profit it assures its prossessor, confirm the results presented by tho official examiuations which lave heen made of the manufacture of muscovado according to my perfected methols, so that it is perfectly proven :

(1) That the muscovado furnished by the beet root is of a quality equal to that of the cane.

(2) That the quantity of muscovalo furnished by beet roots is found so thoroughly proportional to the cost of its extraction aud the profits obtained from the waste prodnets of manufacture in employing them for that of rum or other spirits of the better 'puality, and a very gool viuegar, that these advantages under favorable local circumstinces wholly, and under all circumstances in a great part, compensate for the cost of production of muscovado from beets, as is also the case with regard to tho muscovado from the cane-the cost of extraction of which is more or less compensated for hy the rum extracted from the waste products they leave.

(3) That the manufacture of sugar from beet roots may become tho object of au important industry for Enrope.

(a) By tho very consilerable sums it will savo from exportation.

(b) By the means it will furnish a large number of persons of the indigent classes to procure subsistence in the manual labor it requires.

(c) By the independence in which, with regard to this staple, it places Europo and other parts of the world which are really the principal depositories. (Sigued)

Cunern, near Steinau, Lower Silesia, 1808.

ACHARD.

"The following article, from the Moniteur of March 2, 1811, will also be of interest in this connection, as corroborating the statements of Achard :

His excellency the minister of the interior, in making his report to His Majesty upon the sugar of bcet roots, had hoped to be able to assure him that, according to the testimony of M. Deyenx, this sugar would present the double advantage of enriching those who entered into the mannfacture and cost a price low enough for consumers.

13ut if M. Dejenx was unable to give this assurance on account of the fact that the main end of his work was in the interest of French speculators, to effect an improvement upon the processes of the German chemists, we may find it in tho suceess alrearly obtained in the establishment of the Baron de Koppy, success thoroughly recognized in Germany, and of which we bave an eye-witness in M. Boulet, chief pharmacist to the army.

It will be remembered that $\mathrm{M}$. Acharl, chemist in Berlin, who first conceived the idea of making the extraction of sugar from beet roots in object of speculation and manufacture, anneuneed in the Monitenr of 1802 the allantages of this sugar, which he procured by a process more perfect than that which four years belore had not been unreservedly accepted by the Institute of France.

This number of the Nonitenr having reached Breslan, capital of Silesia, and conseruently in the neighberhood of the two factories said to exist in the province of Prinssia, M. Bondet, being there at the time, considered it of value to verify the facts adranced by Aehard, in order in case of need to be able to destroy or increase the im. pression which the article in the Moniteur mas have produced in France. Ho accordingly lretook himself to the house of Baron do Koppy, at Krain, " near the town of Strelzlen, ${ }^{*}$ and visited the manufactory. He cansed to be sent to M. Parmentier a menoir, an extract of which was inserted in the Bulletin de Pharmaeie of the month of February, 1809.

* In other places these are written Krayn and Strehlen. 
We shall not dwell npon the interesting details into which M. Bondet entered to elneidate for his countrymen the means of establishing similar manufactories in Europe. It is sufficient for our purpose here to make known the profit ohtained by Baron de Koply from his own works at the time of the visit of M. Bondet.

Ile affirms (1) that Baron de Koppy is rery well satisfied with the quantiry of sugar, rum, spirits, and vinegar furnished by his beets, and with the ready and lucrative sale ho had for these different staples; (2) that the culture of beet roots, far from diminishing that of wheat, contributed to procure for him more abundant crops than be obtained before, first, because in employing for beets only the lands formerly left to fallow, his wheat occupied the same area as before he tiought of making sugar; and, second, because beets furnish, hesides their sugar, a large mass of food for cattle and sheep. Ho was able, withont enlarging his domain, to double the number of his cattle, to obtain nore mannre, and with the aid of this mannre to obtain larger quantities of wheat. (3) He adwitted that he owed to the existing war a large portion of the profits given him by a sugar the people were obliged to use in clefault of that from canes, but he asserted that should he in times of peace obtain from his factory only the cost of cultivation of the beets and the manipulation of the sngar, he would guard himself from abaudoning it so as not to renounce the prosperity it had given him and which it conld always preserve on his domain.

The sugar sold by Baron de Koppy was uot refined. M. Boudet wisher to know for himself if it was susceptible of being. The triai he made having succeerled, he thought this sugar would become that of the richer classes, at least until we have tho sugar from grapes M. Pronst had led us.to hope for, the sirup of grapes having already replaced for the poor that of the cane.

The establishment of beet-sugar factories may therefore be undertaken with confidence throughont the empire; but we must observe, according to the memoir of M. Boudet, it is especially to the large proprietors that it will be profitalle, and that they should content themselves with making raw sugar to be sent like that of the islands to the refueries, one of which is able to purify and convert into loaves the products of twenty facturies.

"As Baron de Koppy admits in his statements to M. Boudet, the erents which were brought about by the political conditions of the time dir much to faror the suceess of the enterprise, for shortly after his works were started-in fact, in the years immediately following-Napoleon I issned his famous decrees of Berlin and Milan, establishing the famous contineutal blockade, and excluding from the markets and consumption all material whatsoever of English production or manufacture, and particularly the produets of England's colonies. This, of course, made sugars searce and dear, and enhaneed the profits of the manufacture that Achard and Koppy had so opportumely developed.

"The same conditions stimulated the search for prodncts indigenous to France that might be substituted for those colonial staples which had become articles of daily consumption, and the deprivation of which was most keenly felt, aud sugar seemed to have claimed instant atten. tion. But the source deveioped by Achard seems to have almost completely vanished from the thoughts of both seientists and practical manufacturers. The destruction of external commerce, of course, resulted in the dowufall of the wine trade, and all eyes and all minds naturally turn to the ntilization of the enormous erops of grapes France annually produced, and everybody seemed to look to the sugar this fruit contained. both as a substitute for the wanting colonial staple, and as the 
resene from the ruin which appeared imminent to the proprietors of the vineyards, especially in the south. Parmentier was, among the seientists and members of the Institute, the leader of this movement and the promoter of this apparent germ of a new industry and internal somree of national wealth, and he published a work entitled, "Traité sur l'art de frabrigner les sirops et conserves de raisin." The methods he indicated in this work were mainly followed in the experiments of 1808 and 1809, but were ennsiderably improred upon by Proust and Fonques. They served, however, in the varions sonthern departments of the empire, for the production of considerable quantities of sirup from the vintages of 1808 and 1809 , samples of which were presented to the minister of the interior, who at once ealled the attention of the Emperor to the results represented in the samples in the following report, which will serve to show not only the condition of the enterprise at the close of 180 s and the beginning of 1810 , but also what had been done previous to that time and the appreciation with which he regarded it; and the deeree of Napoleon issued in eonsequence of this report will show the interest he had in this possible source of a substitute for the colonial staple. The report appeared in the Moniteur of June 23, 1810. The minister, Montalivet, says:

SIRE: I have reported to your Majesty the snccessesobtained by M. Parmentier, who has giren very nseful attention to perfecting grape sirup and making it suitalue to replace cane sugar in muy medieal and domestic preparations. Yonr Majesty, who ordered it to be $n$ sed in the palace, seemed satisfied with it. I desire to-day to fix your attention mon more important results. M. Proust, an able chemist, has extracted from grape sirup a concrete sugar. M. Fonques has found a means of bleaching it and giving it not only"tho brilliancy but also the consistency and color of eane sugar. I have called together a commission, composer of Messrs. Berthollet and Chaptal, Senators, and members of the lnstitnte, Parmentier, Vanquelin, and Pronst. 'The sngar of M. Fonques was snbmitted to them for examination. The commission decirled that this substance was worthy of the highest degree of attention, and after having made some tests upon the substance itself, without any preparation, thonght it especially essential to determine what wonld he its effeets in different mixtmres and different proportions. The commission then adjonrned, and came together again at the ministry on the 12 th of this month.

The commission fourl that eonserves containing the triple and qualmple of grapo sugar were ton sweet. Those containing the donble were less sweet than those containing a single proportion of cane sngar. That the grape sugar eruivalent of cano was a little over $2 \frac{1}{4}$ to 1 .

MoNTalivet.

"In eonsequence of this report of the minister of the interior, Ilis Majesty issued, under date of June 18, 1810, the following decrea :

Article 1. There is aceorderl the sum of 100,000 franes $(\$ 20,000)$ to Mr. Proust, ${ }^{*}$ anil one of 40,000 francs $(\$ 8,000)$ to Sienr Fonques, in the form of gratuity and by way of encouragement for the discovery they have made ot grape sugar.

ART. $\rightleftharpoons$. They shall be obliged to use these two sums to establikh grape-sugar factorices in that portion of onr sonthern clepartments designated by our minister of the intrerior.

* By decren of Jume 21, 1810, Napoleon appointed M. Pronst, chemist, member of the Legion of Honor. 
ArT. 3. They shall be obliged to give up the secret of their processes, which shall be reudered pnblic, and be sent to all the prefects of our grape growing deprartments.

Art. 4. From January 1, 18t1, at the latest, the sugar of grapes shall replace in all public establishments the sugar of canes.

A זт. 5. On minister of the interior shall recommend to the prefects to propagate and encourage the estahlishmeut of factories for either grape sirup or concrete grape sugar, so that in the coming year the inestimable arlvantages of this precions discovery shall make itself felt for the good of all our people and the interests of our commerce.

"The same commission to whom was submitted for examination the samples of sirup and sugar produced by Messis. Pronst and Fouques were directed by the minister of the interior to prepare detailed instructions upon the methorts to be followed for the successful and profitable extraction of sirup and concrete sugar from grapes, and the result of the work they at once entered upon, a copy of which may be found in the Monitenr of August 25, 1810, was printed and distributed throughont the grape-growing departments of France, in company with the following circular letter to the prefects of those departments, under date of August 1S, 1810:

Monsieur le pRéfêt: His Majesty the Emperor desires to grive an impulse to the mamufacture of sugar and sirny from grapes, and he has ordered that there be prepared to this effect simple instructions inclicating the best processes to follow. Ho wishes that the instructions prepared by the most celebrated savants, and generally distributed, nay lead proprietors to make sirup and sugar for their own uses, and place manufacturers in the way of naking it in the surest and most economical manner, and completely supplying the markets with products from the next rintage.

I send you several copies of these instructions. Be so good as to distribute them to yonr officers who will uake the best use of them, and canse them to be printed in the journal of your department.

You unst not content yourself with causing the description of the proeess of manufacture of sugar and sirup fiom grapes to be distributed to even the smallest comunnes; you shall stimulate the zeal of your officers; you shall promise and accord prizes to those who shall have made the most of sugar amd sirup of the best quality. I will supply, npon your requisition, the funds you may lispose of.

I also invite yon to immediately confer with directors of hospitals and other charitalile establishments of your department, that they in turu may confer with farmers, proprietors, and pharmaeist who may lesire t. make sirnps and sugars, and arrange with these persons such markets as will assure the sale of the products of this year. You shall preside over these arrangements, and take care that, without injuring the interests of the poor, there may be all-sufficient eneouragenent for manufacturers.

You shall address to me a table of the quantities of sugars and ordinary sirups annually consumed in each hospital, and of the presumed consumption of the comiun year in sirups and sugars of grapes, with indications of the markets which have been recoriled.

'The subprefects and mayors will, I hope, second you in all your efforts. You shall make known to me those functionaries and special persons who shail be most distinumished in this sphere of usefulness which is open to them. I shall report their efforts and their success, as well as jour own, to the Emperor.

Let mannfacturing establishments multiply everywhere. Let it be considered, M. le Prefert, that this is a sort of war we are making against the enemies of the Conrinent, and which his Majesty considers, more than any other sovereign, worthy of recompense to those who make themselves prominent in the ranks.

$25474-B u l l .27--2$ 
"Immediately after this the Emperor issued the following accree, duate August 22, 1810:

Considering that the eeonomical manufacture of sugar from grapes essentially inflnences the prosperity of agriculture and commeree, and desiring to give to this important branch of the industry a particular mark of our special protection, we have decreed and do tecree as follows:

Articli 1. On June 1, 1811, the sum of 200,000 francs $(\$ 40,000)$ shall be distributer among twelve establishments which shall have made the largest quantity of sugar from grapes.

ART. 2. The distribution shall be made among the twelve establishments proportionally to the quantity of sugrar that each one shall have made.

AnT, 3. To secure the right of competition it shall be necessary to have made at least 10,000 kilograms (2:2,000 pounds) of sugar.

ART, 4. The quantities of sugar male shall be verified by a commissioner appointed for that purpose by the prefect of the lepartment and certified to by the mayor of the place.

ART. 5. The prefect shall address these evilences to our minister of the interior before May 1, 1811. Ho shall also send at the same time a sample of the sugar made.

Art, 6. Onr minister of the interior shall make to us a report to this effect. He shall make known to us at the same time the mannfacturers who have perfected the processes of manufacture and shall propose to us the recompensesand encouragements they shall have merited.

"But while these enconragements were being given to the enterprise of producing sirup and sugar from grapes in the south to replace the colonial staple in the home consmmption of France, the results of Achard's later work, as described in his letter to the editor of the Moniteur in 1508, had awaliened anew the interest in the beet root as a source of sugar in the north, and M. Deyeux, reporter of the first committee of the Institute, which eondueted the experiments of 1800 , in compliance with a request made through the Institute by the minister of the interior, agaiu undertook to repeat in 1809 and 1810 the experiments of the former committee, and the later work of Achard, with such modifications as he deemed adrisable and practicable. In this work he was associated with Mr. Barruel, thief of the chemical department of the School of Medieine of Paris, and their labors were rewarded by the production of a certain quantity of' muscovado, which they refined aud thus seenred ' $t$ wo loares of sugar, perfectly crystallized, of great whiteness, brilliaut and sonorous, in a worl enjoying all the properties of the finest cane sugar,' one of which was presented by the minister of the interior to the Emperor, who is said to have' received it with that benevolence which he accords to every usefnl object.' But these experiments, while they showed the practicability of extracting sugar from the beet root by the means proposed, were still not of a character to show the net cost of producing the sugar, becanse the experiments viewed the work ouly in a chemical sense. Messrs. Balruel and Isnard then undertook to determine this part of the question, and repeated these experiments just mentioned, keepling striet aceonnts of the cost of each stage of the processes applied and the quantities of the products obtainer. It was found that by their processes they were able to extract 1,5 per cent, of muscovado, which 
cost 30 ceuts per pound. The refined sugar produced from this lower grade cost 40 cents per pound. It appears, however, that the beets treated, which were grown upon the highly manured lands of the plain of Vertus where their workis were located, were very unfarorable to the results of the experiments. It also appears that these figures represent the actual cost to the experimenter's in the extraction of the sugar, taking no account of the by-products and assigning the maximum price for the beets worked; but the further estimates of cost made up by Messrs. Barruel and Isnard, based upon their own experiments and working by their own processes, supposing the value of the beets to be the actual cost of produeiug them and the amount of roots handled to be the yield of abont 400 acres of land, about 6,000 tous, show that the cost of production should not exceed $S$ cents per pound for good muscovado, or 12.9 cents per pound of refiued sugar.

"The actual condition of the sugar enterprise in France at the close of 1810 may be gleaned from the following report to the Emperor by Montalivet, under date of January 10, 1811.

The production of sirup and sugar from grapes orlered by your Majesty is pursued with activity; and even though the seazon has not been very favorable to the vine, I an in daiiy receipt of proofs of the zeal with which a large number of proprietors are animated in the different departments, but those of the sonth aud the center are the only ones who may engage in this manufacture, and on this accomnt I wonld respectfully submit to your Majosty the resnlts which lead us to hopo that even the departinents of the north may find upon their territory a sugar of very goorl quality. We know that for some years back beet-root sngar has been manufictured at Berlin and Breslau. Messrs. Achard and Koppy addressed to my predecessorvery beautiful specimens of this sugar, but up to the present but slight results have been obtained. M. Deyenx, first pharmacist to jour Majesty and member of the Institnte, has just reundertaken this work and has obtained very remarkable success in the results which he has addressed to me, and which I submit to your Majesty. He has also addressed to we an interesting menoir in which he has reported to the Institute the processes he employed toarrire at his results. Ho helieves these processes to bo more simple and better than those adopted by Messis. Achard and Koppy. Bat M. Deyenx, obliged to devote himself to trials and experiments to find a good method, is unable as yet to establish the price at which this sugar can be produced. Everything shows, however, that this price will be sufficiently low to prove a large source of profit to extended mannfacture. Already, in the department of the Donbs, a rich proprietor, Mons. Secci, has established a mannfacture of this kind aud has sown 80 acres in beets, which have yielded him 500,000 kilograms (500 tons) of roots, from which 25 to 30 milliers $(27,500$ to 33,000 pounds) of refined sugar may be expected. The prefect of Mont Tomnère has also informed me that Mous. Molar, a proprietor in his department has sown 80 hectares (19\%.6 acres) of ground in beets which he proposed to convert into sugar, and for which operation he asks to be aduitted to the prizes which your Majesty has deigned to promise to manufactnrers of sirup and sugar from grapes. In the department of Roer, the manufactnrer of sugar from beet roots is carried on by the brothers Herbem at Urdaiger. The prefect of the Rhine aud Moselle has trausmitted to me samples of a very fine cassonade from beet roots, manufactured by Mons. Anthouin, who asks for encouragement to enable him to enter upon this manufacture on a large scale. Finally, for Holkund, the prince goveruor-general has sent me a sample of beet-root sugar made by M. Liuden at Hemmer, in whose labors he appears to have confidence; and the prefect of the Bouches-rlu-Rhone has shown me samples of beet-root sugar made by M. Vanrroggen, one of his officers. 
I slaall, at at later date, report to your Majesty the results which these differont attempts fromise. At this time, I contine mysclf to presenting the sugnt made by M. 1)eyeux. It in no way difiers from the refined sngar of the colonies. This test shows what may be expeeted from this work as regards the quality of the material. I shall now study (arefully the means of determining to what extent this mannacture may beemo economical and the measures to be taken to render it general in the departmente of the north.

\section{MONTALIVET, Minister of the Interior.}

${ }^{66}$ It is to be remarked further that prizes were also offered by the Société d'Eucouragement pour l'Industrie Nationale for the production of sugar from grapes or beets, the annual prize being ״,400 francs $(\$ 480)$ for the best essay and sample, 1,000 francs (\$200) for second best, and, on February 20, 1811, it received, through its fonder and then president, Count Chaptal, a memoir upon the methods for the extraction of sugar from veets, by M. Drappiez, a pharmacist at Lille, together with a loaf of the sugar, of which he had been able to obtain 50 quintals by the method he described. The committee on chemical arts of the society compared the sample subuitted by 11 . Drappiez with a sample of refined ane sugar they were then able to obtain at a cost of 95 cents per English pound, and failed to detect the "slightest difference" between them. M. Drapuiez obtained hy his method a yield of 1.3 per cent., the cost of which he estimated at 80 cents per pound.

"Shortly after this there appeared in the Moniteur of March 23, 1811, a statement to the effect-

That there had been presented to his Majesty several quintals of refined erystallized beet-root sugar, laving all the qualities of that of the eane; loaves of both kinds have been mixel together, and it was impossible to distinguish between them. It follows from the report of a commission elarged with the examination of the differeut means proposed to replace by indigenons processes the foreign productions so eostly to France, that 70,000 acres enltivated in beet roots wonld furuish the $30,000,000$ of pounds necessary to onr consumption.

"And two dars later Napoleon issued the first decree, in which he provided for direct encouragement of the beet-sngar industry, and which was as follows:

Palace of the Tullenies, Mareh 25, 1811.

NAPOLEUN, Emperor of the French, etc.:

Upon a report of a eommission appointed to examine the means proposed to naturalize, npou the eontinent of our enpire, sugar, indigo, cotton, and divers other productions of the two Indies:

Upon presentation made to us of a considerable quantity of beet-root sngar, refined, crystallized, amd possessing all the cualities and properties of eane sngar :

Upon the presentation made to us at the conncil of commeree of a great quantity of indigo, extricted from the plant woarl, whieh oir departments of the sonth produee in abundace, aud whieh indigo has all the properties of the indigo of the two Indies:

I Iaring reason to expeet that hy means of these two precions discoveries onr empire will shortly be relieved from an exportation of $100,000,000$ franes $(\$ 20,000,000)$ hitherto necessary for supplying the consiamption of sugar and indigo:

We have decreed aud do deereo as follows: 
ARTICLE 1. Plantations of leet root proper for the mannfaeture of sugar sluall be formed in our empire to the extent of ::2,000 heetares (79,040 aeres).

ArT. 2. On minister of the interiol shall distribute 32,000 hectares amoug the departments of onl empire, taking into consideration those departments where the cultme of tobacco may be established, and those which fiom the watme of the soil may be more faverable to the enlture of the beet root.

ART. 3. Onr prefects shall take measures that the number of hectares allotted to their respective departments shall be in full eultivation this year, or uext year at the latest.

ART. 4. A certain number of heetares shall be laid out in onr empire in plantations of woad proper to the manufacture of indign in the proportion necessary for onr manufacture.

Art. 5. Onr minister of the interior shall distribnte the siid number anong the departments of enr empire, taking into particular consideration tho departments beyond the Alps and these of the sonth, where this braneh of industry formerly marle great juogress.

ART. 6. Our prefeets shall take measures that the uumber of hectares allotted to their departments shall be in full cultivation next year at the latest.

Art. 7. The commission shall, before the 4th of Ma $y$, fix upon the most eonvenient places for the establishment of six experimental sehools for giving instruction in the manufacture of beet-root sugar conformaly to the processes of chemists.

ArT. 8. The eommission shall also, before the same date, fix upon the plaees most convenient for the establishment of tour experimental schools for giving instruction upen the extraction of indigo from the lees of woad accordiug to the processes approved by the commission.

Art. 9. Our minister of the interior shall make known to the prefeets in what places these scheols shall be formed, and to which pupils destined to this manuficture should be sent. Proprietors and farmers who may wish to attend a course of lectures in the said experinental sehools shall be admitted thereto.

Art. 10. Messrs. Barruel and Isnard, who have brenght to perfection the processes for extracting sngar from the beet root, shall be specially charged with the direction of two of the six experimental selieels.

Art. 11. Onr minister of the interior shall, in conseqnenee, eause to be paid the sum neeessary for the formation of the said estahlishments, which sum shall bo eharged to the finnd of $1,000,000$ franes $(\$ 200,000)$ in the budget of 1811 at the disposal of the said minister for the eneomagement of beet-root sngar and woad indigo.

ART. 12. From the 1st of Jaunary, 1s13, and upon a report to be made to onr minister of the interior, the sugar and indige of the tro Indies shall be prohibited, and considered as merchandise of Evglish manufacture or procceding from English eommerce.

ART. 13. Onr minister of the interior is eharged with the execution of the present. deeree.

"Early in the following April, 1S11, Decostils, reporter of the committee on chenical arts of the Société d'Enconragement pour l'Industrie Nationale, reported npon a memoir and results presented by M. De. rosue. He was the first to suggest the use of quicklime in the puritication of the jnice. His method was based upon three principal points: (1) The use of eaustic lime; (2) the use of alum; ant (3) the use of aleo. hol. The lime he adds to the fresh juice, of which he succeeded in expressing 63 per cent. the weight of the root. The proportion added was 0.24 gram per liter of juice. After the addition of lime in a thick milk the juice was rapidly brought to boiling and the scums remored as they formed. The jnice was then separated from the sediment, which 
settlerl and concentraterl. It was then purified with alum and blood, and further treated in the usual way. The proportion of sugar extracted by this methorl is staterl to have been 4. per cent.. amd was tho highrst result that had yet been attained. The beets from which this high yield mas obtained were of the white Swelish variety, while the beets of the plain of Aubervillier did not rield as much by $2 \frac{1}{2}$ per cent.

"After the ammomeement of this method of Derosne it appears that little was published ou the subject of the new industry, that was now beginning to assume important dimensions, until the beginning of the following rear, when Montalivet reported to $\mathrm{H}$ is Majesty that $6,-3,5$ liectares (16,75s acres) had been sown in beets in different departments of the empire, producing 98,813 tons of roots.

"The $n$ mber of factories establislied was thirty-nine or forty, and the minister estimated that if the mhole product were worked up the resuit would be 1,500,000 kilograms (3,300,000 pouncls) of sugar; but the plantations mere in many cases too far remored from the factories to make it possible to trausport the roots with profit. He also gare a table slowing the ummber of hectares sown in beets in each department.the quan. tity of roots harrested, and the reasons which prevented more extensive plantiug in each. The latter seemed to be principally lack of sufficient seed and lateness of the season.

"Abont the same time a report was made to the Emperor by Count Claptal showing the cost, by the methorls then known and in use, of the culture of the beet and the manufacture of sugar. The first he estimates at 176 francs per metrieal arpent (about \$3j per acros), the yield of which varies from 12,000 to 15.000 to $50,(1001)$ pommds. The second cost he estimated at 15 cents per pound, supposing all the molasses to be sold: but if no molasses be sold then he estimates that the cost would reach 30 cents per pound. For the cost of refined sugar he makes tro estimates; the first supposing 15 cents per pound as the ralue of the raw sugar, and in the second he ralues it at 3 () cents. Accorling to the first supposition the cost would be 32 cents per pound, and 45 cents according to the second supposition.

"In couchuding his report, Claptal sass an intimate knomlerlge of chemistry is necessary for successful worli; and he recommends, as a means for assuring the prompt prosperits of this enterprise, that there be establisher at one of the factories alrearly establisherl a normal school, and that there be bronght together there thirty or forty young men allearly rersed in chemical knorledge, and forty others taken from amoug the chiblen of refiners of Orleans, Antwerp, Ghent, Marseilles, Nautes, Amsterdam, etc., and from among the chiefs of refineries in the larger towns; and the establishment at which, it seemed to him, such instruction as he referred to could be giren was that of $M$. Barriel. in the plain of Tertus

"On the 12th of Jamuary, 1S12, M. Barruel published a note upon the manufacture of beet-root sugar, and rescribes the method he had finally 
derised for extracting the sugar, and in this description we fund the first mention of the use of earbonic acid for separating the excess of lime remaining after purification of the juice. He proceeds as follows: The juice is heated to $65^{\circ} \mathrm{l}$.; milk of lime is then added (295 grams quicklime per 100 kilograms of juice, or 295 parts in 100,000$)$; the whole stirred thoroughly and heated to $80^{\circ} \mathrm{l}$. The coloring matter, ete., forms in soluble compounds and makes a flocenent precipitate. A solid scum forms on the top. The latter is skimmed off and the liquid decanted. The elear juice is then freed from lime, aud for this purpose an acid whieh forms an insoluble compound with the lime is the best, sulphurie or carbonic acids preferred. Alum may be used according to Derosne's method, but this only acts by the sulphuric aciol it contains, and while for equal weights sulphurie aeid costs more than alum, it will netrtralize more of lime.

"MI. Barrnel cousiders, howerer, that carbonie acid is the most economical of all, and for his purpose he prepares it by passing air through burning coals.

"In the conclusion of his note he sars: "This process, which is very" simple and not costly, always succeels. I guaranty its exactness and success.'

"Manmené states that about this time Napoleon visited a factory at Passy, where Benjamin Delessert had sueceeder in prodneing white sugar from beets, and after having given him the cross of the Legion of IJonor (the same which ornamented his own breast) as a reempense for this splendid initiative, the Emperor caused to be inserted in the Moniteur of the following day the grand evolution that had been cousum. mated in French eommeree. But of this ciremustance we are unable to find any record in the Moniteur or the Journal de l'Empire of that periorl.

"On Jannary 15, 1812, Napoleon issued the following decree, in all probability a result of the report made by Count Chaptal:

\section{Section I.-School for maxufacture of Beet-lioot Sugar.}

Article 1. The factory of Messrs. Barruel anr Chappelet, plain of Tertus, and those establisherl at Waehenhein, department of Mont-Tomnere, at Douai, Strashourg, and at Castelnatulary, are established as special schools for the manufacture of heet-root sugar.

Arr. 2. One Inudred students shall he attached to these sehools, viz: Forty at that of Messrs. Barruel and Chapplet, and fifteen at each of thoso at Wachenbeim, Donai, Strashourg, and Cactelnandary; total, nue hnndred.

ART. 3. These students shall bo selected from among students in medicine, pharmacy, and chemistry.

\section{Sectiox II.-Culture of Beets.}

ArT. 4. Onr minister of the interior shall take measures to eause to be sown throughout our empire 100,000 metrical arpents of leets. The coulitious of the distribution of tho culture shall be printed and sent to the prefects previous to Fehruary 15. 
Section ili.-Manufacture.

ARI. 5. There shall be aceorded thronghont our entire empire five hundred licenses for the manuticture of beet-root sugar.

ART. 6. These licenses shall be aceorded of preference-

To all proprietors of fictories or refineries.

To all who have manufactured sugar during 1811 .

To all who have made preparations aud expenditures for the establishment of factories for work in 1812 .

Aкт. 7. Of these licenses there shall be aecorded of right, one to each department.

AlrT. 8. Prefects shall write to all proprietors of refineries, in order that thes may make their submissious for the establishment of the said factories at the close of 181:. In defanlt on the part of proprietors of refineries to have mate their submissions prior to March 15, or at the latest April 15 , they shall bo considered as having renonnced the preferenco accorded them.

Arт. 9. Licenses slall inclnde an obligation on the part of those who shall oltain them to estalulish a fictory capable of produciug at least 10,000 kilograms (2:2,000 pounds) of raw sugar in 1812-'13.

AnT, 10. Each individual who, lavving received a license, shall have actnally mannfactured nearly 10,000 kilograms of raw sugar resultiug from the crop of 1812 to 1813 shall have the privilege and assurance, by way of encouragement, of being sulbject to no tax, or octroi, upon the produet of his mannfaeture for the space of four years.

Anт. 11. Eacl inchividual who shall perfect the manufacture of sngar in such a manner as to obtain a larger quantity from the beet, or who shall invent a more simple and economical method of manufacture, shall obtain a license tor a longer time, with the assurance that no fnty nor octroi shall be placed upon the produet of his manufacture during the continuance of his license.

\section{Section IV.-Creation of four Imperial, Factories.}

AnT. 12. Four imperial beet-sugar factories shall be establisher in 1812 under the care or our minister of the interior

ART. 13. These factories shall he so arranged as to produce with the crop of 1812 to $1813,2,000,000$ kilograms of raw sugar.

"We find one of the practical results of this generons decree in the announcement made by Charpentier frères of Valencienues, Departement du Nord (Jourmal de l'Empire, of December 2, 1S12), that they har for sale 12,000 kilograms $(26,400$ pounds) of beet-root sugar manufactured from the crop of that year, and during the first two months of work. 'The large quantity of beets they still had in store assured them, it was stated, for the end of $A$ pril, 1813, a product of 60.000 kilograms (132,000 ponnds), which they offered to sell as it should be made.

"But these results are more fully described by the minister of the interior, in his report upon the situation of the empire in the beginning of 1813, in which, under the head of new industries, he says:

To replace in our consumption the sugar, indigo, and cochineal of the colonies; to find in the sontls of Europe and at home the cottons and soda to smply omr mannfactmres seened impossible. It was ardently wished for, and the impossibility disappeared before onr efforts.

1)ming this vear the mannfactnre of sugar which is extracted from tho beet ront will give $1157,700,000$ poumds of this staple. It is prepared in three hundred and thirty-fonr factories, all of which are in actual activity.

$\Lambda$ fter numerous trials, processes are finally employed by which beet-root sugar will not cost nore than 15) cents per ponnd to the manufacturer. Mr. Bommatis, in- 
ventor of this new method, profited by the useful labors of his predecessors, and the goverument, in orler to hasten the fortmnate results of his discovery, charged him to proceer to propagato it in those sections in which the principal mannfactories are ostalilished.

Since the establishment of the high price of sugar, eonsumption has greatly decreased, aud the $7,000,000$ ponuds mam faetured at this time may he considered equal to at least one-half our actual neels. This diminution is not the result of any absoInte privation that may have oceurred, bnt from the equivalents by which sugar has como to be replaced.

Several millious of pounds of sirnps from grapes and honey, the latter better purified and more abundant, have been substituted for sugar in a great portion of the domestic uses with so inuch of ease that the most delicate taste could seareely perceive the ehange.

When the diffieulty of proemring sngar and its cost shall be less; when the first protits, at present so great, if they be considered only as interest upon capital, shall have covered the cost of establishing, the quantity that will be consumed will again increase, the equilibrinm will be renewed, and supposing that one-fifth the consmmption to remain definitely replaced by sirup of grapes and boues, France will consmme $40,000,000$ pounds of beet-root sngar, the valne of which will be 30,000,000 franes, and we may count njon these results for 1814 . Onr retineries now vield a product of $10,000,000$ pomds, which will inerease to at least $20,000,000$ pounds.

In the six years begiuning with 1802 , we received from abroad an amunal average of $52,000,000$ pounds of sugar. During the fonr years beginning with 1009 , the average annual importation has been but $10,000,000$ to $11,000,000$ pounds. It is especially since that time that nothing has been neglected to naturalize this staple at home, and the concuest is finally assured.

"But while all this interest and busy enterprise was being manifested in France, great progress was also being made in Germany. And the generous and worthy action of Napoleon in extending substantial encouragement to the development of the growing industry which produced such happr results had even been anticipated by the Ger'man Government, which came to the aid of Achard, who hat for nearly fifteen years deroted all his time and limited means to the development and establishment of the inclustry, in the ultimate success of which, in spite of all the reverses to which he had been subject, he had never lost faith. His influence and example had led to the establishment of the works of Baron de Koppy at Krayn, and his watchful care orer it had assured its financial success. And this besides those already mentioned was followed by the establishment of works in other sections, notably by Baron von Lorentz, Connselor Mengen, and more especially the Messrs. Mayer, of Breslan, who, we are told by Isnard, director of the special school of chemistry for beet-sugar manufacture at Strasburg, had for ten years sown about 750 acres in beets. In view of the progress attained and the interest manifested, the governmental authorities accorded to Achard, during the conrse of 1810 and 1812 , the encouragement and aid indieated in the following notice sent by Achard to the Moniteur, and published in that journal, June 23,1812 , showing also the progress this pioneer in the industry had made. He says:

The publie has, during the past year, been informed, as mueh by the decrees of the regenes of Silesia as by the several writings I have published, that 1Iis Majesty, the 
King of Prussia, las orleresl me to establish on my two estaties of Upper and Lower Cunern, near Wolnlen, in Lower Silesia, a practical sehool for instruction as complete as possible, to make known to onr prople as well as to foreigners the processes employed in the extraction of sngar from beet roots.

"He further states that he had three distinet methods for extraetion, msing neither lime, earbonate of lime, milk, sulphnrie aeid, nor alum, except for beet of poor quality, or toward spring when regetation has commenced. By the new method he sneceeded in getting concrete sugar in twenty-four hours. The three methods of separating the sugar from sirups of beet juices are: (1) by regular erystallization; (2) by granulation; (3) by immeliate eonversion into bastarl sugar. By the first method 1 quintal of juice gires 5 Silesian ponnds of sugar. By the second 6 ponuds are obtained, and by the third method, which is preferable to all others, the sugar may be extracted in twenty-four hours, yielding 5 pounds of raw sugar.

"This notice of Achard is followed by one from the Royal Regeney" of Silesia, upon the establishments of Achard, stating that-

His Majesty the King of Prussia, in giving to M. Acharo a.consiclerable sum of money, preseribed that he should establish and maintaiu upon his estate, and at his own cost, a factory for instruction iu the manufacture of sugar from beets.

In the month of December of last year (1811), Achard having anuonnced to the Roral Regency that he had established two factories-one factory on a small scale and such as conld be mited with farm management, the other to mannfucture sugar on a large scale; that the building for lodging stulents was finished and ready to receive them; that the enurse of instruction would commence in January; aud that ho wonld be flattered to see an official examination of his work-we consequently appointed for this murpose two iutelligent persons, who fonud that the bnildings intended for the maun facture were actually completed, aud provided with the apparatus and machinery necessary. It also appear's from this report that since January 12 (1812) the manufuctory has been in full activity, and that besides the students there were cmplored in the factory a foreman, nine inale, and four female laborers. During the eourse of instruction 20 quintals are worked upon daily. Five pounds of raw sugar por quintal [110 pounds] are extractel, and, aceording to exact calculations made at the factors, it follows that 100 quintals of beets give a net profit of something more than 111 thalers emrent moner.

"This model factory and school of Aehard attraeted students from nearly all the nations of the continent, and it is probable that it was the stulents he had from hussia who earried back to their conntry the germs of this industry, which has now become so powertu! there, and which in that country received its establishing impulse throngh the aid and euconragement extended by the imperial authority ; for it is related tlat General Blankenagel, who fonmed a factory in the government of Tonla, at the village of Akabef, had received from the Czar of Russia a gift of 50,000 rombles $(35,895)$, and that an nkase or elliet of the emperor gave the assurance that all lands of those establishing sugar factories should be free from tax.

"Such, then, was the progress attained in this new and raluable industry, and its condition in the beginning of 1911 , during which memorable year what had bid fatr to be a great source of national wealth and 
prosperity to all the continental nations received almost its death-blow. 'The beginning of the war with Russia interfered with its progress in that country. The destruetive passage of foreign aud contending armies destroyed completely not only this, but other and more flourishing industries in Germany, and the final conflict on French territory and the downfall of Napoleon, who has been described as the second father of the industry, resulted in its almost complete extinction in France, and the withdrawal on the part of the immediate successor of the great Emperor of the encouragement he had accorded was nearly as disastrous as had been the malicious depredations which were perpetrated by the enemy's troops, and it required the patient labor of more than another decade to accomplish what Napoleon had been able to establish in about one-third that time.

"But it must not be supposed that this new enterprise, which had assumed such formidable proportions, was dnring its derelopment farored with a constaut belief of the entire people of all nations in its ralueand its efficacy to supply a substitute for the staple of the tropical climes, which had formed the basis of much of the maritime commerce of the time. If Achard received ridicule at home and was looked upon by many of his countrymen as an insane enthusiast, but which prejudice by presentation of substantial eridences he was able to dissipate, the eriticisms heaped upon Napoleon were of the bitterest character abroar, and the mutterings which could not under imperial rules enjoy unrestrained expression were not mknown to him, nor did they in any way affect the firmness of his resolution or his charity towarl his critics at home, as is slown in the following address he made to the chamber of commerce March 11, 1811, in which he says :

The Berlin and Milan decrees are the fundamental laws of my empire as regards neutral commerce. I cousider the flag an exteusion of territory, and the nation which suffers it to be vielater sluall not be considered neutral.

The fate of American commerce shall soon be decided. I will faror it if the United States will conform to these decrees; on the contrars, their ships will be exchnded from my empire.

Commercial relations with England must cease. I proelaim it to yon, gentlemen, distinctly. Merchants who have transactions there to settle or funds to withdraw shonld do it as quickly as possible. I gave this advice some time age to the merchants of Antwerp, and they have profitod by it.

I wish for peace, but not a patched-up one. I wish for it sincerely, and for such an one as will afford me sufficient guaranties, for I have not lest sight of Amiens or St. Domingo, or the losses which commerce sustained from the last declaration of war.

I have a knowledge of what is passing in the counting-honses of merchants. I know they denounce in high terms my measures and say I am badly advised. I will not blame them for their impressiens, because, not having a view of the whole ground, they have not an oppertmity to calculate and judge as I do. Nevertheless, those who have lately arrived from England will inform you of the injurions consequeuces pro dnced in that conntry from an interrnption of their commerce with the Continent, and may say it is possible I am right and that my designs may be accomplished. 
I am informed that from late experiments France will be enabled to do without the sugars and indigoes of the two Indies. Chemistry has made such progress in this conntry, that it will possibly prodnce as great a change in our commercial relations as that producen by the diseovery of the compass. I do not say, gentlemen, that I do not wish for maritime commeree or colonies, but it is proper to abandon them for the present, and until Eugland shall return to just aud reasonable principles, or until I can dictate to her terus of peaee.

I know the Euglish have better admirals, and that is a great advantage, but by often fighting them we shall learn to couquer.

The vent of colonial produee upon the Continent being once firmly shut, the English will be obliged to throw into the 'T hames the sugars and indigoes for which they have exehanged oljects of their industry, and whieh have atforded them sueh resourees.

"It is stated that about this time a caricature was exhibited in Paris in which the Emperor and the King of Rome were the most prominent, charavters. The Emperor was represented as sitting in the nursery with a eup of coffee before him, into which he was squeezing a beet-root. Near him was seated the King of Rome voraciously sncking the beetroot, while the nurse, standing near and steadfastly observing, is made to say to the youthful monareh, "Suck, dear, suck; your father says it is sugar!"

"But as the doubt and ridicule here indicated gave way to a large extent in France before the development of the industry, that expressed in the English journals also gave place to an underenrrent of anxious inquiry as to the possible fate of the English colonial commerce, and the probable extent of the development of the new judustries that were being so ardently fostered by Napoleon; and it is related by the Prince Louis Napoleon that the English Government even made anonymons offers to Achard, first of the sum of $\$ 40,000$, and later on of $\$ 100,000$, if he would publish a work deelaring that he had been earried away by his enthusiasm in his former publications, and that the results he then made public had by no means been confirmed by his later work. Failing in effecting in this way the result desired, it is said the Government induced Sir Humphrey Dary to write a brochure, in which he rleclared that, while sugar could be produced from the beet, the product was too bitter for consumption.

"But the impoteney of these attacks upon the new industry is fully illustrated in its subsequent history. Napoleon, in his wislom, contin. ned his substantial encomragement of this and other agrieultural and manufincturing industries in Franee by the appropriation of several millions of francs in their support at a time when the total revenue of his empire did not exeecd $999,000,000$ of franes (less than $\$ 200,000,000)$ amd he was maintaining large armies in Spain and Portugal, and at very formidable navy on the ligh seas.

"But if the industry Napoleon had fostered and established fell with lis downfall, its value had been demonstrated, and was even admitted in the first report of the Abbé de Montesquicu, minister of the interior 
under Lonis X VIII, a report filled with the bitterest criticisms of the policy of the Imperial Government, acensing it of tyramy and imposition upon the rights of the people as coneerns the manufacturing interests. In the conrse of this report the minister remarked that-

Mechanies and ehemistry, enricbed by a erowd of discoveries and ably applied to the arts, had caused rapid progress. The eontinental system, by forcing mannfacturers to seck upon our own territory hitherto unknown resurces, brought about some nseful results.

"The condition in which the wars left France and her industries at the beginning of 1815 necessitated the production of the revenue for the support of the government from external sources, for her fields aud factories could not then bear a tax sufticient for the purpose. The customs duty this required maintained the prices of colonial staples at rates ereu higher than those which prevailed during the preceding reign, and operated as a substitute for the encouragement before given by the Gorernment. It was on this account that the one factory, that of M. Crespel, at A rras, in the department of the North, which had survived the general wreck, was able in a year or two to yield to its enterprising owner and director a fair income with which to retrieve his broken fortune, and to again extend the industry in which it was shown he had such a deep interest. With the profits attained by one factory he established another until he fially became the proprietor of ten of the finest works of his time. His intelligence, industry, and enterprise gave an impetus to the culture and manufacture of the crop, and his example was soon followed by others in different parts of the country, and factories were established and worked with varring success. In 1823, Dubrunfaut published, in his work on the manufacture, information concerning the condition of the industry at that time, that he had been able to obtain on a tour among the principal factories of the day. From this work we gather the facts and fignres tabulated below concerning the cost of culture of the beet and of the manufacture of sugar by some of the most progressire and successful manufacturers he had occasion to visit.

\begin{tabular}{|c|c|c|}
\hline Name of grower. & $\begin{array}{c}\text { Field per } \\
\text { acrein tons } \\
\text { of } 2,200 \\
\text { pounds. }\end{array}$ & $\begin{array}{l}\text { Cost per } \\
\text { tun of } \\
\text { roots. }\end{array}$ \\
\hline 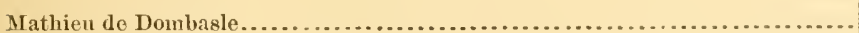 & 5.06 & $\$ 5.80$ \\
\hline 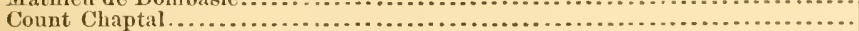 & 12.45 & 3.68 \\
\hline Crespel & 10.12 & 3. 00 \\
\hline 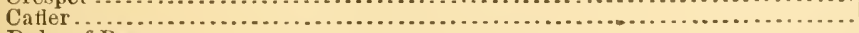 & 12.145 & 2.66 \\
\hline Duke of Ragusa. . . & 10.12 & 3.36 \\
\hline General Preval. & 6. 356 & 3. 60 \\
\hline 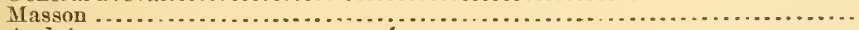 & 6.680 & 3. 44 \\
\hline Audré & 7.217 & 3.18 \\
\hline 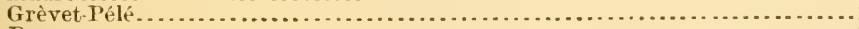 & 10.777 & 2,50 \\
\hline 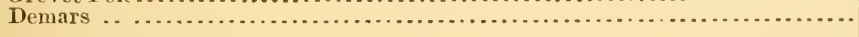 & 15.222 & 4.00 \\
\hline Average.... & 9.611 & 3.52 \\
\hline
\end{tabular}


MANUFACTURE.

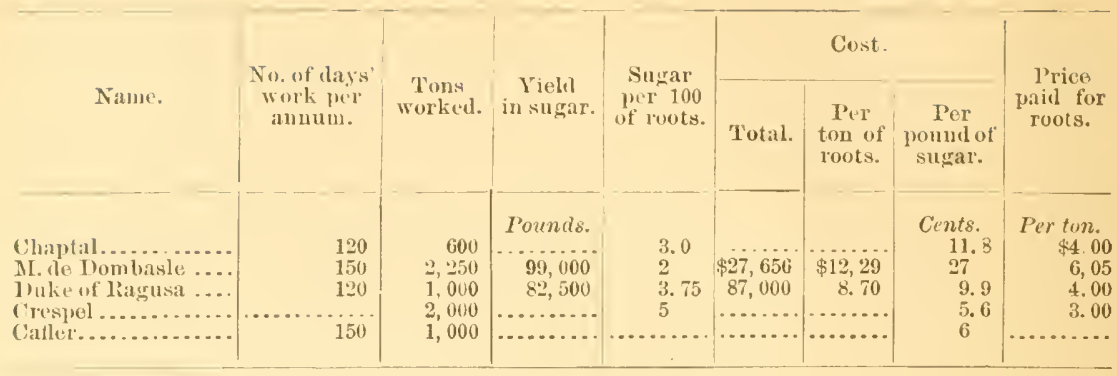

" Dubrunfaut determines from his own observations as the cost of production 5.2 cents per pound avoirdnpois for the intermittent process, and 4.8 cents for the continuous. Colonial sugars were at this time worth 1.40 to 1.50 franes per kilogram, or 12.7 to 13.6 eents per pound, and it was stated to be impossible to produce them at a cost of less than 5.5 cents per pound in the Antilles.

"The abore estimate of cost given by Dubrunfant was for working about 1,000 tons per anmum. For working double that quantity the net cost appears at that time to have been greater, and reached 5.8 cents for the intermittent process and 5.4 for the continuons process.

"From this time the industry continned to spread rapidly, and to produce everywhere fruitful and profitable results, though, strange to say, no reeord seems to have been kept of the statistics of production in France until the year 1829 , when it was stated at 4,000 tons.

"In Germany the industry did not revive until after 1835 , when attention was called to it by Krause of Austria, and Sehubarth of Prussia, who went to France, the first in 1834 and the second in 1836, to study the progress and condition of the manufacture. As a consequence of these trips and the prominence given by the press of the infor.mation they carried home with them, the culture of the beet was iuangurated anew, factories were again erected in large numbers, and the industry soon beeame so powerful as to be competent to contribute to the revenue of the Govermment. 
UISTORY AND PROGRESS OF THE CULTURE OF THE SUGAR-BEET AND THE MANUFACTURE OF SUGAR THEREFROII IN THE UNITED STA'IES OF AMERICA.*

"Notwithstanding the progress that has been made in Europe in the culture of the sugar-beet and the manufacture of beet-root sugar, and immensity and value of the industry it has smpplied to European nations, the knowledge and experience resulting has not been applied in such a way in the United States as to make the production of sugar from this sonrce a matter of any commereial or industrial importance, althongh attempts at the introduction of the industry have not been wanting. In most eases the attempts, which hare had varying suceess or rather failure, seem to have beeu originated and guided by enthusiasm rather than by sound judgment, based upon a previous elose study of all the conditions which should influence or absolntely govern the success or failure of the enterprise. This is rery evident from a review of the records we have of the varions experiments which have been made both on a large and a small scale.

"The first experiment, made by two enterprising Philadelphians as early as 1830 , was almost cotemporaneons with the final firm estab). lishment of the industry in France and the great interest manifested in it there, but it seems that these gentlemen were wholly ignorant of the requirements either of the culture of the root or the extraction of sugar. and failure was the natural result of their efforts.

"Eight years later, David Lee Child, who had spent a year and a half in the beet-growing districts of Europe in eareful study of all the requirements, both of culture and wanufacture, mndertook in a small way the production of beet-root sugar at Northampton, Mass. He wis attracted by the method of drying the roots that had lately been invented by Schutzenbach, both for the purpose of preserving them and for facilitating the extraction of sugar, but being. unable to obtain from Schutzsnluach any information concerning the details of the methor unless he would purehase the exclusive right to use in the United States, and give security for payment iu case success should be obtained in a model factory, Mr. Child operated the method with apparatus of his own derice, by means of which he was able, with a temperature of $1.500^{\circ}$ to $185^{\circ}$ Fahr., to dry 800 pounds in twenty-four hours. The dried product was ground, treated with three times its weight of water, and subjected to pressure, giving, it was said, a liquid twice as rich in sugar as the ordinary juice of the beet. In his little work entitled 'The Culture of the Beet and the Maunfacture of Beet Sugar,' Mr. Child informs us that the cost of culture in the Conmecticut River Valley was, in 1838 to 1839, $\$ 42$ per acre, witli an average yield of 13 to 15 tons; that the erop yielded 6 per cent. of sugar and 21 per cent. of molasses, and the cost

* MicNurtrie, op. cit., p. 167. 
of the sugar 11 eents per pound, pulp and manure not taken into acconnt. But he rloes not mention the surfice sown in beets nor the (fuantity worked mp. From other somres, however, we learn that the quantity of sngar obtained was 1,300 pounds.

"The interest in the beet-sugar industry in the United States seems to have been quite dormant, or at least not sufficiently strong to manifest itself in actire work, and its subsequent history, which, as before stated, was a rather checkered one, began in 1863 with the inauguration of the well-known enterprise at Chatsworth, Ill, by the Gennert Broth. ers, formerly of Braunsehweig, Germany, and later of New York City, which, on aceomut of the ill-ehosen location as regards soil and elimate, really the two prineipal conditious of successful culture, failed after a struggle of nearly six years. Bal management and lack of practical knowledge of the industry in the first few years, bad culture in 1868 , deluging rains in 1869 , and drought in 1870 , in addition to the abundance of nitrates found to exist in the soils, appear to be the causes tending to the disastrous result. As a fiual struggle to maintain an existence the company remored the works to Freeport, in Stephenson County, of the same State, and though the saline character of the soil, which was a bane to the culture in the former locality, did not exist lere, the effi cient management of the able superintendent could not provide against the unfarorable elimatic influences, and one year later the Germania Beet-Sugar Company finally suceumbed, and its superiuteudent removed with some of the machinery of the late company to Black Hawk, Sank County, Wis., to join with the eo-operative enterprise that had been started there a year before. But the lessons of experience appear to have been no guide, for this attempt was made, like the previous ones, in a section not provided with the principal requirements for suceessful work.

"The crop of 1870 partially failed throngh drought. The machinery for the utilization of what there was arrived late, and the ponds upon which the company relied for water supply dried up before all the roots were worked for sugar, and a portion was left to be fied to cattle. Though additions were made to the works during the following year by means of machinery brought from Illinois and Fond du Lac, the result of 1871 does not seem to hare been profitable, for since that time the cnterprise has been so completely lost sight of that it is impossible to obtain any further information coneerning it. The experiment at Fond du Lac, which, however, was not long continued, seems to have been the first to give unquestionably good results. It was started by two Germans, Messrs. Bonesteel and Otto, who organized a company with $\$ 12,000$ capital, and thongh compelled, with their limited means, to work on a small seale, their success was such during the two years of existence of the enterprise as to attract the attention of capitalists on both sides of our continent, and they received an offer from Philadelphia of funds to carry on the work where they had so successfully established 
it, and another from San Franciseo to put them in eharge of the works of the Alvaralo Sugar Company, which had just been organized with a capital of $\$ 250,000$, and, finding the latter offer the most tempting, they abandoned their works at Fond du Lac and migrated to the Pacinc coast, where they managed to earry on the work with varying success until 1873, when it was reported that the company proposed remoring to a more eligible locality. But it does not appear that this proposition was carried out, for what reason we are not informed; though Mr. Otto, who was then superintendent, and who, with his colleague in the Fond du Lac enterprise, Mr. Bonesteel, had become partners in this company, was shortly afterwards transfered to Soquel, in Santa Cruz County, where as late as $\mathbf{1 5 7 6}$ the factory was reported as being in successful operation. The Alvarado Company struggled on until 1S76, when drought having destroyed the crop so completely that there was no raw material for work in the factory in the ensuing winter, the company not having realized enongh to enable them to carry orer until the following season, failed financially, and permanently closed their operations.

"The Sacramento Valley Company was organized in 1S69, and commenced extended oporations in manufacture in 1870, and its existence was maintained until the close of 1875 , when the machinery, which had cost $\$ 160,000$ in Germany, was offerel for sale at $\$ 45,000$, and we have no information to the effect that it has been sold. Concerning the industry, a witer in the Alta California, during 1869, says :

" "Something new and unexpected has revealed itself. In Europe the beet attains its maximnm of sugar in the latest period of growth before the frost sets in. Here it has lost half its sugar in the last six weeks-last of Oetober. The beets taken from the salne soil and milled in December by Wadsworth, superintendent, had the full complement of sugar.'

"The Soquel factory soon followed the fate of the others, but causes of its failure have not been assigned.

"The importance the manufacture attained in Califoruia is shown in the following statisties of beet sugar produced, published in 1874 by the State Agricultural Society:

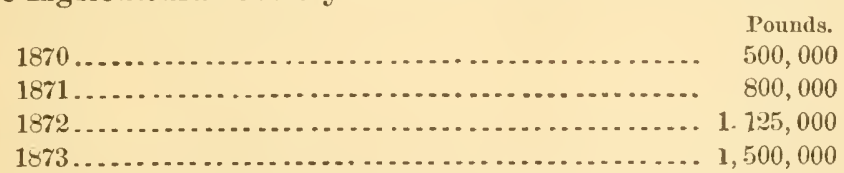

"But notwithstanding these figures, which aro certainly flattering to the industry, there has not been a factory in operation in the State since 1876 , and the capital invested in the manufacture, nearly $\$ 1,000,000$, has been a total loss, the causes of which may undoubtedly be traced to conditions determined in the Department during the present year by the study of European history and practices to be manifestly unfavorable and decidedly deleterious to the successful prosecution of the industry. We refer more particularly to the meteorological conditions $25474-$ Bnll. 27-_3 
prevailiug during the season of growth, which, as appears from the relations worked out, have a clearly defined influence for good or for evil, for success or failure, in the culture of the sugar-beat, and it is an in: teresting fact to note that at none of the localities where the experiments made have been attended with failure are the prevailing meteorological conditions found within the limits determined to be favorable to or governing the extensiou of successful eulture.

"The experiments made up to this time reeeived no aid or encouragement either from the State governments or from the General Govern. ment, with the exception of the provision that no machinery purchased abroad and imported for manufacture of sugar from the beets in this country should be sulject to customs duty, and the limited assistance given by the Department of Agriculture in contributions of seed of the better varieties for experiment, and such information on the subject of the culture of the root and the manufacture of sugar as could be obtained by the means at hand ; but this limited assistance was not of a eharacter to produce any very marked effects.

"In 1870 to 1871 the States of New Jersey and Massachusetts made legislative provision exempting from taxation for ten years from date all capital and property engaged in the beet-sugar industry, but no practical results seem to have followed this provision. In New Jersey, however, Mr. Joseph Wharton, of Camden, has during the past three years devoted a portion of his estate at Batsto to some very intelligent experiments in the culture, which, as regards the quantity of the product, has given unsatisfactory results, and only tend to show that the elimatie conditions of the seetion, possibly combined with the light eharacter of the soil, are not such as to render the permanent establishment of the industry in that locality possible.

"In 1876 the Canadian Government offered a preminu of 1 cent per pound for all sugar manufactured from the beet-root, the total sum paid to any one individual company or eorporation not to exceed, however, $\$ 7,1300$ per annum.

"This premium stimnlated the culture of the crop and the establishment of factories, which have continued in actire and profitable operation.

"The State of Maine followed the worthy example of its near neighbor and in the same substantial terms; the Forest City Sugar Refinery at Portland hastened to take advantage of the premium offered, and the experiment on a small seale in the munfacture by the company, as had been the culture by the farmers in 1878, resulted in such brilliant success that the company have this year so enlarged the eapacity of their works as to enable them to work 150 tons of roots per day and have secured from the farmers a crop from 1,250 acres of land. Their success has also animated the people of Massachusetts, who have organized a company for work at the locality of Child's experiment of 1838-'39, at Northampton, Mass. 
"In 1876 and 1877 Delaware appropriated \$300, and in 1878-79 $\$ 1,500$ to be expended in premiums, ete., to stimulate the culture, and the result has been the establishment of the Delaware Beet Sugar Company at Vilmington.

"In California also interest in the industry has again been awakened through the instrumentality of Mr. Th. Gemert, whose worthy euthusiasm led to the establishment of the enterprise in Canada and in Maine. The work is to be renewed at the factory of the former Alvarado Company, and Gennert's scheme for drying the beets for preservation and transportation, which was attended with such disastrous results at Chatsworth and in Maine, is to be tried onee more. It is understood that Mr. Gennert is now interested in the Alvarado Company and expects to earry out his plan for drying the beet-roots, and, thus diminishing the cost of trausportation, increase the profits of manufacture, in which we hope he may be suceessful. The culture of the beet has also been undertaken in Santa Clara County, where it is proposed to supply defieient moisture by irrigation, and to dry in open sunlight the roots, of which it is declared two crops can be produced in one year. Withont wishing to diseourage the enterprise in any way, we may venture to express the hoje that the promoters are atquainted with the experience of the growers of the sonth of France and Italy, as described by Gustave Henzé in his work 'Les Plantes Fourragères,' page 9, where he says:

" "The beet succeels well in the cold elimates of Enrope. It will grow in sonthern countries, but it suffers there from heat or drought; its root remain small, green, and contains little sugar. An attempt was made to hasten its growth in Lombardy by frequent irrigation during the summer, but irrigation was fatal to it, and growers were forced to adopt other means to assure suceess.'

"We would also call attention to the fact that in Algeria, where the enterprise of preparing beets for preservation and transportation by drying in open sunlight, the suceess, if any was obtained, has not appeared worthy of reeord.

"Besides the arrangements that have been made for the production of sugar from the beet at the different places mentioned active interest has been awakened elsewhere, particularly at Baltimore, MIl., Chester, Pa., and at various localities in New York, but these movements lrave not yet assumed definite shape."

\section{THE EARLY HISTORY OF BEET'SUGAR INDUSTRY A'T ALVARADO.*}

"No history of Alameda County would be complete without some mention of the rise and progress of this promising industry, which, so far as California and the Pacific coast are concerned, had its origin at Alvarado-its failure and its final suceess.

"The first attempt to manufacture beet-root sugar in California was made at Alvarado in 1869. Messrs. Bonesteel, Otto \& Co., who were engaged in a small way in the business at Fond dn Lae, Wis., opened

* Bull. No. 5, Chem. Div. U. S. Department of Agriculture, p. 89. 
a correspondence mpon the subject with General C. I. Hutehinson, E. 11. Dyer, and others on this coast. The matter was pushed with zeal, and the 'California Beet Sugar Company' was organized with a eap)tal stock of $\$ 2 \tilde{5} 0,000$. The stockhollers were: General C. I. Hutchinson, Flint, Bixby \& Co., T. G. Phelps, E. H. Dyer, E. R. Carpentier, E. Dyer, W. B. Carr, W. T. Garratt, and E. G. Rollins, all well-kinown capitalists and enterprising business men of California; and A. D). Bonesteel, A. Otto, and Ewald Klinean, of Wisconsin. The eastern fanties, who were to assume the technical management of the business, arrived in Ualifornia in the spring of 1870, and arrangements were immediately made for the erection of a factory. The location chosen was the farm of E. H. Dyer, at Alvaralo. The work was pushed with such encrgy that the building was completed by the contractor, B. F. Ingalls, esq., in November of the same year.

"It is unnecessary to follow minutely the history of this company. It is sufficient to say that, after rumiug four years at Alvarado, through tho incompeteney of the technical managers, it prover a finaneial failure. Messrs. Bonesteel \& Otto contended that the location at Alvarado, not being a suitable place for the business, was the cause of the failure, and suceeded, by their plansible representations, in or. ganizing a new company, which purchased the Alvaradlo machinery and removed it to Soquel, Sinta Cruz Comuts, where, after operating a few years, subjecting its stockholders to a heavy amual loss, the enterprise was abandoned.

"E. H. Dyer, who had bought the buildings and a portion of the land owned by the old company at Alvarado, still had faith in the business, believing that with goorl management it could be made to pay at that place. He found it very difticult, however, in the face of so many failures, to induce eapitalists to invest a sufficient amount to give the business another trial, and it was not until 1879 that the Standard Sugar Manufacturing' Company was incorporated. 'The company consisted of A. E. Davis, O. F. Giffiu, E. H. Dyer, Prescott, Scott \& Co., J. P. Dyer, and Robert N. Graves, with a capital of $\$ 100,000$. It was soon ascertained that more capital was needed, and thecompany re-incor. porated under the name of the Standard Sugar Refinery, with a capital stock of $\$ 200,000$. The officers are : U. F. Giffin, president; J. P. Dyer, vice-president; E. H. Dyer, generul superintendent; IV. F. Ingalls, secretary; trustees, O. F. Giffin, R. N. Graves, J. P. Djer, G. H. Waggoner, and E. H. Dyer. This company has made a success of the business from the start. It earned 33 per cent. on the capital invested the last or thirl campaign, and is now just commeneing on its fourth cumpaign with rery flattering prospects. The success of this important home industry is greatly dne to the general management of Mr. Dyer, who owns one-fourth of the stock, and who, protiting by former experience, is able to aroid many mistakes which have caused the failures of other establishments of the kind. The present factory has been 
enlarged and improved until it now has a capacity of abont 100 toms per day; employs at the factory 125 men, to say nothing of the great amount of labor necessary to produce the beets, harvest and haul them to the factory. One, to obtain an alequate irlea of the business of this company and the great good it is doing in the way of using the products of the farmers and keeping employed so many of our people, shomla see the works in operation lluring the months of September, Uetoluer, and November, when beets are being received.

"Thereare frequently lines of teams, all lieavily laden with beets, from a quarter to sometimes half a mile in length, pushing along in line to reach the company's scales and deliver their loads. It is a scene of great activity. From tifteen to twenty thousand tons of beets are used each eampaigu, which require for their production ten to fifteen humber acres of land. The eompany dishurses among its rorkmen and the farmers nearly $\$ 150,000$ a year for laborand material used; all produced in Alameda Comty. They have turued out each eampaign one and a half million poumbs of pure white sugar. No low gratles or yellow sugars are put on the market by them."

\section{BEET-SUGAR FACTORIES AT CHATSWORTH AND OTHER PLACES.}

In regard to these factories Prof. W. A. Henry writes as follows: "The history of attempts to manufacture sugar from the beet in A meriea is one of almost eontinuons failure. In 1838 David Lee Child mannfartured sugay in Massaelusetts at 13 eents per pound, lut a small quantity being malle. In 1863 the Gennert Brothers, from Germany, luilt a firetory at Chatsworth, Ill, in what is said to have becu an minfortmute location, as the soil there was not suitable for beet-growing. Barl culture, wet seasous, llonght and a soil too full of mineral matter brought risaster, and about 1570 the enterprise collapsed. From Chatsworth the machinery was movel to Freeport, where the Germania Sugar Combany after a lurief existence dissolved, and the machinery was again moved, this time to Black Hawk, Sauk Comnty, WVis., where failure was again inet. At Fond ln Lae, in this State, Messrs. Bonesteol \& Otto orgunized a company with $\$ 12,000$ capital, and struggled during two years, making, it is reported, considerable sugar. Their success could not have been very marked, for they accepted an offer to join a company at Alvarado, Cal., which started out with $\$ 250,000$ eapital. The Alvararlo Company also went to the wall, as did two or three other California concerns. A factory was also started in Maine, and another in Delaware, but these met the universal fate. The Alvarado factory was reorganized, and for several years male considerable quancities of sugar, the product some years reaching two or three million pounds; but owing to the antiquated machinery and linited capoity the investors received little or no dividends. 
"The beet-sugar industry in America may be said to have closed its first era in couple of years ago, and the results, from a financial standpoint, may be summed up in one phrase, 'complete failure.'

"We are now, I trust, entering the second era, which will cloubtless be more successful than the first, but its history lies in the future, and its making is with the people.

"The second era of the industry may be said to hare begun with the reorganization of the Alvaralo factory upon a sound basis last year, and the building of the Spreckels' factory at Watsonville, Cal. These enterprises are in the hands of men who will succeel if suceess is possible."

For further particulars respecting the Chatsworth factory I wrote to Mr. John P. Reynolds, of Chicago, and received the following reply:

CHicago, December 9, 18s\%.

DEAR Sir: Your favor of 5th instant, requesting written papers or observations I may wish to make npon the subject of beet-sugar mannfacture in this comntry, is received.

Twenty-odd years ago, at Chatsworth, I!l., some fer of us marle abont a $\$ 300,000$ failure in attempting to establish that manufacture. The ficetory was well equipped, as we understood it. The lauls, say 1,000 acres, were first-elass high, rolling prairie. Compared with the present the processes of manufacture and machinery were doubtless imperfeet, but they were snpposed to be the best approverl in Germany at that time. After we gave it up the business was earried to Freeport, Ill, and started up by three gentlemen of large wealth, on good old lands, by the side of a town of 15,000 people. It fitiled again.

Without going into details further, I must say that I have given up hope for the early suceess of beet-sugar industry in this comntry, becanse I believe the essential conditions are not to be found here at present. These conditions relate to the production of the beets. The manufacturer must grow his own beets, or have them grown in the vicinity by others. He can not command the necessary labor to grow them himself, except at a cost that the results will not justify. There is no erop within the whole range of agriculture more diffienlt to prodnce than a crop of heets suitable for the manufacture of sngar. An army of women and children (being the cheapest labor) is required imperatively at special times, and I know of no community where this army can certanly be had when needed and at a fair cost.

If others grow the beets, contracts must be made in adrance for the entire erop of each, a certain number of acres to be cultivated. The product per acre is variable and uneertain in both quantity and quality. There may be a superabundance for the eapacity of the factory, or there may be a failure of the crop almost entirely. As to price per ton the alvantage is always on the side of the farmer. The manufacturer must pay what the farmer may demand, or quit the business and lose his plant. The farmer ean nse his land for other crops; the faetory will make only beet-sugar. 
With irrigated lands and slare labor, or its equivalent, I can nnder. stand that sugar from beets can be prodneed profitably in this country.

I would like to believe this industry will soon demonstrate the error of my present eonvietions thus briefly stated, and certainly the effort to make it successful is worthy any man's ambition.

Yours, truly,

JOIN P. REYNOLDS.

Mr. H. W. WILEY,

Chemist, Department of Agriculture, Washington, D. C.

\section{STATISTICAL,}

TIIE GERMAN CAMPAIGN OF 1888-'89.

During this eampaign the new law lerying a part of the tax on the beets and a part on the sugar produced eame into operation for the first time. The object of this law is to diminish the bounty paid on exports. By the new law the tax on the beets has been rednced to . 80 marks per 100 kilograms, instead of 1.7 marks as by the former law. On the other hand, sugars entering consumption pay 12 marks per 100 kilo. grams, whereas before they paid nothing when made from native beets.

The quality of the beet root harvested in 1858-'89 was much inferior to that of the preceding year. This inferiority was cansed by a late wet spring and an excess of rain in June and July. While the yield of heets was larger, the saccharine strength was lower than had been known before in many years. The yield of sugar was also diminished by early frosts, by which many beets were frozen before they conld be properly harvested and siloed. The juice of such beets was cooked with extreme difficulty, being difficult to filter and granulate. Many factories by reason of these diffienlties were led to refuse to accept beets that had been frozen.

The following table, according to $\mathrm{M}$. Lieht, gices the actual production of sugar in Germany in metric quintals* and the percentage of yield on the weight of the beet from 1871 to 1859 :

[Sugar, A pril, 1890, p. 496.]

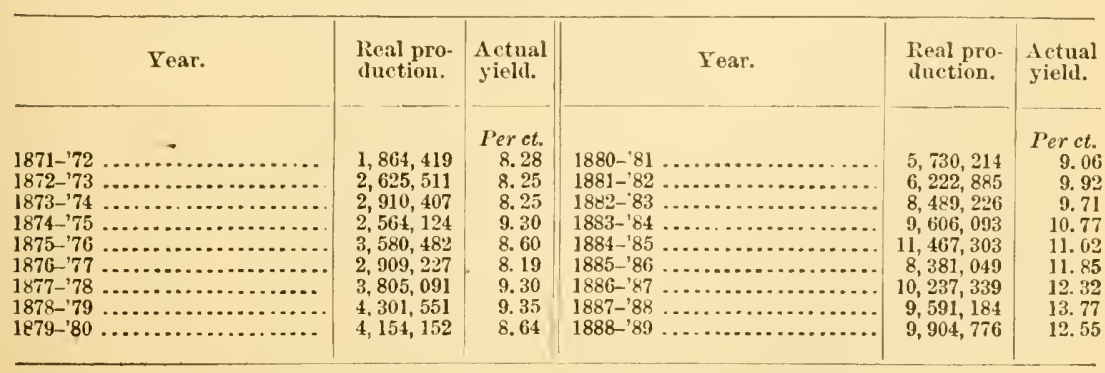

* Divide by 10 to get tons of 2,200 pounds each. 
The following tabie expresses in tons of 2,200 pounds the relative amounts of cane an! beet sugar made in the world during the past seven years:

\begin{tabular}{|c|c|c|c|}
\hline Tear. & Beet. & Cane. & Total. \\
\hline 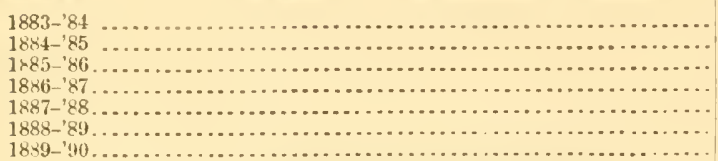 & $\begin{array}{l}2,361,000 \\
2,546,000 \\
2,220,000 \\
3,730,000 \\
2,452,000 \\
2,767,0000 \\
3,500,000\end{array}$ & $\begin{array}{l}2,323,000 \\
2,351,000 \\
2,340,000 \\
2,345,000 \\
2,170,000 \\
2,280,000 \\
2,278,000\end{array}$ & 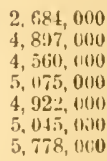 \\
\hline
\end{tabular}

It is seen from the abore table that the production of cane-sugar has remained stationary or even diminislıed during the last septenuial perioul while the production of beet-sugar has experienced an enormous progress.

Willet and Gray (Louisiana Planter and Sugar Manntacturer, April 5, 1590), give the following estimate of the total sugar crop of the world, in tons, for the last fire years:

\begin{tabular}{|c|c|c|c|c|c|}
\hline Country. & $1889-90$ & $1888-' 89$. & $1887-88$. & $1886-87$. & $1885-i 6$ \\
\hline 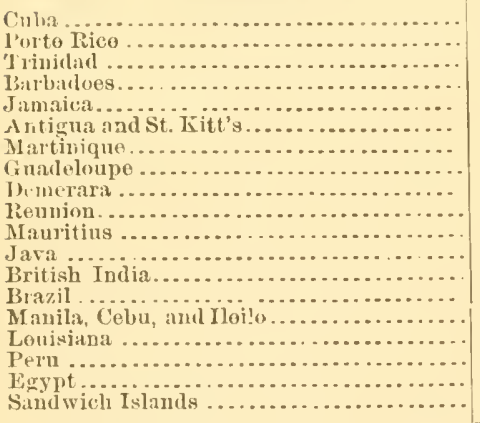 & $\begin{array}{r}600,00 \\
70,000 \\
60,000 \\
60,000 \\
30,000 \\
28,000 \\
40,000 \\
50,000 \\
125,000 \\
30,000 \\
125,000 \\
310,000 \\
60,000 \\
150,000 \\
180,000 \\
125,000 \\
30,000 \\
35,000 \\
120,000\end{array}$ & $\begin{array}{r}530,000 \\
55,000 \\
60,000 \\
50,000 \\
28,000 \\
25,000 \\
38,000 \\
45,0110 \\
108,000 \\
25,000 \\
132,000 \\
364,000 \\
60,000 \\
220,000 \\
210,000 \\
145,000 \\
30,000 \\
35,000 \\
120,000\end{array}$ & $\begin{array}{r}610,000 \\
50,000 \\
60,000 \\
60,000 \\
30,000 \\
26,000 \\
39,000 \\
50,000 \\
110,000 \\
32,000 \\
120,000 \\
396,000 \\
55,000 \\
320,000 \\
174,000 \\
158,000 \\
30,000 \\
35,000 \\
100,000\end{array}$ & $\begin{array}{r}608,900 \\
86,000 \\
69,000 \\
65,000 \\
21,000 \\
25,000 \\
41,000 \\
55,000 \\
135,000 \\
32,000 \\
101,800 \\
363,950 \\
50,000 \\
260,000 \\
180,000 \\
80,900 \\
26,000 \\
50,000 \\
95,000\end{array}$ & $\begin{array}{r}705,400 \\
6.1,000 \\
49,200 \\
44,0110 \\
17,000 \\
25,0110 \\
33,1100 \\
37,000 \\
111,8010 \\
35,000 \\
114,200 \\
365,950 \\
50,000 \\
186,000 \\
186,0100 \\
127,900 \\
27,000 \\
65,000 \\
96,500\end{array}$ \\
\hline 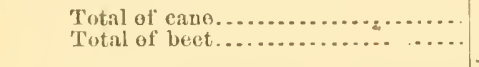 & $\begin{array}{l}2,228,000 \\
3,550,000\end{array}$ & $\begin{array}{l}2,254,000 \\
2,753,844\end{array}$ & $\begin{array}{l}2,465,010 \\
2,451,950\end{array}$ & $\begin{array}{l}2,345,550 \\
2,730,206\end{array}$ & $\begin{array}{l}2,3 i 39,950 \\
2,219,973\end{array}$ \\
\hline 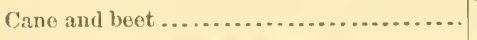 & $5,778,000$ & $5,007,841$ & $4,916,950$ & $5,075,756$ & $4,559,9 \div 3$ \\
\hline
\end{tabular}

La Sucrerie Belge of March 15, 1590, page 37:2, gives the following estimate of the total production of beet sugar in Europe during the past four years, in tons of 2,200 pounds:

\begin{tabular}{|c|c|c|c|c|}
\hline Country. & $1889-{ }^{\prime} 90$. & $1888-89$. & $1887-' 88$. & $1886-8 \%$ \\
\hline 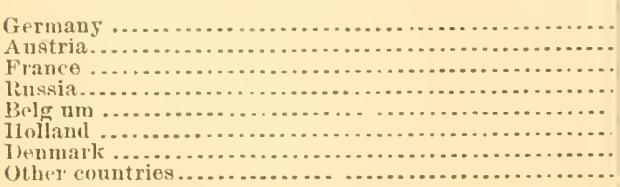 & $\begin{array}{r}1,220,000 \\
730,000 \\
750,000 \\
445,000 \\
172,000 \\
55,000 \\
20,000 \\
25,000\end{array}$ & $\begin{array}{r}978,000 \\
514,000 \\
460,000 \\
503,000 \\
96,000 \\
35,000 \\
19,000 \\
21,000\end{array}$ & $\begin{array}{r}953,400 \\
400,000 \\
420,000 \\
430,000 \\
93,000 \\
37,000 \\
21,000 \\
14,000\end{array}$ & $\begin{array}{r}1,015,600 \\
550,100 \\
497,100 \\
455,000 \\
91,000 \\
36,000 \\
18,300 \\
13,000\end{array}$ \\
\hline Total ........... & $\overline{3,417,000}$ & $2,626,0000$ & $2,368,400$ & $2,675,900$ \\
\hline
\end{tabular}

"Ia Sucrerie Indigenc, Mareh 11, 18!0, 1. 2:3:3. 
STATISTICS OF TIIE PRODUCTION OF CANE AND BEET SUGAR.

Licht, of Magdeburg, in his last report (Jomrnal des Fabricants de Sucre, March 26, 1890), gires the following figures for the production of beet sugar in Europe for the last three campaigns:

[In tous of 2,200 prounds.]

\begin{tabular}{|c|c|c|c|}
\hline Country. & $1887-88$ & $1888-89$ & 1889-'90. \\
\hline 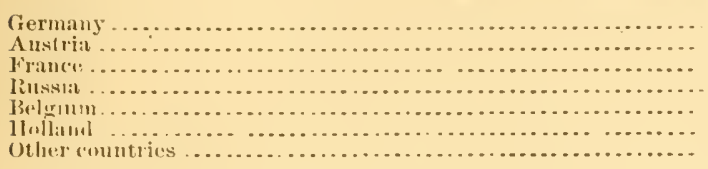 & $\begin{array}{r}956,166 \\
42 \times, 616 \\
392,821 \\
411,342 \\
140,742 \\
39,280 \\
79,980\end{array}$ & $\begin{array}{r}990,604 \\
52,242 \\
466,767 \\
525,3 \times 7 \\
145,804 \\
46,040 \\
87,000\end{array}$ & $\begin{array}{r}1,260,000 \\
750,000 \\
775,600 \\
475,010 \\
200,000 \\
600,010 \\
811,0,0\end{array}$ \\
\hline Total .. & $2,481,450$ & $2,785,814$ & $3,600,600$ \\
\hline
\end{tabular}

\section{PRODLCTION IN RUSSIA.*}

During the campaign of $1859-90$ two hundred and twenty-fire factories were operated in Russia. The harvest of beets amounted to 17,370 kilograms per hectare against 18,6s0 kilograms per heetare the preceding year. The beets also were much poorer in quality during the last year, the mean polarization being 12.93 ner cent. of sugar against 14.20 per cent. the preceding year.

THE PRODUC'IION OF CANE SUGAR IN .TATA, *

During the season of 1889 there were operated in .Java one hundred and serenty-eight factories, producing $5,440,397$ picnls of sugar.

\section{PRODUCTION OF SEED.}

There is, perhaps, no other agricultural erop which has illustrated in so marked a manner the importance of seed seleetion as the sngar bert. By the careful selection of those rariations in the original beet which seemed most favorable to the production of sugar, and the earefin selec. tion of beets in the production of seed during the sneceeding year, and by judicions and scientifie fertilizing for the purpose of increasing the sugar content, there has been a great evolution in the sugar-producing power of the beet which has placed it at the head of the sugar-produeing plants of the world.

The influence of the quality of the seed, according to Vilmorin, is absolutely predominant from the point of view of the results obtained in the culture of the sugar beet. The numerous experiments of scientific investigators has shown that remark to be true. In France the firm of Vilmorin-Andrienx \& Co. has paid spreeial attention to the improvement

* Journal des Fabricants do Suere, March 19, 1890. 
of the standard rarieties of the sugar beet by the method above mentioned. They have endeavored to produce different varicties of beets of which each one would have all the possible adrantages in the different economical and eulture experiments to which manufacturers and farmers will submit them.

It is true, without doubt, that the same variety of beet conld not be the most ad vantageous in every case, and that, according to the results to be obtained, it might be an advantage in one place to cultivate a variety extremely rich and in another place one, which, while still rich in sugar, wonld also produce a heary yield in pounds. To these different needs different varieties of beets respond. In one ease the pure white variety, in another the white variety with green neck or the rose variety with rose neek, or the Vilmorin Improved, a variety which is suitable everywhere and particnlarly in those conntries where the duty on heet-sugar is laid direetly on the beet. Since the introdnction of the new law in France, in 18s4, levging the tax upon the actual weight of beet produeed, the White Improved Vilmorin beet has recommended itself by its exceptional richness, its great purity, and the ease with which it ean be preserved. But in orler to meet all the conditions necessary to the greatest suceess it is necessary to find out by experiment that variety of beet, which, in any giren locality, fulfills most of the conditions required to produce a ligh yield of sugar with a minimum cost and one which will be equally profitable to the farmer and manufacturer.

At the present time, it is necessary in this country to go abroad for beet seed of the highest character. Up to the present time the sugarbeet seed which has been grown in this eomntry has been produced without especial reference to the eonditions necessary to maintain the beet at a high standard and to improve it as is done in foreign countries. In other words, the sugar-beet seed which one will obtain from American dealers, if it shonld be that which is grown at home, does not come with the pedigree of the beet, in regarl to content of sugar and purity of juice, nor with that assurance of care in enltivation which the pro. fessional producers of beet seed in foreign eonntries bestow upon their work. There is no reason, however, to suppose that it is impracticable to produce beet seed in this eountry of as high a grade and of as pure a quality as that which can be obtained in other comntries. The method of loing this will be briefly indieated.

In growing the beets the greatest care shonld be taken to secure all the conditions neeessary to produce a beet of maximnm richness in sugar, compled with a yieh per aere of fair proportions. This can be done by attending to the directions for culture to be giren, combined with judicions application of those fertilizers which will tend to increase the sugar content of the beet without unduly increasing its size. The fertilizers which are most suitable for this purpose are carbonate of lime, when it is not present in suffieient quantities in the soil, a small quantity of magnesia, and larger quantities of phosphoric acid with varying pro- 
portions of potash and nitrogen, according to the eharacter of the soil in which the beets are grown. No certain rnle can be given for the application of fertilizers until the conditions of the season and the character of the soil in each particnlar locality have been earefully studier experimentally. For this reason, it is certain that in this country, as in others, the business of producing beet seed will be one entirely distinet from that of raising beets for manufacture or for the mannfacturing thereof. It is this business which will require not only the highest seientific agrienlture but the most earefnl agronomic skill.

\section{SELECTION OF "MOTHERS."}

The beets which are to be used for produeing the seed should be selected on acconnt of the possession of those properties which are most suitable to secure the highest results in the production of sugar. In the first place, all hects of irregular or unwieldly shape should be re. jected; those selected should be of uniformly eren texture, smooth ontline, and symmetrical shape.

The sugar eontent of these heets shonld be determined by the analy. sis of others grown in the same plot and of the same seed, and thus ob. tain the average content of sugnr for the whole lot. Only that class of beets showing the highest content of sugar combined with the qualities giren above, and the greatest purity of juice, shonld be preserved. In many eases the beets themselves, which are to be used for propagation of seed, are sulyected to analysis by the removal of a cylindrical sec:tion by an instrument provided for that purpose and the analysis of this seetion. In this way the actual sugar entent of the heet which produces the seed ean be obtained. It is said that good results have also been secured by replacing the prortion of the beet removed by sugar at the time of planting, which will afford an alditional food product for the earlier growth of the beet in its second year.

Another method of selecting the beets, which has been willely employed, is that of detirmining their density. A solution of some sulpstance is made in water, such as salt or sugar, of such a density as to permit beets of inferior quality to float on the surface and those of superior quality to sink. These heavier beets, other things being equal, eontain larger quantities of sugar and are more suitable for the production of seed. The bects, of eourse, which are to be used for the pro. duetion of seed must be very carefully harvested so as not to be bruised, leaving the roots as much as possible uninjured, and they must be earefully preserved in silos orer the winter until the time for transplanting in the spring. The transplanting and the successful eultivation of the beets need no detailed lescription.

The character of the beet is also sometimes determined by removing a small portion, as indieated above, for polarization, expressing the jnice and letermining its specifie gravity by weighing in the juice a silver button of known weight. 
The absolute necessity of securing a few beets of the highest sugar co-rfficient and purity for the purpose of producing a erop of seed in thirl, fourth, or fifth year, according to the number selected, has in the last few years been recognizerl to a degree unknown before. At first it was the custom to select the leets, by some of the methorls mentioned above, in large numbers sufficient to grow in the second year seed for the market. A much more rational method, howerer, and one which secures higher results, consists in a more careful selection of the mother beets for the purpose, not of protucing seed for the market in the second year, but only for the purpose of producing for securing an additional crop of beets in the third year which in the fourth year will prodnce seed for the market. The methods employed by different seedsmen vary somewhat, but the principle in all cases is the same. The general method may be indieated by that pursued by Dippe in Quedliuburg: *

First year.--seed planting for mother beets, from seed which eame from the highest polarizing beets of different varieties, which have, of conrse, been liept separate. The planting is in rows 18 inches apart, and the plants are ent away in the rows so as to stand 10 or 12 inches apart. At the time of harvesting the beets are selected ont accorling to form, growth, and leaf formation, as these best approximate the characteristics of the parent variety.

Second year.-In Mareh and April these selected beets are examinol in the laboratoryt in the following manner :

At a certain point which it is presumed will give an arerage of the entire beet, a cylindrical piece is ent out, suljected to strong pressure in a juice-press, which will give, for example, from 17 grams of beot 10 grams of juice, of which 5 enbie contimeters are diluted with leal an' tate and water to 25 enbie centimeters, liltered and polarizerl. For the different varieties minimum limits are established, and the beets aro arranged in three classes accorling to their polarization :

First, beets which go below the limit and are thrown ont; second, beets which are above the limit, and fairls good tor seed purposes, ami, third, beets which show an extra high fignre.

These extra good beets are now examined still further, two more cylinders taken out, and the sugar estimated by the extraction method. From this result and the estimation of the sugar in the juice the (ap)parent) content of juice is ealeulaterl. Those beets which do not reach a standard, estabiished for each variety (between 92 and 94), are thrown out, while those that attain it arr the chosen "mother beets" of the crop, which are to perpetuate the variety, and which furnish the seol for each new successiou, as mentioned in the first paragrapl.

In this second year are planted ont all the beets saved, the extra ant medium as well; the former furnish seed for extra mother beets, which

* Stammer, pp. 200, et scy., Lehrbuch der Zncker Fabrication.

t'This is not dono mutil spring in order that only well-preserved bocts may bo chosen. 
are used as indicated for the normal-sized mother heets which furnish seed for a new succession, while the latter are to prodnce a generation of dwarfs, the seed from both being harrested this year.

Third year.-The seed from the medium and extra mother beets is planted, and the latter produce the mother beets for future breeding purposes, as indicated, but the plants from the former seed, which. was planted a little later than would be the case for beets ordinarily, and in soil fertilized with ammoniacal smperphosphate and also some gnano, in rows 12 inches apart, are cut ont to abont every 3 to 5 inches. The small beets are very carefuliy preserved under a thick covering of earth. In the spring of the

Fourth year.-They are uncovered and planted at abont 26 to 24 inches apart. The seed from these when harrested in the fall is ready for the market, so that it has taken five years to attain this end.

In the establishment of Branne, in Biendorf, the procednre is similar, but the beets are selected by their specifie gravity in the field. A woman sits at a table and cuts from each beet a very small piece and throws it into a solution of salt of known density (for example, with the Klein Wauzleben, $16^{\circ}$ Brix). If the piece of beet floats, the corresponding beet is thrown away, but if it sinks the beet is reserved for further investigation in the laboratory. The beets ehosen in this way are submitted to further selection by the examination of the juice from a eylinder.

In a somewhat different way, but still by means of the examination of imlividnal beets, is the culture of the Klein Wanzleben variety carried on by Rabbethge, in Klein Wanzleben, whose object is not so much to furnish establishments with all the seed they require for planting, but rather with seed for the production of mother beets, and their own seed from these. The fact that Klein Wanzleben has never yet harvested more than 3 tons of seed in a season indicates the eharacter of the work, which is much to be commender.

The seeds are always taken from mother beets of considerable weight, never from small or dwalf beets, and the aim is not so mueh to prodnee inlividnal beets of exceptionally high sugar content, but large beets as well; that is, beets which gire the highest jield of sugar from a given amount of land. These roots, which are chosen from a fieln of the best (Elite) beets, and which possess most distinctly the characteristics of the variety, are weighed and their juice polarized, and this operation is continned until 20,000 beets are chosen which fulfill the requirements as to weight and sugar content.

These 20,000 best mother beets are sufficient to furnish the planting

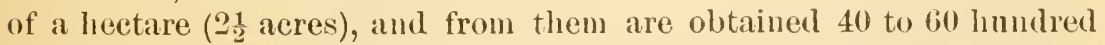
weight of the best (klite) seed, and this gives the following year 60 to 100 heetares of the best (Elite) beets, or $5,000,000$ to $7,000,000$ pliuts. From these are finally chosen the $1,500,000$ seed-hearers which fmmish the planting of 100 herstares and the seed for sale and for the perpetuation of the breed. 
An entirely different method of selection is what is known as "family" breeling. IInudreds of specially-selected beets, excellent in every way, are planted out separately. The seed of each is gathered and planted separately. If annong the beets thus obtained any are found that excel the mother beet in every respeet, and this inprovement endures through several generations, these are incorporated with the other mother beets and used for hreceling. As exampios of weight and polarization of the selected beets the following figures for the highest and lowest weights are given, representing the best mother beets of the years 1883 and 1SS1:

\begin{tabular}{|c|c|c|c|}
\hline Weight. & $\begin{array}{l}\text { Sucroses } \\
\text { in juices. }\end{array}$ & Weight. & $\begin{array}{l}\text { Sucrose } \\
\text { in juice. }\end{array}$ \\
\hline $\begin{array}{c}\text { Crams. } \\
1,550 \\
1,450 \\
1,250 \\
1.500 \\
1,450 \\
1,700 \\
1,8100 \\
2,100 \\
1,900 \\
600\end{array}$ & $\begin{array}{c}\text { Per cent. } \\
11.24 \\
13.68 \\
14.29 \\
15.87 \\
14.60 \\
11.76 \\
14.86 \\
14.35 \\
14.60 \\
16.13\end{array}$ & $\begin{array}{c}\text { Grams. } \\
600 \\
6110 \\
800 \\
400 \\
550 \\
400 \\
550 \\
400 \\
600\end{array}$ & $\begin{array}{c}\text { Ier cent. } \\
15.11 \\
16.2 \mathrm{k} \\
16.28 \\
16.13 \\
15.63 \\
16.83 \\
16.88 \\
16.63 \\
15.63\end{array}$ \\
\hline
\end{tabular}

Among 200 beets were found only 11 with a weight of less than 500 grams; 12 with a weight of 500 to 600 grams; 29 with a weight of 600 to 700 grams; 21 witl a weight of 700 to $\$ 00$ grams; and finally 127 , or 63 per cent., with a weight of over $S 00$ amd up to ats high as 2,100 grams.

The beets between 700 and 1,000 grams are of nearly identical sugar content, a peculiarity of the Klein Wanzleben variety.

The established normal weight varies, accorling to the season, be- tween 600 and 900 granns; in the year 1893 it was 897 grams, corresponding to the aremane of the beets from a ficld.

A still different method is followed by v. Proskowetz (Krassiz). The beets from which selections are to be made are placed in a solution of salt showing $17.5^{\circ}$ Brix, and those which float are used as fodder; those which sink are analyzed for sugar content by the alcohol extraction method, for which purpose a small quantity, lialf the normal weight, is eutout with a rasp and polarized in a 400 -millimeter tube. Beets which give at least 19 per cent. of the bect in sucrose form the first class; those showing 15 to 18.9 , inclusive, the second, and those from 16 to 18 the third. Beets under 16 per eent. aro used for fodder.

\section{PRESERVATION UF BEET'SEED.}

It is recommenled by D'Haussy (Jour. des Fabricants de Sucre, A pril $16,1590)$ to place in each bag 100 pomms of seed, 1 pound of powdered sulphur, and 1 ounce of carbolic acid, and mix thoroughly.

These substances preserve the seed completely from every kind of insect from the time it is plantel mutil the root is levelopel. The outside of the bag should be conted with tar, and the seed kept therein for two weeks before planting. 


\section{VARIETIES OF BEETS GROWN IN FRANCE.*}

THEIR CHARACTERS, HODE OF SELFCTING, L'TC.

"The importance of the variety or race of the beet to be grown for sugar can not be questioned. A beet giving a large enltural yield rich in sugar involves no more cost to the grower in its production than one giving a small yield and low saceharine value. It is therefore nseful to choose those which will give the greatest returns and be at the sime time the most satisfactory in every way to the grower who must produce them and to the manufacturer who must extract the sugal.

"For the latter it is admitted that the raw material-the juice of which contains the smallest pereentage of mineral and organic impurities, other things being equal-will give a larger yield of sugal than juices in whieh these constituents exist in larger proportions, and it is well known and generally unlerstood that these favorable conditions are fomm in roots of moderate size more frequently than in large ones. Thus Brient says - The size of the beet is in the inverse ratio of its content of sugar and salts; the content of water inereases with tìe size and weiglit of the beet'; and Champion and Pellet state $f$ that beets of good quality genérally have an average weight of 700 to 800 grams (1 $\frac{1}{2}$ to $1_{3}^{3}$ pomuds), aud this size seems to be generally adopted as the most favorable by the best anthorities on beet culture in Fiance and by the manufacturers almost unauimonsly.

"The rule that the smaller the beet the rieher in sugar aplpears to find illustration if not complete confirmation in the results of examination of the beets submitted by Professor Deherain $\$$ to experiment at the college farm at Grignom and prodneed from seed fimished by Vilmorin-Andrieux \& Co.

\begin{tabular}{|c|c|c|c|c|c|c|c|c|}
\hline \multirow{2}{*}{ Number. } & \multicolumn{2}{|c|}{$\begin{array}{l}\text { Improved exposition } \\
\text { beets. }\end{array}$} & \multicolumn{2}{|c|}{$\begin{array}{c}\text { Improved beets No. } \\
848 .\end{array}$} & \multicolumn{2}{|c|}{$\begin{array}{l}\text { P'ink-top bests, Ver- } \\
\text { rieres. }\end{array}$} & \multicolumn{2}{|c|}{ Pink top No.34. } \\
\hline & $\begin{array}{l}\text { Weiglst } \\
\text { of bect. }\end{array}$ & $\begin{array}{l}\text { Sugrar in } \\
\text { juice. }\end{array}$ & Woight. & $\begin{array}{l}\text { Sugar in } \\
\text { juice. }\end{array}$ & Weight. & $\begin{array}{l}\text { Sugar in } \\
\text { juice. }\end{array}$ & Wroight. & $\begin{array}{l}\text { Sugar in } \\
\text { juice. }\end{array}$ \\
\hline 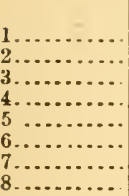 & $\begin{array}{r}\text { Grams. } \\
395 \\
305 \\
720 \\
600 \\
620 \\
740 \\
1,130 \\
850\end{array}$ & $\begin{array}{r}\text { Per cent. } \\
18.1 \\
16.7 \\
16.4 \\
15.6 \\
15.0 \\
13.9 \\
13.4 \\
13.2\end{array}$ & $\begin{array}{r}\text { Grams. } \\
282 \\
330 \\
660 \\
450 \\
385 \\
335 \\
560 \\
580\end{array}$ & $\begin{array}{r}\text { Per cent. } \\
\because 0.0 \\
20.0 \\
18.8 \\
18.7 \\
18.4 \\
18.1 \\
17.7 \\
16.9\end{array}$ & $\begin{array}{r}\text { Grams. } \\
980 \\
460 \\
630 \\
627 \\
890 \\
1,150 \\
\ldots . . .\end{array}$ & $\begin{array}{r}\text { I'er cent. } \\
13.10 \\
12.05 \\
11.30 \\
10.00 \\
9.84 \\
9.20 \\
\ldots . . .\end{array}$ & 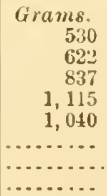 & $\begin{array}{r}\text { P'er cent. } \\
13.75 \\
13.10 \\
12.50 \\
11.25 \\
10.60 \\
\hdashline \\
\hdashline \ldots . . .\end{array}$ \\
\hline Averages... & 677 & 15.5 & 447 & 18.6 & 789 & 10.91 & $8: 8$ & 12.24 \\
\hline
\end{tabular}

"The form of the beet seems also to be an important fieature in the consideration of the proportion of sugar to be obtained, and Chanpion

* MeMurtrie, op. cit. Pl. 71 et. seq.

† Jourual des Fabricants de Snere, October 2:3, 18.8.

† La Betterave à Sucre, p. 98.

Annales Agronomiques. 
and Pellet further state, eoncerning beets of gool quality, " their form is elongated and tapering." This admits of mole thorongh penetration of the root in the soil, more complete contact with the nutritive elemeuts, moisture, etc., insures the plant agaiust variations of existing conditions, and consenuently a healthier state, from which must naturally follow a hetter quality.

"Corenwinder and Contamine f find that there is a relation between the size of the leares and the richness of the roots; that roots which bear leares of broad surface are generally more riel in sugar than those having small leaves upon a contracterl top, and these facts are confirmed by analyses of subjects taken from the same field. At the same time Deherain conchndes from his researches that the weight of leaves of small beets is relatively greater than is produced by larger ones. The relations found are as follows:

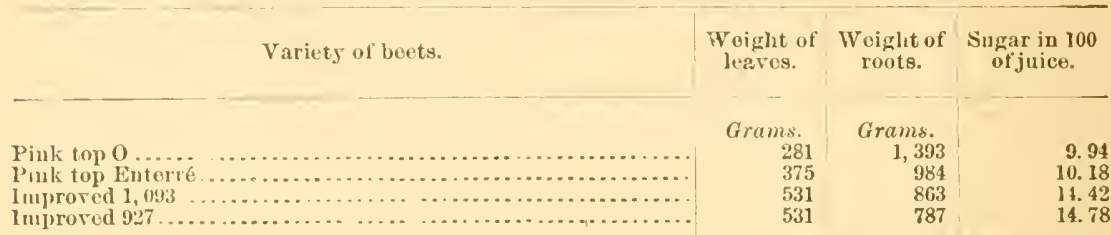

In connection with this relation letween the size and richness of the sugar-beet and the unmber and reight of leaves they bear Champion and Pellet $\S$ give followiug figures.

Variety of berts.

Improved Vilmoris

Simon Legrand (clonico)

()iluntry of sugar tiat torio

\begin{tabular}{|r|r}
\hline $\begin{array}{c}\text { Leares per } \\
\text { 100 of roots }\end{array}$ & $\begin{array}{c}\text { Sugar in } \\
\text { bevt. }\end{array}$ \\
\cline { 2 - 2 } Pounds. & Per cent. \\
56 & 11.5 \\
33 & 13.3 \\
20 & 11.8
\end{tabular}

biets produced in special cullures.

ririety

Ordinary seed, suecial culture

Ordinary secd, ofdinary culture.

\begin{tabular}{r|r|r} 
Tioots. & Leares. & \multicolumn{1}{|c}{ Sugar. } \\
\hline Pounds. & l'ounds: & I'er cent. \\
100 & $5: 2$ & 13.2 \\
100 & 28 & 11.8 \\
\hline
\end{tabular}

"Other tests gave-

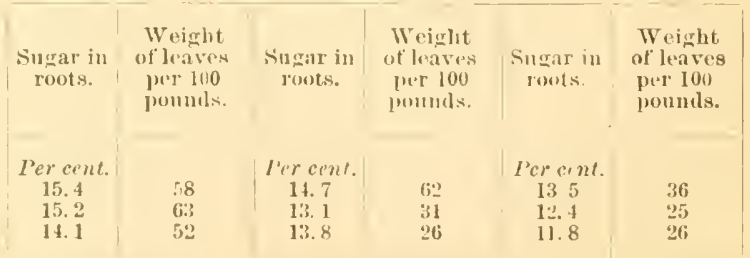

* La Betloriave à sillore.

\$16., 1. III, 98

† Amales $\Delta$ gromomiques, t. $1 \mathrm{~V}, 3 \mathrm{r}$.

ji Lal Betrerave ì sucre. 
"These are the principal external characteristics which seem to hare an influence upon the composition and ralue of the beet, and for the description of the varicties finding greater favor in France and most extensively grown we shall qnote from the writing of Mons. H. Vilmorin :

"It is generally admittel that the saccharine richness of beets is inversely proportional to their volnme. Taken in a general way this proposition expresses a truth, but it is certain that selertion julicionsly applied may canse a rariation of this relation, and enrieh a given race of beets withont diminishing either the volume or the yield. It is in modifieations of this kinl that we shonld seek the practical im. provement of the beet, and the cull proposed is to create, at different degrces of the scale, races of beets uniting with a given yield the maximum saceharine richness compatible with that yield.

"The search for a beet which shows at the same time a maximum of prodnet and a maximum of richness is a ehimera, and the soonerits pursuit is relinquished the more will disappointment and useless enleavor be avoiled. In fact, high saceharine richness is necessarils allierl to a great abundance of leaves and rootlets, and beets rich in rootlets and leaves can not become volnminous withon becoming deformed and losing the external qualitios of regularity and cleanliness which are in a great measnre indispensable to a good race of sngar-beets.

"Starting out, therefore, with the idea that the different circumstances in which the manufacturer or the grower finds hinseli placed demand different beets, let ns examine the really known varieties ind what they may become under the influcnee of skillfully applied selection.

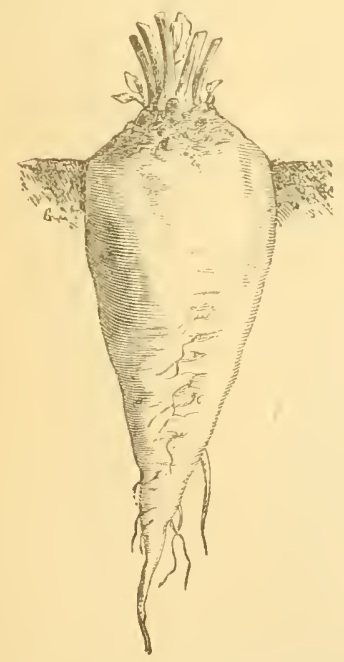

F16. 1. White Silesian Beet.

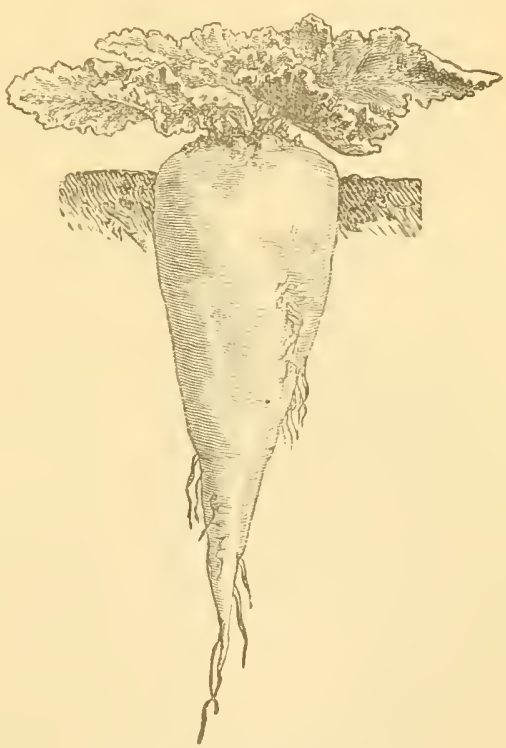

FiG. 2.-Imperial Beet.

"The White Silesian sngar-beet (Fig. 1), origin and point of departure of all the other varieties, is still preferred above all in a large part of Enrope. It is a race of medinm size, almost entirely bnried with white skin, slightly wrinkled, leaves rather sprealing than erect. It is rich in sngar, generally containing 12 to 14 per cent. Its yield in good conditions is abont 20 tons per acre. It is perfectly adapted to close

$25474-B n I 1.27-\cdots 4$ 


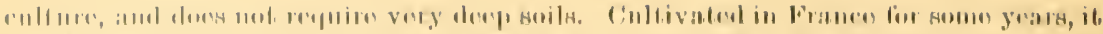

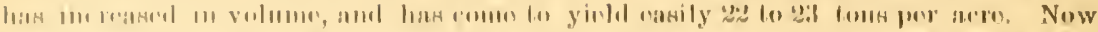

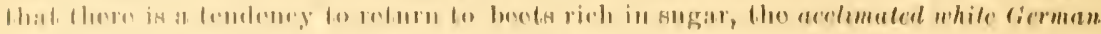

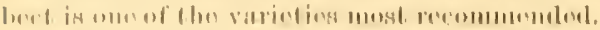

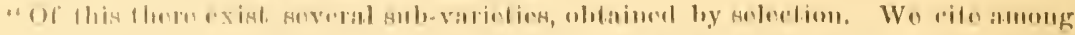

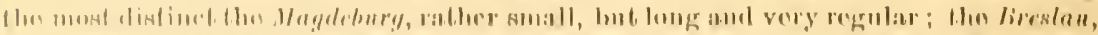

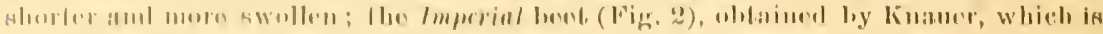

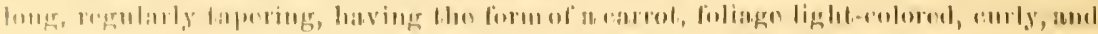

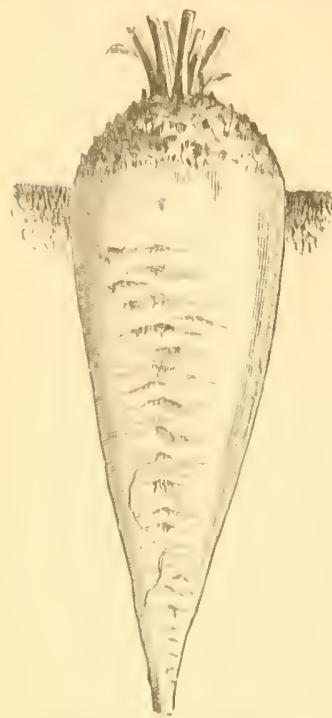

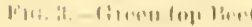

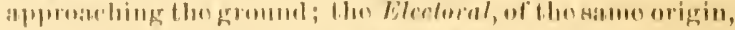

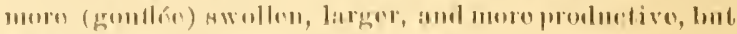

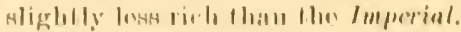

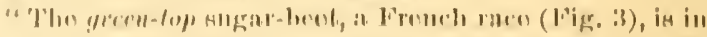

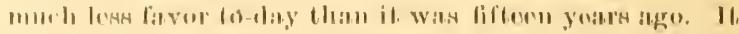

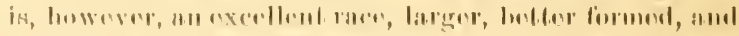

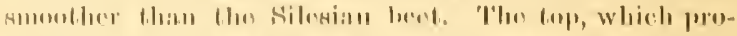

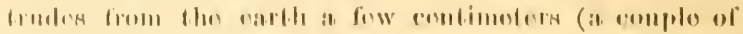

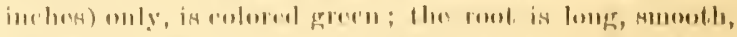

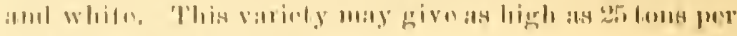

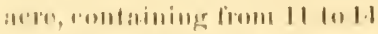

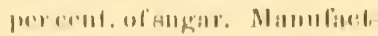

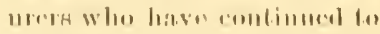
rollivate it hatro hat reasern (a) las nalisliend wilh it. Wo has kn known it. yiold in magner

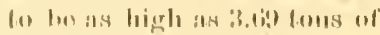

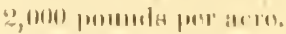

"I'len Fronch pinli top lecet (rig. I) isthat which han landu

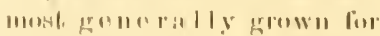

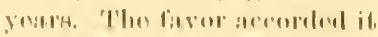

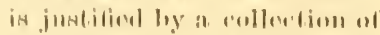

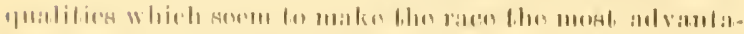

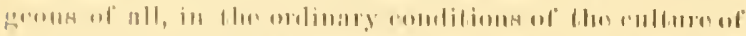

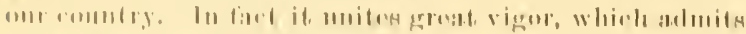

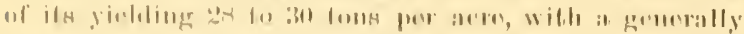

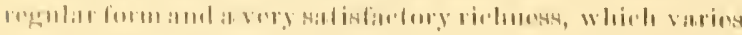

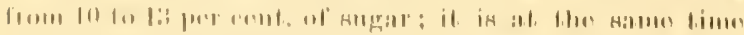

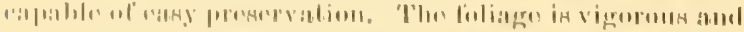

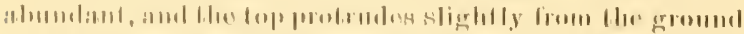

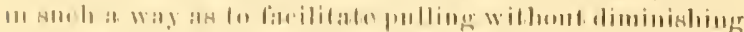

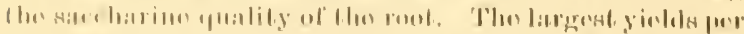

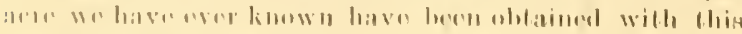

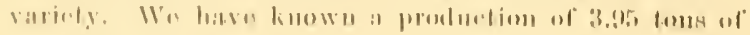

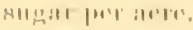

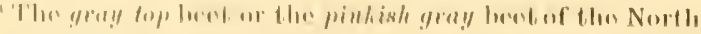

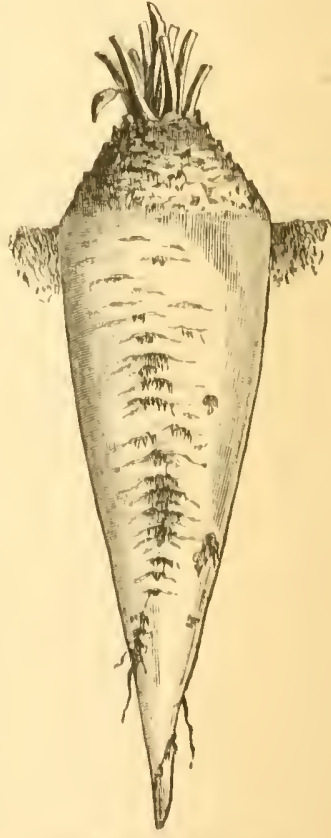

Fint. I. l'iuk top lint.

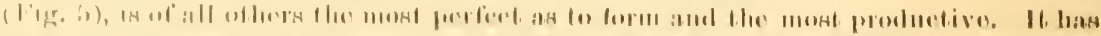

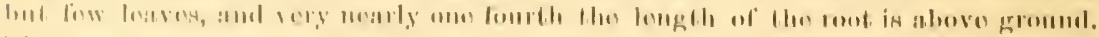

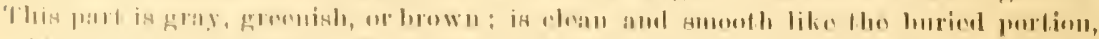

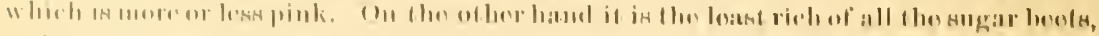

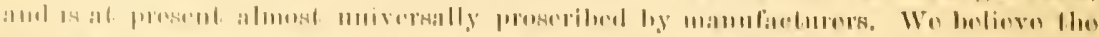

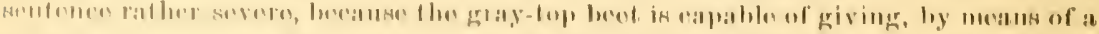

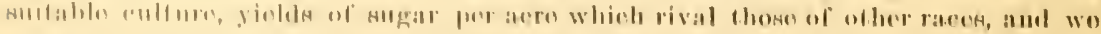

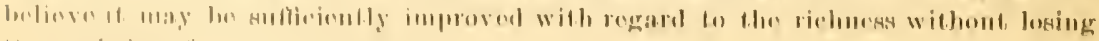

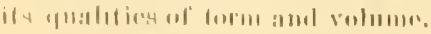

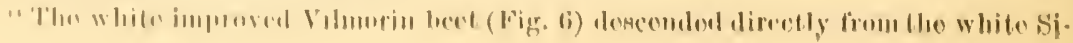


losian, Was bromelat loy Mons. I. Viluorin, by means of soloction, to prosont, aftor

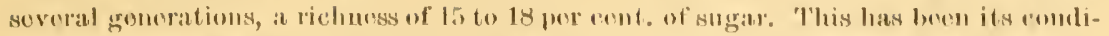

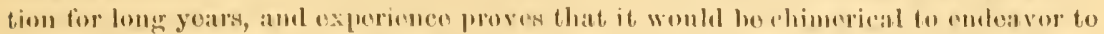

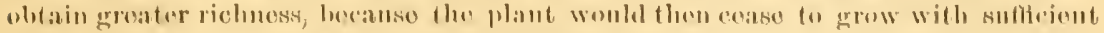

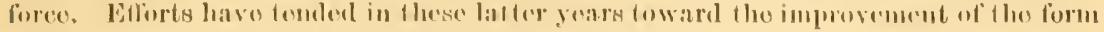
and increaso of tha proslaset, and important prozrass has lwen realizal in this direction, sinen tho improved here, which was representod at tho hergin-

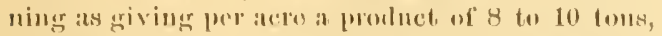
containing 15 to 16 pere rent, of sugar, hats given in data yichls of 18 to 20 lons per acro with a richmess in sugrar varying form 15 10 10 jel cont.

"This race has always leen comsislored partionlarly suifol to spocial comelitions of enltures and mamutacturo which aro not thone of France; it serme to ns, howover, that, in consongence of the

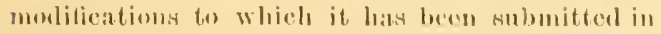
latere limes, and which have inerrased its volumo and its yiold, it may lu adophlol in oortain casts,

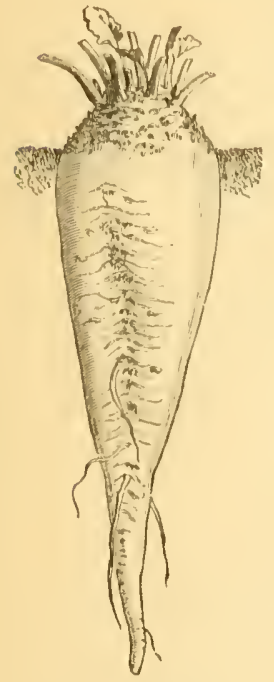

Fis: 6. - Vilmurin's Inproverl limet.

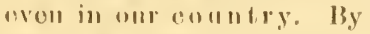
nrowing it vory closely, the infiriorify of itw volmme as compared with that of other racess is in great part (o)mponsated for, and on tho uther hand it has heon provere by musureroms amilyaces, ospureially in the comspetitive oxhibitions of beots at Arras and Sonlis, that this

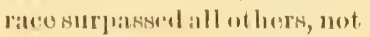

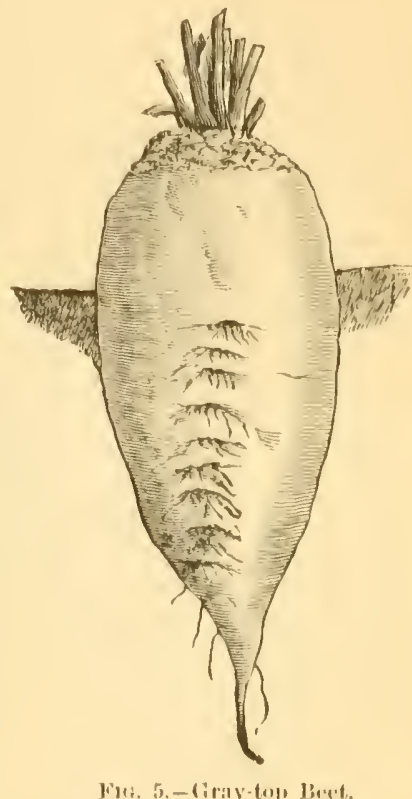

frut, 5,-limy-top linto mly in sacelatrim richness, lont also in the purity of its juicen, which containod less of ashes and salts fhan that of auy othor variety, an alvantare of vary grat importance.

"This lorings us to the consideration of the intemal structure and composition of the heet, which, like the extemal chancteristies, may natmally bo moditied hy the conditions of eulture and mutrition to which the plant is subjected.

"The strueture of the root has been the subjoet of carreliul study by M. Decaisne, the able director of the Department of Vegetable Pliysiology of the Jardin des Plantes at l'aris, and he has manle a complete mieroseopic examination and conserpent deseription of the minute anatomy, but in this report wo shall notice only those physical eharacters which are manifest to ordinary vision, and the relations they hear to the economic value of the root. It is this part of the subject that has heen worked up by Payen, who called attention to the appearance of the altermate opacue and transparent hands when the root is sliced in the diredion of' its longer axis, and of similar zones when ent in thes direction of its shorter axis. Of these, ho shows that the former or 
opaque zones are the richer in sugar, aud in his memoir on this subject he says :*

"If a root be cnt in the direction of its length aud throngh its center, it shows the section represented in Fig. $7 . \quad b \quad b \quad b$ are the parts containing the sugar. They are distingrished by their more decided white appearance; all the tissue which separates them is grayish, and contains little or no sugar. 'This is proven by chemical tests, by cupric liquor among others, or even simply by the taste.

"Champion and Pellet state that-

"If rery thin slices of pink beets he used, after a few minutes' exposure to the air, the zones pointed ont by Payen may each be subdivided into two difierent zones, separa'ed from each other by a series of black points (tubes) distributed in the form of circhis, and seeming to correspond with the leaves.

"The strueture would then be as follows: 1, opaque zone; 2, transparent zone; 3 , opaque zone; 4 , zones of rascular tissue.

"The formation of these zones seems to be in some way allied to the production of leares, as mell as the increased proportion of sugar contained in them, for Bretschneider noticed a relation between the number of leaves and of the concentric lavers, and Gandichaud found that " the leaves of beets correspond directly with the diff'erent zones of ressels in the roots in such a way that the appearance of new leaves shouid always give rise to new zones of ressels;' while in comnection with the above facts Champion and Pellet give the following figures, showing the relation between the pereentage of sngar in the juice, the number of leares on the plant, and the number of zones in the root:

\begin{tabular}{|c|c|c|c|}
\hline Seerl used. & $\begin{array}{l}\text { Sugar per } \\
\text { crut. prev } \\
\text { volume. }\end{array}$ & $\begin{array}{l}\text { Number } \\
\text { of leaves } \\
\text { on root. }\end{array}$ & $\begin{array}{l}\text { Numler } \\
\text { of zone's. }\end{array}$ \\
\hline 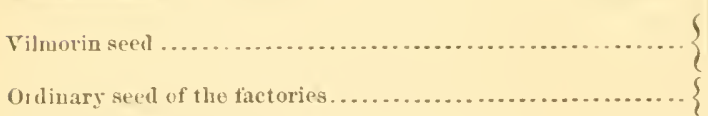 & $\begin{array}{l}15.7 \\
14.8 \\
13.8 \\
12.2 \\
11.5\end{array}$ & $\begin{array}{l}42 \\
39 \\
31 \\
23 \\
19\end{array}$ & $\begin{array}{l}43 \\
36 \\
12 \\
28 \\
20\end{array}$ \\
\hline
\end{tabular}

"Payen's notions found snpport in the results of examinations of the parts made by Jonlie, Violette, and others. Notwithstauding the earlier statements of Violette, he lias published results of analeses showinn that the percentage of sugar in the several parts varies inversely witl, the distance of the part from the longitudinal axis, and that the ligher percentage is found in the opaque zomes. Thus the same beet gave the following figures:

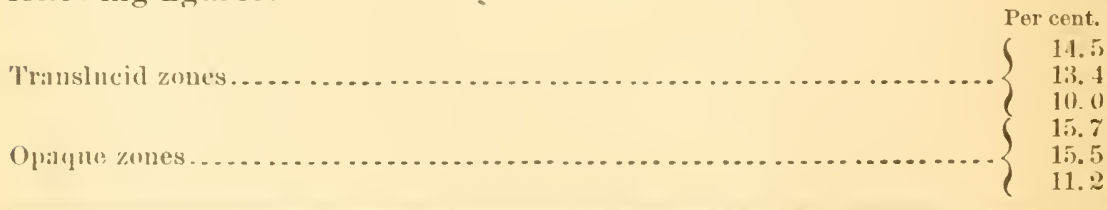

"Comptes reudus, xxiv, 909. Quoted in Traitéde la Fubrication dn Suere, by E. J. Manmene, t. I.

t La Buttrave à Snere, p. $5 \%$. 
"In his earlier work, Violette found little difference in the quantity of sugar present in the two kinds of tissue, but the notions then obtained from it with reference to the loeation of albuminoids and salts have re-

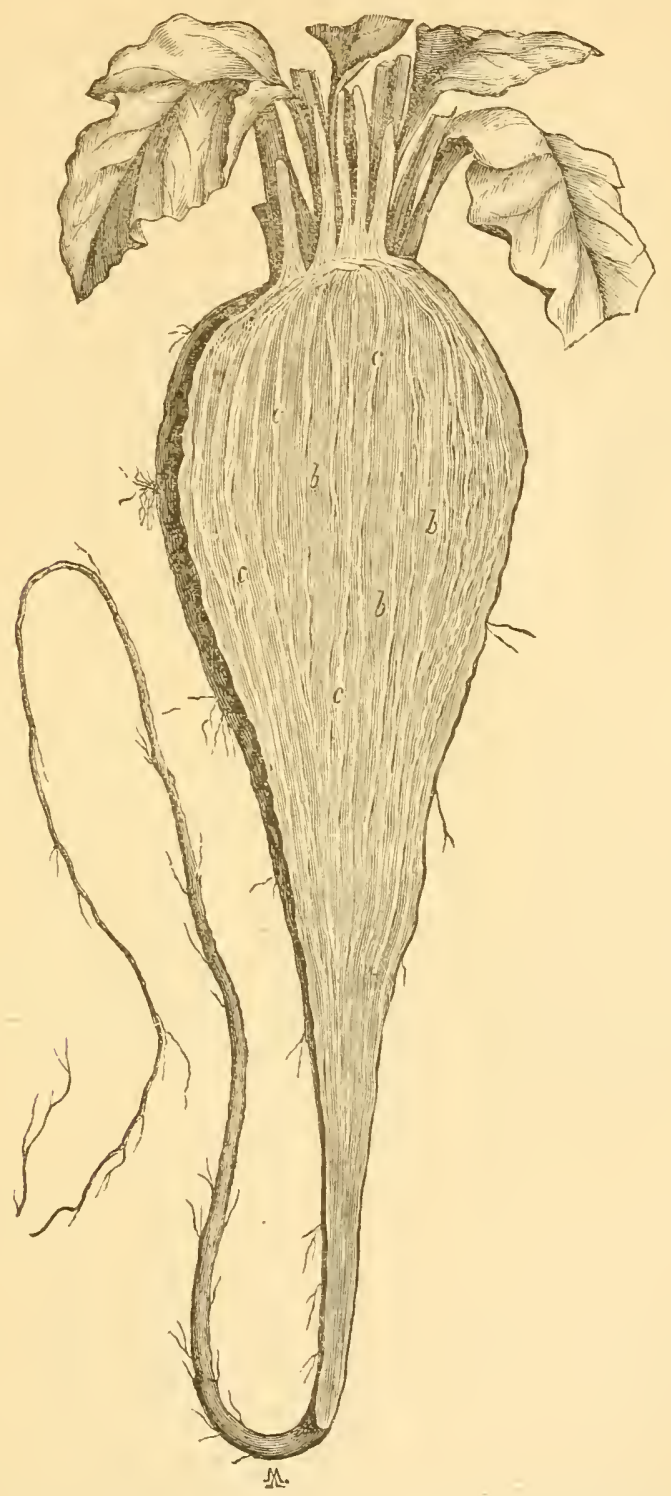

FIG. 7.-Vertical sectiou of beet root to show anatomical structure.

ceived full confirmation in his own later work and in that of Professor Joulie. Thus, he stated-

The former (the translucid zone) appears to contain the higher proportion of mineral matters. The proportion of chlorides may be eight times as great; organic, nitric, and phosphoric acids are about equivalent, but sulphuric acid is much more abuniant in the sacchariferous tissue, probably on account of the predomiuance of the albuminoids. 
The ristribution of the albuminous matters and salts is shown in the following statement giving the composition of the translucid and opanue zones:

\begin{tabular}{|c|c|c|c|c|c|c|}
\hline Zones. & Singrar. & Asli. & $\begin{array}{c}\text { Sialino } \\
\text { quotient. }\end{array}$ & $\begin{array}{c}\text { Nitromen of } \\
\text { mormal mat } \\
\text { ter. }\end{array}$ & $\begin{array}{l}\text { Nitrogenous } \\
\text { matters of } \\
\text { mormal mat- } \\
\text { ters. }\end{array}$ & $\begin{array}{l}\text { Nitrogenome } \\
\text { matters per } \\
100 \text { of kugatr. }\end{array}$ \\
\hline $\begin{array}{l}\text { Opaque zones . . . . . . . . . . . . } \\
\text { Traulslneid zones. }\end{array}$ & $\begin{array}{l}11.27 \\
10.00\end{array}$ & $\begin{array}{l}0.63 \\
0.81\end{array}$ & $\begin{array}{l}5.5 \\
8.4\end{array}$ & $\begin{array}{r}\text { Per eent. } \\
0.263 \\
0.230\end{array}$ & $\begin{array}{r}\text { Per cont. } \\
1.643 \\
1.430\end{array}$ & $\begin{array}{l}14.5 \\
14.3\end{array}$ \\
\hline
\end{tabular}

Violette also found a higher percentage of sugar in the lower portions than in the upper portions of the root, and Joulio fonnd that the tops contained less of nitrogen than the lower extremities. Thus Violette, cutting the root in several slices, beginning at the top, fouml them to contain, respectively, of sugar the following percentages:

Per cent. of sugrar.

First slico

10. 42

Sccond slico

10. 54

Thiral slice

10. 70

Fourth slico

10.80

Fifth slice

10.94

Sixth slice

11.11

Seventh slice

11.33

And Jonlie found :

lereent. of nitrogen in nermial matter.

Tops

Extremiticg of routs

0.30

$0 .: 3: 3$

(1. $2(1) 5$

The relation between the nitrogen and the sugar content of beets has been completely confirmed by the further results obtained hy Professor Jonlio in the analysis of beets grown under different conclitions, as illnstrated in the following table:

\begin{tabular}{|c|c|c|}
\hline " & $\begin{array}{l}\text { Rieliness of } \\
\text { beets in } \\
\text { sugar. }\end{array}$ & $\begin{array}{l}\text { Nitrogen in } \\
\text { beets. }\end{array}$ \\
\hline $\begin{array}{l}\text { From plots having reedived no nitrogen ................ } \\
\text { Plots having received } 57 \text { ponuds nitrogen per acre..... }\end{array}$ & $\begin{array}{l}12.55 \\
13.58 \\
15.24 \\
11.06 \\
11.59 \\
12.97 \\
14.98\end{array}$ & $\begin{array}{l}\text { Tercent. } \\
\text { 0. } 261 \\
\text { 0. } 308 \\
0.515 \\
0.352 \\
0.387 \\
0.429 \\
0.472\end{array}$ \\
\hline
\end{tabular}


"This relation exists not only in the structure of the root, hut also in the juice after its extraction.

Relation betreen content of nitrogen in the beets and in the juice.

\begin{tabular}{|c|c|c|c|c|}
\hline $\begin{array}{l}\text { Sagar in } \\
\text { beet. }\end{array}$ & $\begin{array}{l}\text { Tarts of } \\
\text { sugar in } 100 \\
\text { of juice. }\end{array}$ & $\begin{array}{l}\text { l'arts of } \\
\text { nitrogen for } 100 \\
\text { of beets. }\end{array}$ & $\begin{array}{l}\text { Parts of } \\
\text { nit rogen for } 100 \\
\text { of juice. }\end{array}$ & $\begin{array}{l}\text { Nitrogenous } \\
\text { matters for } 1110 \\
\text { of juice. }\end{array}$ \\
\hline \multicolumn{5}{|l|}{ Percent. } \\
\hline 13.9 & 15.5 & 0.37 & 0.29 & 1.88 \\
\hline 13.9 & 15.5 & 0.45 & 0.21 & 1. 33 \\
\hline 12.4 & 13.7 & 0.30 & 0.24 & 1.56 \\
\hline 11.0 & 12.2 & 0.30 & ….. & . ............... \\
\hline 10.4 & 11.5 & 0.19 & 0,12 & $\ddot{0} \ddot{78}$ \\
\hline & & & & \\
\hline
\end{tabular}

"Or, calculated for 100 of sugar contained in root or juice:

\begin{tabular}{|c|c|c|c|}
\hline Sugar per 100 grams of root. & $\begin{array}{l}\text { Nitrogen por } \\
100 \text { grams sugar } \\
\text { in root. }\end{array}$ & $\begin{array}{l}\text { Parta angar } \\
\text { pel } 100 \text { ol } \\
\text { juice. }\end{array}$ & $\begin{array}{l}\text { T'arts nitrogen } \\
\text { per lou wngar in } \\
\text { state of juice. }\end{array}$ \\
\hline $\begin{array}{r}13.9 \\
13.9 \\
12.4 \\
9.7 \\
1\end{array}$ & $\begin{array}{l}2.6 \\
2.9 \\
2.4 \\
1.7\end{array}$ & $\begin{array}{l}15.5 \\
15.5 \\
13.7 \\
10.5\end{array}$ & $\begin{array}{l}1.8 \\
1.3 \\
1.6 \\
1.1\end{array}$ \\
\hline
\end{tabular}

"The mineral matters, it appears from the above analyses by Tiolette, exist in larger quantities in those portions of the root which contain the higher percentages of sugar, but this relation does not appear to loolel for entiro roots-that is, comparative estimations of sugar and ash in different roots does not seem to establish a lower percentage of ash in roots containing tolerably high percentages of sngar, and that for roots varjing in saccharine richuess of from 10 to 14 per cent. the proportion of mineral matters present will not vary widely from 0.90 per cent., and this view is supported hy the fignres giren by Champion and Pellet.*

\begin{tabular}{|c|c|c|}
\hline Sugar in bert. & Asll in beet. & $\begin{array}{l}\text { Rolation of } \\
\text { ash to augar, } \\
100 \text { to- }\end{array}$ \\
\hline $\begin{array}{c}\text { Per cent. } \\
14.4 \\
13.6 \\
13.3 \\
13.1 \\
12.7 \\
12.0 \\
11.8 \\
11.2 \\
11.0 \\
10.6 \\
10.4\end{array}$ & $\begin{array}{c}\text { Per cent. } \\
1.05 \\
1.13 \\
0.95 \\
0.93 \\
1.06 \\
0.94 \\
0.90 \\
0.93 \\
0.77 \\
1.10 \\
0.74\end{array}$ & $\begin{array}{l}7.2 \\
8.2 \\
7.1 \\
7.2 \\
8.2 \\
7.8 \\
7.6 \\
8.2 \\
7.0 \\
8.1 \\
7.1\end{array}$ \\
\hline Average... & $\ldots$ & 7.6 \\
\hline
\end{tabular}

* La Bettravo a Sucre. 
"But this latter :elation will not hold gool for the juice after extraction, as apyears fiom the following table:

\begin{tabular}{|c|c|c|}
\hline $\begin{array}{l}\text { Richuess of } \\
\text { juice. }\end{array}$ & $\begin{array}{l}\text { Ash pur } 100 \\
\text { volumes of } \\
\text { juice. }\end{array}$ & 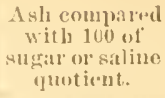 \\
\hline $\begin{array}{r}16.2 \\
14.9 \\
14.7 \\
14.2 \\
13.4 \\
13.2 \\
13.5 \\
12.2 \\
11.8 \\
11.7 \\
11.5 \\
10.7 \\
9.9 \\
9.7 \\
8.0\end{array}$ & $\begin{array}{l}0.78 \\
0.81 \\
0.7 .3 \\
0.78 \\
0.77 \\
0.75 \\
0.77 \\
0.79 \\
0.76 \\
0.79 \\
0.80 \\
0.73 \\
0.72 \\
0.71 \\
0.76\end{array}$ & $\begin{array}{r}4.7 \\
4.8 \\
5.3 \\
5.4 \\
5.9 \\
6.2 \\
6.1 \\
6.1 \\
6.5 \\
6.8 \\
6.9 \\
12.3 \\
14.5 \\
15.6 \\
12.2\end{array}$ \\
\hline
\end{tabular}

"This question of the mineral constituents of the root, and the influence they exert upon the prodaction of sugar and its extraction from the root, is an exceedingly important ono and merits careful study. In this report it will be further disenssed in the consideration of the fertilizers suitable to the crop, aud the time and manner of their application. It is, however, proper to state further here, that, of the mineral matters present in the root, whosphoric acid and the alkalies, which are the most important mineral constitnents of artificial fertilizers, that have the most beneficial influence upon the valne of the crop, seem in the root to vary with the richness in sugar, the phosphoric acid increasing with an increase of the sugar content, and the alkalies decreasing under like conditions. These facts are fully established in the results of the researehes of Professor Joulie, shown below:

\begin{tabular}{|c|c|c|}
\hline & Sugar in root. & $\begin{array}{l}\text { Phosphoric } \\
\text { acid in normal } \\
\text { matter. }\end{array}$ \\
\hline 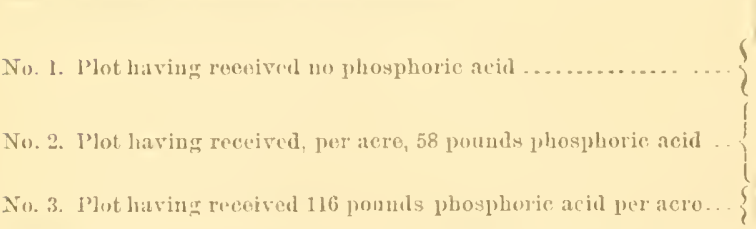 & $\begin{array}{c}\text { Per cent. } \\
12.97 \\
13.01 \\
14.98 \\
11.06 \\
11.45 \\
11.59 \\
13.52 \\
11.00 \\
13.24\end{array}$ & $\begin{array}{c}\text { Percent. } \\
0.042 \\
0.039 \\
0.05 .1 \\
0.042 \\
0.048 \\
0.0650 \\
0.071 \\
0.053 \\
0.086\end{array}$ \\
\hline . & sugar in root. & $\begin{array}{l}\text { Potash and } \\
\text { sodá in normal } \\
\text { matter }\end{array}$ \\
\hline 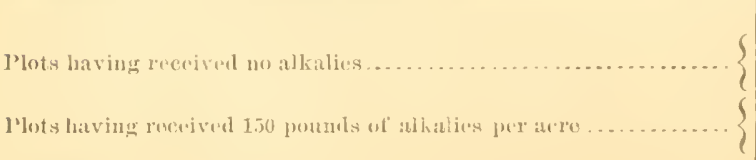 & $\begin{array}{c}\text { Per cent. } \\
13.58 \\
14 . ! 18 \\
11.24 \\
11.45 \\
11.54 \\
13.11\end{array}$ & $\begin{array}{c}\text { Per eent. } \\
0.640 \\
0.415 \\
0.385 \\
0.494 \\
0.480 \\
0.391\end{array}$ \\
\hline
\end{tabular}


"But the quantities of alkalies absorbed by the root seem nerer to ex. ceed a certain limit, as shown by Peligot, Corenwinder, Pagnoul, and Leloup, and it is by no means proportional to the quantities supplied by the soil, and the quantity of sulphuric acid necessary to saturate or combine with the alkalies contained in the ashes of beets will not vary much from $5 S .5$ per cent. their weight. This latter relation has been fully established by the rork of Dubrunfant, Corinwinder, Ragot, Champion and Pellet, and others.

"Not only is the quantity of alkalies that may be absorbed by beets thus limited, but Champion and Pellet have found that the alkalies and alkaline earths, in the absence of those best snited to the plant, may substitute each other in the proportion of their respective chemical equivalents; a fact of importance in the study of the chemistry of soils and fertilizers.

"Of all the qualities of the root, there is none that would afford as realy and easily applicuble a means of separating beets of different quality as the density, and this has long been and still is considered by many growers a strong indication of the saccharine value, but the best anthorities seem to consider it a doubtul one. Dubrunfaut finds this relation to be materially molified by the presence of air or gases in the root. This view is also held by Champomois, who, in examining roots prorlneed in the campaign of $187+4$ to 1875 , fomm that a beet having a lensity of 1.010 may grive a juice having a density of 1.050. The figures griven by Champion and P'ollet are also adverse to the idea. Examination of twelve beets gave the fullowing:

\begin{tabular}{|c|c|c|}
\hline & $\begin{array}{l}\text { Inensity of } \\
\text { roots. }\end{array}$ & $\begin{array}{l}\text { Density of } \\
\text { juice. }\end{array}$ \\
\hline 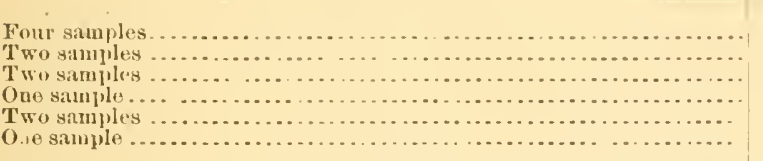 & $\begin{array}{l}1.01: 2 \\
1.02 .3 \\
1.026 \\
1.0311 \\
1.0133 \\
1.038\end{array}$ & $\begin{array}{l}\text { 1. } 043 \\
\text { 1. } 018 \\
\text { 1. } 052 \\
\text { 1. } 0.10 \\
\text { 1. } 0148 \\
\text { 1. } 052\end{array}$ \\
\hline
\end{tabular}

" Other tests gave:

\begin{tabular}{|c|c|c|}
\hline $\begin{array}{c}\text { Denvity of } \\
\text { root. }\end{array}$ & $\begin{array}{c}\text { Density of } \\
\text { juice. }\end{array}$ & S̀ugar iu juice. \\
\hline $\begin{array}{l}1.03 .3-1.030 \\
1.025 \\
1.025\end{array}$ & $\begin{array}{l}1.058 \\
1.056 \\
1.052\end{array}$ & $\begin{array}{c}\text { Per cent. } \\
11.7 \\
12.2 \\
11.3\end{array}$ \\
\hline
\end{tabular}

"Having now studied the interual structure and characters of the beet and the conditions residing within the root itself, we come to the consideration of the juice, the quantity that may be extracted, and its composition and value. I do not propose to discuss the complete analyses of the juices, but to call attention to some of the later facts that 
have been worked ont eoneerning the qualities which may affect the value or may aid in determining it. We have seen above that the deposition of sugar in the roots is almost always accompanied by a propor. tional deposition of albuminoids and salts, and also that the relation found to exist in the root is continued in the juice after extraction. These eonditions have an influenee upon the separation of the sugar which the experience of the mannfacturer has taught him is unfarora. ble, and they will be called up again in the treatment of the subject of mannfacturing processes, but in the present section we desire to call attention more particularly to the quantity of juice that may be extracted, the conditions which may modify it, and the density of the juice as influenced by the proportion of sugar present.

"Wo now come to the methods of selecting seed and secd-bearers, and the prineiples upon which they depend. Of all the experiments and investigations in the direction of improvement of this culture, none seem to have marle snch rapid strides in advance as in this line of work, none have given results more fruitful and of a claracter so well suited to ameliorate the relations between the prodneer and mannfacturer, and at the same time be a source of profit to both.

"The initiatory steps in this work in Franee seem to have been taken by Mons. Lonis Vilmorin, the former head of the great house of VilmorinAndrienx \& Co., of Paris, and his methods of working, followed by similar results, are still being prosecuted with rare intelligenco and skill hy his son and snecessor, Mons. Ifenri Vilmorin, whose contributions to our knowledge of this and other enitures have done so much to clear np the many difficulties which surrond and aceompany the profitable management of the sereral agrienItural industries.

"Of the ontwarl eharacteristics which ail in determining the richness of beets, we have found the most important, as recognized in France, to be size and form of the root, its density, the number and appearance of the leaves, otc., and all these properties will be mentioned in the general rules for selection. But thus far wo have failed to notice the external and internal characteristics of the seed, which have been found to have ani important bearing upon the character and valne of the crop) ; and, before proceeding to the effects of selection in securing desirable crops, wo shall call attention to the relation of the character and composition of the seed npon the quantity and quality of the roots produced from it. In this comnection we must again refer to the valuable little work of Champion and Pellet, in which these authors and investigators take issue with, or rather proceet further than, Walkhoff, who ad vises selection of the larger seeds for planting because they give more robust plants. This is true as far as it goes, hut the anthors above mentioned, also finding the relation of seed to the value of the crop to exist, find further that while the larger seeds give roots of larger volnmo and weight, the smaller seeds give smaller roots, which are richer in sugar. Thus taking two lots of seeds prodneed by Simon Legrand, one lot having an average 
weight of 3.2 grams ber 100 soeds taken, and another lot having an average weight of 4.25 ginm per 100 seeds, the determination of the weight of the roots produced and their saccharine richness gave the following results :

Datog.

\begin{tabular}{|c|c|}
\hline $\begin{array}{l}\text { Average } \\
\text { weight of } \\
\text { four roots. }\end{array}$ & $\begin{array}{l}\text { Sugar in } \\
\text { roots. }\end{array}$ \\
\hline Frams. & Per cent. \\
\hline 75 & 11.4 \\
\hline 125 & 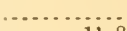 \\
\hline 375 & 11.8 \\
\hline 30 & \\
\hline 50 & 12.0 \\
\hline 75 & (1) \\
\hline 233 & 12.5 \\
\hline
\end{tabular}

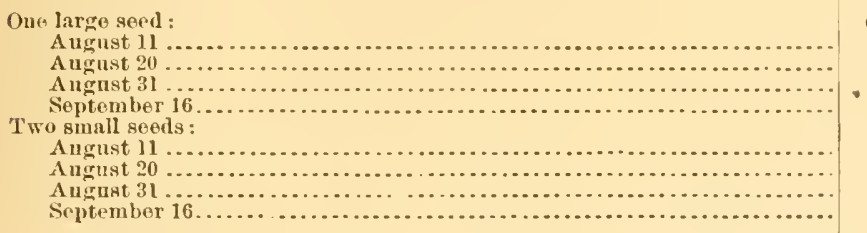

เ

"Dubrunfant is of the opinion that seeds having the highest specific gravity are more suitable for planting than those of lower density. He - effects a separation by placing the seeds in water and after a time removing those which float, preserving those which sink to the bottom of the containing vessel. To states that the two qualities of seed bohare quite differently both in germination and during growth. Champion and Pellet* quote Basset as saying, "It is well to do the same for seeds as is done for roots for reproduction, and choose the hearier ones, or those that fall to the bottom of a bath prepared with water and salt.'

"The chemical composition of the seed has also been the subject of stuily by different ehemists.

"Dubrunfant, $\nmid$ by a chemical examination of the seeds taken finm a erop of 30 acres of sugar and forage beets, and furnished him by the honse of Vilmorin-Andrienx \& Co., in Paris, found that the seeds of the sugar yiclding races give upon incineration a smaller weight of ash than the forage races, and the differences, which vary within certain limits, are all, with few exceptions, in the same direction. Comparing weights of seed taken and aslies prodneed, the proportion for tho sugar-forming races varies between 4.50 and 6.50 per cent. The forage races give from 6 to 14 per cent., making an average of 7 to 8 , which is very different from the proportion given by sugar-yiclding races.

"It also appears that the ash of the sugar-forming races is richer in phosphoric acid, potash, and eren magnesia. Thus the seeds of the sngar races give 0.004 to 0.005 per cent. of their weight of phosphoric acid, while the seeds of forage beets gires but 0.0002 to 0.0005 per cent. A similar relation exists for the potash. Thus for the sugar races a sufficient quantity is alrays present to derolop a green color with the manganese in the ash by fusion, while in the forage races this is not the case. But if to the ash of the latter a small quantity of potash be 
adled, the characteristic green coloration prodnced by manganese is readily developed by the application of heat.

"The eonchissions of" Dubrunfant confirm the results of the analyses of Pellet.*

Per cent of ash in dry matter.

Vilmorin seed (average) (i. 0

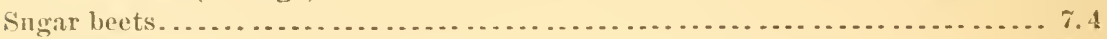

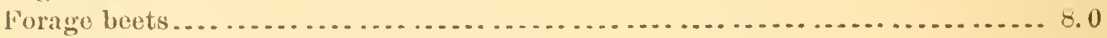

"The results of the cliemicil analyses of the ashes are as follows:

\begin{tabular}{|c|c|c|c|}
\hline \multirow[b]{2}{*}{-} & \multicolumn{2}{|c|}{$\begin{array}{l}\text { Ordinary seed of } \\
\text { the sugat factory. }\end{array}$} & \multirow{2}{*}{$\begin{array}{l}\text { Improred } \\
\text { Vilmonin } \\
\text { seced. }\end{array}$} \\
\hline & No. 1. & No. 2. & \\
\hline l'otash .... & 21.1 & 16.4 & 2 t. 2 \\
\hline Soda.... & 8.9 & 10.4 & $1 \because 8$ \\
\hline Lime & 25.4 & 20.2 & 17.2 \\
\hline (n) & 13.5 & 11.5 & 10.1 \\
\hline 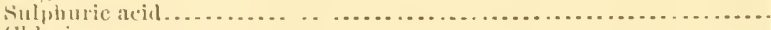 & 4.0 & 2.8 & 4. 3 \\
\hline ('hlorine & 4.7 & 4.1 & 41 \\
\hline P'bosphorie aeid $\ldots \ldots \ldots \ldots$ & 8.4 & 9.3 & 17. 4 \\
\hline 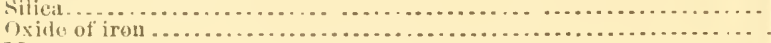 & $\begin{array}{r}13.1 \\
1.2\end{array}$ & 26.4 & 11.0 \\
\hline Mranganeso ....................................... & 0.7 & ........ & ......... \\
\hline 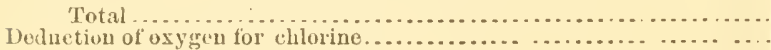 & $\begin{array}{r}101.3 \\
1.3\end{array}$ & $\begin{array}{r}101.1 \\
1.1\end{array}$ & $\begin{array}{r}101.1 \\
1.1\end{array}$ \\
\hline & 100.0 & 100.0 & 100.0 \\
\hline
\end{tabular}

"On the other hand, seeds of rich beets contain a higher proportion of nitrogen than seeds of poorer beets, and at the same time small seeds contain more nitrogen than large ones, as is evidenced by the following results of examinations by Champion and Pellet:

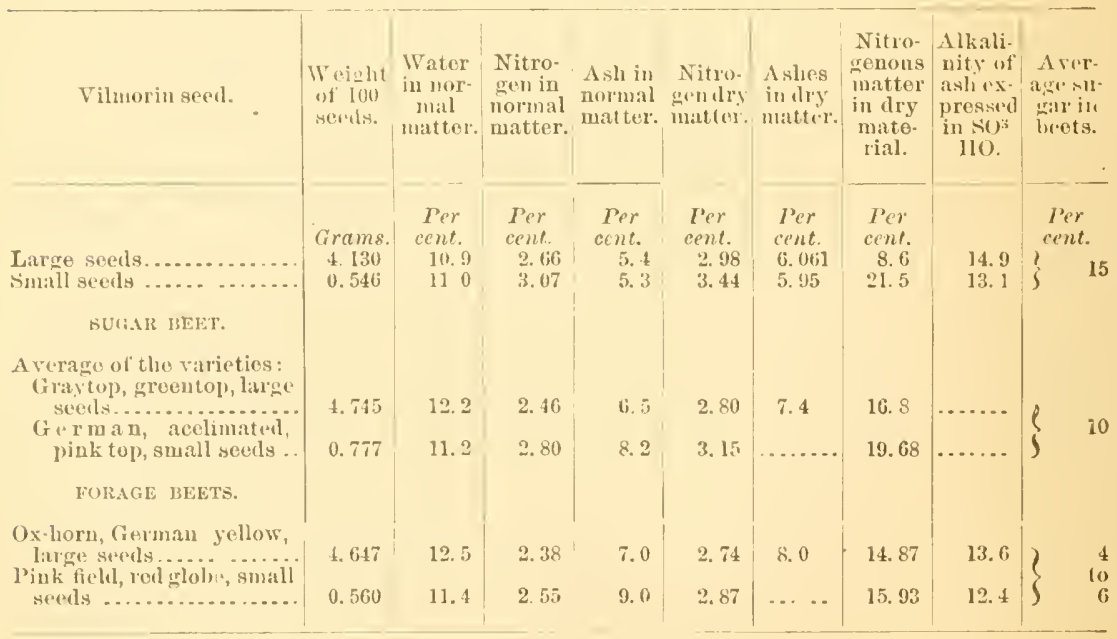

* La Betrave á sucre, p. 31. 
"These relations between the richness of the beet and the composition and size of the seeds, furnish the bases of ready and raluable means of selecting the good and separating them from the worthless. The methor recommended is to pass them orer a screen with meshes of a giren diam. eter, which unfortmuately las never been determined, or at least stated, and to throw those which pass through in water or a solution of salt, rejecting those which float. Those which sink combine the raluable properties above deseribed, of small size and high speeific gravity. In the processes of selection as applied to choice of beets for production of seerl, which really constitutes the production of new races, the end really to be attained is the ultimate development of a race, or of races, which will at the same time satisfy the demands of the producer and the manufacturer; that is, that will give a large yield to respond to the demands of the former, combined with gond quality and high richness in sugar to respond to the demands of the latter. In the opinion of some of those who have deroted themselves to this work, the hope of a resuit such as we have described must be cousidered almost useless, if we depend npon the root and its characteristics, but much valuable as. sistance may be rendered in the attainment of this end, as we shall see later on, by the intelligent application of fertilizers to the crop and the methods of culture adopted and employed.

"In the earlier experiments in this line, those of Hons. L. Vilmorin, attention was more especially directed to the production of very rich beets, with no particular eare to the size, the desire being rather to ob. tain beets of small size, with tapering form and smootb surface; but the lute work of all engaged in this kinl of experiment and research has been directed to the enrichment of races giving roots of larger volume and fuller form, making them betteradapted to all soils and all methods of culture. In most cases, therefore, the work starts from the races most extensively grown.

"Vilmorin began his work by following the method employed in Germany of taking the specific gravity of the roots by plunging them in saline solutions of known density, but he soon found that, in consequence of the almost constant presence of an internal cavity, this method was inexact.

"Dubrunfaut further explains the canse of the inacuracy of this method in the fact of the existence of air and gases within the body of the root. Vilmorin therefore resorted to the methorl of taking from the center of the root under exanination a cylindrical portion by means of a cutting tube, and determining the density of the portion thus ob. tained, in solutions of sugar of known speeifie gravity, but these solutions were disearderl on account of their unstable character, and similar solútions of salt substituted. But the loss of sugar in the sample by osmosis when immersed in the saline solutions renders this mode of procedure also unsuited to the attainment of the end in view, and he finally turned to the determination of the density of the juice itself as the rearliest and 
most exact means of determining the sugar content of the sample. The sample removed from the beet, furnished on grating and pressing sufficient of juice to armit of taking the weight of a metallic enbe of known dimensions immerser in it, from which the density of the juice conki readily be calenlated. This method of determination he found to givo more aecurate results than any other when working upon so small a quantity of material.

"It is useless to add [ he says in his paper read before the Academy of Seiences in November, 18.66] that the temperature takon by moans of a thermometor with tenths of legrees is carried ou tho register after vach weight of the ingot, and that the gange of the vasies, the fineness of the suspending thread, and the identity of all the conditiens of the operation eliminates errors which at first produced cortain irregularities in the manner of working.

"Having thus determined the speeifie gravity of the juices of the varions beets under examination, those considered worthy of propagation are preserved and the others rejected. The surfaces of the wounds produced in the beets examined by the removal of the sample are covered with chareoal dust, which effectually prevents any decay or deterioration in consequence of the treatment to which the roots have been submitted.

"This method was employed in the development of the race of heets known as Vilmorin's Improved, and it is this method or modificitions of it, or some adlitional operations carried on in conneetion with it, that is employed to-day by the most intelligent and responsible prodtucers of improved seed in Franeo.

"Mr. Henri Vilmorin, who has sneeeeded his father in the work, combines the method with examination of the sample of juice, after the determination of its speeifie gravity, by means of the polariscope, while others employ, as suplulementary to the method, estimation of the sugar by means of the copper test.

"But notwithstanding the unfavorable conelusions concerning the method of selection, based upon the density of the roots as determined by inmersing them in solutions of molasses or salt of differing but known strengths, it is still used by many of the leading seel-growers in the north of France. M. Demiatte, in an article on the subject of selection of seed-bearers, states* that he proceeds as follows, accorling to Brabant's method: Seleet subjects weighing at least $700 \mathrm{grams}\left(1 \frac{1}{2}\right.$ pounds). For retermination of their density they are thrown into a vat partly filled with a solution of molasses, having a density of 2.5 degrees by the densimeter; those roots which float are rejected ; those which partly sink are preserved for the production of seed ealled No. 3 . Those which sink completely are thrown into a second vat containing a solntion similar to that just deseribed, but having a density of 3.5 degrees. Those which float here are preserved for production of seed known as No. 2. Those which sink to the bottom are of course of the best quality, and are used for prodnetion of seed No. 1.

* Jourual des Fabricants de Sucre, 1879, February 19. 
"We have seen that the generally adopted opinion concerning the best form of beet to be elosen for production of high yields of sugar is to the effect that the long tapering ones are the most valuable; but this opinion is likely to be subject to modification in consequenee of the results of later observations upon the constitution of the improved varieties and their power to resist the deteriorating influences to which they may be subject in the varying conditions of soil and culture. The tapering, richer, improved races, descended from German stock, have been found more subject to disease in France than the poorer races of the comntry, and M. Decrombecque, at Lens, conceired the idea of incorporating within the latter the sugar producing-qualities of the former, and at the same time retaining the hardiness for which the commoner races are well known. To attain this end he had recourse to the method suggested by Walkhoff,* who believed that the saccharine richness of beets may be improved by erossiug, aud who was able by using seeds of Friekenhouse, and the method referred to, to obtain beets the juice of which marked 18.5 degrees, Balling, and containing 16.5 per cent. of sugar, starting with varieties the juice of which showed but 17.8 degrees, Balling, and eontaining 16.35 per cent. of sugar. In planting, the roots were placed in close eontact so that the blossoms touched each other, and the slightest agitation was suffieient to effect the transport of polleu.

"But the results of the experiments and of the practice adopted by Mons. Decombreeque $f$ are rather more striking than those obtained by Walkhoff. He noticed when he began his work at Lens that the Sile sian beet grown npon a rather shallow soil, and especially when manured with stable manure containing eonsiderable straw, in the spring (well known to be a bad and injurious practice), was hairy, fusiform, and wanting in weight. At the same time the white beet of the country, with green top, gray flesb, and obtuse form, flourished and developed well, though remainiug pyriform in the same field in which the Silesian fared badly. The question was to prodnce a beet having the hardiness of the one and the richness of the other. He chose from his crop the best formed, richest subjects, of size above the average, well covered in the ground, and then, observing the same care, chose specimens of the country roots called toupie (about the poorest of all the beets grown), and the beets thus chosen he preserved for seed. In planting he combined them in the proportion of fire plants of the Silesian with one of toupie. In eollecting the seed he carefully preserved separately that from the Silesian varieties and that from the toupie, and in subsequent sowing used only that from the Silesian. He found that the character of the Silesian beet had changed, and that the beet had the obtuse form. However, after the third year of planting the modified seed, he found that the good qualities of the Silesian had disappeared, and he had only the low-grade beet of the country. His sulsequent practice, therefore, was

- See La bettrave à zucre, par Champiou aud Pellet.

† La sucrerie indigène, xii, $434_{1}$ 
to grow two or more aces of Silesian, and from the erop produced to seleet those he needer for seel, and these roots lie mixed with roots from the ordinary crop in the proportion of 1 to 3 , and thus secmed rontinuously the harliness of the one and the richness of the other combined.

"With the iutlications given by Mous. H. Vilmorin in his description of the learling races of beets grown in France, and the methods lescribed in the preceding pages, it will not be difficult for the prospective grower to determine the valieties that will be hest suited to his purposes, or to produce new races throngh which the results he desires may be obtained, but it will not be ont of place here to call attention to the experiments of Mons. Deromeat Baray ( Nond) made with seeds olotained from various moducers with a view to the determination of the best varieties for cultivators to grow in order to secure a crop of quality and quantity to be satisfactory both to themselres and the mannfacturer. This he conceives to be a variety that will give the most sugur per acre, in conclition to be most easily extruted in the greatest weight. Withont entering into the details of his experiments we sluall simply give in the fol-

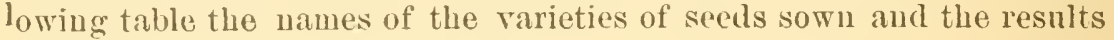
obtained:

\begin{tabular}{|c|c|c|c|c|c|c|c|c|}
\hline \multirow[b]{2}{*}{ Varieties. } & \multirow{2}{*}{ 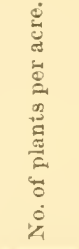 } & \multirow[b]{2}{*}{ 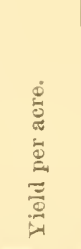 } & \multirow[b]{2}{*}{ 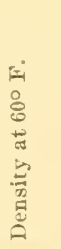 } & \multirow[b]{2}{*}{ 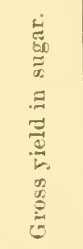 } & \multirow{2}{*}{ 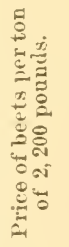 } & \multirow{2}{*}{ 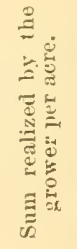 } & \multicolumn{2}{|c|}{$\begin{array}{l}\text { Sugar of } 88^{\circ} \text { ox- } \\
\text { tractable. }\end{array}$} \\
\hline & & & & & & & 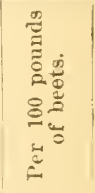 & 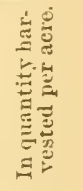 \\
\hline & & Tons.* & 0 & Per ct. & & & Pounds. & Tons.* \\
\hline $\begin{array}{l}\text { 1. Long pinli toupio ............. } \\
\text { 2. Silesiun, pink, fusiforn........ }\end{array}$ & $\begin{array}{l}33,205 \\
31,210\end{array}$ & $\begin{array}{l}20.1 \\
18.0\end{array}$ & $\begin{array}{l}5 \\
5.70\end{array}$ & $\begin{array}{r}8.431 \\
10.766\end{array}$ & $\begin{array}{r}\$ 4.00 \\
4.64\end{array}$ & $\begin{array}{r}\$ 80.00 \\
83.00\end{array}$ & $\begin{array}{l}\text { 4. (i9) } \\
6.84\end{array}$ & 0.94 \\
\hline 3. Silesian, pink, fusiform .......... & 32,388 & 15.9 & 6.40 & 12.841 & 5. 64 & 81.00 & 8.34 & 1. 3.3 \\
\hline 4. Silesian, white, first eluice .... & 32,344 & 11.9 & 7.15 & 13.769 & 6.80 & 78.00 & 9.27 & 1.07 \\
\hline 5. Silesian, white, recond cloice. & 32,266 & 16. 0 & 5. 95 & 10.921 & 4. 94 & 79.00 & 6. 84 & 1. $0 \mathrm{~s}$ \\
\hline 6. Silesian, white, acclınatul .... & 35,060 & 15.9 & 6.10 & 11.473 & 5. 16 & 32.00 & 7. 34 & 1. 16 \\
\hline 7. Silesinn, white, acclimated ... & 34,656 & 14. 9 & 6. 15 & 11.194 & 5.48 & 65.00 & 6. 97 & 1.04 \\
\hline 8. Whito pink top............... & 37,627 & 16. 8 & 5. 75 & 11. 538 & 4. 70 & 79. $\mathrm{Co}$ & 6. 50 & 1. 09 \\
\hline 9. White improverl ............. & $32,75 !$ & 11.4 & 7. 20 & 11.368 & 6.92 & 78. 00 & 8.68 & 0.99 \\
\hline 10. White green top . ............ & 34.210 & 15. 3 & 5.90 & 10. 912 & 4. 88 & 73.00 & 6. 89 & 1.05 \\
\hline 11. Pink acclimated ............ & $31,9 \times 3$ & 13.8 & 5. 90 & 10.736 & 4.88 & 68. 00 & 6. 67 & 0.92 \\
\hline 12. Whito silusian ............... & 32,874 & 14. 2 & 6.10 & 11. 126 & 5. 10 & 73. 00 & 6. 93 & 1.98 \\
\hline 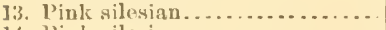 & 33,966 & 15.1 & 6.05 & $10.8 \div 5$ & 5.08 & 79.00 & 6.69 & 1.01 \\
\hline 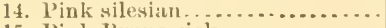 & 33,400 & 17.9 & 5.45 & 9.957 & 4. 36 & 78.00 & 6. 02 & 1.08 \\
\hline 15. Pink Brunswick .......... & 31.583 & 17.5 & 5. 40 & 9. 709 & 4.32 & 75.00 & 5.86 & 1. 02 \\
\hline
\end{tabular}

Of 2,201 pounds.

"He concludes from the figures obtained and here given that the best beets to be grown, and which he consilers the races of conciliation, are those representerl by the numbers $2,3,5,6,7,8,10$, and 14 . If sold accorling to the density of the juice and the scale of values in the form of arbitration adopted by the sugar manufacturers at Lille, ${ }^{*}$ the grower will receive a higher return per acre than with any of the other varieties mentionerl.

* Seo later on in diseussions of relations between the grower aud maunfacturer. 
"In this connection the results of the experiments of Deherain are relevant and interesting. He says:*

"It follows from our experiments and analyses that beets submitted to different modes of feeding or fertilizing, preserve in their development the native qualities of the seed, i. e., their race.

"In several of the experiments, pink tops and improved Vilmorins were submitted to exactly the same conditions, same sterile soil, same manures given in equal quantities, yet in one case while the pink top) contained 7.5 per cent. of sugar, the improved beet contained 16.2. In another case when the fertilizer was more nitrogenons, the richness of the pink-top beet fell to i.j.) per cent. and the Yilmorin to only 13.4. This shows clearly the influence of race upon the saceharine quality of the beet. The conclusions would appear premature were these experiments the only evidences to support them, but they are also confirmed in the results of experiments male by Mons. H. Vilmorin at Terriers, aceording to Professor Deherain's suggestions.

With reference to the type of beet to be shosen, Mons. Demiattef says :

"The uature of the soil and methou of culture being known, the form should change with the nature of the soil; should bo long and tapering in deep sandy or alluvinm soils; short and more obtuse in shatlow soils like that near Arras, where the thickness of the arable layer will not exceed 6 inches. But whatever be the type chosen the top of the mother beet should not protrude from the soil more than one-fourth its total lengtb.

"With the facts and figures presented, which have all been worked out in France ly carefin experiment and investigation, no further comments on the different French races will be neeessary. "The selection of rarieties for eultivation can best bo left to the realer. We believe, howerer, it will be of interest, and we shall, therefore, conclude the consideration of this subject by giving the names and adhresses of sereral of the leading prodncers of seed in France who made exhibition of their products in the late Paris Exposition of 1875, with short notices of the eharaeter of their exhibits.

Desprez pere et fils, Capelle.-The rarieties prodneed are No. 1, white or pink, containing 15 to 1 s per cent. sugar, requiring deep, rich soil, plenty of manure, and excellent culture; yields 16 to 20 tous per acre. No. 2, white or pink, 12 to 15 per cent. sugar, for ordinary soil, fertil. izing, and care; yields 20 to 25 tons per acre. No. 3, 10 to 12 per cent. sugar for inferior soils and cultures; yields 25 to 30 tons per acre.

"Simon-Legrand, Auchy._Different varieties containiag 12 to 20 per cent. of sugar; some varieties of special selertion containing from 20 to 23 per cent.

"L. Dervau-Ibled, Warynies-le-Grand.-Cultivates seed by special method of selection repenting upon taking specific gravities of eylin-

* Annales agronomiqnes. † Journal des Fabricants de Sucre, Febrnary 19, 1879. 35474-B!1l1. 
drieal samples cut from the roots and immersing them in saline solutions of given strengrth.

"Brabant fières (Innaing.-Cultivate seed of special variety bearing their name; claimed to prodnce 21 tons per acre, of beets of average richness of 14.85 per cent. of sugar.

"Vilmorin-Andrieux of Co., No. 4 Quai de la Mégisserie, Paris.-Produce seed from five varieties, given in the table below, showing the in. dustrial value of each variety."

Yield per acre............. long toms Sugar, per gallou of juices..... promels . Singar, per acre................... dlo... Sucar, per long ton of hepts....

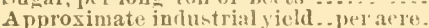

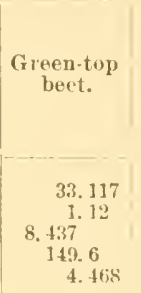

\begin{tabular}{c|c|c|c}
$\begin{array}{c}\text { Improved } \\
\begin{array}{c}\text { Vilmorin } \\
\text { bect. }\end{array}\end{array}$ & \multicolumn{2}{|c|}{ French races. } & $\begin{array}{c}\text { German } \\
\text { raco. }\end{array}$ \\
& Pink top. & Green top. & \\
\hline & & & \\
\hline 16.639 & 30.121 & 30.049 & 23.360 \\
1.63 & 1.24 & 1.20 & 1.30 \\
5,601 & 8,754 & 8,595 & 7,029 \\
290.4 & 182.6 & 173.8 & 222.2 \\
3.095 & 4.893 & 4.739 & 2.308 \\
\hline
\end{tabular}

\section{THE IMPROVEMENT OF THE SUGAR-BEET.*}

"6 'The improvement of the sugar-beet' is a term essentially capable of great expansion, inasmuch as its significance embraces the bringing abont of the fullest adaptation of the beet, to the industries of sugar and spirit manufactures, and under very varsing conditions on tho one hand of the manufacturing process, and on the other of the operation of the tariff laws.

"The question, howerer, may be so far restricted as to consider one of two purposes-either, according to the laws of phrsiology and agricultural chemistry, and to the observations of practical experience, by seeking that process which will yield the greatest amount of sugar per acre at a given cost, or by following artificial methods, endeavor by obedience to those, to obtain such beets as will give the greatest profit. By the adoption of one of those courses beets will be grown best adapted to the manufacture of sugar and spirit in France.

"The improrement of the method of beet-prodnction is not more difficult with these roots than in the examples of other plant kinds; in fact, in given respects, it is more simple and stable. It is quite possible to establish given properties and specialities in the beet providing those properties are not in actual opposition to the nature of the plant, and that they are eapable of transmission to the following generation. In brief, those given speeialities and characters are to be seeured by selection. Nevertheless, not every man will succeed in such a course of improvement by selection. It is necessary (1) that the enltivator shall

" By II. de Vihuorin, Sucrerie Indigine, vol. 34, p." 3:8, and Z/4itseh. RübenzuckerIndustrie, October, 1889, 1. 888 , 
have a elear grasp of his purpose, and (2) that he shall be fully cogni zant of the nature of the plant and of the conditions of its growth.

"The first of these conditions is a general one and applies to all experiments. The second condition, however, requires a knowledge of the advantages and disadvantages of the varieties chosen for cultivation, and that the conditions of grosth shall not be artificially influenced, or at least not in a way prejudicial to the strengthening of the natural proclivities of the plant. The latter condition is of the first importance and demands all cousideration. The rules for such experiments in the enltivation may be given as follows:

"(1) The individnal plants which are seleeted for enltivation must be planted under those conditions which allow of the full derelopment of the natural merits and demerits of the variety.

"(2) The experiment plants must, moreover, be grown under the same eonditions, in respect of the leugth of the periol of growth, the distance between the single plants, the properties of the soil and fertilizers applied, as the roots grown for the actual making of sugar.

"In order that the size, form, the sugar-content, and the purity of the juices of given varieties may be properly aljudged it is essential that the roots shall have been grown under the conditions in which those several characteristic features and properties could be uormally developed. Strange to say, a rule so natural has been consistently ignored, and beets have been provided for purposes of the laboratory strongly at variance with those requirements. The soil has been rery deeply cultivated, and the roots grown in the closest proximity in order to produce beets long and thin aud free from side roots, and, naturally, rich in sugar-a directly opposite procedure were probably the most reasonable.

"As an example of a bad quality may be given the nature of certain roots, or varieties of roots, to run to seel. Roots for propagating must be selected which are free from this inclination; and, in order to pro. vide a trustworthy test, the seeding must be made very early which thus induces the disposition to 'run.' The plants which do not show the 'runniug' disposition shonld be selected for further propagation.

"Another example: How is it possible to sort ont the representatives of a rery fibrous nature when the roots are growu under conditions whereby the side roots are not developed?

" $A$ s the average weight of the roots is a matter of consideration it may be observed that both home and foreign seed-growers aim at the production of beets weighing from 600 to 1,200 grams.

"As the characteristies of beets are several the selection must be spread over, and depend upon, certain different observations. The size, form, color, leaf growth, the season of growth, as well as the period of maturity, are suitable for such observation, and experienced seedgrowers will be readily able to make their distinctions from the observation of those several phissical properties. The determination of the 
sugar-content and of the purity of the juice depend upon purely chemical estimations. The specific gravity of the roots and of rootjuices is determined, and the sugar quantity is ascertained by means of the polariseope and copper solution. The determination by use of the polariscope is to be preferred for the reason that little time is required and the purity of the juices is observed by the same process.

"It is not enongh, however, nor is the main purpose accomplished, when beets have been secured, rich in sugar, of a pure juice, and possessing the sereral physical qualities which have been specified. The greater purpose is to distinguish those beets in which the given properties and ralues are fixed, and which are capable of transmitting those specialities to successive generations; in other words-which are true in propagation.

"1 have, with great labor and eare, endeavored to secure seeds and beets with fixed characteristics by planting the secds of selected representatives and growing those with the single view to the observation of their hereditary values. At the end of the year those plants which had not preserved the given physical properties were thrown ont aud the 'true' beets preserved for propagation.

"In my opinion, the problem of securing practically the best beet seeds is to be attained ly observing the following means:

"(1) The organizing of the prodnction of beets possessing definite and fixed properties and specialties by the use of the most rigid system of 'selection.'

"(2) A system of cultivation and planting most approved, in view of economy, by somnd experience. These rules may encounter considerable controversy, but they are resting upon a loug personal experience and the opinions and practices of French and German experts and practical men.

"The growiug of seed from small roots-250 to 400 grams-has no disadvantage in respect of the value of the seed; nevertheless this will only apply in the instance where the practice is not repeated with the seed from the same. Seed grown from beets of a large growth ean not be so economical as from the smaller size, and when the condition attaching to the use of the smaller beets is observed, no disadvantage oceurs.

"Anongst the many most excellent kinds of French lieets, one in special must be meutioned, althongh I may stand in a close relation to its history. The beet was introduced by my father, and I have given all possible care and endeavor to increase the form and weight-producing guality to the highest iggree compatible with a projortional increase in the sugar-yielding value of the same. And, in the face of all controversies, I must maintain that no other system of culture would have established and sustained the same excellence of the beet in respect of form, weight, and purity of the juice as the system adopted in our ex. periments and specified in the rules aIready laid down. 
"Amongst other French representatives may be mentioned the Brabant-beet, whose habit of growth is typified by the upright leaf, long, thin, and smooth root, and distinguished by its richness in sugar. This kind may be classed as one of the best French varieties and distinctly differing from the German.

"Of many excellent German beets which have been introduced into France the 'Klein-Wanzlebener' has had an experience of ten years in our elimate and appears to thrive better eren than in its native sphere. The variety is known by an abundant leafage of a bright green, and broad, multiplied roots.

"The 'crossing' of different varieties is a rich source of varying kinds, but the course has a fatal effect upon the hereditary principle and properties. The characteristies of the 'cross,' which may be the prodnct of a single year, are transient and may be lost in as short a time as they require to be prodncerl.

"I would specially state that the assertions which I have made in respect of the best beet kinds are not merely devolving upon my own experience, but maly be supporter by comparison with the statements of other experimenters.

Experiments of M. Dupay in Chervy-Cossigny, given in the year 1888 .

\begin{tabular}{|c|c|c|}
\hline & Yield. & $\begin{array}{l}\text { Sugar per } \\
\text { hectare. }\end{array}$ \\
\hline 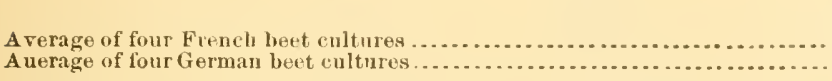 & $\begin{array}{r}\text { Filograms. } \\
36.000 \\
35.140\end{array}$ & $\begin{array}{r}\text { Kilograms. } \\
5,665 \\
5,537\end{array}$ \\
\hline
\end{tabular}

Experiments of MH. I'orion and Déhérain-1885.

\begin{tabular}{|c|c|c|c|c|}
\hline & $\begin{array}{l}\text { Yield of } \\
\text { roots. }\end{array}$ & $\begin{array}{l}\text { Sugar in } \\
\text { juice. }\end{array}$ & $\begin{array}{l}\text { Sugar in } \\
\text { beet. }\end{array}$ & $\begin{array}{l}\text { Money } \\
\text { value. }\end{array}$ \\
\hline 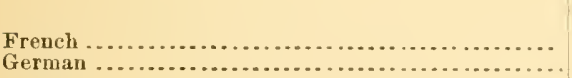 & $\begin{array}{r}\text { Kilograms. } \\
43.100 \\
45.100\end{array}$ & $\begin{array}{r}\text { Per cent. } \\
16.74 \\
16.39\end{array}$ & $\begin{array}{r}\text { Per cent. } \\
14.77 \\
14.50\end{array}$ & $\begin{array}{r}\text { Franes. } \\
1,659 \\
1,623\end{array}$ \\
\hline
\end{tabular}

"The yield is in faror of the German, but the money value is greater actually in the French."

Experiments of the Sugar-House Bourdon (Pny-de-Dóme).

\begin{tabular}{|c|c|c|c|}
\hline & $\begin{array}{l}\text { Tield per } \\
\text { lectare. }\end{array}$ & $\begin{array}{l}\text { Density of } \\
\text { juices. }\end{array}$ & $\begin{array}{c}\text { Sugar per } \\
\text { hectare. }\end{array}$ \\
\hline $\begin{array}{l}\text { French.. } \\
\text { German. }\end{array}$ & $\begin{array}{r}\text { Kitograms. } \\
41.854 \\
40.296\end{array}$ & $\begin{array}{l}\circ .9 \\
7.7\end{array}$ & $\begin{array}{r}\text { Kilograms. } \\
7,970 \\
6,979\end{array}$ \\
\hline
\end{tabular}




\section{VARIETIES OF BEETS.}

The varieties of beets which are cultivated are perhaps more numerous in name than in distinct qualities. In France the White Improved Vilmorin beet is very largely eultivated. Its generai type is shown in the following figure:

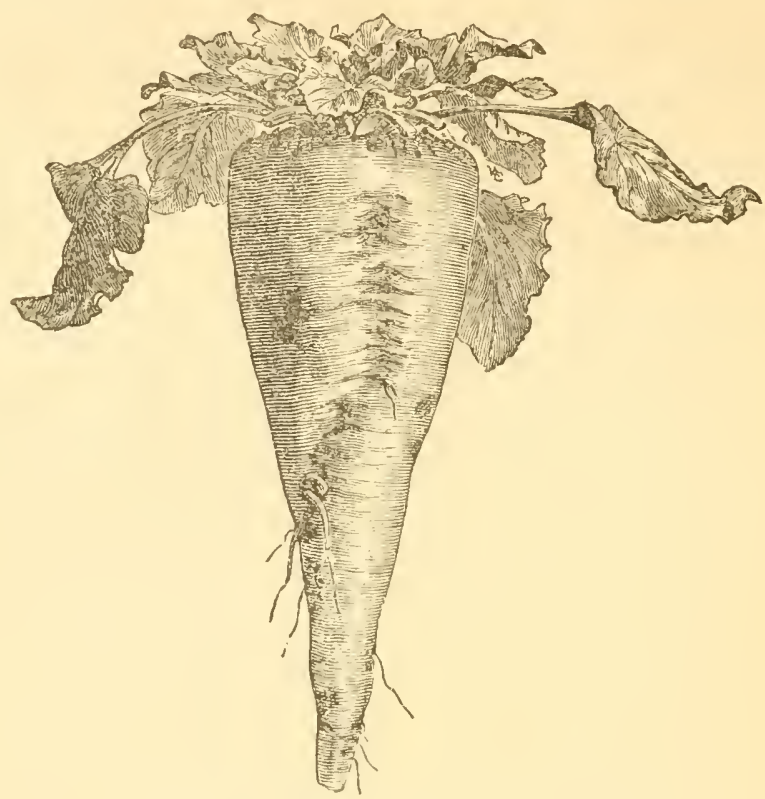

Fir. 8.- White Improved Vilmorin Sngar Beet.

This beet has ieen the result of thirty years of methodic and persevering selection based upon the lines atrove indieated. In regard to its preservation it is recognized that it holds its sugar content better than any other variety. In those factories in which the Improved Vilmorin is mannfuctured in comnection with other varieties it is the custom to reserve this for the end of the season aud to work up the less reliable beets at an earlier date. It is also said to resist better than any other variety the unfarorable intluence of certain characters of soil and of certain manures. In black soils, rich in organic matter, it will give great industrial resnlts, while most other rarieties of beets beeome wa. tery or saline in excess. Excessive quantities of nitrogenous fertilizers, which are carefully exeluded from ordinary varieties, can be applied with safety to the Improver Vilmorin. A great mumber of experiments has shown that this ean be done without serious deterioration in the quality of the sugar and with a eonsiderable inerease in weight. From thonsands of analyses it has been ostablished that the pereentage of sngar which can be obtained with this rariety is about 16 . In regard to its yield under favorable conditions it can be stated to be between 30 and 35 kilograms per heetare. 
Perhaps more important for general cultivation than the Vilmorin variety is the beet known as the Klein-Wanzleben, which at the present time has probably a wider eultivation than all other sugar-beets. The general character of this beet is shown in the figure.

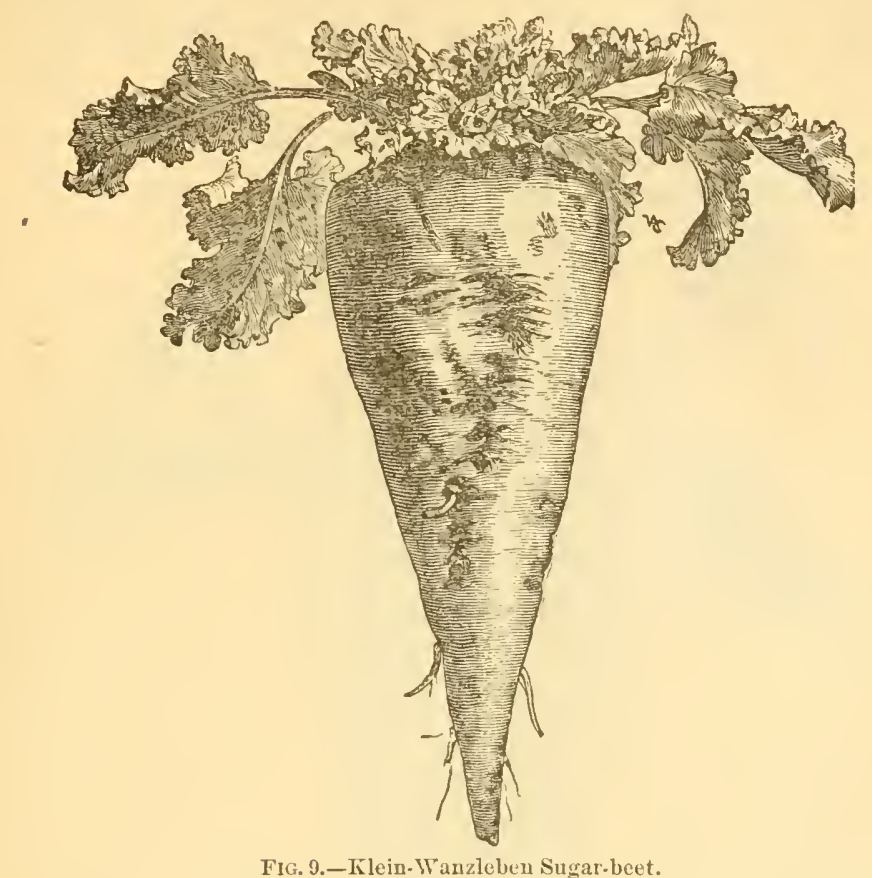

This beet has a conical root, straight and eren, quite large at the head and rapidly taperiug. It is distinguished from the Inproved Vilmorin by its brighter color and its lighter-colored leaves, which are beautifully undulating or sealloped ahout the edges. Coming from a cross in which the Improved Vilmorin entered largely, the Klein-Wanzleben is to-day a fixed rariety, and is equally well prodneed in France and Germany. It sncceeds equally well in soil of an allnvial nature and mean richness and on level plateans. In soils very rich in humus it ripens poorly and loses much of its richness. Like the Vilmorin Improverl, toward the end of regetation its leares are completely spreat. In those conditions of eulture where the Improved Vilmorin gives 34,000 to 36,000 kilograms, the Klein- $W$ anzlehen will give 40,000 kilograms. It is, howerer, always inferior to the Improved Vilmorin in point of view of its sacharine richness, which the whiter and more watery appearance of its flesh would make known at first view. Nevertheless from 13 to 15 per cent. of sugar can be obtained in the beet.

The Brabant sugar-beet is altogether different in aspeet from the preceding rarieties. It is long, rising well above the level of the soil, carrying a foliage vigorous in growth and npright in position. This variety would seem at first view to have come from the white rarieties 
used for forage; nevertheless its great rigor, its abundant production, and its content of sugar suffieiently ligh make it a beet quite valuable in those conntries where the tax is placed upon the amount of sugar made rather than upon the beet. The Brabant Sugar-beet will give easily 50,000 kilograms per heetare and may be made to coutain 12 per cent of sugar. Its general appearance is indieated in the figure.

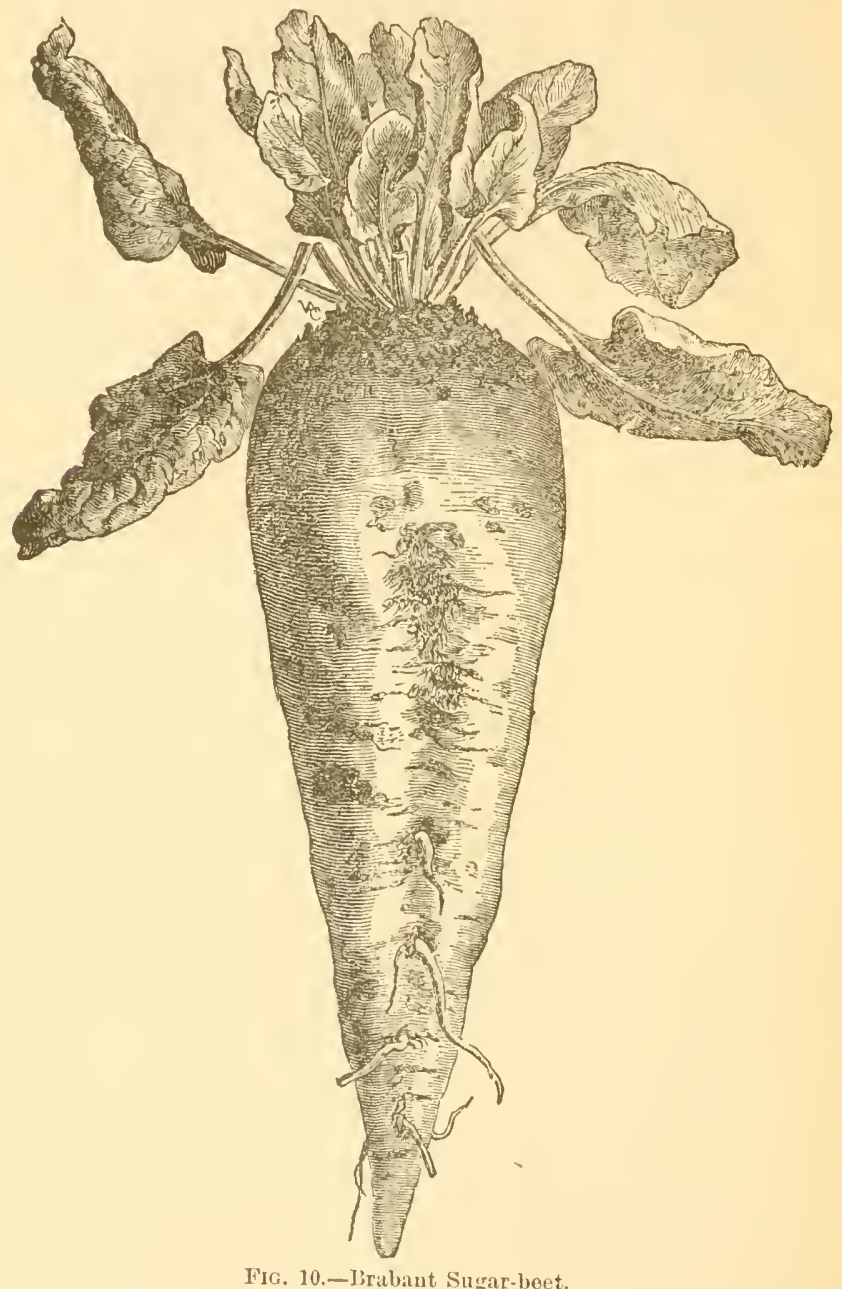

In France the arloption of legislation placing the tax upon the beet itself has not entirely banished the Brabant variety, but it has sueceeded in transforming it into one of greater richness in sugar. This variation of the Brabant beet has been called the French Rich Sugarbeet; and seems destined to lave a brilliant future, preserving in its general aspect, and notably in its foliage, many of the characteristies of the Brabant. The French Rieh Beet differ's distinctly from it in the fact that it grows entirely muler the soil, is more slender, with a more 
reddish skin and more compact flesh. Its yield is superior to the Vilmorin Improved and even to the Klein- Wanzleben, amounting to from 40,000 to 43,000 kilograms per hectare in good conditions. Its general appearance is indicated in the figure.

The content of sugar of this new variety is rarely inferior to 14 per cent on the weight of the root.

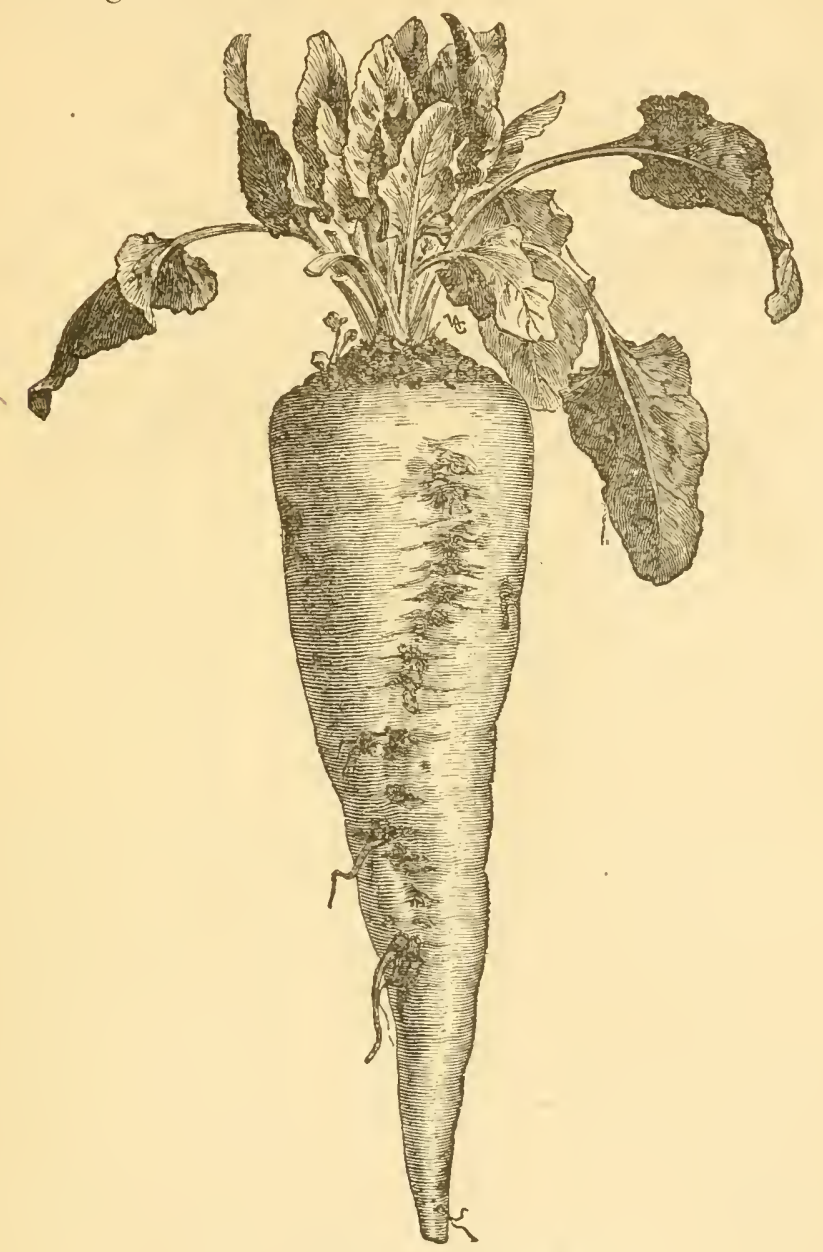

FIG, 11.- White French Rich Sugar-beet.

The Imperial sugar-beet is one which is largely grown thronghout Europe. It has a regular conical ontline with a top-shaped top and with leaves with rather short stems. There are different varieties, such as the Old Imperial, Improved White Imperial, and the Improved Rose Imperial. Other varieties which are also grown are the Electoral, the Improved Elite, the Improved Imperial Elite, the Imperator, Olivesliaped, and the Excelsior.

Some of the most celebrated firms in Europe producing sugar beet seed are Vilmorin-Audrieux \& Co., Maison Simon Legrand, of Paris; Messrs. 
Brumme, of Beruburg, Germany; Dippe Bros., Quedlinburg, Germany ; Ferdinand Knaner, of Gröbers, Germany; Le Maire frère et sœur, and Florimond Dèsprez.

\section{BEE'I'SEED AMELIORATION.}

For many years past there has been a constant improvement in the quality of sugar beets raised in France. While it is true that for more than tweuty years beets have been grown with high sugar percentages, their irregular shapes and special requrements did not bring them within the practical demants of farmers.

The best method of seleetion is yet an open question, and the seedgrowers do not all agree as to the most desirable size of the "mother." Some use roots weighing abont one-fonrth ponnd, and several agronomists maintain that 2 or even 3 pounds (?) is not too heary a weight. While in the latter case the seeds attain their full development (whether this is the case with the smaller trpes it is diffienlt to deeide), many experiments appear to prove that there is rery little diffierence in the seed in the two cases.

Pellet recommends that "mothers" be planted very close together, with the view of preventing any further development of the root, and so that the entire ritality of the plant may be expended in this seed development. Another argument in favor of very small beets is, that there is an economy of space, and the planting may follow on the soil that had already yielded a crop the same year; the expenses also are less.

One argument is that the "mothers," with their numerous stalks, require room, and hence the importance of roots of a certain size and planted at reasonable distances apart. On the other hand, the stalks of small beets attain a far greater height, owing to their desire (so to speak) to derive from the air the oxygen which close spacing certainly keeps out. Again, some assert that with large roots and stalks the size of the seed and quality is inferior to that obtained with the smaller roots. These facts are mentioned simply to show how very difficult is the question of selecting and ameliorating existing varieties of beets.

Peligot, Leplay, Pellet, ete., have coneluded upon some interesting facts respeeting the requirements and the changes "mothers" undergo during the proeess of seerl formation. Thestems, leaves, and seed, yet green during July, do not eontain sugar in their composition, but the sugar of the "mothers" constantly diminishes from the time the second growth eonmences mutil the seeds are matured. The density of the juice diminishes in the root and increases in the stalks, then in the leares. Vegetable acids, with potassie or lime base, exist in the juices of the root and stalks.

Respecting the potassie and lime salts, there apprars to be an as. cending movement between the soil and the stallis, leaves, ete. Car. bonic acid in the mean time molergoes the same changes as it does during the first year's vegotation. An interesting fact is, that the requirements 
of regetation for potassic and lime salts dnring the second jear is very much greater than during the first jeal's growth. These salts in combination with regetable acids, in solntion, appear to have important inflnences on the formation and quality of the seed obtained.

As early as 1850 Vilmorin called attention to the possibility of selecting beets, by depending npon the proportion that exists between the density and the sngar percentage. The classification was rery simple, and consisted in placing the roots in solntious having a specific gravity known in adrance, prepared with chloride of sodium and water. The selection, according to the density of the juice, followed; bnt while the results were more satisfactory than the foregoing, it was faulty, and it does not necessarily follow that the richest beets are those having juices of the highest specific gravity. The roots resulting from this selection were very irregular in shape, and conld not be used in the factory; they were also diffieult to harvest.

The size of the neck, shape of the leaves, their abnndance, etc., were elements to be considered in the onter characteristics of selection. M. Desprez's seleetion has demonstrated that beets which have been selected according to analysis will result in seed-yielding beets testing 2 yer cent more sngar than those which have not been analyzed. Some years since it was customary anong many seed-growers in France to send seed to Germany and receive them back from that conntry to France. The roots raised from those "mothers" were selected; a change of climate was supposed to have been beneficial.

Twenty varieties of seed were experimented upon by Desprez; all had been prodnced upon the firms. It was noticed that beets penetrated the soil very much more during a dry than in a wet period. An abnormal number of beets went to seed the first year ( 12 per cent.); this means a large amount of sugar; it is contended, however, by somo that this loss is never more than 2 per cent. Beets of cousiderable length and having rough skin gave the largest yield, and were but little affected by insects. The observatious on inflnence of clistance between beets in rows mpon the sugar percentage and yield are worth recording.

It was conelnded that mpon an average soil there shonld be cultivated about seven to eight beets per square meter; on well prepared soils with suitable fertilizers the number could be twelve to fifteen. The spacing between roots should depend upon the soil and fertilizers used; selection of the best variety best suited to a given locality also depends upon these factors.

Without donbt the most important beet-seed exhibit at the Paris Exhibition was that of $\mathrm{M}$. Legrand, who devotes aunually 50 to 55 acres to seed-raising. Most of this seed is nsed in the rieinity of his farm and the remainder is sold for a nominal sum, considering the quality and the pains taken in selection. "Mothers" exhibited were much larger than those shown by other exhibitors, and yet the sngar percentage was in some cases over 20. An important fact is that in the selection no beet is accepted unless it weighs at least one pound. 
The beets are taken from the field by a liarrester, with the view of aroiding bruises which oceur with use of spade, etc. This work is performer by the farming hands, who make at once a preliminary classification. Circular piles are formed with leaves ontside to protect them from any changes in the weather; but soon as possible these leaves are remored and a second and more complete assortment follows; then the roots are placed in small silos. The laboratory selection by the Violette method is carried ont on a most extended scale, there being made 2,500 analyses per diem, and a total of 175,000 during the season of 1859. When in 1855 the raising of superior beet seed was determined upon, the roots on M. Legranl's farm diul not test on an average over 11 per cent sngar, and now the standard has reached 16 per eent.

M. II. Saguier, a well-known agricultural expert, says that during a recent visit he fond that two fifths of the total roots raised by M. Legrand tested 15 to 17 per cent sugar, two-fifths fiom 17 to 18 , and onefifth had a saccharine pereentage heyond the latter limit. The richest beets are known as "gyandmothers," and are used for the production of seed which is planted alone for obtaining "mothers;" those of the second eategory are used fol the same purpose. The seeds from the lateral stalks always give the finest grain. Before the flower appears the central and lateral stalks are pinehed off, resulting in a greater development and vitality of those remaining; and even before the "mothers" are planted the extreme end of their necks are sliced off.

There can be no donlot of the importance of this extended system of analysis, with the view to a seientifie selection, as carried on by Legrand. A nember of the jury at the Paris Exhibition, howerer, reproached the seel-grower in question for the tronble he lad taken, as the shapes were so regular that outer sigus alone rouhl have been sufficient to decide the quality. There appears to be no limit of time or amonnt of money that can deter Legrand from obtaining the desired results in beet raising; and his methols, while in many respects original, are destined to have a great future.

In discussing the history of the sugar beet it is too frequently asserter that the best varieties have a German parentage; we are assured that the original types, as adopted by Legrand (who has constantly in mind a beet possessing considerable density and yet jnicy) has been obtained after years of carefnl selection from "mothers" of French origin entirely.

On the Carlier farm the "mothers" are taken from the best fields that are sown in April, and a cultivator is used four to five times before thiming ont; eighteen to twenty beets are grown to a square meter. The first selection is male on the field at once after harvesting, the regular shape and size, denoting maturity and quality, being the main basis for the preliminary selection. The roots chosen are silotted near the laboratory, and the second selection is made in Junury; the beets preferred weigh 350 to 600 grams. For many years it was argued that the greater the density of the beet the higher its saccharine quality, hence a selection offered no difficulty. Latre experiments soon demonstrated that 
such methods were not reliable; as a preliminary operation, however, there can be no reason why baths of salt water or molasses, hariug a known density, conld not be used, throwing aside those roots which wonld float in the bath of 1.045 density, and keeping, say, three piles from 1.045 to 1.050 , from 1.050 to 1.055 , and from 1.055 to 1.060 .

The classification as adopted by Carlier, depending npon the density of a core taken as a sample from the beet, was not entirely satisfactory; frequently the rolume of air, ete., a heet may retain in its composition is to be considered. Aceorling to Dnbrunfint, beets retain 115 cnbie centimeters of air per 1,000 grams in weight, and frequently there is, owing to this fact, considerable difference between the density of beets, considered as a whole, and the juice. At the Wargine-le-Grand farm these variations were shown to be:

\begin{tabular}{|c|c|}
$\begin{array}{c}\text { 1)ensity of } \\
\text { entirubet. }\end{array}$ & $\begin{array}{c}\text { Iensity of } \\
\text { juice. }\end{array}$ \\
& \\
1.012 & 1.043 \\
1.0120 & 1.048 \\
1.025 & 1.052 \\
1.025 & 1.056 \\
1.030 & 1.058 \\
1.038 & 1.052 \\
\hline
\end{tabular}

This fact alone would condemn any method of solution depending upon density.

In the Lemaire system of selection roots weighing 500 to 800 grams have preference; snch as remain well under ground, and having a special depression on both sides, commencing with the neck and ending with the tip end. Legrand, Lemaire, and others attach considerable importance to these outer charaeteristics, and many maintain that the more pronounced they are the higher will be the saccharine quality of the root.

Lemaire and others also maintain that their careful selection by onter signs, combined with ehemical analysis, has enabled them to ereate new types; in fact, most seed-growers may claim that their special rarieties have been " creations." The beets in the latter case are placed in silos, where they remain until Felornary or March. The experimenters last named and others consider it a mistake to commence analysis sooner, as there would be no certainty as to the preservation of the roots, a quality as essential as the sugar percentage. The one withont the other has but little importance, as they both may be transmitted to their descendants.

When we consider that beets must be kept in silos frequently four to five months before being used at the factory, the element of preservation becomes of the first importance. Those roots which have mudergone little or no change in their saceharine percentage during the sev. eral months of preservation are seleeted, and there is very little donbt that just as their conservation was satisfactory so will be the beets raised from the seed they furnish, 
M. Lemaire informs the writer that experiments were made with seed from beets baving lost in sugar during their silotting and were compared with seed from those that retained their sugar percentage. The conclusion was jnst as expected ; the roots from seed that kept well had a higher sugar pereentage than others. The hereditary quality of beets shonld be constantly borne in mind in these selections andameliorations.

M. Lemaire also states that all analyses made by the eopper test are repeated with the polariseope, and in most cases their seed give roots with a ligh co-efficient of purity. The "mothers" when planted are platerl at distances of 60 to 70 centimeters. Abont one month before maturing the tops of the highest stalks are ent off so as to permit the sap to center itself upon the seed. Lanreut-Monchon has had some little reputation of late years, his beets being of a satisfactory quality. Their selection does not differ from that above mentioned.

To gire some ideal of the impor tance of growing forms of seed as above describerl, we may mention that the Legrand estate at Besuy has over 200 acres planted in beets for the factory at Loan, the yield areraging 10 to 12 tons to the acere, and roots testing from 12 to 16 per eent sugar. Abont 55 aceres are devoted to seed-raisiug; 3,600 roots ("mothers") are planter to the arore. In the Despre\% seed producing farm whent follows the production of "mothers" in rotation; barn-yard mannre, rags, etco, are also used to the value of $\$ 10$ to $\$ 130$ per hectare. It is considered that the "mothers" absorb two-thirds of the fertilizers, the other one-third remaining for the wheat. Of the farming lands twofiftls are devoted to beet seed cultiration, two-fifths to wheat, and onefifth to beets, flax, etc. All soils used for beet eultivation are worked to a depth of 35 centimeters. Soils intended for the "mothers" are worked in two operations, abont 20 eentimeters in depth in the fall and the remainder in the spring, so as to plow under the fertilizer.

The "mothers" when growing have the enltivator passed between the rows fonr or five times. The area uncler cultivation at Orehies is 432 hectares, of which 150 heetares are mnler Carlier's direct supervision, 54 hectares in "mothers" for seed, and 30 heetares in beets of inferior quality intended for eattle feeding. Efforts are made to keep these separate so that there will not be hybrids formed by the combination of their pollen. The Lennire plantation at Nomain eonsists of 275 hectares, in five farms, on each of which a special variety of seed is prodneed. Besides this 400) lectares of beets are controlled for an agricultural distillery. The anmal production here is estimated at 500,000 to 600,000 lilograms of beet-seed.-(The Sugar Beet, vol. 10, No. 4, 1850.)

\section{SOIL, PLANTING, AND CULTIVATION.}

PRIEARATION OF 'THE SOIL.

Land which is to be planted with beets, if manured with farm-yard mannre, should have this coating applied in a well-rotted state in the antumn and plowed in to the depth of 5 or 6 inches. In the spring the 
soil shonld be plowed to a greater depth, from 8 to 10 inches, and if the subsoil be at all bard a subsoil-plow shonld follow, loosening the subsoil to the depth of 12 to 15 inches. The surface of the soil is then redneed to the proper tilth by harrowing, and, if necessars, rolling to break up the clods. It shonld not be forgotten that inuch of the cultivation of the beet may be aceomplished in this way before planting and the process of seeding should not begin until the surface of the soil is in the perfect condition mentioned above. Care shonld be taken not to apply fresh or unrotted stable manure, or any other manure containing large quantities of undecomposed organie matter, to a fiels seeded to beets except in the manner leseribed above.

It is scarcely neeessary to add that eare must be taken in plowing the soil to have it in the proper condition of moisture, since, if plowed too wet, it is likely to bake, and if too dry clods may be formed which will be diffienlt to reduce to the proper state of tilth. A field prepared as above will afford the beet opportunity for growth downward, thus pre. venting its being projected above the surface of the soil. It will also guard the beet against the daugers of excessive moisture or dronght, as stated above.

\section{SEEDING.}

In small plots the beet seed ean be placed in the soil by hand. For large fields drills are provided which are bnilt to operate precisely on the principles of ordinary grain-drills, the opening for the seed made to correspond to the size of the beet seed. Simple drills may be used or compound drills for planting the seed and distributing fertilizers at the same time, such as are used in sowing wheat and other cereals. A convenient drill for this purpose is represented in Fig. 12, the Planet, Jr., No. 2 seed drill, made by S. L. Allen \& Co., Philadelphia.

Distance of rows.-No definite rnle can be giren for the space between the rows of beets. In an ordinary soil this space should be abont is inches. In very fertile soil the rows should be placed closer together, in a less fertile soil farther apart.

The distance at which the beets should be placed from each other in the rows also varies according to the nature of the soil and elimatic

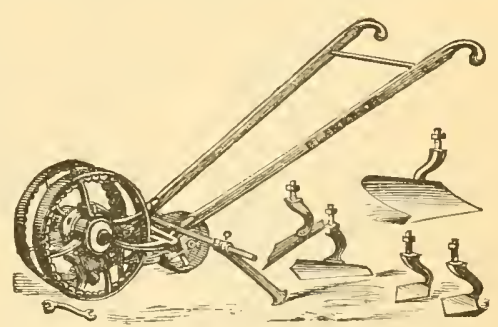

FIG. 13 . conditions. In general, it may be said that there should be one plant for each 6 inches.* In very rich soils the beets should be eloser together, anc in very poor soils they shonld be farther apart. With rows 18 inches apart, the beets planted at a distance of 6 inches in the rows, the number of beets per square yard would be twelve and the approx-

* The beet seed should be plunted elose together. Some authorities recommend fifteen pounds per acre. 
imate number of plants per acre, 49,000. Supposing that each beet will weigh 1 pound, this wili give a yield of $24 \frac{1}{2}$ tous per aere. The above conditions may represent a fair average beet field under favorable conditions, althongh it must be admitted that the average yield of beet fields loes not reach so high a figure. If, however, there is a complete stand of the plant, so that every space is occupied, with a fair soil, properly prepared and cultivated and supplied with a proper fertilizer, the above yield can be secured. In every case, however, an attempt should be inade to plant the beets close enough together to secure a matured plant, after the separation of the heal and tops, weighing abont 1 pound. This is formd to he the size which best secures a high content of sugar with a large yield of roots, and therefore represents conditions most favorable both to the farmer and manufactmer.

\section{IMPLEMENTS FOR CUL'TYATION OF SUGAR-BEETS.}

Any ordinary plow may be used for preparing the land for sugar-beets, care being taken that the ground be erenly and eompletely broken and at an even depth. Instead of plowing to the depth of 12 to 15 inches in the first plaee, it is best to use the frst plow to the deptlo of 9 or $\mathbf{1 0}$ inches, following with a subsoil-plow to the repth of $4 \mathrm{or} 5$ inches. A subsoil-plow suitable for this purpose is manufactured by the Moline Plow Company, of Moline, 11l., and its general character is shown in Fig. 13.

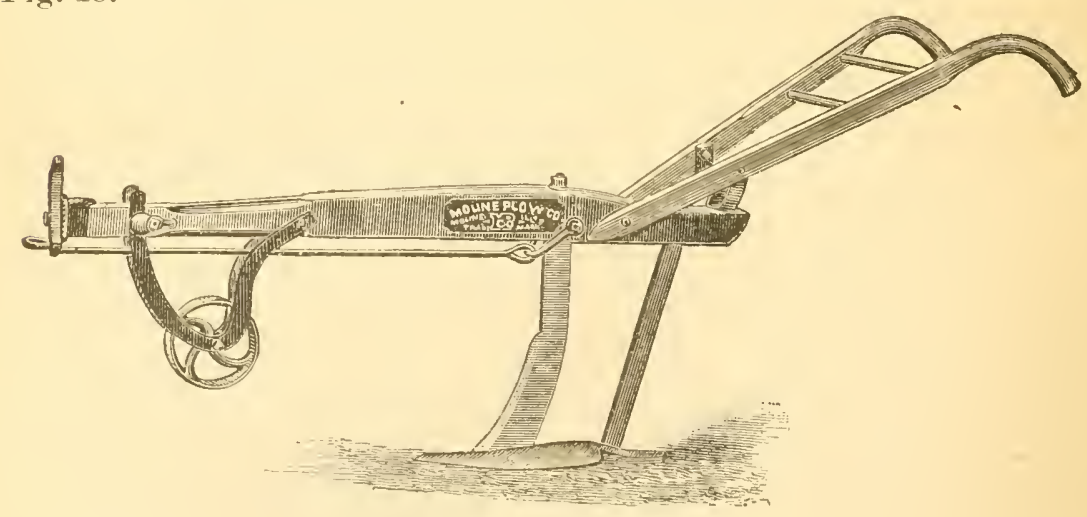

FIG. 13.-Subsoil-plow.

It is often convenient to lave the plow and subsoil-plow combined in the same instrmment, thus saving the labor of one man. So little:nbsoiling is done in this conntry that very few such implements are to be fomd in the market. A plow of this kind, largely employed in France, is manufactured by Bajac at Liancourt (Oise), and its general form is slown in figme 14 .

The subsoil plow is removable, and when the instrmment is to be nsed as an ordinary plow it ean be taken off. In plowing with subsoil attachuents care shonld be taken to make marrow furrows, so that 
the whole subsoil may be loosened and not left in a series of trenehes. In no case, in plowing for sngar beets, should the furrow be wider than the entting capacity of the plow itself. Any good harrow can be used for reducing the plowed land to the proper tilth, and no deseription of this instrument will be necessary in this place.

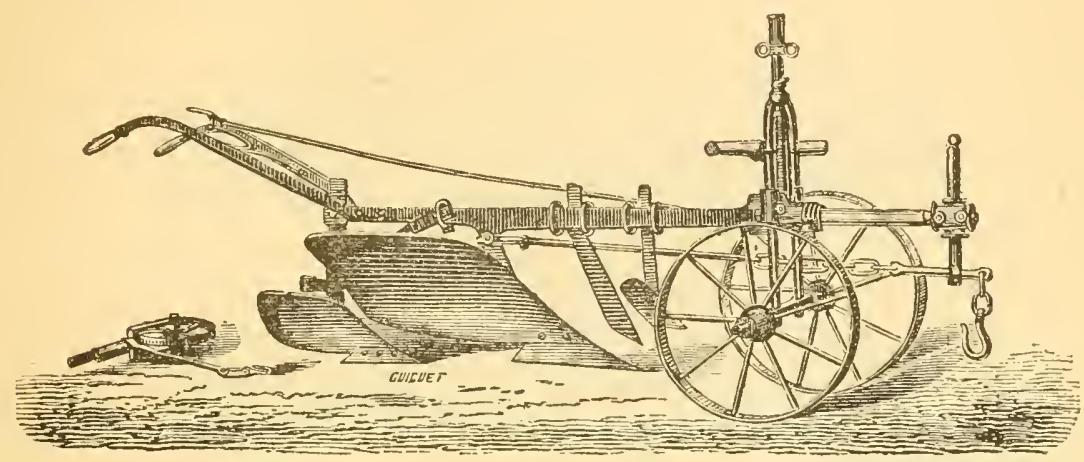

FIG. 14.-Subsoil-plow, at tached to plow.

For planting the seed it, is best, in small patehes, to do it by hand, or by the implement represented by Fig. 12, but when large areas are to be sown in beet seed, power drills should be provided. A drill made by the Moline Plow Company for eotton seed ean be easily adapted for use with beets. This is shown in Fig. 15.

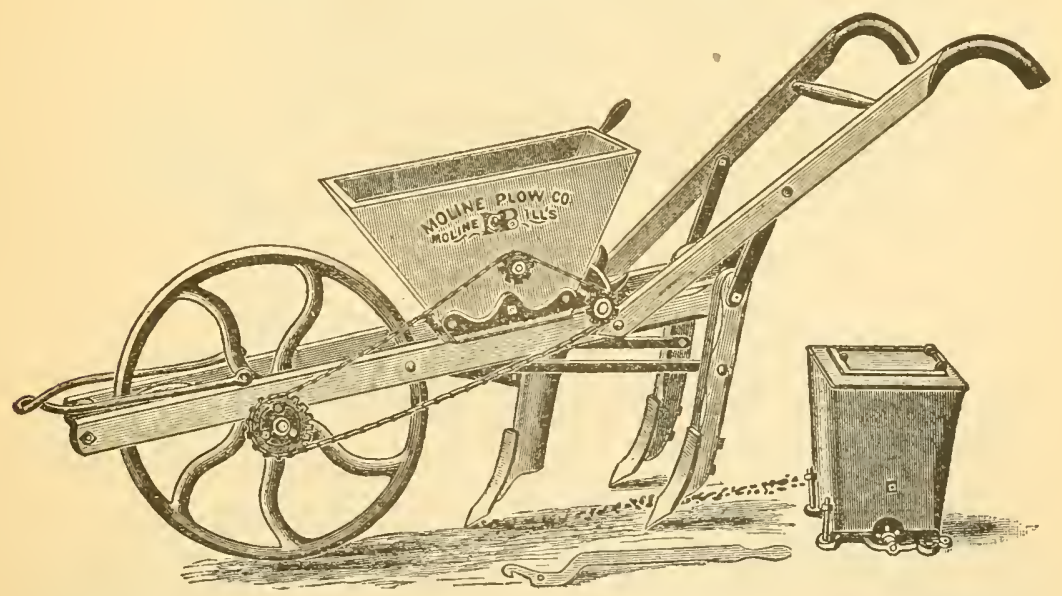

FIG. 15.

An ordinary drill for planting Indian corn ean also be easily adjusted for planting beet seed. Great care, howerer, should be taken in drilling the beet seed not to eover it too deep, and all drills shonld be arljusted so that the average depth of the seed shall not be more than 1 inch. 25474-Bull. $27-6$ 
CULTIVATION.

In addition to the hand-hoe, Fig. 16, for early cultiration, the horse-

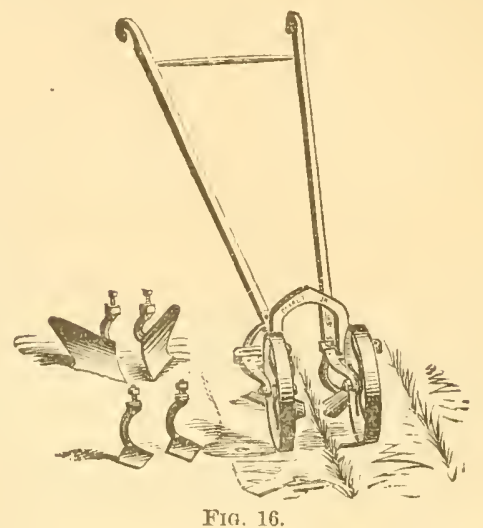

hoe manufactured by Bajac can be used with great advantage. Its general construction is shown in Fig 17 .

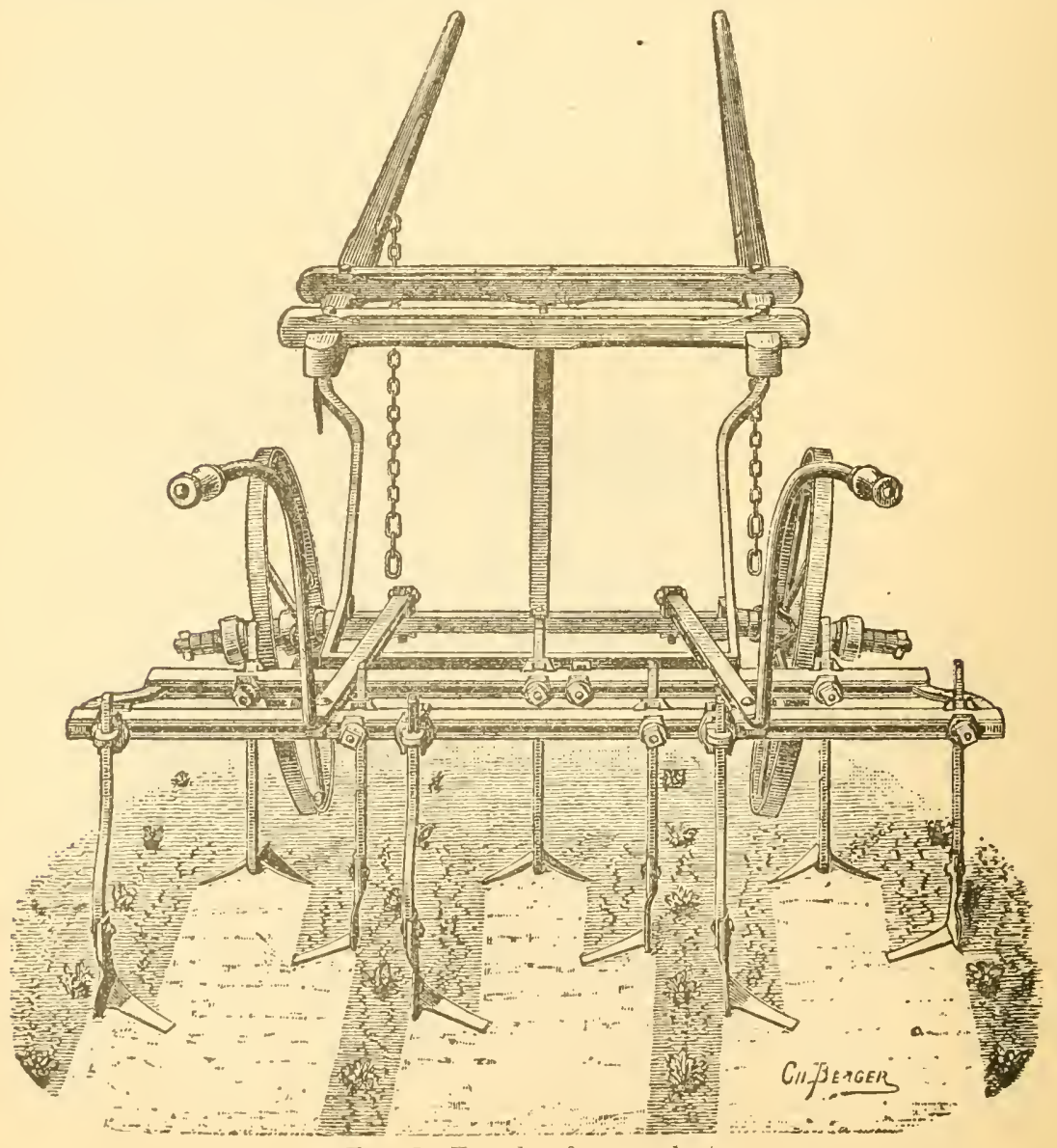


Other forms of apparatus used in cultivating beets are shown in the following figures, 17 to 21 , inclusive.*

Bertel's ridyer, drill and cultivator.
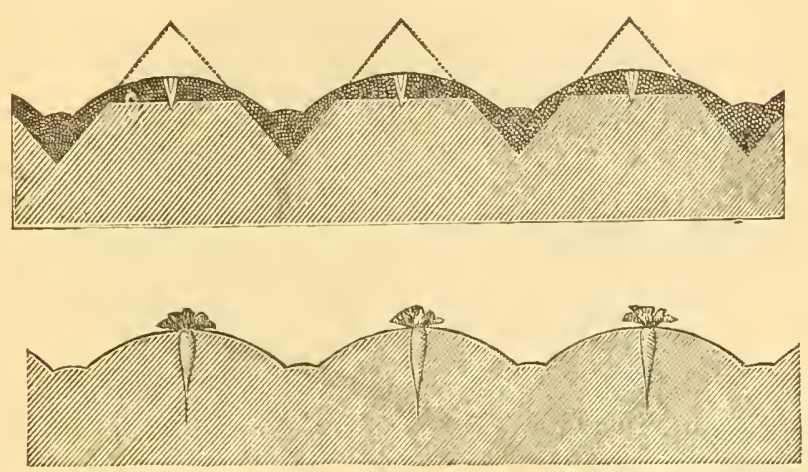

FIG. 18. - Ridges after passage of drill.

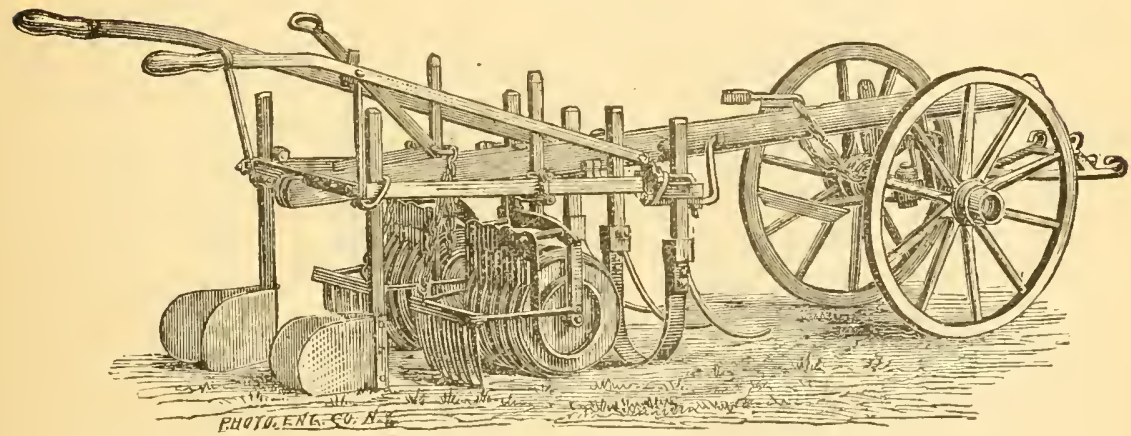

FI: 19.-Cultivator for working between rows or rilgos.

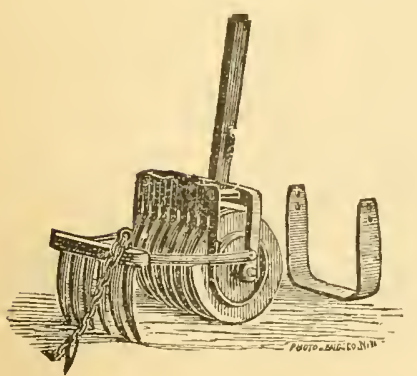

Fig.-20. Scarifiers and rollers for flat culture.

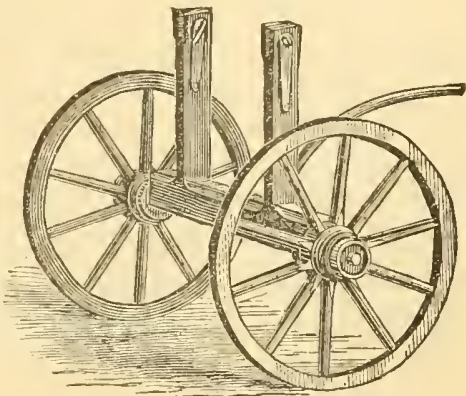

Fig.-21. Leader to cultivatur.

* From MeMurtrie's special Report No. 28. 
The hoes are arranged so as to enltivate three rows of beets at a time, and are so arljusted as to completely clean the spaces between the rows without throwing any of the soil upon the joung plant itself. Inasmuch as each seed of the beet may give one, two, or three plants, form.

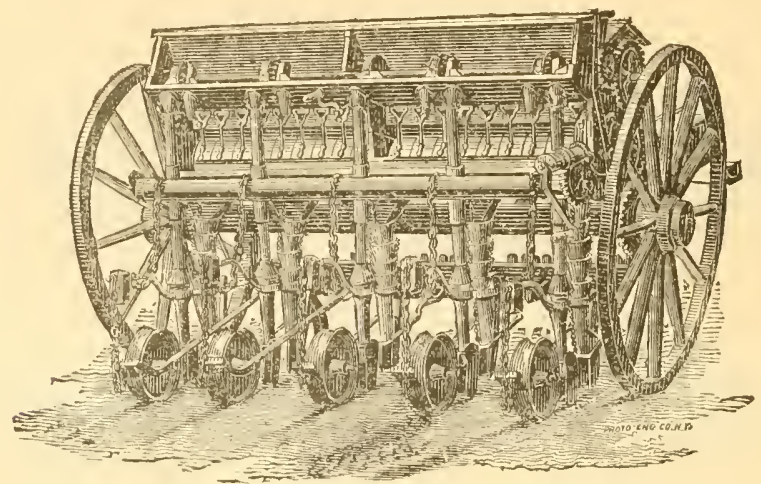

FIG. 22.-Combincel beet-seerl and fortilizer drill for flat culture.* (James Smyth \& Sons, Peasenlall, Suffolk, England). The machiue has a range of five hoes 18 inches apart, but the machines vary in number aud interval of tho loes, and in prico.-(Knight.)

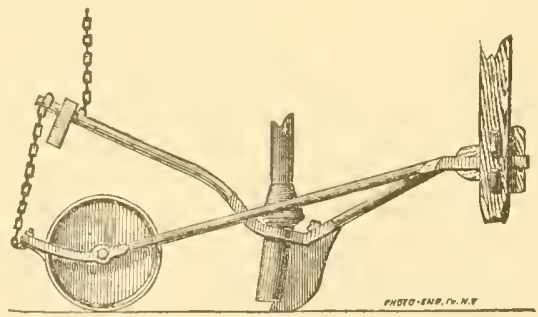

Fig. 23.- Vetail of hoo and covering wheel.

ing clusters in the rows, it is necessary that the thinning should be done as carefully as possible withont injuring the plants remaining in the soil. It is best that the planting shonld be elose together so as to give a large excess of beets, since in ease replanting is necessary it will be noticed that the replanted beets, are uni formly of poorer quality than those of the first planting, aud if possible the surplus beet plants should be removed by a sharp-cutting hoe without tonching the one which is to remain. In this way one liealthy plant should be left from every 6 to 10 inches in the rors. When the beets begin to show the neck above ground, it is well to throw a little clirt against them so as to form a slight ridge. This can be done by a ridging hoe, such as is indicated in Fig. 24.

\footnotetext{
* From MeMurtris's special report No. 28.
} 
This hoe, as well as the one mentioned previonsly, is made by Bajae.

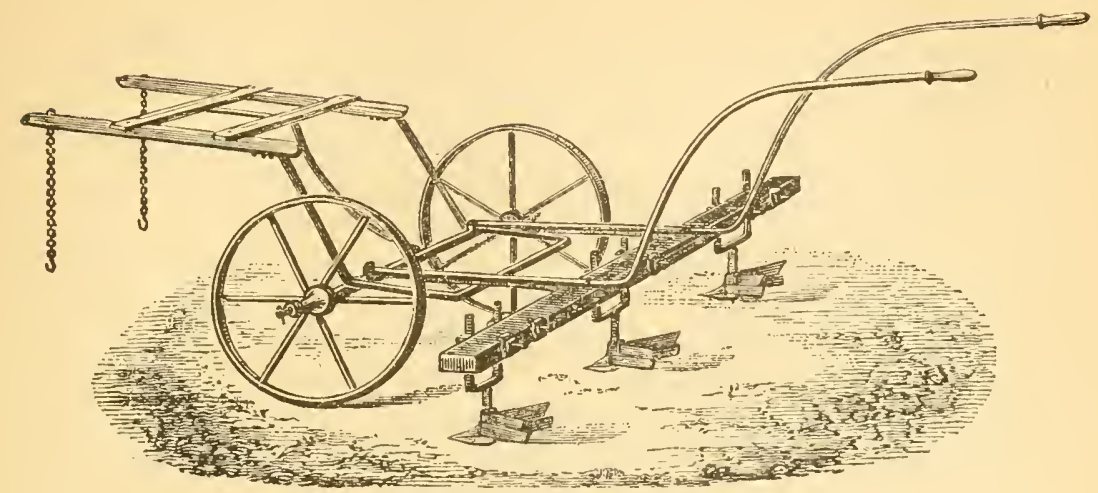

FIG. 24.-Ridging hoe for sugar-beets.

After the ridging is done it is recommended to go between each row with a subsoil plow of very narrow cut to the depth of 12 to 15 inches.

\section{CULTIVATION.}

Whatever kind of cultivator may be employed it will be found necessary to protect the young plants from being covered by dirt. Various kinds of shields may be nsed for this purpose, such as are often nsed in the plowing of young corn. Sometimes it is eustomary to cultivate the beets before they are $n$ ). For this purpose at the time of sowing a few grains of rye are placed in the furrow with the beet-seed. Rye, spronting sooner than the beets, marks the rows so that the eultirator may be used as if the beets were already ont of the ground. The cultivation should take place at least every two weeks, and oftener if the ground is rery weely, till the mildle or the end of June. Unless some shield is used, as above indieated, for the young plants it will be found that many of them will be destroyed by the early cultivation, leaving large spaces nnocenpied in the rows, thus giving a smallel yield, and permitting at least a portion of tho beets in the fields to grow to an unusual size.

\section{METHOD OF CULTIVATION USED A't ALVARADO, CAL.}

The methor of cultiration emplosed by the Alimerla Sugar Company, of Alrarado, Cal., has been kindly sent to me by the president of the company, Mr. E. C. Burr, and is as follows:

"Plowing begins soon after the 1st of January and continues until late in the spring, varying aceorling to circumstances of weather anc soil. The lands are subjected to two plowings, the first about 8 inches deep and the second to the depth of 12 inches, seldom more, although it would be better in results. After plowing the lands are rolled to 
break elods, then harrowed and planked with a rude contrivanee made of boards.

Rude as it is, it is quite effectual in reducing the lnmps and giving the surface a smooth appearance. The preparation of the soil is one of the ehief factors for a good erop. The plowed lands are now allowed to stand for a sliort period, generally a week, until, as farmers sas, "the under moisture comes to the surface," an expression which may mean the reverse, for intelligent farmers claim that the lower layer turned to the surface is too cold and damp to germinate the seed readily, and by letting it stand open to sun and air it becomes drier and warmer. After the resting perior seeding begins with horse drills, in rows 15 inches apart, and eight rows to the machine, the seeds being dropped in an almost unbroken row in order to induce a good stand. The depth to which the seed is planted varies from oue-half to 2 inches, but our instructions this year are to plant one-half inch deep only, as onr observations last year showed a large percentage of ungerminated seed at the greater depth, owing probably to too low temperature. As soon as the plants form three or four leaves, that is, large enough to distinguish from weeds, they are thimed ont to 4 inches apart in the rows and freed from weeds. In abont sixteen to twenty days the second weeding and emltivating takes place. Last sear the cultivation part by Clinese labor was a farce, but this year we have introduced some French implements in the shape of "extirpators" and scarifiers which we hope will free the farmer from the Chinese, and do the work more effectually. The "extirpateu." we imported from Mr. H. AmiotLemaire of Bresles, France, ant which, acting similar to a harrow, is intended to loosen the soil to a deptlu of 8 inches. The searifier, as its name implies, is to go between the rows and destroy the weeds. It is built like our eultivators, but with entirely different blades.

"Last year the cultivation was flat, but with the new implements there will be more of a tendency to ridges. The firmers use no fertilizers as yet, althongh they woild be benefited thereby. Were this company raising its own beets, I should certainly insist on it. Yet the lands so far seem to show no deterinration. Last year the whole State suffered from drought and our crop was meager in conseqnence.

"The average number of plants per acre was 57,000. The average weiglit per root, topped, on the highlands near Centerville was 121 grams; near Alvarado, on lowlands, the weight, under same conditions, was 307 grams. There is no agreemeut between the number of roots per acre and the weight. The estimate was earefully male when the first weeding and thimning was done, for roots per acre, and the weights were determined at the factory from every load delivered. In July, near Centerville, the roots ceased growing and we worked hnndreds of tons of beets no larger than a eigar. In some places the yield was not over two tons per acre. Of course, under these circumstances, many roots did not mature. 
"The methods of farming here must be altered toa very greatextent, but it is very diffienlt to eonvince the farmers and will take time to effect. We hope during the current year to make some improvement, and shall continne our system of obtaining data. Two men are constantly in the field (one a chemist) from the time the first seed is giren out until the crop has matured, and they survey each man's plot, estimate the number of roots per acre, obtain weights weekly of beets with and without leares, and make reekly tests of sucrose, non-sugar, quotient, etc., from each man's pareel. They also note method of cultivation, eondition of crop, ete.

"The sowing begins toward the end of March and continues, working from the highlands to the lowlands, until the middle of May.

"The crop matures about Angust 15, and is all at the factory by December 1 , our storage eapacity being for about 6,000 tous only. We tried some experiments with beets in cold storage, but the figures are not before me. One test is worth noticing. We tested beets which had been continnously orertlowed from December 1 to March 1 and foumd them to contain 14 per cent. sucrose, with a quotient of 81 per ceut."

\section{DISTANCE AT WHICH SUGAR-BEETS SHOJLD BE PLANTED.}

Formerly the author had recommended that beets shonld be planted so that there should be about 10 plants to the square meter. Since, however, the change of law in regarl to the taxation of beets requires that they should be grown with great saccharine richness he recommends that they be planted so as to have from 15 to 20 plants per square meter. In this way a beet of great richuess can be secured, while the quantity produced per hectare will remain about the same as when only 10 plants per square meter were cultivated.*

\section{METHODS OF CULTIVATION IN BOHEMIA.}

The methods of enltivation used in Bohemia are described by Commercial Agent Howes, as follows : $†$

\section{" PREPARATION OF THE LAND.}

"The sugar-beet needs well-cultivated land. First, a snrfaee loose and fine, which allows the air to enter and facilitates germinating and swelling; second, deep, loose, uniform soil, becanse the beet should develop a sleuder root withont side rootlets. Both can be olstained only by good cultivation. Cultivation differs according to the soil.

\footnotetext{
* A. Ladurean, La Snererie Indigene, Vol. 33, No. 23, p. 58*.
}

+ Cousular Report pp. 248 et ser. 
"The following suggestions are of value: Loosen the subsoil without bringing it to the surface. If the subsoil be not gool, this is doubly important. The depth should be from 30 to 40 centime ters, and a plow similar to that shown in Fig. 25 should be used.

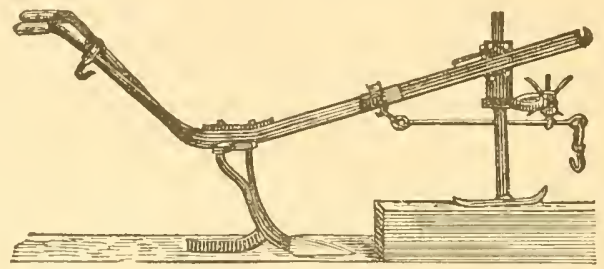

FIG. 25 .

"To begin deep plowing, 30 centimeters will be deep enough. After several years it may be made $t^{0}$ centimeters, but should be deepened only gradually, because, if too much dead soil comes up, the land is ruined for at least one year. Deep plowing should always be done before winter, so that the frost has time to work on the soil.

"Steam plowing.-By the introduction of the steam-plow an implement was put in the hands of the firmer, the work of which can not be equaled. The reasons why the steam.plow works so well are-

"(1) By the spreed with which it operates the soil is well mixed and mulverized.

"(2) The depth of all the furrows is the same.

"(3) It plows to any depth, especially in heary soils which would require a large number of animals. G(enerally the soil is loosened to a deptl of 35 to 50 centimeters, and the plants are entubled to talie nourislment from a larger quantity of soil.

"(4) In dry seasons soils plowed by steam retain longer their humidity. In wet seasons the water descends quicker to the subsoil. The steam-plow increases the crop and renders it certain.

"(5) The animals leave foot-prints (four oxen make about three hun. dred and sixty thousand in plowing 1 hectare), and therefore cause a not unimportant loss.

"(6) It is possible to work in spring and fall, when with animals it would be impossible.

"(7) A large unmber of animals can thus be used for other purposes.

"If we ccnsider that with a steam-plow 3 hectares can be plowed in a day, while with a common plow one-third of a hectare can be gone over, then nine common plows are needed to do the work of one steamplow; and, as four oxen are needed for each plow, thirty-six oxen would be employed, and, as they should be used only half a day, seventy-two oxen wonld be required, and their work is not equal to that of one steamplow.

"The excellent work of the steam.plow can increase the crop of beets from 4,000 to 5,000 kilograms per hectare. The cost of plowing by 
steam is between $\$ 11$ and $\$ 16$ per heetare for a depth of 32 to 40 eentimeters.

"Deep plowing can be done in such a way that two plows go one after the other, the first cutting 15 to 20 centimeters deep and the second 10 to 18 centimeters.

"Another way to loosen the deeper soil is as follows: The land is plowed from 15 to 20 eentimeters, and laborers then spade up the deeper soil from 20 to 24 centimeters, the undersoil being seattered over the surface. 'This method is expensice, but produces very good results.

"Still another way to proeure most of the advantages of deep plowing, and one which is generally used on very heavy soil or on lands exposed to inundations, which eonsequently dry at a late period, is to form ridges.

"This is done in the following manner: The land is plowed in the fall in such a way as to form a ridge. For this purpose a hill plow is used, or a machine invented by Dr. Bïrtel and ealled a ' ridge former.'

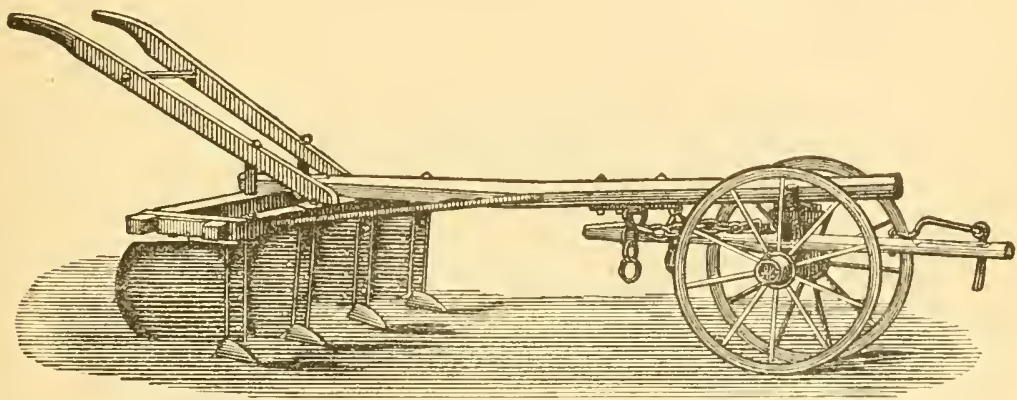

FIG. 26.

"In spring these ridges are split, and thus new ridges are formed. These mist be rolled to an even surfice.

"The advantages of preparing the land in this way are: The water gathers in the furrows and runs off; the soil in the ridge is always in a good condition and the air ean penetrate it.

"If grain las been grown on land about to be planted in beets the preparation goes on in the following way: The stubble is plowed as

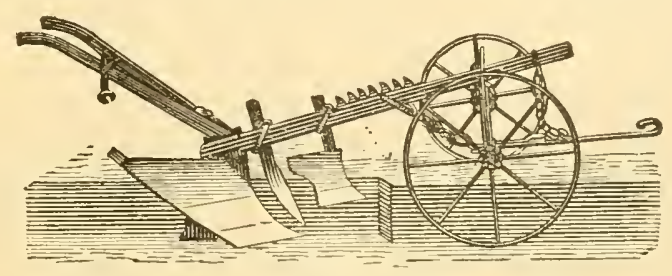

FIti, 2:

soon as possible to a depth of 5 to $S$ centimeters. For this work gang plows, as shown in Fig. 27, are used. 
"As soon as weeds eome up the land is harrowed and rolled. Before winter the deep furrow is plowed, aud, if stable mannre is used, it should be applied before the middle of Norember. In sueh cases only a moderately deep furrow is needed, becanse, as before remarked, the manure thus deeomposes better.

"The land remains in this state during the winter, and is therefore exposed to the influence of frost, rain, etc. In spring it is ready for the beets. Then, as soon as possible, it should be harrowed. The harrows used are, if the land is erusted, 'The Extirpator,' or, if necessary; it must be plowed 15 centimeters deep. Then the "Acme" harrow is used.

"If sugar-beets follow beets, potatoes, or corn, the land is simply plowed before winter.

"Before planting all land should be rolled.

"PLAN'ING.

"The time of planting intlnences the crop) in a high degree.

"It is shown that in a warm, dry season the crop of an early planting is larger than in a cold, humid season. The time of planting is the micldle of spring, with a temperature of from $9^{\circ}$ to $12 \circ \mathrm{C}$. ( $48^{\circ}$ to $54^{\circ} \mathrm{F}$.) Early planting begins with April and lasts until the end of that month; late planting is in May. In general, early planting is to be preferred, because the danger from frost is not so great as that of drought. It should always be remembered that the seeds should be put in a soil warm enongh to germinate in six or eight days, not twelve to sixteen days, as is the case in cold, humid soil.

"Distance apart.-This has a great inflnence on the crop and the quality of the beet. The experiments of Vilmorin show that the largest crop will be grown if the beets be planted comparatively near together. If the distance increases, the proportion of leaves increases. The lighter and poorer the soil the further must the beets be planted apart, and experiments show that this influence is greater than that due to manuring, or even the elsoice of the rariety. Distances vary from 30 to 50 centi. meters from row to row, and from 10 to 25 eentimeters in the row.

"Depth for planting.--The seeds need only a very light covering-2 to 3 centimeters is the right depth. If part of the seeds are not covered at all, it does not cause so much damage as if they are covered too deeply.

\section{"Cultivation.}

"From the time of planting up to that of harresting the following suggestions should be observed: As soon as the sowing is done the roller must be usel, because in pressing the surface the humidity, which is very necessary for the process of germinating, is drawn by capillary attraction ont of the deeper soil, and the surface is thins kept moist. The roller may be smooth or have rings; the latter is better, because it makes the surface of the land rough, and therefore a heavy rain can 
not form a crust. If, after sowing, a crust corers the field, the ringroller is the best implement for breaking it, and after this a light harrow is recommended. Thus is the soil loosened, the air can enter, and germinating and growing are facilitater. When the plants have grown so that the rows are visible, hoeing must be done, and the earlier the better, not only becanse the weeds are destroyer, but aiso because the plants need a loosened soil. The oftener the plants are hoed the better will be the erop as regards quantity and quality. Indeed, quantity and a high sugar percentage can only be obtained by hoeing. The first boeing must be only superficial, that all the weeds are thrown on the surface to dry, and care must be taken that no soil covers the young plants. The hoeing shonld be done eren if the land be dry, as hoeing prevents the evaporation of the water from the deeper soil. If laborers can be had, it is preferable to first hoe by band in such a way that only the soil about 50 centimeters distant from the beet is hoed and the soil between the rows is untouched. This is then hoed with the eultivator. If hoeing must be done by horse-power, the cultivator showu in Fig. 28 is used.

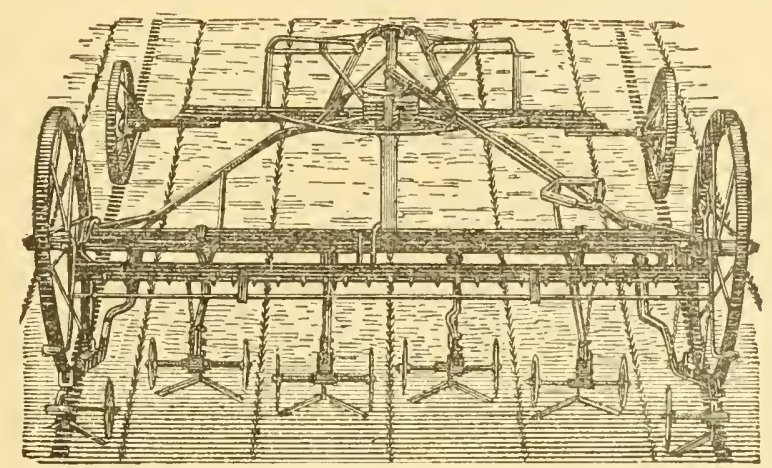

FIG. 28.

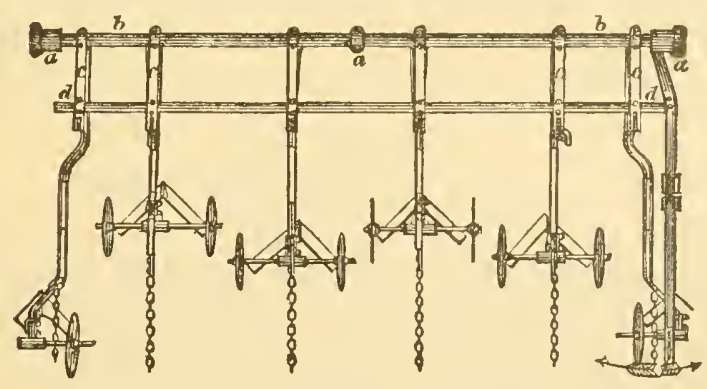

FIG. 29.-View from above of same machine.

" After the hoeing comes thinning out. This must be done as early as possible, and generally, plants sowed by the Dippel machine must be 
thinned ont earlier than those planted by the drill, the reason being that the latter have more light and air than the former. It is practical to thin ont when the plants have three or four leaves. The root is then as thick as a straw, and the whole plant has a length of $S$ to 10 centimeters.

"If planted with a drill, the work of enltirating ean be done in two ways :

- "(1) The field is erossed with the cultivator at right angles to the rows, and the knives are set so that they leave about 2.5 centimeters on each side of the beet untonched. Of the plants which remain in this space the weakest are removed by hand.

"(2) The whole work is tone by hand. By means of hoes the laborers remore the superfluons plants, learing spaces about 20 to 25 centimeters between. Children are employed here for this work, as they can best get down to it.

"Cutting the leaves off" is not sufficient, as the leaves grow again ; or, if not, the plant becomes a harbor for insects. One person can thin ont one-ninth to one-eighth of an acre a day. After thimning, hoeing by hand should follow immediately to loosen the soil around the plants; then, between the rows should be hoed, and the time this shonld be done depends npon the weels and the soil. As a rule, the intervals should not be more than a fortnight. I fourth, and possibly a fifth, hoeing would increase the crop. Of course, hoeing can not be done when the plants are large enongh to be damaged.

"Hilling up now follows. This must be done becanse, by eovering the beets with soil, it prevents the heads from growing ont, and therefore this part of the root, which is of no value to the mannfacturer, as it contains little sugar, is lessened. Water can run off and evaporate better, and the soil will not become inernsted. In heary soils this is a very important point. The time for hilling up is important, as if this is done too early the plants are buried, and if too late the leares are damaged. Hilling np ean only be done when the soil is in good condi. tion, $i$. e., neither too wet nor too dry. For this can be used a plow with a single share, or that already shown in Fig. 29. On small farms it is usually done by hand.

\section{"HARVESTING.}

"This is done when the beets are ripe, i. e., when growing stops and all the products of the leares go to the root, where they are deposited. In Bohemia beets ripen from the end of September to the middle of Oetober.

"Signs of ripeness. - The leaves beeome sellowish green, fall and form a kiud of a wreath around the plant. The middle leaves, so-called "heart leaves," also of a jellowish green, do not fall.

"Harvesting should not be too early, as the loss occasioned thereby 
may amount to as much as 2 per cent. Of course harvesting must take place before heary frost, though the beet can stand frost from $3^{\circ}$ to $4^{\circ}$ C. $\left(24^{\circ}\right.$ to $27^{\circ} \mathrm{F}$.). If early frosts should come, it is best to let the beets thaw in the soil, as the loss will be thus lessened.

"How harvesting is done.-(1) Bý hand. To each man is apportioned a certain tract of land, which he works by contract. The soil around the plant is loosened, and then the plant is drawn from the ground by hand. Work with the fork would be easier, but might injure the beet.

"(2) By team. A subsoil-plow is used, which should be set for a depth of 35 centimeters. A still better implement is the beet-lifter, shown in Fig. 30. This machine can be worked by a boy, and also does not injure the plauts which are left loosely standing upright in their places, where they are better protected against sudden rain or frost than if lying upon the ground. As work can be done much faster with the lifter than by hand, this machine will no doubt be of much use in the United States.

"Cutting off the heads.-The green heads must now be cut off, as they are of no use. This is done in the field, and here it is the work of women and girls, who accomplish their work rapidly, using sharp knives. About 1 to 2 centimeters of the beet is removed.

"Piling up the beets.-This is necessary, as it is impossible to immediately transport an entire crop to the factory, and they must be proteeted from rot and frost. Perhaps the best plan is that recommended by Kinater, espeeially if the beets must remain a long time on the field. $A$ diteh 1 foot deep and 6 feet wide is dug, and of the required length. Beets are then piled up with roots toward the center for a height of 1 foot, and covered with 6 incles of soil. Then another layer of beets, covered also, is added, and then another, until the pile, tapering, is of the shape of a prism. If the soil is very dry, water should be applied. Beets so buried will keep six or seven months with little loss.

"It is best to grow only one crop in four or five years on a single field, as otherwise the soil will be exhausted aud insects and parasites increase, so that great losses would oceur. Beets should follow grain or barley, and after the beet the best erop to plant is barley."

\section{HARVESTING THE BEETS.}

The beets may be harcested either by hand with a hoe, spade, or fork, or by simply pulling them from the ground, or by a harvester drawn by horse power. Some adrantages are claimed for each method. If the harvesting be carried on by hand, care should be taken that the instrument used should not strike the beet, since it is certain that every time the beet is punctured or bruised a certain loss in sugar will ensue unless it is immediately worked. It is estimated that in harvesting by 
hand each hect, on an arerage, will lose from 15 to 20 grams of its weight, or very nearly a ton per acre. For the Bajac harvester figured it is claimed that the beets are entirely loosened from their position, so they can be easily remored by hand with mnch less dauger of being bruised or broken than any other method of harresting. It is also estimated that by mechanical harvesting a more complete removal of the beets from the soil is secured, since when the harresting is done by hand many roots are left umoticed in the soil. According to some estimates from 1 to 3 tons of beets may be left per acre when the harvesting is done by lankl. It is further claimed that by the mechanical method of harresting the beet, being neither bruised nor punetwed, is more readily handled for the purpose of preservation, without being exposed to the least source of loss.

It is probable that in this comntry the meehanical method of harresting beets will be almost tho sole one employed for all eommercial pur-

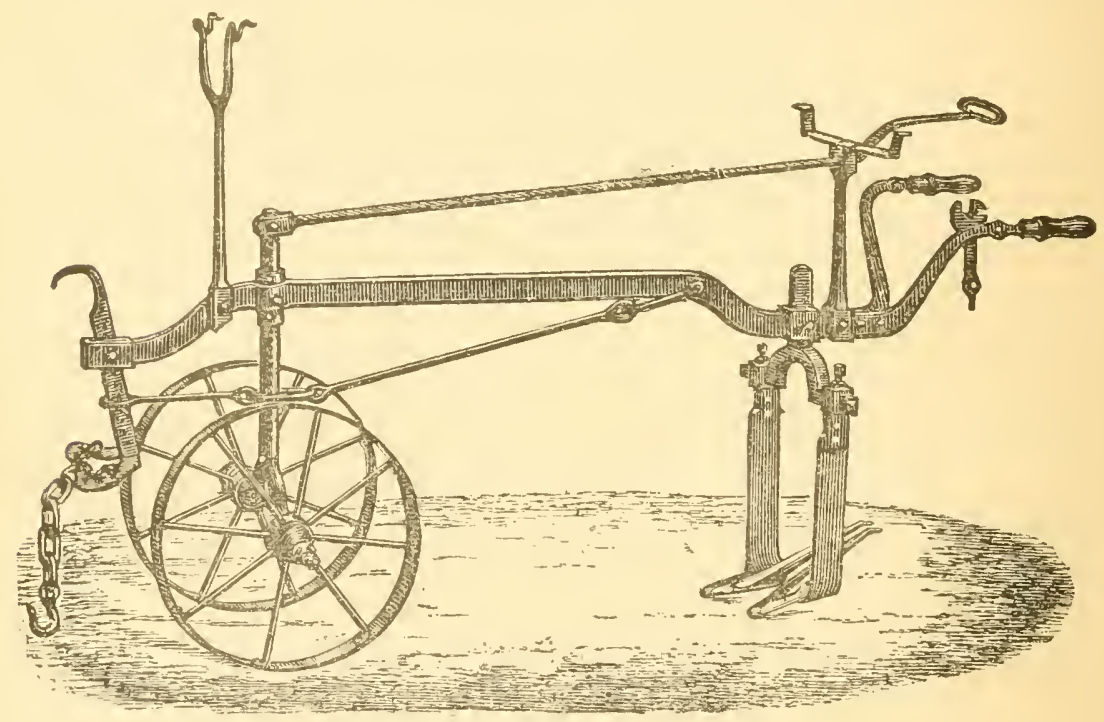

Fig. 30.- beet harvester for one row.

poses; but meanwhile, where beets are grown only in small quantities and before the introduction of the proper machines for harvesting, it is probable that harvesting by hand will be more common, especially for small plots.

A note has already been given in regard to the time of harresting, which should begin as soon as the beets are thoronghly matured and before they have an opportnuity to take a second growth or be exposed to freezing temperature. In some places in California, as has alrealy been stated, the harresting begins as early as the middle of Angust, while in the Northern, Central, and Eastern States it had best be postponed at least mitil the middle of September, and perhaps better until the middle of October. 
Harvesting the hects is best done by implements derised for that purpose, two of which, made by Bajac, are shown in Figs. 30 and 31.

The first one is a machine for harresting a single row at a time and the second one indicates the beets canght in the prongs of the apparatus arranged for two rows. Harvesters are also built to take three rows of beets at a time.

Mr. Lewis S. Ware, editor of the "Sugar Beet," who attended the Universal Exposition in Paris in 1859 for the purpose of making astudy of the sugar-beet exposition at that point, makes the following remarks in regard to harvesting: *

"Beets, like other plants, require a certain number of legrees of heat for their complete maturity. Just when this periorl is reacher is diffi. cult to determine; one tact, however, remains certain, that whaterer the theories are respecting onter signs ther can not possible hold good for all conlitions of weather, elimate, ete. That the leaves are brown

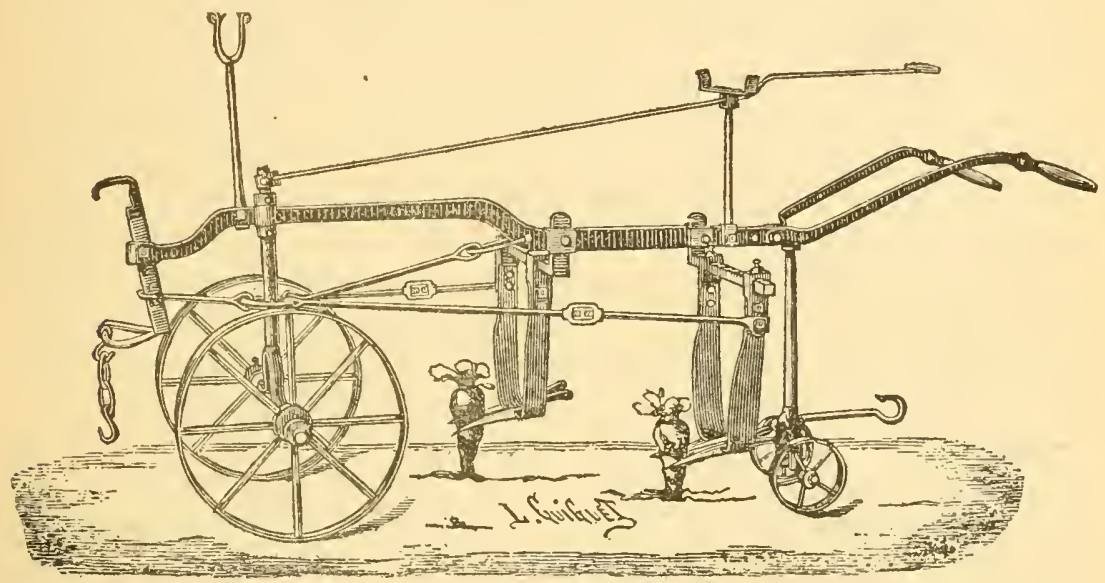

FIG. 31.-Beet harrester for two rows.

or corered with charaeteristic spots or other indications when the greater purity of juice has been reached must remain vers empirical. Many manufacturers have suffered from early barvesting where farmers have depended upon outer signs of the general appearance of the field, sucl as a yellow or green color, ete. Some agronomists maintain that there exists a proportion between the weight of the leaves and the root, the latter being almost a constant at 65 and 35 for the leares in a weight of 100 pounds. This ean not be a constant, as it varies with the variety of beet. Others contend that a proportion of this kind is more reliable than any system of analysis.

"In France the harresting oceurs at the end of September, and during October cold weather frequently commences. The farmer too fre. quently considers his own interest, and neglects that of the manufact- 
urer; if he leares the beet in the ground for a considerable period it is solely with the hope that the weight may increase; when this ceases, from his point of riew, the roots shonil be harvested.

"There are, however, cases where experience teaches that certain portions of the field should be harvested earlier than other parts; but unfortmuately it frequently happens that hands are then secured with diffienlty, and the famer is mable to furmish the roots at the faetory in the best possible condition. One plantation may be in the most clesirable conlition, while another may not reach the necessary maturity for several weeks afterwarls. It necessarily follows, that if the entire crop is harrested at once, it will fiequently result in a considerable loss to the manulicturer, and may represent 1 per eent. difference in the yield.

"On small areas special harvesting spales are used, or frequently a sort of fork. The latter has evidently the disadvantage of bruising the root, resulting in a lecreuse in sugar percentage. Whatever be the method adopted, the roots when taken from the ground are shaken to rid them of adhering particles; frequently the neeks are then sliced off, and the roots covered with leaves to protect them from the sun, rain, ete. Many farmers simply make piles of their roots, covering the same with thin layers of earth, awaiting the time for hanling either to the factory or the silos. It has been frequently noticed that there results an increase in the sugar percentage of the roots during the several days they remain in the piles. All the hand methods of harresting havo one important objection, viz, the dificulty of obtaining the full labor of men or women, owing to the fatigning nature of the task.

"Viallette recommends harresting with a plow, the coulter being taken off.' Two horses are required and the plow is rum alongside of the row, about "s eentimeters beyond the bect, throwing the earth to one sicle; children follow the plow, and collect the roots. The objection to this method is, the fields are always in bad condition after a rain and carting from them is almost impossible. 'The cost of harvesting with the plow is $\$ 7.40$ per lectare.

"It has not been many years since the Bajac beet harrester was introduced to the publie, and since then it has mulergone lut few modifications ats regarls the general working. It is constructer entirely of steel, and is very light and simple in its mechanical working and ar. rangement. 'To the fore wheels is attached a well-balaneed rertical bar, with a series of horizontal holes, into which is run the pin holding the horizontal shaft for the support of the harvesting blades.

"The blates are manle of the very hest steel, and are so constructed as to offer hut little tration during their working; their penetration in the soil haldy affects the upper surface. The slight slaut of the blades, when in contact with a bect, forces it "pward, and the operation is completer ly a peculiar vibration given, caused by a portion of the blacle haring an elliptical section. As soon as the implement moves 
forward, the loosened roots fall back in to their respective holes. Under these circumstances, there ean be an interval of several days before collecting them for the factory. During this period, as they are not exprosed to the open air, there is no danger of second growth prodnced by rain, ete. The workivg of the Bajae harvester requires but little experieice, and at a f'ew minutes' notice hands are said to be able to handle it.

"The lireetion of the harvester is letermined by a lever within easy reach of the conductor. The depth of the harresting blates may bo regulated according to requirements. It is rery evident that the work of this machine is preferable to hand harvesting; not only is it better done, but the cost is rery much diminished, aud need not be more than $\$ 1$ an acre, regardless of the distance between rows. Practical experience appears to demonstrate that the siving is about 30 per cent. of the amount harvested. Small, alhering roots not being removed, the beets are in a perfert eondition when clelivered at the fictory.

"Before mentioning other allantinges of the implement unfer consideration, it is interesting to gire some eren more recent types of the Bajac liarvester.

"Owing to the success obtained with this machine it has been sug. gested that a two or three line implement wight render excellent service; both of such are on exhibition. The general arrangement is the same as with the one-line description.

"The work in both eases is rery satisfactory, and 4 acres with the two-line implement and 5 acres with the three-line type may be harvested in a day of ten hour's. In the latter case the traction is cousiderable, and requires at least four horses. If, in certain cases, beets are harrested rapidly, the operation may result in eonsiderable profit to all interested. Interviews and conversations with farmers have convinced the writer that the Bajac harvester is the best in existence. Beetsover 1.12 feet in length are extracted from the soil, which conld not be aceom. plished by any previons appliances. The fact is, we have seen with their tip enls, so to speak, a distance of nearly 3 feet from the neck, taken from the soil after these harresters had finished their work. When we consiler that the richest portion of a beet is that which was previously left in the ground after harvesting, we have no difficulty in realizing the excellent services these implements are destined to render.

"Candelier's beet harrester appears to be very original in design, and was in use for the first time in 1885. Its work is very satisfactory, and certainly much more economical than could be done by hand. The arrangement of its several parts is calculated for the best results.

"The necessary traction to work this implement is said to be very slight, two horsis, howerer, are rerpired. A fact not to be disputed $25174-$ Bull. $27-\ldots$ 
is, that the soil is very slightly disturbed; the fore wheels determine the direction of the work and supyrort the working parts. The depth of penctration may be regulated by a serew, while the conlter, placed in front of the harresting device, opens the soil. This is said to dimin. ish the resistance the barresting tool and its flat slanting smport woukl offer. The circular disk between the fore wheels slices off the leares as the row of beets is harresterl. Under these cirenmstances, as is frequently the ease, they lo not eollect against the coulter or form an obstacle dificult to surmount.

"Camblelier hat on exhibition another type of harrester much simpler in its eonstruction than the foregoing. The arrangement of fore wheels and attachnents permit the slanting of the implement in any direction. In the working of this harvester the beet is seareely touched, the blatle fassing under the root without bruising the same."

REMOVING TIE NECK OF THE BEET.

The upper part of the beet buaring the stems of the leaves and the part which is most exposed to the sun and hight is known as the neck. Before the beets are manufactured it is necessary to remove this neck, both on aceomut of the poor quality of sugar juice which it contains and on acemut of the large amount of mineral salts found therein. Two methods of procedure are followed. In one case the neeks are removed at the time of harvesting, and before the beets are siloet. This method saves one handling of the beets and prepanes them at onee for washing and mannfacture. The other method eonsists in siloing the beets before the removal of the necks, and postponing this process mutil they are reatly for manufacture. This method is preferred for the following realsons:

When the neeks of the beets are ent the juices of the plant escape, incluting a portion of the sugar, and fermentation is easily set up in the silos. It is therefore probable, on the whole, the beets will be preserved much better in the silos withont having the neeks removel. According to Bajac (Bulletin de L'Association des Chimistes, April, 1S90), harresting should take place before the beets lose their vigor, and in place of removing the neeks and sembing the beets at once to the factory, or silo, they should be placed in small piles, together with their leares, of from 70 to so centimeters in diameter and of equal height. These piles shonld he quite conical and with the leaves turned out. The smmmit should be envered very carefully, in order that the water and fiost may not penetrate it. In place of separate piles, rows of such berts conld be established along the length of tho field, aud being left thus for a fortnight, the beet would finish its maturation with its leaves still at:ached to it. It would lose scarcely anything in weight, and it would gain in tensity and, probably, in sugar. 
In regard to density, experience has shown that beets harvested ou the 20 th of Sentember and showing at that time a juice of $1.072 \mathrm{sp}$. gr. which were preserved with their leaves as above mentionel, gained in six lays .006 in deusity. Experiments carried on for a month from week to week upon beets from the same field, some having the necks ent and the other's preserved with their leaves, showed in each instance an increase in tensity, while the decrease in weight of the whole beet was most sensibly marked in those in which the neck was cut off. Some of these beets exposed to rain on the 20 th of November showed some cnrions phenomena. Those in which the neck was cnt had lost.003 in Iensity, while those with their leaves remaining had lost ouly from .001 to .005. Beets with th necks cut which had bern liept for a loug time wre found almost dried out, while those in which the leaves had not been renoved were but little affected.

\section{IIRVEST AND I'RESERVATION UF THE BEETS.*}

"If circumstances of labor, commencement of mannficture, weatler, etc., allow, the beets should be gathered at the time when their out warel "lplearance indicates their maturity; that is when the bright green of the leares gives place to a lightor and nore yellowisl color and the older leares wither and fall off. This is a sign that an arrest of the develop)ment has commenced and beets gathered then are best adapted for pres(rvation and mannficture even thongh they may not have the highest sngar eontent. Bents which are harvested a short time beforo this period ripen somewhat afterwards in the silo, hut generally do not keep so well.

"When the beets are gathered the leares are cut off and they ane immediately covered with eath in small heaps. With beets that are not to be liept very loug it is hest to eut off only so much of the head as may be necessary to remove the leaves so that they hang together. It it is desired to remove more of the crown it is better to lo it in the filctory immediately before the beets aro worked up. OnlF at the commencement of the campaign when the beats are talien directly from the field is it alvisable to ent ofl at once all that is necessary. Generally the beets that have beeu cut close show no tendency whatever to sprout, that is to show leaves in the silo. But their mot sprouting is a sign of the cessation of all vegetable life and is generally accompanied by an undesirable change known as "harkening" in the juice, which is more injurious in the manufacture than the development of spronts, and which latter, if it has not progressed too far, is preferred by the manufacturer.

"Varions forms of plows are in extensive use for harresting the beets; they are imlispensable where hand-labor is searce. They simply loosen the beets $n$ the ground so that they may easily be drawn out, and do no: injure the roots. 
"Tlie preservation of such beets as are to be worked up during a season extending over sereral months flemands the grreatest care and attention to the climatic conditions. They must be protected from frost, which womld burst the plant cells of the beets amil cause them to spoil rapiclly after being thaweal ont. Moreover, tro much evaporation of the water must be guarled against, as this produces a wilting of the beet, which wonkl have the effect eventually of injuring the juice and the keeping qualities of the roots. Finally, too large piles of bects produces an elevation of temperature which heats them, and the spoiling of the beets follows in consequence. From these requirements it may be laid down as a rule, at least for the climate of Northern Germany, that beets should be placed in heaps or silos whose hright and breadth are small cnough to prevent the rlevelopment of heat, and these should be immediately covered with a layer of earth, which should be sufficiently increased from time to time so that frost cun not reach the beets. The layer of earth also afforts protection agaiust too nuch spronting or wilting in consegnence of too much warmth. The proper treatment varies somewhat in conserguence of differences in climate and peculiarities of soil, but the following general directions may be given as of universal application.

"The beets should not be alowed to lie and wilt after harvesting, but covered as soon as possible. The silos, made as small as it is safe to make them, shonli point north and south.

"The use of straw is to be aroided except as a temporary protection against wind, sun, aud frost, and should then be replaced with earth as joon as possible. Large beets shonld be preserved in small silos; with small beets the silos may be larger.

"Care must be taken not to clamage the beets in pntting them away, and injured roots should be carefully picked ont. As a winter covering, 3 feet of earth is given in north Germany, thongh the last foot is not alded at once. To facilitate their remoral the piles should be arranged lengthwise along the drireways.

"For loug keeping the top of the silo is generally roof-shaperl, sometimes roundel off; the bottom is male either on the surface or slightly below it. In some cases such a form is chosen as gives a right-anglederosssection. There nothing to show that the form of the silo or the nature of the soil exerts any influence on the preservation of the heets. The size of the silos used varies, and especially according to their situation, whether they are placed in the tields or near the factory. In the east of Germany large silos prevail, in the west small ones seem to be preferred. Breadth and depth vary less than the length; the breadth from 4.13 to 6.1 feet, the depth from 3 to 6 feet, seldom over 6 , and only in a few instances less than 3. Where the silos are sunk below the surfice it is generally 1 to $1 \frac{1}{2}$ feet, sehlom less. The quantity of beets that can be placed in a silo depends principally npon it length, and varies all the way from 6 or 7 tous up to 25 or 50 and more. When 
placed in the field generally each aere or half acre has its special silo. Generally the contents of the silo are giren in running yards of the length of the silo, and are usually about 1 to 2 tous per yard. Where the beets are heaped up according to the Belgian method, the piles hold rery considerable amounts, eren up to 1,200 tons.

"The covering is done with loose soil packed closely at the bottom, lout being less dense toward the tol. In the first weeks the top is left open, or very lightly covered, and heaped up when it becomes colder. The thickness of the covering raries from 1 to 3 feet, the latter thickness not being found rery generally in the east. The nse is sometimes made of other materials, for example, straw, etc. A thin layer of straw is covered over with earth, except at the top of the rilge. Some spread a layer of straw below the beets. It is generally accepted that in the silo a loss of sugar of about 1 per cent. takes place.

"A special method of siloing consists in learing openings in the earth covering at the sides of the silo to keep the temperature low inside. The objection to this is that the beets quickly wilt around these openings, and that they can not be closed quick enough to provide against a sudden fall of temperature. Some places and climate require especial precautions.

"Babrinsky has formulated the following rules for silos in southern Russia, based on many years of observation and experiment:

"(1) No beet should be further than 1 meter from fresh air.

"(2) For every cubic meter of bects there should be 30 square decimeters of evaporating surface.

"(3) The air in preserving cellars slonld be daily renewed if it be abore $40^{\circ} \mathrm{F}$. in temperature.

"(4) Beets do not lose more than 10 to 12 per cent. of their weight by evaporation.

"(5) If the beets are wilted ou harresting they should be moistened with water, and a large number of rentilating canals be built in the silos or cellars.

"According to Walkhofi", in sonthern Russia the bects are entirely buried in the ground, in a eanal with steep, sloping walls. The bottom is corered with a sort of a grate of firewoorl, on top of which the beets are piled "1p to within a few inches of the surface of the earth. In the center on top is laid a triangular-shaped wooden gutter to increase the amoint of evaporating surface. The whole then receires a covering of straw, which is increased or diminished in thickness according to the temperature indicated by the thermometer inserterl. A sort of ventilation is accomplished by canals at the side leading outward, so that at night the cold air may be permitted to enter, while during the warmth of the day they are elosed.

"Preservation in eellars is also much used in Russia, according to Walkhoff. These are built to project but slightly above the surface of the ground with their roofs, which are covered with earth. The bottoms 
are covered with interlaced twign, and the laser of beets is about 3 feot thick. Ventilation is secured by air-passages in the sides and roof. This method is rather more expensive, but the preservation is better insured.

"It has long been a desideration, so far unfulfilled, to find some means whereby the heets might be protected, on the one hand from the consequences of overbeating and on the other from freczing, as well as from too rapid sprouting and from rotting; that is to say, in a good sound condition and without loss of sugar, for some length of time. On accomnt of this not being yet attained, the tendency is to shorten the working season and to increase the quantity worked each day. The discussion of this question and the proper limits to set is of little advantage. It is to be hoped that more attention will be paid to observations on the changes mulergone in the silo, upon which improrements in the methods used may be based." 


\section{SILOS AND CELLARS.}

The following illustrations of silos and cellars are taken from II Inrtrie's Report 28. In California silos are not required, and the beets may be preserred in large heaps as shown in Fig. 43:

Preserring treneh (Basset).

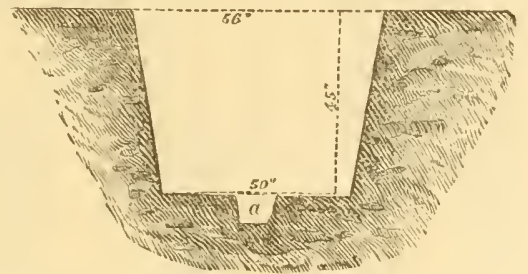

FIG. 32.-Trench open; $\boldsymbol{a}$, drain trench.

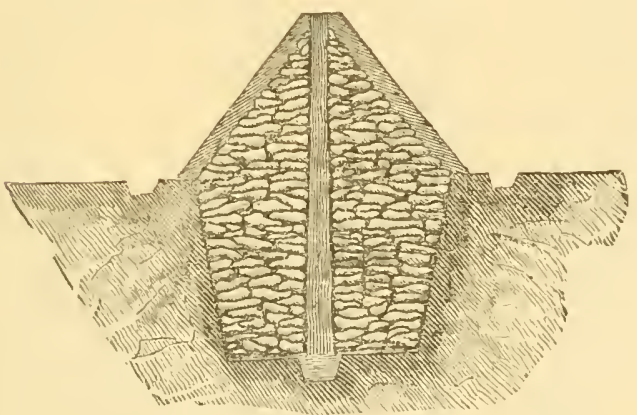

Frr. 33.-Trench filled, with ventilating shaft arranged.

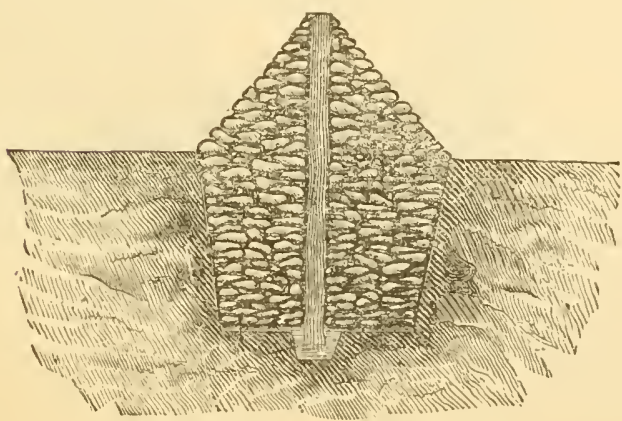

FIG. 34.--T'rench filled ant covered. 


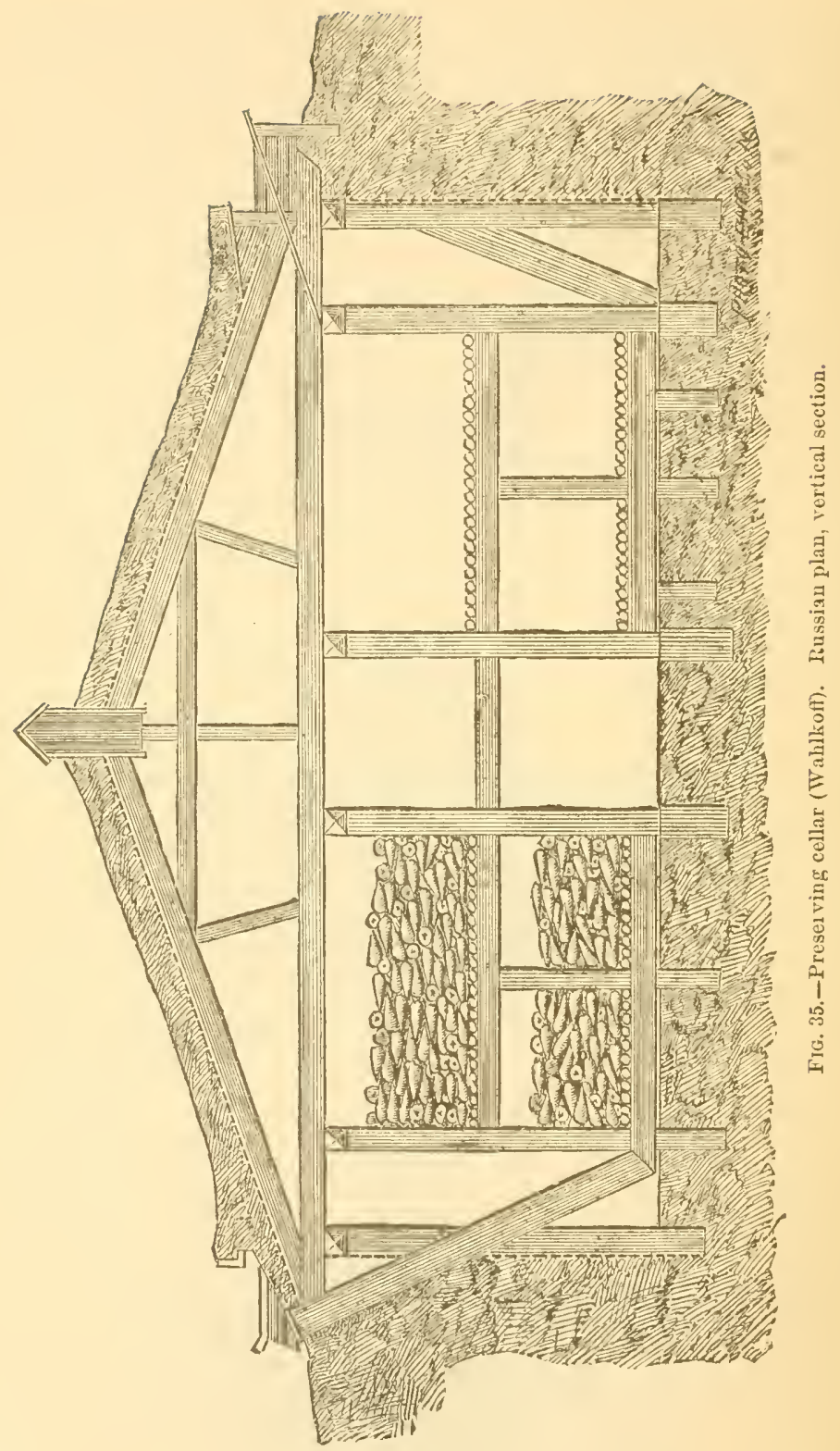


SOIL.

As has been indicated alrealy, the character of the soil for the production of beets should be determined by actual trial. No definite rule can be given in regard to a soil from its chemical composition alone. In general it may be said that any soil which will give goorl erops of the cereals and other farm products will produce good sugar-beets. A sandy loam with a clay subsoil is sometimes recommended as the best for sugar-beets. In California the deposits of the eoast valleys which are alluvial or lacustrine in nature have heen found to produce a sugarbeet of remarkable riehness. The sauds loams of the P'latte Valley in Nebraska have also been found to produce a rieh beet. I do not know that any scientific trials have been made in the growth of the sugarbeet on the black prairic soils so common in the prairie regions of Indiana, Illinois, and Iowa. It seems to me reasonable to suppose that these soils, after they hare been enltivater for a few sears in other crops, might in many localities produce a sugar-beet of high quality. The black color of the soils allows them to become most easily warmed by the early suns of spring and would tend to give an impetus to the growth of the beet which would help to carry it through in all the ricissitudes of elimate mhich it miglit subsequently meet. There are many of these prairie soils which are not only lark in color but are of a loamy nature in texture and eapable of being easily worked to a considerable deptl. Soils which have been in eultivation for a few years are better suited for the production of the sugar-beet than virgin soils containing large amounts of organic nitrogen. All soils deroted to sugar-beet eulture should have good natural draiuage or eise be artificially lrained, so that the tap root of the beet may not reach the water-liue of the soil. Very thin soils, or those which reach a hard clay subsoil at a small depth, are not suitable to beet culture, on account of afforling no facilities for the penetration of the tap root. Beets grown in such soils are likely to protrude above ground and thus lose a large part of their sugar-storing room. Any soil, selected for the purpose, should hare a tillable rlepth of from 12 to 15 inches, shonld be well dirainel, mellow in texture, not. hecoming hard and impacted after rains, and lendiug itself easily to tillage.

It is not necessary, in this place, to gire many chemical analyses of soils which are found suitable to beet eulture since these analyses differ very little from those of soits suitable for other crops. In general, it may be stated that the ehemical analysis of a soil suitable to the growth of beets must show the ordinary percentages of the mineral substances necessary to plant growth, viz, phosphoric acid, potash, and lime. Other mineral substances which enter in minute quantities into beets are always found in sufficient quantities in all soils except those of an 
extremely sindy nature. The presence of a consiclerable quantity of carlsonate of lime is highly essential in soils growing sugar-beets, not only on account of the pirt it takes in supplying plant mutriment but because of its tenflency to prevent the soil from becoming son by neutralizing any acids which may be foum therein, and further from the well-known effect of lime in prodncing flocenlence of the soil which renders it difficult to impact and makes it more easily tillable. The presence of a large amonnt of earbonate of lime in a soil makes it porous and easily penetrated, both by the rootlets of the plant and by capillary moisture. 'This condition of the soil tends both to free it easily from water during times of excessire rains and to supply it with moisture in seasous of drouth. It may he well to ald also that the field in which the beets are planterl shonld be one freely exposed to the light and air, not shaled by surrounding forests nor lying in a position where its natural inclination will potect it from the rays of the smo. The importance of sunlight in the production of sugar in the beet will be mentioned in another place.

Stammer makes tile following statements respecting the soil :*

"It may not be alsolutely reliable to say that a soil, because of given chemical and physical properties, is perfectly alapted to the growth of beets; nevertheless, it is in general safe to accept that a soil which is of a porons nature, deep in staple, rich in humus, and more disposed to a loam or calcareous, than to a saud character, is very suitable for the cultivation of the beet, and especially if the subsoil drains off the water freely and the surface of the gromml lies well towards the sun. Of comse, it is inclndel that not any of the ehemical elements, sueh as potassimn or phosphorus, which the beet is in great request of, are meagerly present in the soil.

"The lime content of the soil is most important to the beet, and soils which appear to contain but little of that compound in a free state, which is indicated by the absence of the $\mathrm{CO}_{2}$ greneration when treated with hyrlrochloric acid, should be well limed for the growing of beets. The action of lime upon clay soils anci such as are of a som nature, is improving physically as well as chemically by giring a milder tone to them composition and effects.

"It is further essential, or at least arrantageons, that a soil for the cultivation of beets should be located at a good altitude in order that it have a free expanse to air and light. This observation has been recently established by Hanamann in his experiences, extending over several years, in growing beets in an experiment garden, the products of the experiment plots heing meager and poor in quality in comparison with beets grown in the open field. A series of experiments conducter by him have led to the conclusion that the free and elevated position of the land has a decirled inflnence upon the nature and ruality of the

\footnotetext{
"Stammer, Lehrbueh der Zuekerfabrication, p. 169.
} 
beets; and further, that the size of the beets stands in inverse proportion to their content in sugar and salts, and finally that the fine pulverized condition of the soil exerts a great effect upon the grow th of the roots, i. e., upon the yield of the crop.

" With the beet the ehoice of a suitable soil has its special difficulties, as it grows so deep in the earth, and draws much of its essential nutriment froni stratas which enter less into consideration in the question of its adaptability for other erops. The nature of the so called subsoil is, withont dloubt, of more decirled influence upon the growth of the beet than of most other erops, and for the determination of its quality many of the essential stand-points are lacking. 'This is also the reason why previous experiments have given so few reliable conclusions upon the action of fertilizers. The part of the soil is fertilized from which the beet draws its nourishment during a large part of its existence, it is true, but not during the perion of sngar formation, and the chemieal means (such as the almixture of chloride of soda) which carry the fertilizing materials to the subsoil, are by no means suffieiently certain in their action that immediate results can be expected from experiments with them.

"On the other hand, the subsoil enltiration which brings up the lower layers of soil for the nourishment of the plant, has produced the best and most desired results in beet enltiration, and all the observiltions upon the inflnence of the use of the steam plow npon the beet harrest, and they hare resulted favorably withont exception, lead to the sime eonclnsions.

"Chemicil analysis, especially in its present condition, has little ralue for beet cultivation, in so far as it relates to the composition of soils gen. erally known as loams, and as regards physical properties, actual experiment is the best means to determine whether a soil is adapted to beet culture or not.

"Naturally soils which do not possess the above general characteristies, for example, sandy, wet, stony, ete., are extuded. while, on the contrary, such as are known from their origin to contitin an ample sup). ply of the eonstituents of beet ash may be presumed in all probability to be well adapted to beet eulture. Snei a eonchusion, however, should not be draw too hastily from a single experiment; the effect of the necessiny preparation of the soil makes itself felt but slowly, so that it is bronght gradnally into proper eondition."

'TIE CLIMATE AND SOILS OF CALIFORNIA IN THEIR RELA'TIONS TO BEET CUL'TURE. *

"The soils and climate of California have been carefully studied by Prof. E. W. Hilgard in his report published in Volume VI, Tenth Cen. sus, p. 665, et seq. 
"The following table contains clata of thermal observations. It will be seen at once that the summer temperature of the interior valleys of the western or coast division is entirely too high for successful sugarbeet culture.

WESTELN OR COAST DITISION.

[Fom vol, vi, Tenth Census, p. 668.]

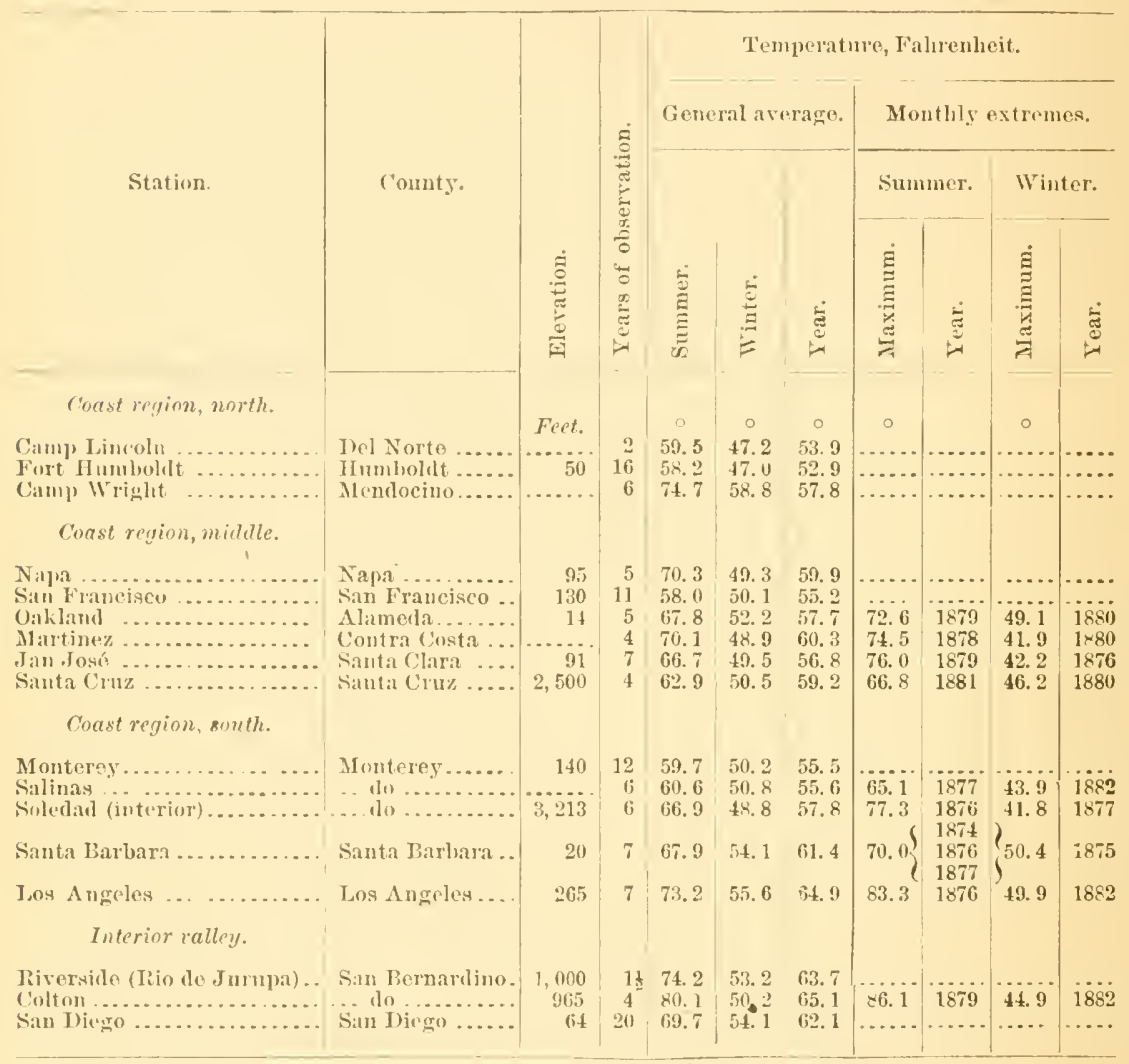


INTELUUR ANU E.ISTELAN HIVISION.

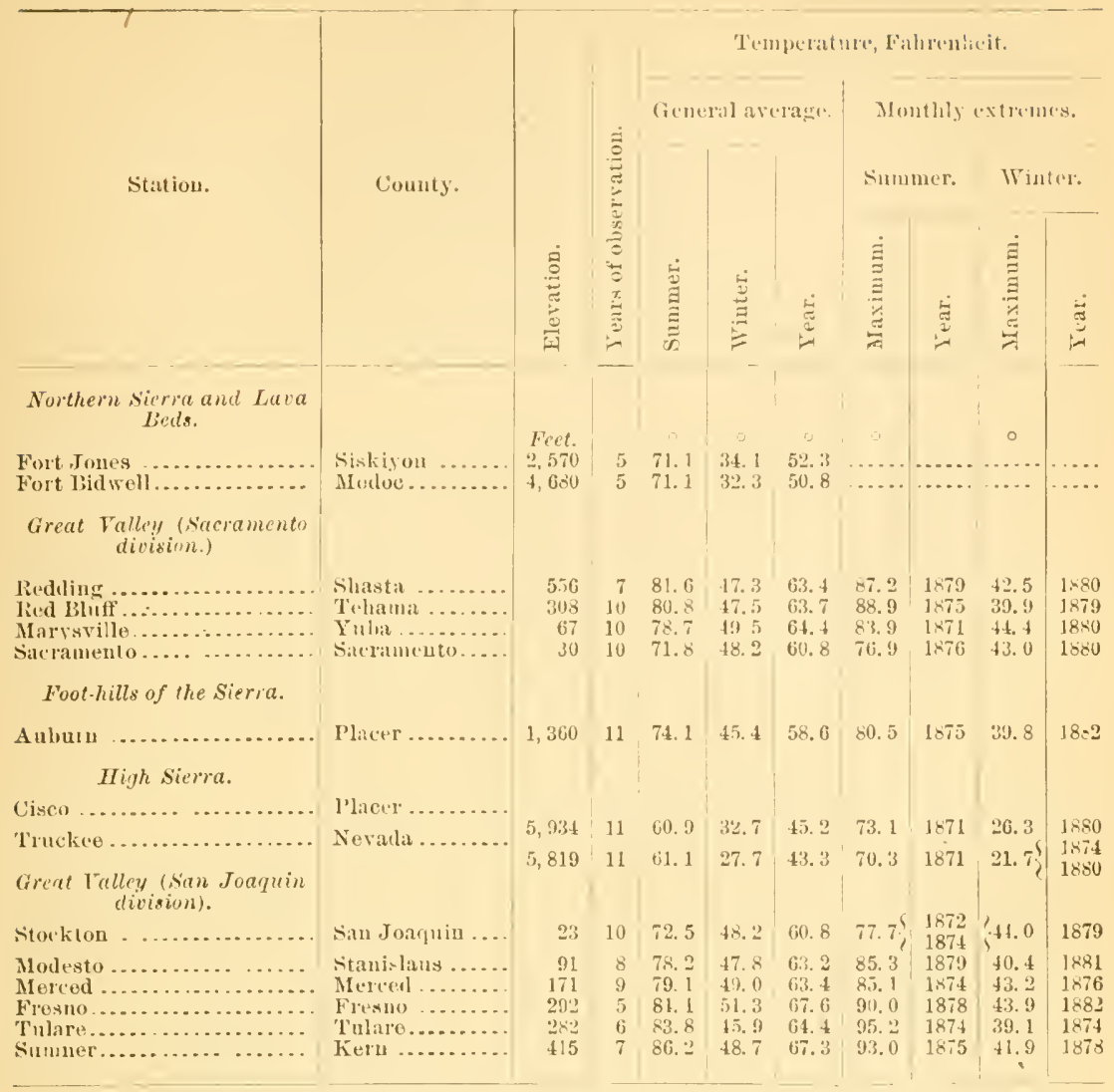

"Following is Professor Hilgard's description of the climate of Calliforuia :

As to the change in temperature in ascending the Sierra from the valley, the following statement is made by Mr. B. B. Redding in a paper read before the California Acadeny of Sciences in 1878.

"It has been found that the foot-hills of the Sierra up to the height of about 2,500 feet have approximately the same temperature as places in the valley lying in the samo latitule. It has also been found that with the increased elovation there is an inerease of rain-fall over those places in the valley having the same latitude, as, for iustance, Sacramento, with an elevation above the sea of 30 feet, has an amual mean temperature of $60.5^{\circ}$, and an average raiu-fall of 18.8 inehes, while Colfax, with au elevation of $:, 421$ f eet, lias an aunual mean temperature of 60.1 aud an aunual rain-fall of 42.7 iuches. 'Tlis nniformity of temperature and increase of raiu-fall appears to be the law throughout the whole extent of the foot-hills of the Sierra, with this variation as relates to tenperature, viz, that as the latitude decreases the temperature of the valley is contiuned to a greater elevation. To illustrate, approsimately, if the femperature of Reddiug, at the northeru end of the valley, is continued to the height of 2,000 feet, then the temperature of Sacramento, in tho eenter of the valley, would be continued up to 2,500 feet, and that of Sumer, at the extreme southeru eud of the valley, to 3,000 feet." 
"It is eurions to note that, as appears from Mr. Redding's statement, the lowest temperature thus far observed at the two opposite ends of the valley, Redding and Sumner, are the same, viz, 270 .

"It will be noted that in the sonthern region the difference between the snmmer means or between winter means, as well as between the anminl means, is quite small when Sinta Barbara and San Diego, both lying immediately on the coast, are compared. At Los Angeles, 20 miles inland, all these means are notably ligher; still farther inland, and with increasing elevation, the summer mean rises, while tho winter mean falls at Riverside, as well as more strikingly at Colton, although at the latter point the ammal mean is almost the same as at Los Angreles.

"To convey an easily intelligible idea of some of the climatie differ ences indicated in the table, it may be stated that while in the great valley a few inches of snow cover the ground for a short time nearly every winter as far south as Sacramento, and snow flurries are occasionally secn ereu at the upper end of the San Joaquin Valley, snow has fillen in the streets of San Francisco only once since the American oceupation to such a depth as to allow of snowballing (which during a few hours created a state of anarehy, and only a few times has enongh fallen to whiten the ground for a few minntes or hours. Hence the heliotrope, fuschia, calla lily, and similar plants endure year after year in the open air, while at a corresponding latitude in the interior they require some winter proteetion. Lemon and orange trees never suffer from frost on the bay, but their fruit also rarely ripens save in favored localities. In the interior these trees more frequently suffer from frost, but the high sum. mer temperature matures the fruit some weeks earlier than eren in the sonthern coast region. Cotton would, as a rule, be frost-killed in the great valley in November, while on the easst it might endure throngh several mild winters; but within reach of the snmmer fogs of tho coast it fails to attain a greater height than eight or ten inches the first season, and sometimes ean searcely sneeeed in coming to bloom before $\mathrm{O}$ ctober. Snbtropical trees, which in the cotton stages grow rapidly and luxuriantly, such as the crape myrtle, panlowia, eatalpa, mimosa (Julibrissin), and others, (ither grow very slowly or remain mere shrubs in the coast elimate, while in the interior they develop as in the Gulf States. The vine flomrishes near San Franeiseo, but fails to mature its fruit, yet it yields abundant and eboice erops near San Jusé, where the immediate access of the coast fogs is intereepted by a range of hills. It is thus obvions that, with the varying topography, the change in the direction of a valley or mombtain range, the occurrence of a gap or of a ligh peak in the same permitting or intereepting eommunication with the coast on the one haml or with the interior on the other; there exists innumerable local elimates, 'thermal belts,' sheltered nooks, and exposed locations, each of which has its peculiar adaptations apart from soil, and the reegnition and utilization of these adiptations require 
knowledge and good judgment, and eount heavily in the scale for or against success in agrienlture in California.

"Rain-fall._A s regards the rain-fall, the prominent peculiarity throughont the State is the practically rainless summer. While it is true that rain las been known to fall in every month in the year, the average amomt of precipitation during the three summer months is less than 1 inch in the greater portion of the States, and less than 2 inches eren in the most favored part, viz, the counties just north of San Francisco Bay. Frequently not a drop of rain falls in the interior valley and the sonthern region from the middle of May to November, and as the agricultural system of California is based upon the expectation of this dry weather, summer rains are not even desired by the farmers at large. Northward, in the mountainous ant platean regions adjoining Oregon, the season of drought becomes shorter, as is also the case in the high Sierras, and thus there is a gradual transition toward the fumiliar régime of smmmer rains andi occasional thunder-storms which prevail in Oregon ant Washington west of thé Cascade Range.

"Since the growing season, in the case of unirrigated lands at least, thus practically lies between November and June, and each harvest is essentialiy governed by the rains occurring within these limits, it is the universal and unconscions practice to count the rain-fall by 'seasons' instead of by calendar years; hence the current estimate of local rain-fill averages in California differs not immaterially from that of the nsual meteorological tables, in which the paranount distinction between the agriculturally 'dry' and 'wet' seasons is more or less obliterated. The data hereinafter given are therefore, as a rule, 'seasonal' and not 'annual,' and are largely those of the observations conducted along its lines by the Central ani Southern Pacific Railroad.

"The mean anr alal rain-fall of the greater (middle and southern) part of the State is less than 20 inches, the northeru linit of that region lying between Sacramento and Marysville, in the great valley; while on the Sierras, the region of rain-fall, between 20 and 26 inches extends as fur sonth as the heads of King's and Kern River's, furnishing the waters upon which depeuds the irrigation of the San Joarnin Valley; thence sonthward the rain gange rapidly descends to 8 and 4 inches, and less in the Kern Valles, the Mojave Desert, and the basin of Nevadil.

"A rapid decrease of rain-fall is observed in the great interior valley. From 42 inches at Redding, at the northeru end of the ralley, and 24 inches at Red Bhuff, 24 miles to the sonthwarl, the anmual mean falls to abont 19 inches at Sacramento and to 16 at Stockton. Thence sonthwatrl the rain-fall descemls to a mean of only 10 inches at Merced, 7 at Fresno, and 4 at Bakersfield, near the sonthern end of the San Joaruin Valley, separated only by the Tehachapi llountains from the western margin of the Mojave Desert, in which the rain fall is still less.

"Along the eoast proper Cape Mendocino bears the repntation of a kind of weather divile. Mariners expect a change of weather whenever 
they romul this cape, and on land it malks the region where the character of regetation begins to change rapidly from that of southern or midale California toward that of Uregon. At and immediately north of the cape the rain.fall reaches an anmul mean of 40 inches. A short distance sonthward, at Point Arenas, the annual fall is 26 inches, and from 23 to 21 inches in the region of Sam Franciseo; it falls to 16 inches at Monterey and Sauta Barbara, 12 at Los Angeles, and 9 at San Diego.

"Northward of Cape Mendocino the rain-fall increases rapiclly, rising to over 70 inches in the northwestern corner of the State. Inland from the coast the increase is less rapid, but the rain-fall rises at points in the Shasta region to as much as 108 inches in some years. Southwarl the region of rain-fall exceding 20 inches extends in the coast range slightly farther sonth than in the great valley, so as to include all lut the most sontherly portions of the comties of Somoma, Napa, and Marin. Southward of San Francisco again a region of more abundant rain-fall ineludes the westeru Sauta Clara Valley, Santa Cruz Mountains, Monterey Bay, and the lower Salinas Valley, where from 13 to 16 inches fall anumally.

"Ascending the Sierra from the great valley there is a rapid inerease of rain-fall, which, from data furnished by the records of the railroad, may be estimated at 1 inch for every 100 to 150 feet of ascent.

"The following tables show more in defail the rain-fall averages for representative points, the data being lericed mainly from the observation made under the amspices of the Central and Southern Pacific Railroad and given for 'seasous' reaching' from July to June inclusive.

WESTERN OR CO.AST DIVISION.

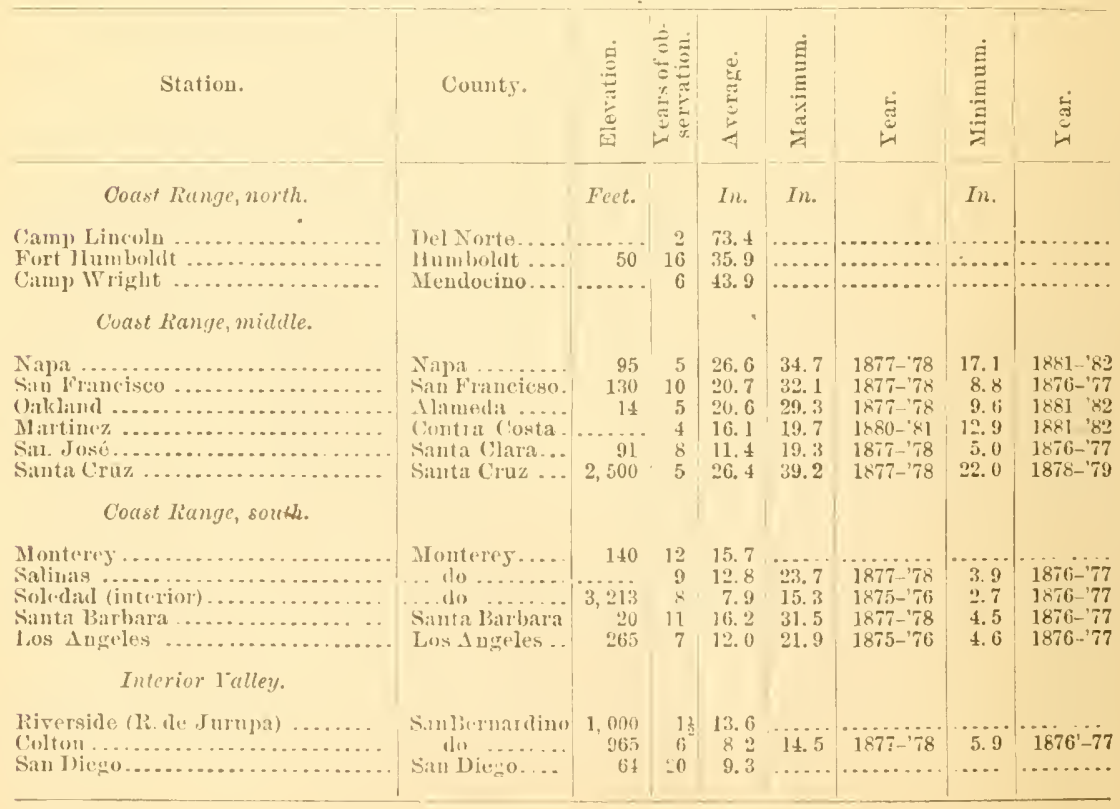


INTELIOR AND FASTELI HIVISION.

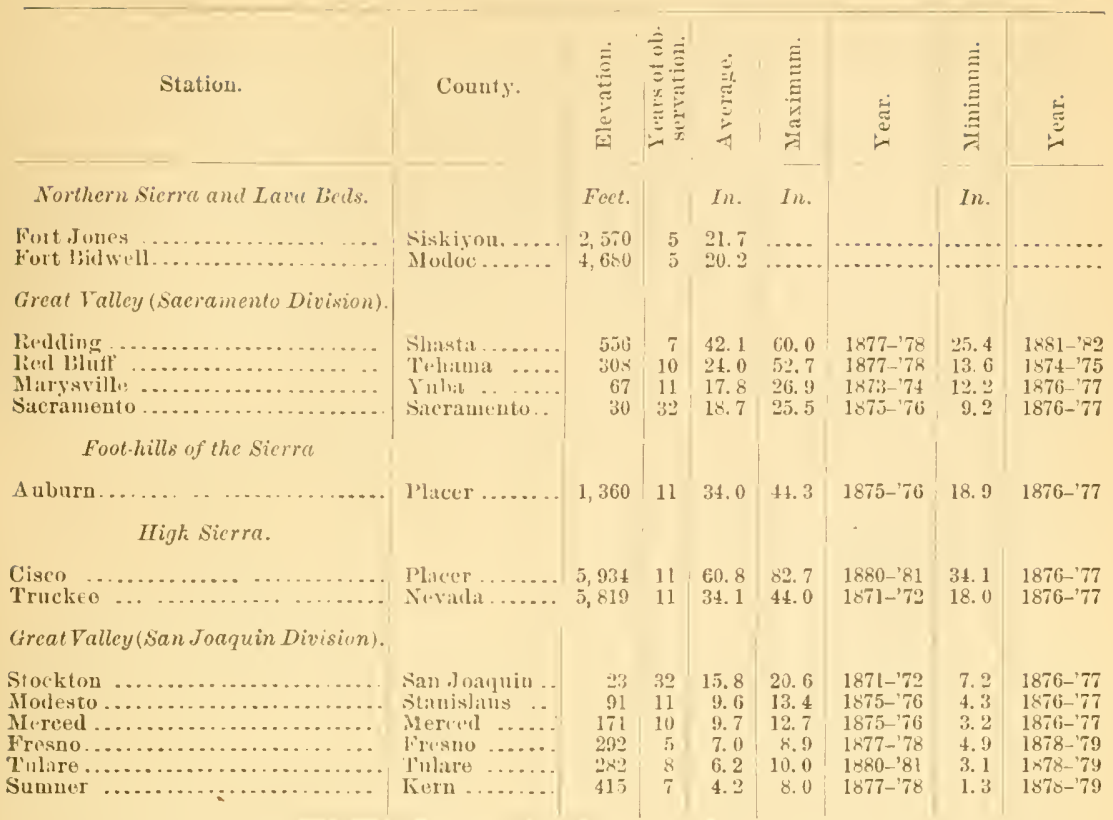

"Were the rainfalls of 20 inches and lesis distributed over the whole or even the greater part of an ordinary season of the temperate zone, it would be altogethel in adequate for the growing of cereal or other usual crops of that zone; but since in California nearly the whole of it usually falls within six months (November and April inclusive), and by fir the greater part within the three winter months, during which a 'growing temperature' for all the hardier erops commonly prevails, it becomes perfectly feasible to mature grain and other field crops before the setting in of the rainless summer, provided only that the aggregrate of moisture has been adequate and its distribution reasonably favorable. The grain sown into the dust of a summer-fallowed field begins to sprout with the first raiu, and thenceforwall grows move or less slowly, but continuously, through the winter. It is ready to head at the first setting in of warm weather, from the end of March to May, "tecording to latitude, aud becomes ready for the reaper from the end of May to the end of June. Once harvested, the grain may be left in the field for several mouths, thrashed or unthrashed, without fear of rain or thunder storms. As a matter of course, the grain-grower may also, at his option, sow his grain at any time after the beginning of the rains, and good erops are sometimes obtained from sowings malle late in February. Usually, however, the late-sowu grain is cut for hay when in the milk, in April and May, for, since meadows call form no part gf the agricultural system, except where irrigation is feasible, the $2 \check{1} 44-$ Bull. $27-8$ 
hay grasses commonly grown in the Eastern States are available only to a limited extent, and wheat, baley, and oats take their place. $A$ gain, there is no striet distinetion or limit between fall and spuing grain, since the sowing season extends from Oetober to February, Thus the winter months are a very busy season for the farmer in Californial, ats he has to wateh his opportunity for potting in his crops hetween rains. The time between lying-by and harvest is nearly filled up by gardening and haying operations. The latter are occiasionally interrupted by one or two light showers, rarely enongh to injure the quality of the hay. Protrated rainy spells or thunder-storms, ealling for hasty gathering of the ent grain into shocks, are mnknown in harvest time, as aro also spronted or spoiled grain, except when the sacked grain is left out in the fields so late as to catch the first antumn rains. It will thus be seen that midsummer finds the California graingrower comparatively at leisure.

"But while the culture of hardy plants of rapid development was the first and most obvious expedient resort ed to by the Ameriean settler's, in order to ntilize the fertile soils of the region of rainless summers, that of selecting eulture plants adapted to arid climates was the one naturally suggesting itself to the missionary padres, who bronght with them from the Mediterranean region of Europe the vine, the fig, the olive, the citrus fruits, as well as from adjacent portious of Mexico the culture of cotton, to which, however, but little attention was given by them, the growing of wool being better atlapted to the temper of their native laborers. And as they relied largely on irrigation for the success of their annual crops, it was only in very extreme cases that a deficient rain-fill so affeeted their interests as to give the fact a place in their records.

"Variation and periodicity of rain-fall.-While the means of rain-fall given above will not vary widely when any large numbers of years are taken together, the variations from one year to another are often sufit. ciently great to tempt many to invest hearily in putting in erops on the chances of a fitvorable season, which would bring a fortune at one venture, but sometimes results in a total loss and consegnent ruin to investor: Snch cases of agrienltural gambling were at one time not uncommon in the San Joaquin Valley esprecially, the turning point of protit or loss being a single light shower at the eritical time or the ocenrrence of a norther for a day or two. More ingennity has been spent in trying to forecast the weather for the season in time to letermine the chances of suceess, but it will generally be found that the oldest citizen, if he is candid, will be far more reserved in lis opinions than later comers.

"Howerer steady and reliable the summer climate may be, that of a California winter is most difficult to forecast from day to day and from week to week, and while there are certain rules that are ordinarily' comnted upon, the eases where 'all signs fail' are very fiveguent, and surprises are abundant. A discussion of the observations made from 
1849 to 1877 , by Dr. G. F. Beclier, late of the University of California, and now of the United States Geological Surver, seems to indicate as probable a cycle of thirteens years between extreme minima of drought years, and some data I have since obtained from the records of the missions seem to confirm still further this conclusion. The first minimum within the time of the American oceupation of California occurred in the season of 1850-'51, when the rain-fall at San Franciseo was 10.1 inches, and the third was the season of $1876-77$, with 10 inches. The next snceeeding season of minimum would be that of 1589-90. 
Chemical analyses of C'alifornia soils and

\begin{tabular}{|c|c|c|c|c|c|}
\hline 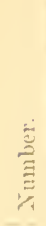 & Suil title. & Lociality. & $\stackrel{1}{\vdots}$ & Vogretation. & 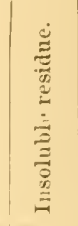 \\
\hline & 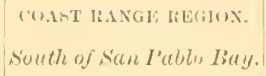 & & & & \\
\hline $\begin{array}{l}16 \\
182 \\
170\end{array}$ & $\begin{array}{l}\text { Yalley soil ............. } \\
\text { levidishmontainsoil } \\
\text { beweh-land subsoil ... }\end{array}$ & 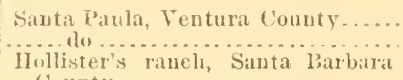 & $\cdot \begin{array}{r}12 \\
12 \\
12-18\end{array}$ & $\begin{array}{l}\text { Grass, horbs } \\
\text { Oaks....... }\end{array}$ & $\begin{array}{l}85.664 \\
74.930 \\
83.065\end{array}$ \\
\hline $\begin{array}{l}600) \\
6016 \\
7(12\end{array}$ & $\begin{array}{l}\text { Tpland soil ......... } \\
\text { Epland ham soil...... } \\
\text { Elhaparral soil ....... }\end{array}$ & 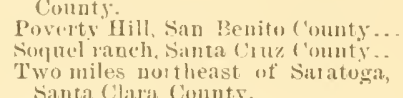 & $\begin{array}{l}12 \\
12 \\
12\end{array}$ & 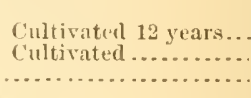 & $\begin{array}{l}85.596 \\
80.426 \\
57.449\end{array}$ \\
\hline 680 & $\begin{array}{l}\text { Valley soil ........... } \\
\text { Sandstone soil ........ }\end{array}$ & $\begin{array}{l}\text { Peseadero, San Mateo County...... } \\
\text { San Frincisco, San Francisco }\end{array}$ & 8 & $\begin{array}{l}\text { Redrood, pine, oak. } \\
\text { alder, buckeye, and } \\
\text { madrone. } \\
\text { Scrubby live-oak...... }\end{array}$ & $\begin{array}{l}78.084 \\
78.135\end{array}$ \\
\hline 682 & Saudstone subsoil.... & $\begin{array}{l}\text { County. } \\
\ldots\end{array}$ & 8-18 & & .70 .224 \\
\hline 613 & blark wax y arlobesnil. & Cobton ranch, Contra fosta County. & 12 & Sunflower & $50.961)$ \\
\hline 692 & Wark soil, rolling $11 \mathrm{p}$ - & Livermore Valley, Alaneda County. & 6 & $\begin{array}{l}\text { Seattering white oak } \\
\text { and poison-oak. }\end{array}$ & 80.262 \\
\hline 693 & $\begin{array}{l}\text { Ditrk subsoil, rollin:r } \\
\text { uplands. } \\
\text { Redt grivells soil, roll. }\end{array}$ & .......do & $0-10$ & ..... & .80 .658 \\
\hline 649 & $\begin{array}{l}\text { Fed gial velle soil, roll- } \\
\text { ing nplands. } \\
\text { Sediment soil.......... }\end{array}$ & Arroyo del Valley, Livermore $V$ al. & & Slarubs & $71.156^{\circ}$ \\
\hline 1 & $\begin{array}{l}\text { black atlobe soil...... } \\
\text { Subsoil No. } 1 \text {........ }\end{array}$ & $\begin{array}{l}\text { ley Alamedic County. } \\
\text { University grounds, Alameda } \\
\text { County. }\end{array}$ & $\left|\begin{array}{l}12-22 \\
22-30\end{array}\right|$ & $\begin{array}{l}\text { some: sycamore. } \\
\text { Live-0aks, large...... } \\
\text {... } 10 . . . . . . . . . . .\end{array}$ & $\cdots$ \\
\hline 1 & $\begin{array}{l}\text { Solobe ridge subsoil.. } \\
\text { North of San Pablo Ia } a y .\end{array}$ & ....... do $\ldots . . . . . .$. & $10-20$ & $\begin{array}{l}\text { Scatterer livo-oak, } \\
\text { swall. }\end{array}$ & ....... \\
\hline 185 & Valley soil ........... & $\begin{array}{l}\text { (x. F. Hoopor's rineyard, Sonoma } \\
\text { Cointy. }\end{array}$ & 12 & Oaks and gape-vines. & 76.089 \\
\hline Ins & licd mountain soil... & .......d $v^{\prime}$ & 12 & $\begin{array}{l}\text { Oaks, manzanita chap. } \\
\text { artal. }\end{array}$ & 34.392 \\
\hline 207 & Eel River bottom soil. & $\begin{array}{l}\text { Three miles east of Fermdale, Hum- } \\
\text { bolit county. }\end{array}$ & & ................. & 65.346 \\
\hline 205 & $\begin{array}{l}\text { Subsoil of No. } 207 \ldots \\
\text { lied volcanic soil .... }\end{array}$ & Flat on cloas Lake, Lake County... & $\begin{array}{r}12-25 \\
12\end{array}$ & Not knor & $\begin{array}{l}69.373 \\
49.604\end{array}$ \\
\hline 672 & Gray valley soil ..... & $\begin{array}{l}\text { Two wiles soutl of St. Ilolona, } \\
\text { Najea County. }\end{array}$ & 12 & Large white oak...... & 77.017 \\
\hline
\end{tabular}


subsoils. [Vol, vi. Tenth Census, 1. 7:38.]

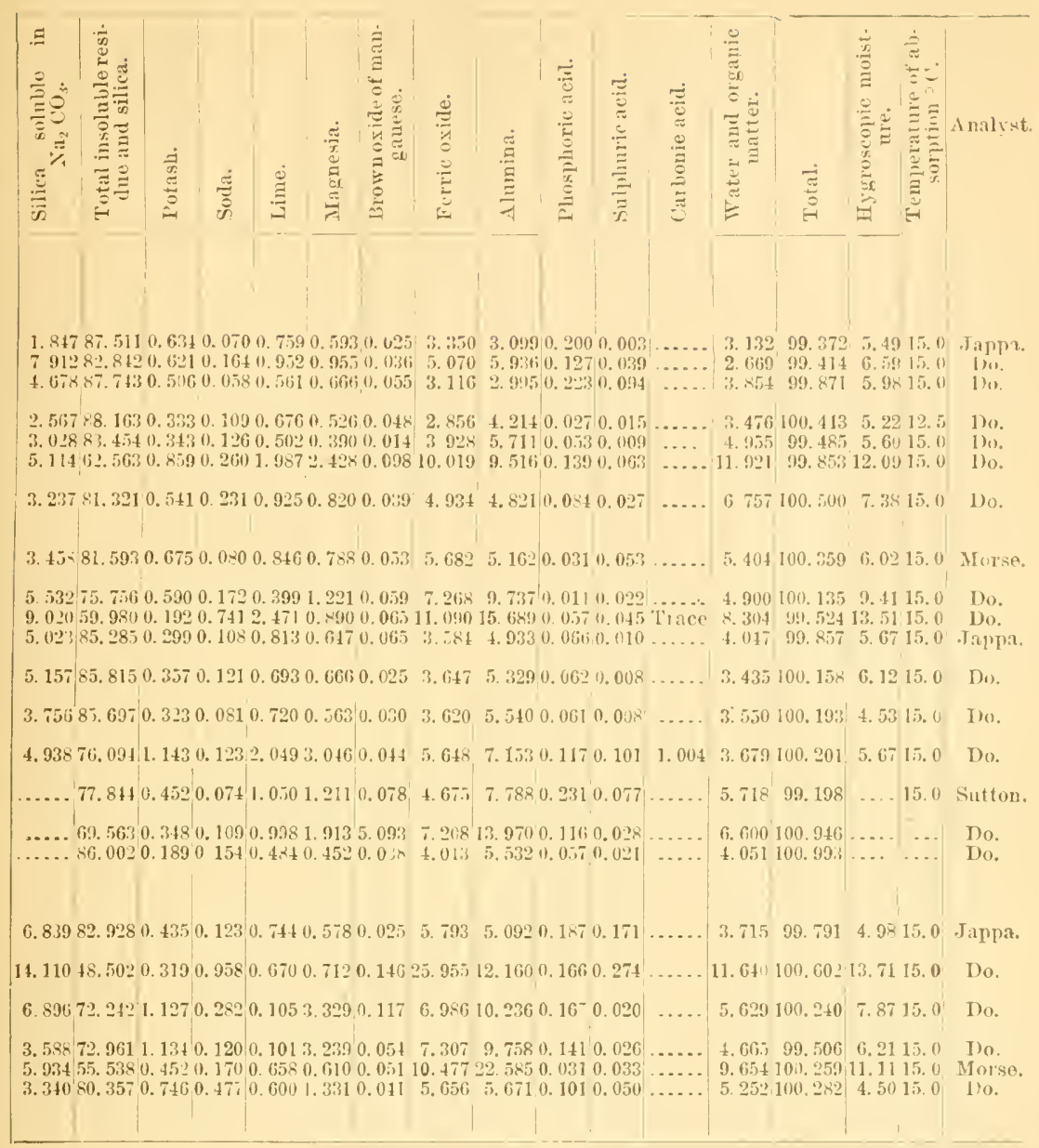




\section{8}

Sorls of the southern region.

\begin{tabular}{|c|c|c|c|c|c|}
\hline \multirow{4}{*}{ Constitnents. } & \multicolumn{3}{|c|}{ Los Angeles } & \multicolumn{2}{|c|}{ Sin llecgo County. } \\
\hline & \multirow{2}{*}{$\begin{array}{l}\text { Sioil of } \\
\text { san } \\
\text { rabricl } \\
\text { valley. }\end{array}$} & \multicolumn{2}{|c|}{ l'omona Colony. } & \multirow{2}{*}{$\begin{array}{l}\text { Soil ol } \\
\text { mesa } \\
\text { land. }\end{array}$} & \multirow{2}{*}{$\begin{array}{c}\text { Bottom soil } \\
\text { Coloralo } \\
\text { liiver. }\end{array}$} \\
\hline & & Low mesa snil. & Siubsoil. & & \\
\hline & No. 130. & No. 382. & No. 381. & No. 48 & No. 506. \\
\hline $\begin{array}{l}\text { Insulubife malter ... } \\
\text { Soluble silica. . . . }\end{array}$ & \} 81.12 & $\left\{\begin{array}{l}73.519>77.640 \\
5.1215\end{array}\right.$ & $\left\{\begin{array}{c}75.204\} \\
3.8725\end{array} 79.176\right.$ & $86.21:$ & 58.574763 .901 \\
\hline Potasli............ & 0.21 & 0.839 & 0.962 & 0.48 & $(5.32,3,172$ \\
\hline Suda ........... & 0. 17 & 0. 296 & 0.301 & 0.14 & 0.162 \\
\hline Lime & 0.68 & 2.351 & 2.1152 & 0.36 & S. $6 i 1$ \\
\hline Magnesia ... ............ & 1.77 & 2. 225 & 2.154 & 0.54 & 2.966 \\
\hline Brown oxire ol manganese ......... & 0.10 & 0.039 & 0.043 & 0.10 & 0.015 \\
\hline peroxide of iron........................ & 6. 30 & 8.097 & 7. 342 & 3. 69 & 4. $13 ! !$ \\
\hline Alumin: & f. 79 & 5.974 & 5.835 & 5.12 & $8: 579$ \\
\hline Phosphoric acid... & 0.16 & 0.018 & 0.049 & 0.23 & 0. $13: 3$ \\
\hline Sulphuric acid $\ldots$............... & 0.07 & 0.022 & 0.020 & 0.03 & 0.115 \\
\hline Water and organic matter & $\begin{array}{lll}3 & 07\end{array}$ & 2.5 .30 & 2.546 & 2.60 & $\begin{array}{l}7.818 \\
3.344\end{array}$ \\
\hline Total & 100.50 & $\overline{100.054}$ & $100 . \overline{4 \times 0}$ & 90.50 & 100860 \\
\hline Humus. & $\ldots$ & 0.324 & .. & 0.555 & 0.752 \\
\hline A vailable innreanic...... & ...... & 0.263 & $\cdots$ & 1. $43 !$ & 1. 151 \\
\hline $\begin{array}{l}\text { Arailable phosphoric acid } \ldots \ldots \ldots \ldots \\
\text { Il ygroscopic moisture ............ }\end{array}$ & 2.30 & 3.460 & 2.370 & 2.310 & $\begin{array}{l}0.133 \\
9.204\end{array}$ \\
\hline 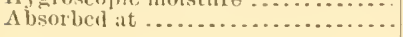 & $150 \%$ & $150 \mathrm{C}^{0.700}$ & $15 \circ \mathrm{C}$. & $15^{\circ}(:$ & $15^{\circ} \mathrm{C}$ \\
\hline
\end{tabular}

"There are many parts of the "vallegs of the Coast Range' where the soil is suitable for beet culture. The following table gires the areas of this soil in regions where the climate will permit heet culture. The areas for each county are as follows:

"The area of soil suilable for beet culliration, by counties.

Square miles

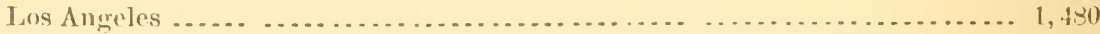

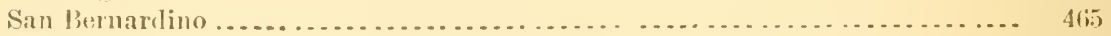

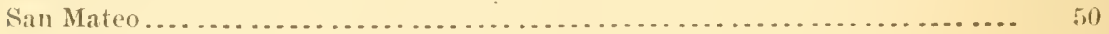

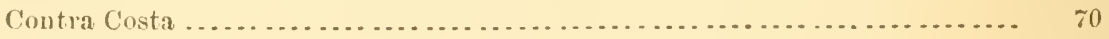

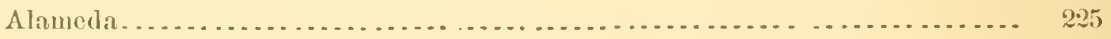

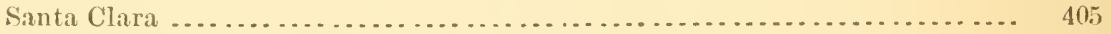

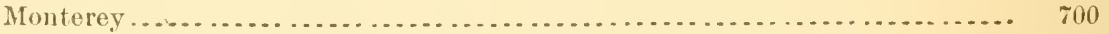

San Benito ................................................ 115

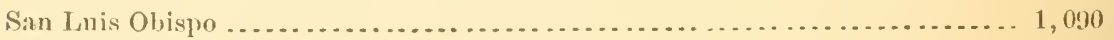

Sunta barbara ............................................... 300

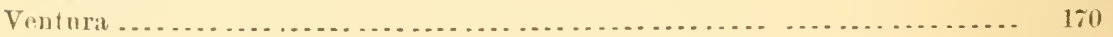

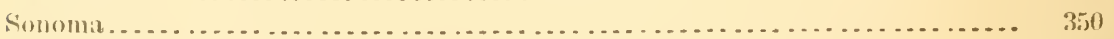

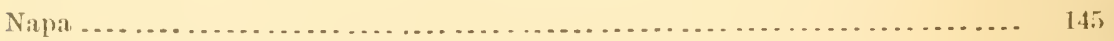

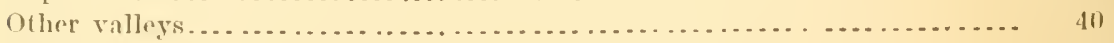

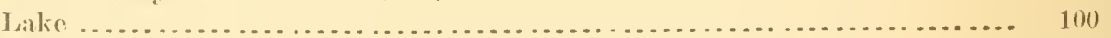

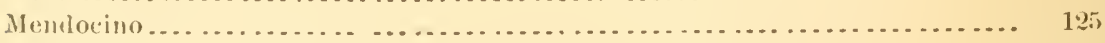

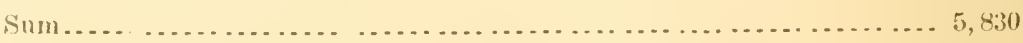

"This gives a total area in acres of $3,731,200$. Franting that two thirds of this area are unfit for beet culture fur lack of moisture and focal canses, there remains orer a million and a quarter acres ou which 
bects could be grown. Of this area not less than half a million acres conld be cultivated annually. From the data of yield of beets per acre and sugar per ton of beets, already given, the arerage may be put at 15 tons and 9 per cent, respectively, or 2,700 pounds of sugar per acre. For 500,000 acres this wonld give 1,200, 100,000 pounds.

\section{TIE SUGAR-BEET IN OREGON AND WASHINGTON TERRITORY.}

"I was anxions to extend my investigations of the possibilities of beet culture into Oregon and Washington Territory, but the limiterl time at my command prevented this design from being carried into execution.

"Haring learned that Mr. E. Meeker, of Puyallup, Wash., han been engaged in the cultiration of beets, I adrlessed him a letter making inquiries concerning the matter.

"In answer I reccived the following communication. I regret to say the samples of beets which Mr. Mecker hoped to he able to forward for analysis have not been receirer.

"Mr. Meoker says:

"I am in receipt of your faror of 21 st nltimo from San Francisen, and heremith inclose an article to answer your question with reforence to growing sugar-beets in Oregon and Washington.

"I will send you samples of beets grown by myself, and from others if I can obtain them. T. M. Alvord, White River, Wastr., takes great interest in this question ; als: J. W. Spragne, Tacoma, Wash., and James MeNaught, Seattle, Wash. I would also suggest to send to the secretaries of the chambers of commerce of both Seattle and Tacoma.

"I send son paper containing an article of mine giring the cost in letail of our present year's crop.

"My article refers only to Pnget Sonnd country, or what is here known as western Washington. I an not fully advised as to the valley lands of Oregon, hut I think their heavy clay wheat-lands nusnitable. I also think the prairie, or in fact any lands of eastern Oregon or Wilshington, aro unsuited from the excess of alkali contained in the soil, also from scarcity of fuel.

"The climate of western Washiugton is mild aud equable, neither vers cold in winter nor hot in summer, anil seens to be exactly snited to growing the sugar-beets to perfeetion.

"There is always an abundant rain-fall in summer, so that we never have a failure of crops; the antumns are free from heary frosts or freezing weather (at this writing, Decomber 1, there has as yet been no freezing weather), but nsnally there is considerable rain.

"We do not irrigate; in fact the soil is loose andfavorable, so that onr crops grow well the wholo scason, and remain green even dnring a 'ily spell,' which, however, seldom occurs of sufficient duration to cudanger crops. The growing season is very long, and all harily vegetalileg are prodnced in great abnudance and perfection.

"Soil suitable for producing the sugar-beet is in the allnviai bottobss aljacent to varions rivers flowing from the Cascade range, of mountains towarls salt water.

"These rivers are not largo nог the valleys wide, but are numerous; in the Pugot Sound Basin there are eleven or more sitnated north of the Colmubia River and sonth of onr northern boundary. I shonld say the area of land in each of these ralleys suitable for beet-culture would averago sixty sections of land, or say about 40,000 
acres eacls. This is nearly all timbor lamb and requires elearing, is a deep alluvial sandy loasu, very rich, aurl protuces an abumlant aud certain erop.

"Finel is aloundant, and is widely distributel. Tho coal is muler the table-land or foot-hills of the Caseade range of mountains, and is reached lys short lines of rail. roauls. The agrregato montlily ontput of the mines opened is, I think, alont 30,000 toms. It can be inereased intefinitely, as the coal area is lisge, the veins numerous and heavy (thick).

"So far, our sugar-boets hare been not nuly ricl lut also singularly pure. This is probably to he aceonted for from our heary rais-lall and agreeable climate. The actual cost of raising per tou for a periou of fivo years lias been less than \$2.50 per ton, aul the present yax \$2.25 per ton. We lave grown them for eattle, and eould utilize the pulp to great alvantage in stall-teerling beef.

"Our wiuters will admit of working sngar-bects nearly the whole time, the weather selklom heing cold enongl to interfere with lanvesting the beets. Locations can be had where transportation is cheap, whero fnel is cheap, where land is cheap, aud where thomarket for sngar is good. It would seem to be difficult to find botter eoulitions for the successful iuanguration of this business than here exist, and we tirmly rest in the conviction that sooner or later the capital will be fom to develop thess favorableconditions, aud that the day is not fur listant when wo shall see umerous bect-sugat factories producing not only enongh for the inmediate home consumption, but also for the great interior eonutry of this continent.

\section{ter :}

"Following are the results of culture mentioned in the foregoing let-

"I raised the present year 65 tons of beantiful suras hects from 2 acres of land. There was no guess work; it was 65 tons of 2,240 ponnds from the two uneasured acres. These cost me $\$ 2.25$ per ton, aurl I will give this in detail that your farmers may ponder this question and see that I do not mulerstate the cost:

Plowing and subsoiling $t$ wo aeres. . . . . . . . . . . . . . . . . . . . . . . .

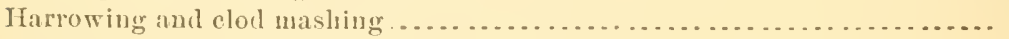

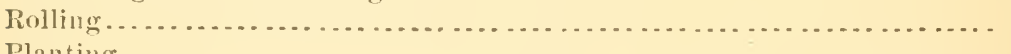

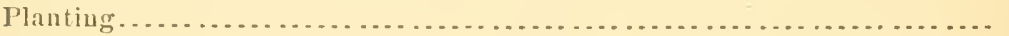

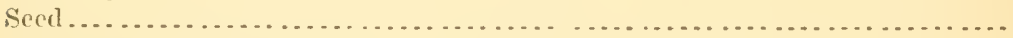

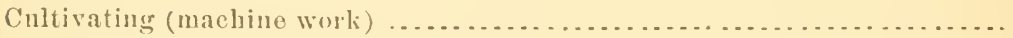

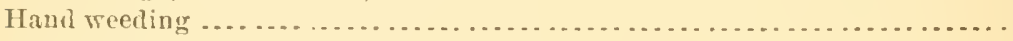

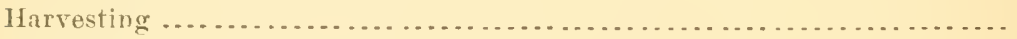

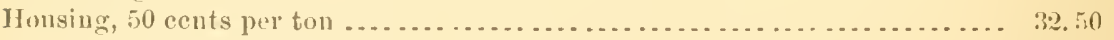

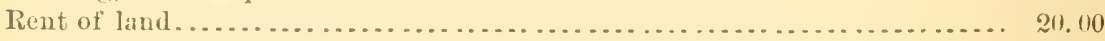

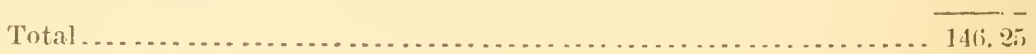

6. 00

4. 00

2. 10

4. 00

16. 25 20.00 21.50

"My neighhor, Mr. T. M. Alvorl, of White River, las for five years raised an arerage of 100 tons a jear at an average cost of less than 8.50 per tom and an averare yield of 20 tons per aere. IVo know that the beets ean be raised; that the crop) is certam; that the quality is goou, pure, rich-in a word, eversthing desiren to make this imlustry profitable, and now shall we thow this opportmuty away, enconrage the importation of foreign sugar mare hy eleap, sprvile lahor, or shall we enconrage lsome proluction and all the benefits that follow ?"

"The following aceount of the topograply, elimatr, and soils of the Chehalis Valley is talen from an article printed in Gray's Harhor News, Chehalis County, Wasls,, April 19, 1ఠ34:

\section{"TOPOGRAPHICAI, TEATUIEN.}

"Western Wasbington is a name given to that portion of comntry 3 ying between the Parifie Oeenn and the Caseale Momtans, the Columbia Riverand British America. On its easteru border the Cascale Range, an moroken duan containing the 
highest peaks in the United Stutes, stands like a lofty wall, slutting ont and hiding the beantifnl and fertile conntry west fon the rest of the world. West of this lofty range lies a strip of eountry about ome-half the size of the State of New York, alont 110 miles wide and from 200 to 250 miles long. In the sonthwestern portion of this conntry, lying near the Pacific and jutting close upon the Colnmbia River, is a eluster of high hills, and in the northwestern portion, on the peniusula formed lig Puget Somud and the Pacific, is the Olympic Monntains, another elnster rising to the height, of \&,000 feet. In the north is Puget Somnd, perlaps the nost heantifnl inland sea in the world, with its lofty wooded shores, its immurerable windings and islands, and its deep, clear water. The shores of this somnd are high and rocky. But few stroms flow into it, and these chiefly on its easteru side. In the sontheastern part the Cowlitz River flows along the base of the Cascades in a sontherly direction and empties into the Columbia. But in the central part, rising among the hills in the sonthwestern corner and flowing first east then north, so that the Kalama Branch of the Northern Pacific passes along it, and then west, is a magnificent stream, the Chehalis River, emptying into Gray's Harbor and so into the Pacitic Ocean. This is the largest river in Western Washington. It is the only river of any size not subject to smmmer thods caused by the melting of monutain snows. This river, with itstribntalies aul includiugr Gray's Harbor, drains a basin of some 3,500 supare miles; (the map slows sixty townships, and a greater amonnt mas farly be reckoned as part of this river valley). As will be seen, Chehalis Connty is the rery heart of western Washington, and it is the heart in a very trme sense, in that all that is desirals le in western Washington is centered here in its lust condition, and here are the means, the forces that are to give life and growth to all the rest.

\section{"CLIMATE.}

"From Oetober 13 to November 13, thirteen rainy days, thirteen fair days, and five elear days; from Norember 13 to December 13, twelve raing dass, thirtern fair, and four rain and shine; from December 1:3 to January 1:3, one lay suow, six rain, three rain and shine, fourteen fair, and eight elear days; from Jamnary 13 to Fehrnary 13, three days snow, four rain, two rain and shine, ten fair, and twelve clear days; from February 1:3 to March 13, five dass snow, three rain, oue rain and shine, sixteen fair, aud four elear days; total for the winter, nine days of snow, thirty-eight rain, ten min and shine, sixty six fair, and thirty clear clatss. Daşs are called clear when net a clond appears. During this time the range of the thermometer was: First monthlowest $10^{\circ}$, highest $65^{\circ}$, and the arerage $5.3 \frac{1}{2}$; second mouth-lowest $34^{7}$, highest $55^{\circ}$, average 4150 ; third month-lówest $2-$, lighest 50 , arerage $3 \tau_{\frac{1}{2}}$; fourth unouthlowest 9, highest $45^{\circ}$, average $: 33_{6}^{\prime}$; fifth month-lowest 27, , highest 42 , arerage 368. The record of 9 above was the lowest point reached during the last seven years. There was one fall of suow that reached a deptli of 6 inches. The record of lowest thermometer for the last seren years is: For 1876-77, 220; for 1-77-78, 200;

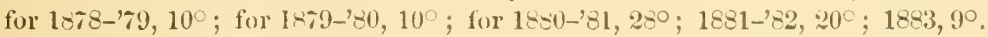

\section{"TIIE SOIL.}

"The soil of the mplancls, or hills, is loamy, in places grarelly. It is quick, warm but uot strong land as a rule. In some localities where upland elearings luave been made reports are given of large crops. It is better adapted to truit and general garlening. Some of the hills are doubtless good land. It all grales ofí into bottomland. It is diticult to clear for the inmense growth of timber. Bnt in this climate most of these hills will be profitalily firmed. Indeen, aluost anywhere clover and timothy grass will flomrish luxuriantly. Bnt it is the bottom-land that is chietly valuable at present for farming. Thus far the most part is easily eleared, ant is as good lame as can be found anywhere. It will prodnce good crops of almost any thing, and its fortility is inexhanstible. One piece that has been cultivated aliuost continnonsly 
for twenty yoars, with no manming, is to-clay as rich as when tirst plowed. This land

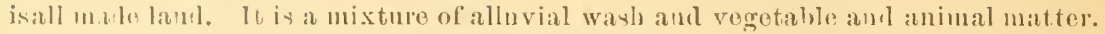
It is more like gamlen than field lanel. A few acres will gield more tlan a quarter secetion of mucle of the land East.

"The bottom-lands in general are sulject to winter overtlow, though some of" them rarels, if ever, aro covered. They are apt to he broken loy cluamols which this ovortlow lias macle and by sloughs and streams which flow through.

"There is much of this botfom-land. Along eash of the principal streams there aro wids stretches of it, and along in each strean in this whole Chehalis anmtry there is more or less. But as thure are few quarter-scetions across which somo stream does wot tlow, so there are few which do uot possess some of this bottom-lamul.

"These bottom-lands that lie down toward the sea aro subject to periodical oforflow ly the tide, and there is a large amount of this abont Gray's Harlon amb the

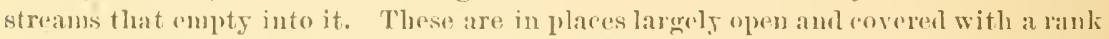
growth of wild grass. The are used now principally for pasture. But a diko from 1 to :3 feet high would keep ont this tide, aud when so diked they are equal to the best of bottom-land. Nobetter land ean be fonnd.

"In view of the preceling deseription I am inclined to helieve that in Washington and Oregon soil and elimate are rery farorable to the glowth of a sugar bect of high saceharine strength.

"The mildness of the wintru is, though to a less degree than in California, favorable to the season of manufacture. With a wise and care. ful enconragement of tho iudustry I have no hesitation in saying that the prospects for the development of an indigenons sugar iudustry in the extreme northwestern part of our comtry are decidedly bright. It is a field worthy the attention both of experimenters and eapitalists."

\section{SOIL AND CLIMATE IN BOIEMIA.}

In respeet of the soil in Bohemia best suited to the sugar-beet, John B. Howes, commercial agent, makes the following observations:*

"The best soil for quality, as well as quantity of prodnction, according to the experiments of Orth, are those that consist of mill, moist loam abont 50 centimeters dreu, then loan or marl 1 to '2 meters, and muler this sand. Snch soils, which are easy to cultirate, have a high degree of absorption, can combine nourishments, and give the plant physically a good start. Snch soils are called 'uatural sugar-beet soils.'

"It is possible to l'aise beets on soils that do not inve all these qualities, but the erop will bo the better the nearer this standard is approached.

"The conditions required for a goon sugar-beet soil are-

"(1) Depth, because the roots mostly take their nourishment from a depth of 30 centimeters, and the soil must therefore be loosenerl and contain nourislnment np to this rlepth.

"(2) Porousness of the subsoil, because it is impossible to cultivate a (lamp, cold soil at the right time. Such a soil will become cuscked if very dry, and the gonng blants snfler, while the beets will contain little sugar. In such a case drainage must be employed. Clay soils can be 
improverl by manuring, by the nse of lime, and drainage; light soils by manuring and loamy marl.

"Leplay fonnd that the heariest beets will be raised in deseendant sucession, from clay, lime, loam, and sand soils; beets with the greatest percentage of sugar in lime, clay, sand, anil loam soils; the most leaves in s:ml, clay, lime, and loam soils. Accorling to experiments of Marek, the more noisture in the soil the greater will be the development of leares. This influence is stronger in sand soil than in one of elay. The normal development of the root depends npon organie matter in the soil. The more moisture there is in the soil the looser the texture, the poorer the quality, and the less sugar will be in the beet.

"The following soils are alapted for the culture of the beet, if they lave a good subsoil : Loamy soils, mild, clayey, or sandy, and elay marl. Of chay soils, the mild and loamy ones; if the amonnt of elay is excessive, the soil must be made suitable by manuring. Strong elay soils are nseless for beets, but clay marl soils are good. Sandy soils are least adapted to the cultivation of the sugar-beet, with the exception of loamy sand soil not defieient in humidity and the subsoil possessing enongh water-holding power. Lime soils are, with the exception of loamy lime soil, not good for beets. From moist soils are raised good quantities, but poor qualities.

"The best locations for sngar-beet planting are on lerel or only slightly sloping lands, beeanse work is done best on such lands, and it is impossible for the beets to be swept away by heary rains."

In regarl to climate, Agent Howes has collected the following data (op. cit. p. 242) :

"In Europe the sugar-beet is suecessfully planted between the fortyseventh and fifty-fourth degrees of northern latitude; in Germany, be. tween the fifty-first and fifty-fourth; in France, between the forty.serenth and fiftieth; in Austria-linngary, between the forty-eighth and fiftieth; and in Russia, betreen the forty-eighth and fifty-third degrees.

"Like all plants, the sugar-beet requires certain eonditions of climate to arrive at perfeetion.

"According to the experiments of Briem, director of the experimental station in Grussbach, Moravia, concerning the distribntion of waruth and rain-fall during the period of regetation of the sngar-beet in the first period, $i . e$, in the first two months, the time of germinating, the daily temperature was $10.70^{\circ} \mathrm{C}$; in the second perion (the time of the derelopment of the regetative organs), $15.5^{\circ} \mathrm{C}$.; and in the third perion (in which the storage of the reserve substances takes place), $16.5^{\circ} \mathrm{C}$; and during the whole vegetation, $15.3^{\circ} \mathrm{C}$.

"The total warmth in the first periorl was $6500^{\circ} \mathrm{C}$; ; in the second, $1,1500^{\circ} \mathrm{C}$; ; and in the third, $1,000 \circ \mathrm{C}$.

"The rain-fall was in the first period 97 millimeters; in the second, 
114 millimeters; and in the third, 100 millimeters-together 311 millimoter's.

"The sugar.beet needs much warmth and light, sunny days, and a certain amount of moisture.

"The best climate for sugar-beets is the so-ealled 'wine elimate,' with a temperature from 90 to $100 \mathrm{O}$. in April and $M \mathrm{ay}, 170$ to $18^{\circ} \mathrm{C}$. in June and July, and 150 and 120 in August and September, respectively.

"The sea-coast is not warm enongh and has not enongh sunny days in June and July to be successful for sugar-beet raising.

"For the first period of regetation it is necessary that a certain amonut of winter moisture be in the gromul, as the seeds need moisture to germinate. In the second period warmth and moisture is required for the production of roots and leaves. In the third period, in which the saccharification goes on, dry warmth. If the lays be sumy, the beets will become rich in sugar; but if this period be wet, the crop will be great in quantity, but poor in quality. If, after a dry summer, a warm and rainy fall follows, new leaves spring up at the cost of the sugiar."

The following observations on soil, culture, and fertilization will be found interesting in connection with the foregoing discussion.*

"The cultural conditions to be regarded as of greatest importance in securing wops of maximum quantity and quality, when a seetion has been determined upon by a consideration of all other conditions, are choice of soil, ete., its physical character and chemical compositon, aud the methods by which these may be modified or improved; the first by the mechanical methods of culture, and the second by the proper and judicious applications of fertilizers. After this will naturally follow the moles of planting and the care to be applied during the season of growtl.

"With reference to the choice of soil suited to the culture of the beet. root, opinions seem to differ somewhat, thongh the principles which ap. pear to govern them tend to the same end. 'The illustrious Chaptal, $†$ as a result of his study of the plant and its requirements, arrived at the following eonclusions :

"Soils which aredry, calcareous, light, etc., are not well suited to the beet.

"Stroug clay soils have little aptitule for the culture of this root.

"In order that the root may prosper, it needs, in general, a mellow, fertile soil, the arablestratum of which shonld be 12 to 15 inches thick.

"The root sneceeds more or less well in all arable soils, but the products rary wonderfully aceording to the uature of the soils.

"Basset $\neq$ considers that "a fresh soil, rather sandy or silico-calcareous than too calcareous or argillaceous, rich in humus, and deep," should be

* MeMurtrie op. cit., Pp. 95-11\%)

tQuoted hy Basset in Guide Praturue dn Fabricant de Sucre.

+ Ibill. 
ehosen. Briem,* in his late work on beet-root enlture and sugar manufacture, says, of the physical character of the soil to be ehosen, "it should not be too light nor too moist; it should be bare; its subsoil permeable; it shonld be warm, free from stones, ealcareons, and should contain humns." Deherain, $†$ from the results of his experiments and investigations at Grignon, publishes as one of the conclusions arrived at that the nature of the soil does not seem to exercise any sensible ac. tion upon the development of the beet, for the same results were obtained in soils consisting of pure silica, of ealcareous matter, or of a mixture of calcareous matter and elay.

Vivien $\ddagger$ found in traveling through the prorinces of the Rhine, Hanover, Brandenburg, and Saxony in Germany, that, though in each section there is a wide difference in the nature of the soil, there is a partienlarly marked homogeneity in the character of the beets.

"Vilmoriu considers that any good soil that will grow wheat and eorn and has au arable stratum of 12 to 15 inches, will be well suited to this culture; that where ehalk exists in large proportion the yield will be small, but the juice pure. All soils should be thoroughly drained, so that the tap root may not find stagnant water in the subsoil.

"Notwithstanding the differiug notions expressed above, it will appear that the physieal characters of the soil whieh tend to render it best suited to the cultivation of the beet are porosity of surface and subsoil, to admit of drainage of superflnous water and of free cirenlation of the air, and power of absorbing and holding in a condition convenient for ready assimilation the elements of plant-focd existing within it or coming from external sources. Unless the supply of these elements be continuons and regular, a purely sandy soil would be undesirable. If no means were provided for the removal of surplus water which might be found in a purely elay soil, or to so improve its condition as to admit of free circulation of air as well as water, it is too heavy, and becomes absolutely useless. The same is true of purely calcareous soils, since the same unfavorable conditions would prevail, though perhaps to not quite the same extent. These soils would also be unsnited to the plant itself, because they would not admit of the free progress of the tap root nor of the lateral fibrons roots in their seareh for untrition or in following the natural course of development, and, as will appear later on, these conditions have a powerful influence upon the ultimate yield of sugar from the surfaee cultivated. But if the sandy soil described be mixed with either or both of the others mentioned, and with humus, in suitable proportions, the eonditions most favorable to the maintenance of a reg. ular and plentiful supply of food, the healthy condition of the root, and its consequent normal development, will be assured.

\footnotetext{
* See Critique in Journal des Fabricants de Sucre, 1879.

+ Annales Agronomianes.

$\ddagger$ Journal des Fabricants de Sucre, 1878, 27 Míarch.
} 
"The chemical chanater of the soil is of quite as great importance as its physical condition. For the proper development of the beet for the production of sugar it shonld contain in a sutable and assimilable form all the elements usually necessary to the normal existence aud develop. ment of plants, and attention must therefore be had to the conditions in which these substauces exist in the soil. Phosphoric aeid, potash, nitrogen componuds, and lime are especially necessary to the life of the plant, hut if these exist in insoluble combinations on the one hand, or in forms suitalle for assimilation but in excessiro quantities on the other, they will eicher be useless in the economy of nntrition in the first instance, or will stimulate the plant to abnormal growth musuited to the realy extraction of sugar in the second. It is this branch of the subject that has oecupied the attention and enlisted the energies of scientists and landed noprietors, and the inflnence of the rifferent combinations of the varions leading elements of plant.food, and more especially, during later years, of nitrogen in the soil, has coustituted the subject of fiequent and continued investigation.

"Basset* salys :

"Soils charged with mineral salts are injurious to the culture of the beet for extraction of sugar, and aro only suited to the cultivation of heets for distillation. In fact, we know that the beet easily absorbs saline matters and that the alkaline salts constitute oue of the greatest obstacles to sugrar extraction.

"New ground, or that lately eleared of forest, should not be applied to the culture of the beet, and it is considered by good anthorities to be detrimental to the ruality of the crop to make use of lands for this purpose that have not been under continued enltivation at least ten or fifteen years. 'This insures an almost complete removal of the nitrates and the organie matters containing nitrogen, which are always presenc in large quantities in new soils, and which it is well known exert an injurions influence upon the quality of the root.

"Basset, in his work, grives elaborate tables of analyses of soils to show the chemical composition of those most farorable to the culture, but we will here give the more suceinct tables of Champion and Pellet, showing the composition of soils from different departments in the north of France in which beet-root culture is most extensively emried on, and

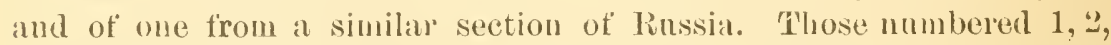
3 vielded beots of fair quality, eontaining 1's to 14 parts of sugar per 100 of juice, while that numbered 4 gave beets of barl quality. The last, that from Russil, is quoted by Walkhoti as boing well suited to beet culture.

\footnotetext{
*Guide l'ratigne du Fabrieaut de Suere. $\ddagger$ La Bettrave a Sucre, 1) 82 .
} † Guide Praticlue du Fabricunt de Suero. 


\begin{tabular}{|c|c|c|c|c|c|c|}
\hline \multirow[b]{2}{*}{ 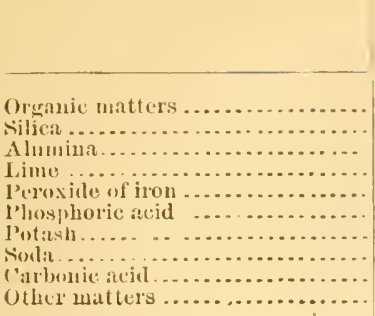 } & \multirow{2}{*}{$\begin{array}{l}\text { 1. Sontule: } \\
\begin{array}{r}5.600 \\
81.800 \\
7.210 \\
0.570 \\
2.880 \\
0.070 \\
0.0644 \\
0.055 \\
0.460 \\
1.351\end{array}\end{array}$} & \multicolumn{2}{|c|}{ 2. Nord. } & $\begin{array}{c}\text { 3. Aisue. } \\
5.70\end{array}$ & $\begin{array}{r}\text { 1. Somme. } \\
8.200\end{array}$ & $\begin{array}{l}\text { 5. Kaibuof- } \\
\text { skatsoil. } \\
6.207\end{array}$ \\
\hline & & $\begin{array}{c}4.42 \\
\cdots \cdots \\
0.476 \\
\cdots \\
0.008 \\
0.130 \\
0.600 \\
\cdots\end{array}$ & $\begin{array}{r}4.810 \\
8.500 \\
8.620 \\
0.420 \\
2.180 \\
0.077 \\
0.110 \\
0.700 \\
1.523 \\
\end{array}$ & 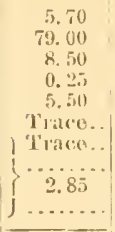 & $\begin{array}{r}8.200 \\
4.000 \\
3.91 \\
23.220 \\
2.310 \\
0.345 \\
0.014 \\
0.054 \\
19.050 \\
0.823\end{array}$ & $\begin{array}{r}6.207 \\
7.699 \\
9.971 \\
1.930 \\
2.8: 51 \\
10.0 \div 3 \\
2.11 .7 \\
11.911 \\
1.2811 \\
2.022\end{array}$ \\
\hline & 100.000 & 10.000 & 100.000 & 100.000 & 100.000 & 100.000 \\
\hline 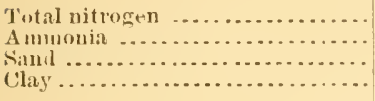 & $\begin{array}{r}0.088 \\
0.013 \\
72.100 \\
22.000\end{array}$ & $\begin{array}{r}0.140 \\
10.040 \\
85.000 \\
9.000\end{array}$ & $\begin{array}{r}0.120 \\
0.030 \\
80.0000 \\
14.000\end{array}$ & $\begin{array}{r}0.154 \\
0.010 \\
62.000 \\
30.000\end{array}$ & $\begin{array}{r}0.270 \\
0.010 \\
35.770 \\
10 \text { t0 } 12\end{array}$ & 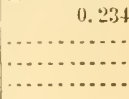 \\
\hline
\end{tabular}

6: Tlie same anthors quote Schiibler as giving the followiug as the general composition of gool soil for beet culture :

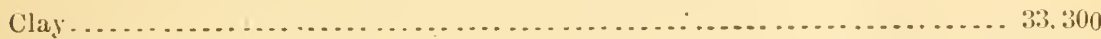

Siliceous sand . . . . . . . . . . . . . . . . . . . . . . . . . . . . . . . . . . 63.000

Caltareous sand ................................................ 1.200

Calcareous earth, humus........................................ 2.500

"We now come to the study of the means employed to supply the deficiencies of plant-food in the soil, dne either to the natural condition or the exhanstion by crops, and the influence of the meaus employed upon the production of rich and valuable roots.

"The general composition of the beet root and leaves is given by Champion and Pellet, as follows: They state that for rich beets the weight of leaves is abont 50 per cent. that of the root, and 25 to 30 per cent. that of roots containing 9 to 11 per cent. of sugar.

"The table shows the general composition of leares and roots of beets containing 15 per cent. of sugar :

IYater...

Nitrogen

Aslies.

\begin{tabular}{|c|c|c|c|}
\hline In roots. & $\begin{array}{l}\text { In dry } \\
\text { matter. }\end{array}$ & In leaves. & $\begin{array}{l}\text { In dry } \\
\text { matter. }\end{array}$ \\
\hline Per cent. & Ter cent. & l'er cent. & Per cent. \\
\hline $\begin{array}{r}1.00 \\
0.40\end{array}$ & 3.55 & $\begin{array}{r}83.50 \\
0.38\end{array}$ & 2.30 \\
\hline 0.80 & 3.10 & 4.35 & 2620 \\
\hline
\end{tabular}

"For a vield of 20 French tons* of beets and 10 French tons of leaves per acre, there would be remover firom the soil: 
"Or, for an arelage richuess of 11 per cent of sugar :

Watir.

Nitrogen

Aisho

"( ) 1 , for a vield of 20 French tous per acre:

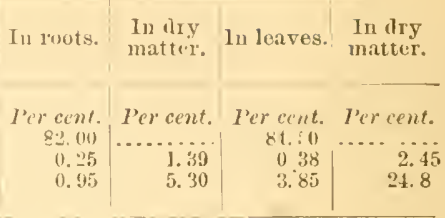

\begin{tabular}{r|r}
$\begin{array}{c}\text { Total } \\
\text { rituogen. }\end{array}$ & Totalaslues. \\
& \\
I'ounds. & I'ounds. \\
110 & 418 \\
50 & 508.2
\end{tabular}

"The composition of the ashes of the leaves and roots referred to 1,000 parts grem matter is as follows:

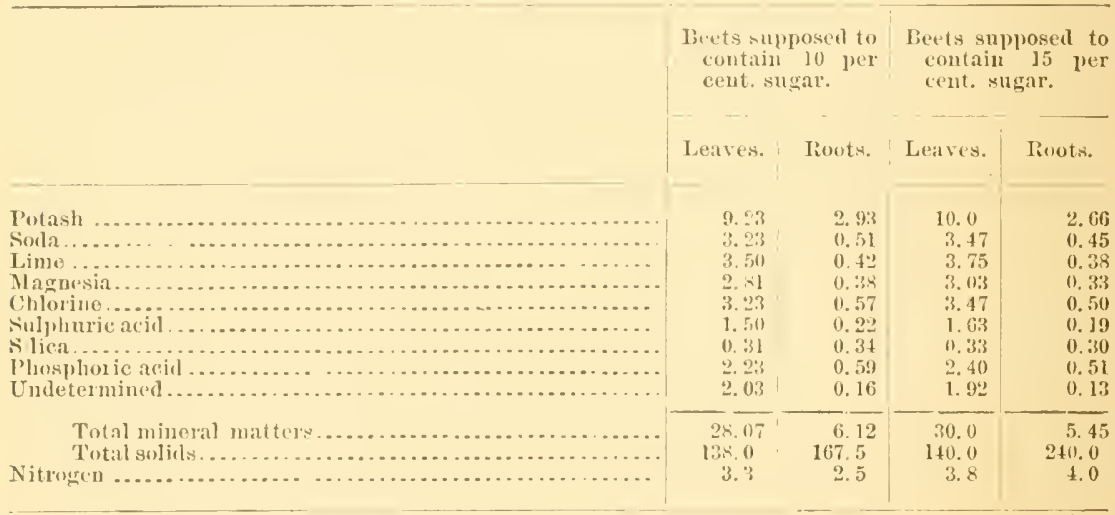

"From these figures we may easily determine the quantity of the different constituents lenoved by average crops. Suplosing the arelage to be 20 toms of roots per acre, the consumption of the different constitnents would be, for beets of differing richness, as shown in the following table: 


\begin{tabular}{|c|c|c|c|c|c|c|}
\hline \multirow[b]{2}{*}{ - } & \multicolumn{2}{|c|}{$\begin{array}{l}\text { For beets contain- } \\
\text { ing } 10 \text { per cent. } \\
\text { sugar. }\end{array}$} & \multirow{2}{*}{ Total. } & \multicolumn{2}{|c|}{$\begin{array}{l}\text { For bets contain- } \\
\text { ing } 15 \text { yer cent. } \\
\text { sugar. }\end{array}$} & \multirow{2}{*}{ Total. } \\
\hline & $\begin{array}{l}\text { Six tons } \\
\text { loaves. }\end{array}$ & $\begin{array}{l}\text { Twenty } \\
\text { tons } \\
\text { roots. }\end{array}$ & & $\begin{array}{l}\text { Ten tons } \\
\text { leaves. }\end{array}$ & $\begin{array}{l}\text { Twen } 15 \\
\text { tons } \\
\text { ruots. }\end{array}$ & \\
\hline 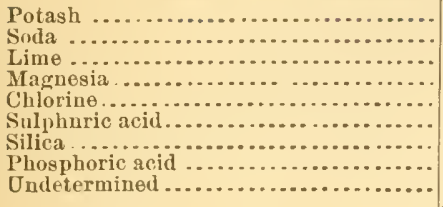 & $\begin{array}{r}121.8 \\
42.6 \\
46.2 \\
36.1 \\
42.6 \\
19.8 \\
4.09 \\
29.43 \\
26.79\end{array}$ & $\begin{array}{r}128.9 \\
22.4 \\
18.48 \\
16.72 \\
25.08 \\
9.68 \\
14.96 \\
25.96 \\
7.04\end{array}$ & $\begin{array}{l}250.7 \\
65.0 \\
64.68 \\
42.82 \\
47.68 \\
29.48 \\
19.05 \\
55.39 \\
33.83\end{array}$ & $\begin{array}{r}220.0 \\
76.34 \\
82.50 \\
66.66 \\
76.34 \\
35.86 \\
7.26 \\
52.80 \\
31.24\end{array}$ & $\begin{array}{r}337.04 \\
96.14 \\
89.22 \\
81.18 \\
98.34 \\
44.22 \\
20.46 \\
75.24 \\
36.94\end{array}$ & $\begin{array}{c}117.01 \\
19.8 \\
16.72 \\
14.52 \\
22.0 \\
8.36 \\
13.2 \\
22.44 \\
5.70\end{array}$ \\
\hline 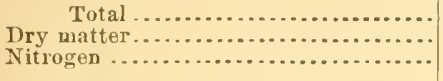 & $\begin{array}{r}369.11 \\
1,821.6 \\
43.56\end{array}$ & $\begin{array}{l}248.32 \\
7,370.00 \\
110.0\end{array}$ & $\begin{array}{r}6.8 .50 \\
\cdots \ldots \\
\cdots \ldots \ldots\end{array}$ & \begin{tabular}{|c|}
651.00 \\
3,080 \\
83.6
\end{tabular} & $\begin{array}{r}888.18 \\
\ldots \ldots \ldots \\
\ldots \ldots\end{array}$ & $\begin{array}{l}239.78 \\
10,560 \\
176.0\end{array}$ \\
\hline
\end{tabular}

"In France the general sources of supply of the various nutritive principles for the restoration of those removed by the erops, or to provide those required, are found in stable manure, seed cakes, animal wastes, woolen scraps, sulphate of ammonia, nitrates, superphosphates made from bones and minerals, potash salts, gypsum, and the scums and refuse from the sugar factories. Of all these substances, that which combines in itself in the highest degree all the elements of plant-food, aud which is naturally the most economical, is the stable manure produced on the farm, and this being generally the result of keeping cattle to be fed upon the pulps from the factory is one of the sources of real profit to the producer.

"Joulie gives the following as the composition of French stablemanures of arerage qualits, estimated in pounds per ton of 2,000 pounds:

\begin{tabular}{|c|c|c|}
\hline & $\begin{array}{l}\text { Manure } \\
\text { of fifteen } \\
\text { oxen. }\end{array}$ & $\begin{array}{l}\text { Manure } \\
\text { of } \\
\text { ten cows. }\end{array}$ \\
\hline 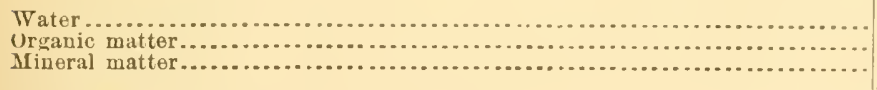 & $\begin{array}{r}1,492.576 \\
406.044 \\
101.380\end{array}$ & $\begin{array}{r}1,398.656 \\
476.928 \\
124.416\end{array}$ \\
\hline 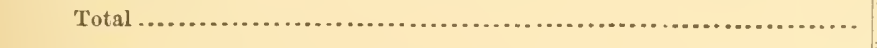 & $2,000,000$ & $2,000.000$ \\
\hline 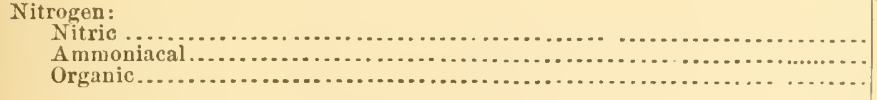 & $\begin{array}{r}0.000 \\
1.880 \\
11.822\end{array}$ & $\begin{array}{r}0.000 \\
1.331 \\
11.950\end{array}$ \\
\hline 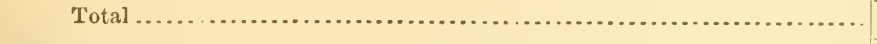 & 13. 702 & 13.284 \\
\hline 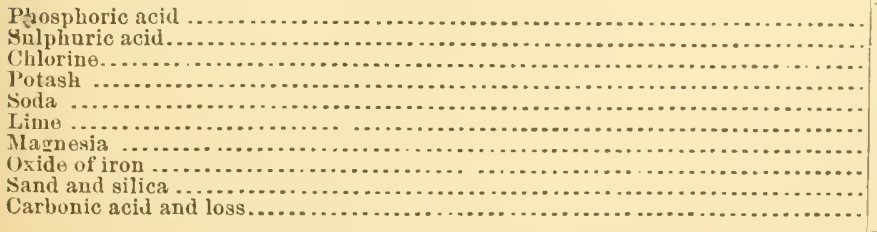 & $\begin{array}{r}\text { 5. } 288 \\
3.010 \\
2.740 \\
19.104 \\
5.164 \\
14.538 \\
3.770 \\
1.304 \\
3 ! 1.888 \\
6.574\end{array}$ & $\begin{array}{r}3.142 \\
\text { 3. } 000 \\
4.000 \\
20.852 \\
6.284 \\
14.060 \\
3.478 \\
1.250 \\
60.913 \\
7.438\end{array}$ \\
\hline 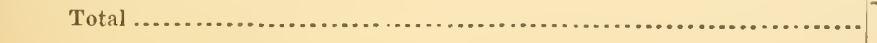 & 101.380 & 124.416 \\
\hline
\end{tabular}


"A comparison of this table with that given before will show that in order to supply in stable manure the required nitrogen and phosphoric acid for the proluction of an average crop of 20 tons per acre, it will be necessary to apply at least 20 tons of stable manure to the samo area. But this quantity will contain a considerable excess of alkaline matters over the quantity demanded by the erop, and will only tend to iucrease the saliue constituents of the root at the expense of the sugar. This exeess of mineral matters is often nsed to explain the prockuction of roots of low sacehariue valne. Let us bring together the figures for the constituents of plant.food mentioned, as found in 20 tous of stable manure from cows and as found in the yield of an acre giving 20 tons of beets:

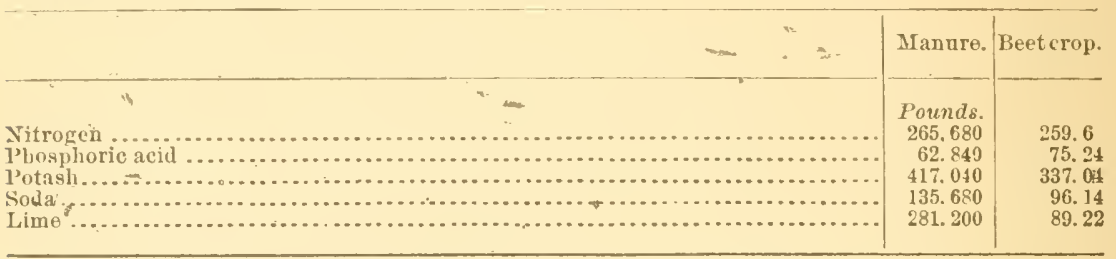

"In practical work, therefore, it is found better to reduce the quantity of stable manures applied, and to supplement them with the other substances mentioned above. A comparison of the productive influences exerted by stable mauures and by the artificial compounds usually employed to supplement it, or as substitutes for it, will be found in the following table, showing the results of the experiments made by Professor Deherain at the Grigwon agrieultural school, working with the Vilmorin improved race of beets. These results are interesting as showing the advantage of moderate applications of stable manures, and the choice that should be made in the supplementary compounds that should be applied :

Infuence of manures on yield in weight and richness in sugar."

\begin{tabular}{|c|c|c|c|c|}
\hline $\begin{array}{c}\text { No.of } \\
\text { the } \\
\text { p'ots. }\end{array}$ & Manuro distributed per acre. & $\begin{array}{l}\text { Tield per } \\
\text { aeru. }\end{array}$ & $\begin{array}{l}\text { Sugar in } \\
\text { juice. }\end{array}$ & $\begin{array}{c}\text { Sugar pro- } \\
\text { dnced per } \\
\text { acre. }\end{array}$ \\
\hline & $\therefore$ & & Per & Bound \\
\hline 1 & 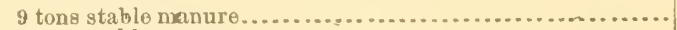 & 9.2414 & 12.67 & 2,351 \\
\hline$\hat{2}$ & 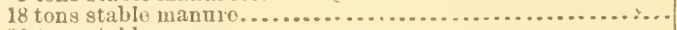 & 8. 9893 & 12.58 & $2,228.60$ \\
\hline 3 & 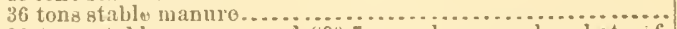 & 8.4378 & 11.28 & $1,896.59$ \\
\hline 4 & 36 tons stable manure and s 80.7 pounds superphosphate of & & & \\
\hline & 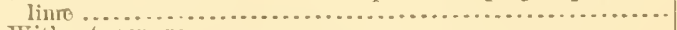 & 8.7220 & 12.26 & $2,137.78$ \\
\hline 5 & 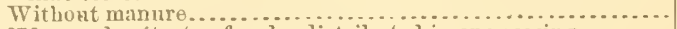 & 6.1080 & 14.58 & $2,257.04$ \\
\hline 6 & 356 pounds uitrate of soda, distributed in one sowing......... & 8.4378 & 12.75 & $2,184.01$ \\
\hline$\grave{8}_{8}$ & $\begin{array}{l}356 \text { pounds nitrate of sola, distribnted in four sowlings...... } \\
336 \text { pounds nitrate of soda and } 356 \text { pounds superphospate, in }\end{array}$ & 8. 7660 & 12. 75 & $2,834.70$ \\
\hline & 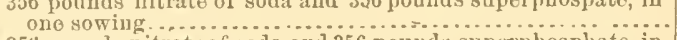 & 9. 1220 & 13.23 & 2415.46 \\
\hline 9 & 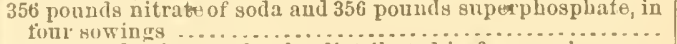 & 235 & 13. 08 & $2,568.24$ \\
\hline 10 & 1,068 pounds nitrate of soda, distributed in fonr sowings ..... & 8.5230 & 12.43 & $2,367.40$ \\
\hline 11 & 356 pounds sulphate of ammonia, distributed in one sowine.. & 8. 4378 & 13. 89 & $2,336.25$ \\
\hline 12 & 356 pounds sulphate of ammonia, distributed in four sowings & 7. 7985 & 12.75 & $1,962.45$ \\
\hline 13 & 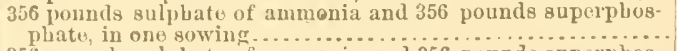 & 6.5860 & 13. 08 & I, 722.15 \\
\hline 14 & 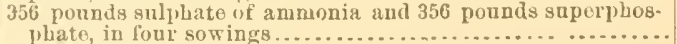 & 6.9360 & 13. 08 & $1,827.17$ \\
\hline 15 & 356 pounds superphosphate witlout nitrogen or manure..... & 7.5205 & 13. 24 & $1,990.93$ \\
\hline 16 & 1,008 pounds sulphato of ammonia, in four sowings.......... & 6.4970 & 12.42 & $1,093.57$ \\
\hline
\end{tabular}


"Jonlie* also found, in his experiments with stable manure and the different fertilizing componnds made according to his formula, that the largest jield was obtained with the complete manure containing all the leading elements. The next best yield was secured with the complete manure without potash; the next with nitrate of soda alone. The yields with the others decreased regularly in the order in which they are named. Without phosphate and withont lime; with sulphate of ammonia; with stable manure; with nothing; with guano. From his experiments he concludes as follows:

"(1) The manure especially suited to tho beet, and and which establishes the best conditious, as well for the yield per acre as for quality, is the complete manure B, of which the following is the composition :

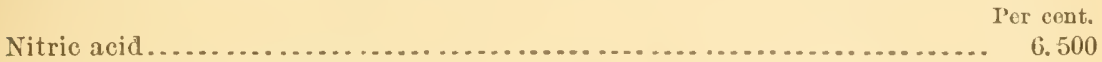

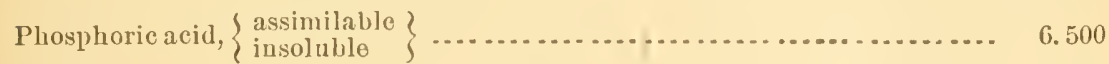

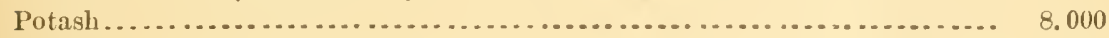

Soda ................................................... 9.000

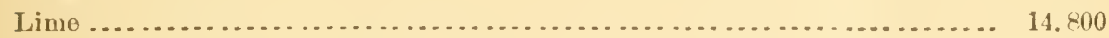

Water, sulphuric acid, silica, and other accessory elements............. 55.200

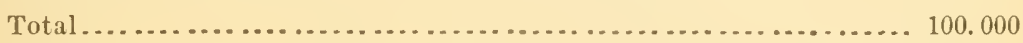

The nitrogen corresponds to ammonia........................... 8.000

The phosphoric acid corresponds to tricalcic phosphate............... 14.200

"(2) In soils provider with potash it (the manure B) is adrantagenusly replacod by tho manure $F,+$ which ditiers only in tho substitution of soda for potash.

\begin{tabular}{|c|c|c|c|c|c|c|c|c|c|c|}
\hline \multirow{2}{*}{$\begin{array}{l}\text { Denomination of } \\
\text { manuro. }\end{array}$} & \multicolumn{3}{|c|}{ Nitrogen. } & \multicolumn{3}{|c|}{ Phosphoric acid. } & \multirow{2}{*}{ Potash. } & & \multirow{2}{*}{ Lime. } & \multirow{2}{*}{$\begin{array}{l}\text { Acces- } \\
\text { soryele- } \\
\text { ments. }\end{array}$} \\
\hline & $\begin{array}{l}\text { A numo- } \\
\text { niacal. }\end{array}$ & Nitric. & Total. & $\begin{array}{l}\text { Assim. } \\
\text { ilable. }\end{array}$ & $\begin{array}{l}\text { Insol- } \\
\text { uble. }\end{array}$ & Total. & & & & \\
\hline $\begin{array}{r}\text { Manuro A completo. } \\
\text { B complete. } \\
\text { C conplete. } \\
\text { D completo. } \\
\text { E without } \\
\text { potash ... } \\
\text { E concen. } \\
\text { trated.... } \\
\text { E withont } \\
\text { potash No. } \\
2 \text {........ } \\
\text { F without } \\
\text { potash ... } \\
\text { G without } \\
\text { nitrogen } \\
\text { G without } \\
\text { nitrogen } \\
\text { No. } 2 \ldots . . .\end{array}$ & $\begin{array}{r}4.14 \\
\ldots . . . \\
\cdots \ldots . . \\
\cdots . . . \\
6.50 \\
9.00\end{array}$ & $\begin{array}{r}2.36 \\
6.50 \\
4.00 \\
2.50 \\
\ldots \ldots . . \\
\ldots \ldots . .\end{array}$ & $\begin{array}{l}6.50 \\
6.50 \\
4.00 \\
2.50 \\
6.50 \\
9.00 \\
3.00 \\
6.50\end{array}$ & $\begin{array}{l}\text { 5. } 00 \\
5.00 \\
5.00 \\
8.00 \\
5.00 \\
\\
9.00\end{array}$ & $\begin{array}{l}1.50 \\
1.50 \\
1.50 \\
2.50 \\
1.50 \\
\\
2.00\end{array}$ & $\begin{array}{r}6.50 \\
6.50 \\
6.50 \\
10.50 \\
\\
6.50 \\
11.00\end{array}$ & $\begin{array}{r}8.00 \\
8.00 \\
14.00 \\
8.00 \\
\ldots . . .\end{array}$ & $\begin{array}{c}9.00 \\
\ldots \ldots \ldots \\
\cdots \ldots . . \\
\ldots . . .\end{array}$ & $\begin{array}{l}17.00 \\
14.80 \\
19.00 \\
20.00 \\
19.50 \\
12.00\end{array}$ & $\begin{array}{l}62.00 \\
55.20 \\
5650 \\
59.00 \\
67.50 \\
68.00\end{array}$ \\
\hline
\end{tabular}

* Guide ponr l'achat et l'Enploi des Engrais Chimiques, pl. 250 and 251.

t The conclusions of Professor Joulio will be better understood if referonce is made to the accompanying table, showing the composition of the fortilizcrs, made according to his various formula. 
"(3) These two manures should be applied at the rate of 400 pounds per acre upon soils in good condition and withont stable mannres.

"(4) Stable manure, applied at the rate of 20 to 25 tons per acre in the same year that the crop is grown, constitutes a bad condition, which it is prudent to avoid. It is better to reduce the stable manure to 10 or 12 tons and supplement it with a suitable addition of chemical mannres. Thus putting the minimum of salts, particularly of potash, at the disposition of the roots, a better quality will be obtained.

"(5) If stable manuro be applied at the rate of 10 to 12 tons per acre, which rate it has been found advisable not to exceed, the manure $\mathrm{F}$ without potash should preferably be employed at the rate of 200 pounds for good soils and of 400 pounds for poor soils. We thus avoid excess of potash, and establish between the useful elements an equilibrium favorable to the crop.

"(6) If fossil phosphates have been added to the stable manure after the method suggested by Baron P. Thenard, the manure F may be replaced by nitrate of soda at the rate of 260 pounds per acre for good soils and a maximum of 350 pounds for poor soils.

"(7) In no case should salts of potash (nitrate, sulpbate, or chloride) bo added to stable manure, which is al ways suffieiently rich in this element.

"From these and later experiments Mons. Jonlie conclnded, in general, concerning nitrogen of various compounds in its relation to the beet root and the influence upon its sugar content, that the nitrogen of the nitrates is more effective than that of ammonia, which in its turu is more valuable than that of organic matter.

"This difference in the elements of plant-food has also been noticed and determined by other workers, who have arrived at conclusions quite as marked as those of Joulie just giren. Pagnoul * states that experiments made at Arras and elsewhere lead to the following conclu. sions concerning the use aud abuse of nitrogenous compounds :

"(1) Abuse of all nitrogenous compounds, nitrates, stable-manures, seed-cake, etc., is always iujurious to the quality of the beet.

"(2) Excess of nitrates by application before sowing is less injurious than cxeess of nitrogenous manures of organic origin. In fact the first are at once absorbed by the young plant favoring the development of leaves. Ou the contrary, the others act slowly and in decomposing may undergo nitric fermentation, which, favored by metenrological conditions, such as probably existed in 1875 to 1876 , ereates in the soil an abundance of nitrates, the retarding action of which impoverishes the root in the last days of growth.

"Concerning stable-manure, it is a fact that there is no necessity for prohibiting its use, because growers are generally wantiug in it, and they will not be tempted to use it in excessive quantity to the same extent as they may be induced to use the mineral manures. But it is useful to show that this excessive use, if it were possible, would be even more fatal than the use of nitrates, as regards the quality of the root.

"(3) For the same reason the use of nitrates after sowing, and especially in the months of August and September, is absolutely bad, and may be characterized as fraudulent.

"(4) The abuse of nitrogenous manures, nitrates, and others is much less fatal when nsed upon rich varieties, and roots closely planted than upon poor varieties aud roots cultivated at greater distances.

"(5) The-causes to which the bad quality of the beets in our region (department of Pas-de-Calais) should be attributed are " * * the too great richuess of our soils in nitrogenous matters, the abuse of manures, and the application of nitrates after sowing.

* Journal des Fabricants de Sucre, 1878, October 13. 
"Concerning stable-manures and the other nitrogenous manures used, M. Georges,* in a lecture on beet-root culture, adrises that the quantity of stable-manure should not exceed 10 to 15 tons per acre, since this quantity will supply sufficient of salts for the needs of the plant. Nitrogen being the deficient constituent, should be supplied by some very soluble and easily-assimilable compound, such as from 250 to 350 pounds per acre of nitrate of soda, with an addition of a like quantity of superphosphate of lime, the latter element especially intervening to increase the richness in sugar. The prejudice against uitrate of soda is unjust. Judiciously applied it is useful. Only its abuse is disastrous, but neither more uor less than the excessive use of all others, and even stable-manure worked into the soil prerious to sowing; it hastens the vegetation of the plant at the start and helps it through the first stages of growth. When it is exausted, the stable-mantres, by their slow decomposition, supply the subsequent demands of the plant. But nitrate of soda should not be applied during the growth of the plant, because it may then remain in nature in the adult beet, which will not have time to elaborate it and secure all the useful effect. Sulphate of ammonia, with an equal quantity of nitrogen seems to be less farorable than nitrate of soda, because it is a salt which tends to rise to the surface in the soil, while the other descends to an equal extent. Other matters, such as seed-cakes, woolen wastes, etc., may be substituted for the nitrates, but they should in all cases be worked into the soil before sowing, that they may have time to decompose in adrance and may be thoroughly mixed through the entire arable stratum.

"These ideas expressed by M. Georges were reiterated by M. Drouyn de l'Huys, t and express the views of all scientists and cultivators in France. But while all admit the value of the judicious application of the nitrates, it appears also to be the universal opinion that it should be accompanied by the application of a corresponding quantity of the phosphates, which have a tendency to counteract any prejudicial influence that the nitrates may exert by hastening the maturity of the plant and increasing its sugar content. This fact has been rery nicely elaborated by Professor Maercker, of Halle, in a lecture lately delirered upon the subject of beet culture, an abstract of which may be found in the Journal des Fabricants de Sucre. He says it is a well-accepted fact that strong doses of nitrogenous manures are injurious to the beet crop, in that it increases the weight of the nou-saccharine contents and reduces the sugar. The discredit into which the use of nitrates has fallen is due to its abuse and the manner of applying it. The difficulty appeared to be to determine the quantity to use and the best time to apply it. When applied too late it retards ripening. Applied in spring the plants develop vigorously in leaves and root and the period of growth is lengthened. So strongly nitrogenous manures always produce growth.

* La Sucrerie Indigène, 1878.

†Compte-rendu des Ś́ances du Congrès Agricole et Sucrèire tenu a Compiègne Mai, 1877. 
"But the sugar-bect must ripen to aecnmulate sugar within it. Its growth should therefore be arrested to admit of ripening, which late distribution of nitates prerents. At Magdeburg part is applied in the fall and the remainder before the preparation of the soil in spring. Heary doses of strongly nitrogenous manures also necessitate heary doses of phosphoric acid to annihilate the injurious effect of an excess of nitrogen. Phosphoric acid applied in large quantity induces early ripening of the plant. A mellow, permeable, clay soil may receire doses that would be injurious to a cold soil.

"Pagnoul lias developed by his researches and obserrations that phos. phoric acid gires varying results. In some soils no appreciable effect can be noticed, while in others its use has been found rery farorable, and these differences are attributed to the greater or less proportion of phosphoric acid already existing in the soil. Notes should therefore be kept of the effects of rarious manures in order to aroid unnecessary expense in their application. M. Decrombecque considers that in all cases the phosphoric acid in the soil should be increased as the nitrogenous principles increase, and Woussen considers phosphoric acid a corrective for the deleterions influences of nitrates, because upon soils where nitrate of soda has been applied in large doses it is only necessary to increase the proportion of phosphates of lime to secure good maturation of the crop which would otherwise remain green.

"Pellet* has adranced some interesting notions concerning the comparative valnes of the different elements of plant-food in their relation to the production of sugar in the beet, deduced from the study of analyses of different plants obtained by rarious persous in their experiments. Lawes and Gilbert, discussing the analyses of wheats growu upon the Rothamstead farm, and of French wheats analszed by Boussingault, conclude that wheat scarcely admits of a change in the composition of its ashes, whatever may be the composition of the fertilizers applied; the same is true of potatoes.

"But Pellet finds that the beet, on the contrary, may grow with equiv. alent substitutions of the alkalies necessary to the formation of sugar, so that, as shown by the experiments of Joulie, soda may be found in the ash of some beets in the same quantity as potash, while in others the quantity of potash is seren times that cf soda. This substitution mas also be noticed between lime and potash, but experience shows that though the alkalios mas thus substitute each other, and lime, by equiralents, certain other bodies, such as phosphoric acid, will not admit of being replaced. The experiments of Champion and Pellet also show that in all plants we may observe a relation between the total weight of ashes and the special organic matters for which the plant is cultivated. Thus in wheat between the starch aud total ash, and in the beet between the sugar and total ash. They coustruct the following table, showing 
in general that for the formation of 100 pounds of sugar in beets, the roots and leares in their development must consume-

1 to 1.20 pounds of phosphoric acid.

5 to 6 pounds of potash.

1.5 to 2 pounds of soda.

1.5 to 1.6 pounds of lime.

1.2 to 1.4 pounds of magnesia.

2.7 to 3.5 pounds of nitrogen.

"Excess of all may be present in the soil, but if phosphoric acid be wanting sugar will not be produced, while if lime is wanting it will be replaced by potash or soda or magnesia, and this rule holds good for the other alkalies. The author therefore concludes that 1 of phosphoric acid corresponds to 100 of sugar, while 5 to 6 of potash corresponds to the same amount, and consequently phosphoric is worth 5 or 6 times more than potash in the formation of sugar, if potash replaces no other alkalies; in other words, if a soil be wanting in 60 pounds of assimilable potash per acre, there will be a deficit of 1,000 pounds of sugar, while for the same deficit only 10 pounds of assimilable phosphoric acid need be wanting. Phosphoric acid he consilers a non-dominant but indispensable element or base for the formation of sugar in the beet.

"Reasoning from these data, they conclude that without experiment, but by examination of the average composition of the ashes and of the quantity of nitrogen in the plant, and comparing the total weight of the different constituents with that of the given proximate principle to be produced, for instance, sugar in the beet and starch in wheat and potatoes, it is possible, they say, to determine the order in which the elements of plant-food are indispensable for each plant. Thus, for the beet they range: 1, phosphoric acid; 2, lime or magnesia; 3, nitrogen, 4, potash or soda. On the other hand, the order for whent is : 1, lime or magnesia; 2, potash ; 3 , phosphoric acid, etc. These are facts of great importance in the economy of providing supplies of plant-food, and they will aid greatly in the selection of the compounds to be emplojed for the fertilization of rarious crops.

"From what precedes and what we learn from the long.established practices followed in France in the application of fertilizers to the land on which beets are to be produced, it appears that nitrogenous organic compounds insoluble in water should be worked into the soil a long time in advance of the crop, and that to enjoy a beneficial result from their use they should be distributel at least during the autumn preceding the season of planting, and for stable-manures it is preferable that they be given to a preceding crop, which in France is generally oats or potatoes.

"Stohmann* says it is generally recoguized as a rule that the sugarbeet should nerer be cultirated upon a fresh mantre or barnyard ma. nure, because this system of culture gives a large yield in weight, but roots so rich in foreigu matters that they ean not be worked with profit.

* Journal des Fabricants de Suere, November 20, 1878. 
The beet should always form the second rotation when the manure is strong.

"Other organic nitrogenous eomponuds, such as seed cakes, refuse animal matters, and even ammonia salts, may be applied in the fall or in the rery early spring, while the nitrates, which are more soluble, may be applied either immediately before or immediately after planting.

"In no ease should the latter be applied during the period of growth, on aceount of its influence, as shown by numerous experiments, to retard the time of ripening and the eonsequent maximum derelopment of sugar.

"The quantity of stable manure per acre that may be applied to land to produce the most favorable effect seems in France to be from 8 to 15 tons, accorling to the character of the soil, and it is generally more profitable to use a smaller quantity and supplement it with nitrates and phosphates. The value of lime in its relations to the beet is no less than for other crops. Its disintegrating influence upon the nitrogenons organic matters is as important as its power to take the place of other alkalies which may be wanting. In fact, on aecount of this property, many of the most intelligent growers are inelined to use it, aud by means of it to avoid in the juice many of the more objectionable soluble salts that the alkalies are likely to introduce. Another important considerition is its low market value, and the convenience of its applieation. At the same time, deficiencies of the other alkalies in the soil should not be overlookel, and they should be in all eases made up.

"It is searcely neeessary to further eall attention to the importanee and ralue of the phosphates in connection with this erop, after all that has been said. They may be applied at all times, and many growers consider it of arlvantage to distribute small quantities with each working or hoeing. The general method employed, howerer, is to distribute it in advance of the last plowing, in the course of which latter operation it becomes distributed throughout the entire arable layer. But if applied in the spring, it is considered by many that it should be deposited in the rows with the seed, and M. Derome is of the opinion that 100 to 250 pounds per acre applied in the rows will produce quite as good effeets as 400 to 800 applied broadeast. He coneludes from all his experiments, the results of whieh are coufirmed by those obtained by Corenwinder, Pagnoul, Ladurean, and others, that artifieial fertilizers worked in with the plow will give an average of abont 3 tons more of beets than the same quantity of manure applied on the surface and worked in with the enltivators.

"The next consideration in the culture of the beet is the improvement of the physical qualities of the soil, and its preparation for the erop. The importanee of drainage, etc., has already been referred to in the review of the inherent physical qualities of the soil which make it snited to this erop, and we may therefore proeeed at once to the consideration of its manipulation to bring it to the favorable conditions before quoted. 
$\Lambda$ ud we shall first of all review the ideas advaneed on this subject by some of the later writers who may be considered good authorities. Briem* says :

"The development of the beet depends, in the first place, upon grood preparation of the soil, and its continned and careful maintenance. A preparation carefully effected brings about a mellowing of the soil, access and change of air and water, destruction of weeds, and deep growth of the root. Deep plowing (with steam where this is possible) is the first coudition of a rational culture. This operation should be effected in advance of winter. Snbsequent cultivation should not be spared. It improves the size and quality of the plant, and should be repeated as often and as long as the leaves will permit. The nore tho culture approaches that of a garden the more the quantitative and qualitative field will be increased.

"Aceording to Stohmann, beets do better after well-manured gramina. They naturally find place in rotation after wheat and ba:ley. In some cases beets' have been produced two years in suceession, but this is possible only in exceptional cases. It is injudicious to recommend a rotation of beets of less than two years. Immeliately after a crop of cereals, the ground is broken up. In the fall, plow as deeply as the nature of the soil will permit, and leave the field with the furrows thus exposed during the winter to atmospheric influences. In the spring, prepare the soil for sowing by means of the roller and harrow; and in order not to lose the accumulated moisture of winter, aroid, as far as possible, plowing again in the spring:

"Vilmorint directs to begin with an ordi ary plow in the fall, followed by a draining plow, so that the ground will be broken up to a depth of 6 to 8 inches; and plow in the spring, and follow with harrow and roller. We can not more clearly give the prevailing opinions of French growers upon this inatter of preparation of the soil than is expressed in the discnssion on the subjeet in the meetings of the agrieultural and sugar congress held at Compiègne in May, 1877, and published in the report of the procedings; and I therefore present below a translation thereof:

"M. Boursier said that it is, above all, necessary to work tlie ground and put it in such conclition that it may be at the same time permeable and firm enough to adhere - to the roots. 'This is effected by deep plowing and energetic harrowing and rolling. It would, nevertheless, be useful to elucidate this point, whether it is better to give a single deep plowing in autumn, followed by cultures with the scarifier and the harrow in spring, or to giveseveral plowiugs, the first in advance of winter and the second immediately preceding sowing. For himself he considered it better to give a singlo deep plowing in the fall or winter.

"M. Debains prefors the system which consists in first giving a plowing to break up the stubble, followed by another to bury the manure, and finally a third beforo sowing.

"M. Blin said there was no necessity to have an absolute system with this regard. It would be dangerous to givo a deep plowing to land having a shallow stratum of arable soil.

"M. Decrombecque had not adopted deep plowing, for the nature of his soils would

* Journal des Fabricants de Sucre, October 23, 1878.

$\dagger$ Ibid., February 27, 1878. 
not permit it; but in order to submit the greatest possible surface of soil to the beneficial atmospheric influences, he practiced the methorl of ridging.

"M. Boursicr explained that by deep plowing he did not mean absolutely to say 14 to 16 inches; plowing is considered deep when it exceeds by 1 or 2 inches that of preceding culture. A plowing of 10 inches would be deep in ground which had never been broken np more than 8 inches; the depth is moditied according to the soil.

"M. Demot called attention to the excellent effocts of breaking up without displacing the subsoil (i.e., subsoiling). With this system the production is sensibly increased. The use of the draining plow should be strongly recommended.

"M. le. Vte. de Chezelle called attention to the favorable effect of deep plowing shown by the vegetation on the sides of ditches opened for lrainage.

"M. X. — responded that this fact does not constitute an argument in favor of dcep plowing. In fact, in draiuage the regetal earth is always returned to the top while plowing brings the subsoil to the surface, and if this is not regetal (fertile) it is evident that the operation is defective. He also insistod upon the use of the draining plow.

"MI. Barral recognized the fact that deepening the arable layer is always advantageons in the long run, and he recommended attacking tho subsoil only with precantion, and after taking into account its chemical composition. In this connection, as in the most of agricultural questions, it is impossible to fix an absolute principle, and it is always necessary to take account of circumstances. Besides it can not be denied that the heetis one of the plants for which the depth of the arable lacer is of the, greatest importance.

"M. de Rougé has proven the excellent effects of deep plowing upon the poor clay soils of the extremity of the Aisne. Like M. Bonrsier, he connseled plowing in autumn. During the winter the land to be sown in the spring should be impregnated with the substances of the air and submitted to the favorable atmospheric influences. Broad furrows should be made in the first plowings giren in antumn, because the more the earth is formed of large lumps the more the frost may penetrate by the wide spaces which separate them.

" $\mathrm{M}$. Ch. Gossin remarks two unfortunate effocts in the plowing which immediately precedes sowing the beet. (1) This plowing stirs up the soil iu the interior. Now, the beet does not like light soils. (2) By this plowing we bring to the surface a quantity of barl seeds, which germinate at the same time as the beet, and cover the gronnd with weeds, while if the ground be plowed in the fall, the seeds which germinate in the early spring are killed in the operations of culture which precede sowing. Therefore in the triple regard of contact, of atmospheric agents, of the mellowness aud internal cohesion of the soil and cleanliness of the ground, fall or winter plowing should be advised.

"The method of preparation folloted in practice by M. П. Vilmorin is as follows: Begin plowing in November and break up the land 8 or 10 inches, and follow this with a subsoil plowing to a depth of 8 or 10 inches more, so that the ground will be thoroughly stirred up to a total depth of at least 15 inches. During the progress of this work, and as far as possible, the artificial fertilizer employed is distributed in the furrows before subsoiling. The ground is then left in the rough condition consequent upon plowing, and after that is twice plowed in spring, in February and April. It is finally prepared for sowing by harrowing and rolling.

"M. Champonnois considers it of adrantage to prepare the ground in ridges before sowing, especially in working rery shallow soils, in order to provide depth for the long tapering root, and put the ground in better condition for the circulation of air and water. He claims for his 
method of culture that it is less costly than the ordinary method, and gives a better quantitative and qualitatice result. In his experiments he obtained 40 tons of beets per acre hariug an average richness of 18.50 per cent. and a co-efficient of purity above $\$ 3$.

"The results of his experiments in 1878 do not seem to be as good as those obtained in previous years, as shown by the following table:

\begin{tabular}{|c|c|c|c|c|}
\hline & No. 1. & No. 2. & No. 3 . & No. 4. \\
\hline 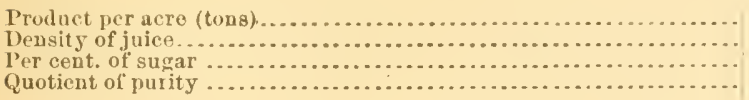 & $\begin{array}{r}28.300 \\
69.17 \\
11.37 \\
69.70\end{array}$ & $\begin{array}{r}40.150 \\
5.45 \\
9.61 \\
66.69\end{array}$ & $\begin{array}{r}22.500 \\
6.75 \\
14.90 \\
83.94\end{array}$ & $\begin{array}{r}11.725 \\
70.5 \\
16.91 \\
86.0\end{array}$ \\
\hline
\end{tabular}

OBSERVATIONS.

\begin{tabular}{|c|c|c|c|}
\hline No. 1. & No. 2. & No. 3. & No. 4. \\
\hline 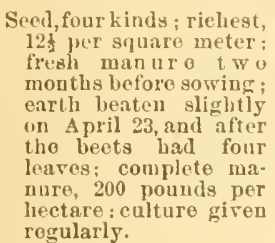 & $\begin{array}{l}\text { Same culturo and care; } \\
\text { tour kinds of seeds } \\
\text { productive of woight; } \\
\text { at Norember } 1 \text { beets } \\
\text { were in full growtl } \\
\text { due tokind of numure } \\
\text { and time of its appli. } \\
\text { cation; beets short } \\
\text { and rooty. }\end{array}$ & $\begin{array}{l}\text { Manure well rotted: } \\
\text { plowed in ridges; rell } \\
\text { beaten by rolling; ma. } \\
\text { nure.residnes of elu. } \\
\text { tion containing salts } \\
\text { and nitrogen of mo- } \\
\text { lasses; culture rega. } \\
\text { lar througbout eutire } \\
\text { growth. }\end{array}$ & $\begin{array}{l}\text { No manure plowed in; } \\
\text { cluenical manure, } 625 \\
\text { pounds per acre, } \\
\text { worked in; sowed } \\
\text { late; culture contin- } \\
\text { ued tbroughout rege- } \\
\text { tation; quality good; } \\
\text { quautity wanting, ex- } \\
\text { plained by latesowing. }\end{array}$ \\
\hline
\end{tabular}

"However, in this matter of preparing the soil, as in all others, it ap. pear's that the grower, while following the general prineiples enuneiated, must be guided by his own judgment and the character of the soil with which he has to deal.

"Sowing is generally effected by means of a drill especially designed therefor, but any drill that will deliver the seed regularly and in sufficient quantity will satisfy erery purpose. The forms employer in France vary with the different inventions, but the spoon drill is the most common.

"The best time for sowing is considered to be the last week in April and the first fortnight in May, when the temperature should range from $50^{\circ}$ to $60^{\circ} \mathrm{Fahr}$., for at this temperature the seed will germinate most surely and most rapidly. The germinating faculty is materially increased by immersing it in water at $120^{\circ}$ Fahr., and the beets produced are often richer in sngar on aceount of this treatment.

"Messrs. Champion and Pellet* gire the following results of an experiment in growing seeds soaked in water and those not soaked:

\begin{tabular}{|c|c|c|c|}
\hline & 1)ate. & $\begin{array}{l}\text { A verage } \\
\text { weight. }\end{array}$ & $\begin{array}{l}\text { Sugar in } \\
\text { beots. }\end{array}$ \\
\hline $\begin{array}{l}\text { No. } 1 \text {, normal seed... } \\
\text { No. } 2 \text {, soaked seed... }\end{array}$ & 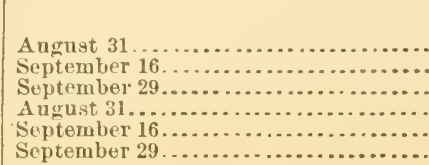 & \begin{tabular}{r} 
Grams. \\
400 \\
460 \\
580 \\
\hdashline .300 \\
580
\end{tabular} & $\begin{array}{r}\text { Percent. } \\
16.4 \\
13.4 \\
17.0 \\
16.9 \\
14.9 \\
17.2\end{array}$ \\
\hline
\end{tabular}

* La Bettrave à Sucre. 
"Besides this, the beets produced with soaked seed had a better form than those from normal seeds.

"Varions solutions have been suggested to be employed for soaking the seed, among others water slightly acidulated with nitric acid. Humbolkt suggested rery dilute chlorine water, but Ducharte showed that this was of no value.

"In many sections of France and Grermany the juices flowing from the manure heaps are used for this purpose. They are diluted with an equal volume of water, and the seeds immersed in them for forty-eight hours. The seeds are after this time taken out, mixed with ashes, and passed over a screen. After this treatment they may be put in bags and kept in a cellar or other cool place until needed. When ready to be sown they must be quite dry on the surface, in order that they may not ad. here to each other in sowing. Other solutions for the purpose have been used in France and Germany, the values of which, Basset states, range in the orler in which they are named:

"1. Mixture of urine and water in equal parts.

"2. Purin, or manure juices, pure or dilute, for which may be substi. tuted ordinary water in which has been macerated guano, fowls' or pigeons' dumg, so as to obtain a solntion of a density of 1.015 or 1.020 .

"3. Solution of nitrate of potash of 5 per cent.

"4. Solution of phospluate of ammonia of $2 \circ \mathrm{B}$.

"5. Solution of superphosphate of lime 2 per cent.

" 6 . Solntion of 2 to 2.5 parts chloride of lime in 100 of water.

"7. Dilute acid solntions of 1 to $1 \frac{1}{2}$ per cent., prepared ouly with lychrochloric, sulphuric, or phosphoric acids.

"Solutions of nutritice matters are considered more favorable to the jurpose than pure water, because the latter in prolonged soaking will often remove from the seads some of their soluble constituents. The length of time during which the soaking should be continued might vary somewhat, accorling to the temperature, but it is generally confined to forty-eight hours, and twenty-four are often considered sufficient. Basset states that during trenty-four bours seeds will absorb-

69 per cent. their weight of water at $39.9 \circ$ Fah.

91 per cent. their weight of water at $50.8 \circ \mathrm{Fah}$.

95 yer cent. their weight of water at 600 Fah.

97 per cent. their weight of water at 650 Fah.

"Experiment has shown that seeds require, in a soil sufficiently moist and aerated, a total sum of degrees of average temperatures equal to 6500 Fah. for germination. Thus if the average daily temperature be 50 , thirteen days will be required for germination; if it be $55^{\circ}$, then twelve days will suffice; and if $65^{\circ}$, only 10 days will be required. If, however, the seed be soaked for twenty-four hom's in water at $1000^{\circ}$ 
then the total sum of thermometric degrees, and consequently the number of days required for germination, will be correspondingly reduced. If they be soaked forty-eight hours at $100^{\circ}$, then only nine days will be required for germination in the ground at an average temperature of $500^{\circ}$, and a correspondingly less time with a higher temperature.

"With regard to the best time for sowing them, Basset* directs as a rule: "Sow as early as possible according to the temperature of your locality, whatever may otherwise be the method chosen." Thus, when the temperature of the air is from $50^{\circ}$ to $54^{\circ} \mathrm{Fah}$. at noon, $46^{\circ}$ to $50^{\circ}$ in the evening, and $32^{\circ}$ to $36^{\circ}$ in the morning, sowing may be begun without fear of unfarorable temperature. This may be combined with observations of the temperature of the soil, which shonld at the same time have an average of about $45^{\circ}$ at a depth of 4 to 6 inches.

"Concerning the depth to which the seed should be corered in the ground, opinions differ somewhat, but it will naturally follow that mnch must necessarily depend upon the temperature of the season, the physical condition of the soil, and the proportion of moisture. The seed requires the presence of oxygen for germination, and, therefore, if the penetration and circulation of atmospheric air be rendered diffienlt or impossible on account of a close, hard character of the soil, this function can not be exercised, and the seed will rot in the ground. If the soil be permeable and contain sufficient moisture, the depth of corering the seed will vary with the temperature. If this be too low, again, the seed will rot. But with a favorable temperature and a good physical condition of the soil, less attention may be giren to the depth of seeding. However, it is considered a good rule not to bury the seed under any cirenmstances more than 1 to 2 inches, and experience has shown that at this depth, other things being equal, a higher pereentage of the seeds will grow than at any other.

"In all of the beet-growing districts of Europe the system of planting in rows has been adopter, but in later years the attention and experiments of the progressire men have been directed to the determination of the influence of the distance between the rows and the beets in the rows upon the yield per acre and the saccharine value of the erops. In earlier years the practice was to separate the roots to such an extent that each square yard of surface should be devoted to six roots, but the experience of later years has shown that it is better to inerease the number for this surface to ten. The extent of separation must uaturally vary with the character of the soil and the seed grown. If in rich soils the roots be widely separated from each other they have at their disposition more of nutritive materials, and there is, of course, a tendency to the production of large roots, which, we have seen, will contain more of mineral and organic impurities and less of sugar. On the other hand, if grown more closely the stock of nutriment is less, the beets are smaller

* Guide Pratique du Fabricant de Sucre, p. 38\%. 
and longer, and consequently richer. Yet, notwithstanding the smaller rolume of the beet produced, the weight of the total sield per acre is very mueh larger than when the roots are separated to greater distances. These facts are amply illustrated in the resnlts of the experiments of various workers in the sugar-growing districts of France.

"The following table shows the arerages of the results obtained from experiments made by the Soeiété d'A grieulture de Compiegne in eoncert with the Comité des Fabrieants de Sucre de l'Oise. This recapitulation is made simply aceording to the separation, and withont regard to the fertilizers employed.

[Distance between the rows, 18 inches.]

\begin{tabular}{|c|c|c|c|c|c|c|c|c|c|}
\hline \multirow{2}{*}{$\begin{array}{l}\text { Distance bet } \mathrm{t} \text { oen } \\
\text { beets in the rows. }\end{array}$} & \multirow{2}{*}{$\begin{array}{l}\text { Beets } \\
\text { per } \\
\text { acre. }\end{array}$} & \multirow{2}{*}{$\begin{array}{l}\text { Arerage } \\
\text { weight of } \\
\text { a beot. }\end{array}$} & \multirow{2}{*}{$\begin{array}{l}\text { Density } \\
\text { of pure } \\
\text { juice. }\end{array}$} & \multicolumn{3}{|c|}{ Per bundred of juice. } & \multirow{2}{*}{$\begin{array}{l}\text { Degree } \\
\text { of } \\
\text { purity. }\end{array}$} & \multirow{2}{*}{$\begin{array}{l}\text { Salino } \\
\text { coeftic. } \\
\text { ient. }\end{array}$} & \multirow{2}{*}{$\begin{array}{l}\text { Sugar } \\
\text { per } \\
\text { acre. }\end{array}$} \\
\hline & & & & Sugar. & Salts. & $\begin{array}{l}\text { Organic } \\
\text { matters. }\end{array}$ & & & \\
\hline $\begin{array}{l}\text { Ten inches....... } \\
\text { Fourteen inches... } \\
\text { Eighteen inches... }\end{array}$ & $\begin{array}{l}\text { Tons: } \\
32,533 \\
29,515 \\
31,018\end{array}$ & $\begin{array}{r}\text { Pounds. } \\
1.88 \\
2.23 \\
2.85\end{array}$ & $\begin{array}{r}\text { Degrees. } \\
6.79 \\
6.06 \\
5.05\end{array}$ & $\begin{array}{l}11.55 \\
12.68 \\
12.40\end{array}$ & $\begin{array}{l}1.0823 \\
0.8195 \\
0.8700\end{array}$ & $\begin{array}{l}2.0910 \\
2.2976 \\
1.0142\end{array}$ & $\begin{array}{l}81.93 \\
80.19 \\
86.71\end{array}$ & $\begin{array}{l}13.58 \\
15.61 \\
14.43\end{array}$ & $\begin{array}{r}\text { I'ounds. } \\
8,473 \\
7,480 \\
6,691\end{array}$ \\
\hline
\end{tabular}

"Pagnoul's experiments, condueted dnring a series of eightyears, gare similar results. He concludes that close planting gires beets which are (1) richer; (2) better quality; (3) of larger yield in weight; (4) less exhausting to the soil. He took, for his wider separation, 20 inches between the rows and 20 inches between the roots in the rows, and for the smaller separation 17 inches between the rows and 8 inehes in the rows.

"(1) The riehness of sugar in percentages of the weight of root was:

For the large listances........................................ 10.2

For the small distances .......................................... 12.2

"(2) The proportion of alkaline salts, giving at the same time the measure of the foreign organic matters, was for 100 of beet:

With large listances............................................... 1.512

With small distances......................................... 0.722

"(3) With large distances there were 16,326 roots per aere, and with the small distances 46,122 , or nearly triple. The yield in weight per acre was:

Tons.

With large distances........................................ 28.0.... $0 . \ldots 5$

With small distancos............................................ 36. 045

"(4) The quantity of salts remored per acre would be equal in romud numbers to :

With large distances ... Pounds.

With small distances........................................... 520

"M. Pagnoul says in conclusion:

"Beets at small distances, while producing more of sugar, absorb less of saline matters. 
"Now we know that the constituent principles of sugar are entirely furnished by the atmosphere, and that the saline matter's are furnished by the soil and by fertilizers; therefore, bcets at small distances from each other ( $i$ e., elosely planted) are less exhausting to the soil.

"Close culture is more profitablo at the same time to the grower and the manufacturer.

\section{Dubrunfaut says :*}

"The multiplication of subjects to avoid large roots, and to facilitate at the same time the production of a good constitution of the cellular tissuo, is another condition to which great importanco should be attached in the interost of richness in sugar.

"Briem sayst ' the separation of the roots should be 15 by 10 inches.'

"In a late discussion in the meeting of the Cercle agricole du Pas-de. Calais, ț it was developed that though the distance of 17 inches between the rows was still in use, it is gradually giving way to the wider separation of 20 inches, on account of the diffeulties experienced in horsehoeing and the deficient aration of the improved races of beets with strong foliage, which require more room.

"At the same time that the wider distance between the rows is adopted the roots are left closer to each other in the row about 8 inches; that is to confine them to from seven to nine roots to the square yard of surface.

"The experiments of M. Pagnoul, and results he obtained, together with tho other facts and figures given, will be sufficient to show the imprortance of this matter of close planting, without quoting the re. sults of the same character obtained by Corenwinder, Ladureau, Mariage, Pellet, Deherian, Vilmorin, and others; and we may conclude that for the methods of eulture that must be employed in the United States where hand labor can not bo obtained, the wider distanee between the rows, 20 inches, should be adopted, separating the roots not more than 8 inches in the rows.

"The cultural manipulations proper of the crop should begin as soon as the beets are up and the leaves sufficiently developed to distinguish tho rows; and we mas accept the statement so unicersally reiterated by those who speak and those who write on the subject, as sup. ported by the success of tho practice, that ' early and frequent cultivation call not be too strongly recommended; it kills weeds scarcely started aud forms a stratum of mellow earth which constitutes an ob. stacle to dryness by day and assimilates the moisture of the night.'

"As before stated, as soon as the rows are defined by the development of leaves the first cultivation by hoeing begins.

"In France this is, in many sections, performed by hand, while in others it is effected by means of the horse eultivator, the object being, of course, the destruction of weeds and stirring up the soil. At this time, also, many growers make an application of nitrate of soda or

* Isa Sucerrie Indigène, xiii, 460 .

tJournal des Fabricants de Sucre, October 23, 1878.

\$ Ibid., June 4, 1879. 
potash. Two weeks later the beets are thimned ont, so as to leare the roots about 8 inches apart from center to center, after the manner deseribed above. After this the erop reeeives abont three hoeings or cultivations, and more than this if time allows, for the work should be discontinued abont the 1st of July, according to some anthorities, or it may be continued as long as the leares will allow, according to others. The latter will probably be for all localities and elimates the better indication.

"After the final hoeing, about the 1st of July, no other care is necessary, with the exeeption of the removal of seed-stalks that may oceasionally appear, especially if July and August be dry, until the harvesting, which should take place before the appearance of hard frost. If the roots be frosted in the ground they are rendered unfit for storing and preservation in eaves or trenches for extraction of the sugar in the late winter, which is, of course, often necessary.

" Harresting is generally begun about the middle of September, and mas, according to the condition of maturity of the crop, continue until the middle of October.

"Pulling the roots is sometimes effected by machines that have been devised for the purpose, but the method generally employed is handpulling, the latter faeilitated by the assistanee of the piek or plow. In many cases a narrow furrow is made near to the row, which loosens the earth abont the root and renders its extraetion from the ground easier. The operation must in all cases be exereised with great eare, in order that the roots be not bruised or cut, aeeidents which inerease the tendency of roots to deeay when stored. They shonld also be pulled when the ground is in the driest condition. If the ground be wet at the time of pulling, the earth will adhere to the root, and this will also produee a tendency to deeay. Besides this, trouble will arise in the determination of the tare in the delicery of the erop to the manufacturer. In most cases the leaves are remored from the beet in the field, either at the time of pulling or at the time of charging them to the earts or wagons in which they are to be transported, either direetly to the factory or to storage. If there be danger from the frost the roots are piled in. pyramidal heaps, either before or after the remoral of the leaves, in such a manner that they may be covered by their leaves or by straw. The leares are removed by a knife or other instrument suffieiently strong and heary that the operation may be effected at a single stroke. It is estimated that twenty laborers* (women and children) will be required to pnll and prepare for transportation from the field the crop of an acre of beets in one day.

"But this estimate is made for French laborers, and we may calculate

*In the department of Seine-Inférienre ten laborers are generally employed for pulling the crop and preparing for transportation, five to pull the roots, and five to remove the leaves and tops. 
that only half the number of laborers will be required in the United States to do the same amount of work.

"The beets to be preserved, if all suface moisture has not already eraporated from them, should, before being placed in trenches or cellars, be temporawily stored under sheds. Here the wounded, withered, or frosted roots, which would be subject to rot, are separated, if they have not already been in the field. The larger roots are also separated for the same reason. When thus separated and prepared they are ready to be stored. In the preservation the conditions to be aroided are too low or too high a temperature, too moist or too dry an atmosphere. With too low a temperature they deteriorate by freezing. This is not so injurious if the roots can be worked before they have an opportunity to thaw ; otherwise, wuch of the eane-sugar changes over to inrerted sugar, and must necessarily pass into the wastes in the processes of extraction. If too warm, similar effects will bo produced by growth of leares, as shown by Corenwinder and others. If teo much moisture be present the roots have a tendeucy to rot, and if too little be present there will be a tendency to wither, and this effect is always accompanied by a loss of sugar, besides iucreasing the difficulty of extracting the juice from the root.

"The best temperature for preserving the roots in the fresh state, which is the eondition of preservation most employed in France, is between $35^{\circ}$ and $40^{\circ} \mathrm{Fah}$. The equilibrium of moisture between the air and the root should be so mfintained that evaporation may not take place; at the same time, as before stated, exeess of moisture must be scrupulously aroided. Prudent eultirators consider that the roots should be so arranged in storage that they shall never be more than 3 feet from an air passage, in order to secure constant and regular renewal of the aị to earry off noxious gasses, superflnous moisture, and regulate the temperature which always has a tendency to rise. The cellars or trenches must also be thoronghly drained, so that any water that may collect in the bottom may flow off. Temporary trenehes are often made in the fields, but the more advaneed growers are preparing permanent ones with well-paved bottoms and walled sides. They are generally $S$ to 10 feet wide and 6 to 8 feet deep. I have seen them with walled sides 9 by 9 by 85 feet.

"Along the bottom of the diteh and through the middle of it is made a small trench to conrey any water that inay percolate through the walls or through the roots. Before the beets are placed in the trench the bottom is eorered with poles, or in any other convenient manver, to keep the roots off the bottom and provide for free cireulation of air under them and drainage of water. Straw is often used for this purpase, but is considered bad, because it is subjeet to packing and decay, and the latter will, of course, be eommunicated to the stored roots. They are then packed in the trench and covered with straw or leaves and finally with 
earth. The depth of covering must be determined by the climate. In the case of permanent walled trenches, which amount in reality to elongated cellars, I have seen them covered with a very thick thatch of straw, proper openings being provided for the necessary rentilation. In this way the roots may be preserved throughout the entire winter. If they should by accident be frozen they should be preserved in this condition until they are worked. Indeed this condition constitutes one of the modes of preserving them where a sufficiently low temperature may bo maintained to keep them in this way unchanged withont au opportunity for thawing, and is recommended by some authorities. In sections where excessively cold winters prevail it might be found a rery courenient method for the purpose.

"Desiceation may be practiced where the method of diffusion or maceration has been alopted as the means of extracting the juice. It has the advantage of preserving the beet perfectly, with no danger from variations of temperature if the product be kept free from moisture or a moist atmosphere. They are also in the most favorable coudition for ready transportation to any distance.

"For the purpose of drying, the roots are cutin slices, and in warmer clinates placed in the sun, but in ordiuary climates they are dried in orens ly artificial heat. The method has the disadrantage of requiring a double expenditure of fuel in eraporation, $i$. e., for the remoral of the water of regetation and the water of diffusion employed for extraction of sugar.

"We see therefore that the experience of French growers and scientists proves that to secure the greatest profit from the culture of the beet the following points must be observed:

"Choose well-drained permeable soils, not overcharged with nitroge. nous organic or soluble mineral matters. Choose the best qualities of seed. Give preference to smaller seeds. The best beets for all purposes are long, tapering, and smooth; do not grow out of the ground; are of moderate size and are dense and heavy. Plow deeply and as frequently as may be necessary to make the soil mellow. The more it approaches that of a garden in physical condition the more favorable it will be for culture of the beet.

" Be careful in choice of manures to be employed. Remember that insoluble and not easily assimilable nitrogenous organic compounds, before they can be of use to the erop, must be thoroughly disintegrated and decomposed. They must therefore be applied sufficiently in adrance of the crops to secure this effect. Soluble nitrogenous compounds may be applied immediately in advance of or simultaneously with planting, and of these the nitrates are preferable. Nitrogenous compounds have a tendency to extend the period of growth and delay the time of ripening. This teudency is counteracted by the phosphates, in cousequence of which they increase the production of sugar.

"Stable manures must in all eases be worked into the soil with the fall 
plowing. Do not apply more than 10 to 15 tons per acre, and supplement it with nitrate of sola and superphosphate of lime at the rate of from 200 to 400 pounds of each per acre, according to the character of the soil.

"Alkaline salts should be applied with great caution, and only to soils manifestly wanting them. They add to the cost of culture, and often reduce the industrial value of the erop. Plant closely; 18 to 20 inches between the rows will be found the most convenient and favorable for culture in the United States. Separate the beets by about $S$ inches in the row.

"Cultirate early and often, and continue as long as the leares will permit, but not longer than the middle of July. Do not harrest until the crop is thoroughly ripe, but it must not be allowed to be injured by frost.

"Store the roots in such a way that they may be protected from extremes of temperature and moisture, and observe care in rentilating trenches or cellars; otherwise the roots will rapidly deteriorate."

\section{FERTILIZERS.}

In respect to fertilizers, Stammer makes the following observations:*

"Manuring should first of all give baek to the soil what the harvest has removed, both as regards mineral substances and nitrogen. Nothing ean be more certain than that a soil to which this restoration is not fully made will gradually lose its faculty to produce plants in normal quantity and composition. Culture experiments with artificial food liquids have not been earried so far with the beet as with some other plants and, therefore, the dependence betreen the composition of such liquids and the erolution of the beet has not jet been determined. The basis is also wanting whereon the direet working of the manure on the beet can be predieted; aud here is met the well known difficnlty of getting the manures into those lasers of the soil from which the beet chiefly draws its supplies

"From the present stand-point of our knowledge, therefore, the chief object of fertilization is the preservation of the favorable nature of the soil for beet culture.

"After what has been said it will not be matter for surprise that the numerons and laborious fertilization and cultivation experiments with beets have hitherto prodnced no generally applicable results; such ean only be expected from the laws which will be established by the artificial cultivation of the beet in known nutrient solutions, and it is by no means a contradiction of this fact that the beet farmer should be advised to undertake fertilization experiments upon his particular soil. It is only a matter of ascertaining the particular form and quantity of 
fertilizer which will best give necessary restitution under the local conditions, and such a form will doubtless in many eases be found, but it will be selaom possible to obtain from it a certain and constant influence upon the crop. The influence of those factors, over which we have no control-climate and weather-is always more powerfnl than the slight alterations which can be made in the character of the soil by the restitution of the elements taken from it, or by the preservation of the good character of the soil by fertilization.

"Since experience has tanght that beets raisod on fields freshly manured with stable manure are inferior for purposes of manufacture, the rule has long been established that not the beets, but the previons crop should be fertilized, or that the beets should be raised in rotation as the seeond or even third crop. Unfortunately this rule, so important to the factories, has not been so generally observed of late, and as a consequenoe of heary manuring heavy crops have been produeed, but at the eost of diminished sugar content or lessened price. This rule applies especially to stable manure and night-soil, as well as for Chili saltpeter, the misuse of which has had such serious consequence for factories, but not for phosphatic manures, which usually exert a favorable influence upon the crop.

"The constituents which are especially to be taken into aecount in the necessary restitution to the soil for beets are potash, phosphoric aeid, magnesia, and nitrogen. Following are the quantities of these constituents contained in 1,000 pounds of beets and beet leares, as given by averages from numerous analyses:

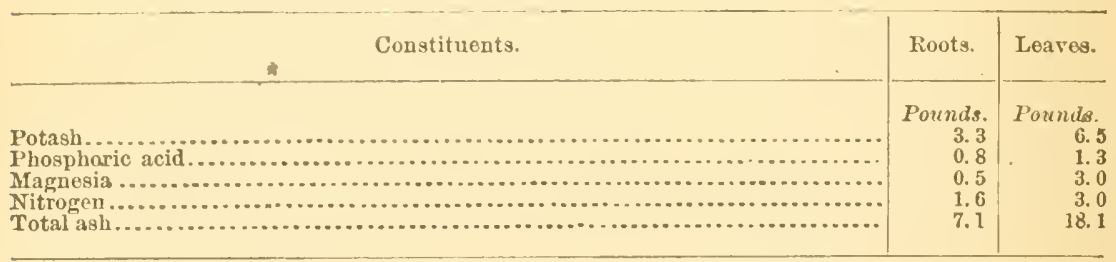

"It will be seen from the relation between the roots and leaves that the amounts abstracted by the latter is considerably greater and deserves especial consideration in case the leaves are not left in the field. From this point of view the extensive practice of paying for the work of digging with the leares is to beconsidered an evil and should be condemned. It is certain that a complete restitution can not be made in such fields. * * The form in which the above mentioned plant constituents shall be returued to the soil is estaplished for phosphoric acid and maguesia, and partly for nitrogen; superphosphates, with greater or less content of phosphoric aeid, or with addition of nitrogen. ous element, are of universal application. The magnesia is returned in the press-cakes, as has been shown by direct investigations, pretty completely, though a more uniform distribution is much to be desired, which 
can be improved by thorough subdivision. It is advisable to institute investigations from time to time in regard to the phosphoric acid, and especially the magnesia in the waste products, and use them according to the results obtained.

"The question of returning the potash abstracted is more difficult; its computation is complicated by many uncertainties which can not be entirely aroided. Still this should not prerent the return of at least the difference between the potash in the entire crop and that contained in the refuse as nearly as it can be ascertained. Potash fertilization has largely fallen into disrepute chiefly because large and definite returns are expected from it, whereas the principal effect is to be expected in the preservation of the crop-producing qualities of the soil. These will surely suffer a decrease sooner or later in the succession of seasons if the restitution is not complete. A change can doubtless be expected when it is possible to fertilize the subsoil. Then for the first time will it be possible to judge of the direct influence of potash fertilization on the beet. A broader question, howerer, and one that may essentially influence the results in the case just mentioned, lies in the form of the potash componnds to be used, which is likewise true of the other fertilizing materials. There is scarcely a single point on which the riews of practical men differ more widely, and new compounds are continually being recommended as the best. Only one rule seems to be of general application, that the potash salt should always be mixed with some common salt in order to insure its reaching the lower layers of soil ; also the advantage of admixtures of magnesia salts if these are not giren to the soil in some other way. Of the various potash compounds found in natural deposits none deserre preference over the others; this is due only, it seems to me, to compounds with organic substances. To gire the reasons for this would require too much space; they will be apparent to the obserrant student of plant-life. Consequently the molasses, or its residue after distillation or the liquors of the molasses-working processes, all rich in potash, are themselres the most valuable materials for potash fertilization and should be carefully preserved for such use. It must not be supposed, however, that the demand of beet cultivation for potash will be satisfied by returning to the soil the molasses from the crop of beets in the form of waste products. Asicle from the leares, for which if taken from the field a largely increased potash return must be made, the molasses itself docs not represent the entire amount of potash taken. Factories which produce raw sugar sell with it also potash, and in all factories the waste waters carry potash compounds, in small quantities it is true, but sufficient to account for the difference between the amount of potash in the beets and in tho molasses. This is not simply a theory, but is based upon exact analy. ses of the factory waters.

"Although factories which sell refined sugar only, and by the purchase of after-products, or of foreign beets, may increase the amount 
of potash in their molasses above that taken from.the soil in their own beets, and thus be able to make eomplete restitution by means of their molasses liquors, in most instances the eontrary is the case, and to the sources of loss mentioned others must be added.

"That the potash fertilization is not sufficiently accomplished by the returu of the molasses waste, howerer, is no reason why they shonld not be utilized as the most natural and suitable means towards that end. * * *

"To be sure there are great traets of beet-fields where this is diffienlt or impossible, owing to peculiarities of location. For such, as well as for the unaroidable deficit, recourse must be had to potash salts, as must also be the case at first with many estates until an easier plan of molasses fertilization is discorered. Without going into the question as to what potash salt is to be preferred, or why such different results have been obtained from them, I would eall attention to the faet that the certain results obtained from molasses-liquor fertilization indicate that the ordinary method of distributing the potash salt on the ground could well be supplanted by the solntion of the salts in liquids which are rich in organie substances. It could certainly be expected that the application of, for example, sewage water in which potash salts had been dissolred, would be more likely to secure uniform distribution of the potash in the soil and in a better condition for plant nourishment than the applieation of small crystals of an inorganie potash compound. The same end can, of eourse, be attained in other ways. The salt may, for instance, be incorporated either as a fine powder or in concentrated solution with other fertilizing materials in a eompost heap, etc. Experience and a few trials will soon indicate the best method.

"The adrantages of such a mixture of potash fertilizers with stall liquor (the distribution of the salt in the stalls themselves is reeommended by many) are given as follows by Frank:

"(1) The sulphate of magnesia in the potash salt holds the ammonia and the phosphorie acid of the manure.

"(2) Too rapid fermentation of the manure is aroided.

"(3) The prerention of the ammonia vapors arising from fermentation keeps the air of the stable purer and healthier.

"(4) The laborious application of the potash fertilizer is saved, and a much better distribution secured.

"(5) The cost of potash fertilization is cheapenen, since the less expensire salt is better adapted for use on aceount of its eontent of magnesia.

"(6) The expense of the gypsum, which would otherwise be used, is aroicled.

"There are also various methorls for the use of molasses liquors; the simplest, sprinkling from potash casks, has been chiefly used heretofore, although illy adapted for an extensire establishment. The more eomplete system of underground pipes with the neeessary openings in vari- 
ous places, as practiced, in England, is excluded on aeeount of its cost. As a consequenee the liquors have long been burned, and the slop ashes brought upon the field; but the fertilizing effect was lacking, althongh the restitution of potash was complete. Another difficulty was encountered in the loss of the nitrogen in the molasses, the value of this being nearly equal to that of the potash content. ****

"The eharring of the liquor is therefore inad visable on two accounts, and only one resort is left ; the eraporation of the liquor to such a degree as will admit of its profitable transportation. True, a very concentrated liquor can not be uniformly distributed on the field and must be further diluted on the spot, or mixed in compost with other fertilizers and thus brought upon the land. But a uniform distribntion of the fertilizers, especially one saturated with liquids, demands very careful work.

"The absorption of either the thin or the concentrated molasses liquor by soil has also been produetire of good results. But this method can not be unirersally used. The question of a cheap and uniform method for utilizing the molasses residues has become a rery serious one in regard to molasses working, and can only be considered as settled for eertain conditions.

"As for the relation which the quantity of material returned should bear to the quantity abstracted, it may he said in general that it is desira. ble to return as much nitrogen, one and a quarter to one and a balf times as much potash, and two and a half times as much phosphoric acid as has been abstracted.

"I will say further that greater additions of potash and phosphoric aeid have no disadvantageous effects upon the crop. $*^{*} *$ Direct investigations in regard to the relation between the sugar and potash in consecutive crops for many years hare failed to give the least ground for a contrary conclusion. But it must not be expected on the other hand that increasing fertilizations, especially potash fertilization, will produce proportionately inereasing crops, as has been asserted by some."

\section{INFLUENCE OF NITROGENOUS MANURES ON THE QUALITY OF THE} BEET.

The opinion has generally prevailed among beet-growers during late years that heavy nitrogenons manuring, especially with nitrate of soda, exercised no injurious effect on the quality of the beet. This opinion was based on the fact that in such beets the sugar per cent was only slightly diminished. Nevertheless the quality of a beet may be impaired eren with little or no diminntion of the sugar content by reason of the increase of the percentage of non-sugars present.

Herzfeld* has shown that heavy manuring with nitrogenous substances greatly injures the quality of the beet for sugar growing pur- 
poses. In beets grown at Warmsdorf in 1887 the true co-efficient of the beet was found on unfertilized plots to be 69.2 , while on the plots which had received large quantities of nitrogen it was only 65.1. In other words the unfertilized beets require that 31.8 parts of non-sugars must be remored in order to isolate 69.2 parts of sugar; while the proportions for the fertilized beets are 34.9 parts of non-sugar for only 65.1 parts sugar.

In beets from Atzendorf the injurious effects of Chili saltpeter were noticed in all cases; 30 per cent more of the nitrogen present in the beets being in the form of melassigenes than was the case with the unmanured beets.

The apparent eo-efficient of purity of the juice is also frequently misleading since it takes no account of the nature of the non-sugars present. In beets grown at Bernberg the influence of strong Chili nitre on the maturing of the plant was notioed. Judged by the apparent coefficient of purity of the jnice alone, the beets which had recetved large quantities of phosphoric acid were the poorest, while those manured with Chili nitre were next, and the ummanured were the best. But no conclusion could be further from the truth than to suppose the beets grown with phosphoric acid were poorer than those which received the nitre. The latter contained threo times as much nitrogen in the form of melassigenes as the former. The nitrogen, therefore, should be separated into albuminoid, betain, and ammoniacal groups. The term betain includes all organie bases which are precipitated with phosphotungstic acid. The real purity of the beet is also to be distinguished from the apparent purity of the juice. The real purity of the beet is obtained by dividing the percentage of sugar in the beet by the total solid matter thereiu; the apparent purity of the juice by dividing the percentage of sugar therein by the apparent percentage of solids as indicated by the Brix spindle. Judicious fertilizing with nitrate of soda, however, is benefieial, as will be seen by the statement of Dr. Peterman further on.

EXPERIMENTS WITI BASIC PIOSPHATE SLAG AS A FERTILIZER FOR THE SUGAR BETT.*

"Kuster concludes in the following expression that 'the basic phosphate slag is not adapted for application to heavy soils, and that the easily soluble phosphates are to be preferred in such instances.' Although some doubt may attach to a generalization based upon a limited number of experimental observations, the above conclusion may have a value in comparison with our experiments, notw1thstanding that the methods adopted were not the same and the respective fertilizers contained differing quantities of phosphoric aoid.

- By Em. v. Proskowetz, jr. Zeitschrift Riibenzucker Industrio, Webruary, 1888, p. 127. Abstract. 
"The experiments to be given were carried out at Kwassitz upon a heavy, humous, lowland soil, which had been previousl $\delta$ planted with clover and wheat, and receiving a liberal dressing of farm-yard manure before taking the latter crop. The phosphate slag applied contained a total of 20.5 per cent phosphoric acid, of which only 0.04 per cent. was soluble in 'citrate solution.'

"The superphosphate used in comparative experiments contained in total phosphoric acid $\mathbf{1 7 . 3}$ per cent, of which 12.44 per cent was soluble in water.

I. Three plats received 6 kilograms slag in the fall.

II. Three plats received 8 kilograms slag in the fall.

III. Three plats received 8 kilograms slag in the spring.

IV. Three plats received 4.2 kilograms superphospate in the spring.

"Field in beets (roots without leaves) of the several plats.

Kllograms.

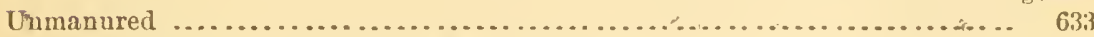

I. For 35 kilograms phosphoric acid, yielded..................... 714

II. For 47 kilograms phosphoric acid, sieltled ......................... 859

III. For 47 kilograms phosphoric aeíd, yielded....................... 934

IV. For 20.7 kilograms phosphoric acid, jielded..................... 1, 600

"Percentage of sugar contained in beets grown upon the several plats.

\begin{tabular}{|r|c|c|c|c|}
\hline Unmanured. & I. & II. & III. & IV. \\
\hline \begin{tabular}{r|rr} 
Per cent. \\
14. 3
\end{tabular} & $\begin{array}{r}\text { Per cejt. } \\
14.3\end{array}$ & $\begin{array}{r}\text { Per cent. } \\
\mathbf{1 4 . 1}\end{array}$ & $\begin{array}{r}\text { Per cent. } \\
14.3\end{array}$ & $\begin{array}{r}\text { Per cent. } \\
14.4\end{array}$ \\
\hline
\end{tabular}

"In this special instance it appears to be demonstrated that phosphate slag is less operative upon the heavy soils of this locality than the usual applications of superphosphates.

\section{EXPERIMENTS WITH FERTILIZERS UPON SUGAR IBEETS.*}

"The experiments were condacted during the year 1889, and the resülts may be summarized as follows:

"(1) In two experiments it was shown that exclusice fortilizing with $\mathrm{N}$-manures was effective and economically practicable.

"(2) In most experiments this year the application of $\mathrm{P}_{2} \mathrm{O}_{5}$ caused an increased yield. Most observable was the excess of value obtained from the nse of the $\mathrm{P}_{2} \mathrm{O}_{5}$ in the form of superphosphate orer the $\mathrm{P}_{2} \mathrm{O}_{5}$ contained in basic phosphate slag. It has been concluded that $2 \frac{1}{2}$ kilograms of $\mathrm{P}_{2} \mathrm{O}_{5}$ in form of phosphate slag are necessary to substitute 1 kilogram of $\mathrm{P}_{2} \mathrm{O}_{5}$ of the water soluble phosphate. The operation of the $\mathrm{P}_{2} \mathrm{O}_{5}$ of the slag phosphate is more moderate and constant than the $\mathrm{P}_{2} \mathrm{O}_{5}$ of the superphosphate, which latter has an earlier and more pow. erful effect on the young plant. 
"(3) The percentage of optically active non-crystallizable matters has been extremely high this year, and was the highest where N-fertilizers were used and the lowest where the superphosphates were applied.

"(4) The experiments indicate that the basic phosphate slag should be used with reticence and discretion. Further, that the use of nitrogen mixed with superphosphates is in given localities the most safe and economical fertilizer."

The following observations in respect of fertilizing are taken from the report of Commercial Agent Howes: *

\section{" MANURING.}

"The sugar-beet, of all the cultivated plants, needs the greatest amount of nourishment in the soil. It is, therefore, very necessary to use such a manure as will supply it with the best nourishment and in such a condition that it can be taken up by the beet. Possibly some soils are rich enough to do without manuring, but this seldom occurs. There are cases were beets hare been raised in the same fields for ten sncessive years without fertilizer, and yet good crops have been ob. tained.

"The ability of the sigar-beet to disclose and take up nourishment is not very high, and, therefore, if a large crop is desirerl, much manure must be used. Manure must be used that will iucrease the percentage of sugar as well as the quantity of the crop.

"Accorling to E. Wolff, in 1,000 kilograms of sugar-beets are-

\begin{tabular}{|c|c|c|}
\hline Constituents. & Roots. & Leares. \\
\hline 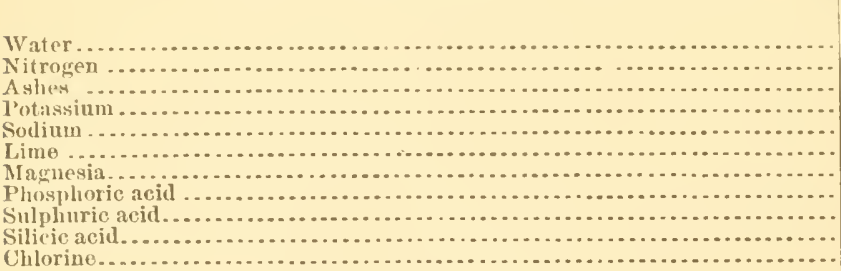 & \begin{tabular}{|r|} 
Filograms. \\
815 \\
1.6 \\
7.1 \\
3.8 \\
.6 \\
.4 \\
.6 \\
.9 \\
.3 \\
.2 \\
.3
\end{tabular} & $\begin{array}{c}\text { Kilograms. } \\
897 \\
3 \\
15.3 \\
7 \\
2 \\
3.1 \\
1.7 \\
.7 \\
.8 \\
1.6 \\
1.3\end{array}$ \\
\hline
\end{tabular}

"If we calculate per hectare (2.5 acres) 30,000 kilograms of beets $(67,500$ pounds) and 7,000 kilograms (15,750 pounds) of leaves, thero is removed from the gromud by beets-

\begin{tabular}{|c|c|c|c|}
\hline 1) seription. & Nitrogen. & Potassium. & Phosphates. \\
\hline $\begin{array}{l}\text { lRoota } \\
\text { Leaves . . . }\end{array}$ & $\begin{array}{r}\text { Kilograms. } \\
49 \\
21\end{array}$ & $\begin{array}{r}\text { Kilograms. } \\
114 \\
28\end{array}$ & $\begin{array}{r}\text { Filograms. } \\
27 \\
5\end{array}$ \\
\hline Total.... & 69 & 142 & 32 \\
\hline
\end{tabular}

* Sngar-beet industry of Bohemia. 
"The direct application of stable manure to the beet is not good, because the beet will then not ripen at the right time, and the quality will be poor. Stable manure should not be put in the soil in the spring. It should be plowed nuder in the fall. The manure of sheep is worthless, as it contains too mucl nitrogen and potassium, and the amonnt of salts in the beets is so increased that they are lially fit for the fac. tory. Manure of cattle can be used if mixed with that of horses. This manure contains sufficient nourishment, but the amount of nitrogen in proportion to phosphoric acid is tou high. This should be 1 to 2 , but in this manure it is just the contrary. The amount of manure usually needed per hectare (2.5 acres) is between 20,000 and 40,000 kilograms. According to a table by Wolff there is produced in the ground by apply. ing 30,000 kilograms of mauure, 150 kilograms nitrogen, 78 kilograms phosphates, and 189 kilograms potassinm. From this nourishment the result of applying freshly decomposed manure is, in the first year, 35 to 50 per cent; in the second year, 40 to 35 per eent; in the third year, 25 to 15 per cent. An average crop of sugar beets (30,000 kilograms) needs 69 kilograms nitrogen, 32 kilograms phospliates, and 142 kilograms potassium. Compost is a rery good manure, but it is not good to use any sugar-beet soil in its preparation, as it may contain nematids.

\section{"FERTILIZERS.}

"In applying fertilizer not only the crop but the quality of the beets will be better if it be used alone or employed to modify stable manure. Generally nitrogen, salts, and phosphates are used; exceptionally, potassium. According to P. Wagner the following amount of phosphoric acid and nitrogen slionld be used.

\begin{tabular}{|c|c|c|c|}
\hline Description. & $\begin{array}{l}\text { Minimum } \\
\text { per hectare. }\end{array}$ & $\begin{array}{l}\text { Mean } \\
\text { per heetare. }\end{array}$ & $\begin{array}{l}\text { Maximum } \\
\text { per hectaro. }\end{array}$ \\
\hline $\begin{array}{l}\text { Dissolved phosphates...... } \\
\text { Nitrogen......................... }\end{array}$ & $\begin{array}{r}\text { Kilograms. } \\
40 \\
20\end{array}$ & $\begin{array}{r}\text { Filograms. } \\
60 \\
30\end{array}$ & $\begin{array}{r}\text { Kilograms. } \\
80 \\
60\end{array}$ \\
\hline
\end{tabular}

"If nitrogen, as Chili nitrate, is used, then there will be needed 150 kilograms minimum, 250 kilograms mean, and 400 kilograms maximum.

\section{"TIME FOR IIANURING.}

"Manuring should always be done as early as possible in the fall. The longer the manure has been in the ground before the regetation of the beet the greater will be the amount of nourishment and its distribution. Experiments show that manuring in spring is wrong, and there are many reasons why. For instance, if the season is dry the manure can not decompose, the ground remains loose, and consequently 
the young plant siuffers for water. On the other hand, as soon as a heavy rain comes after a drought the leaves grow very fast, but the plant does not ripen well, aud a large crop is raised, but of a poor quality. If the manure is not decomposed the work in the field can not be done in good shape, and insects have a good refuge. On heary, loamy soils fresh manure is good for loosenlng it and allowing the air to enter.

"How deep to put the manure.-It is best first to put the manure in the ground as shallowly as possible, because it decomposes better until the deep plowing is done. The more nitrogen the beet finds in the first period of its vegetation the better. The less nitrogen found in the ground in the first period the more will be taken up in the last period, and that means a loss for saccharification.

"The following table shows, by the experiments of Liebscher, that the crop may be increased without losing in quality, if the manure be properly applied and the beets planted closely :

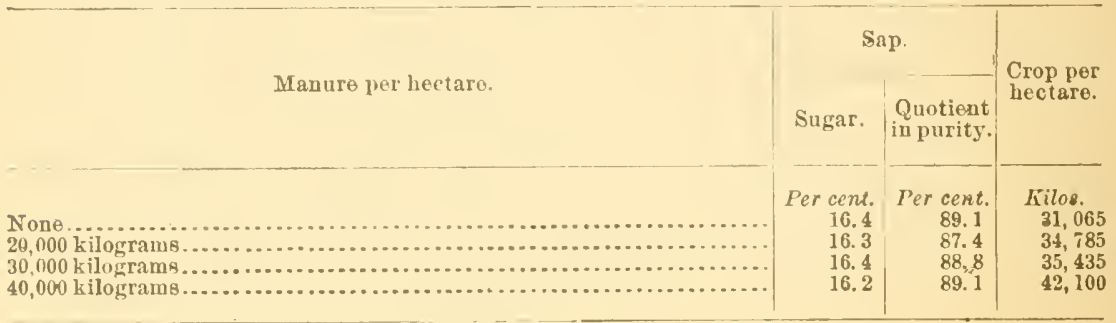

"The moro nitrogen there is in the soil the less fertilizer will be required, but the more phosphate.

"The increase of the crop by fertilizing with nitrogen is, according to experiments by Wagner: 100 kilograms Chili saltpeter with $15 \frac{1}{2}$ to 16 kilograms of nitrogen increase the crop about 4,500 kilograms of beets and 900 kilograms of leaves. Fertilizing with nitrogen should take place only when enough phosphate, lime, and potassium is in the soil, because large and good erops can only be expected when these sub. stances are present. Whether enough phosphate is present ean only bo learned by experiment. Fertilizing with nitrogen should only be done in the spring. Chili nitrate should alwass be preferred, and the follow. ing rules should be observed:

"(1) A good variety must be planted.

"(2) Seeds should be obtained from the best sonrees.

“(3) In addition to Chili nitrate, phosphate must be added, or the crop will mature too late.

"(4) Fertilizing with Chili nitrate should be done before sowing, not after.

"(5) Beets must be thickls planted, and eultirated four or five times.

"Accorling to the calculations of Stntzer, the use of more than 400 kilograns to the hectare of Chili nitrate does not pay: 
"Professor Mærker has experimented upon the influence of phosplates with the following results :

"Phosphates do not always produce an effect. If the soil is supersaturated with it, it can cause loss. This has often been observed by practical farmers. The cause is that $\mathrm{P}_{2} \mathrm{O}_{5}$ quickens maturity or causes an early death of the leaves, and that may lessen the crop, especially in a dry, rainless season.

«Ten experiments have gireu the following results:

\begin{tabular}{|c|c|c|}
\hline Fertilizer. & $\begin{array}{l}\text { Crop per } \\
\text { hectare. }\end{array}$ & Increaso. \\
\hline 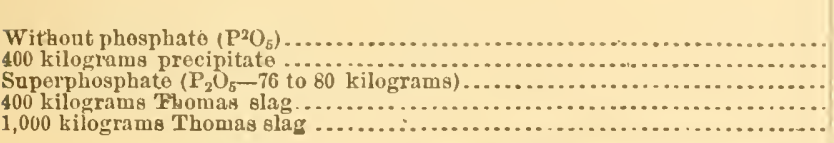 & $\begin{array}{r}\text { Filograms. } \\
32,063 \\
34,456 \\
35,316 \\
33,589 \\
34,756\end{array}$ & $\begin{array}{r}\text { Eilograms. } \\
2,303 \\
3,283 \\
1,5 \pm 6 \\
2,693\end{array}$ \\
\hline
\end{tabular}

"There is not much difference in the effect of the various phosphate fertilizers so far as sugar in the beet is concerned. If it be necossary to use phosphate fertilizers in spring, superphosphate is always to be preferred.

\section{" SPREADING THE FERTILIZER.}

"Spreading broadcast has been found to be better than drilling. This is done by the machine shown in Plate 1.

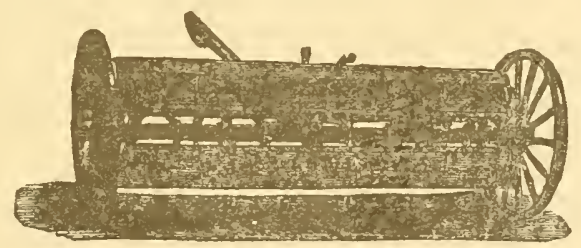

FIG. 36.

"There are, howerer, drills which have an attachment fer drilling fertilizer, as is shown in Plate 2.

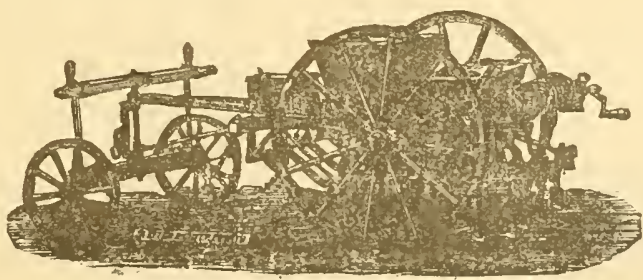

FIG. 37 .

"It is very important to put the fertilizer in the right depth. Prac tical experiments have shown that it should not be used after sowing. In using Chili nitrate, a shallow harrowing is sufficient, because the 
next rain will carry it deeper. Potassinm and phosphate, which are absorbed immediately, must be put sleeper. 'This can be done witl a sharp harrow, or, better still, by shallow plowing. It is said that a depth of 20 to 22 centimeters is the best.

"The following table shows the results of different depths in sandy loam soil per hectare:

\begin{tabular}{|c|c|c|c|c|}
\hline \multirow{2}{*}{ Yrar. } & \multicolumn{2}{|c|}{ Ineptb. } & \multirow{2}{*}{\multicolumn{2}{|c|}{ Difference. }} \\
\hline & 10 to $12 \mathrm{ce} u$. & 20 to 22 ces. & & \\
\hline 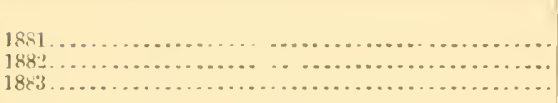 & $\begin{array}{r}\text { Filograms. } \\
32,674 \\
36,217 \\
65,726\end{array}$ & $\begin{array}{r}\text { Kilograms, } \\
38,543 \\
39,030 \\
69,596\end{array}$ & $\begin{array}{r}\text { Iilograms. } \\
5,869 \\
2,813 \\
3,870\end{array}$ & $\begin{array}{r}\text { Percent. } \\
17.96 \\
7.77 \\
5.89\end{array}$ \\
\hline
\end{tabular}

" MIIED FERTILIZER (PIIOSPIIATE AND NITROGEN).

"Of these are used: Perurian guano (7 per cent nitrogen to 10 per cent $\mathrm{P}_{2} \mathrm{O}_{5}$ ) ammonia superphosphate; blood manure with superphosphate. Bone-dust is seldom used, as its effect is too slow; if used, it must be applied in the fall.

"Although most soils hare potassium enough, it may oecur that lands where beets are raised every sear may need it. The direct application of potassium salts to the beets is not good, because all these salts contain a chloride which injures the plants. The best is to give potassium mixed with stable manure two years before the beets are planted. When thus mixed, the ammonia is kept from becoming volatile.

"Lime.-Quicklime is a good fertilizer, especially on rery heavy soils, which it loosens. For 1 hectare 24 to 40 kilograms should be used.

"For sandy soils marl is excellent, the best containing 30 to 50 per cent of lime. The amount of marl needed for 1 hectare, if containing 30 per cent of lime, is 220 kilograms; if containing 50 per cent, only 130 kilograms."

In general it may be said of fertilizers that they must be judiciously applied if a maximum benefit is to be secured. Especially is this true of nitrogenous fertilizers, which, when applied to soils already rich in nitrogen, or in excessive quantities or at inopportune seasons, may, by delaying the maturation of the crop and decreasing the relative percentage of sugar, prove injurious. Nitrogenous manures should be applied to the soil and thoroughly incorporated therewith before seeding, and should in general be supplemented with phosphate and potash fer. tilizers. The quantity of nitrogen may vary from 15 to 30 pounds per acre. A fertilizer containing about 14 per cent. of nitrogen should therefore be used in quantities of from 125 to 250 pounds per acre. 


\section{STUDIES ON THE DEVELOPMENT OF THE SUGAR.BEET.*}

In a most valuable brochure of 87 pages, with six figures and ten heliograph plates, $f$ Girard has traced the development of the beet from the beginning of its growth to complete maturity. In its rarious stages the proportional weight of roots, stems, and leaves has been established and the development of sugar traced. In Plate 1 complete plant at maturity is shown.

This weight of the entire plant was found to be 1,527 grams.

This weight was divided as follows:

Leaves :

Stems .............................................grams.. 161

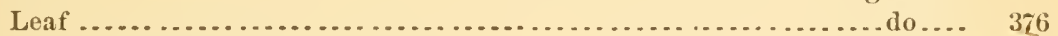

Body (containiug 19.19 per cent sugar) ........................ do... 965

Top, root, aud rallicles........................................ 25

, $\overline{1,527}$

Extreme length of root........................................ 2.5

Surfaco :

Foliage........................................ sq. centimeters.. 3,520

Body .................................................. 417

Radicles............................................... 2,920

GENERAL CONCLUSIONS.

Girard, as a result of his studies, calls attention to the origin of the sugar which the body of the beet has stored up and the fact that its derelopment has been followed step by step.

To comprehend well the storage of sugar it is necessary to get an exact statement of the absolute and relative growth of the three principal parts of the beet, riz, body, foliage, and radicles. These proportious at various periods of growth are shown by the following table:

\begin{tabular}{|c|c|c|c|}
\hline & Borly. & Foliage. & Radicles. \\
\hline 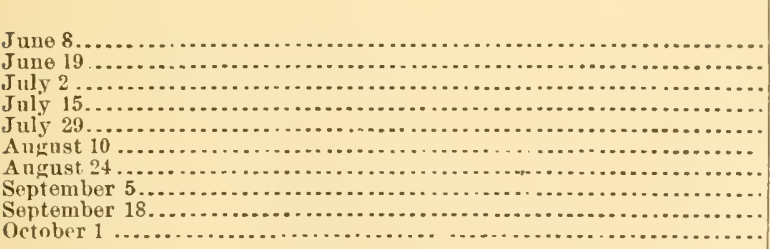 & $\begin{array}{r}\text { Per cent. } \\
6.8 \\
15.1 \\
24.8 \\
29.5 \\
38.9 \\
45.7 \\
52.0 \\
57.3 \\
59.8 \\
63.3\end{array}$ & \begin{tabular}{r|} 
Per cent. \\
83.1 \\
80.1 \\
72.8 \\
68.5 \\
59.3 \\
52.8 \\
46.2 \\
41.2 \\
38.7 \\
35.2
\end{tabular} & $\begin{array}{r}\text { Per cent. } \\
10.1 \\
4.8 \\
2.4 \\
2.0 \\
1.8 \\
1.5 \\
1.8 \\
1.5 \\
1.5 \\
1.5\end{array}$ \\
\hline
\end{tabular}

The preceding numbers permit the general character of the plant to be recognized at once during the various periods of its growth. During the first two months the organs pertaining to the foliage are predominant and the activity of the plant is principally direeted towards

* By Prof. Aime Girard. Abstact.

†Published by Gauthier-Villars, 55 Quai des Grands-Augustin, Paris. 
the produgtion of these parts. The importance of the body during this time is of little moment. In respect of the rootlets, their relative importance is pronounced at the beginning of growth, but rapidly diminishes and soon less than 2 per cent of the weight of the plant represents the radicles. During the last two months of the season regetation goes on under entirely different eonditions.

The foliage and rootlets inerease, it is true, but in such feeble proportions as to often seem stationary. The body on the eontrary increases rapidly in weight, and at the end of the season it represents about twothirds of the entire weight of the plant. For each of the parts of the plant in normal conditions of soil humidity this increase is regularly proportioned to the time of growth, and would be represented graphically by almost straight lines, and this is true of body, rootlets, and also for the foliage, provided the normal weight of the withered leaves is taken into account.

Unequal in point of riew of intensity for each of the parts, feeble for the foliage and roots, considerable on the other hand for the body, this increase preserves its regularity in respect of the components of all the parts, viz: Cellulose, mineral matters, organic solable matters, that is to say, matters in course of elaboration. In such a manner is this growth carried on that by leaving out of aecount intermediate products, it may be said that all the parts of the plant maintain a sensibly eonstant composition during the most important period of growth, viz, from the month of July on. There are, however, some exceptions to this rule, and although they are not numerous, they are of great importance both from a vegetative point of riew and from industrial considerations. Thus the analysis of the roots and rootlets shows them increasing rapidly in raseular tissue and acquiring, by reason of the increase in cellulose, a daily increasing solidity. In like manner the study of the foliage, and motably of the leaf, discloses the presence of sucrose, varying in a relatively important manner under the influence of the light, while en the other hand the products comprising the other vegetative tissues rary in a memner much more restrained.

Also, finally, the stady of the body at different epochs of regetation shows an increasing saccharine richness, intimately connected with meteorologieal conditions, and notably with the measure of rain which the plant has receivet. In a word, it is shown that the body inereases regularly in weight, whatever be those conditions, but being charged either with water or sugar according to circumstances, and preserving in all cases the sugar which previous vegetative activity has stored up.

From the considerations which preeede, it seems possible to define the conditions under which the sugar-beet is developed, the conditions under which the important quantity of sugar is formed which the body has stored away.

From the first months of 1 ts regetation the sugar-beet asserts its coming character, for ever when its weight does not exceed 1.5 grams 
it contains alrealy 1.5 per cent sugar. Its chief actirity at that time, howerer, is to perfeet its foliage and rootlets. But soon, from abont the middle of July, its vegetation takes on a different character. Each day, under the direct influence of the sunlight, the leaves form a new quantity of sugar. Each day along the petioles a quantity of sugar, which may be roughly estimated at $i$ gram, passes to the body. In the same time there is taken from the soil in aqueous solution a quantity of mineral matter which may be estimated at.15 to .20 gram, and this matter is directed throngh the body toward the leaves.

The essential part of the plant, that body which at the end of the season represents two-thirds of the whole weight of the plant, onght therefore, no longer to be considered only as a vegetable plesus which, during the first year of the life of the beet, increises regularly with the time, and of which the eellulo-vasenlar tissue of a composition, sensibly constint during the entire period of vegetation, is filled regularly with water and sugar, the one replateing the other according to meteorological eiremstances, and forming in all eases a sum which represents abont 94 per cent of the weight of the beet.

\section{CONTRIBUTION TO THE CHEMISTRY AND PHYSIOLOGY OF THE SUGAR.BEET.**}

"(1) The application of thechemical fertilizer composed of nitrate of soda, chloride of potash, and superphosphate of lime in quantities which replace the fertilizing principles romoved by the last erop is calpable of retarding the germination of the seed, in some cases, for as much as three days, according to the degree of humidity in the soil. Two canses contribute to produce this phenomenon; on the one hand the free phosphoric acid and alkiline salts act as antiseptics on the ferments which cause the germination, and on the other hand the chemieal fertilizer being very hydroscopie, takes from the seed a portion of the moisture neeessary to soften the ontside of the seed.

"(2) The morphologieal development of the sugar-beet is modified under the influence of its euvironments, that is to say, under influence of different mutriments.

"(3) Maturation of the sugar-beet, which is indieated by the disappearance of the chloroplyll in the leaves, is retarded by the application of nitrogen in the form of nitrate of sodia.

"(4) In spite of the production in the same soil of eleren successive crops of sugar-beets the nematoid has never been discovered.

"(5) The quantity of water which traverses a enbie meter of the earth depends on the one part npon the rain-fall, and npon the other on the vigor of vegetation, being clirectly as the first eanse, and inversely the second.

* By A. Petermann. Bulletin of the Association of Freuch Sugar Chemists, Do. cember, 18:9, p. 253. Abstract.

25474-Bull. 27 11 
"(6) Drainage water is more rieh in nitrogen where nitrate of soda has been used than where other mineral salts have been employed.

"(7) In a elayey, sandy soil, the regular restitution of the mineral matter alone and of the nitrogen alone, and of the minemal matter associated with the nitrogen, remored by the preceding erop has increased for the ten years of experiment, the production of organic substances respectively from 27 to 50 and 93 per cent, compared with the production obtained withont restitution of the nutritive elements. The natural somress of nitrogen are insuflicient to show the maximum utilization of the mineral matters restored alone; and, moreover, the decomposition of the soil does not render assimilable sufficient quantity of the mineral inatters to permit the sugar-beets to produce, with the aid of restored nitrogen alone, the maximum of organic matter.

"(S) The great oscillations observed in the weight of organic matter produced from year to year, cau be eaused ouly by those factors of the experiment which are ehangeable, namely, meteorologieal conditions.

"(9) In the experiments made, the production of organic substances the minimm of heat necessary to normal development being furuished, is shown to depend rather upon the height of the rainfall than with the degree of heat.

"(10) All the conditions being equal and the minimm of the heat neessary to the normal vegetation being furnished, the quantity of sugar contained in the beet at the moment of harvest is in direet proportion to the intensity of light which has prevailed during the whole duration of vegetation.

"(11) In onr assays, the centesimal composition of the ash has varied essentially with the environment and has been modified from year to jear.

"(12) 'The quantity of eertain mineral elements, plosphoric aeid, lime, and magnesia found for a given year are almost in the same proportions in the beets where they are not fertilized as in the others. It is therefore shown that this regetable absorbs for a given weight of organic substance produced these mineral elements in a certain proportion more or less fixed aceording to whatever be, the projortion of the quantity placed at its disposal.

"(13) The absorption of mineral matters has taken place in the case of lime and magnesia, in the state of phosphate and carbonate, and in the ease of potash aud soda in astate of chloride, sulphate, and nitrate.

"(14) The quantity of water contained in the beet is a characteristic of the variety; certain variations are noticed from elimatic eonditions, etc., but in general, the character of the food furmished the plant is without influence upon its richness in water.

"(15) Albuminoids and fats vary greatly in the beets and the extract matters also, while the content of sugar and of cellulose is more constant.

"(16) Of the total nitrogenous bodies contained in the beet at ma- 


\section{3}

turity, 58 per cent belong to pure albumens, and 42 per cent to the albuminoids such as the amides and albuminoid glucosides.

"(17) The application of nitrate of soda has exerted a slight depression on the formation of sugar. The diminution of the percentage of sugar due to the nitrogen is more than compensated by the energetic action of this fertilizing principle on the production of total organie substance, and it may be definitely stated that in spite of the decrease in percentage, the total weight of sugar is increased. The total sum of the varbohydrates lias been almost the same in all the ten ex. periments irrespective of the food furnished the plant and has raried chiefly by reason of the intensity of the light.

"(18) The cellulose also has shown little variation."

\section{TYPICAL FORMS OF SUGAR-BEETS.}

The shape of the sugar-beet has much to do with its value as a sugar. producing plant. A smooth and symmetrical exterion permits the beet to be easily harrested and washed. An irregularly shaped beet may easily carry into the cutter's sand and earth, and even stones of consirlerable size, quickly dulling and even breaking the knives of the slicing machine. In selecting mothers, therefore, only beets of smooth and symmetrical exteriors are chosen.

There is thus a tendeney to establish a typical form, which varies with the rariety of beet. These typical forms for the most approved varieties of beets liave bcen carefully studied and photographed by Professors Eckenbreeher and Naereker, and a few of the most important of these types are reproduced here. In adlition to the beets of normal types, there are noticed a few instances of reversion to older and less desirable forms. 


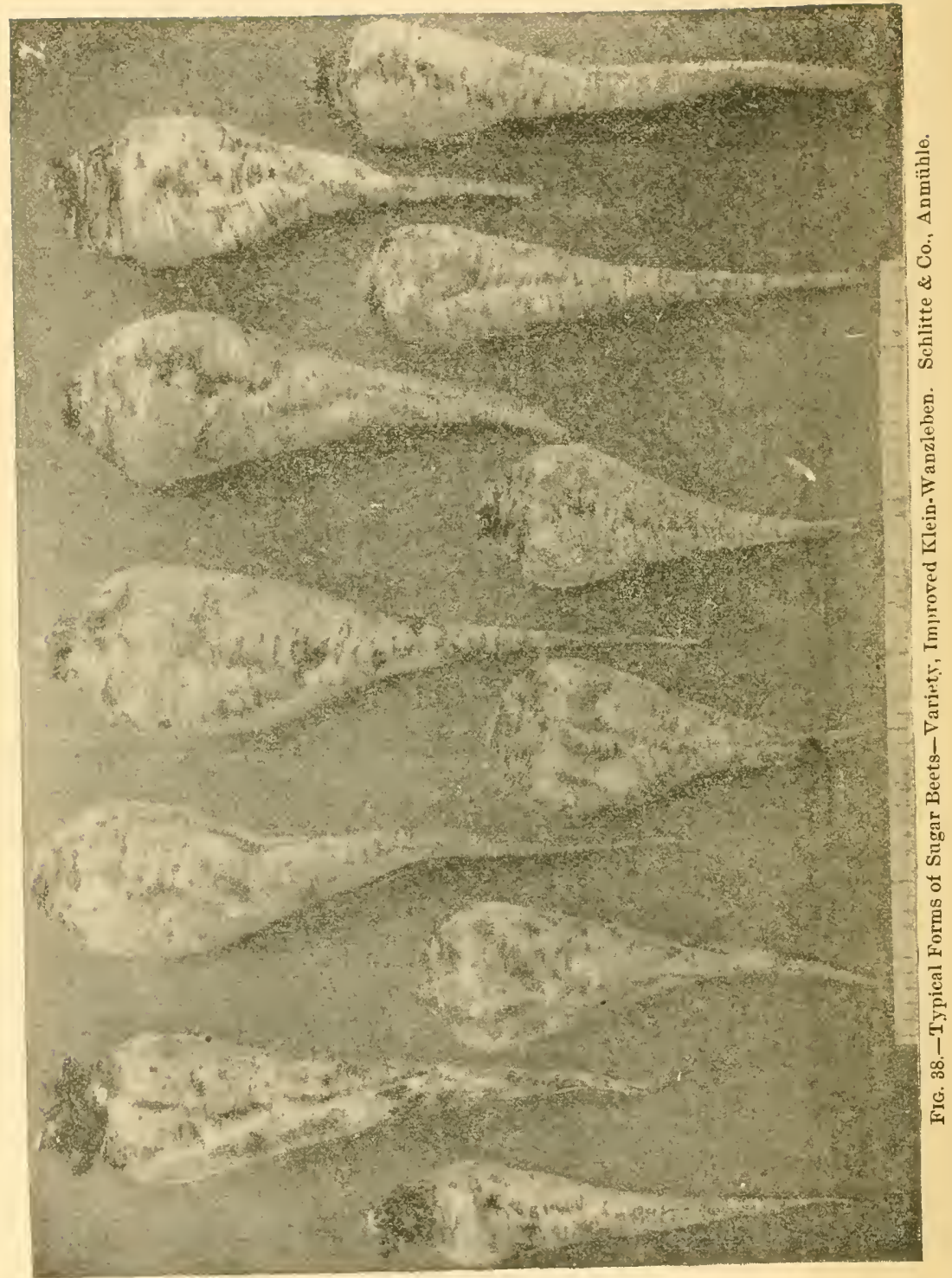




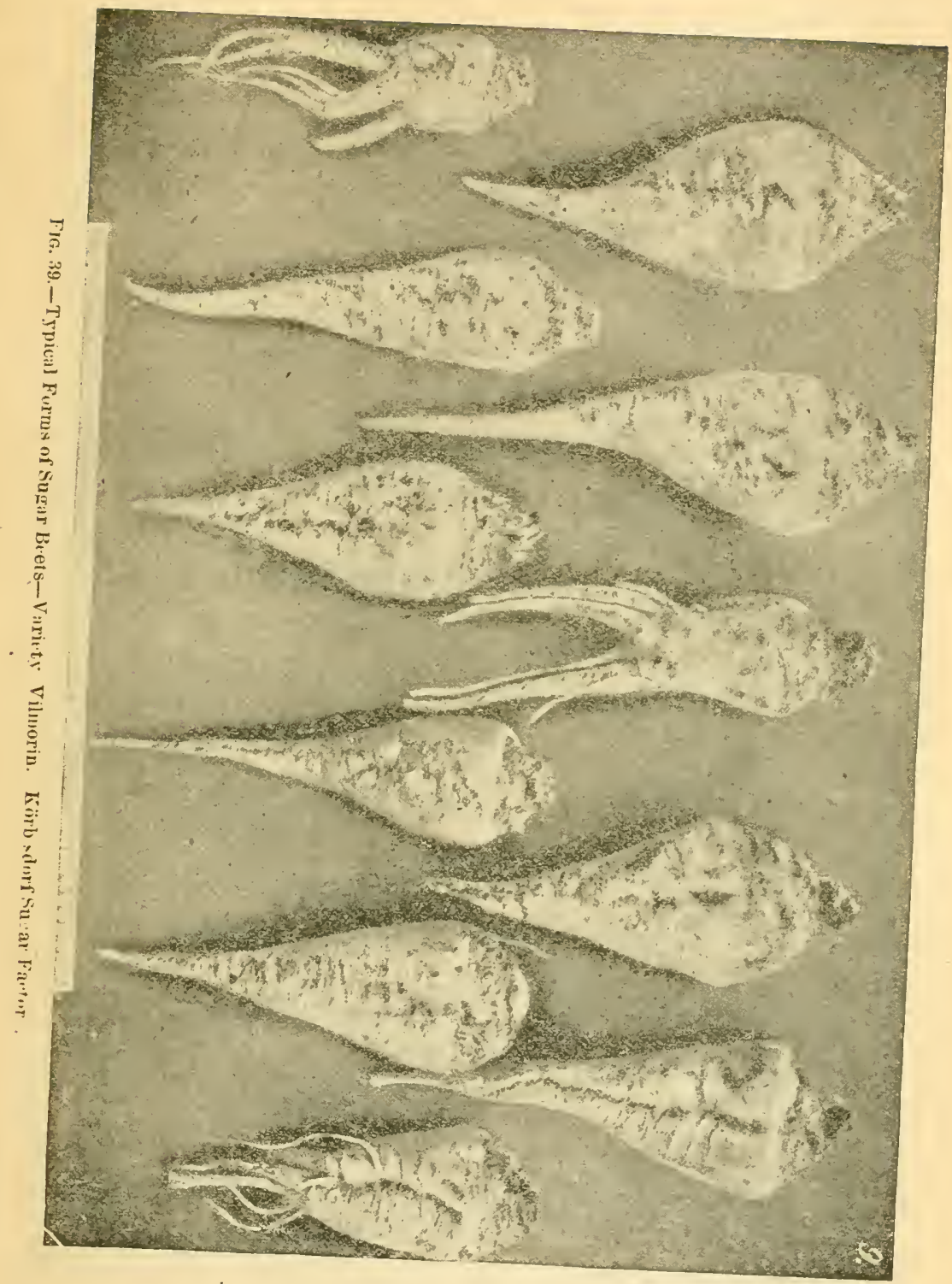




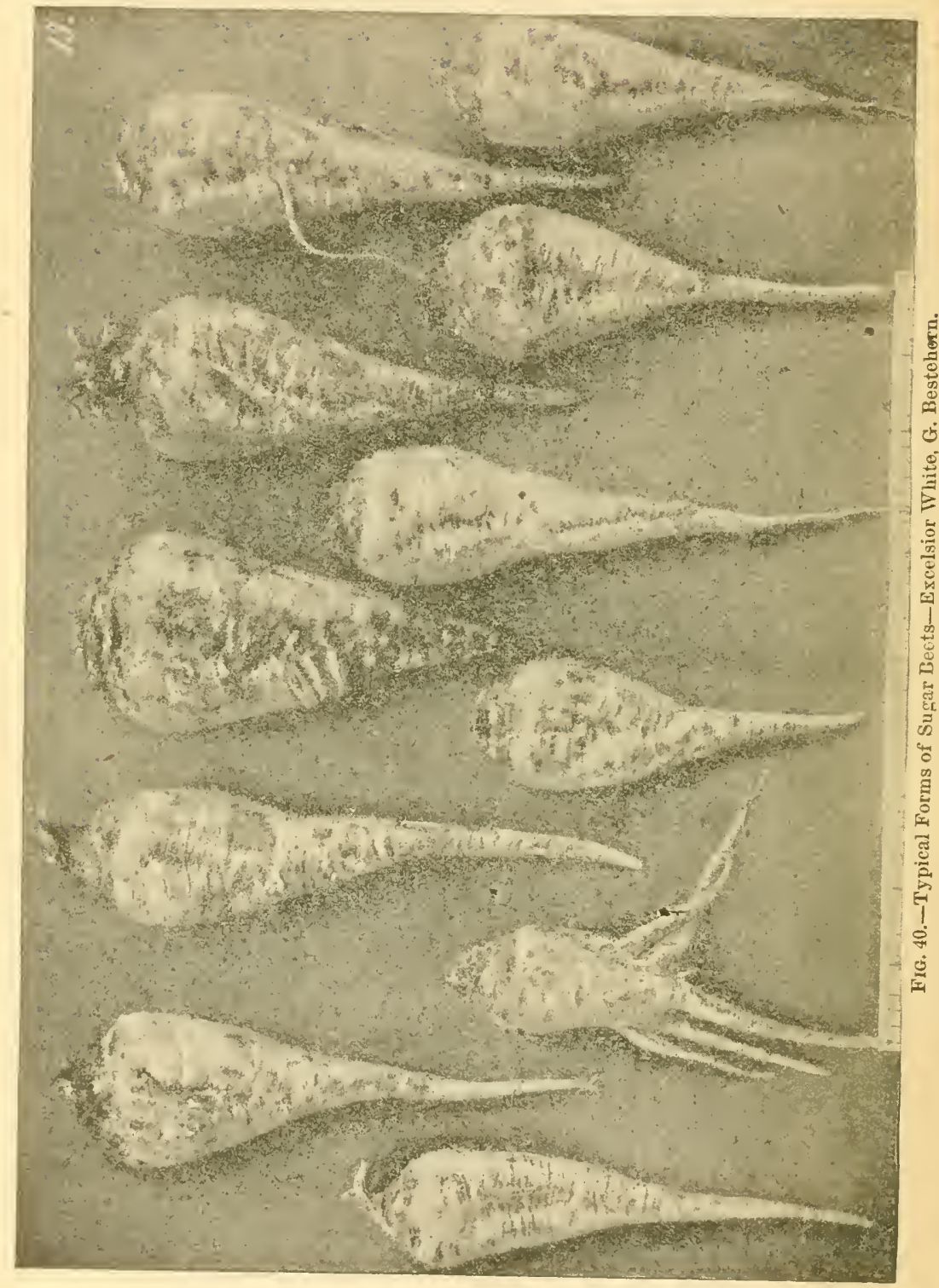




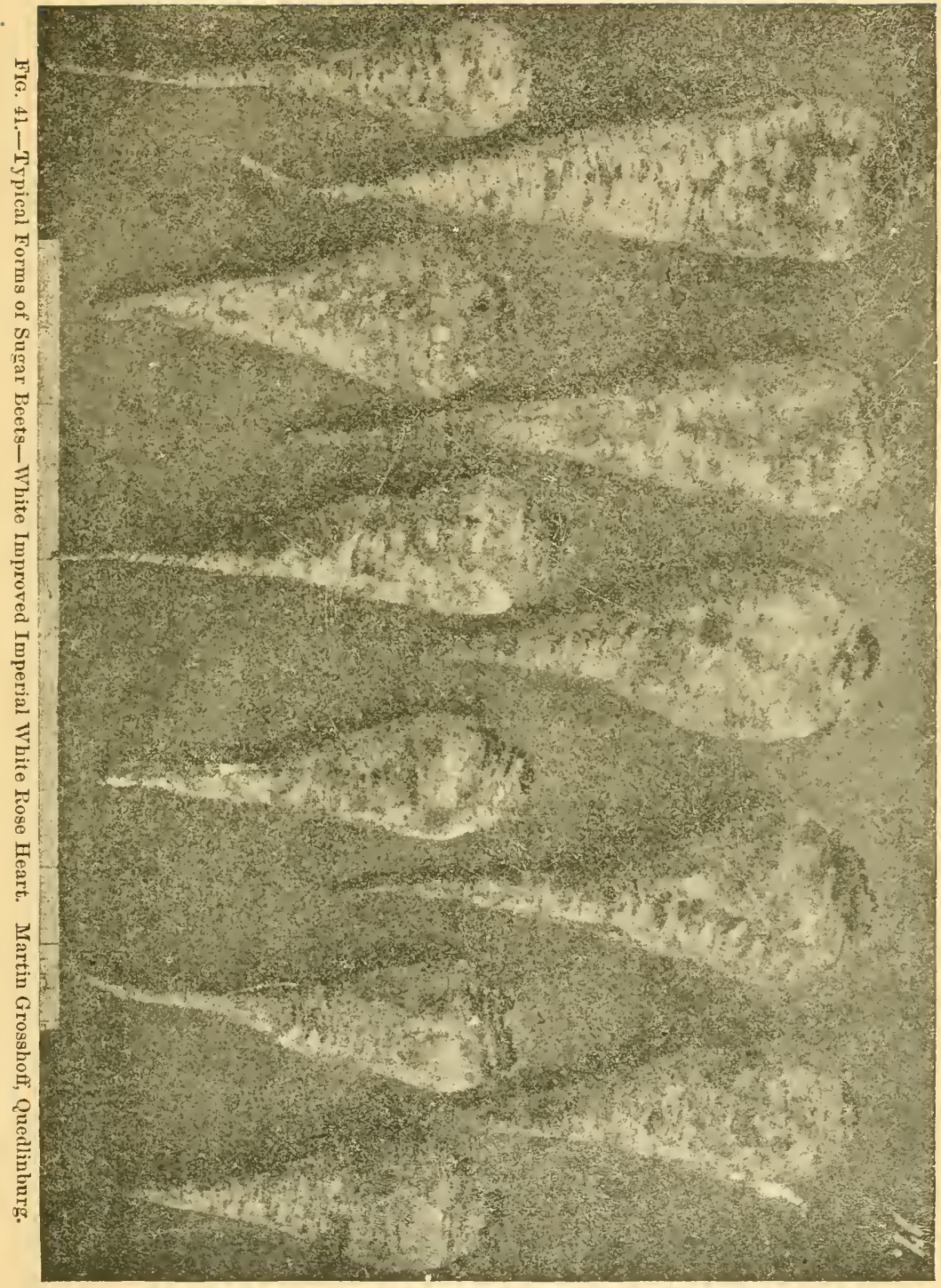




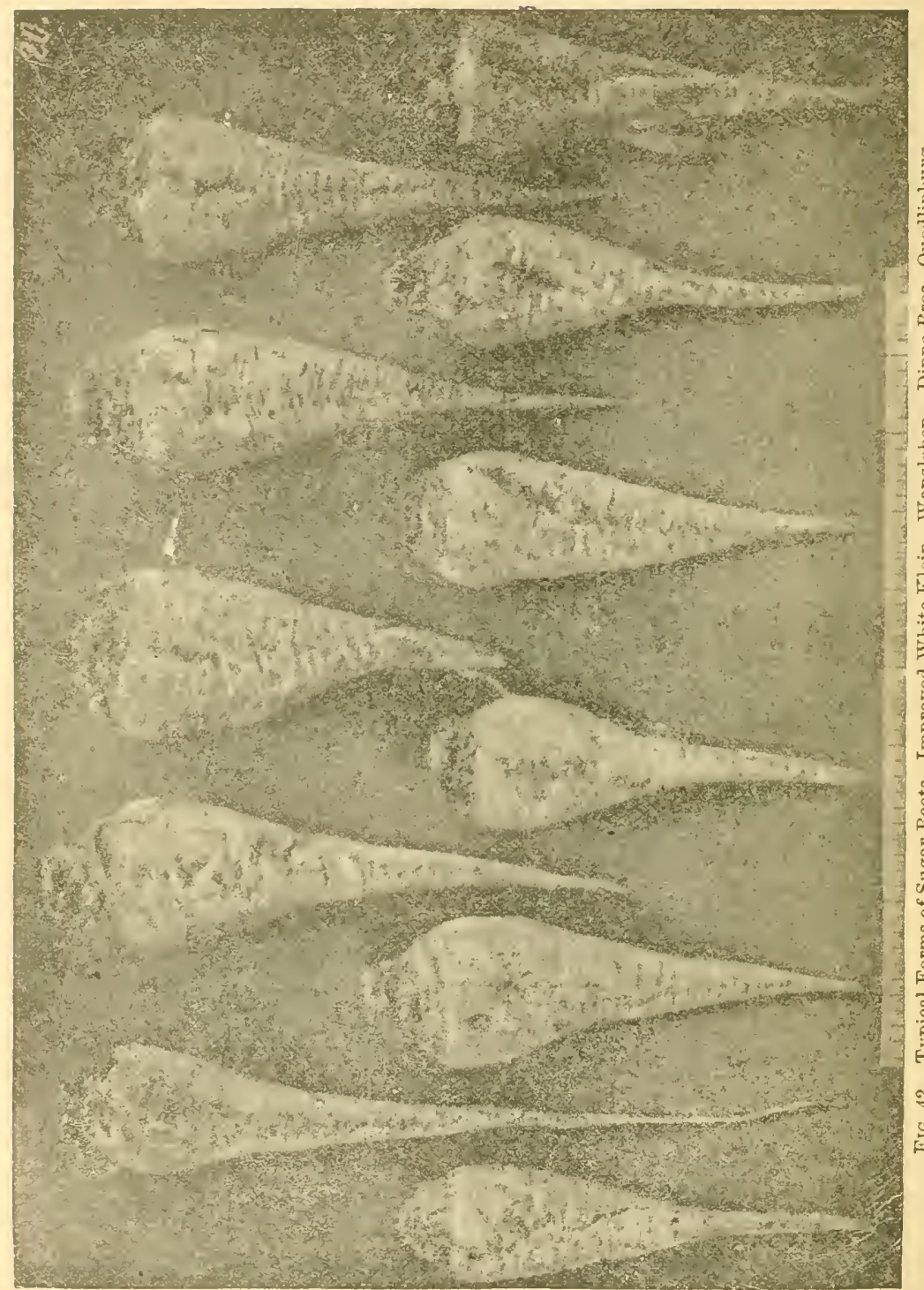





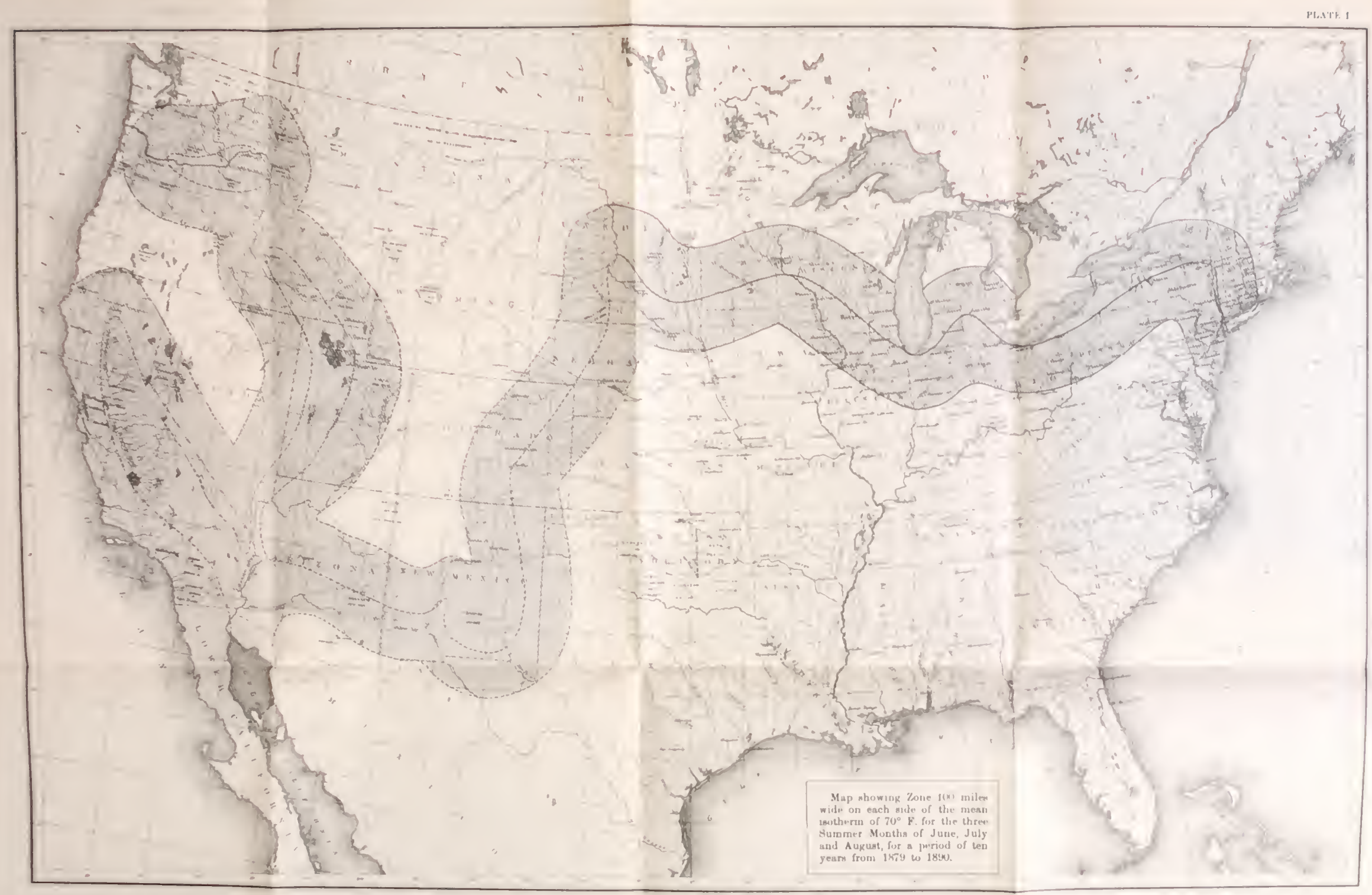






\section{METEOROLOGICAL CONDITIONS.}

In arlition to suitable soil fertilizing and cultivation the sugar beet requires certain meteorological conditions for the highest prodnetion of sugar. Temperature and rain-fall exereise the most pronomneer in. flnence, not only ou the yield of beets but also on their saceliarine qualities.

A mean summer temperature of $70 \circ$ Fah. for ninety days is suffieient to push the heet well on to maturity, while a mols higher degree than this tends to diminish its saccharine strength.

The experience of beet-growers in California indicates that in certain latitudes the beet can Hourish with a much less rain-tall than has hitherto been deemed a minimum for its proper growth; but this is not co:Ichsire evidence that in all localicies so small a supply of moisture would be suffieient. In regions of dry and hot winds or where the subsoil was less porons, or aerial evaporation much more vigorous, less favorable results would be obtained. Dr. MeMurtrie traced his area of heet-sugar limits with an isotherm of 70 Pah. for the summer montlis, and a minimum rainfall of 2 inches per month for the same periol. ly. the kindness of the Signal Office I have obtained a record of mean temperatures and precipitation for each month in the year for a perion of tell years of those portions of the country in which the eulture of the sugar-beet is most likely to succeed. Also from the samesource a tracing of the mean isotherm of 700 Fah. for ten years for the three months of June, Jnly, and August. Extenrling for 100 miles on either sirle of this line, the mall shows a helt extending from the Atlantie to the Pacific, within whose limits the most farorahle eonditions for growing berts, as fir as temperature alone is concerned, will be fomn.

The mistake must not be made of supposing that all the region in. cluced within the boundaries of this zouc is suitable for beet culture. Rivers, hills, and monntains oecupy a large portion of it, and much of the rest would be excluded for various reasons. In the western portion, perbaps all but a suall portion of it would he excluded by monntains and dronth. Beginning at a point mirlway between the one hundredth and one hundrerl and first meridian, as indieated by the rlotter line, beets conlu be grown only in exceptional places withont impigation. On: the Pacific coast, only that portion of the zone lying near the ocean will be found suitable for beet unlture.

On the other hand, there are many iocalities lying outside the indicated belt, both north and south, where doubtless the sugar bretwill he found to thrive. The map, therefore, must be taken to indicate only in a general way those localities at or near which we should expect sncecss to attend the growth of sugar beets in the most favorable conditions other than temperature alone.

In respect of the rain-fall it is necessary to call attention to the fact that a wet September and October are more likely to injure a crop of 
sugar beets than a moderately dry July or Angust. A wet antumn succeeding a dry summer is almost certain to materially injure the sac. charine qualities of the beet before it can be properly harvester. In this regarl it will be seen from the tables of precipitation that the two Dakotas are more favolably situated than Oregon and Washington.

The rain-fall in Oregon and Washington for September and October is $2.17,3.25$, and 2.24 , and 4 inches, respectively, while in the two Dakotas it is only 1.11, 1.27, and 1.54 and 1.26 inches. The importance of this slight rain-fall in securing a safe harvest withont danger of second growth is easily recognized.

During the winter months the temperature that is best for beets is one of uniformity and sufficiently low to prevent spronting or heating in the silo. Sudden and extreme variations are alike injurious-on the one hand causing danger from freezing and on the other from spronting. On the coast of California the winters are so mild that the beets require very little protection, in fiset more from the neat than the cold, while in Nebraska and the Dakotas the temperature often falls so low as to eudanger the beets even in well-walled silos.

All these problems in meteorology leserve the most careful consideration from those proposing to engage in the sugar-beet industry, and it is hoped that the subjoined tables and map may help to elueidate them.

Table showing the arerage precipitation, for each month of the year, at the stations specifict.

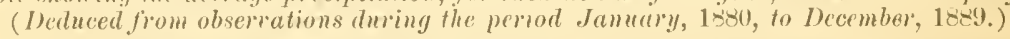

\begin{tabular}{|c|c|c|c|c|c|c|c|c|c|c|c|c|}
\hline State itud station. & Ja1. & Fels. & MIar. & Apr. & May. & Jиแ⿰㇒⿻二丨冂. & July. & Aug. & Sinpt. & Oet. & Nov: & Dee. \\
\hline \multirow[t]{2}{*}{ 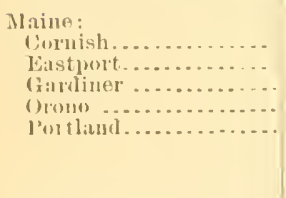 } & $\begin{array}{l}\text { In. } \\
4.24 \\
4.64 \\
5.02 \\
4.52 \\
4.22\end{array}$ & $\begin{array}{l}\text { In. } \\
\text { 4. } 47 \\
\text { 4. } 4 ! \\
5.20 \\
\text { 4. }(i 1 \\
\text { 4. } 72\end{array}$ & $\begin{array}{l}\text { In } \\
3.24 \\
4.68 \\
4.27 \\
4.06 \\
3.23\end{array}$ & $\begin{array}{l}\operatorname{In} . \\
2.65 \\
3.14 \\
3.31 \\
2.76 \\
2.90\end{array}$ & $\begin{array}{l}\ln . \\
3.36 \\
4.8: \\
3.5 .3 \\
3.60 \\
3.42\end{array}$ & $\begin{array}{l}\operatorname{In} \\
2.94 \\
3.7 * 2 \\
3.09 \\
3.29 \\
3.04\end{array}$ & $\begin{array}{l}\text { In. } \\
4.51 \\
4.49 \\
3.47 \\
3.70 \\
3.96\end{array}$ & $\begin{array}{l}\text { In } \\
3.19 \\
2.22 \\
2.48 \\
3.33 \\
3.23\end{array}$ & $\begin{array}{l}\text { In. } \\
3.76 \\
3.16 \\
3.62 \\
3.38 \\
3.51\end{array}$ & $\begin{array}{c}1 n . \\
3.86 \\
4.89 \\
3.80 \\
3.76 \\
4.02\end{array}$ & $\begin{array}{l}\text { In. } \\
4.43 \\
4.422 \\
3.86 \\
4.44 \\
4.21\end{array}$ & $\begin{array}{l}\text { In. } \\
3.93 \\
5.26 \\
4.64 \\
4.45 \\
4.44\end{array}$ \\
\hline & 4. 53 & 4.70 & 3.90 & 3.15 & 3.75 & 3.22 & 4.03 & 3.01 & 3.49 & 3.87 & 4.23 & 4.54 \\
\hline \multirow[t]{2}{*}{ 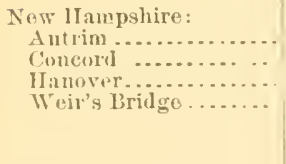 } & $\begin{array}{r}+4.61 \\
3.83 \\
+2.84 \\
3.84\end{array}$ & $\begin{array}{r}* 4.27 \\
3.55 \\
12.55 \\
3.73\end{array}$ & $\begin{array}{r}\text { *3. } 72 \\
2.79 \\
+1.84 \\
2.89\end{array}$ & $\begin{array}{r}2.80 \\
2.14 \\
+1.30 \\
2.32\end{array}$ & $\begin{array}{r}3.95 \\
2.88 \\
\uparrow 2.70 \\
3.11\end{array}$ & $\begin{array}{r}3.37 \\
3.03 \\
+2.90 \\
3.18\end{array}$ & $\begin{array}{r}4.53 \\
3.67 \\
+3.38 \\
4.01\end{array}$ & $\begin{array}{r}3.43 \\
2.98 \\
+2.87 \\
3.17\end{array}$ & $\begin{array}{r}4.32 \\
3.74 \\
12.49 \\
3.94\end{array}$ & $\begin{array}{r}4.00 \\
3.16 \\
+2.48 \\
3.40\end{array}$ & $\begin{array}{r}4.30 \\
3.12 \\
+3.27 \\
3.68\end{array}$ & $\begin{array}{r}4.11 \\
3.41 \\
+2.47 \\
3.90\end{array}$ \\
\hline & 3.76 & 3.52 & 2.81 & 2.14 & 3.17 & 3.12 & 3.90 & 3.11 & 3.62 & 3.26 & 3.59 & 3.47 \\
\hline \multirow[t]{2}{*}{ 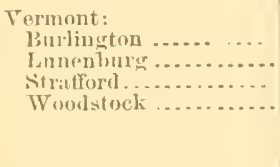 } & $\begin{array}{r}1.68 \\
2.99 \\
3.64 \\
+3.00\end{array}$ & $\begin{array}{l}1.48 \\
2.49 \\
3.16 \\
2.77\end{array}$ & $\begin{array}{r}1,78 \\
2.33 \\
3.14 \\
2.68\end{array}$ & $\begin{array}{r}1.67 \\
1.15 \\
1.90 \\
\$ 1.66\end{array}$ & $\begin{array}{r}2.86 \\
3.14 \\
3.06 \\
53.16\end{array}$ & $\begin{array}{r}2.98 \\
3.35 \\
2.95 \\
\$ 2.24\end{array}$ & $\begin{array}{r}2.82 \\
3.60 \\
1.52 \\
* 3.98\end{array}$ & \begin{tabular}{|}
3.08 \\
3.25 \\
3.61 \\
+3.00
\end{tabular} & $\begin{array}{r}3.64 \\
3.41 \\
3.70 \\
\mid 13.41\end{array}$ & $\begin{array}{r}3.12 \\
3.76 \\
3.02 \\
\star 2.68\end{array}$ & $\begin{array}{r}2.88 \\
3.10 \\
3.92 \\
\star 2.09\end{array}$ & $\begin{array}{r}1.85 \\
2.82 \\
3.28 \\
* 3.27\end{array}$ \\
\hline & 2.83 & 2.48 & 2.48 & 1.60 & 3. 06 & 2.88 & 3. 73 & 3.24 & 3.54 & 3.14 & 3.00 & 2.80 \\
\hline \multirow[t]{2}{*}{ 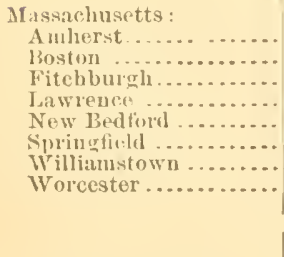 } & $\begin{array}{r}4.23 \\
4.81 \\
4.61 \\
5.44 \\
4.78 \\
+4.44 \\
+3.31 \\
+4.56\end{array}$ & $\begin{array}{r}3.72 \\
3.99 \\
3.56 \\
+4.28 \\
4.76 \\
+4.36 \\
13.25 \\
+4.42\end{array}$ & $\begin{array}{r}3.62 \\
3.61 \\
2.66 \\
* 3.91 \\
3.99 \\
13.23 \\
3.10 \\
+3.49\end{array}$ & $\begin{array}{r}2.53 \\
2.73 \\
2.56 \\
2.75 \\
3.45 \\
+2.65 \\
+2.60 \\
+2.67\end{array}$ & $\begin{array}{r}3.59 \\
3.86 \\
3.14 \\
3.30 \\
3.61 \\
+3.48 \\
3.02 \\
+1.13\end{array}$ & $\begin{array}{r}3.45 \\
2.81 \\
2.79 \\
\$ 2.81 \\
3.07 \\
13.80 \\
2.98 \\
+3.63\end{array}$ & $\begin{array}{r}469 \\
3.51 \\
4.05 \\
54.18 \\
4.00 \\
+4.97 \\
+4.61 \\
+3.38\end{array}$ & $\begin{array}{r}4.08 \\
3.58 \\
3.85 \\
\$ .87 \\
4.08 \\
+4.09 \\
+3.72 \\
+3.33\end{array}$ & $\begin{array}{r}4.50 \\
3.30 \\
3.74 \\
\$ 3.59 \\
3.45 \\
13.52 \\
3.05 \\
+3.84\end{array}$ & $\begin{array}{r}3.40 \\
3.62 \\
3.24 \\
53.77 \\
3.56 \\
+3.62 \\
2.62 \\
+3.85\end{array}$ & $\begin{array}{r}3.77 \\
3.38 \\
3.31 \\
4.69 \\
3.97 \\
+3.72 \\
3.24 \\
+3.96\end{array}$ & $\begin{array}{r}3.67 \\
3.27 \\
3.31 \\
3.58 \\
3.93 \\
+3.84 \\
+3.40 \\
+4.06\end{array}$ \\
\hline & 4. 53 & 4.04 & 3.46 & 2.74 & 3.52 & 3.17 & 4.17 & 3.95 & 3.62 & 3.46 & 3.76 & 3.68 \\
\hline
\end{tabular}

* For seven dass. † For nine days. † For eight days. \$ For six years. II For five sears. 
Tuble showing the average precipitation, etc.-Continued.

\begin{tabular}{l|l|l|l|l|l|} 
State and station. Jan. & Fob. Mar. Apr. May. June. July. Aug. Sept. Oet. Nor. Dee.
\end{tabular}

Rhode Island :

In. In. In. In. In. In. In. In. In. In. In. In.

Narragansett Pier .... *5.81 *4.95 *4.28 $+3.27+2.88+2.69+3.89+3.99+3.40 \div 4.46+4.32 \quad+3.78$

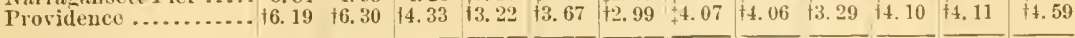

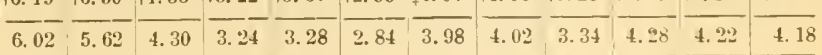

Consecticut:

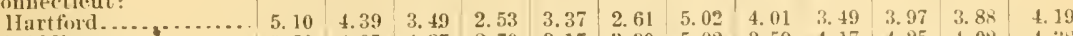

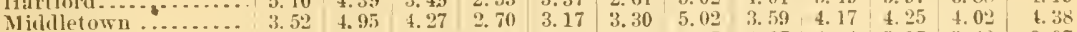

New llaven .........

\begin{tabular}{ll|l|l|l|l|l|l|l|l|l|l|l} 
New London ......... & 5.25 & 5.41 & 4.46 & 3.36 & 3.94 & 3.47 & 4.04 & 4.55 & 3.77 & 4.72 & 4.40 & 3.77 \\
\hline
\end{tabular}

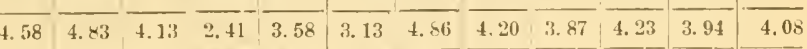

Northern Niw Fork:

Albing .

()

Piochester ............

\begin{tabular}{ll|l|l|l|llllllll}
2.95 & 2.56 & 2.72 & 2.24 & 3.13 & 3.58 & 3.68 & 3.67 & 3.98 & 3.18 & 3.46 & 2.94 \\
3.18 & 2.45 & 2.49 & 1.99 & 3.02 & 3.61 & 2.60 & 2.41 & 2.66 & 2.92 & 3.47 & 3.66
\end{tabular}

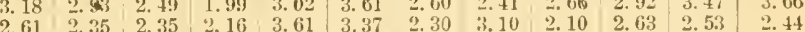

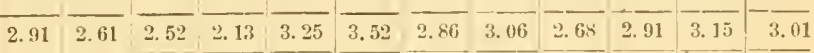

Northwesten Pennsyl. vania :

Erie ................. $\frac{3.90}{3.64} \frac{3.58}{3.58} \frac{2.52}{2.55} \frac{3.41}{2.58} \frac{3.50}{3.48} \frac{6.12}{5.20} \frac{4.04}{3.38} \frac{3.54}{3.42} \frac{3.27}{3.49} \frac{2.89}{2.48} \frac{2.94}{3.70} \frac{3.22}{3.36}$

Northern Ohio:

\begin{tabular}{|c|c|c|c|c|c|c|c|c|c|c|c|} 
Cleveland.............. 2.44 & 3.37 & 2.34 & 2.20 & 2.52 & 4.03 & 3.47 & 2.53 & 3.38 & 2.56 & 3.07 & 2.54
\end{tabular}

\begin{tabular}{ll|l|l|l|l|lllllll} 
Sindusky............ & 2.14 & 3.18 & 2.38 & 2.34 & 3.64 & 4.29 & 3.08 & 3.37 & 2.59 & 2.51 & 2.72 & 2.54
\end{tabular}

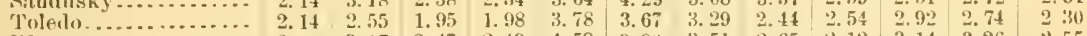

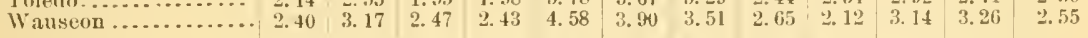

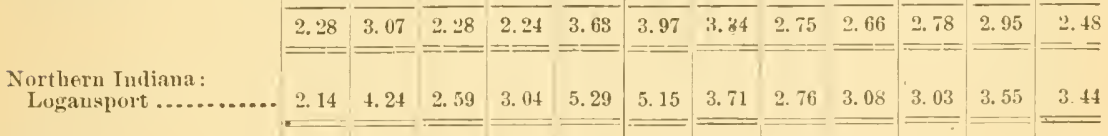

Michigan:

\begin{tabular}{ll|l|l|l|l|l|l|l|l|l|l|l} 
Adrian................ 2. 25 & $\$ 3.48$ & $\$ 2.47$ & 2.60 & 4.44 & 4.90 & 3.81 & 3.24 & 3.38 & 3.79 & 3.44 & 2.70 \\
\hline
\end{tabular}

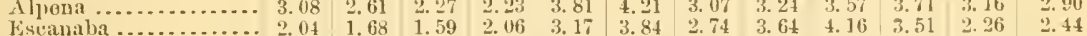

\begin{tabular}{ll|l|llllllllll} 
Grand Hlaven ........... & 2.78 & 3.21 & 2.38 & 2.45 & 3.21 & 4.04 & 3.57 & 3.23 & 3.50 & 3.75 & 2.75 & 3.14
\end{tabular}

\begin{tabular}{ll|l|l|l|llllllll} 
Kalamazoo............... & 2.46 & 2.96 & 1.87 & 2.24 & 4.36 & 4.96 & 2.93 & 2.52 & 3.06 & 2.84 & 2.39 & 2.93
\end{tabular}

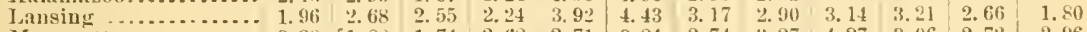

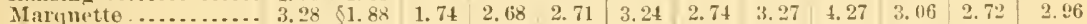

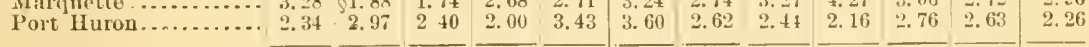

Northern Illinois :

\begin{tabular}{|l|l|l|l|l|l|l|l|l|l|l} 
Chicano & \\
Ch.
\end{tabular}

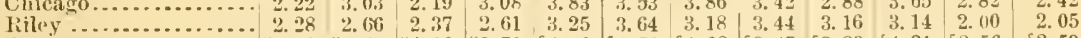

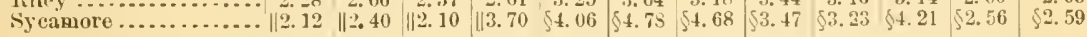

Iowa:

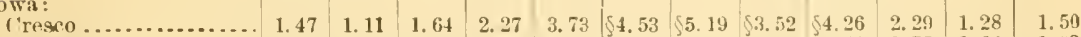

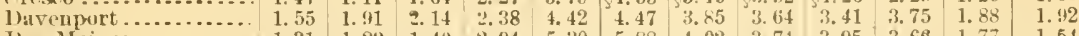

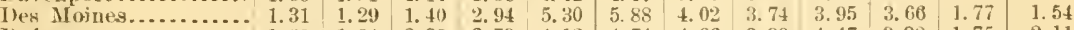

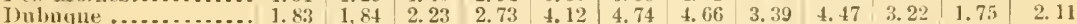

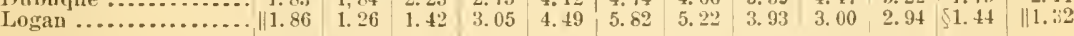

Wisconsin :

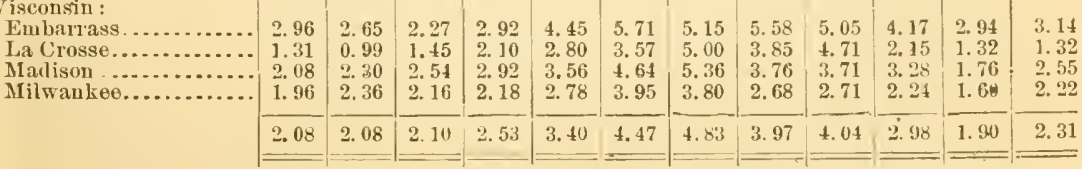

*For seven dajs. †For nine days. †For eight days. \$For nine yoars. \#For eight years. 
Table showing the arerage precipitation, etc.-Continned.

\begin{tabular}{|c|c|c|c|c|c|c|c|c|c|c|c|c|}
\hline Stitte and & Jan. & Irob. & Mar & Apr. & May. & June. & Juls. & Augr. & Sinet. & Oct. & Nov. & Dere. \\
\hline \multirow[t]{2}{*}{ 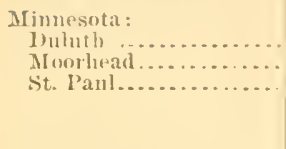 } & $\begin{array}{l}\ln . \\
1.26 \\
0 \quad 82 \\
1.21\end{array}$ & $\begin{array}{r}\operatorname{In} . \\
.34 \\
* 0.86 \\
1.04\end{array}$ & $\begin{array}{r}I n \\
1.35 \\
\times 0.76 \\
1.21\end{array}$ & $\begin{array}{r}I n . \\
2.44 \\
\times 2.18 \\
2.69\end{array}$ & $\begin{array}{l}I n . \\
3.50 \\
2.75 \\
2.58\end{array}$ & $\begin{array}{l}\ln \\
4.52 \\
3.24 \\
3.55\end{array}$ & $\begin{array}{l}\text { In. } \\
3.32 \\
1.37 \\
3.53\end{array}$ & $\begin{array}{l}I n \\
1.14 \\
2.70 \\
2.99\end{array}$ & $\begin{array}{l}\text { In. } \\
3.90 \\
\times 6.40 \\
3.24\end{array}$ & $\begin{array}{r}I n \\
3.14 \\
* 2.25 \\
1.64\end{array}$ & $\begin{array}{l}\ln \\
1.76 \\
+0.93 \\
1.22\end{array}$ & $\begin{array}{l}\text { In. } \\
1.33 \\
0.83 \\
1.33\end{array}$ \\
\hline & 1. 10 & .07 & 1.11 & 2.41 & 2.98 & & 3.74 & 3.28 & 3.18 & 2.31 & 1.30 & 1. 16 \\
\hline \multirow[t]{2}{*}{ 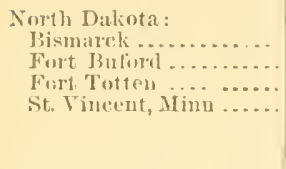 } & $\begin{array}{r}0.52 \\
0.67 j \\
0.48 \\
-0.46\end{array}$ & $\begin{array}{r}0.61 \\
0.43 \\
\text { ग. } 59 \\
* 0.50\end{array}$ & $\begin{array}{l}0.67 \\
0.42 \\
0.38 \\
0.53\end{array}$ & $\mid \begin{array}{ll}1 . & 86 \\
1 . & 11 \\
1 & 2 ! \\
\star 1 & 26\end{array}$ & $\begin{array}{r}2.11 \\
1.51 \\
2.11 \\
+2.001\end{array}$ & $\begin{array}{r}2.98 \\
3.07 \\
3.81 \\
3.01\end{array}$ & $\begin{array}{r}2.68 \\
1.96 \\
2.62 \\
* 2.70\end{array}$ & $\begin{array}{l}1.98 \\
155 \\
2.66 \\
2.28\end{array}$ & & & $\begin{array}{l}0.52 \\
0.35 \\
1.02 \\
0.56\end{array}$ & $\begin{array}{ll}0.75 \\
0.56 \\
0 & 75 \\
0 & 71\end{array}$ \\
\hline & 54 & 0.53 & 0.50 & 1. 37 & $1 . \overline{93}$ & $2 y$ & 2. 49 & 2.12 & 1.11 & 1.27 & 0.61 & 0.69 \\
\hline \multirow[t]{2}{*}{ 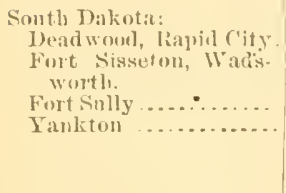 } & $\begin{array}{l}1.25 \\
0.39 \\
0.51 \\
0.59\end{array}$ & $\left\{\begin{array}{l}1.34 \\
0.37 \\
0.43 \\
0.77\end{array}\right.$ & $\begin{array}{l}1.78 \\
\times 0.87 \\
0.5 .3 \\
1.0 .5\end{array}$ & $\begin{array}{r}3.98 \\
\times 1.78\end{array}$ & $\begin{array}{l}\text { 4. } 19 \\
2.33 \\
2.10 \\
4.83\end{array}$ & $\begin{array}{r}3.66 \\
\times 3.50 \\
3.16 \\
3.14\end{array}$ & $\begin{array}{r}2.70 \\
3.16 \\
2.67 \\
3.16\end{array}$ & $\begin{array}{r}2.31 \\
3.38 \\
2.23 \\
3.30\end{array}$ & $\begin{array}{r}0.86 \\
\times 1.30 \\
0.82 \\
3.17\end{array}$ & $\begin{array}{r}1.06 \\
* 1.81 \\
0.52 \\
1.66\end{array}$ & $\begin{array}{r}1.24 \\
+0.56 \\
0.36 \\
0.24\end{array}$ & $\begin{array}{l}1.12 \\
0.52 \\
0.49 \\
0.87\end{array}$ \\
\hline & 68 & 073 & 1. 16 & 2.74 & 3.36 & 3.36 & 292 & 2.60 & & 1. 26 & 0.75 & 0.75 \\
\hline \multirow[t]{2}{*}{ 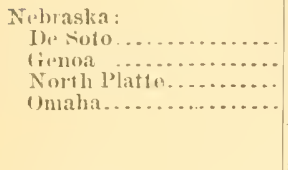 } & $\begin{array}{l}1.00 \\
0.93 \\
0.34 \\
0.82\end{array}$ & $\begin{array}{l}0.86 \\
0.67 \\
0.38 \\
0.91\end{array}$ & $\begin{array}{l}\text { I. } 55 \\
1.73 \\
0.70 \\
1.73\end{array}$ & $\begin{array}{l}2.29 \\
285 \\
2.113 \\
2.94\end{array}$ & $\begin{array}{l}3.61 \\
3.96 \\
3.30 \\
4.64\end{array}$ & $\begin{array}{l}4.71 \\
4.21 \\
3.78 \\
5.76\end{array}$ & $\begin{array}{l}3.86 \\
4.77 \\
3.76 \\
5.26\end{array}$ & $\begin{array}{l}3.55 \\
286 \\
2.79 \\
3.5 .5\end{array}$ & & $\begin{array}{l}2.45 \\
1.07 \\
1.37 \\
2.97\end{array}$ & & $\begin{array}{l}1.10 \\
0.86 \\
0.55 \\
0.94\end{array}$ \\
\hline & 0.77 & 0.70 & 1.15 & 2.52 & 3.88 & 4. 56 & 4.11 & :2. 17 & 2. 63 & 212 & 0.71 & $0 . x+j$ \\
\hline \multirow[t]{2}{*}{ 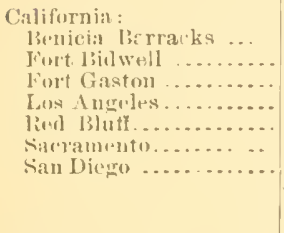 } & $\begin{array}{l}2.87 \\
3.51 \\
9.9 ! \\
2.39 \\
3.05 \\
3.1 .5 \\
1.91\end{array}$ & $\begin{array}{r}2.06 \\
2.46 \\
6.45 \\
3.38 \\
2.04 \\
2.28 \\
2.38\end{array}$ & $\begin{array}{l}2.75 \\
2.03 \\
4.30 \\
3.35 \\
2.10 \\
3.17 \\
2.05\end{array}$ & $\begin{array}{r}2.62 \\
* .31 \\
5.69 \\
1.92 \\
2.54 \\
3.01 \\
1.19\end{array}$ & $\begin{array}{r}0.70 \\
+1.11 \\
2.70 \\
0.41 \\
1.00 \\
0.77 \\
0.50\end{array}$ & $\begin{array}{r}0.30 \\
+1.13 \\
0.96 \mathrm{j} \\
0.11 \mathrm{j} \\
0.65 \\
0.25 \\
0.09\end{array}$ & $\begin{array}{l}\text { Trace } \\
0.32 \\
0.111 \\
0.04 \\
0.01 \\
0.10 \\
0.01\end{array}$ & $\begin{array}{l}\text { Trace } \\
* 0.09 \\
* 0.011 .4 \\
0.06 \\
0.00 \\
0.00 \\
0.05\end{array}$ & $\begin{array}{c}0.25 \\
0.27 \\
\times 11.88 \\
0.07 \\
0.63 \\
0.03 \\
0.02\end{array}$ & $\begin{array}{l}11.33 \\
1.66 ; \\
* 3.55 \\
1.07 \\
1.43 \\
1.2 ! \\
0.63\end{array}$ & $\begin{array}{l}* 2.10 \\
1.90 \\
4.7 i \\
1.67 \\
3.33 \\
2.5: 1 \\
0.7 i\end{array}$ & $\begin{array}{r}4.60 \\
* 3.47 \\
10.68 \\
4.29 \\
5.44 \\
4.616 \\
2.40\end{array}$ \\
\hline & 8: & .01 & 2. 92 & 2. 75 & i. 01 & & 0.07 & 0.03 & & 1. 62 & 43 & 5. 12 \\
\hline \multirow[t]{2}{*}{ 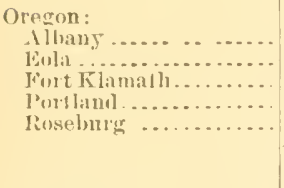 } & $\begin{array}{l}7.92 \\
7.36 \\
3.162 \\
7.2 x \\
6.06\end{array}$ & $\begin{array}{l}5.70 \\
4.73 \\
2.14 \\
4.97 \\
3.92\end{array}$ & $\begin{array}{r}3.67 \\
\therefore \therefore .27 \\
* 1.42 \\
3.72 \\
2.30\end{array}$ & $\begin{array}{l}\text { 3. } 51 \\
\text { 2. } 73 \\
\text { 1. } 52 \\
\text { 3. } 66 \\
\text { 2. } 87\end{array}$ & $\begin{array}{l}2.27 \\
1.84 \\
1.35 \\
2.48 \\
1.55\end{array}$ & $\begin{array}{r}1.71 \\
1.39 \\
+1.49 \\
1.71 \\
1.48\end{array}$ & $\begin{array}{ll}0 & 60 \\
5 . & 48 \\
5.70 \\
0 & 61 \\
0 . & 51\end{array}$ & $\begin{array}{l}0.40 \\
5.22 \\
\text { 1. } 11 \\
0.56 \\
0.15\end{array}$ & $\begin{array}{l}8 \\
4 \\
3 \\
3 \\
8\end{array}$ & $\begin{array}{r}3.76 \\
3.40 \\
+1.68 \\
4.31 \\
3.01\end{array}$ & & $\begin{array}{r}8.76 \\
7.616 \\
* 4.19 \\
9.56 \\
6.78\end{array}$ \\
\hline & 6.41 & 4.35 & $2.8 x$ & 2.86 & 1. 90 & 6 & 2. 58 & 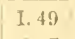 & 7 & 3.25 & & T. \\
\hline \multirow[t]{2}{*}{ 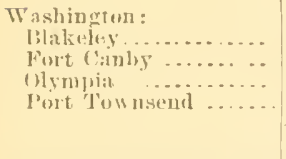 } & $\begin{array}{l}6.25 \\
8.08 \\
8.168 \\
2.71\end{array}$ & $\begin{array}{l}\text { 1. } 32 \\
7.15 \\
5.78 \\
1.46\end{array}$ & $\begin{array}{l}\text { 4. } 02 \\
\text { 5. } 9.1 \\
\text { 4. } 14 \\
\text { 1. } 33\end{array}$ & $\begin{array}{l}2.81 \\
\text { 4. } 63 \\
\text { 3. } 83 \\
\text { 1. } 73\end{array}$ & $\begin{array}{l}2.05 \\
3.116 \\
2.50 \\
1.43\end{array}$ & $\begin{array}{l}\text { 1. } 48 \\
2.37 \\
1.70 \\
1.28\end{array}$ & $\begin{array}{l}0.83 \\
1.26 \\
0.71 \\
0.98\end{array}$ & $\begin{array}{l}0.80 \\
0.57 \\
0.56 \\
0.74\end{array}$ & $\begin{array}{l}2.15 \\
3.37 \\
2.54 \\
0.80\end{array}$ & $\begin{array}{l}3.73 \\
6.26 \\
4.31 \\
1.93\end{array}$ & & $\begin{array}{l}7.86 \\
9.84 \\
9.199 \\
3.198\end{array}$ \\
\hline & 0.43 & 4. 68 & 3.86 & 3.25 & 2.26 & & 0.94 & 0.71 & 24 & 4. 06 & 1. $5 x$ & 1.41 \\
\hline
\end{tabular}


Tableshowing the menn tenperature in degrees $F$. for each month of the year at the stalions specified. (I)duced from observations during the period, Jaunury, 1880, to Deeember, 1889 , inclusice.

State and station.

Maine:

fornish.

Fing

Gavdine.....................

Grono . . . . . . . . . . .

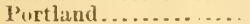

Naw IInmpishire:

(ines)rel

llimovert.

V.rmont :

Bulliugton.

I.11uilubur

Siratloril

lituodstock .........

Massachusetta :

Amlerst.

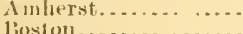

Fitrhlutren .............

l.awrench............

New bidford .... . .
Sirringfield .........

Williamstown ........

Worcester

l'rovidence

Conncetient

II:attiord...

lind

New IIaven .........

New London .........

Northern Now York:

Allany ... ...........

lincliester

hocliester ...............

Nortliwestern Peunsflva nin:

Frit

Friuklin

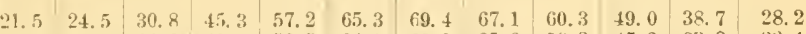

\begin{tabular}{ll|l|l|l|l|l|l|l|l|l|l}
\hline 17.5 & 18.8 & 20.6 & 40.6 & 56.5 & 64.1 & 693 & 65.6 & 58.2 & 45.6 & 33.8 & 22.4 \\
\hline
\end{tabular}

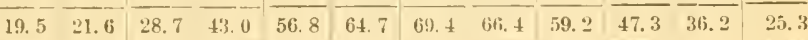

\begin{tabular}{llllllllllll|l}
16.7 & 20.6 & 27.5 & 42.8 & 58.6 & 66.6 & 71.0 & 60.2 & 61.6 & 47.6 & 37.1 & 25.6
\end{tabular}

\begin{tabular}{lllllllll|l|l|l|l}
14.5 & 16.8 & 24.0 & 38.8 & 55.4 & 63.3 & 67.3 & 65.1 & 57.9 & 44.2 & 33.2 & 21.5
\end{tabular}

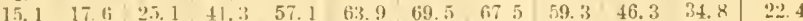

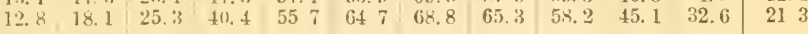

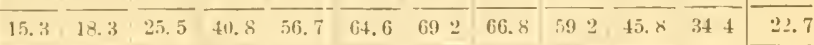

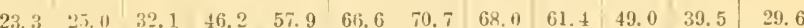

\begin{tabular}{llllllllllll}
\hline 6.7 & 14.1 & 33.3 & 446 & 55.7 & 6.9 .9 & 70.3 & 18.5 & $(12.2$ & 511.8 & 41.8 & 32.3
\end{tabular}

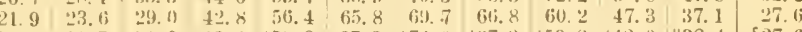

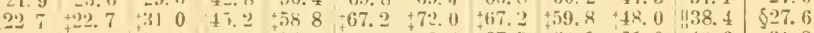

\begin{tabular}{ll|lll|lll|l|l|l|l|l|l}
.27 .5 & 28.4 & 33.1 & 43.9 & 54.1 & 64.1 & $(19.2$ & 67.3 & (6i). 1 & 51.0 & 42.6 & 318
\end{tabular}

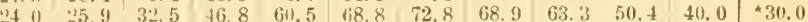

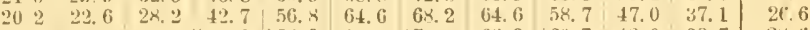

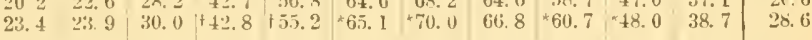

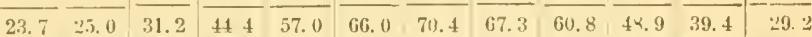

$=-\cdots$

$25.3 \div 28.5+32.2+45.4 \div 6.5+67.6 \S 73.1 .698+62.1+51.2+41.9+31.1$

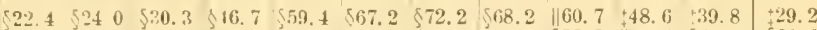

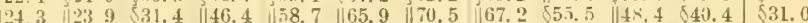

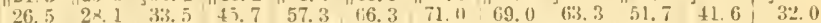

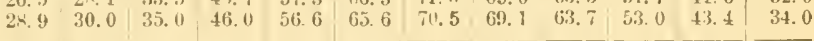

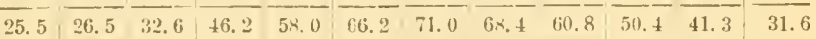

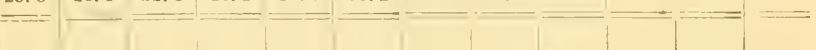

\begin{tabular}{|l|l|l|l|l|l|l|l|l|l|l|l}
23.4 & 25.6 & 32.1 & 47.1 & 60.7 & 69.0 & 73.1 & 70.7 & fi3.8 & 51.1 & 40.7 & 30.0
\end{tabular}

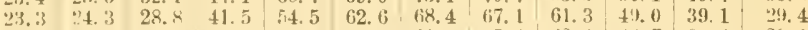

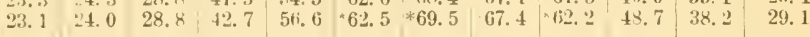

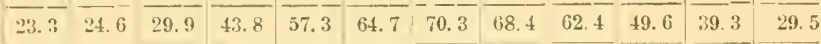

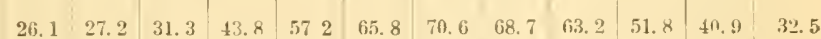

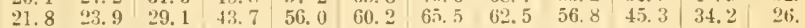

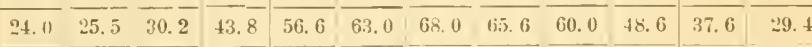

Northern Ohis:

\begin{tabular}{|l|l|l|l|l|l|l|l|l|l|l|l|l} 
Eleveland........... & 25.3 & 27.8 & 32.5 & 45.1 & 58.8 & 66.7 & 71.1 & 69.0 & 63.8 & 52.1 & 40.1 & 31.4
\end{tabular}

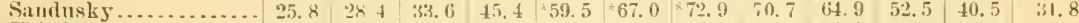

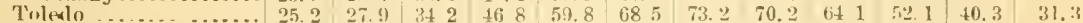

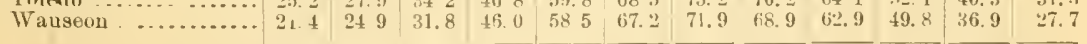

\begin{tabular}{|c|c|c|c|c|c|c|c|c|c|c|c|c|}
\hline & $\overline{24.4}$ & 27.2 & 33.0 & 4.5 .6 & 59.2 & 67.4 & 72.3 & 69.7 & 63.9 & $5 \nmid .6$ & 39.4 & 30.6 \\
\hline $\begin{array}{l}\text { orthern Indiana: } \\
\text { Logansport ........... }\end{array}$ & $\star 24.0$ & $\nmid 29.9$ & 136.7 & 52.9 & ${ }^{*} 64.7$ & +71.2 & $* 76.2$ & *73.9 & 167. 2 & +5.5 .3 & $* 10.0$ & $\star 30$. \\
\hline
\end{tabular}

* For nine years. + For eight jears. ‡For seven yoars. \$ For six yeara. $\|$ For five jears. 
Table shouring the mean temperature in degrees $F$. for each month, etc.-Continued.

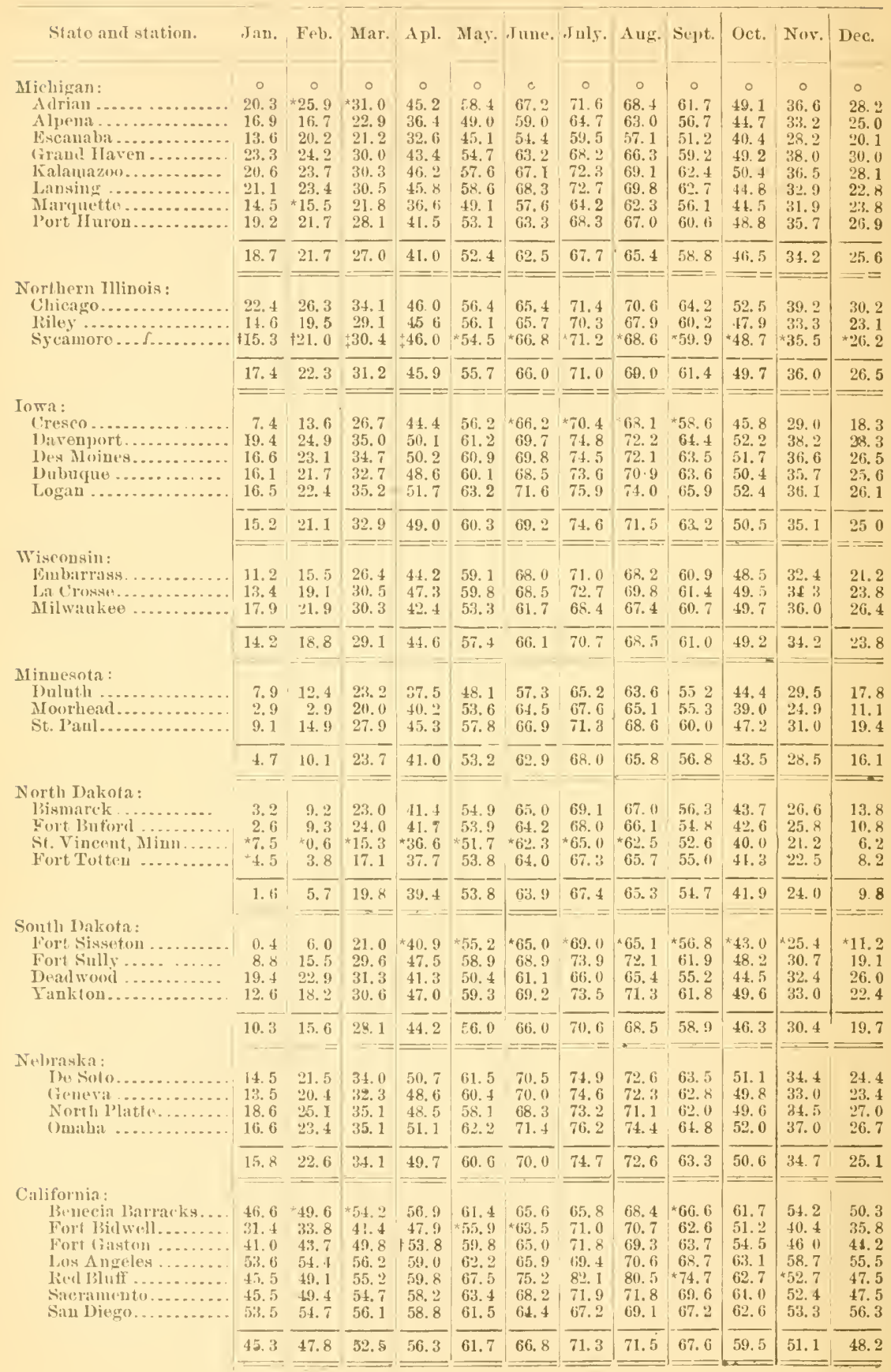


Table showing the mean temperatwe in degrees $F$. for each month, eic.-Continued.

\begin{tabular}{|c|c|c|c|c|c|c|c|c|c|c|c|c|}
\hline State and station. & Jan. & Feb. & Mar. & Apl. & Mas. & June. & July. & Aug. & Sept. & Oet. & Nov. & Dec. \\
\hline 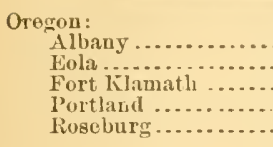 & $\begin{array}{c}0 \\
38.6 \\
37.6 \\
126.4 \\
37.0 \\
40.4\end{array}$ & $\begin{array}{r}0 \\
40.9 \\
39.8 \\
+26.8 \\
40.0 \\
41.6\end{array}$ & $\begin{array}{r}\circ \\
47.5 \\
46.8 \\
+34.7 \\
47.6 \\
47.5\end{array}$ & $\begin{array}{l}\circ \\
51.8 \\
50.1 \\
140.0 \\
51.8 \\
51.6\end{array}$ & \begin{tabular}{r}
\multicolumn{1}{c}{} \\
57.9 \\
55.8 \\
+49.7 \\
58.0 \\
57.1
\end{tabular} & $\begin{array}{r}0 \\
61.0 \\
60.3 \\
+56.9 \\
62.1 \\
61.4\end{array}$ & $\begin{array}{r}0 \\
66.3 \\
60.7 \\
+61.6 \\
66.4 \\
66.5\end{array}$ & $\begin{array}{r}\circ \\
65.4 \\
64.4 \\
+62.1 \\
65.3 \\
65.0\end{array}$ & $\begin{array}{r}0 \\
62.1 \\
59.1 \\
+51.7 \\
60.6 \\
61.4\end{array}$ & $\begin{array}{r}\circ \\
+49.0 \\
51.6 \\
\$ 41.5 \\
53.0 \\
52.2\end{array}$ & $\begin{array}{r}\circ \\
43.2 \\
43.7 \\
+33.2 \\
44.8 \\
445\end{array}$ & \begin{tabular}{r}
\multicolumn{1}{|c}{$\cdot$} \\
41.8 \\
41.5 \\
+30.4 \\
41.6 \\
43.2
\end{tabular} \\
\hline Roseburg............. & 36.0 & 37. 8 & 44.8 & 49.1 & 55.7 & 60.3 & 64.3 & 64.4 & 59.0 & 49.5 & 41.9 & 39.7 \\
\hline \multirow[t]{2}{*}{$\begin{array}{l}\text { Washington : } \\
\text { Blakeley ............. } \\
\text { Fort Canby ........... } \\
\text { Olympia ........... } \\
\text { Port Townsend..... }\end{array}$} & $\begin{array}{r}38.5 \\
41.0 \\
37.6 \\
\times 38.7\end{array}$ & $\begin{array}{r}40.3 \\
41.7 \\
39.0 \\
* 39.3\end{array}$ & $\begin{array}{r}46.1 \\
46.0 \\
44.5 \\
+46.2\end{array}$ & $\begin{array}{l}50.8 \\
49.0 \\
48.7 \\
51.3\end{array}$ & $\begin{array}{l}56.0 \\
53.2 \\
54.5 \\
55.0\end{array}$ & $\begin{array}{l}61.2 \\
56.5 \\
59.2 \\
60.0\end{array}$ & $\begin{array}{l}63.3 \\
59.0 \\
62.3 \\
62.0\end{array}$ & $\begin{array}{l}62.7 \\
59.5 \\
61.9 \\
61.2\end{array}$ & $\begin{array}{r}57.6 \\
57.8 \\
56.2 \\
+56.4\end{array}$ & $\begin{array}{r}51.0 \\
53.0 \\
50.1 \\
* 53.4\end{array}$ & $\begin{array}{r}45.1 \\
47.1 \\
43.8 \\
* 44.0\end{array}$ & $\begin{array}{r}41.8 \\
44.1 \\
40.6 \\
* 40.9\end{array}$ \\
\hline & 39.0 & 40.1 & 45.7 & 50.0 & 54.7 & 59.2 & 61.6 & 61.3 & 57.0 & $\overline{51.9}$ & 45.0 & 41.8 \\
\hline
\end{tabular}

-For nine years.

† For eight yeary.

$\ddagger$ For six years.

$\S$ For seren years.

Dr. McMurtrie, in special report No. 28, has made a careful study of the climatic conditions in the United States favorable to the production of the sugar beet. Maps are given showing the southern limit of a mean temperature of $70^{\circ}$ Fah. for the three summer months, coupled with a minimum mean rain-fall of two inches per month for the same period. The tables of temperature and rain-fall, from which these lines were computed, are also given in detail. The observations made on the data collated are as follows:

"We see from this that the sections of the Uuited States most favorable to beet-root culture are confued to the uorth, including New Eng. laud, New York, a narrow band south of the lakes, Michigan, parts of Wisconsiu, Minnesota, and Dakota. Here the line of the sonthern limit passes into the British possessions and enters the United States again in Washington Teritory, and, crossing Western Oregon, passes to the coast to the extreme north of Califoruia. In most of this baud we find a favorable temperature, and the average raiu-fall is sufficient in quantity, but we are ungble to make any observations concerning the number of rainy lays. In California, as the tables will show, the temperature is sufficiently moderate, but, from examination of the figures for the stations for which the rain-fall has been recorden, we find it to be remarkably deficient. Here, in orler to make the culture a suceess, it would appear that the intervention of irrigation during the summer months would be an absolute neeessity.

"We also note a few counties in the southrestern portion of Pennsylvania, and one conuty in Uhio, without the general band, where suitable meteorological conditions seem to exist. These comnties are surrounied by the red line in the more detailed map that has been prepared, showing the connty lines near to or over which the lime of the limit of favorable meteorological conditions passes. This maly is intended for more realy reference for those who may contemplate establishing the culture in the sections in the near neighborhood of the line. 
"Now, I lo not mean to assert that the band of conutry I hare thus plotter on the map is exclusively that in which the introduction of beetroot culture may be attempter with prospects of suceess, but it is certain that withiu this band the chances of suecess are greater than they are without it, and it also appears that all the unsuccessful attempts that have lieretofore been male to establish the iudustry have been at points without it. It is therefore advisable that farmers or manutacturers who may resign entering upon the prosecution of this industry should stud with greatest care these influences which operate with so much benefit or injury upon the protit of the erop). It is evident from what precerles that the beet requires a cool or at least a moderate season for suitable progress in lerelopment, that it may not reach maturity in advance of the time for worling it into sugar, and under the influence of the rains and elevated temperature of the antmmn months enter into a second growth, thereby destroying the valuable constituents which renders it so desirable as a sugar-proulucing crop.

"In this connection it has been suggestel that in sections of pro. tracted wam seasons, when the root will develop and attain full maturity in August, aud doring the summer drought, the crop conld be talien up before the appearance of the autumn rains, and by slicing and drying the roots preserve them until the arrival of the proper season. This mode of procedure has in fact been recommended to the agricul. turists of the south of France, and has, it has been stated, been the sul)ject of experiment in Algeria. 'The method has the objection of being a lather precarious one on aceount of the chances of the crop being canchl after a loug-continued dronght by late heary summer showers that would prove almost as injurious as the antumn rains.*

"After the lirections griven by Briem and others it is surcely neces. sary to recapitulate here the meteorologieal conditions which appear to be required by this culture, yet the conclusions arrived at from our study of the subject, in additiou, may not appear superfluous. The conditious, then, are in general, comparatively dry and warm spring months during the time for fleparation of the soil, planting, and cultivating the crop; moderate temperature, abuulant and frequent rains Inring the summer months, the time for ultimate development of the crop and its valuable constituents; cool dry fall, the time for ripening, - harvesting, and storing the erop. If these conditions preval, the results will be good; otherwise they will be but medimm or even bad."

'The amount of rain-fall necessary to the proper growth of sugar-beets depeuds largely on the character of the soil, the mean temperature, and the degree of saturation with aqueous rapor of the prevailing winds. In the coast valleys of California, where the proximity of the sea preserves alow temperature through the summer, and where the porous soil permits the tily root of the beet to descend after moistnre and moisture to

* The oxperiment of drying buts for peeservation in Maine, in the fall of 1878, proved quito disastrous liuancially for those who eugaged in the onterprise. 
asceud to the root, excellent ireets are grown with littie rain. The conditions would be ertirely reversed in inlaud localities with high summer heats, stiff clayes soils, and arid winds.

In general, the amount of rain-fall during the summer months in the Northeru, Central, and Easteru United States is sufficient to secure a good growtl, and therefore it may be said that proper soil and locality being provider, beet culture might be undertaken in such localities with little fear of disaster fron dronght, save in a few exceptional seasons.

In fact, with thorough under drainage and deep subsoil plowing, it would be possible to secure a good crop of beets in the regions indieated quite independently of the rariation in the amonut of rain-fall.

The chief question, therefore, to be considered, is one of temperature rather than of rain-fall. In the present state of our knowledge it would not be safe to establish beet factories very far sonth of the mean isotherm of $70^{\circ}$ Fahr. for the three summer months, without a more thorough study of the character of the beets produced than has hereto. fore been made. The possibility of tinding localities south of this line, where sugar-beets may be grown with profit, is mot denied, but the necessity of further investigation is urgent. There are many places situated only a short distance south of this line where the soil, water supply, cheap fuel, and other local cousideratious supply peculiarly farorable conditions for beet culture, and in snch places the industry wonld donbtless flourish, although the beet might not be quite as rich in sugar as when grown in a more northern locality. In all cases the length of the growing season should be sufficient for the complete maturity of the beet, and the freezing temperatures of winter should come sufficiently late to allow the beets to be safely harvested and covered. The shaded belt of the map, Plate 2, indicates fairly well those portions of the United States in which areas suited to successful beet eulture are most likely to be found.

\section{RECENT EXPERIMENTS LOOKING TO THE INTRODUCTION OF THE BEET.SUGAR INDUSTRY.}

\section{EXPERIMENTS IN INDIANA.}

Sugar beets have been grown for two seasons at the $\Lambda$ gricultural Station at La Fayette, viz, 1888-'89. The experiments for 1889 were conducted as follows:

The seeding took place on the 29th of April in rows 3 feet apart, and the plants were thinned so they stood from 4 to 6 inches apart in the rows. No information is given concerning the method of preparing the land and no note is made of any fertilizers used. The beets were harvested on the 23d and 25th of October. Analyses were made by the chemist of the station, Professor Huston, aud a comparison of the yield $25474-B u l l .27-12$ 
per acre aud the percentage of sugar found in each rariety is found in the following table:

\begin{tabular}{|c|c|c|c|c|}
\hline \multirow{2}{*}{ Varioty. } & \multicolumn{2}{|c|}{1888.} & \multicolumn{2}{|c|}{1889.} \\
\hline & $\begin{array}{l}\text { Tield per } \\
\text { acre. }\end{array}$ & Sugar. & $\begin{array}{c}\text { Yield per } \\
\text { acr } \theta .\end{array}$ & Sugar. \\
\hline 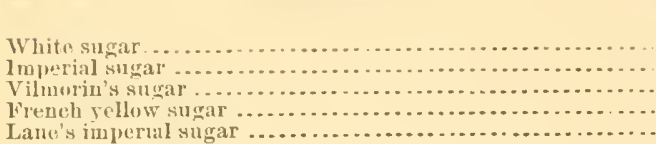 & $\begin{array}{r}\text { Tons. } \\
14.48 \\
14.48 \\
12.08 \\
12.07 \\
8.74\end{array}$ & $\begin{array}{r}\text { Per cent. } \\
11.37 \\
11.67 \\
9.92 \\
11.64 \\
16.40\end{array}$ & $\begin{array}{c}\text { Tons. } \\
13.59 \\
15.60 \\
13.20 \\
15.99 \\
16.80\end{array}$ & $\begin{array}{r}\text { Percent. } \\
13.05 \\
12.80 \\
12.85 \\
9.20 \\
10.40\end{array}$ \\
\hline
\end{tabular}

The mean temperature for June, July, and August, 1S59, was $69.2^{\circ}$ Fah., which is about 3 degrees below the average of this period for ten years.

EXPERIMEN'T'S IN MICIIIGAN.

Analyses of sugar beets grown in . Iichigan in 1859.-There are no cletails given of the method of planting and enltivating the beets or the time of planting and harvesting. The following data were furnished by Dr. R. U. Kedzie, Chemist of the A grieultural Experiment Station, in a letter under date of October 5,1889 :

\begin{tabular}{|c|c|c|}
\hline No. & Variety. & Sucroso. \\
\hline $\begin{array}{l}1 \\
2 \\
3\end{array}$ & 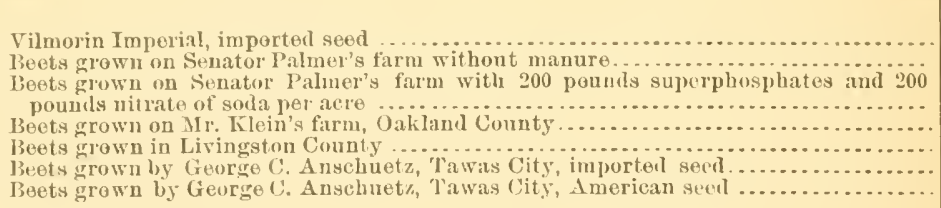 & $\begin{array}{r}\text { Per cent. } \\
14.58 \\
11.40 \\
11.40 \\
12.87 \\
7.86 \\
12.78 \\
13.40\end{array}$ \\
\hline
\end{tabular}

\section{EXPERIMENTS IN WISCONSIN.}

Under anthority of the Secretary of $\Lambda$ grienlture I made arrangements with Prof. W. A. Henry, director of the Wisconsin Agrienltural Experiment Station, for eulture experiments with the sugar beet.

The interesting and instructive report of Professor Henry follows.

The remarkably favorable weather during October is a factor in the produetion of sugar beets which shonld not go unnoted. Only a trace of rain fell at Madison in October, and the season for harvesting and siloing conld not have been better.

The general results are encouraging, sufliciently so to justify further cultural work, a kind of work which may eventually result in the establishment of factories. 
REPORT ON INVESTIGATION OF „BEETS FOR SUGAR PRODUCTION IN 1889, AT THE WISCONSIN AGRICULTURAL EXPERIMEN'T STATION, UNDEL DIREC'TION OF THE DEPARTMENT OF AGRICULTURE, WASHINGTON.

Varieties and planting.-Three rarieties of seed were furuished by the Departmeut, one, not named, being received from the California Beet Sugar Company; the other two, viz, Vilmorin's Improved and Lane's Imperial were received direetly from Washington. The seed from California arrived in April, and was planted May 5. The other varieties, for some reason, did not reach Madison until June, and were plauted June 6, too late to give entirely satisfactory results as the season after this time was exceptionally dry, causing the beets to grow slowly.

The beets were planted in rows 3 feet apart and were thinned to about 8 inches apart in the rows. They were carefully enltivated, the soil being kept free from weeds, and in good tilth throughout the season.

Meteorology.-The season of 1859 was most remarkable for the very small rain-fall, not one-half the average amount of preeipitation being registered for the growing season.

May, June, and Oetober were somewhat eooler than the average, while July and August were slightly warmer.

TABLE I.-Showing temperature and rain-fall.

\begin{tabular}{|c|c|c|c|c|c|c|}
\hline \multicolumn{3}{|l|}{ Rain-fall. } & \multicolumn{4}{|c|}{ Temperature. } \\
\hline & 1883. & $\begin{array}{l}\text { Mean for } \\
\text { thirty- } \\
\text { three } \\
\text { Jears. }\end{array}$ & $\begin{array}{c}\text { Mean } \\
\text { for } 1889 .\end{array}$ & $\begin{array}{l}\text { Mean for } \\
\text { thirty- } \\
\text { three } \\
\text { years. }\end{array}$ & $\begin{array}{c}\text { 1Lighest } \\
1889 .\end{array}$ & $\begin{array}{c}\text { Lowest } \\
1889 .\end{array}$ \\
\hline 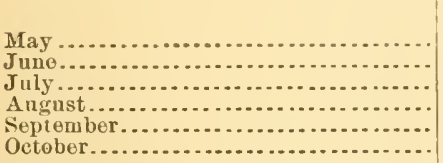 & $\begin{array}{r}\text { Inches. } \\
3.28 \\
2 \\
2.12 \\
.72 \\
1.93 \\
\text { trave. }\end{array}$ & $\begin{array}{c}\text { Inches. } \\
3.6 \\
4.7 \\
4.31 \\
3.49 \\
3.37 \\
3.04\end{array}$ & $\begin{array}{l}\circ F . \\
56.1 \\
63.4 \\
74.3 \\
70 \\
61.18 \\
46.1\end{array}$ & $\begin{array}{r}F . \\
57.9 \\
67.2 \\
72.6 \\
69.5 \\
61.2 \\
48.8\end{array}$ & $\begin{array}{l}F . \\
82 \\
83.3 \\
91.6 \\
90.5 \\
90.2 \\
75.5\end{array}$ & $\begin{array}{l}\text { F. } \\
34.2 \\
42.2 \\
54.7 \\
51 \\
34.8 \\
29\end{array}$ \\
\hline
\end{tabular}

Development of the sugar in the beet root.-The first analyses were made September 20, and after this date beets from each lot were frequently examined until they were harvested to protect them from the frost on October 22.

The following table gives the per cent. of sugar in the juice from each variety at the dates when examined. The determinations were made with the polariscope.

TABLE II.-Showing per cent. of sugar in juice of beets at different periods.

\begin{tabular}{|c|c|c|c|c|c|}
\hline \multicolumn{2}{|c|}{ Vilnorin's Improved. } & \multicolumn{2}{|c|}{ Lane's Imperial. } & \multicolumn{2}{|c|}{ Califoruia Beet Sugar Company. } \\
\hline Date. & Per cent. & Date. & Per cent. & Date. & Per cent. \\
\hline 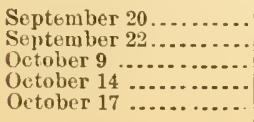 & $\begin{array}{r}8.07 \\
10.35 \\
10.60 \\
11.95 \\
15.60\end{array}$ & 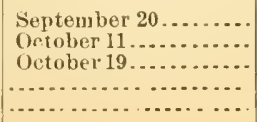 & $\begin{array}{r}7.97 \\
14.40 \\
15.60 \\
\ldots \ldots . . .\end{array}$ & 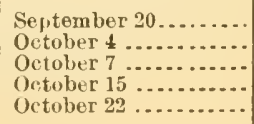 & $\begin{array}{r}8.074 \\
9.68 \\
10.05 \\
11.54 \\
14.50\end{array}$ \\
\hline
\end{tabular}


Grading the bects.-The beets were harvested October 22, at whieh time they were divided into two grades, the elassification being based upon the shape and manner of growth. The first grate represents those roots that were comparatively smooth and couical in shape. The beets of the second class were irregular in shape, with large, scraggly roots.

This second type of beets was not seattered nuiformly through the plot, but grew in patches of three, four, or a dozen together. inclicating that some local peculiarity of the soil or treatment was the canse of their irregular development.

Abnormal bects.-A few beets differed in type from the others in growing partly ont of the ground. Analyses to determine the sugar trom the parts above and below gronnd are presented in the following talle.

TABLE III.-Showing percentage of sugar in different parts of beets.

\begin{tabular}{|c|c|c|}
\hline Part of beet. & Teight. & $\begin{array}{l}\text { Sngar in } \\
\text { juice. }\end{array}$ \\
\hline 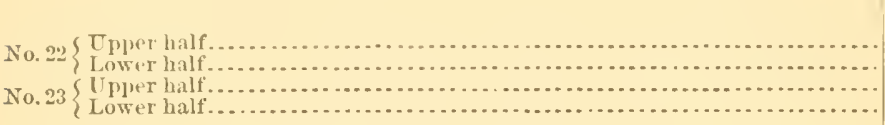 & $\begin{array}{r}\text { Grams. } \\
664 \\
449 \\
345 \\
570\end{array}$ & $\begin{array}{r}\text { Percent. } \\
9.89 \\
10.12 \\
11.81 \\
11.46\end{array}$ \\
\hline
\end{tabular}

Though the percentage of sugar in the two parts of the beet does not rary much, the pereentage for the whole beet is low.

Field per acre.-At harresting; the beets and tops were weighed separately. In the following table is shown the weight of the two grades, the tops, and the arerage weight of each beet-root.

TABLE IV.-Showing yield of beets and weight of tops per acre.

\begin{tabular}{|c|c|c|c|c|c|}
\hline Tariety. & $\begin{array}{l}\text { No. of } \\
\text { beets. }\end{array}$ & $\begin{array}{l}\text { Treight } \\
\text { of No. } 1 \\
\text { beets. }\end{array}$ & $\begin{array}{l}\text { Weight } \\
\text { of No. } 2 \\
\text { beets. }\end{array}$ & $\begin{array}{c}\text { Total } \\
\text { weight. }\end{array}$ & $\begin{array}{l}\text { Arerage } \\
\text { weight. }\end{array}$ \\
\hline 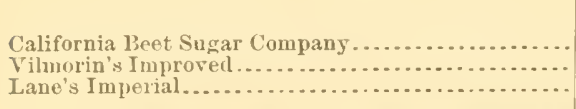 & $\begin{array}{l}16,233 \\
15,770 \\
14,713\end{array}$ & $\begin{array}{r}\text { Pounds. } \\
13,353 \\
12,211 \\
11,856\end{array}$ & $\begin{array}{r}\text { Pounds. } \\
5,938 \\
3,384 \\
4,501\end{array}$ & $\begin{array}{r}\text { Pounds. } \\
19,291 \\
15,595 \\
16,367\end{array}$ & $\begin{array}{r}\text { Pounds. } \\
1.18 \\
1.99 \\
1.11\end{array}$ \\
\hline
\end{tabular}

The total yield of beets is mueh smaller than is usually reported. This is partly clue to the season, but ehiefly to the distance of the roms a part, it being the custom to plant them only 17 or 18 inches instead of 3 feet, as in this case.

The table shows that from a fourth to a third of all the roots graded as No. 2.

Both types of beets from the California Beet Sugar Company's seen were examined for sugar, two analyses of each being malle, with the following results, which show that the No. 1 beets are the richest in sugar : 
Tarle V.-Showing per cent. of sugar in No. 1 and No. ¿ bects.

\begin{tabular}{|c|c|c|}
\hline & $\begin{array}{l}\text { No. } 1 \text { beets. } \\
\text { Sugar in } \\
\text { juice. }\end{array}$ & $\begin{array}{l}\text { No. } 2 \text { beets. } \\
\text { Sugar in } \\
\text { juice. }\end{array}$ \\
\hline $\begin{array}{l}\text { No. } 1 \text {.... } \\
\text { No. } 2 . \ldots .\end{array}$ & $\begin{array}{r}\text { Per cent. } \\
14.83 \\
14.47\end{array}$ & $\begin{array}{r}\text { Per cent. } \\
14.12 \\
13.50\end{array}$ \\
\hline Average........ & 14.54 & 13.81 \\
\hline
\end{tabular}

Impurities in the juice. - Analyses were made to determine the quality of the juice for the mannfacture of sugar. The following table gives tho per cent. of sugar, of solids, and the specific gravity of the juice at the dates mentioned.

TABLE VI.-Showing per cent of solids and sugar in the juice.

\begin{tabular}{|c|c|c|c|c|}
\hline Variety. & $\begin{array}{l}\text { Date of } \\
\text { analysis. }\end{array}$ & $\begin{array}{l}\text { Solids in } \\
\text { juice. }\end{array}$ & $\begin{array}{l}\text { Sugar in } \\
\text { juice. }\end{array}$ & $\begin{array}{l}\text { Specific } \\
\text { gravity of } \\
\text { juice. }\end{array}$ \\
\hline 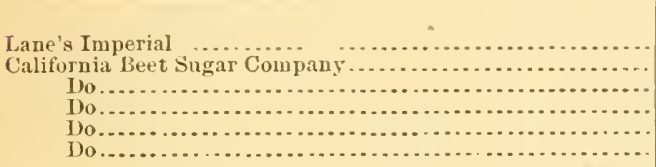 & $\begin{array}{l}\text { Oct. } 11 \\
\text { Oct. } 15 \\
\text { Nor. } 29 \\
\text { Dec. } 4 \\
\text { Dec. } 5\end{array}$ & $\begin{array}{r}\text { Percent. } \\
18.43 \\
17.30 \\
15.29 \\
15.07 \\
15.22 \\
14.96\end{array}$ & \begin{tabular}{r|} 
Pcr cent. \\
14.40 \\
14.53 \\
14.12 \\
14.83 \\
14.47 \\
13.50
\end{tabular} & $\begin{array}{l}1.10 \\
1.08 \\
1.085 \\
1.09 \\
1.0825 \\
1.08\end{array}$ \\
\hline
\end{tabular}

Quality of the juice in stored beets.-The harrested beets were stored in a barn cellar, the door of which was left open for circulation of air until danger of freezing. The temperature of the cellar ranged from $44^{\circ}$ to $41^{\circ}$ Fah. by a dry-bulb thermometer, and uniformly 1 degree lower by a wet-bulb thermometer, showing that the air was quite damp. Under these conditions the beets kept well. For the sugar content we way refer to Table VI, where the California beets show 14.53 per cent of sugar in the juice October 15, one week before they were taken from the gromd for storage. The analyses for November 29 and the three succeding dates show the percentage of sugar in the juice of the stored beets.

Conclusion.-Considering the season, the time of planting, and thr conditions of culture, the beets certainly showerl a very satisfactory sugar coutent. The weather being quite abuormal, it is but fir to withlod, general statements until the work is repeated for at least one season. It this line is continuer, an effort will be made to plant and cultivate after the manner of beet fields in sugar districts.

\section{EXPERIMENTS IN IOWA.}

Experiments were made at the Agricultural Experiment Station at Ames during 1858 and 1859, and the results of these experiments are published in Bulletin No. $S$ of the Station, pages 321 to 326 , inclusive. 
These experiments were condueted under the direction of Prof. G. E. Patrick.

Four varieties of sugar-beets were grown in 1888 and two in 1859. Those grown in 1858 were from seed purehased from seedsmen in America under the names given bolow. The roots were harrested in due season and stored in a good root-eellar, but wero not analyzed till January, 1S59. For the methods of sampling and aualysis referenee is made to the bulletin above noted.

The varieties grown in 1958 were White Sugar Beet, Excelsior, Valmoriu's Improved, and Lane's Improved. The mean weight of the first variety was 14.5 ounces; of the seeond, 17 ounces; of the third, 19 ounces, and of the fourth, 15 ounces. The results of the analyses of the juice of the different varieties are as follows:

\begin{tabular}{|c|c|c|c|}
\hline Variety. & $\begin{array}{l}\text { Solids, Brix } \\
\text { at } 17.5^{\circ} \mathrm{C} \text {. }\end{array}$ & Sucrose. & $\begin{array}{l}\text { Purity coef- } \\
\text { ficiont. }\end{array}$ \\
\hline 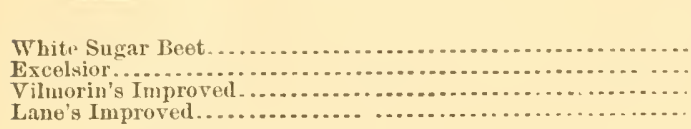 & $\begin{array}{l}19.50 \\
16.14 \\
19.33 \\
19.10\end{array}$ & $\begin{array}{r}\text { Per cent. } \\
14.12 \\
12.73 \\
15.00 \\
14.47\end{array}$ & $\begin{array}{l}73.7 \\
78.8 \\
77.6 \\
75.7\end{array}$ \\
\hline
\end{tabular}

Professor Patrick makes the following remarks on the analyses:

These results taken by themselves lend some encouragement to the hope that the climate and soil of lowa may prove well adapted to the development of sugar in the sugar-beet.

But a single year's trial in a single locality goes but little way in settling so great a question.

Different seasons as well as different soils will have their influence, and sometimes a marked one, on the quality of the crop. This truth, or if not this then another one which the investigator of these subjects must alwags bear in miud, namely, that seeds purchased from dealers are not alwajs true to their eatalogne names, is well illustrated by the results obtained in 1889 as compared with those of 1888 , above recorded.

Two varieties were grown in 1S59, viz, Lane's Improved and Vil. morin's Improved. The analyses were made ou November 20-23. These beets were planted on the same gromnd as those of the previous year, but the ground had received a good dressing of barn-yard manure for the erop of 1859 . The mean weights were as follows :

Lane's Improved, 42 ounces; Vilmoriu's Improved, 25 ounces. The results of the analyses of the expressed juice were as follows:

\begin{tabular}{|c|c|c|c|}
\hline Variety. & $\begin{array}{l}\text { Solids, } \\
\text { lsrix., at } \\
17.5^{\circ} \mathrm{C} \text {. }\end{array}$ & Sucrose. & $\begin{array}{l}\text { Purits, } \\
\text { coollicient. }\end{array}$ \\
\hline $\begin{array}{l}\text { Lane's Improved ............ } \\
\text { Vilmorin's Improved ..... }\end{array}$ & $\begin{array}{l}\text { 13. } 32 \\
17.80\end{array}$ & $\begin{array}{r}\text { Per cent. } \\
7.82 \\
12.64\end{array}$ & 58. ${ }^{m}$ \\
\hline
\end{tabular}

The disastrous results of manuring beets with baru yard manure are easily seen from the ahore table. The beets grew to an enormons size, 
and were consequently low in sugar. P'rofessor Patrick supposed that the low content of sugar was due only in part to the manuring, and he accounts for it as follows :

First, by the charaeter of the season in 1889-dry in the early part, cold and wet toward the end-fogether with the enrielment of the land with barn-fard manure.

Second, and with reference to the Lane's Inproved mainly, ly the ruality of the seed, the same having eome, without doubt, from stock badly erossed with an inferior kind of beet. This conchsion is reached as much from the appearance of the beets within and withont, as from the results of analysis. The similar experience of many besile ourselves makes it evident that sugar-beet seel pnrehased from Ameriean seeds. men is very liable to prove untrue and disappointing.

For these reasons we do not regard the resilts of 1889 as having any real signifieance in the question of the adaptability of Iowa's soil and elimate to the needs of the sugar-beet.

In addition to the work done with the beets grown at the Station a box of beets was received on the 19th of November, 1S89, from Mereer Comnty, Ill., sent by Edrard H. Thayer, of Clinton, Iowa. The seed from which these beets were obtained was purchased in Germany, but the names of the varieties are not known. The mean weight of the beets was 23.5 ounces. They contained of sugar 15.25 per cent in the juice, and a purity coefficient of 75.73 . It is erident fiom the above that the beets from Illinois were grown without the use of barn-yard manure and, although a little above size, were much better in every way for the production of sugar than the beets grown at the Station.

From the results obtained, it is not difficult to see that the soil and climate of Iowa are far better suited to the growth of the sugar-beet, for sugar-producing purposes, than for sorghum. In the experiments made with sorghmm at the Iowa Station, and which are given on pages 327 to 336 , inclusive, of the bulletin above mentioned, the mean percentage of sucrose in the juice of the Early Amber was found to be 14.11, while the pmity coeffieient was 76.76. The hopelessmess, however, of expecting to make sorghum sugar profitably in Iowa is suffieiently indicated by the statement made on page 328 of the bulletin, which is as follows:

On the night of September 18 there came a killing frost, which within three dass withered the cane leaves and soured the sap in the stalks, thus relneing our season for seleetive work to only ten days.

With a season of such brief duration, which is almost certain to be ended in September, it is not to be expected that sorghum sugar can be made successfully. With the beet it is quite different, since by proper siloing the season for manufacture ean be continued indefinitely.

\section{EXPERIMENTS IN NEBRASKA.}

The following report*, by Professors Nicholson and Lloyd, on the growth of the sugar beet in Nebraska from seed received from the Department of Agrienlture, shows the progress made in that State during 
the past year in the cultivation of the sngar beet under the auspices of the agricultural experiment station of the State.

REPORT ON TIE DISTRHUTION OF SEEI RECEIVED BY THE DEPARTMKNT OF CHEMISTRY, UNIERSTY OF NEBHASA, FROM THE DEPARTMENT OF AGRICULTURE, AT WASIINGTON, D. C.

Taricties reccicel.-I. Sugar beets, Lane's Imperial and Vilmorin II. Sunar Cane, Early Amber, and Red Siberian.

But two persons reported results from sugar caue seed, in both cases a large proportion of the sced faileri to germinate.

Analysis of two specinems of Early Amber eane sent in, gare,respectively, 13 and 12.41 per cent of sncrose.

In regard to sugar beets, twelve samples of seed of Lane's Imperial were sent ont.

Seven persons retumed specimens of beets raised accompanied by very brief reports; all reported poor seed.

Average per cent of sucrose in these beets was 4.66 ; highest, $6.0 \mathrm{~s}$; lowest, 2.50 .

Thirty-three samples of seed of Vilmorin were sent ont.

'Twenty-three persons returued to us speeimens of beets raised, accompanied by brief reports which gave but little information, exeept that a large proportion of the seed did not germinate.

In fifteen of the beets the per cent of suerose ranged above. Average of the fifteen specimens, 14.07; average of the eight (under 10) specimens, 6.97 ; average of the entire lot, 11.99 ; highest per cent. in whole lot, 20.28 ; lowest per cent. in whole lot, 4.73 .

Analysis of sugar beets, chemical laboratory, University of Nebrastia.

\begin{tabular}{|c|c|c|c|c|c|c|c|c|}
\hline No. & Date. & Consignor. & Variets. & Sucrose. & Glucose. & Brix. & $\begin{array}{l}\text { Specific } \\
\text { gravity. }\end{array}$ & $\begin{array}{l}\text { Co-efti. } \\
\text { cient of } \\
\text { purity. }\end{array}$ \\
\hline $\begin{array}{l}1 \\
2 \\
3 \\
4 \\
5 \\
6 \\
7 \\
8 \\
9\end{array}$ & 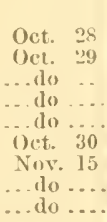 & 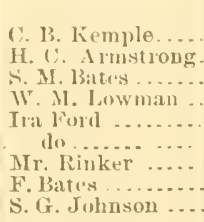 & 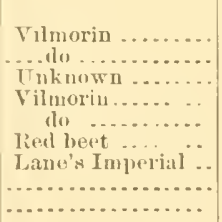 & $\begin{array}{r}\text { Percent. } \\
13.28 \\
11.49 \\
19.52 \\
9.91 \\
10.14 \\
10.13 \\
15.32 \\
13.51 \\
9.69\end{array}$ & $\begin{array}{r}\text { I'ercent } \\
0.370 \\
0.010 \\
0.010 \\
0.052 \\
0.009 \\
0.017 \\
0.230 \\
0.100 \\
0.160\end{array}$ & $\begin{array}{l}21.6 \\
17 \\
23.7 \\
19.3 \\
20.4 \\
19.3 \\
23.7 \\
23.7 \\
23.7\end{array}$ & $\begin{array}{l}1.098 \\
1.070 \\
1.100 \\
1.082 \\
1.085 \\
1.080 \\
1.100 \\
1.100 \\
1.100\end{array}$ & $\begin{array}{l}61 \\
61 \\
80 \\
51 \\
50 \\
50 \\
6.7 \\
58 \\
40\end{array}$ \\
\hline
\end{tabular}

H. H. Nicholson, Dirretor. RACHEL LlOYH, A nalyst.

FXPERIMENTS $\Lambda$ ' GR ND ISL $A N D$, NEBRASK $\Lambda$.

Great suecess also attenled the growing of sugar beets in Nebraska, at Grand Island, in 1s8s. As will be seen by the following table, samples of these hects were malyzed by varions chemists, and all found them excellent for sugar-making purposes. 


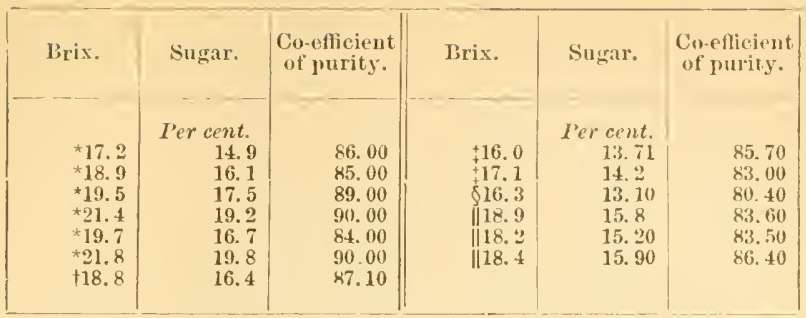

* Analyzed by Prof. William Huch, from Shoemingen, Germany.

+ Beets harrested Octoher 15, 1888 preserved in silo, analyzed Januars 2, 1889.

+ Analyzed by Dr. Pauly, of Mublberg, Germany.

$\$$ Aualyzed by Dr. Mueller. of Ottleben, Germany.

II A nalyzed by Dr.Janke, Treullebush, Germany.

Samples of these beets were also sent to the Dejartment for analysis and entered as Nos. 6077 and 607 . The results of these analyses were as follows :

\begin{tabular}{|c|c|c|}
\hline & 6077 & 6078. \\
\hline 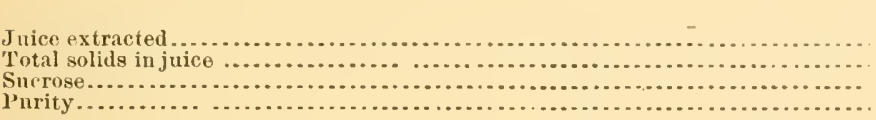 & $\begin{array}{r}\text { Per eent. } \\
56.16 \\
18.40 \\
15.38 \\
83.59\end{array}$ & $\begin{array}{r}\text { Per eent. } \\
54.70 \\
18.80 \\
15.75 \\
83.77\end{array}$ \\
\hline
\end{tabular}

As will be seen by the above analyses these beets were very rich in sugar, and if they conld be grown in large quantities, which there is no reason to loubt, wonld indicate that in that locality the beet sugar industry could be successfully established.

\section{EXPERIMENTS IN SOU'H DAKOTA.}

Experiments were made at the Agrieultural Experiment Station at Brookings, which are reported in Bull. No. 16, by Luther Foster, agrieulturist, and James H. Shepard, chemist.

THE SUGAR-BEET.

The Station has completed its second season's test of the sugar-beet, and the result gives us still better evirlence of its crop value to South Dakota both for stock feeding and sugar making. While the erop was not as great either in per cent of sugar or yield of roots per acre as may reasonaibly be expected in more favorable seasons, or by following more strictly the French and German methods of fertilizing and cultivating, it was still sufficiently large to insure it a profitable erop eren under the opposing influences of the past season.

Preparation of soil.-In the whole matter of soil preparation, fertilizing, and enltivating, nothing has been attempted that is not within the reach of the ordinary farmer, and our results are no better than he may reasonably expect. In mechanical preparation the soil was almost perfect for such a crop, the ground having been leeply plowed and thoronghly pulverizen. The results of long-continued experiments in 
beet-growing countries indicate an average depth in plowing of from 12 to 15 inches to insure the largest and best yield. Deep plowing prevents forking; it also provides a deptin of mellow soil sufficient for the growth of the root entirely beneath the surface. Where beets grow partly above the soil the protrnding portion becomes tinted and requires extra work in clarifying the sugar. Fall is the hest time for plowing. It leaves a rough, uneven surface to weather, catch moisture, and settle. The final preparation should be made at planting time, avoiding any plowing or deep stirring that would cause a loss of the accumulated moisture of the winter. Thorough preparation before planting is of prime importance. Anj neglect here will be a sonree of frequent annoyanee and delay throughont the season of planting and cultivation. The clod.crusher and roller will greatly assist in this work.

Fertilizing.-The ground used for the experiment had received a heary coat of well-rotted manure last year and was in excellent condition to nonrish the season's crop. It is a fact well established by beetgrowers that a too abundant supply of stable manure lessens the per cent of sugar. This results from a period of growth too rark and too much prolonged. To produce sugar the growth must be arrested in time for complete maturity. The dry, clear weather of this climate is farorable to this result. Stable manure should be applied and plowed under in the fall and not more than 15 tons per acre used.

Planting.-Experience has taught that the method of planting is of rastly greater importance than is ordinarily considered. It has been shown that not only the field per acre but also the per cent of sugar depends largely on the manner of planting. Thin planting-rows wide apart and plants well separated from each other in the row-gives loets of the largest size but containing a small per cent of sugar, while the largest yield per acre both in per cent of sugar and quantity of beets is obtained from the thickest planting-rows uarrow and beets elose together in the row. In Dakota the high price of hand labor and eheapness of land would place the limit of thick planting to that willth of row that can be easily cultirated with horse implements. That limit has been placed at 20 inches, but even 24 inches seems quite narrow for most of our single cultivators. Our planting in most cases has been made in rows thirty inches apart with the plants thinned to 8 inches apart in the row. One-half more plants can be grown witl rows 20 inches apart, and with almost a half grenter yield in pounds and a decidedly larger per cent of sngar. Onr thickest planting was made in rows 14 inches apart with plants thinned to 6 inches apart in the row. This planting produced heets smallest in size bnt uniformly richest in per cent of sngar. It is generally admitted that the saccharine richness is inversely proportioned to the rolume of the beet and that close planting gives beets of richer, better quality, of larger yield in weight and per cent of sngar, and at the same time exhansts the soil less. 
The past season's planting was done the 10th day of May by hand. The furrows were made with an ordinary hand marker to whose runners had been attached small triangular pieces of wood to deepen and widen the marks. The furrows were $1 \frac{1}{2}$ inches deep; in these the seeds were drilled with a garden seeder and covered with the hoe, the covering being well-firmed to make it hold the moisture. The porous shell encasing the seed makes an extra amount of moisture necessary to reach the real seed within and eause it to grow. In this dry climate care should be taken to put the seeds down fully an inch and a half in order to secure the moisture needed to start them. Garden seed drills when used for planting should be in the hands of skillful operators to insure satisfactory results. Hand-planting has resulted best in onr work.

Germination may be hastened by soaking the seeks in hot water for twenty-four hours just before planting. They can easily be made dry enough to plant with a machine by rolling them in plaster or dry soil.

Varieties planted.-The following is a list of the rarieties planted with the names of the firms from which the seeds were purchased and the price paid for them per pound. When planted with a drill from 6 to 10 pounds per acre will be required, the amount depending upon the distance the rows are placed apart. Imperial, Silisian and red-top were furnished by D. Landreth \& Sons, Philadelphia, at 40 cents per pound. Vilmorins imperial, Lane's improved and white sugar came. from J. C. Vaughan, Chicago, the first at 60 cents and the others at 40 cents per pound. Salzer's imperial and sweet white, John A. Salzer, of La Crosse, snpplied at 20 cents per pound.

In some instances the rarieties are the same, no doubt, with different names.

Cultivation.-Early cultivation will kill the weeds at starting and form a layer of mellow earth which constitutes an obstacle to dryness.

The loosened layer acts as a mulch and tends to keep the soil below cooler while it prevents the water from reaching the surface to be evaporated.

The crop of the past season was twice boed and four times cnltivated. The implement used for the latter was an adjustable spring-tooth cultivator. This work began soon after the plants were up and continued until the middle of July.

Thinning. - This work can best be done just after a rain. The plants should be thinned to the proper distance in the row before the roots begin to develop. Where the planting is done with a drill, a sharp hoe may be used for thinning. The entting must be deep enough to prevent any after growth of the roots cut off. In case the extra plants are pulled out, eare shonla be taken not to loosen those that remain standing and thus check their growth. If the weather is farorable at the tıme of thimning the blank places may be filled in by transplanting, 
but the roots of the latter are usually found in several divisions instead of a single talp root.

Havesting.-The crop should be pilled and stored in the root cellar or put in piles convenient for covering in the field before there is any danger of injury from freezing. In this respect they require more atbention than other root erops. A temperature low enough to freeze the surface of the ground will destroy their keeping qualities. Beets injured in this manner should be fed out at once that they may not he an entire loss. Though the injury may seem at first very slight experience has shown us that they soon become spongy, then turn black, and finally rot. The usual plan of twisting off the tops as the heets are pulled has proven in our experience the safest and most economic method. While turnips, rutabagas, and earrots are not materially injured for lieeping by having the root cut or broken, a beet so injured is apt to decay when stored.

Storing.-Sugar-beets and mangles require the same treatment in storage.

They shonld be placed in cool, moist cellars, maling the piles not to exceed 4 feet in depth. In our dry Dakota cellars it is best to cover with damp earth to keep them from wilting. This will also help to protect from freezing. The dirt must be put directly on the beets, no straw or litter of any kind interrening. In this way we have kept them in the best condition into May.

VALUE FOR STOCK-FEEDING.

For feelling, the sugar-beet and mangle are the most reliable of all the root crops. Taken as a whole they have fewer enemies and are less liable to failure than almost any other crop grown in the State.

They are less liable to disease than either rutabagas or turnips, and less easily affected by dronght. They also surpass them for feed in per cent of digestible nutrients. When the feeding value of 100 pounds of sugar-beets is 19 cents, that of 100 pounds of rutabagas is 15 and of turnips only 11 cents.

When properly stored they keep in good condition for feeding longer than any other root crop, under favorable circumstances keeping elear through the feeding season until the grass is rearly to pasture in the spring. Both the feeding and keeping qualities depend upon complete maturity. Bulk of erop is not the only thing to be sought, neither are roots of unusually large size desirable. For the most satisfactory results in feeding, seek rather the weight in many roots of medium size períectly ripened. Roots ean not be relied on to supersede either hay or grain, but by being fed with them they greatly increase the value of both. Their succulence makes them an excellent stomach regulator, preventing the constipation that frequently comes form the continmed use of dry foods. It is this quality, too, that makes them of special valne to the dairyman for lieeping up the flow of milk. They replace 
to a large degree the green sucenlent food of summer. All the stock on the furm relish sugar beets in winter. Sheep do excellently on them, and the greater part of their winter's supply of food may come from this souree. A quantity should always be kept for ewes that wean their lambs before the grass starts. It should be noted, however, that for some time before the lambs eome the ewe's ration of roots shonla be small since it is generally concerled that a full supply at this time has a tendeney to produce abortion.

Hogs kept throngli the winter for breeding purposes should hare a daily allowanee of ent or pulped beets in eonneetion with their dry food. They can thus be more economically kept, and they come through the winter healthier and in every way better prepared to farrow and raise their pigs. In all cases the roots ferl should be ent into pieces small enongh to prerent ehoking. A spade may be used for this purpose, but a root cutter is more conrenient and does the work better and much more rapidly.

The beets were analyzed the last week in Oetober. All the samples were in good condition. Samples 10, 11, and 12 were of the same variety, and were planted in different widths of rows and at different distances apart in the row. No. 11 was planted in rows 30 inches apart and thinued to 8 inches. No. 11 was thinly planted aud No. 12 was planted very thickly. From an inspection of the table which follows it will be seen that the sugar yield depends largely on the manner of planting, other things heing equal. It will also be interesting to compare the yield of sugar with the size of the beets :

[Four beets taken in each sample.]

\begin{tabular}{|c|c|c|c|c|c|c|c|c|}
\hline & & \multicolumn{7}{|c|}{ Weights. } \\
\hline & & No. 1. & No. & 2. & No. & 3. & No. 4 & 4. \\
\hline Sample & 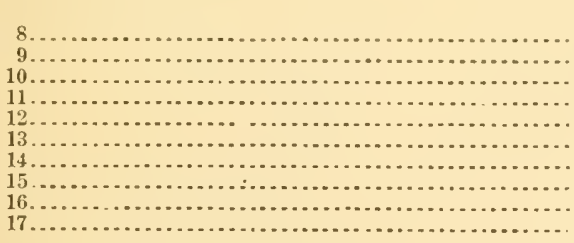 & $\begin{array}{cc}L b s . & \text { oz. } \\
0 & 12 \\
0 & 103 \\
0 & 11 \frac{1}{2} \\
2 & 13 \\
1 & 1 \frac{3}{3} \\
1 & \frac{3}{3} \\
0 & 9 \frac{1}{2} \\
1 & 2 \frac{1}{4} \\
0 & 15 \frac{1}{4} \\
0 & 13 \frac{3}{4}\end{array}$ & $\begin{array}{c}L b s . \\
1 \\
2 \\
1 \\
4 \\
1 \\
1 \\
1 \\
1 \\
2 \\
0\end{array}$ & $\begin{array}{l}0 z \\
4 \frac{3}{\frac{3}{3}} \\
4_{4}^{\frac{1}{3}} \\
13 \\
8 \frac{1}{4} \\
15 \frac{1}{2} \\
6 \\
13 \\
3 \frac{1}{4} \\
15\end{array}$ & $\begin{array}{c}L b s . \\
1 \\
2 \\
2 \\
7 \\
1 \\
3 \\
3 \\
2 \\
2 \\
2 \\
1\end{array}$ & $\begin{array}{c}o z . \\
10 \frac{3}{3} \\
10 \frac{1}{2} \\
12 \\
15_{4}^{\frac{3}{4}} \\
14 \frac{3}{3} \\
4 \frac{1}{4} \\
2 \\
7 \\
9 \frac{1}{2} \\
13_{3}^{3}\end{array}$ & $\begin{array}{c}L b s . \\
2 \\
2 \\
3 \\
15 \\
2 \\
5 \\
3 \\
4 \\
5 \\
2\end{array}$ & $\begin{array}{r}o z . \\
2 \frac{1}{2} \\
14 \frac{3}{1} \\
13 \frac{3}{3} \\
8 \frac{1}{2} \\
7 \frac{3}{4} \\
4 \frac{1}{2} \\
14 \frac{1}{2} \\
7 \frac{3}{4} \\
12 \frac{1}{4} \\
14\end{array}$ \\
\hline
\end{tabular}

In selecting samples for analysis, twelve beets of each variety were sent to the laboratory. These ranged from the smallest to the largest arerage beet which the variety afforded. At the laboratory four piles were made and from each pile an average beet was taken, thus securing a fair representation for each sample.

In obtaining the degree Brix, the pulp was placed in a canvas bag and the juice was forced out by hand. No press was available. 


\begin{tabular}{|c|c|c|c|c|c|c|c|}
\hline 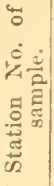 & Name. & 营 & 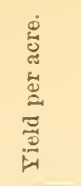 & 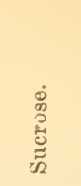 & 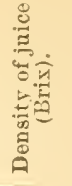 & 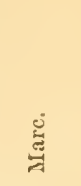 & $\begin{array}{l}\text { Condition of } \\
\text { pulp. }\end{array}$ \\
\hline $\begin{array}{r}8 \\
9 \\
10\end{array}$ & 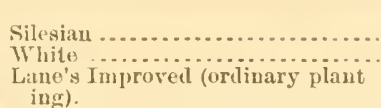 & $\begin{array}{r}\text { Per } c t . \\
75 \\
94 \\
88\end{array}$ & $\begin{array}{l}L b s . \\
23,600 \\
27,900 \\
31,200\end{array}$ & $\begin{array}{r}\text { Per ct. } \\
10.0 \\
8.2 \\
10.2\end{array}$ & $\begin{array}{l}14.2 \\
12.4 \\
15.3\end{array}$ & $\begin{array}{r}\text { Per ct. } \\
3.76 \\
3.00 \\
3.56\end{array}$ & $\begin{array}{l}\text { Dry. } \\
\text { Somewhat dry. } \\
\text { Do. }\end{array}$ \\
\hline $\begin{array}{l}11 \\
12 \\
13 \\
11 \\
15 \\
16 \\
17\end{array}$ & 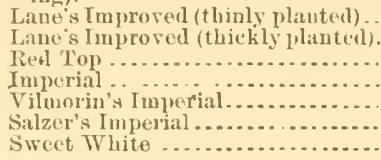 & $\begin{array}{l}50 \\
50 \\
75 \\
67 \\
75 \\
88 \\
63\end{array}$ & $\begin{array}{l}14,840 \\
16,680 \\
23,850 \\
15,320 \\
25,400 \\
29,070 \\
32,500\end{array}$ & $\begin{array}{r}5.4 \\
9.9 \\
10.2 \\
9.9 \\
12.3 \\
11.0 \\
11.2\end{array}$ & $\begin{array}{l}10.4 \\
15.2 \\
15.1 \\
14.0 \\
17.4 \\
14.6 \\
15.6\end{array}$ & $\begin{array}{l}3.12 \\
3.63 \\
3.85 \\
3.94 \\
4.10 \\
3.27 \\
3.91\end{array}$ & $\begin{array}{l}\text { Mloderately dry. } \\
\text { Dry. } \\
\text { Do. } \\
\text { Do. } \\
\text { Do. } \\
\text { Moderately dry. } \\
\text { Dry. }\end{array}$ \\
\hline
\end{tabular}

Again hope is expressed that farmers will raise small quantities of the sugar-beet. All samples delivered at the Station laboratory will be analyzed firee of charge.

Samples which had been harrested for three months were sent to the Department from Sturgis, S. Dak., in Jannary, 1889, and entered under No. 6162, a rose-colored beet, and No. 6163, a white beet. These samples were sent by WV. C. Buderus, of Sturgis, S. Dak. On examinatiou of these beets the following numbers were obtained:

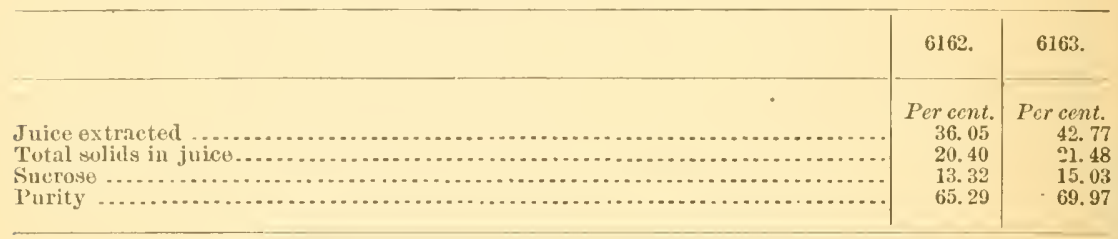

The low purity of the beets represented above was doubtless due to the fact that they had been harvested for a long time and no precautions taken to preserve them from deterioration. The analyses show that such beets could also be profitably used for sugar-making if worked up in a fresh state or preserved in proper kinds of silos.

EXPERIMENTS IN KANSAS.

Tht Medicine Lodge Sugar Company last year' (1SS9) made a series of experiments in the growth of sugar beets and the manufacture of sugar, the details of which follow:

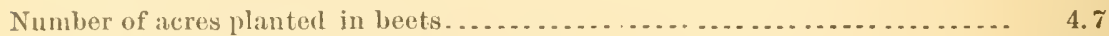

'Tons of topped aud cleaned beots produced .......................... 60.23

Ponnds of sugar mado ... . . . . . . . . . . . . . . . . . . . . . . . . . . . 10, 158

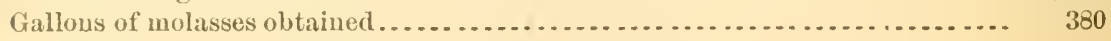

Of the total sugar made, 2,800 pounds were second sugars.

The beets dicl not receive altogether the attention which they shonld have had, and many of them grew quite a distance above gromnd. The beets were worked without any special applianees, but solely with 
the sorghum machinery which was at the factory. For this cause it is reasonable to suppose that the best mannfacturing results were not obtained. Nevertheless, the results are gratifying, and show that with such a season as last, sugar beets ean be grown in Kansas with a fair percentage of sucrose. In many eases the beets grown last year were of extraordinary size, in one instance weighing 12 pounds. By more careful preparation of the soil, and planting the beets closer together, and proper enItivation, it is reasonable to believe that a higher mean content of sugar might be obtained. The details of the analyses of the beets, by Mr. T. F. Sanborn, of this division, and the manufacture thereof are found in the following table:

Medioine Lodge, Kransas, season of 1889.-Sugar beets.

\begin{tabular}{|c|c|c|c|c|c|}
\hline & Date. & $\begin{array}{l}\text { Serial } \\
\text { No. }\end{array}$ & $\begin{array}{l}\text { Degree } \\
\text { Brix. }\end{array}$ & $\begin{array}{l}\text { Sucrose } \\
\text { in the } \\
\text { juice. }\end{array}$ & Purity. \\
\hline 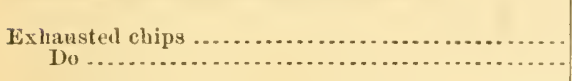 & $\begin{array}{l}\text { Nov. } 14 \\
\text { Nov. } 15\end{array}$ & $\begin{array}{l}264 \\
269\end{array}$ & $\begin{array}{l}\text { 1. } 60 \\
2.24\end{array}$ & $\begin{array}{r}\text { Per cent. } \\
.62 \\
.82\end{array}$ & $\begin{array}{l}38.75 \\
32.14\end{array}$ \\
\hline Mean... & & & 1.92 & .72 & 35.44 \\
\hline $\begin{array}{l}\text { Frosh chips } \ldots \ldots \ldots \ldots \\
\text { Do } \ldots \ldots \ldots\end{array}$ & $\begin{array}{l}\text { Nov. } 14 \\
\text { Nov. } 15\end{array}$ & $\begin{array}{l}265 \\
270\end{array}$ & $\begin{array}{l}13.74 \\
12.09\end{array}$ & $\begin{array}{l}9.00 \\
9.67\end{array}$ & $\begin{array}{l}65.50 \\
71.71\end{array}$ \\
\hline Mean... & & & 12.92 & 9.32 & 68.60 \\
\hline 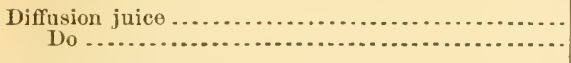 & $\begin{array}{l}\text { Nov. } 14 \\
\text { Nov. } 15\end{array}$ & $\begin{array}{l}266 \\
271\end{array}$ & 10.83 & $\begin{array}{l}7.88 \\
7.37\end{array}$ & $\begin{array}{l}72.76 \\
67.15\end{array}$ \\
\hline Mean... & & & 10.91 & 7.62 & 69.95 \\
\hline 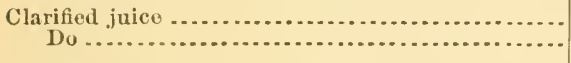 & $\begin{array}{l}\text { Nov. } 14 \\
\text { Nov. } 15\end{array}$ & $\begin{array}{l}267 \\
273\end{array}$ & $\begin{array}{l}11.64 \\
10.65\end{array}$ & $\begin{array}{l}7.77 \\
6.35\end{array}$ & $\begin{array}{l}66.58 \\
59.62\end{array}$ \\
\hline Meau.. & & & 11.14 & 7.06 & 63.10 \\
\hline $\begin{array}{c}\text { Semi-sirup .... } \\
\text { Do } \ldots . . . . .\end{array}$ & $\begin{array}{l}\text { Nov. } 14 \\
\text { Nov. } 15\end{array}$ & $\begin{array}{l}268 \\
274\end{array}$ & $\begin{array}{l}29.39 \\
25.26\end{array}$ & $\begin{array}{l}18.80 \\
18.10\end{array}$ & $\begin{array}{l}64.12 \\
71.61\end{array}$ \\
\hline Mcan... & & & 27. 29 & 18.45 & 67.87 \\
\hline $\begin{array}{r}\text { Masse cuite } \ldots \ldots \ldots \\
\text { Do }\end{array}$ & $\begin{array}{l}\text { Nov. } 16 \\
\text { Nov. } 24\end{array}$ & 22 & $\begin{array}{l}77.71 \\
85.68 \\
\end{array}$ & $\begin{array}{l}34.04 \\
49.51\end{array}$ & $\begin{array}{l}43.82 \\
57.78\end{array}$ \\
\hline Mean... & & & 81. 69 & 41.77 & 50.80 \\
\hline & $\begin{array}{l}\text { Nor. } 14 \\
\text { Nov. } 15\end{array}$ & & ........... & $\begin{array}{l}4.69 \\
5.01 \\
\end{array}$ & (n........ \\
\hline Meau. & & & & 4. 85 & \\
\hline
\end{tabular}

Sucrose.

Nov. 15. Semm from clarifiers ............................................... per cent. 5.00 Nox. 15. Scum from clarifiers, less lime ....................................................

POLARIZATION OF SUGARS.*

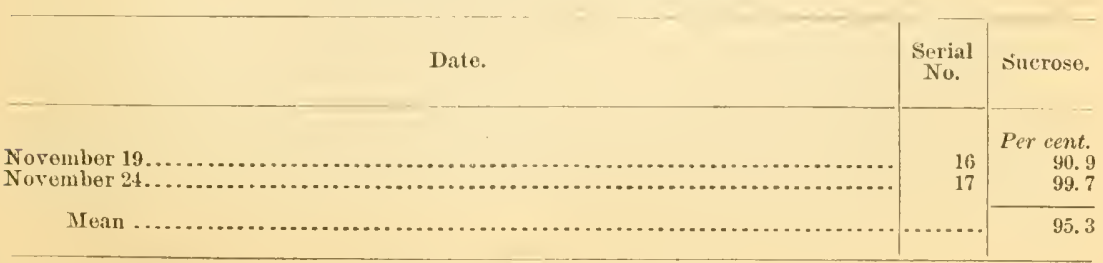


Miscellaneous sanules of beets from field.

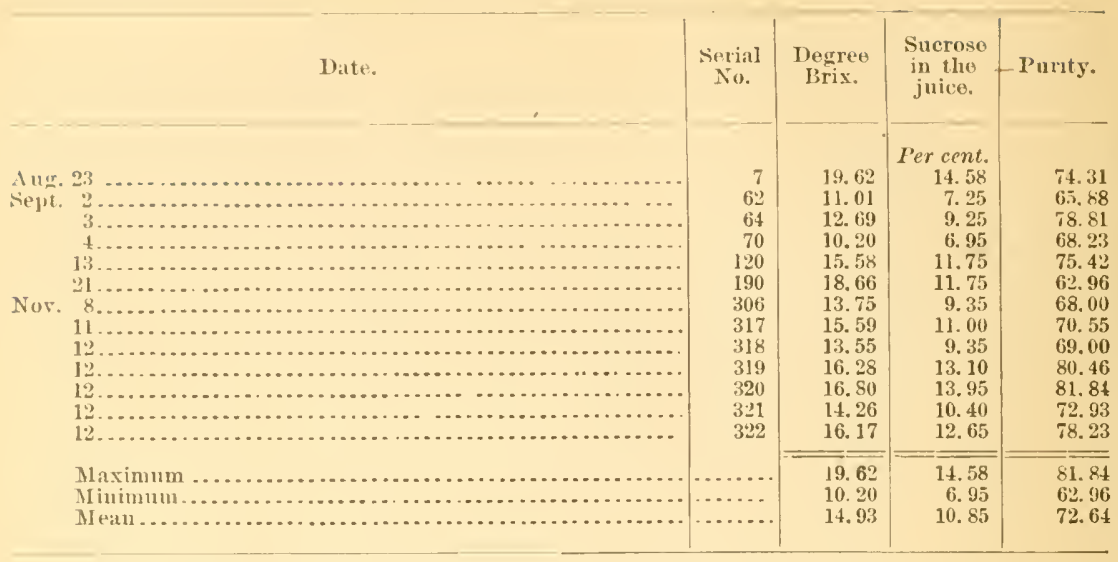

Mr. Fred Hinze cultivated an experimental plot of sugar beets at Donglass, Kans., during the season of 1SSS. Cousidering the dryness of the climate and the high temperature reached during the summer, the results appear to be farorable. I am inclined to think, howerer, that the suceessful cultiration of the sugar beet for manifacturing purposes can not be looked for in such a climate as obtains at Douglass in competition with more favorable localities.

The analyses of the sugar beets at this station were made from time to time by my assistants at Donglass who had charge of the chemical work at the sorghum factory at th at place. Following are the results of the work:

\begin{tabular}{|c|c|c|c|}
\hline Date. & $\begin{array}{c}\text { Degree } \\
\text { Brix. }\end{array}$ & $\begin{array}{l}\text { Sucrose in } \\
\text { the juice. }\end{array}$ & $\begin{array}{l}\text { Coefficient } \\
\text { of purity. }\end{array}$ \\
\hline 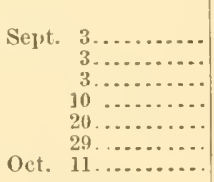 & $\begin{array}{l}13.58 \\
11.67 \\
12.45 \\
16.74 \\
14.70 \\
14.43 \\
15.95\end{array}$ & $\begin{array}{r}\text { Per cent. } \\
9.27 \\
7.96 \\
8.16 \\
12.38 \\
9.47 \\
10.47 \\
11.98\end{array}$ & $\begin{array}{l}67.64 \\
68.30 \\
65.46 \\
73.96 \\
61.42 \\
72.69 \\
75.11\end{array}$ \\
\hline $\begin{array}{l}\text { Highest........ } \\
\text { Lowest ..... } \\
\text { A rerage .... .. }\end{array}$ & $\begin{array}{l}\text { 16. } 74 \\
11.07 \\
14.22\end{array}$ & $\begin{array}{r}12.38 \\
7.96 \\
9.36\end{array}$ & $\begin{array}{l}75.11 \\
64.42 \\
69.65\end{array}$ \\
\hline
\end{tabular}

\section{EXPERIMENTS IN CALIFORNIA.*}

The Alrarado, Cal, beet-sugar factory is situated on the east side of the bay, 24 miles from San Francisco.

The climate of Alrarado is a peculiar one, and, as experience has shown, very suitable to the derelopment of a first-elass sugar beet.

The winters are milk. Planting begins in February and can be contimed up to the midnle of May. The early planting matures in the 


\section{3}

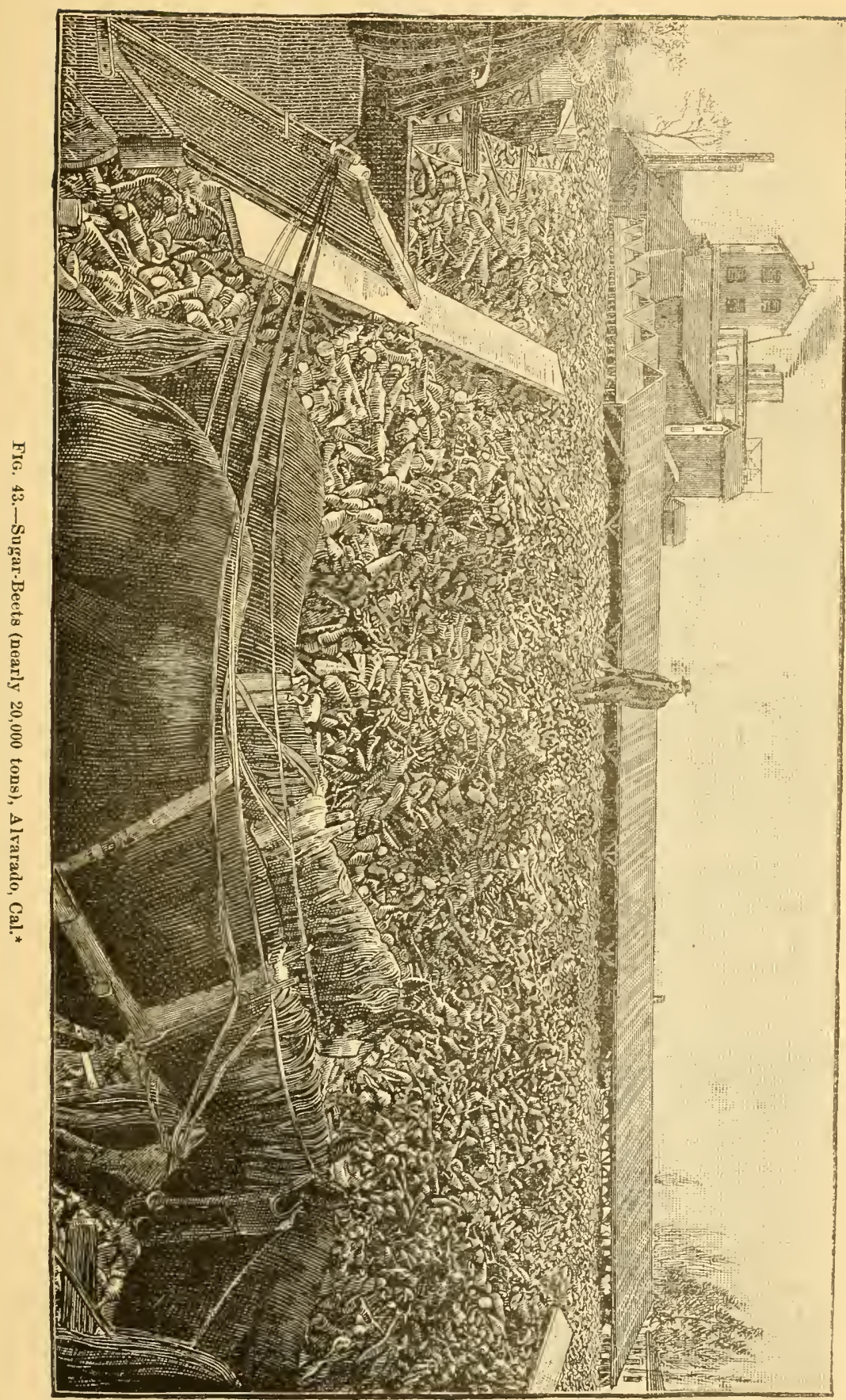

* From Sugar Industry of the United States, p. 77, Bulletin No, 5, Chemical Division, U.S. Depart. ment of Agriculture. 25474-Bull, $27-13$ 
sunmer and the fitetory can be started by the middle of August. From this time until December there is a consecutive maturity of beets. The snmmers and falls are dry, and there is little danger of the beets taking a second growth by reason of early rains.

When harvested the beets do not require to be siloed, but are kept in heaps either with no covering at all or at most a little straw.

In the midlle of December, 18st, the company had nearly 20,000 tons of beets on hand.

In Fig. 43 is seen this immense pile of beets, covering over 2 acres of surface and of $S$ feet mean depth.

The land on which these beets are grown is level, the soil sandy and fertile, stretching from the bay eastward to the hills, a breadth of from 5 to 10 miles.

The following tables, prepared at my request by Mr. W. Dyer, super. intendent of factory, exhibit the data collected from twelve different fields, representing a fair average of all the land in cultivation for beets in 1884 .

The analyses represent a fair sample of beets taken from all the wagons during each day the beets were brought to the factory. The kind of seed used is also indicated in the tables.

Formerly all the seed planted was imported, but the company is now raising its own seed, and with the most encouraging results.

The expression "first and second year" indicates that the seed was native and one or two years from the imported seed.

In all the analyses made at Alvarado the sucrose is calculated on the weight of the beet and not of the juice.

FIEI,D OF JOHN LOWRIE.

\begin{tabular}{|c|c|c|c|c|c|c|}
\hline Date. & Kind of seod used. & 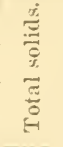 & 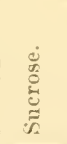 & $\begin{array}{l}\dot{\mathscr{D}} \\
\stackrel{\Xi}{0} \\
\dot{0} \\
\dot{a} \\
\stackrel{0}{0}\end{array}$ & 苞 & kemarks. \\
\hline 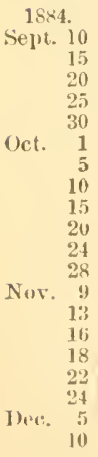 & 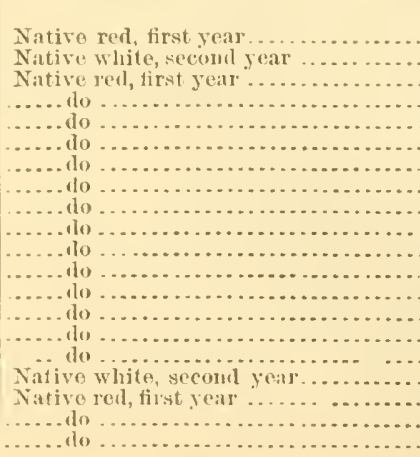 & $\begin{array}{l}12 . c t . \\
15.9 \\
16.9 \\
17.3 \\
17.9 \\
17.2 \\
18.5 \\
17.7 \\
17.8 \\
17 . \\
16.6 \\
13.7 \\
17.4 \\
16.5 \\
11.8 \\
11.5 \\
13 . \\
17 . \\
16.2 \\
1.5 .4 \\
15.6\end{array}$ & $\begin{array}{l}P . c t, \\
13.4 \\
13.9 \\
14.9 \\
15.6 \\
15.1 \\
15.7 \\
14.7 \\
15.5 \\
14.4 \\
14 . \\
12.6 \\
14.3 \\
13.5 \\
11.5 \\
12.5 \\
10.4 \\
14.9 \\
13.7 \\
13.2 \\
13.2\end{array}$ & $\begin{array}{c}1 . c t . \\
2.5 \\
3 . \\
2.4 \\
2.3 \\
2.1 \\
2.1 \\
3 . \\
2.3 \\
2.6 \\
2.6 \\
3.1 \\
3.1 \\
3 . \\
3.3 \\
3 . \\
3.6 \\
2.4 \\
2.5 \\
2.2 \\
2.4\end{array}$ & $\begin{array}{l}1 . \text { ct. } \\
81.2 \\
83.2 \\
86.1 \\
85.7 \\
87.7 \\
84.8 \\
83 . \\
87.6 \\
84.7 \\
84 . \\
80 . \\
82.1 \\
81.2 \\
77.1 \\
86.2 \\
80 . \\
87.1 \\
84.5 \\
85.7 \\
84.4\end{array}$ & $\begin{array}{l}\text { L'lanted } 315 \text { acres; not all } \\
\text { harrested yet; will arer- } \\
\text { age between } 15 \text { to } 20 \text { tons } \\
\text { per acre. }\end{array}$ \\
\hline
\end{tabular}


FIELI) (IH T. AZEVAI)

\begin{tabular}{|c|c|c|c|c|c|c|}
\hline Date. & Kind of seed used. & 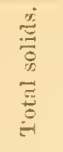 & $\begin{array}{l}\stackrel{0}{0} \\
\stackrel{0}{0} \\
\stackrel{0}{\pi}\end{array}$ & 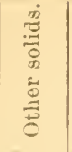 & 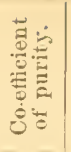 & Remarks. \\
\hline $\begin{array}{rr}1884 . \\
\text { Nov. } & 5 \\
6 \\
9 \\
13 \\
13\end{array}$ & $\begin{array}{l}\text { Native white, sceond year............ } \\
\text { Native red, tirst y eal ................ } \\
\text { Native white, second year ............. }\end{array}$ & $\begin{array}{l}P . c t . \\
17 . \\
16.2 \\
16.8 \\
17.4\end{array}$ & $\begin{array}{l}1 . c t . \\
14 . \\
13.2 \\
14.3 \\
1.5 .4\end{array}$ & $\begin{array}{l}\text { P.ct. } \\
3 . \\
2.4 \\
2.3 \\
2 .\end{array}$ & $\begin{array}{l}l \cdot 1 t . \\
82.9 \\
85.1 \\
-6.3 \\
88.5\end{array}$ & $\begin{array}{l}\text { Planted } 10 \text { acres; had } 152.8 \\
\text { tons; yield per atre, } 15.3 \\
\text { tons. }\end{array}$ \\
\hline
\end{tabular}

FIELD OF JAMES NARCISSO

\begin{tabular}{|c|c|c|c|c|c|c|}
\hline Oeí. & 23 & Native white, second year. . . . . . . . . . . & 16.1 & 13.1 & 3. & 81.3 \\
\hline Now. & 5 & .....do & 16.5 & 13.6 & 2.9 & 82.4 \\
\hline & 7 & 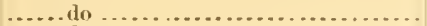 & 15. 2 & 13. & 2.2 & 85.1 \\
\hline & 13 & 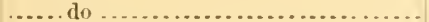 & 15.2 & ]2. 3 & 2.9 & 80.9 \\
\hline & 26 & 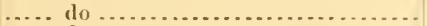 & 16.9 & 13.5 & 3.4 & 79.8 \\
\hline & 23 & 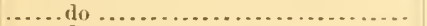 & 17.1 & 14.3 & 3.8 & 83. 6 \\
\hline & 24 & .....do.......... & 15,6 & 12.8 & 2. & $8: 2$ \\
\hline
\end{tabular}

Planted 10 acres; had 237 toms; yielt per acre, 23.7 tons.

FIELD OE J. G. TANDEIEER.

\begin{tabular}{|c|c|c|c|c|c|c|}
\hline \multirow[t]{2}{*}{ Out. } & 21 & Native white, second year ... & 16.8 & 13.9 & 3.1 & 82.7 \\
\hline & 24 & 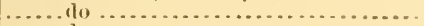 & 17.9 & 15. & 2.9 & 83.2 \\
\hline \multirow[t]{10}{*}{ Nov. } & I & 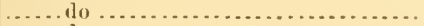 & 15.6 & 13.5 & 2. 1 & $8(3.5$ \\
\hline & 3 & . . . . do ........................... & 17.8 & 15. 1 & 2.7 & 844 \\
\hline & 4 & 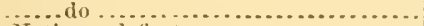 & 15.2 & 12.5 & 2. 7 & 82.2 \\
\hline & fi & Native red, first year ..... . & 14.3 & 12. & 2.3 & 83.9 \\
\hline & 7 & $\ldots \ldots d 0 \ldots \ldots . . . . . . . . .$. & 14. 2 & 12. & 2.2 & 81. \\
\hline & I3 & Native: white, second sear - & 17. 2 & 14.3 & 2.9 & 83.1 \\
\hline & 15 & Native red, first year....... & 14.2 & 12. & 3. 2 & 84.5 \\
\hline & 17 & Native white, second year ... & 18. & 16.1 & 2.4 & 87.5 \\
\hline & 24 & 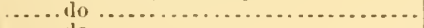 & 17. & 14. & 3.1 & 82.3 \\
\hline & 26 & ...... do .................... & 16.3 & 11. & 2. 3 & 85. 9 \\
\hline
\end{tabular}

l'lanted 20 ac'res; had 360 stons; yickl per acre, 18 tons.

FIELD OF FLANK MUNYAR.

Nov.

\begin{tabular}{|c|c|c|c|c|}
\hline 1 & Native white, secoud yeur .......... & 16. 2 & 13.9 & 2.3 \\
\hline 6 & 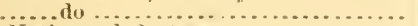 & 15.6 & 13. & 2. \\
\hline ! & Natire red, lirst year ........ & 16.8 & 14. & 2.8 \\
\hline 11 & 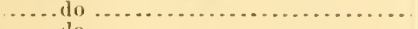 & 16.9 & 14. 2 & 27 \\
\hline & 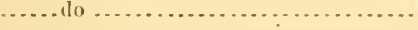 & 15. 2 & 12. 6 & 2. \\
\hline
\end{tabular}

FIELI OF M. B.IN
Planted 12 acres; had 246 tons: yield per aere, 20.5 tons.

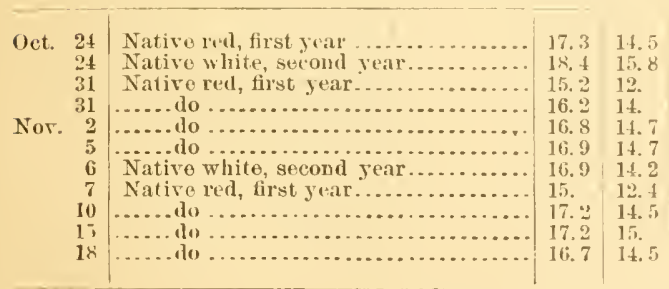

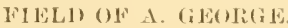

\begin{tabular}{l|l|} 
15. & $1:$ \\
14.6 & 12.1 \\
14.5 & 11.5 \\
14.6 & 12. \\
16.1 & 11. \\
16.7 & 13.1
\end{tabular}

\begin{tabular}{l|l|}
2.8 & 83. \\
2.6 & 85.9 \\
3.2 & 78.9 \\
2.2 & 86.4 \\
2.1 & 86.3 \\
2.2 & 86. \\
2.7 & 83.7 \\
2.6 & 83. \\
2.7 & 84.3 \\
2.2 & 17.2 \\
2.2 & 86.8
\end{tabular}

l'lanted If acres; had 414 tons; yiclel per acre, 23 tors. ()ot. 3

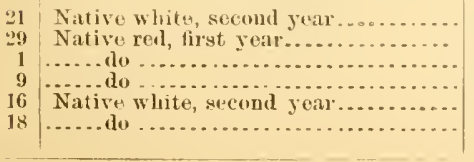

3. 279.

$2.5 \quad 82.8$ 3. $\quad 79.3$ 2. $9 \quad 83.1$ 2. 186,9 \begin{tabular}{l|l}
\hline 3.6 & 78.4
\end{tabular} l'lauted 10 acres ; had 1538 tons ; yield per acro, 15.3 tolls. 
FIELI) OF' 1 . 1'. MACII IJ).

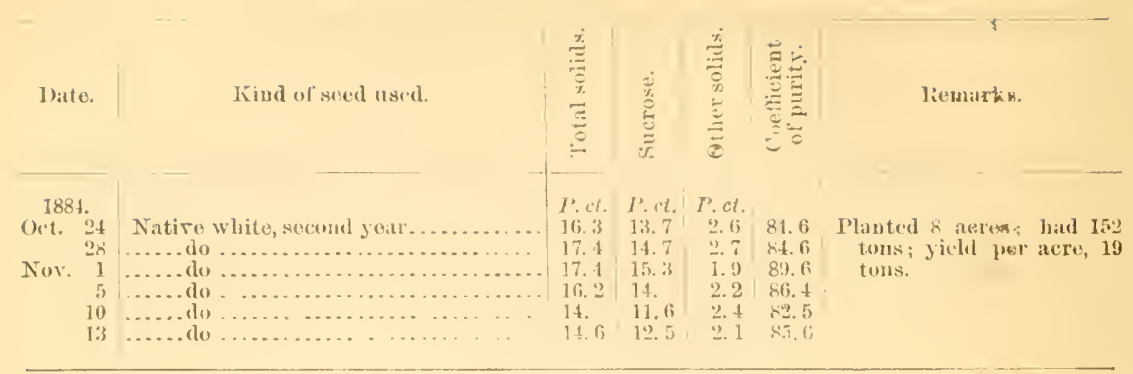

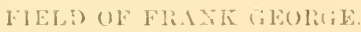

\begin{tabular}{|c|c|c|c|c|c|c|c|}
\hline \multirow{2}{*}{ Oet. } & 21 & Importril white lmperial & 18.3 & 15.5 & 2.8 & 84.7 & \multirow{5}{*}{ 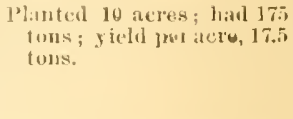 } \\
\hline & 23 & 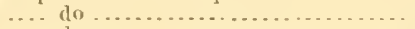 & Iti. 8 & 13. & 3.8 & $\pi ; . ;$ & \\
\hline Nov. & 2 & 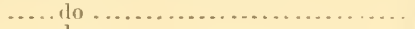 & 16.2 & 12.9 & 3.3 & 79.6 & \\
\hline & 5 & 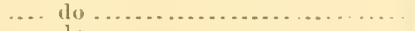 & 15.9 & 13. & 2.9 & 81.6 & \\
\hline & 10 & $\ldots d_{19} \ldots \ldots \ldots \ldots \ldots \ldots \ldots \ldots \ldots$ & 15.5 & 13. & 25 & 8i3. 8 & \\
\hline
\end{tabular}

F1ELI) () A GASI'ER.

Oet, 21 Imported whito Imperial ........... 16.6 1:3.

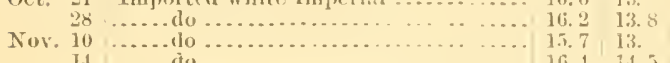
It $\ldots \ldots$ do ........................
3.678 .3 J'lantoul 7 aceres; had 105

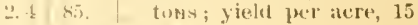
3 8.2. 7 tous.

FIELD OE JAMES FIREIRA.

\begin{tabular}{|c|c|c|c|c|c|c|}
\hline (x)t. & 24 & $\begin{array}{l}\text { Imporlet whik: from Fred. Kuaner } \\
\text { Gernany. }\end{array}$ & 15. 3 & 12.5 & 3 & 89.1 \\
\hline & 24 & ... do .................... & 15.2 & 11.5 & $\because 7$ & 75.5 \\
\hline Nos: & 4 & ..... (do & 16.4 & 12.8 & 3 & is \\
\hline & 11 & ...... do & 1 i. 6 & $1: 3$ & $\because .1$ & 811.1 \\
\hline & 13 & $\ldots . .$. d & 16.5 & $1: 3.3$ & $\therefore 2$ & 801. 6 \\
\hline & 19 & $\ldots \ldots$, $\ldots \ldots \ldots \ldots$ & 14. 2 & 111.2 & $t$ & 91.8 \\
\hline & 20 & 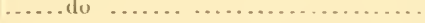 & 13.7 & 9.1 & t. $x^{\circ}$ & $66 .+$ \\
\hline
\end{tabular}

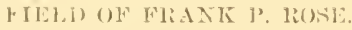

Plutuled 5 arres ; hatl 130 tous: yruld per aere, 26 . tors.

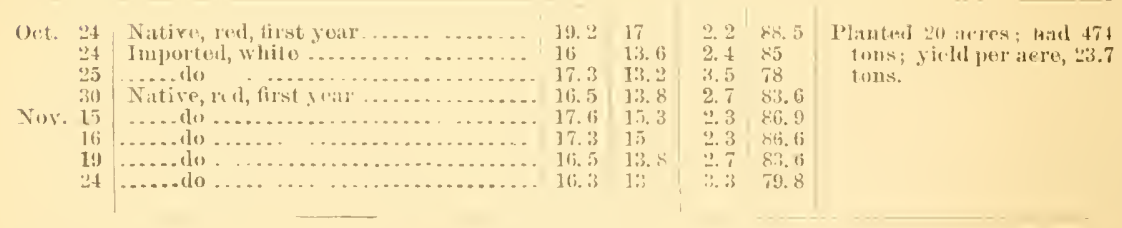


TALBES OA. WORK AT FACTORY FOR LARII WERK FROM SEPTEMBER 16 TO NOVEMIBET: 11.

Mir. E. F. Dyer also kindly furnisher me with the following data illustrating the workings of the factory in detail for nine eonsecutive weeks.

These tables contain a large amount of most practical information as well as valuable scientific data.

FXPLANATION OF TABLES.

The analyses were malle daily, and these are given as well as the mean for the week. The column hearled "Diffusions" gives the number of diffusion cells filled each day. The degree Brix represents the per cent. total solids in the juice. The polarization gives the percentage of sucrose in the juice. This subtracterl from the total solids gives the differenee or solids not suerose.

The percentage of snerose divided by the pereentage of total solids gives the "quotient" or eo-efficient of purity.

The colsmns under "Filtration" show the density and alkalinity of the juice and semi-sirup as they come from the filter presses.

The loss of sugar in the pulps and waste waters is also given.

The percentage of lime carbonate in the animal elareoal when it is taken out for washing and reburning is also given. Last of all are the analyses of the melada as it comes from the strike pan on its way to the centrifugal. The summary gives the tons of beets worked per week and the yield of pure grannlated sugar in percentages of the beets worked. 


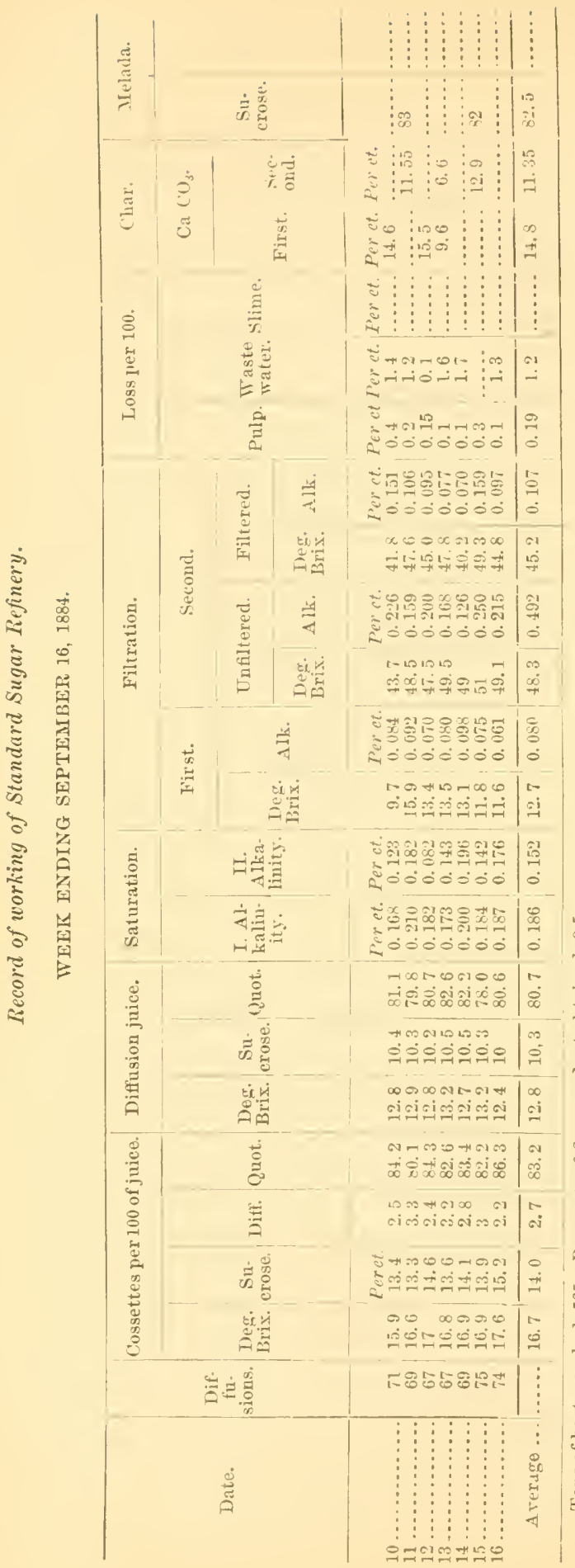

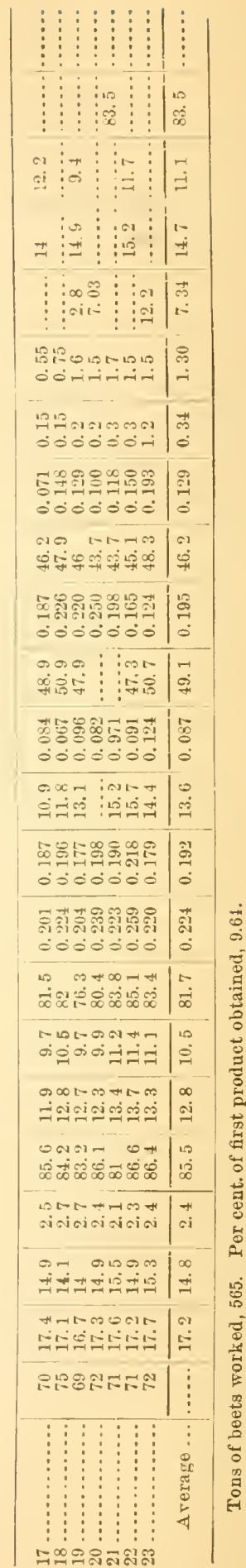




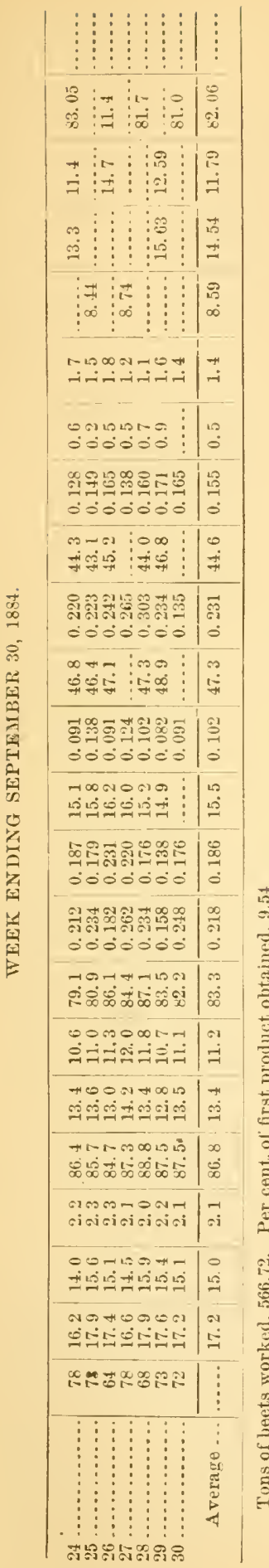

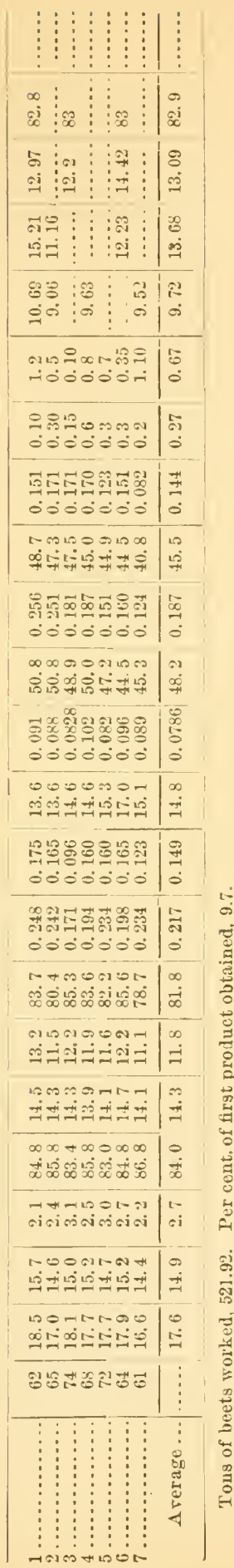

\begin{tabular}{|c|c|}
\hline 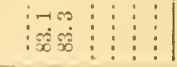 & \begin{tabular}{l}
$\infty 1$ \\
\hdashline 8
\end{tabular} \\
\hline 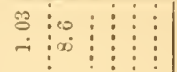 & $\begin{array}{l}\vec{\infty} \\
+ \\
+\end{array}$ \\
\hline 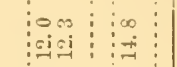 & 然 \\
\hline $\begin{array}{c}0 \\
\vdots \\
\infty\end{array}$ & $\begin{array}{l}8 \\
0 \\
0\end{array}$ \\
\hline 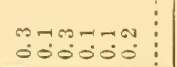 & $\stackrel{\infty}{\infty}$ \\
\hline 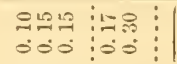 & $\stackrel{5}{\circ}$ \\
\hline 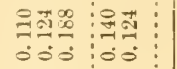 & 㟢 \\
\hline 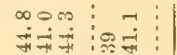 & 定 \\
\hline 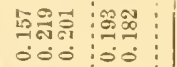 & $\mid \begin{array}{c}\stackrel{9}{9} \\
\\
0\end{array}$ \\
\hline 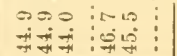 & 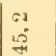 \\
\hline 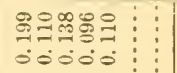 & 虹 \\
\hline 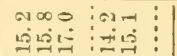 & 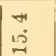 \\
\hline 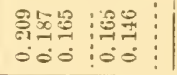 & $\mid \begin{array}{l}\overrightarrow{2} \\
\stackrel{2}{0}\end{array}$ \\
\hline 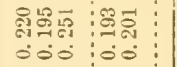 & 量 \\
\hline 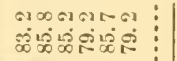 & 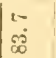 \\
\hline 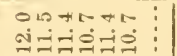 & $\stackrel{\infty}{=}$ \\
\hline 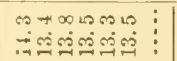 & in \\
\hline 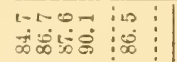 & $\mid \begin{array}{l}10 \\
0 \\
0\end{array}$ \\
\hline 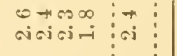 & an \\
\hline 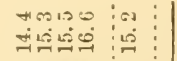 & is \\
\hline 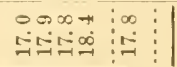 & $\mid \begin{array}{l}\infty \\
\stackrel{1}{\sim}\end{array}$ \\
\hline 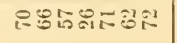 & $\vdots$ \\
\hline 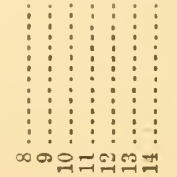 & 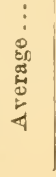 \\
\hline
\end{tabular}




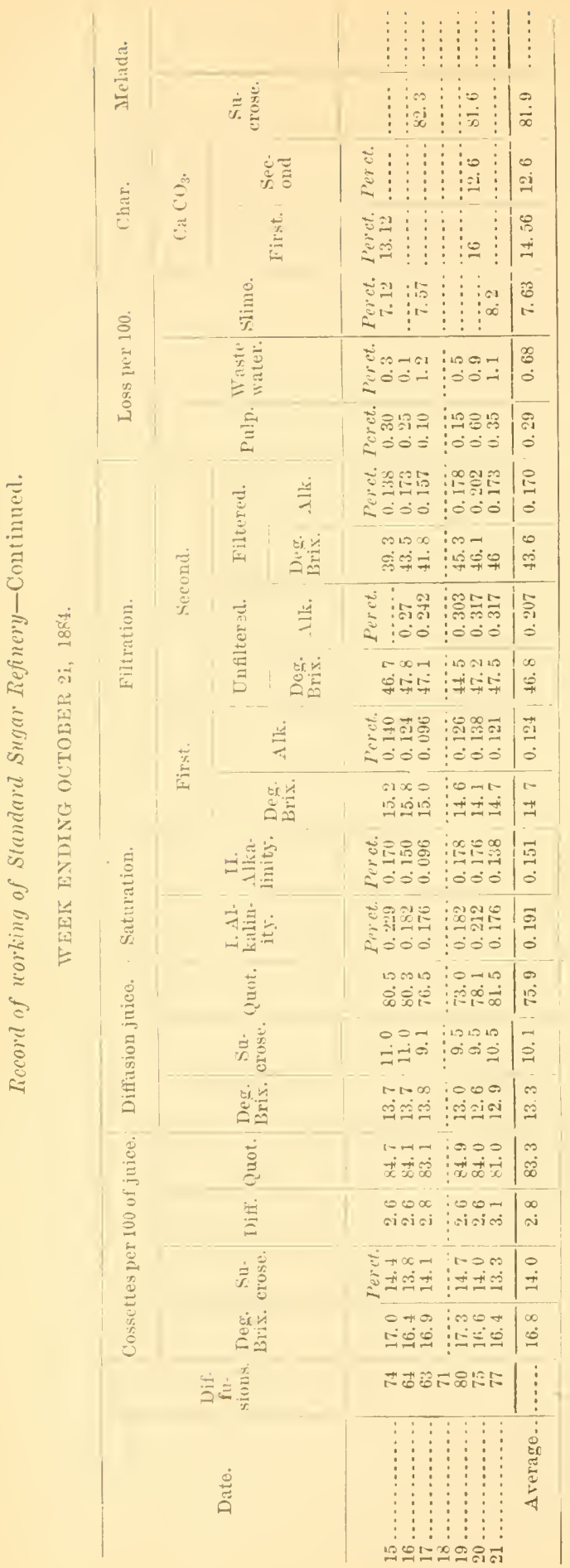

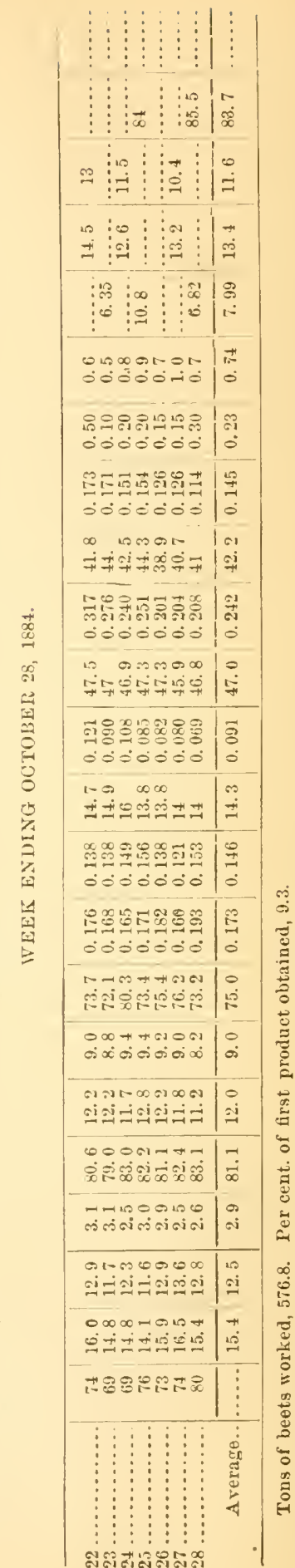




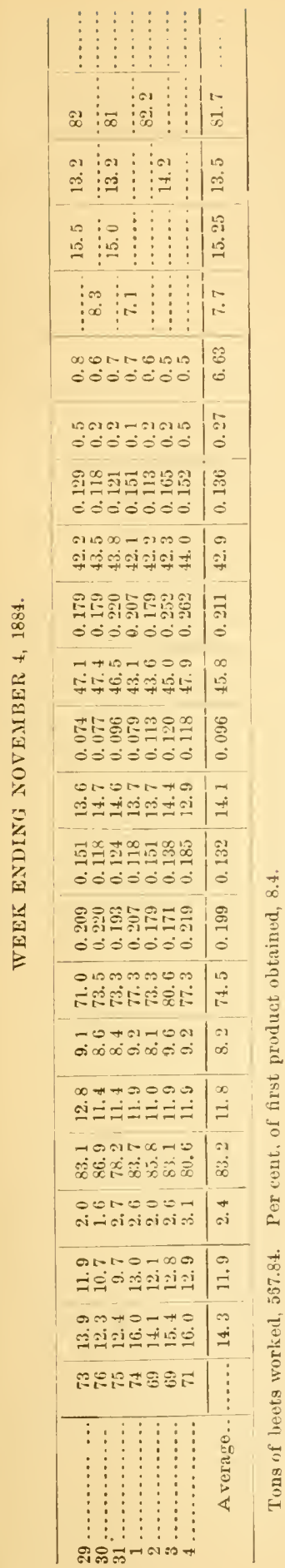

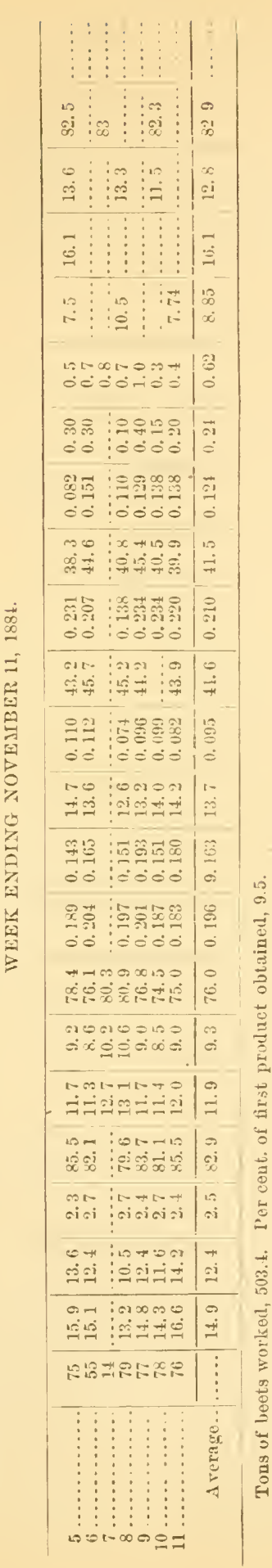


In orler to render the results of the analyses made by Mr. E. H. Dyer more emphatic, I selected ten samples of beets, some from wagons as they were unloading, and some from the large pile of beets on hand, and sent them to Washington for examination.

The resnlts of the analyses of these beets are given in the following table:

Analyses of California beets.

\begin{tabular}{|c|c|c|c|c|c|c|c|c|c|c|c|c|}
\hline Variots. & 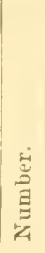 & 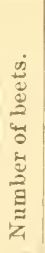 & 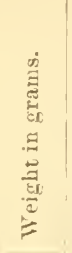 & 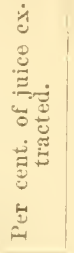 & 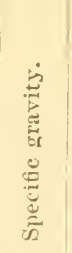 & 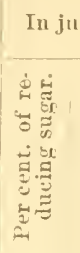 & 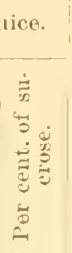 & 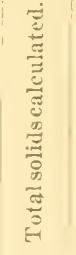 & 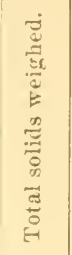 & 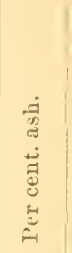 & 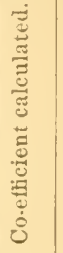 & 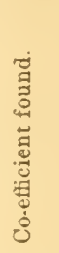 \\
\hline 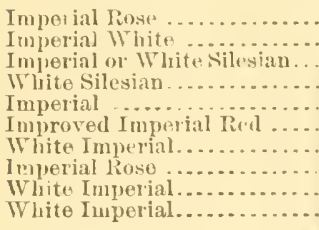 & $\begin{array}{r}1 \\
2 \\
3 \\
4 \\
5 \\
6 \\
7 \\
8 \\
9 \\
10\end{array}$ & \begin{tabular}{l|}
8 \\
7 \\
7 \\
8 \\
8 \\
6 \\
6 \\
6 \\
7 \\
6 \\
8
\end{tabular} & $\begin{array}{l}4,237 \\
4,350 \\
4,565 \\
3,555 \\
3,902 \\
3,490 \\
3,285 \\
3,585 \\
3,253 \\
3,530\end{array}$ & $\begin{array}{l}51.80 \\
65.61 \\
59.08 \\
58.41 \\
64.13 \\
65.07 \\
62.34 \\
66.63 \\
62.68 \\
58.06\end{array}$ & $\begin{array}{l}1.071 \\
1.068 \\
1.070 \\
1.071 \\
1.063 \\
1.069 \\
1.075 \\
1.063 \\
1.062 \\
1.067\end{array}$ & $\begin{array}{l}.190 \\
.081 \\
.082 \\
.057 \\
.069 \\
.061 \\
.129 \\
.075 \\
.109 \\
.050\end{array}$ & $\begin{array}{l}14.46 \\
13.59 \\
14.69 \\
15.85 \\
14.92 \\
13.59 \\
15.19 \\
13.65 \\
12.71 \\
15.19\end{array}$ & $\begin{array}{l}17.23 \\
16.53 \\
17.01 \\
17.92 \\
15.39 \\
16.77 \\
18.14 \\
15.39 \\
15.16 \\
16.30\end{array}$ & \begin{tabular}{|l|}
17.41 \\
16.23 \\
17.13 \\
18.29 \\
17.40 \\
17.60 \\
18.40 \\
15.62 \\
15.29 \\
18.58
\end{tabular} & $\begin{array}{r}1.136 \\
.930 \\
1.134 \\
.822 \\
.814 \\
.956 \\
1.009 \\
1.233 \\
.928 \\
.950\end{array}$ & $\begin{array}{l}83.9 \\
83.2 \\
86.4 \\
88.5 \\
96.9 \\
81.0 \\
83.7 \\
88.7 \\
83.8 \\
93.2\end{array}$ & $\begin{array}{l}83.1 \\
83.7 \\
85.8 \\
86.7 \\
85.7 \\
77.2 \\
82.6 \\
87.3 \\
83.1 \\
82.1\end{array}$ \\
\hline $\mathrm{N}$ & & & 3,675 & 61.38 & & .91 & 14.38 & 16.58 & 17.20 & .994 & 9 & 7 \\
\hline
\end{tabular}

REMarKs.-No. 1, Imperial Rose; in sheds from October 15 to Normber 20. No. 2, Imperial White; natice seed. two years; wagon. No. 3, Imperial or White Silesian: in sheds from October 15. No.t, White silesian ; native seed, two years: wagon. No. 5, Imperial; native seed, ono yoar. No. 6, In. proved lmperial Red; native seed, one ferar; wagon. No. 7 , White Imprerial; native sced, two years; wagon. No. 8. Imperial Rose : native seed, one year; wagon. No. 9, White Imperial; native soed, two yoars; wagon. No. 10, White Imperial; wagon.

\section{REIIARKS ON PRECEDING TABLES.}

The richness of the beets worked during the nine weeks is fully equal to the average European standard.

Thirteen per cent. of sucrose indieates a kind of beet that can be suc. cessfully mamufactured.

The yield of pure granulated sugar, designated as "first product," is for the nime weeks nearly 9.5 per cent., or 190 pounds of sugar per tou of beets. This large yield is obtained by remelting the second sugars and working the solution with the fresh juices. This method gives a maximum of "first proluet," no second produet at all, and searcely any in sugar of "thirds," or molasses. Indeed the quantity of molasses made by the Alvaralo factory is quite insignificant.

Placing the yield in beets per acre at 15 tons, the lowest arerage, it is found that the total yield of sugar per acre is $190 \times 15=2,850$ pounds. The actual yield, however, in all except a few poorly cultivated fields, has been nearly 4,000 ponnds, or 2 tous per acre.

Later in the season, i. e., during late winter and early spring, the content of suerose in the beets will slowly deerease, and by May 1 it is 
expecter that it will be so low that the further manufacture of sugar will not be protitable. But even by that time the company will have still several thonsand tons of beets on hand, on which it now seems probable they will suffer financial loss.

This excess of heets came abont in this way: In former seasons the difficulty has been to get the farmers interested in beet laising to grow enongh to sesure a liberal supply. The company, therefore, harl uracel farmers to plant, and agreed to take all the beets offered at a stipnlated price.

During the eampaign of $1853-3 \pm$ the farmers elearly saw that beetraising was far more profitable than the culture of wheat or ay of the usual crops. They therefore gare much more land and labor to beetculture for the campaign of 1S51-55 than they had ever done before. The result has already been stated.

In a letter dated January 31, 1855, Mr. Dyer says:

Our total receipts of beets this campaign were 20,358 tous ( 2,000 lbs.). The total amount of refined sugar manufactured aud sold this campaign to date is $1,819,266$ ponnils.

Under date of Mareh 9, 1SS5, he writes:

We have beets to last throngh April. They keep well, anil still show a co-efficient of purity of over 75 .

If the yield continues, as expecterl, through April, the total ontput of refined sugar will exeeed $3,000,000$ pounds.

The sturly of the preceding tables is a most encouraging one for the farmers. These soils are easily cultivatel. In no case was any fertilizer employed, and yet the yiekl and quality of the roots are fully up to the standarl of the forced and expensive enltivation of Germany.

Although the price of labor in California is so moch greater than in Germany, I doubt rery much whether the cost of the beets per ton is greater. The largest item of expense to the beet farmer in these valless of the coast range is rent. As mueh as $\$ 20$ per acre is paid anmully for beet lands.

Lands of equal fertility and adaptation for beets farther from San Francisco could doubtless be obtained on better terms.

\section{YIELD PER ACRE.}

The large differences in yield per aere shown in the preceding tables are not so much due to variatiou in the fertility of the soil as to methods of cultivation.

The experience of six years has shown that the average yield of beets per acre has steadily increased, and this increase has been ane to improved agriculture aloue.

At first the farmers (the eompany does not grow beets) were largely ignorant of the correst method of beet enlture, and as this ignorance disappears the results are seen in an increase of the crops. 
The faretory at Alamela has lately been reorganized and supplied with new mashinery. It is now linown as the Alameda Sugar Company, and its operaions (lnring the past season are given in a letter from the presirlent of the company publisherl in another place.

[From the Rura] Californian, October, 1889.]

RUGAR-BEET CULTURE IN SOUTILRN CAIIFORNIA.-TIF NADEAU FXPERIMENT. THE CHINO AND SANTA ANA BEETS,-CLIMTIC CONDITIUNS.-VILMORIN ON TIE SUGAR IBEET, -ARE WE TO HAVE SIGAR FACTORILS?

"The eulture of the sugar beet in southern California has been in fits and starts, lather than a stearly undertaking like the growing of other crops. That the beet will do well in our soil and elimate has long since been demonstrated, ant its sugar-bearing qualities being above those of the European growth, has always male its extensive propagation desirable, and a very interesting subject from a commercial point of view. The principal objection to its extensive cultivation has been the want of a market to enable the grower to rispose of lis product at a remunerative price. This can only be created by the investment of capital in buildings and machinery to convert the raw material into merehantable sugar. Owing to this difieulty our farmers have not taken the actire nterest in the sugar beet that they undoubtedly would if they had the assurance of a good market. On the other hand, eapital has also been shy in seeking investments in sugar factories, not knowing for a certainty that a suffieient fuantity of beets would be grown in convenient proximity to the factory, or within easy aceess by rail, to warrant the construction of immense buildiugs and machinery for this purpose. The experiments that have been malle are for the most part very satisfactory, and elearly show that by proper enltivation, and planting only the best varieties, our soil and elimate will yield a beet giving a large per cent. of saceharine matter. Wrhen once demonstraterl that a large area of onr land is allapted to the sugar beet, and onr farmers will take a live interest in its culture, eapital will be found realy to invest in the necessary buildings and machinery for purposes of refining.

"In this connection it will be of interest to refer to the experience of the late Mr.Nadean. In 1880 he planted about 700 acres to sugar beets, with the intention, if we recollect correctly, of erecting a factory of his own to convert them into sugar. lise this as it may, he did raise an immense quantity, which on analysis demonstrated that in sugar-producing qualities they were up to if not above the standarl of beets grown in Germany and France. The following correspondence gives the ro. sults of two analyses, one by Prolessor Elilgard, of the State University, and the other by Mr. Kulburg, ehemist of the Standart Sugar Company, Alvaralo :

Alvakado, CaL., November 1, 1886.

DEAR SIR: 'The 20 th day of September' we received ahout 50 toms of dried beets from Mr. R. Nadean, of Los Angeles, to be manufactured into sugar. As we were rumning on our own beets at the time we conld not stop to work the whole 50 tons, but manu- 
factured about 8 tous into a fair quality of sugar, sufficient to thoroughly test the feasibility of making sugir from sun-dried beets.

Mr. Nadean sent us at the time some green beets. By polarization they gave about the samo resnlt as the dried beets. We mado two polarizations with the following results, both taken from two ditferent fields:

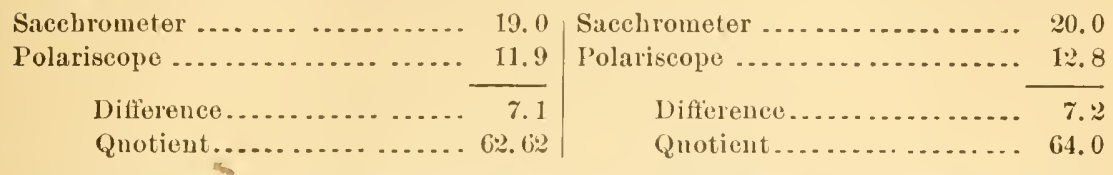

These beets were worked and the polarizations were male by Mr. Wm. Kulburg, who has charge of the teclunical department of onr sugar works, and who has had experienco in working dried beets in Enrope.

* * * We havo proeured from Mr. Nadeau samples of his fresh beets, as well as those dried by him, and take the liberty to forward the same to yon to enablo you to make a further test from reliable samples. The samples of beets are somewhat wilted and dried in consequence of having been so long in reaching this place, consequently will polarize nore than if taken fresh from the ground. I give the result of Mr. Kulburg's polarization, carefully made by lim, October 30,1880 :

Saceharine........ 16.5 Sacelıarine....... $18.5 \mid$ Saceharine....... 17.0 Polariscope ....... . 11.5 Polariscope ........ 13.6 Polariscope ....... 13.2

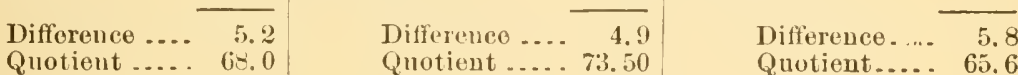

Hoping you will fivor us with au early reply, wo remain, Respectfully yours,

Standaru Sugal Manufacturing Company, By E. H. DYER,

E. W. HILGARD, General Superintendent.

Professor of Agriculture, State University, Berkeley.

University of California, College of Agriculture, Berlieley, November 6, 1880.

Dear SIr: Yours of tho 1st inst., with packages of fresh and dried beets, duly received.

The dried beets are $110 \mathrm{w}$ in process of analysis. The fresh beots were polarized immediately after receipt. The results agree substautially with those obtained by Mr. Kulburg, viz. :

Saccharine.

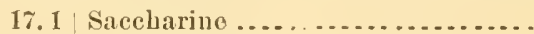

17. 2

Polarization

12. Polarization...................

Purity co-efficient ...............

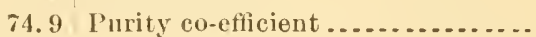

71. 5

Except in a bigher furity co-efficient as an avorage, but that can easily happen. Except as to the same point, your polarization of beets takeu from two fields as given on page 2 of your letter, also agrees; that is, all sbow a sugar prercentage above 12 , averaging about $42.5 \mathrm{in}$ the juico. Now, since tho juice constitutes about 95 per cent. of the fresh beet, this wonld correspond to a litte less than 1: per cent. of sugar in the green beet; and this, at the rate of four to oue, accepted by you, would nake up about $4 \triangleleft$ per ceut. in the alssolutely freo beets, or 43.2 in those containing 10 per eent. of moisture. A letermination of the sugar is a sample of dried beets furuished me by Mr. Nadean, gives 42.1 per eent. of s:-gar, corrohorating, as nearly as possible, the polarizations nade and the assmuptions of the proportion of four of fresh beets to one of dry. I am at a loss to mderstand the statement apparently male on page 1 of your letter that the polarization on page 2 arroes with the assumption of 20 per eent. of sugar in the dried beets at the rate of four to oue. On its face it gives it fully 
donble, or over 40 per cent. Please revise and oxplain your position on this point. I remark that tho dried sample sent by you is much more noist and to the taste much less sweet than tho simples furuished ly Mr. Nalsau. I am, of conrso, unable to determine which samples represents the tifty tons most correctly.

Very respeetfully,

E. H. DYER, EBI.,

E. W. HILGARD.

Superintendent Standurd Sugar Manufucturing Compuny, Alvarado.

"The facts are substantially as follows: Mr. R. Nadeau had about 700 acres of sugar-beets glown. The samples of green beets grown here upon comparison with the standari sugar-beet of Germany, show that those growu in this county are fully up to the standark. The exhibit of beets made by this gentleman at the horticultural fair in October was exceedingly fine, and from the juigment of non-professionals they were considered first-class for sugar-making purposes.

"There were several other letters passed between Professor Hilgarl and the Standard Sugar Company, the tenor of which, on the part of the former, seemed to intimate that the Nalleau beets had not been fairly lealt with by the latter. Unsatisfactory, in so far as pertained to the manufacture of sngar, as this initial experiment proved to be, it clearly showed that with the crude appliances used by the Standard Sugar Company, according to Mr. Dyer, only 12 per cent. of sugar was obtained from these beets. The late inprovements in machinery make it not improbable to increase the per cent. of sugar from these same beets to 17 and 18 jer cent., and possibly still more.

"Owing to other investments and business cares the bniiding of a sugarbeet factory was abandoned, Mr. Nadean sun-dried his beets and fed them to ins stock. This has been the largest experimental effort that has ever been made in Southern California to grow sugar-beets, and proved that in our soil and climate it luxuriates as nowhere else. Theso beets were grown withiu a few miles south of Los Angeles, on a sandy loam soil.

"From that time to the present the enltivation of this crop has more or less occupied the attention of our farmer's and business men, but no systematic effort has been made to prove the arlaptability of large areas of our lands to the cultivation of the sugar-beet as an artiele of commerce.

"Recently, howerer, sugar-beet cultivation has again been agitated owing to the fact that it is reported that the corporation of which the Spreckles are the learling spirits is contemplating building a series of suchar-lnet finctories in valums portions of the State, and asking farmers to experinent growing loets in their respective localities. As a preregnisite for the ereetion of a finctory in any loeality, Mr. Claus Spreckles writes to the State Poard of I frricultme:

Before erreting a firctory any where I must be gunantied that at loast two thonsand

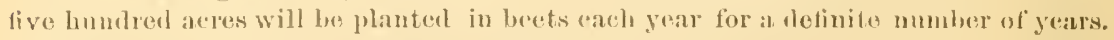
I must also be assured of sulfient supplies of woon, water, and limo in tho noighborhose and good transportation tacilities. 
"The Los Angeles Chamber of Commeree sought to stimulate the interest in sugar-beets, and distributed some fifty packages of seed among the farmers of this county, hoping, by excellent returns to induce a sugar factory to locate here. Somehow, the experiment did not "pan." The recipients of seed paid rery little attention to properly seeding and cultivating, and the result on the whole was rery nnsatisfactory. The few samples submitted to the chamber for analysis in July did not quite reach the standard, though it is conceded that under proper cultivation mnch better results conld have been obtained. The best beets submitted were grown in the Cahuenga Pass, giving a rery encouraging percentage of saccharine matter. Farmers in this favored locality are confident that it will grow a fine quality of bcet, and are going to keep on experimenting.

"The results obtained from plantings made in last February aud March on the Chino rauch, Sau Bernardino County, are more enconraging. The following, giving the particulars of the analysis of beets grown on the Chino ranch is taken from the Chino Champion:

Mr. J. G. Oxuard, of the American Sugar Refinery in San Francisco, spent part of Tuesday on the Chino ranch. In comprany with Mr. D. McCarty, he inspected several patches of sugar-beets and malu tests of a few samples with satisfactory results. Among the tests made was one from J. E. Bettler's third planting of French seed on April 23 , which gave 15 per cent. caue sugar and $83 \frac{1}{3}$ purity. By the way, the results thus far obtained are favoral. le to the French ratlier than to the Germau. Mr. Oxnard inspected beets grown by Messrs. Lawrence, Karcher, Bettler, Mrs. Rice, and others. In the case of the Lawrence beets the samples were taken from the outside atd inside rows, which was not quite just, as it is well knowu that outside rows run low iu slygar, and set the result was 14 per ceut. cane sugar.

Mr. Oxnard did not hesitate to say that he hal never seen better beets, that he was well pleased with general shape aud cork-screw form of growth, and also of the quality.

This much ean now be stated with absolnte certainty: The Chino damp and dry lauds will grow sugar-beets, in fact lave grown them, to the satisfaction of expert manufacturers; that in several cases the laud upon which the experiments have been made has been cultivated but one year and none of it more than two, and experience proves that the first year land is cultivated the hest results are rarely obtained. In some iustances where the per cent. of sugar and purity are above the staudard the seed was planted aud the beets left to grow their own way except that the weeds were kept down, and in but few cases were they given the care required to insure the best quality of beet. To sun np there is not a siugle element lacking bere for a successful beet-sugar manufactors.

"Tests made by different parties and at different times raried in some particulars. The sangnine report that some of the prodnct goes as high as 20 per cent. of sugar, but it is safe to say that the average will he about 17 per cent. 'Though, according the The Champion, "the trusterl chemist," to ruote its own words, "of the Messis. Spreckles has analyzed Chino beets and reports that they contained 19.33 crystallizable sugar with a co efficient of $\$ 6.5$ purity,-both far above the average in the most fivored beet districts of Europe or America. Beet seed planted on the Chino dry land in May in but a single row and other unfavorable 
conditions produced heets that garre 14 per cent. of eane sugar." 'The beets will go about 18 tons to the acre on Chino lands under favorable conditions, valued at \$5.01 per ton (which was the average price at Watsonville for last year) the crop will prove very profitable, and greatly enhance the value of the land. Mr. Gird, the owner of the Chino ranch, is rleeply interested in the subject, and other eapitalists, notably the Oxnard Brothers and the Spreckles, are interested in the subject with a view to establishing a factory at this point. Indeod, it is said that the former have an option to put up the works, and investigations are now going on. The factory, if built, will give employnent to a large munber of hands, and use large quantities of beets during the beet season, necessitating an area of about 3,000 acres planted to sugar-beets.

"Our enterprising neighbors at Santa Ana have also been trying their haud. While there has been no attempt at growiug sugar-beets on an extensive scale, the farmers of this favored region seem to be alive to the importance of this new industry, and they are ably seconderl by the enterprising business men of Santa Ana. The boarl of trade has taken hold of the matter, and we look for substantial encouragement from this quarter. The analysis of beets sent some time ago to the sugar factory at Watsonville is as follows:

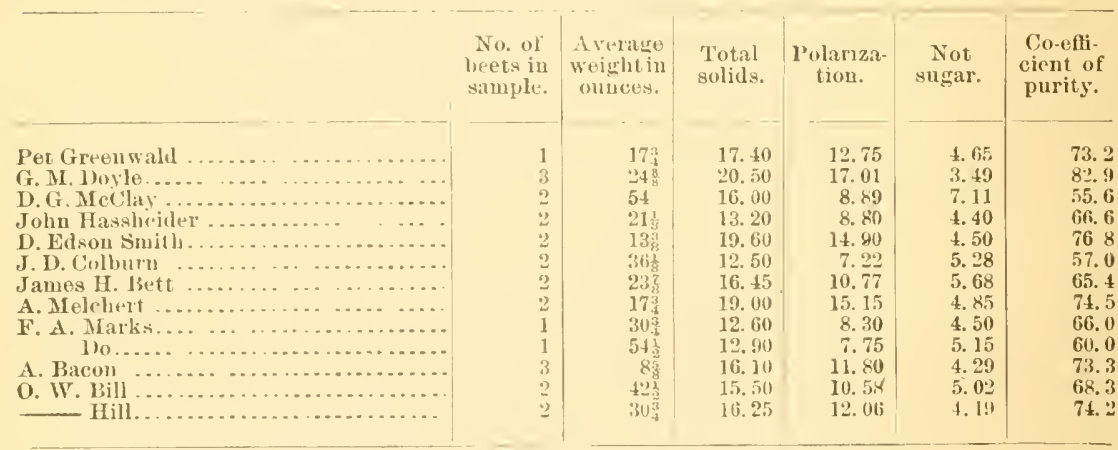

"The above demonstrates that the Sauta Ana Valley is adapted to this plant. Thongh the analysis was below that of the Chino beet, yet it was very eneouratug, and Warrauts future development. The business in. terests of the valley are nsing every legitimate moans to foster and encourage beet cultivation.

"Since the foregoing there has been another analysis made showing a higher per cent. of saccharine matter that is very encouraging.

"Experiments have also been male in other portions of Southern California, all tending to show that the beet can be grown here aud that it finds a congenial home in our climate." 
EXPLIIMENTS AT WATSONVILLE.

The Western Beet Sugar Factory at Watsonville has been in operation two years and apparently with facorable results. The officer's of the company kindly furnished the Department with data respecting the season of 1S58-'59, an abstract of which follows. A request from us for similar data for the season of $1589-90$ has not been complied with.

Recapitulation of the workings of the Western Beet Sugar Company's factory at Watsonville, Santa Cruz County, Cal., for the campaign ending Decembor 19, 18-s.

Sugar, freight from Watsonville to San Franciseo.

$\$ 2,9: 36,55$

Coal.

total cost

$17,267.00$

Colie.

do.....

$1,658.93$

Fuel oil

$11,356.02$

Wood

do......

990. 50

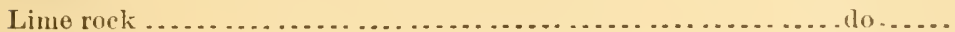

$1,750,30$

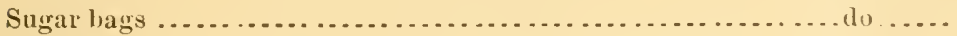

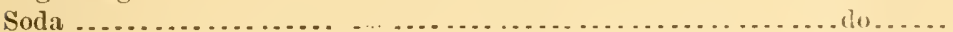

$1,740.34$

12. 39

5). 21

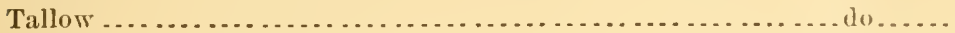

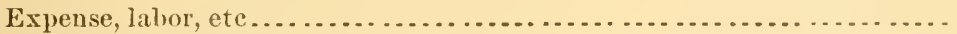

(Beets) incidentals.

$21,091.27$

Cost. of bects.

$2,575.82$

$71,055.83$

$13 \cdot, 522.22$

Which is the cost of manufacturing 1,640 tous sugar delivered freo ou boarl in Sañ Franciseo.

We have received for $3,280,000$ pounds sugar

$16 \% .454 .70$

Maỉing cost of sugar $\$ 80.80$ per ton of 2,000 pounds.

Profit.

29.932 .48

Bzots consumed

$14,07 \tau$

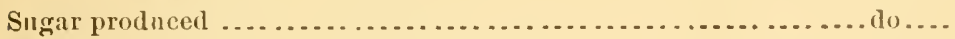

Men emplosed

1,640

135

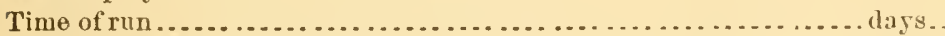

Bects, average polarization ......................... per cent.

Beets, average sugar recovered . . . . . . . . . . . . . . . . . . . . . . do...

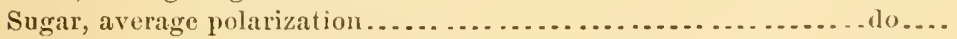

Sugar, average price ............................... . per poutud..

Beets, average price................................. . per ton..

\section{Manufacturing work at Alvarado.}

No report bas been received of the operations of the factory at Alrarado during the past season, and therefore I am not able to say whether or not the work was suecessfully condueted.

\section{MISCELLANEOUS EXPEIIMENTS AT THE DEPARTAEN'T.}

Samples of beets were sent from various localities to the Department for analysis during the autumn of 1959. These beets were grown usually by persons who had no knowledge of the proper methorls of agrientture $25474-B u 11.27-14$ 
as appiied to the production of a beet rich in sugar, and hence it is not at all remarkable that many of them show a low content of sucrose. It must further be considered that the seeds were nut in all cases of guarantied purity, and this would naturally lean to the production of many beets of low sugar content. On the contrary, the exeeptionally high percentage of sucrose found in some samples shows very conclusively that there are many parts of this conntry where sugar beets of the highest grade ean be produced. In the case of No. 6562 there is a phenomenally high percentage of sucrose, which probably was due to some adventitions circumstances with which we were not made acquaiuted. The table of analyses grives the percentage of juice expressed, the pereentage of solids determined by actual drying, the percentage of snerose in the juice, aud the purity en-eficient. The simples are described as fullows:

\begin{tabular}{|c|c|c|}
\hline No. & From- & variets. \\
\hline 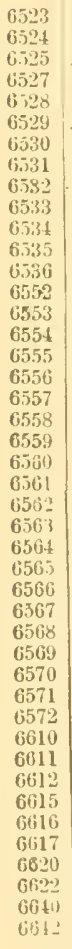 & 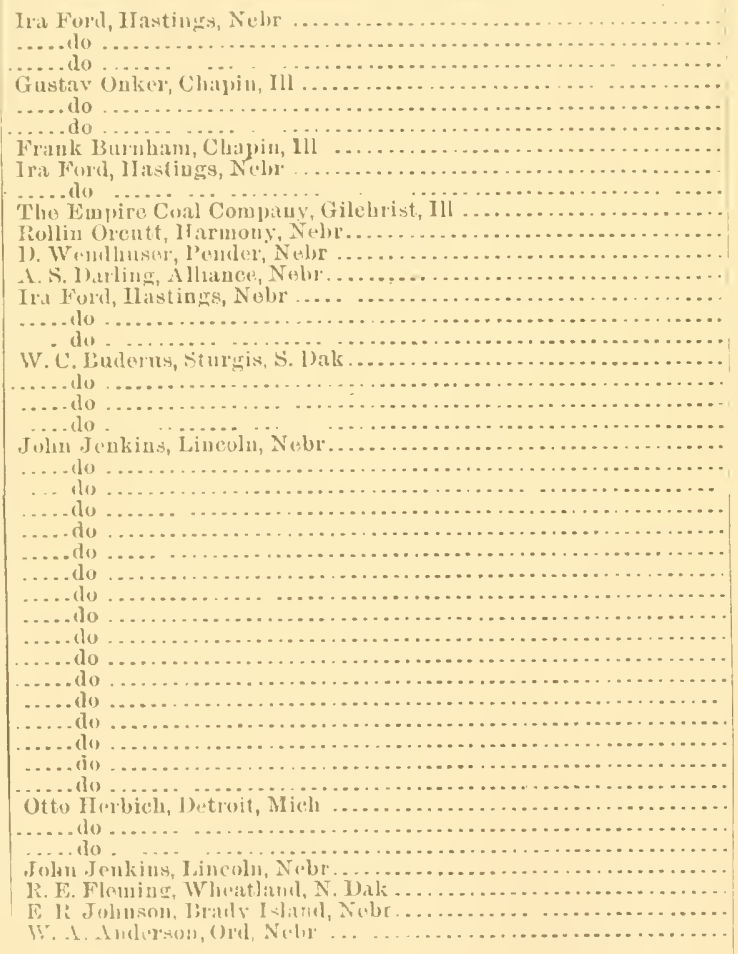 & 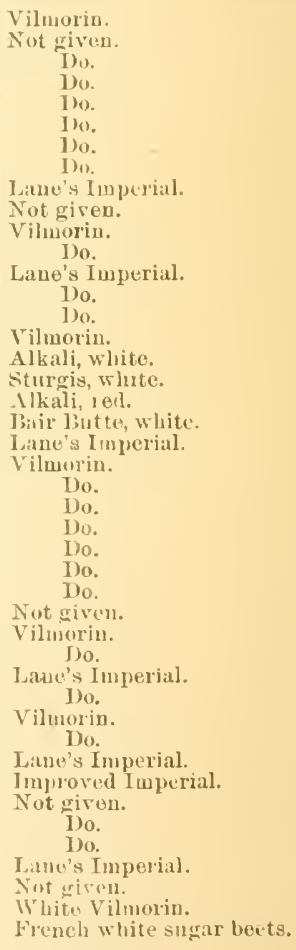 \\
\hline
\end{tabular}




\begin{tabular}{|c|c|c|c|c|}
\hline Serial number. & $\begin{array}{l}\text { Juice, ex- } \\
\text { pressed. }\end{array}$ & $\begin{array}{l}\text { Total } \\
\text { solids in } \\
\text { the juice. }\end{array}$ & $\begin{array}{l}\text { Silerose } \\
\text { in the } \\
\text { juice. }\end{array}$ & P'urity. \\
\hline & Percent. & Percent. & P'er cent. & \\
\hline$\ldots \ldots \ldots \ldots \ldots$ & $\begin{array}{l}67.52 \\
62.65\end{array}$ & $\begin{array}{r}9.55 \\
13.02\end{array}$ & $\begin{array}{l}5.70 \\
9.10\end{array}$ & $\begin{array}{l}59.69 \\
69.89\end{array}$ \\
\hline 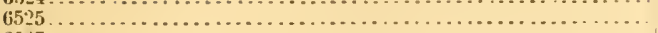 & 62.02 & 13.02 & 9.10 & 7f. 50 \\
\hline 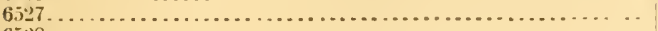 & 44. 66 & 12.17 & 8.10 & 02 \\
\hline 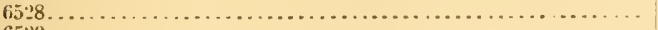 & 52.94 & 14.02 & 9.50 & 76 \\
\hline 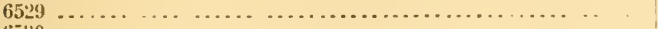 & 57. 79 & 7.62 & $\$ 05$ & 3.14 \\
\hline 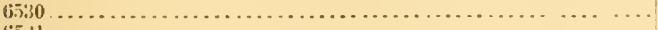 & 59. int & 11.32 & 7.10 & 72 \\
\hline 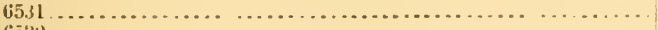 & 51. 50 & 14.02 & 9.25 & .90 \\
\hline 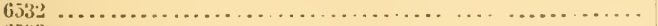 & C1. 83 & 13. 77 & 9.75 & 80 \\
\hline 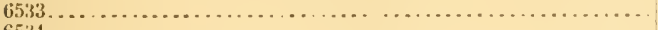 & 14 & 16.67 & $13 . \pm 0$ & 38 \\
\hline 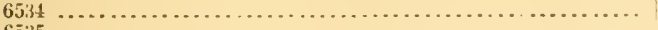 & 5 & 02 & 12.50 & 02 \\
\hline 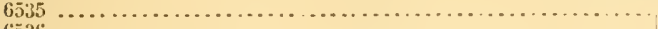 & $5 \tilde{5}$ & 14.37 & 9.00 & 63 \\
\hline 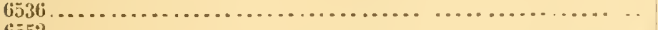 & 51.83 & 17. 60 & 12.30 & 9. 88 \\
\hline 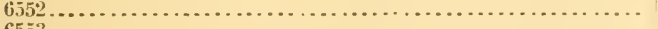 & 41. 71 & 3. 90 & 6. 00 & 67. 41 \\
\hline 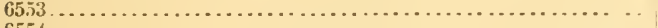 & 95 & 17.07 & 12.50 & 78. 22 \\
\hline 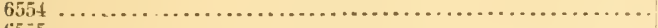 & 5 & 14.20 & 10.20 & 71.80 \\
\hline 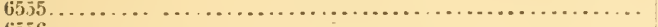 & 95 & 16. 20 & 10.75 & 66.35 \\
\hline 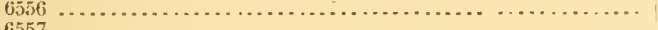 & 1 & 14. 87 & 8.30 & 57.16 \\
\hline 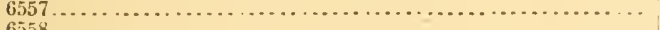 & $1 \mathbf{1}$ & 19.37 & 13.5 .5 & 69.95 \\
\hline 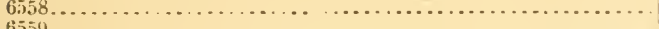 & 4 & 23.25 & 17.00 & 40 \\
\hline 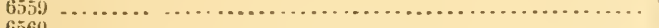 & 3 & 14.00 & 9.35 & 78 \\
\hline 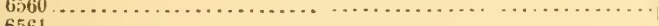 & 4 & 57 & 5 & 11 \\
\hline 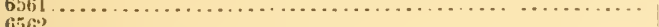 & 1 & 20 & 30 & 17 \\
\hline 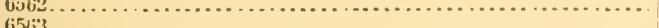 & 4 & $\begin{array}{l}28.80 \\
18.35\end{array}$ & 22.30 & 43 \\
\hline 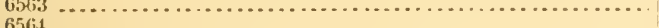 & & 35 & . 5n & 73.56 \\
\hline $65644_{0.2}$ & 5 & 12.82 & 10. 10 & 78. 17 \\
\hline 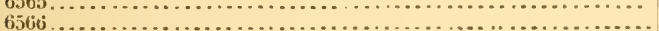 & 37.14 & 07 & 6.50 & 85 \\
\hline 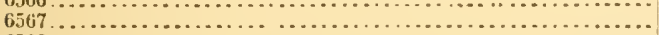 & ....... & 16. 20 & 13.50 & $\begin{array}{l}12.99 \\
83.33\end{array}$ \\
\hline 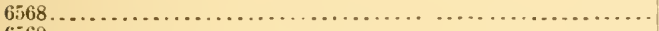 & 48.13 & 14.52 & 10.65 & 74. 73 \\
\hline 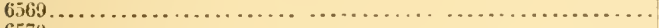 & 5.5 .66 & 6. 92 & 3.55 & 51. 44 \\
\hline 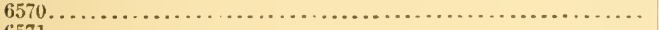 & 55.13 & 15.37 & 11.40 & 74.16 \\
\hline 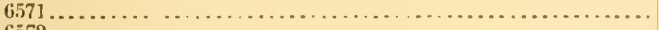 & 46. 89 & 14. 6.5 & 10.40 & 70.98 \\
\hline 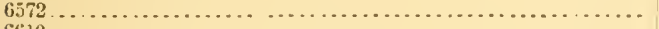 & 46.15 & 20.27 & 17.05 & 84. 11 \\
\hline 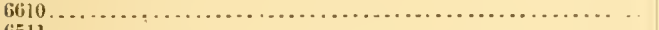 & 43.69 & 17. 48 & 12. 70 & 72. 65 \\
\hline 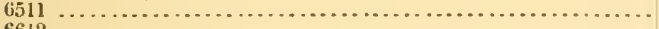 & 53.80 & 10.37 & 5.85 & 56.41 \\
\hline 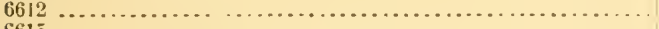 & 4.5 .95 & 17. 30 & 12.90 & 7456 \\
\hline 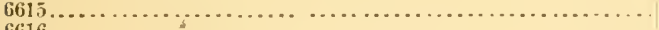 & 55. 65 & 15.52 & 11.70 & 75.38 \\
\hline 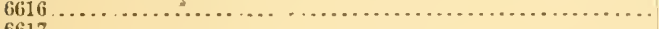 & 54.71 & 18.05 & 14.15 & 78. 38 \\
\hline 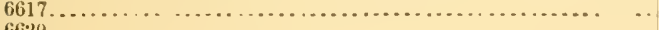 & 47. 76 & 17.97 & 12. 90 & 71. 78 \\
\hline 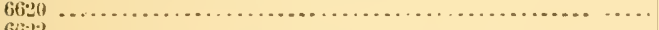 & 48.81 & $1.5,20$ & 12.00 & 78.94 \\
\hline 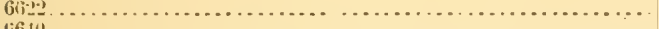 & 43. 78 & 15.27 & 9.85 & 64.50 \\
\hline 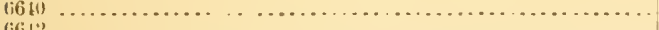 & $\because$ & 23.03 & 10. 40 & $\because \ldots$ \\
\hline 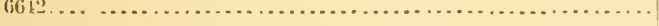 & 43.87 & 22.05 & 16.45 & 74. 60 \\
\hline
\end{tabular}

\section{BEET-SUGAR INDUSTRY IN CANADA.*}

"In orier to encourage the beet-sugar industry ini Canada it has been decided by the directors of the factories at l'arulam to ask of the Gov. ermment of Quebee : bounty of $\$ 1$ per tou for all sugar-beets grown duriug the year 1S90. In order to re-establish the beet-sugar industry at this point the proprietors offer the following inducements in the eircular sent to farmers: The seed for planting the beets will be furnished gratis to cultivators; $\$ 4.50$ per tou of 2,000 pounds will be paid for beets on board cars; the payment will be made on the iclivery of each car-load of beets as soon as they are weighed; au advanee of $\$ 10$ per arpent will be made in the mouth of Jinue to cultivators who have at least 3 arpents in beets; a second advance of $\$ 10$ per arpent will be made in the month of July to all cultivators who, having properly thinned and hoed their beets, will have at least 25,000 plants left per arpent. Two premiums of $\$ 50$ and $\$ 100$ will be given for tie best 3 arpents of beets."

*Journal des Fabricants de Sucre, March 19, 1590. 
FAC'TORIES IN CANADA.*

"Of the three beet-sugar factories in the I'rovince of Quebec only one worked this year. For varions reasons the profits were not satisfinctory. The snecess of this inlustry is possible, and the manufucture of sugar from beets will in time come to be considered the most remunerative of the comntry.

"The failures are dne to two causes: First, bad management; second, want of working capital.

"The writer (Mr. Mussy) intends to renew his elforts, with French eapital, and rent and work the Farnliam fictory. It is without donbt demonstrated that it is not possible to raise and delirer beets at the factory for less than $\$ 5$ per ton. Each of the factories, Berthier and Faruham, has a working cupacity of 15,000 tous. The writer suggests that American capitalists secure these factories where the farmers are already educated in bect-raising, in preference to buhling new works. These factories are located only a few hours from Ioston and New York.

"The writer further states that in the vicinity of these factories many farmers are growing sugar-beets for their cattle. The Berthier factory worked this year. Fro $n$ an agrieultural standpoint the eampaign has been a great success, beets were purchased at $\$ 4$ per ton and farmers were willing to contract for almost unlimited areas for next year. Unfortunately only 30 tons of roots have been worked per aliem, while the capacity is 200 tons, and luring the campaign of 1582 there was an average of 150 to 170 tous utilized per twenty-four hours."

\section{THE BEET SUGAR INDUSTRY IN ENGLAND.}

Dr. Schack-Sommert contributes a paper setting forth the advantages which would acerne from the introlnetion of the beet-sugar industry into England. Four varieties of beets were grown by him from seeds obtained firom 1)r. Scheibler. The four varieties grown were:

1. Dippe's Richest Singar-beet.

2. Dippe's Improved.

3. Diple's Inproved Red-hearledl.

4. Dippe's Improved Klein Wanzlebhen.

The fertilizer recommended for the beets is 200 to 300 pounds of nitrate of soda and from 400 to 600 poumls of smperphosphate per acre. It is recommended to plow the soil 14 to 15 inches deepe.

Experiments were male at two loealities, one on the farm of Mr. John Funis in Springwood, Ireland, and the other on the farm of Mr. John Gibbonsmin Wavertree, near Liverpool. An analy sis of beets made on

"Alustraet of a letter to the editor of the Sugar lient, from A. Mussy. From "Th." Singar Cane," lebruary 1, 1890.

f.Jominal of the sueicty of Chemical Lutustry, Felnenary $20,1890$. 
the 26 th of September at the two stations, showed at the English sta. tion the following pereentages of sugar: $15,15.6,14.7,14.2$; and at the Irisly station, 16.7, 17, 18.2, 16.8. On the 10th of October another set of analyses was made at the $t w n$ stations with the following results: At the English station, the percentages were $16.5,17,16.7,16.4$, and at the Irish station 18.2, 17.5, 17.2, 18.8.

The apparatus invented by Meser and Bnettner for drying the sliced beets is also described and it is elamed that with this apparatns it is possible to dry 225,000 kilograms of slieed beets per day at a cost of 8 cents per 100 ponmols. In regard to the quantity obtained per acre at the English station the yield was 42 tons and $19 \mathrm{cwt}$.

\section{BEET SUGAR IN THE NORTHWEST.}

POINTS FOR CONSIDERATION WITII REGARD TO TIE INTRODUCTION OF TILE SUGAR-BEE'T AND TILE MANUFACTURE OF BEET-SUGAR IN THE MOR'THEST AS COMPARED WITH THE BEET-SUGAR PRODUCING COUN'TIES OF EUROPE, BY J. D. FREDERICKSEN.*

"1. Climate.-In Enrope the northern part of the temperate zone at: fords the most favorable conditions for the growth of the sugar-beet and the development of a pure juice from whieh the sugar is easily extracted. The northern part of Germany, Prussian Saxony, Brunswick, and Hanover; Denmark and the sonthern and middle seetions of Sweden; Belginm, Holland, the northern departments of France; Bohemia and a section in the midlle of Russia, all produce beets from whielı sugar can profitably be mannfictnred. Seetions with complete inland climate seem to prodnce richer sugar-beets than those with coast climate. In northern Germany and certain parts of Russia and Sweden the beet is generally richer in sugar than in France, Belgium, Holland, or Denmark, the latter conntries being more exposed to the sea. In England, where the elimate is moist and temperate all the year romul, the beets grow bulky bnt poor in sugar, and there the beet-sugar industry has proved a complete failure.

"As to Denmark the elimate is not so farorable to the derelopment of sugar in the beets as it might be. The spring is rather dry, so that it is hard to get the plants started, and the fall is so wet that there is a danger for the beets to set flesh at the expense of the quality of the juice. For the same reason the harvest is difficult. Still the industry is flourishing, so that the climate may not be called bad. 
"The following table shows the arerage temperature and rain-fall at Copenhagen, in Demmark, and in Mimnesota:

\begin{tabular}{|c|c|c|c|c|}
\hline \multirow[b]{2}{*}{ Montlis. } & \multicolumn{2}{|c|}{ Minnesota. } & \multicolumn{2}{|c|}{ Denmark. } \\
\hline & $\begin{array}{c}\text { Tenipera. } \\
\text { tu1'. }\end{array}$ & liain. & $\begin{array}{c}\text { Tempera- } \\
\text { ture } \\
\text { (85years). }\end{array}$ & $\begin{array}{c}\text { Rinin } \\
\text { (4tyears). }\end{array}$ \\
\hline 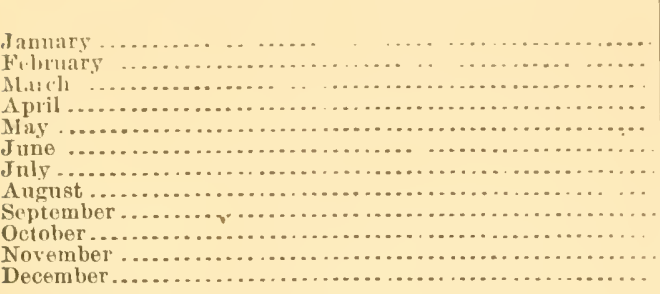 & $\begin{array}{l}\text { Fahr. } \\
15.85 \\
14.40 \\
23.66 \\
37.5: \\
6321 \\
18.70 \\
71.72 \\
70.54 \\
60.95 \\
49.36 \\
28.72 \\
18.81\end{array}$ & $\begin{array}{r}\text { Inches. } \\
.49 \\
1.07 \\
2.24 \\
.95 \\
1.65 \\
11.67 \\
1.94 \\
3.90 \\
5.76 \\
3.21 \\
1.90 \\
.72\end{array}$ & $\begin{array}{l}\text { Falur. } \\
29.84 \\
30.92 \\
33.80 \\
42.08 \\
51.62 \\
59.90 \\
63.14 \\
62.24 \\
56.12 \\
47.84 \\
38.84 \\
33.80\end{array}$ & $\begin{array}{r}\text { Inches. } \\
1.74 \\
1.52 \\
1.56 \\
1.46 \\
1.49 \\
2.12 \\
2,30 \\
2.48 \\
2.18 \\
2.17 \\
2.04 \\
1.69\end{array}$ \\
\hline 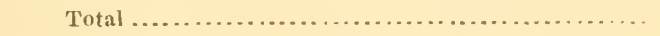 & 43.62 & 35.50 & 45.84 & 22. 75 \\
\hline
\end{tabular}

"Comparing these figures, it would sugesest itself that the excessive rain-fall in Minnesota in June might firor the derelopment of the young beets, but at the same time make it rery tronblesome to perform the work of harrowing and hoeing to keep the land clean from weeds. The months of August, September, and Oetober also seem rather moist, makiug it possible that too much inorganic matter may enter the juice at the time when the beets get ripe. Still, when falling in heary showers at long intervals, as it probably loes in Minnesota, the rain is neither likely to influence the beets nor to bother the harrest in the same way as when coming down gradually at short intervals. More water will evaporate from the soil, and therefore more rain is neederl in Mimnesota than in Demmark on acconnt of the higher temperature of the former. Accorling to another account the fall of rain in Miunesota is as follows:

\begin{tabular}{|c|c|c|c|c|c|}
\hline Seasouss. & $\begin{array}{l}\text { Stinne- } \\
\text { apolis. }\end{array}$ & Wulnth. & $\begin{array}{l}\text { Breckin- } \\
\text { rilge. }\end{array}$ & Pembina. & New UIm. \\
\hline 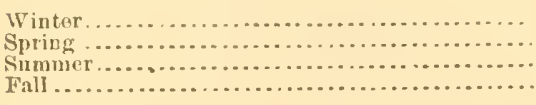 & $\begin{array}{r}3.105 \\
7.960 \\
16.301 \\
5.108\end{array}$ & $\begin{array}{r}2.160 \\
6.480 \\
20.850 \\
8.060\end{array}$ & $\begin{array}{r}4.980 \\
\text { f. } 2.50 \\
14.1 .50 \\
3.580\end{array}$ & \begin{tabular}{l|}
2.750 \\
2.450 \\
7.250 \\
6.910
\end{tabular} & $\begin{array}{l}\text { 2. } 260 \\
6.300 \\
7.020 \\
9.280\end{array}$ \\
\hline Annual ........ & 32.456 & 37.556 & 28.960 & 19.360 & 24.860 \\
\hline
\end{tabular}

"With such extraodiuary differences within the same State it would seem likely that some sections, at least, may be farored with the proper elimate for a successful cultivation of the sugar-beet. The temperature of the summer does not seem exeessively high, for eren far sonth on the continent of Enrope the beet is grown sucessfully, and just in those of the above sections where the beets are ricliest in sugar the summer heat is eomparatively high. 
"2. Soil.-The proper soil for the sugar-beet is neither too heary (clayish) nor too light (sand), nor containing too much organic matter. A well enltirated, rich, and deep soil, that would produce a good erop of barley for malt, is well adapterl for the sugar-beet. New and rich land, that in a crop of cereals wonld develop the straw at the expense of the seed, would make a bulky erop of beets, but they would be poor in sugar and rich in non-sngar, detrimental to the extraction of the former from the juice. Land of oll enltivation, made rich by continned plowing and mannring, is better than newly broken land. Therefore, withont knowing from personal experience, one wonld imagine the soil of Illinois to be better allapted to the sugar-beet than that of Minnesota. The land shonld be well drained, either by nature or lyy pipes laid deep in the ground, allowing no water to remain on the surface at any time.

"The limits for the phrsical condition of the soil are, however, very wide, for we have grown riel sugar-beets on enmparatively heavy and on comparatively light soil, the former being made porous by deep drainage and intense stirring with steam-plow and cultivator But, whether heary or light, only land in a state of high eultivation conld produce beets rich in sugar.

"3. Labor.-One of the worst drawbacks to the successful introduction of the sngar beet in the northwest would seem to be the labor question. Even with the advantage of the best implements to stir the land, thin and clean the ridges, and gather the erop, the hand-labor needed to grow sugar-beets is considerable. Wages being abont tliree times as high in the northwest as in Denmark, this would increase the expenses at a great rate. Supposing one hand to be needed for 3 aeres of land for four months, about thirty days' work would he necessary to enltirate 1 acre. Supposing 1 acre to field 15 tous of beets or 2,400 pounds of sugar ( 8 per cent.), thirty days' work, at $\$ 1.50$ a day, wonld mako $\$ 45$ an acre, or $\$ 3$ per ton of beets, or $18_{4}^{3}$ cents per hmulred-weight of sugar, while in Denmark, at 50 cents a day, the Jabor wonld only amount to one-third of these expenses. And supposing the product conld bear such expenses, would it be possible to gather a sufficient number of hands so as to grow 1,500 acres of beets within the limit for the area of one sugar factory? For it is a cleplorable fact that, at the present development of the industry, sugar ean not be manufactured from beets on a small scale, but must be produced in large establishments, which require the raw material from a large number of acres. And, on account of the bulky quality of the heets, they ean not bear long transportation, and must therefore be grown within a certain eom. paratively narrow distance from the factory. Again, duriug the mannfacturing season, which only lasts about four or fire months, the factory would employ a number of bands who, after all of the beets hare been disposerl of, would have to look for employment elsewhere. While at the time between the elearing of the beet land and tho harvesting of 
the beets the regular larvest of the eerials might give employment to the beet hands, mould the forests of Minnesota or other industry dis. pose of the laboring hands during winter and early spring, until the beet field again might need them? Sngar beets shonld not he attended to ouly when the other work of the farm is done and there is nothing else to do, but should be worked when they need working. Without independent labor at the proper time their enltivation always proves a failure. So also should the mamnfacture of sugar begin when the beets are ripe aud contain most sugar, and it should be contimed energetieally as long as any beets are left, in orler to dispose of the whole crop before too much sugar is lost, for every day after the beets are ripe they grow poorer in sugar. Therefore laboring hands must be at disposal at any time when they are wanted, independent of other work that might need them.

"In the factory the high rate of labor in the the Northwest would add eonsiderably to the expenses; while in the beet field where, in Denmark, female hands are employed in a great measure, the labor would probably be three times higher in Hinnesota than in the old conntry, the manufactming labor expenses would, no boubt, be twice as high in Minnesota as in Denmark. In the latter eountry the labor expenses in the factory amount to $\$ 1.15$ per tou of beets, or about .72 eent per pound of sugiar.

"4. Other expenses.-Quite different is the ease with regard to other expenses than laboring: The eheapness of the land in the Northwest as compared with rieh land in the old country will, no doubt, do mueh towards reducing the expeuses of the growing of beets in Minnesota. In Demmark the rent for rich land amounts to $\$ 7$ to $\$ 8$ an acre. In Germany as much as \$16 per acre is pail yearly for a rentage lasting ten or twenty years. In the Northwest, improved land could probably be had for less than half the rent in Denmark.

"In the factory eoal plays a prominent part among the expenses other than labor. In Denmark this item amounts to $\$ 1.20$ per tou of beets or .75 cent per pound of sugar-the price for coal being $\$ 0$ per ton. This price being reduced to $\$ 2$ per ton, the oxpense for fuel would he 40 cents per ton of beets or .25 eent per pound of sugar only.

"5. Duty.-In the old country the duty paid to the government by the manufacturers makes a heavy reduction of the profit realized by the production. In Germany the duty is laid on the beets, being raised gradually from 1836, when it was only one fourth silver groschen per hundred weight (11 cents per ton) of beets, to the present time, when it amounts to 9 silver grosehen per 100 pounds (\$4 per ton). This is, in a great measure, the reason why in Germany the manufucture of beet sugar is developed to such admirable perfection as is the ease. The more sugar that could be gained from the beets, the less the duty drew on the profit of the manufacturer, for the duty on 1 ton of beets re. mained the same whether 6 or 10 per cent. of sugar were extraeted. 
All the efforts of the farmer and the mannficturer had the aim to pro: duce much sugar from a certain weight of heets, not to piouluce much sugar from an acre of land. Therefore the quantitative yield of beets was neglected, while beets were produeed which yielded as much as 10 per cent. of sugar.

"In Sweden the same system is adopted. In Belgium and partiy in Holland the duty is ealculated on the basis of the quantity and richness of the juice extracted fiom the beets. In France and in Denmark the duty is liul on the sugar produced. For this reason it is in these comtries the aim of the producer to get the largest yield of sugar from an acre, only provided that it can be profitable extracted. Therefore the yield of beets is larger, but their contents of sugar less than in Germany. In Demmark the duty is equal to that ou imported sugar, amounting to 2.16 cents per pound of raw sugar (below No. 18 Dutch standard), or about $\$ 3.45$ per ton of beets. The duty in this country being about 3.5 cents for average raw sugar, this item would anount to $\$ 5.60$ per ton of beets in faror of the manufacturer, provided $s$ per cent. of raw sugar can be extracted (besides the molasses).

Summing upthese items the following figures are arriced at in faror or in disfavor of the sugar iudustry in Minnesota, as compared with Denmark, provided 8 per cent. of sugar is realized in both countries:

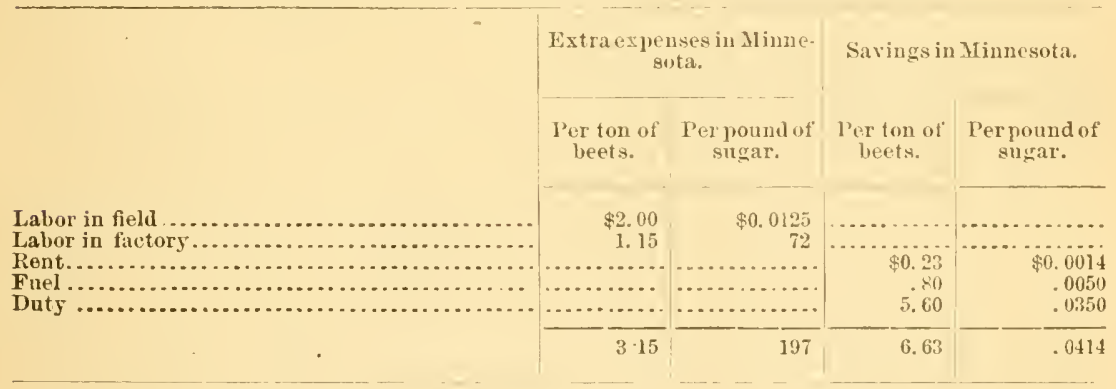

"Deducting the extra expenses from the savings, we arive at the following real savings in favor of Minmesota:

Per ton of beets........................................... $\$ 3.48$

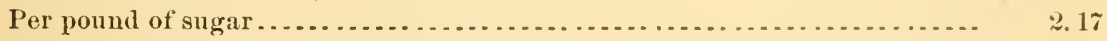

"But the whole calculation depends upon the question, can beets be grown in Minnesota which will yield 8 per cent. of sugar? The most careful study of tables of rainfall and temperature, and of analysis of the soil, can not decide the question. The only way is to try. Seed of rich sugar beets should be distributed to intelligent farmers throughout the Northwest, accompanied by direetious how to grow beets. The farmers who undertake to carefully make the experiments should be requested to return an average sample of the erop, describing the soil in which the beets are grown, and the treatment of it; the fruits which the land bore in previous years; the manure, if any, that was used; 
the time in which the manure and the seed were somn, and at which the thimningont, the harrowings and hoeings, and the harrest were performed ; the yieln per acre, ete. The samples shomld be analyzed, not only for sugar (and especially that kind of sugar which wonld turn the polarized light to the right, and which would crystallize), but also for organic aud inorganic non-sugar. Such material for one year would already afford valuable suggestions, and, carried on for several years, such experiments wonld justify a decided opinion about the propriety of the introduction of the industry. To start a large and expensive factory without such foundation would be to rum a great risk, and to establish small and cheap factories would always prove a failure.

"As to the plan for establishing sugar factories, sereral systems prerail in Enrope. One is the co-operative, very much like the system of cheese factories and creameries in certain sections of this comntry. The farmers in a section intending to establish a sugar factory form a joint stock company, and are bound to (lelirer to the factory the beet crop) of a certain number of acres for each share in their possession in Brunswick generally 8 acres for each share of $\$ 100)$.

"For the last ten years the sugar factories have become very expensive, being profitable only when rery large, and when furnished with the latest inrentions. Therefore, the farmers could not afford to build their own factories if it were not for large stock companies which under. take to build and furnish factories for the farmers, leaving the greater part of the cost at low interest to be paid off gradually, against mortgage in the buildings. This plan does not work well in a country where the industry is new, and, though it is no doubt hest of all, it can not be introduced mutil the beet sugar industry has proved an unquestionable success, and is known to the people as a safe thing to invest in.

"Another plan is for a stock company to establislr a factory, buying the beets from the farmers, and return the refuse (pulp) to be consumed on the land, so as not to exhaust the latter. It is, howerer, not an easy task to induce the farmers at once to grow an area with beets large enough to furuish a factory with sufticient raw material of good quality for a successful starting. It takes time and experience to learn how to grow rich sugar-beets; the best way to learu it is to get direct interest in the profit. Therefore such concerns who build factories, intending to buy the beets in a section where the industry is not prerionsly known, are generally forced to grow a large portion of the beets themselves, by establishing some kind of bonanza farms, or by renting suitable land for the purpose, returning it to the farmers after the crop las been gathered. In fact, this is the only way to secure within reasonable time enough of goorl raw material, until, by and by, the farmers are educated for the task.

"In Denmark the beet-sngar industry was introdnced in 1873, when it had been ascertained by experiments during several years that sufficiently rich sugar-beets could be grown. 'Two factories were started, one hy an old concern that previously commanded the whole sugar-refining business of the country, the other by a new stock company prom- 
inently made mp of landed propriotors. The former company lonit a

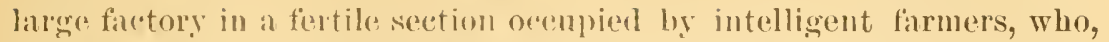
it was thonght, shonld furnish the beets. The factory was capable of working up 12,500 tons uf beets a year. The first year only 2,500 tons of poor bects were received, and the second year proved but little better. Then the managers were convinced of the necessity of adding farming to their business, and hought a farm of 300 aeres, to manage which an expert was engaged. Another year more land was added to the farm, and suitable fields were rented for one year and grown with beets by the manufacturers. On these lauds rich sugar-beets were grown. In the meantime the farmers leamed how to grow the beets, and the cuantity received at the factory increased yearly, until now sufficient raw material is furnished so as to run the factory profitably. Large amonnts of money were lost during the first five years. The business sermed condemned to failure, but the managers sncceeled in keep. ing it going until the balance turned, and now the factory is fion rishing.

"The other company went at onee to work and rented for twenty raturs three large farms, of 2,000 acres of land in all, every acre of which was in a state of high enltivation and well drained. This land was divided into four fields and sown suceessively with wheat, beets, barley, and elover, so that every fourth year beets were grown on the same lami. Steam-plows and tirst-class machinery were introdnced. The factory was built so as to work 11 ) 7,500 to 10,000 tons of beets a year. Besicles those grown on the 500 acres of the company, more beets were gromn by the compans on laud rented pearly aud being returned to tho farmers after use, and as many as possible were bought. In this way the company sncceeled in gathering 6,000 tons of tolerably rich beets the very first year, sufficient to make a rather snccessful start. The factory being built at a time when all materials were as expensive as ever; the price of sugar falling abont 30 per cent; hard competition being bronght to bear from the sngar refiners; an excessive duty eren higher than that on imported sugar * being atunce enforced as soon as the manufacture was started; and finally entering the time of universal financial depression, commanding insufficient capital, the company conll, howrever, not carry the work throngh, and failed in 1876. A new company took the matter in hand, and carrying on the business on the same principle as it was hitherto managed, have succeded in making it pay well.

"Having passed throngh extraorlinary difficnlties, the beet-sugar industry in Denmark is now successful. Int though a handsome profit is realized by the manufacturers, it is nothing compared with the indirect profit which is the result of the improvement of the land where

* The duty at once laid on the mannfacture of beet sugar in Denmark was a few years later ackuowledged bs the goverument to he higher than that on imported s'dgar, and was redned accordingly. In no other eountry in the world has this indinstry suffered an immediato imposme of dnty, time bejug everywhere elso allowed for the industry to develop and arepuire stability. 
heets have been grown. The influnce on the land of the deep and thorongh cultivation, and the nse of fertilizers, which go hand in hand with the growth of the sugar-beet, of the beet itself by opening and mannring the soil, and of the stable manure which is prodnced by this system, is simply wonderful. All other crops are increased and their funality improved. On sueh land as would previously produce only rommon barley, a highly praised malting grain is now raiser, which brings far better price than the old prodnct. Those farmers who at first looked suspiciously on the new indnstry are now quite enthusiastie in favor of it, and several factories are about to be bnilt this year."

\section{USE AND TREATMENT OF PULPS.}

PRESERVATION OF DIFFUSION PULPS IN SILOS.

Instead of feeding the diffusion pulps at once they may be kept in silos for future use. A silo suitable for this purpose is deseribed by Minangoin.* In silus made of earth there is a considerable loss of material on acconnt of mixture of the earth with the pulp. On the other hand, the cost of silos eonstructed in masonry is very great. The pressure of the pulp is so great that such silos must have an unusual thickness to withstand it. A eheaper form of silo is therefore indispensable for farmers' use.

A silo marle of heary planks appears best suited for preserving the pulp.

The silo deseribed by Minangoin is about 70 feet long and 6 feet wide. The bottom is made of a layer of stone, but without cement. The surfuce is slightly raised in the eenter to permit of the ontllow of liquid on both sides. A ditch surrounding the silo is disposed in such a man. ner as to properly dispose of the drainage water. The boards of the silo are supported by oak posts 4 inches square, deeply set in the earth, and placed at distances of about 5 feet apart. These posts are connected from side to side by iron rods one-half inch in diameter.

Between each plank in the sides and ends of the silo is left a space, 1 inch, to faeilitate the drainage of the pulps. The planks shonld have a willth of about 1 foot. For convenience in filling, as well as for use, it is well to divide the silo into parts by rumuing a partition from post to post. By leaving out the iron rods until each partition is filled and filling the farther part first the charge may be brought directly into the silo from its open end. The silo shotild be 5 feet high at the sides and 8 feet in the center, and will then contain orer 300 cubic rards of pulp. The pulps are preserved perfectly. The pulp gradually acquires a remarkalble dryness and density, and there is no waste either at sides or bottom. It is not necessary to furnish it with a corer.

+Sucterio Incligéne, Manch 25, 1890, page $28 \%$. 
"On well-organized sugar-beet plantations there should be special arrangements for keeping refuse pulp during the winter, a period when green fodder (so essential to the health of live.stock) is diffienlt to procure.

"In p,revious issues of The Sugar Beet we mentioned experiments made from year to year in pulp preservation, and how this refuse may

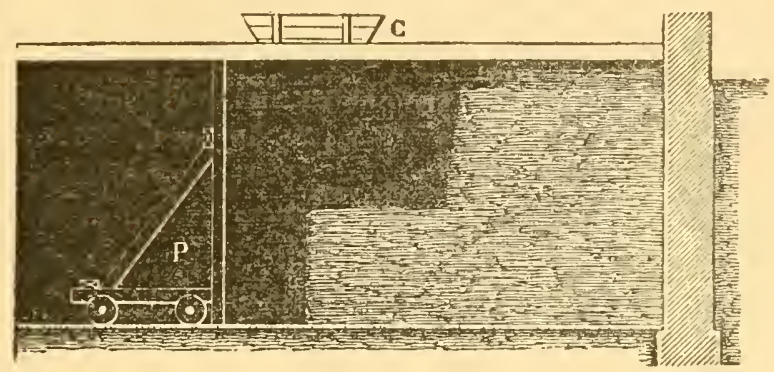

FIG. 44.-Vertical section of silo for beet pulp.

be kept in good condition by a liberal use of salt, ete. The greatest difficulty to contend with is the water retained by the pulp; fermentation soon follows. The organic transformations are not objectionable if

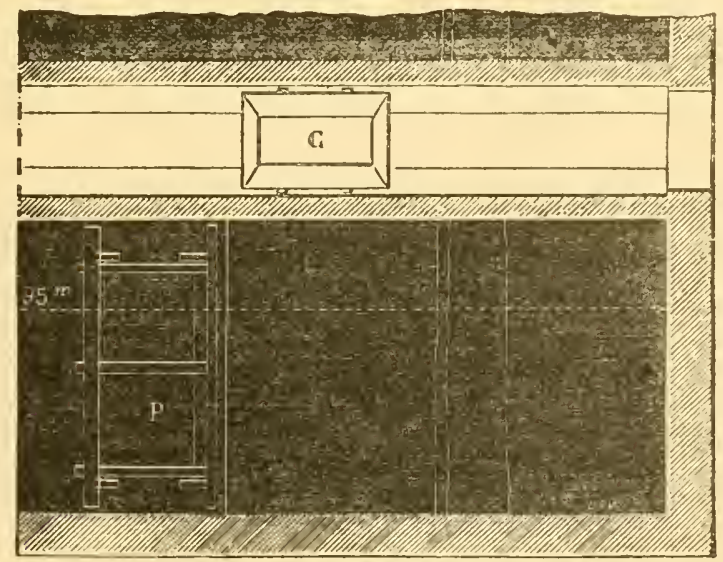

FIG. 45.-Horizontal section of silo for beet pulp.

arrested at the proper moment; on the contrary, live-stock seems to eat with considerable avidity pulp having slightly somred, or of acetie taste. 
If the cattle to be led are numeroms, their daily comsumption may be equal to the supply; silos muler such ciremustances are unnecessary. On the other haud, duriug the one himbled days representing au ordinary campaign of beet-sugar factories, the fatteuiug results can not, be satisfactoriy obtained, because the period is too limited. From a general point of view pulp silos may be a sonree of considerable revenue to all interested.

"At the Ferme de la Briche (France) may be seen a silo of 4,000 cubic meter's eapacity used for distillery pulp. The refuso is carried from masl tubs in ears C, Figs. 44 and 45, in which it is mixed with chopped straw, hay, etc. A movable partition P (19.6s by 11.48 feet), haring the exact dimensions of the silo's cross-section, is mounted on wheels and placed a short distance from the end wall. The intervening space is filled with closely-pated pulp, thus preventing fermentation, and a layer of 10 inches earth eovers the top. The partition is mover backward, and the foregoing operations lepeated. It is said that beet pulp, under such conditions, will keep for yours; it is taken from the silo in vertical slices."

DRYING OF 'THE PULPS FOR PRESERVATION FOR FEEDING PURPOSES.

In an address made at the agrieultural association of the Province of Hanover, Mr. Koester described tho process of the drying of pulp) for the purpose of preserving it for cattle fool. 'This new feeding' stuff is known by the name of 'dried diffusion pulp, and is being largely discussed in Frauce lately. Very little is kuown in regard to it by the farmers themselves mp to the present time. The cost of the dry. ing plant and the expenses of the process are great and there is much donbt whether any profit results from it. Some of the data in regard to the matter have been collected by Mr. Koester. He silys if he had received, during the present year, the whole of his pulp in the humid state he would have been compelled to transport 57,000 quintals. Of this quantity 9,000 wonld baro been consumed during the campaign, and 48,000 would have been preserved. It' these 48,000 quintals had been dried the expense of placing them in silos, and the transportation of them from the silos to the feediug-stalls, would have been saved. This extra expense is estimated to be from 2.5 to 3 pfennigs per quintal, or, expressed as a mean of the whole cost, 1,330 marks. The drying of 45,000 quintals of pul ${ }^{\prime}$, would have cost 4,320 marlis; deducting from the abore the 1,330 marks for the expense of preserving the wet pulp, there would remain a net expense of 3,000 marks for the desiccation. It is estimated that the undrierl pulp), in liseping, lose in all about one-third of its nutritive value, whide would. be equiralent to 16,000 quintals. If, howevel, these 16,000 quintals had been dried they would have vielded 1,850 puintals of dried pulp. It is estimated that the feeding value of $1,5 s 0$ quintals of dried pulp is equal to 7,500 marks; 
deducting from this sum the net expense of desiecating, viz, 3,000 Inarks, there would have resulted a net gain on the whole mass of 4,500 marks. One fatetory at Rethen workel up nine times as many beets as were furnished by Mr. Koester; they would, therefore, have realized 40,000 marks profit by drying all of their pulp. The process of drying the pulp employed was that of Buttner and Meyer. The dried pulp furnishes a food which is preserved indetinitely without alteration, movided it is put in a dry place. Accolding to Wolff it contains:

Per cent.

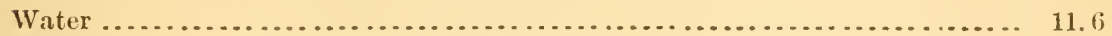

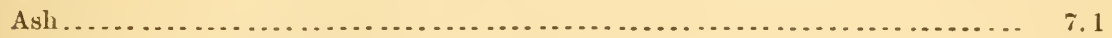

Crnde protein (of which digestiblo 4.1 per cent.) .....................

Fiber (of which digestible 16. per cent.) .......................... 19.3

Non-nitrogen matter's (of which digestible 45.9 per eent.) ................ 54.8

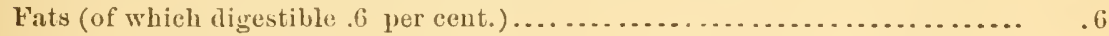

It is therefore a nutriment especially rich in carbohydrates, but one which should be anplemented $b_{y}$ some food furnishing the missing qualities; for instance, some food rich in uitrogen.

It is not necessary to saturate the dried pulp with water before giving it to cattle. Animals consume the pulp willingly in the dried state, and the experiments of Professor Maercker have shown that the nutritive effect is at least as good with all kinds of animals as when ferl the moist pulp. Mr. Kooster has had equal suecess in feeding this food to milch cows, to cattle preparing for the market, and to sheep. He has even fed it to calres of four months old, and young lambs, who tako it willingly. It has also been given to horses with success, in the proportion of from 5 to 6 pounds for each one. We seem, therefore, to have in this dried pulp a nutriment capable of any application, and which appears destined not only to play a grand role in the alimentation of cattle, but also to reuder superfiuous many other kinds of forage, and to give an opportunity to use to a considerable extent such materials as cotton-seed and linseed cakes rich in nitrogen matter. In the case of five beeves which were fattened, they received, beiscle straw and moist pulp, a mixture of dried pull, peanut cakes, sesane cakes, and cotton seed meal. During four wecks in which the effect was noted, the animals increased at the rate of from 2 to 3 pounds per day.*

FHEDING EXPERIIENTS WITI THE LEAVES AND DIFFUSED PULP OF BEE'TS. †

At the general meeting of the Central Agricultural. Society of the Duchy of Brunswick, February 25, 1890, Professor Materker gave an address upon certain recent feeding experiments, which were of special interest to the sugar interests, as the experiments treated of the values

*Jomnal des Fabricants de Snere, April 9, 1890.

† By Professor Maerker, Halle. 
of beet leares, also of the pulp, after diffusion, both in the moist and dry conditions.

Professor Maerler commenced by stating that the tables of Irolff, which allow 3 pomels of nitrogenous food matter per 2,500 pounds of the living weight of the animal, are no longer to be accepted in view of existing standards of cattle feecing. It is more advantageous to raise the allowance of nitrogenous matters, and gradually, to the relation of 5 pounds per "2,500 prounds of living weight. Contrary to the inereasing of the proportion of non-nitrogenous matters, as arvised by the Woiff tables, it may be a detriment to the animal system, and, econonically, an actnal disadrantage.

Experiments were conducted in orler to ascertain the approximate value of beet pulp after the act of diffusion. Three classes of experiment animals were fecl resprectively, with 50,75 , and 100 pounds of diffinsed pulp, dednetions being male in the other foods ferl to the animals in proportion to the respective increments of nitrogenons matter contained in the three rations specified. An increase was observed in the volume of milk given by the animals of from 12.6 and 12.7 quarts respeetjvely to 13.2 and 14.2 quarts without any depreciation of the quality of the milk being observad. On the other hand, not any increase in the living weight of the animals hat occurred, and in the examples where 100 pounds of the julp had been served to the cattle an actual diminution of weight har taken place. The maximum quantities of the diffusion pulp which it apprears alrisable to serve to the different classes of aninals are as follows: To cows in milk, 40 pounds; feerling oxen, 90 pounds; and to feeding sheep, 5 pounds. It las been further ob. served that the distillery residues ma. be served to cattle in double the quantity of the diffusion pulp providing that the animals receive the former in a wam state. As a result of this observation artificial preparations of potatoes and cotton-seed neal have been made and fed to eattle in the warm state, and with a clear gain of 4 cents per cow pere day.

There is ome other source of food for eattle which bas not received the attention which it deserves: That is the leaves of the beet. At present those materials ale merely browsed by sheep on the land where they lic, and the greater part is trodken into the soil. In some instances the leaves are mixed with the diffusion pulp and preserved in silos, or the leares are preserved in the silo alone. Professor Maerker has made several experiments at Siegersleben for the purpose of determining the food value of the beet leaves and he proposes to continue his experiments during this yual.

Ile gave to ten sleep 125 pounds of beet leaves in the form of ensilage, and to ten other sheep 90 pounds of diffusion pulp, taking care that the other foods given to the animals contained the same amounts of nitrogenons matters. The increase in wejght of the ten sheep fed with bret leaves was 3.4 jomols, and of the ten sheep fed on diffusion 
pulp, 4.1 pounds, showing an apparent advantage in favor of the latter of 23 per cent. From the stand-point of economy, however, the case was otherwise: The gain of the ten sheep fed on diffusion pulp was 4.6 cents per heal, whilst the money value of the inerease of the ten sheep fed on the beet leaves was 6.4 cents per head. It is thus seen that the greatest increase in weight may not essentially represent the greatest gain.

In certain other experiments the foods already specified were supplemented with respectively $\frac{1}{3}$ pound of cattle food prepared from poppy seed and 1 pound of rice meal for each ten sheep, when an increase of weight was observed of 4.1 pounds and a gain of 10 cents per head.

In feeding the ten sheep with beet leares, allowing the animals to consume what they liked, 169 pounds were consumed without damage to health, and yielding an increase of weight of from 4.17 to 4.8 pounds and a money value of fiom 11 to 14 cents.

In the leares of the beet there is thus found an excellent article of diet for the feeding of cattle. The leares may be valued at from 25 to 30 cents per 250 pounds. If it be calculated that one acre wili yield varying from 12,500 to 25,000 pounds, that amount would represent a food value per acre of from $\$ 25$ to $\$ 60$.

Professor Macrkel has also conducted comparative experiments with diffusion pulp in the humid and dry states, respectively, and has found the results to be demonstratively in favor of the latter. The pulp in the dry state contained from 55 to 60 per cent. of non-nitrogenous matter and $6 \frac{1}{2}$ to 7 per cent. of nitrogenous matter, 85 per cent. of the latter being digestible, whilst only 75 per cent. of the nitrogenous matter in the humid state becomes digested.

The cost of purchase of the diffusion julp in the dry state may be calculated as follows:

A Cents.

Average price of 250 pounds of dry pulp............................. 12

20 per cent. loss of waterial in ciepot .................................. 2

Cost of transport .................................................. 1

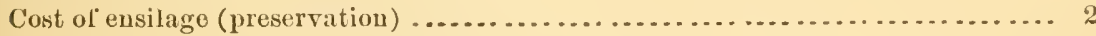

The feeding of eattle with the material in the noist state is not only inconvenient but eondncive to eertain forms of disease.

The best process for the drying of the pulp is that adopted by Messrs. Biittuer and Meyer. These gentlemen have guarantied the cost of drying shall not exceed $2 \frac{1}{2}$ cents per 250 pounds of pulp. Hadmersleben has reduced the east of desiceation to 2 cents, and expects to reduce it still further to $1 \frac{1}{2}$ cents per 2.50 pounds.

The experiments were carried ont as follows: On the one hand the moist pulp was fed to the cattle with hay or grass and a good portion $2547.1-$ Bull. $27-15$ 
of the eattle cake. On the other hand the animals received the dry pulp and a portion of cattle cake less rich in nitrogen. It has been established that the quantity of milk obtained was on the average the sime from the dry as fiom the moist pulp, and the eost of feeling with the dry julp was 2 cents per head per day less with the dry than with the moist pulp. In taking all the conditions into aecount it is estimated that the advantage in feeding cattle with dry pulp over tho moist is on an average about $\$ 14$ per head. About 20 pounds of the dry pulp is equal to 130 pounds in the moist state.

The cultivators shonld endeavor to get the sugar manufacturers to commence the system of desiceating the pulp, either alone or in agreement with the eultivators, in orler that a large proportion of that feed. ing material which at present is allowed to waste may be wholly utilized in the feeding of cattle.

\section{MANUFACTURE OF SUGAR.}

The process of the inanufacture of sugar from the sugar-beet is one which interests the agriculturist only from secondary considerations and for this reason will be treated of in this bnlletin in the briefest possible manner to give an intelligent idea of its methods. 'The process of manufacture is no longer an experiment but a positive method, from which, with beets of a given richuess, a definite output of sugar cau be caleulated.

The beets, having been properly harvested and delivered to the faetory, the general process of manufacture is as follows:

The beets are first conveyed to washing-tanks provided with suitable apparatus for keeping them in motion and transferring them toward the end from which the fresh water enters, in order that the whole of the adhering soil, together with any sand and pebbles, may be completely removed. By a suitable elevator, the beets are next taken to a point above the center of the battery, whence they are dropped into a slicing apparatus. This apluratus is provided with kuives with serrated edges, by which the beets are slicel into pieces of greater or less length and of small thickuess, so that when placed in the cells of the battery they will not lie so elosely together as to prevent the cirenlation of the diffusion juices. The slices, eommonly ealled cossettes, vext pass into the diffusion battery in which the sugar is extracted in the usual way. The extracted cossettes are carried through a press by which a portion of the water is removed, and they are then in suitable condition for use as cattle food. The diffusion juices are carried to curbonatation or saturation tanks, where they are treater with from 2 to 3 per cent. of their weight of lime and afterward with earhonic acid nutil nearly all of the lime is precipitated. The slightly alkaline juices are next passed through filter presses by which the percipitated 
lime and other matter are removerl. The juices pass next to a second set of earbonatation tanks in which they undergo a treatment in each particular similar to the one just mentioned, except that the quantity of lime added to the second saturation is very small as compared with that of the first. The refiltered juices from the second saturation are carried to the multiple effect vacum-pan and reduced to the condition of sirup. The sirups are taken into the vacunm strike pan and reduced to sugar called masse cnite, containing from 6 to 10 per cent. of water. The uncrystallized sirups together with the water are separated from the sugar by the ecutrifugals, and form the molasses. The molasses is either reboiled and a second erop of crystals obtaineil, or is treated in various ways for separating the sugar which it still contains. One of these methods which has come into general use is known as the Steffen process, and is deseribed in detail further on. Another method consists in separating the salts which prevent the erystallization of the sugar by the process of osmosis. A third method consists in the use of strontium salts for the separation instead of line salts as in the Steffen process; or, fiually, the molasses may be subjected to fermentation and distillation and the sugar therein contained thus converted into alcohol.

The above is the general method used for the manufacture of raw sugar. If refined sugar is to be made the juices aud sirups are prassed over bone-black to decolorize them and the crystals are washed in the centrifugal in order to make them perfectly white. Another method of purifying the erystals consists in washing them with sirnps of rarying degrees of consistency until all the molasses aldhering thereto is washed away. For the details of the rarions processes with the exception of the Steffen process, which is given further on, standard works on beet-sugar mannfacture may be consulter.

The following observations on the manufacture of beet sugar are taken from Mr. Spencer's report in Bulletin No. 5, of the Chemical Division, Department of Agrieulture, pages 107, et seq.

\section{${ }^{6}$ EXTRACTION OF THE JUICE.}

"The most usual methou for extracting the juice from the beet is by diffusion. This process has been so snecessful that now but comparatively few sugar-houses employ presses, either hydraulic or continulols.

"Diffusion batteries may be divided into two classes:

"(1) The ordinary, cousisting of a number of cells.

"(2) The continuous, having but one cell. The first may be divided into (1) battery in line, (2) circnlar batters.

"The ordinary diffusion battery is composed of several cells, usually twelve in number. They are so arranged that as soon as one cell or diffuser is charged with beet cuttings it is closed and warm witer forced 
into it. The water takes up a portion of the sugar aud then enters a second diffuser charged with fresh euttings or cossettes.* This operation is repeated, nutil the juice from the first diffuser, laving passed through a certain number of cells, leaves the last heavily charged with sugar.

"In working a diffusion battery, one diffuser is being charged and a second emptied while the rest of the battery is under pressure.

"The arrangement of a battery, whether in a line, a donble line, or a circle, depends quite often upon the space at the disposal of the sugar maunfacturer. The cirenlar arraugement requires a higher building

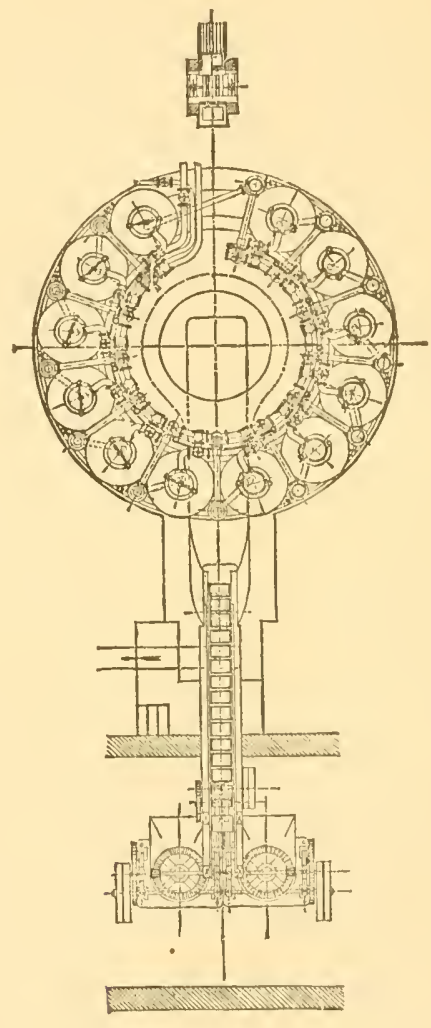

Fir. 46 ,

owing to the position of the slicing machines, but nevertheless it is usually considered preferable to a line battery. Among the special advantages of a cirenlar battery is the economy of labor. Another advantage, and quite an important one, is that all the diffisers are under the immediate control of the workman in charge. The beet slicer is placed above the battery, a swinging fumel conlucting the cossettes

*Cossettes in Froueb, Schuitzel in German. 



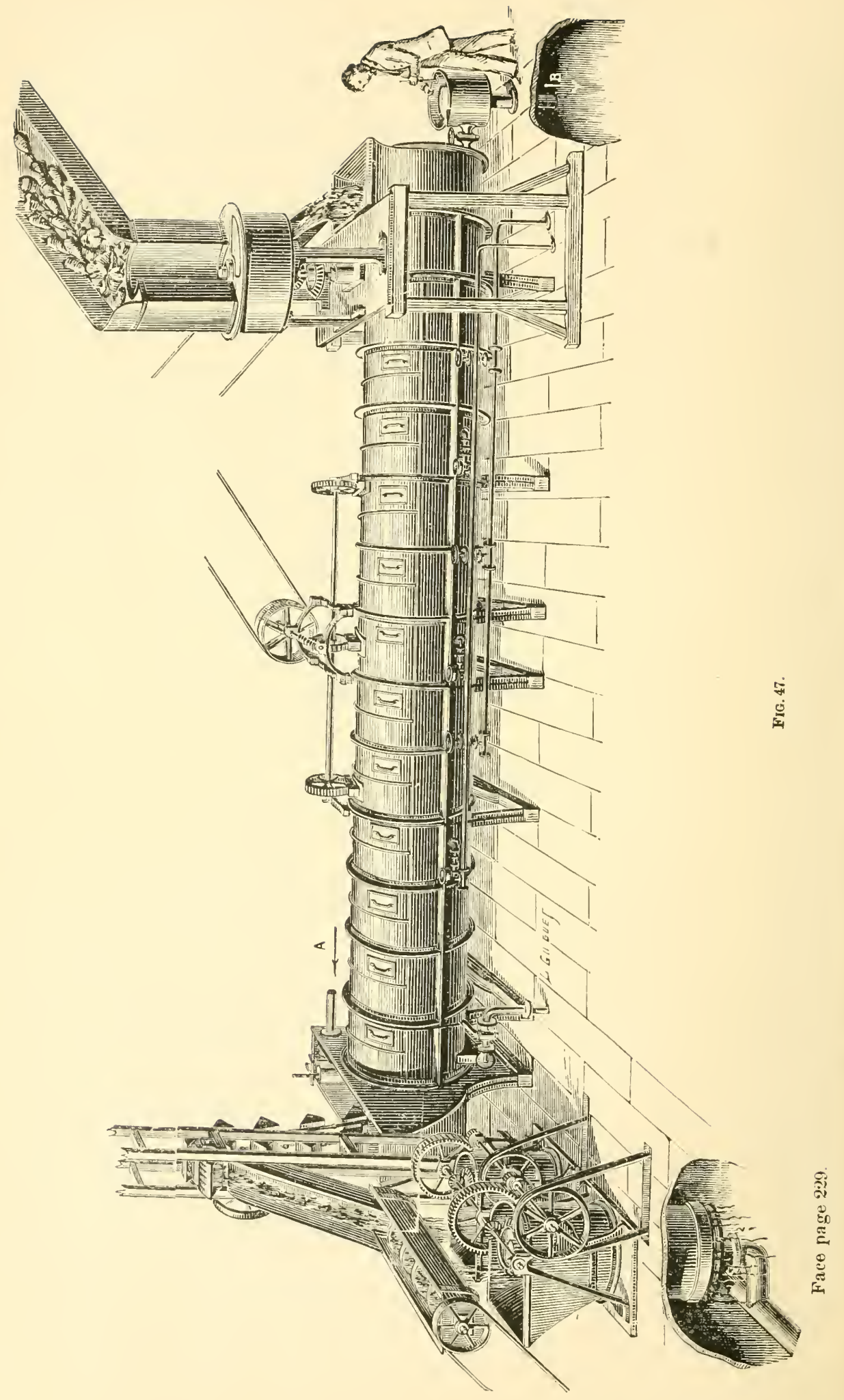


into the diffusers. The exhausted cossettes, or pulp as they are termed, are dropped into a channel below and thence carried to the continuous presses by a chain and bucket elevator.

"As I have indicated, the line battely differs from the circular only in the arrangement of the diffusers and the carrier necessary to charge them.

"Fig. 9 illustrates a circular battery, Riedel's system, constructed by the Hallesche Maschinenfabrik, Halle a. S.

\section{" THE CONTINUOUS DIFFUSER.}

"Shce the inrention of what is termed the German diffision process, by liobert, it has been a farorite idea to derise a coutinuous diffuser. Robert himself attempted this, but without success. About six years ago Mr. Charles invented a continuous diffuser, which was afterwards successfully modified by Mr. Peret, of Roye, France. The following description of the continuous diffuser has been taken from the Bulletiu de la Société Industrielle d'A miens, 1882:

"The continnons diffuser consists of an iron cell, cylindrical in form, resting horizontally npon a foundation of masonry. Witlin this cell is a perforated irou cylinder, 1.30 meters ( 4.26 feet) in diameter and 11.20 meters ( 36.74 feet) in length. The axis is formed by a smaller eylinder. Between these two cylinders is a helix, pitch 70 centimeters (2.3 feet). The inner eylinder is revolved by a suitable commection with a shaft. The speed of revolntion is so adjusted that it recunires 60 minutes for the beet cuttings to traverse the length of the helix. The cossettes are eontinually inmersed in water. The water enters the cell at the end where the exhaustel cossettes are expelled. An antomatic arraugement controls the amount of water admitted and keeps it at a certain level. The water gradually becones charged with sugar and finally leaves the cell at the end where the fresh cossettes enter it.

"The conditions for a good diffusion are fulfilled when the cossettes and water move in opposite directions, the juice becoming more aud more concentrated as it passes cossettes richer and richer in sugar.

"The water enters at a temperature of $30^{\circ} \mathrm{C} .\left(86^{\circ} \mathrm{F}\right.$.). It is heated as it passes the coils placed between the fixed cell and the revolving cylinder, and its temperature is gradnally increased to $75^{\circ} \mathrm{C}$. or $80^{2} \mathrm{C}$. $\left(167^{\circ}\right.$ or $176^{\circ} \mathrm{F}$.), and then, as it strikes fresh cossettes, it gradnally becomes colder and leaves the diffuser at a temperature of $50^{\circ}$ C. to $60^{\circ} \mathrm{C}$. ( $122^{\circ}$ to $140^{\circ} \mathrm{F}$.).

"Three small vertical test eylinders are placed at equal distances from one another and serve for determining the specific gravity and the temperature of the juice. These observations are uade at regular intervals and the results are entered in a note-book.

"In the ordinary form of diffusion battery the ten or twelve eliffusers demand the constant attention of a skilled workman. He must open and close the varions valves from six to seven hundrerl times in the twelve hours he is on dnty.

"The continuous diffuser requires but little attention after one has regulated (1) the speed of the slicer, (2) the speerl of the elevator which removes the exhausted cossettes, (3) the speed of rotating cylinder, (4) the pressure of steam on the coils, (5) the exit of the juice whieh controls the entrance of the water.

"It is only necessary to note the temperature at intervals and regulate the pressure on the coils. The temperature and the quality of the beets are the only variables. Oue man and a boy are suthicient to contuct the dliffuser, leet slicer, and pulp presses. 
"The following certificate will (xplain itself.

"Complete machinery for working "2,000 hectoliters (14,000 gallous) of juice in twenty-four hours, including engines, beet stieer, tho diffuser (with clevator for exhansted cossettes), Klusemann pulp presses, and transmission of power, ete; total cost, 50,000 francs $(\$ 10,000)$; cost of repairs per season, 500 to 700 tranes $(\$ 100$ to $\$ 140)$.

"Isabor per ton of beets worked, not including washing the beets, 16 centimes (3.2 cents).

\section{Results obtained.}

Mean density of 2,000 hectoliters of juice -1. 036 Beats, per 100 liters, and rach legreo of Jensity ............. kilogranı.. Masse cuite per 100 kilograms of beets . . . . . . . . . . . . . . . . . . liters..

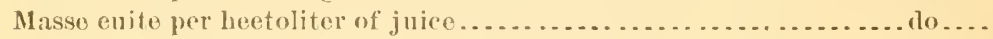
First sugar, white, per 100 kilograms of beots.............. kilograms.. Sngar per 100 liters of nasse cuite..............................

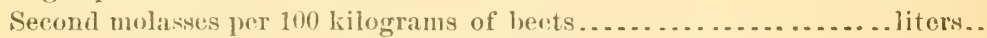
Seeond molasses per 100 litere of first masse enito . . . . . . . . . . do ....

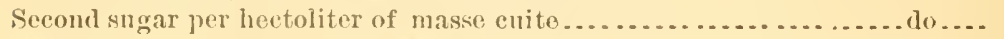
Molasses per 100 kilograms of masse cuite .......................... 44. Beets, pel 100 kilogramis of masso cuite................... kilograms.. $\nmid 1,000$.

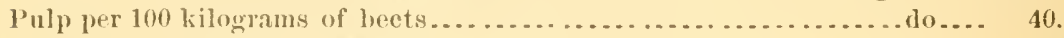
Sugar por 100 kilograms of pulp............................... 0.41

The following table shows the results obtained in the sugar honse at Roye (Somme), France:

Table showing the extraction-Roye sugar house (France), 1881 and 1882.

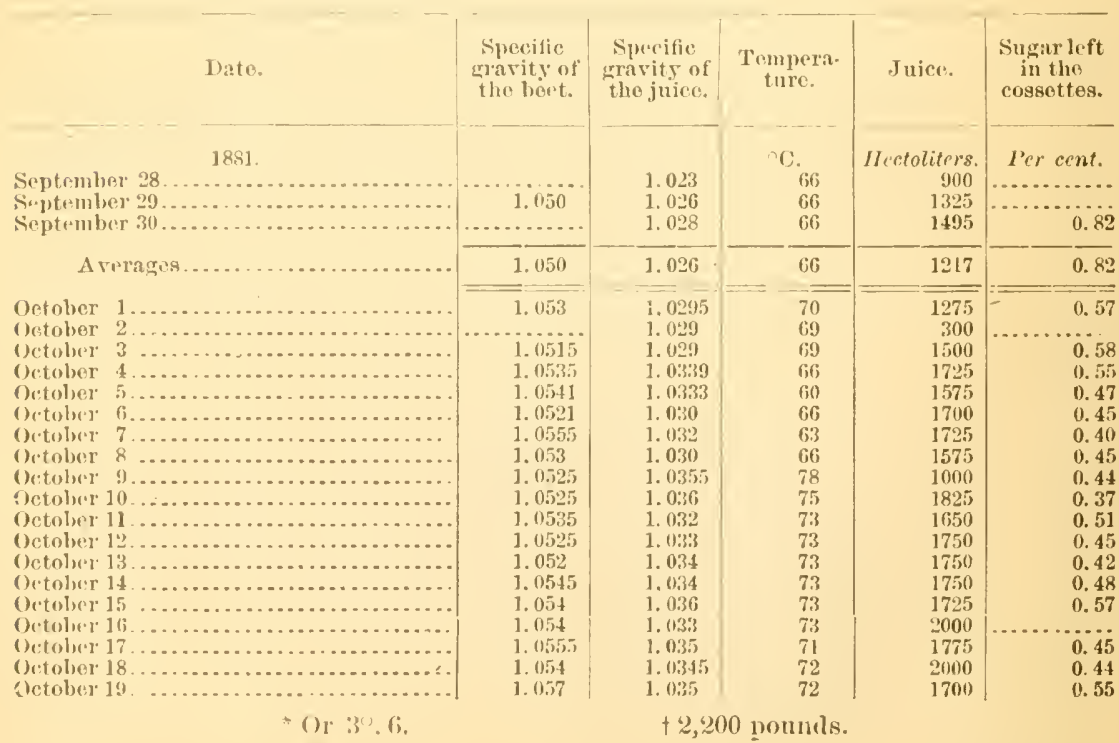


Table showing the extraction, etc.-Continned.

\begin{tabular}{|c|c|c|c|c|c|}
\hline Date. & $\begin{array}{l}\text { Specifie: } \\
\text { gravity of } \\
\text { the beet. }\end{array}$ & $\begin{array}{l}\text { Specifie } \\
\text { gravity of } \\
\text { the juice. }\end{array}$ & $\begin{array}{c}\text { 'J'mpera. } \\
\text { turo. }\end{array}$ & Juice. & $\begin{array}{l}\text { Sugar loft } \\
\text { in tiue } \\
\text { cossettes. }\end{array}$ \\
\hline 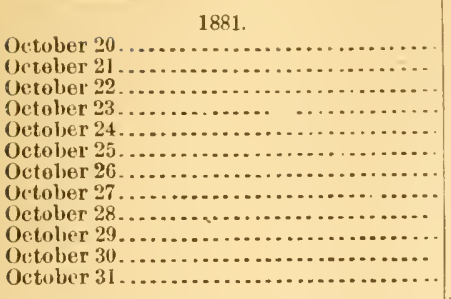 & \begin{tabular}{|l|}
1.0535 \\
1.055 \\
1.0548 \\
1.055 \\
1.0535 \\
. .055 \\
1.055 \\
1.049 \\
1.051 \\
1.055 \\
1.055 \\
1.054
\end{tabular} & $\begin{array}{l}1.032 \\
1.033 \\
1.033 \\
\ldots . . .2 . \\
1.030 \\
1.030 \\
1.0347 \\
1.0349 \\
1.035 \\
1.0353 \\
1.0377 \\
1.0378\end{array}$ & $\begin{array}{l}70 \\
66 \\
69 \\
76 \\
77 \\
78 \\
78 \\
78 \\
78 \\
77 \\
78 \\
78\end{array}$ & \begin{tabular}{|r|} 
ITectoliters. \\
1675 \\
1600 \\
1200 \\
300 \\
1700 \\
1800 \\
1800 \\
1850 \\
1900 \\
1975 \\
2000 \\
1875
\end{tabular} & $\begin{array}{r}\text { Per cent. } \\
0.50 \\
0.57 \\
0.60 \\
0.45 \\
0.48 \\
0.52 \\
0.40 \\
0.38 \\
0.39 \\
0.40 \\
0.41\end{array}$ \\
\hline Averages......................... & 1. 0549 & 1.0339 & 71 & 1725 & 0.51 \\
\hline 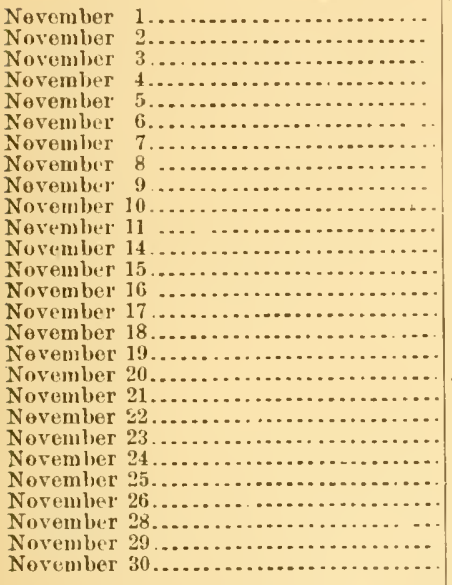 & 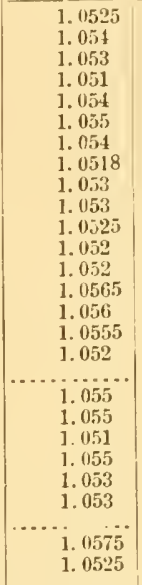 & $\begin{array}{l}1.0367 \\
1.0367 \\
1.0364 \\
1.0369 \\
1.0378 \\
1.0366 \\
1.0365 \\
1.0365 \\
1.0365 \\
6.0363 \\
1.0368 \\
1.0381 \\
1.0372 \\
1.0372 \\
1.0366 \\
1.0363 \\
1.0358 \\
1.0357 \\
1.0357 \\
1.0357 \\
1.0351 \\
1.035 \\
1.0357 \\
1.0349 \\
1.0348 \\
1.0348 \\
1.0346\end{array}$ & $\begin{array}{l}78 \\
79 \\
79 \\
79 \\
79 \\
79 \\
79 \\
80 \\
80 \\
80 \\
80 \\
89 \\
72 \\
75 \\
76 \\
75 \\
78 \\
78 \\
72 \\
74 \\
76 \\
77 \\
78 \\
78 \\
78 \\
77 \\
77\end{array}$ & $\begin{array}{r}1950 \\
1950 \\
1925 \\
2025 \\
1975 \\
1450 \\
1875 \\
1900 \\
2000 \\
1825 \\
1625 \\
1275 \\
1925 \\
2000 \\
2000 \\
1925 \\
1950 \\
1400 \\
1775 \\
2625 \\
2000 \\
2000 \\
2000 \\
2000 \\
575 \\
1950 \\
2025\end{array}$ & $\begin{array}{r}0.40 \\
0.39 \\
0.39 \\
0.40 \\
0.43 \\
0.41 \\
0.54 \\
0.14 \\
0.14 \\
0.37 \\
0.44 \\
0.36 \\
0.40 \\
0.39 \\
0.39 \\
0.40 \\
0.44 \\
\ldots .30 \\
0.40 \\
0.32 \\
0.34 \\
0.36 \\
0.25 \\
0.30 \\
\ldots .50 \\
0.48 \\
0.48\end{array}$ \\
\hline A verages........................ & 1. 0535 & 1.0361 & 77.5 & 1940 & 0.40 \\
\hline 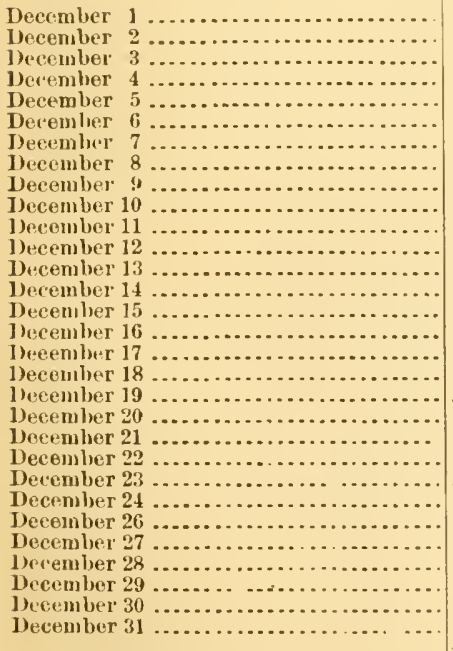 & $\begin{array}{l}1.0525 \\
1.051 \\
1.052 \\
1.051 \\
1.0505 \\
1.050 \\
1.051 \\
1.053 \\
1.049 \\
1.0505 \\
1.050 \\
1.051 \\
1.050 \\
1.0477 \\
1.0495 \\
1.0495 \\
1.0485 \\
1.050 \\
\ldots .25 \\
1.0525 \\
1.053 \\
1.0508 \\
1.25 \\
1.0461 \\
1.051 \\
1.050 \\
1.050 \\
1.0148 \\
1.045 .5 \\
1.046 \\
\text {. }\end{array}$ & $\begin{array}{l}1.0351 \\
1.036 \\
1.0365 \\
1.0353 \\
1.0352 \\
1.0356 \\
1.0350 \\
1.0358 \\
1.0369 \\
1.0357 \\
1.0364 \\
1.0355 \\
1.0361 \\
1.0359 \\
1.0363 \\
1.0357 \\
1.0356 \\
1.0352 \\
1.0326 \\
1.038 \\
1.041 \\
1.0403 \\
1.0: 392 \\
1.0380 \\
1.0387 \\
1.0383 \\
1.041 \\
1.039 \\
1.0395 \\
1.0396\end{array}$ & $\begin{array}{l}78 \\
78 \\
79 \\
83 \\
86 \\
84 \\
84 \\
86 \\
86 \\
85 \\
85 \\
82 \\
81 \\
80 \\
81 \\
80 \\
86 \\
82 \\
85 \\
82 \\
87 \\
87 \\
88 \\
86 \\
87 \\
89 \\
90 \\
90 \\
90 \\
91 \\
\end{array}$ & $\begin{array}{r}2000 \\
2050 \\
1950 \\
1900 \\
2000 \\
1975 \\
2000 \\
1975 \\
2000 \\
1950 \\
845 \\
2000 \\
2000 \\
20000 \\
2000 \\
2000 \\
2000 \\
1375 \\
450 \\
2000 \\
2050 \\
2050 \\
2000 \\
1575 \\
1400 \\
2060 \\
2000 \\
2000 \\
2000 \\
2050 \\
\end{array}$ & $\begin{array}{r}0.43 \\
0.33 \\
0.36 \\
0.38 \\
0.37 \\
0.38 \\
0.39 \\
0.35 \\
0.48 \\
0.39 \\
0.36 \\
0.32 \\
0.35 \\
0.42 \\
0.37 \\
0.37 \\
0.44 \\
0.44 \\
0.65 \\
0.79 \\
0.88 \\
\ldots \ldots \\
\ldots .59 \\
0.52 \\
0.51 \\
0.52 \\
0.46 \\
0.45 \\
0.48\end{array}$ \\
\hline Averages.. & 1. 050 & 1. 038 & 84.5 & 2000 & 0.44 \\
\hline
\end{tabular}


Table showing the extraction, cte.-Continned.

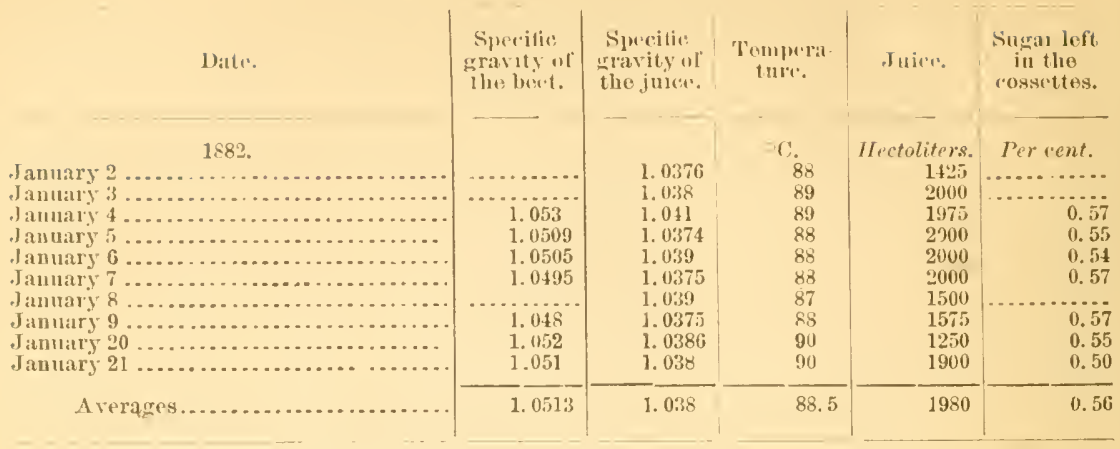

"It may be safely stated that in Germany and Austro-Hungary not less than 90 per cent. of the sugar-houses employ the diffusion process for extracting the juice. The proportion in France is much smaller, owing to the tax being basel upon the sugar actually extracted. Since the passage of the new law, levying the tax as in Germany, many French sugar-houses have arlopter this process. I believe that in a fow years the affusion wili be the only process employed for extraction, except in a few districts where local conditions prevent its adoption.

\section{"EVAPORATION.}

"The economical eraporation of the juice is one of the most important problems with which the sugar manuficturer has to deal.

"The hydraulic presses yield 100 pounds of dilute juice per 100 pounds of beets. With the diffusion process this proportion is considerabiy larger, being 120 pounds dilute juice per 100 pounds of beets. It is evident from the above statements that a beet-sugar house employing the diffusion process must be supplien with evaporating facilities at least one-fifth greater than one employiug hydraulic presses. Inventors have not been backward in their efforts to meet this demand for improvements in the apparatus for rapid and economical evaporation.

"One of the most recent and important improvements in multiple. effect apparatus is known as the Welner.Jelinek system.*

* Since the ahove was written three or four new multiple-effect pans have been invented in this country. Information concerning them may be had by aldressing the Kilby Manufacturing Compauy, Clevelaud, Ohio; Thouns Gaunt, 115 Broadway, New Tork; Geo. N. Newhıll Company, Philakelphia; Fort Scott Foundry, Fort Scott. Other makers of evaporating apparatus are John 'Turl \& Sons, No. 534 West 'Twentyeighth street, New York; Erwards \& Hauptunan, 22 Front street, New Orleans; Josepl Oat of Sons, 2:S Quarry street, Philadelulsia; Whitney Iron Works, New ()rleaus; John S. Moore, 169 Gravier street, Now Orleans; John H. Mnrphy, 123 Magazine street, New Orleans; H. Dulloy Coleman \& Co., No. 9 Perdidlo street, New Orleatus; Iderls d Co., New Orleans; Colwell Iron Works, 74 Cortlandt street, New York; The J'nsey of Jones Manutacturing Company, Wilmington, Del.; 'Tho Sifuier Manuficturing Compang, Buftiılo, N. Y. ; Rolert Deely, Brooklyn, N. Y. 
"In this system the pans are arranged horizontally and the heating space is divided into two chmbers-an mper and lower. This division into ehambers permits the passage of the vapors from the npper to the lower, facilitating the discharge of the water of eondensation, and increases the heating surface. These chambers are each subdivided into two others of unernal size. The shape of the pan reduces the danger of loss throngh particles of the juice becoming entangled with the disengaged vapors. In addition there is also the nsual arrange. ment for diminishing this loss."

¿TREATMENT OF TIIE JUICE.

"Preliminary to describing a few of the more important processes employed in the mannfacture of sugar from the beet, it mas be well to indicate briefly the usual method for treating beet juices.

"Un fortnuately, the simple proeess employed for clarifying cane juices is not at all sneeessful with the beet. Beet juice contains but slight traces, if any, of glucose or reducing sugar, whereas the eane juice usually carries a notable quantity of this substance.

"In treating beet juices a large excess of lime is adderl, nsualls from 21 to 3 per cent. Carbonie acid gas is then forced throngh the juice, and the excess of lime is precipitated in the form of a carbonate, and carries lown with it mechanieally many of the impurities. This operation is terminated when the lime preeipitate beeomes granular and settles readily. At this point there still remains about a gram and a lialf of lime $(\mathrm{CaO})$ per liter of juice. After having been passed through filter presses the juice is treated, boiling hot, with $\frac{1}{2}$ per cent. of lime, and carbonic aed is passed through it, until all the lime is precipitatea. This operation is termed the saturation, the former the first carbonatation. The juice is again filtered through presses. Its further treatment is very similar to that of the eane.

"Experiments have been made by Dr. Wiley* which indieate that a modification of this process could be suceessfully emplosed with eane juices. This methor would be espeeially applieable in the manufaeture of sugar fromt sorghum or in the treatment of very dilute diffusion juices.

"The raeum pans emplojed in boiling beet sugar are nsually vers high in proportion to their diameter, in order to enable the panman to build up large crystals.

"As a rule, in Germany, the first sugars are not washed, and polarize 96 per eent. In France, on the eontrary, those houses having facilities for making white sugar usually do so, and turn out an article polarizing $\mathbf{9 9} \cdot$ per cent.

* Bulletin No. 3, Chemical Division, Uniterl States, Department Agrienlture, 1884. t For more recent experiments ou a maufacturing scale, see Bulletins, Nos. 6 aud 14. 
"This sngar-house is located about 15 miles from IIalle. The works were erected by at stock company. The stock is divided into 150 shares of 6,000 marks $(\$ 1,500)$. Each share-holder bunds himself to furnish the beets from a certain number of aeres of land, for which he receives 22 marks (\$5.17) per 1,000 kilograms (2,200 pounds), and, in addition, the pulp from his beets. Other farmers are paid 25 marks (\$5.87) per ton of 1,000 kilograms, and receive no pulp; but, if they prefer it, they are paid in the same way as the share-holders. This insures a plentiful supply of beets, and is the plan generally adopted by German sngar-houses.

"The soil of the surrounding country tribntary to Stoebnitz is rather a light clay, easily worked, and eapable of producing an exeellent beet. The sugar-house furnishes the seed to the farmers. Selected samples from the field have polarized as high as 22 per cent. suerose. Glueose is only present in immature beets, or in those which have sprouted in the silos.

"The Stoebnitz sugar-house is located in the center of a great depression, the neighboring hills sloping gradually to it. It is readily accessible by good country roads radiating in all direetions. Its location possesses many advantages, and but one serious disad vantage. This latter . is its distance from rail eommunication.

"The greater part of the machinery has been constructed by the Hallesche Maschinenfabrik. Mr. Roediger, a mechanieal engineer connected with this establishment, kindly accompanied me on my visit to Stoebnitz.

"As the acreage tributary to Stoebnitz has inereased from time to time, the works have gradually reached their present magnitude through suecessive enlargements; hence, as one would naturally expect, the arrangement of the buildings and machinery is not such as would give the greatest econony of labor. Old walls, constructed for a smaller sugar-house, hare imposed many restrictions upon the manager in the disposition of his machinery. Notwithstanding the disad vantages under which he labored, he has succeeded in building up a model sugar-honse.

"The carts and wagons are driven direetly into the beet shed and discharge their loads through trap-doors into the receiving-room below. Here a large force, composed mostly of women, throw the beets upon the earrier, which transports them to the washers, two in nnmber. The washed beets are then earried by an elevator to an upper story and dumped into ears, to be weighed by the excise officer. The weighed beets are then sliced and conreyed to the two diffusion batteries. These batteries are ranged in a double line, twelve diffusers in each line. They have an united eapacity of 600 tons of 2,200 pounds, in twentyfour hours. The batteries are of the Riedel type, construeted some years since. Between the two lines is a large trough to receive the 
exhausted eossettes, whence they are conreged to six eontinuons pulppresses, four of the type kuown as Klusmam and the other two Bergreen.

"The pressed pulps still contain from 75 to 85 per cent. of water, and in this moist condition are 40 per cent. of the weight of the beets worked. This pnlp is very valuable as cattle fool, and sells for about $\$ 1.70$ per ton. The relative values of diffusion and the old hydraulie press pulps is still a much debated question in some sugar comntries. The juice from the diffusers is condncted to a calorisator, where it is heated to abont $90^{\circ} \mathrm{C} .\left(194^{\circ} \mathrm{F}\right.$. $)$ and is then treated with lime.

"By the use of calorisators (Fig. 15) it is claimed that the heat expended in the process of diffusion is not lost, and that subseruent op-

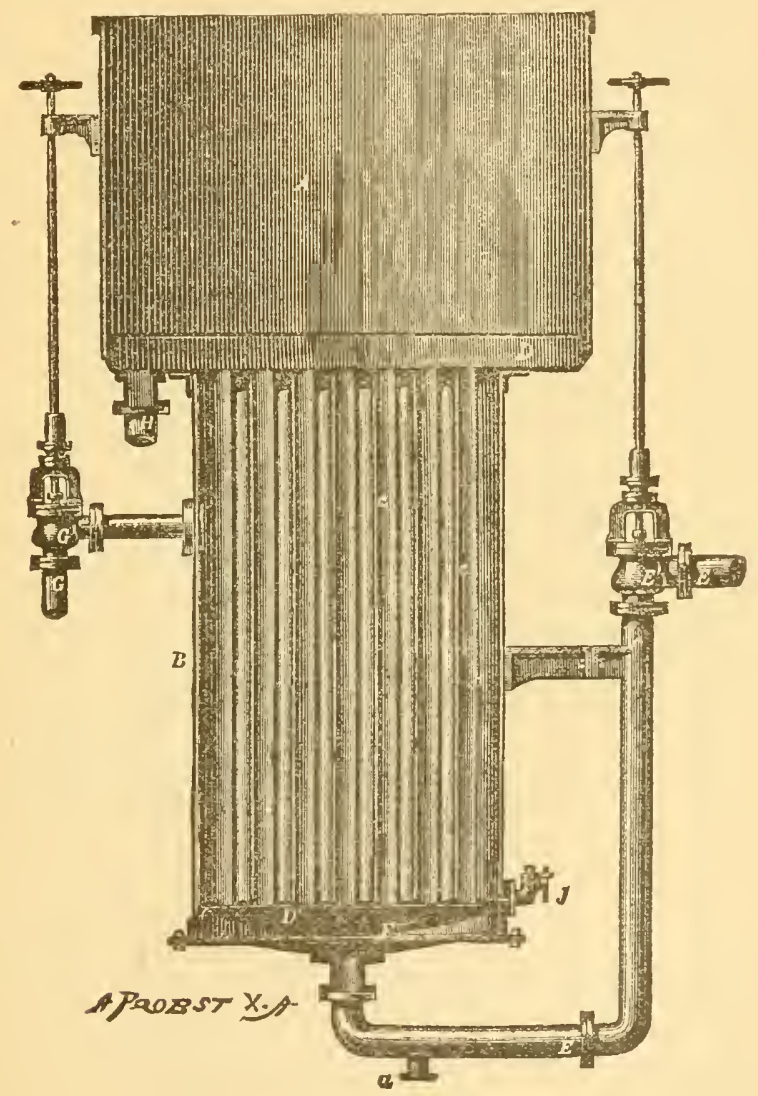

Fig. 48 .

erations are carried on much more rapidly than by the old metlod. Generally in France the juice is conducted into tanks, whence it is drawn off as neeled for the carbonatation pans. Consequently it loses much of its heat, and the first carbonatation demands a longer time. This entails a much larger number of earbonatation pans. As at Stoebnitz, 
also generally in Germany, the carbonatation pans are covered and the foam is kept down by a jet of live steam. In many French sugar-houses, where large open pans are employed, the foam is beaten down hy an arrangement of paddles, driven by machinery, and often in addition by a jet of steam.

"The French mannfacturer usnally commences his first carbonatation at a low temperature, $40^{\circ} \mathrm{C}$. (104 F.), which he gradnally increases as the carbonatation progresses. By this means he claims that he avoids dangerous combinations between the lime, carbonic acid, and the sugar.

"At Stoebnitz ahout $2 \frac{1}{2}$ per cent. (of the weight of the beets) of lime is employed in the defecation, and the usual quantity, abont $1 \frac{1}{2}$ grams per liter, is left in the juice after the first treatment with carbonic acid.

"The carbouatated juice, including the suspended precipitate, is sent to the filter-presses. The precipitate is washed with hot water and the washings are added to the filtrate. The filtered juice is treated with a second portion of lime, one-fourth of 1 per cent. of the weight of the beets; the lime is again precipitated by earbonic acid and the juice is passed throngh the filter-presses; a third portion, abont a liter and a half of cream of lime, is then added and afterwards saturated with sulphurous acid. After passing the filter-presses, the juice is concentrated to $23 \circ \mathrm{B}$.

"This sirup is treated with a final and very small portion of lime, which is precipitated by carbonic acid, and the sirnp after filtration is boiled to grain.

"Tliss sugar-house has two double effeets, one of the ordinary tyle, and the second the Welner.Jelinek system.

"The vacuum pans have a capacity, one of 60,000 pounds dry sugar, and the other 25,000 poimds.

"The massecuite is dropped into small coolers, each of about one liectoliter capacity. These coolers are shaped like the frustum of a pyramid, and ean be readily transported by means of a small twowheeled carriage. (See Fig. 49.)

"It requires but little more time to fill these coolers than to drop the masse-cuite into the larger mixers common in Louisiana. The massecuite is expelled from the cooler by compressed air. The cooler itself weighs abont 50 pounds, aud when filled with masseenite: 400 pounds.

"The manager of the Stoebnitz sugar-house stated that he obtains from 4 to 6 per cent. (of the weight of the massecuite) more sugar by allowing it to become perfeetly cold before swinging out.

"The next portron of these works that deserves more than this pass. ing notice is the chemical laboratory. It is evident, from the fact that a rery large proportion of sugar-houses employ chemists, that the German manufacturers fully appreciate the advantage of a chemical control of the work. Most of the important improvements in processes have had their origin iu the laboratory. 
"The Stoebnitz works have an excellent laboratory. It is located on the second floor and oceupies two large, well lighted and rentilated rooms. The chemist and his assistant keep a chemical control of all the processes. The juice and diffusion pulps are eximined at frequent intervals. Samples of the beets from each lot brought to the sugarhouse are also analyzed. The laboratory is one of the busiest parts of the sugar-house.

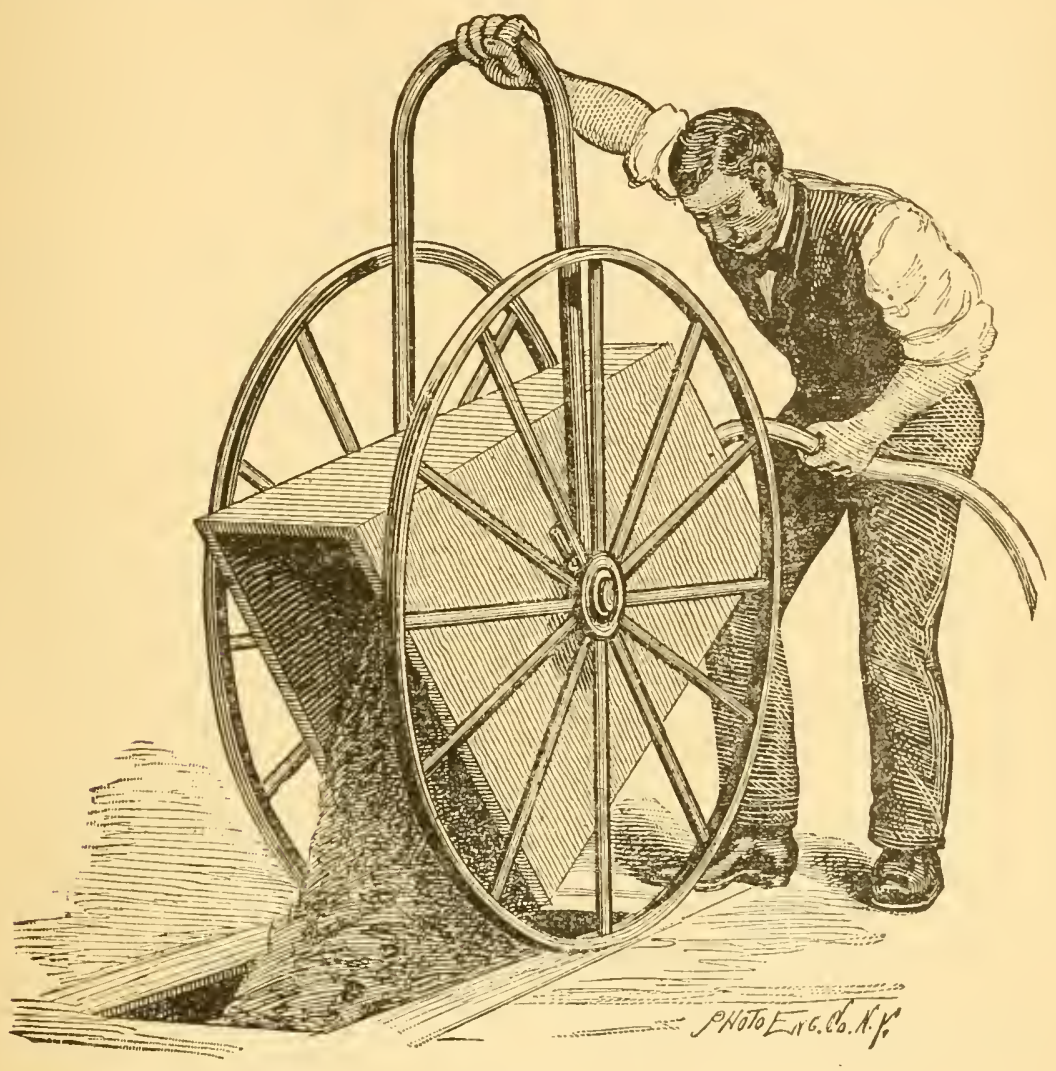

Fig. 49

"Stoebnitz has uusurpassed advantages for the economical generation of steam. Within 600 yards of the sugar-house there is an inexhanstible mine of lignite or brown coal. This lignite is mined very extensively, and trausported upon a tram-way to the works, and is dumped into large hins ahove the boilers. By au automatie arrangement it is fed directly nipon the fires.

" Lignite furnishes an excellent fuel, but yields only alront a third as much heat as bitnminous coal. 'The ash amonnts to about 14 per cent. The cost of lignite delivered at the machine works in Halle is less than $\$ 1$ per ton. Good bituminous coal costs in the same locality from $\$ 3.75$ to $\$ 4.50$ per ton. 
"The surgar fiutory at Camburg is situated on the river Saale, about 25 miles from Halle. The buildings are located abont 100 yarks from the river, from which the works derive an unfailing supply of water.

"Comparatively fow beet-sugar houses have equal water advantages. In most factories the rapors from the evaporating juices are contensed and the water is used again and again. This necessitates a special arrangement for cooling the water. This consists of a framo-work, supporting bundles of willow twigs, over which tho water passes, falling from one bindle to another, until it finally reaches the reservoir which supplies the factory.

"A branch railway has been constructer, connecting with the main line, and beets are bronght in and dumper directly into the carriers. These latter consist of a system of narrow cement-lined trenches, through which a constant stream of water is 1lowing.

"The rapidly-flowingenrent propels the beets, and finally drops them into a box, from which they are carried by an elevator to the washers, two in number.

"This hychaulic carrier, as it is termed, is a rery convenient and eco nomical method for transporting beets, and for factories having a good water supply can be highly recommended. The trenehes are easily constructed, and are so arranged that they admit of ready access for repairs. The water of condensation furnishes the supply for the conduits.

"The washed beets fall upon a perforated plate, which is rapidly shaken by machinery in order to thiow off the water and dry them as much as practicable. This is evidently very important, as an excise tax is levied on the washed beets. The wator so thrown off amounts to at least 2 per eant. of the weight of the beets.

"The diffusion battery is of the Hallesche Machinenfabrii construc* tion, and has all the latest improvements.

The diffusers are arrangel in a circle and discharge the pulp into a central basin, whence it is lifted to the presses by a chain and bucket elevator. The helix form of elevator for pulp is no longer used with Riedel's battery, as it will not work satisfactorily at so great an angle as $45^{\circ}$.

"The presses are of the Bergreen type. It will be noticed that two presses only are required to do the same work as three at Stoebnitz. The plocess employed at Camburg for extracting the sugar from th juice does not differ materially from that in rogne in most of the sugarlouses in France. The only difference is in the reheating of the juice coming from the cliffusers, before earbonatation; this is accomplished by two calorisators, in one of which the temperature is raised to a certinin degree by exhaust-steam and in the other to $90^{\circ} \mathrm{C}$. by direct steam. I wonld again call attention to this idea of conducting the first carbonatation at a high temperature. 
"Not laving been able to seeure analyses of the juice, I ean not say whether the results are better than hy the old process or not." This method certainly has the advantage of hurrying the precipitation, and by diminishing the time required, a few pans will do the work of several working in the old way, and there is still another adrantage. Since the preeipitation is accomplished so much more rapilly, it is evident that the carbonic acid is better utilized and that the waste is reduced to a minimum.

"A series of montes jus are employed to foree the juice to any part of the sugar-house. Instead of steam pressure,compressed air is employer. As soon as a monte jus is emptied, the air-pmin is connected with it and the air is foreed into another. By this method the power expender in compressing the air is economized. The use of compressed air instead of high-pressure steam is not only much more economieal, but in addition possesses the alvantage of not injuring the juice.

"The quantities of lime (CaO) employed are as follows: 1st. Carbona. tation 2.25 to 2.5 per cent. of the weight of the beets. Saturation, .25 per cent. 1.0 to 1.5 grams lime per liter of juice is left after the first earbonatation; after the saturation 03 to .04 gram.

"The lime is placed in wire baskets, which are lowered into the earbonatation pans. This plan is considered preferable to adding slacked lime.

"The lime precipitate, usually termed seum o" mul, is washed in the filter-press by a stream of water. This preeipitate amounts to about 6 per eont. of the weight of the beets worked.

"While on this subject it may be well to speak of two of the more important processes for the recovery of the sugar left in the scums.

"The proper treatment of the seums is of very great importance. Unwashed seums contain about 4 per eent. sugar, and amount to at least 9 or 10 pounds per hundred pounds of beets. This corresponds to a loss of .36 to .40 per cent. sugar, or 7.9 to $\$ .8$ pounds of sugar per long ton of beets.

"By means of an ingenious device for washing, Mr. Charles Gallois has sueceeded in reducing the loss of sugar to from. 20 to .40 per cent. of the scums.

"This device consists of a three-way valve, so arranged that the filterpress can be placed in communication with either the monte jus containing the scums, a mixture of scum and hot water, or boiling water. This simple device can be attached to any filter-press.

"To operate the press: Upen wide the valve connecting with the seums. The press soon fills. When the volume of juice flowing from the press climinishes perceptibly, ehange the valve and admit scums diluted with water. The density of the juice will now rapidly diminish. Open the water valve and pass boiling water through the press until the density indieates that but little juice is being extracted. The last portions of dilute juice are employed to slack lime for the defecation. 
"Another suceessful method is as follows: The scums are pressed in an orlinary filter; the residue, or precipitate, is removed from the filter, thoroughly mixed with rater, and is again pressed. This results in a very decided decrease in the weight of the scums, showing that a large proportion of the sugar has been extracterl. It is claimed that this method reduces the danger of redissolving the jmpurities contained in the lime precipitate.

"When this factory was constructed two years since the process for treating the junce with sulphurous acid and entirely suppressing the use of bone-b]ack was not yet an assured suceess, consequently, rather than risk a new and still uncertain process, the new works were supplied with a battery of closed filters and a Langen-Sehatten bone.coal kiln. Since this time the sulphurous acid process has adranced very much in favor with sugar manufacturers, and now many sugar-houses entirely supposs the use of bone-black.

"For evaporation this honse las one triple-effect, and for boiling to graiu, one vacuum pau. The barometrie vaceum pump is used.

\section{"TREATMENT OF TIIE MASSECUITE.}

"The masseenite is dropped into small coolers, similar to those at Stoebuitz (Fig. 16). 2 feet 6 inches deel), 10 inches long, 1 foot 6 inch('s wirle at top, and 1 foot at the bottom. Capacity approximately 1.4 hectoliters.

"After remaining 12 hours in the eooling room the massecnite is expelled from the cooler by compressed air, and is dropped into the mixer below. It is claimed that by the use of these coolen's the yield of first sugar is largely increased.

"Dr. Prella, superintendent of the Camburg works, made an experiment two or three years since, to chetermine if this is really the casc. He took equal rolumes of the massecnite, then swming out the sugar from one immediately after dropping it from the pan; the yield was 62 per cent. sugar. The second portion he set aside 12 hours, nutil it was perfectly cold ; this yielded 68 per eent. sngar, a gain of 6 pereent. He now invariably allows the massecuite to become cold before swinging ont. The following ale a f'ew pereentages taken from Dr. Prella's notebook and show the amount of sugar obtained several days in snceession last season: 75 per cent., 74 per cent., 74.2 jer cent., 77 per cent., 71 per cent., 72 per eent., 76 per eent.

6. The Camburg sugar-house has not yot finished its second eampaign. Its first yeau's work was remaliably suceesstul. The house being sup)plied with every facility for good work, and laving an exeeptionally good harvest of beets, both as resurds quantity aud quality, yielded at very large profit to the owners. The cost of the sugar-house was about $\$ 225,000$. Its capacity is 300 loug tous per 24 ilomis, or 30,000 tous for the eampaign. This establishment at Camburg is in every respect a model sugar-house. 
"DETAILED STATEMEIT'S OF 'THE WORKINGS OF SEVENTEEN GERMAN SUGAR-IIOUSES.

"In order to determine a basis for taxing the bect-sugar industry, the German Government selects certain sugar-houses and requires them to make detailed reports. In these reports each sugar-house is designated by a letter of the alphabet. Care is taken to select only those factories which are fair representatives of the districts in which they are located.

"The eopy of these tables for 1882 and 1883 , which aceompanies this report, is given to show as briefly as possible statisties of the yield and expenies in the manufacture of beet sugar.

$25+74-$ Bull. $27-16$ 


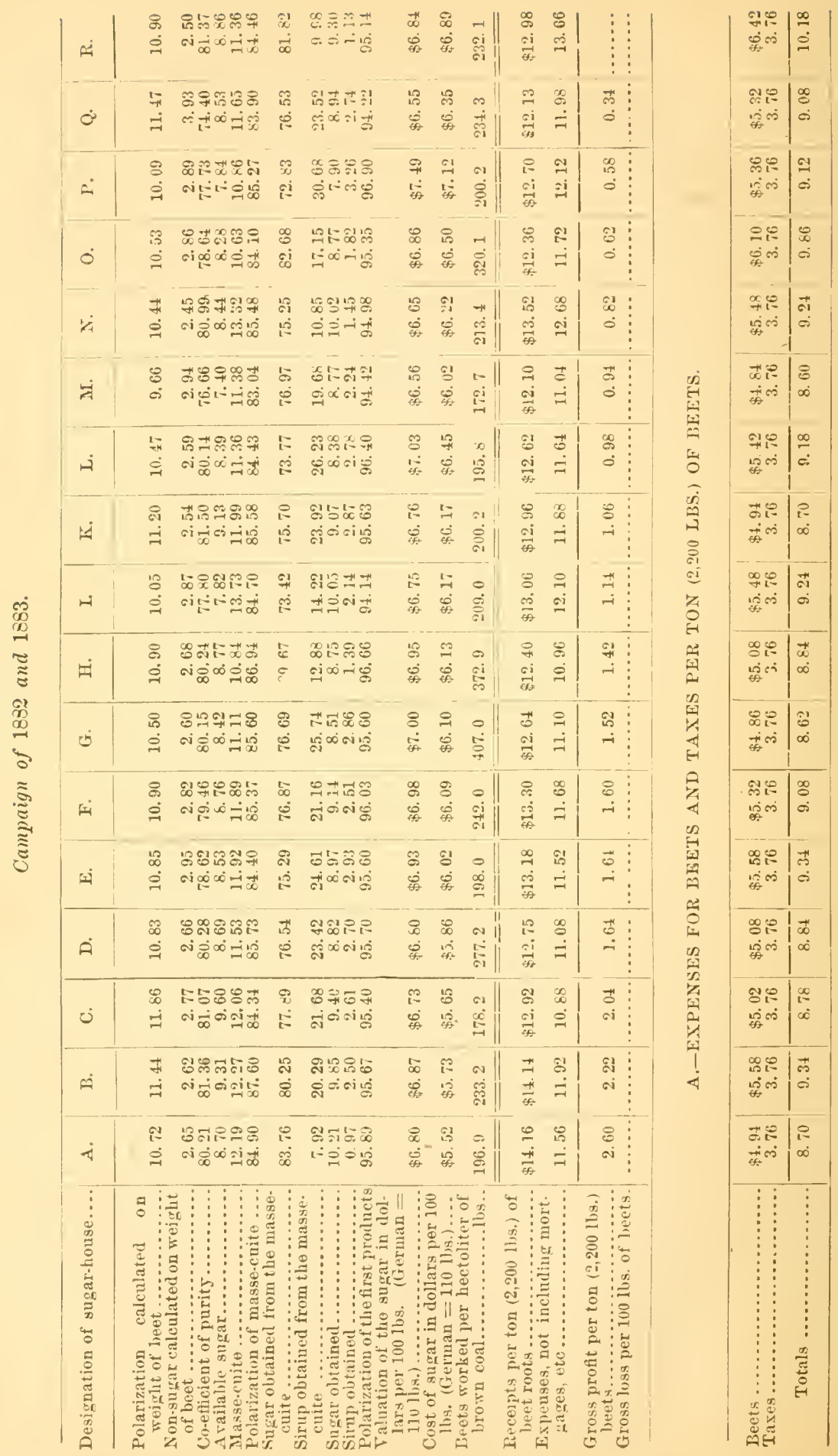




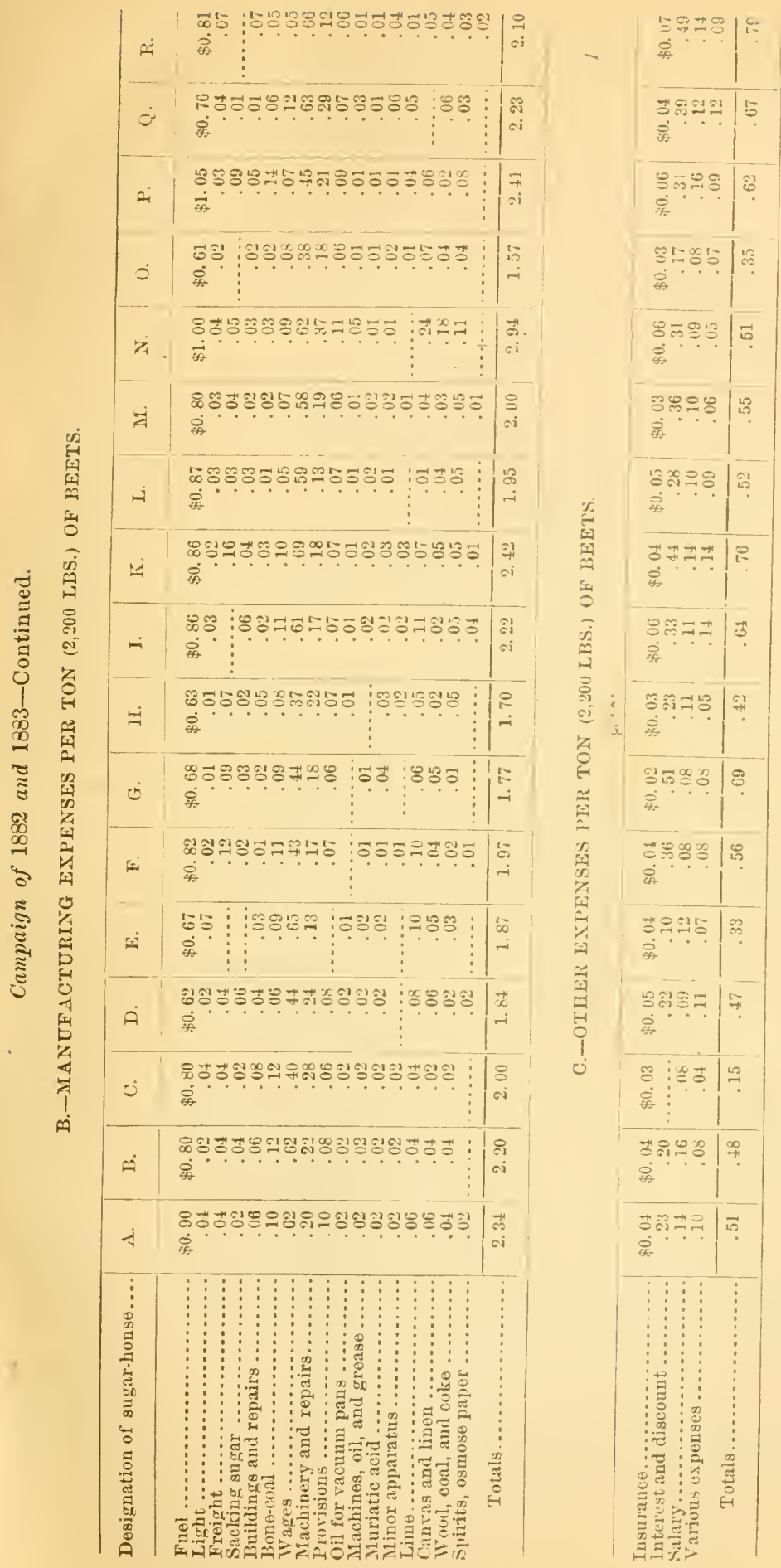


"TIE EXTRAC'IION OF THE SUGAR FROM 'THE MOLASSES.

"It has long been a problem with sugar manufacturers to devise a method for extracting the sugar from the molasses. The importance of this problem is such that it has led many of the most noted inventors in the field of sugar manufacture to investigate it. It is stated that in France 15 per cent. of the sugar in the beet remains in the molasses. 'This corresponds to a loss of about $1 \frac{1}{2}$ per eent. on the weight of the beet. This loss is even more important in the beet than the cane sugar maunfacture. The beet molasses is very lighly colored aud has an extremely disagreeable taste. In fact, it can only be utilized for the manufacture of vinegar or for distilliug purposes.

"Quite a number of processes hare been proposed for the extraction f the sugar from molasses, a few of which have been successful. From a ehemical point of view this is a comparatively easy problem, but com. mercially or mechanieally speaking it is an extremely difficult one.

"It is a well-known fact among manufacturers that all the sugar can be readily separated by precipitation as a barium saccharate, but the cost of the barium salt precludes its use. A gain, the processes known as "elution," depending upon the precipitation of a lime saccharate and subseynent washing of this precipitate with dilute alcohol, are both chemically and mechanically successful. The elution processes, howerer, can only be emplojed in those countries where alcohol either pays a very low excise tax, or is entirely free from tax when used for man. ufacturing purposes. These brief statements merely indicate the difficulties which the ehemist and manufacturer liave been compelled to face. In many iustances, after a long series of experiments in his laboratory, the chemist has been compelled to yield to difficulties not always chemical, but often of a purely mechanical nature.

"For example, he has succeeded in prorlucing a saccharate of lime, containing all the sugar in the molasses; but the saccharate would coutain many impurities which conld only be eliminated by eareful washing. On attempting to wash this combination between the lime and sugar the filter-press would soon elog and refuse to do the work. Had the precipitated saccharate been granular this would not hare been the result. Notwithstanding these difficulties and failures two successful processes have been devised. In the more recent, the Steffen separation process, the inventor has succeeded in readily producing a granular precipitate of tribasic saceharate of lime. The other process is termed the Strontium Process. Not haring had an opportunity to visit works employing strontium, I shall ouly describe the Steffen process.

"CHEMISTRY OF THE SEPARATION PROCESS.

"Very complete investigations have been made of the lime saccharates, with the especial object of ntilizing their properties in the separation of sugar. The lime saccharates are three in number:

Monobasic $\left(\mathrm{C}_{12} \mathrm{H}_{22} \mathrm{O}_{11}\right)$, $\mathrm{CaO}$.

Dibasie $\left(\mathrm{C}_{12} \mathrm{H}_{22} \mathrm{O}_{11}\right), 2 \mathrm{CaO}$.

Tribasic $\left(\mathrm{C}_{12} \mathrm{H}_{22} \mathrm{O}_{11}\right), 3 \mathrm{CaO}$. 
"Some chemists claim the existence of a fourth, the tetrabasic.

"If a portion of finely powdered pure quicklime be added to a 6 to 12 per cent. sugar solution, in the proportion of one moleenle of lime for each molecule of sugar, the temperature of the solution being kept below $30^{\circ} \mathrm{C}$. ( $\left.86^{\circ} \mathrm{F}.\right)$, the monobasic saccharate of lime will be formed. This saccharate is perfectly soluble in water. It is necessary for the success of this experiment that the quicklime be recently calcined and finely powdered.

"If this solution of monobasic saccharate be heated it will be riecomposed and the tribasic saceharate precipitated. To form the dibasic saccharate it is necessary to add an additional molecule of lime, under the same plysical conditions as before. The dibasic saccharate may be separated by crystallization in the cold.

"Tho tribasic saccharate is much more important from a commercial point of view than the others. It is with difficulty soluble in 200 parts of water, but insoluble in a saturated water solution of the tribasic salt itself. When precipitated under certain well-defined conditions it is granular. Sugar can be completeiy precipitated in this combination from a dilute solution. This precipitate being crystalliue can readily be washed in a filter.

"To form the tribasic saccharate proceed as follows : Dissolve a certain quantity of sugar in water, making a 6 to 12 per cent. solution. By means of some suitable arrangement keep this solution at a temperature below $300^{\circ} \mathrm{C}\left(\$ 6^{\circ} \mathrm{F}.\right)$. For every molecule of sugar add three molecules of very finely-powdered and freshly-burned lime. The lime must be arded in small portions, the solution being stirred coustantly. The tribasic saccharate of lime will be precipitated.

"The following analyses show the composition of the saccharate ob. tainerl by the above method:

\begin{tabular}{|c|c|c|}
\hline & By analysis.* & Calculation. \\
\hline 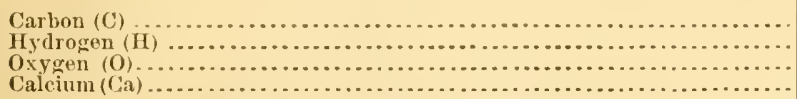 & $\begin{array}{r}25.30 \\
5.14 \\
38.12 \\
21.44\end{array}$ & $\begin{array}{r}25.53 \\
4.96 \\
48.23 \\
21.28\end{array}$ \\
\hline
\end{tabular}

* Do la Diffusion. Par Jules Cartuyvels, p. 263.

"This saccharate is readily soluble in a sugar solution.

"The tribasic saccharate of lime can not be preserved any great length of time. Even at the end of two or three weeks the proportion of sugar decreases. The sugar decomposes and forms organic salts with the lime.

* "The crystals of sugar obtained by the sepanation process resemble a confused mass of needles. If these crystals bo dissolved in water and recrystallized they will assume the normal form. 
"TIIE SEPARATION PROCESS.

"I visited the sugin-house at Elsilorf, near Cologne, Germany, to examine into the practical workings of this process. The Elskorf sugarhonse was the first, 1 helieve, to alopt it, and experiment upon a large seale. I afterwards visited the works of Mr. Max Le Docte, at Gemhloux, Belginm. and exanined the machinery, as adopted by Mr. Steffen after a rear"s experience in the practical application of his separation process. J'ates Nos. 3, 4, 5, and 6 are from dowings kindly furnished me ly Mr. Girard Oyens, of Paris.

"Before (leseribing the separation process it may be well to speak of the

"(1)MPOSITION OF BEET MOLASSES.

"The arerages of a large number of analyses of heet molasses show its romposition to be alont as follows:

Per cent.

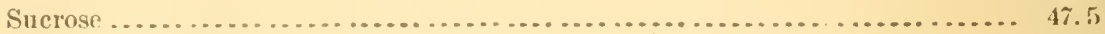

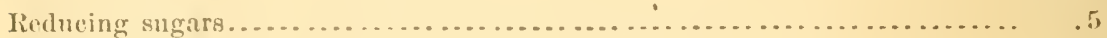

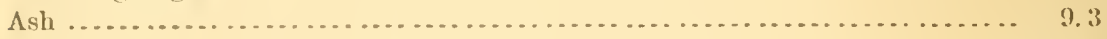

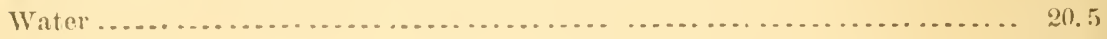

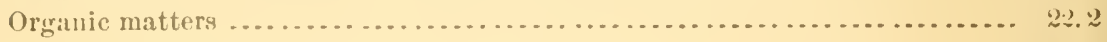

100.0

"The pereentage of reducing sugars as giren above is rather high, ats leet molasses does not usually contain more than a trace.

6. The ash consists principally of' salts of potassinm, sodimm, and magnesinm. Phosphate of potassium is one of the principal constiturnts.

"The recovery of these mineral substances forms quite an industry in connection with the distillation of the molasses. One hundred pounds of molasses yiclds 10 ponnds of black ash.

"The Steffen separation process lepends upon the precipitation in the cold of the tribasic lime saccharate, spariugly soluble and of a granular structure.

"The freshly burned quicklime is first broken into small pieces by an ore-crusher, such as is used in the mining regions of this conntry. The broken lime is carriel by an elevator to a mill, where it is gromul to a very fine powler. This mill resembles in every respect an ordinary flomring mill. Special precantions are taken to prevent the lime powler from heing inlaled by the workmen.

"The powdered lime is next conveyed by an elevator to another room, where it is passer through a fine wire gauze sieve. It is extremely im. portant in this process that the lime be redneel as nearly as possible to an impalpable powere. Precantions are taken to remove any particles of iron from the pow rer by means of magnets. The powdered limo falls into a box holding a certain quantity, and is divided antomatieally into equal portions. From this hox the portions are rropped at intervals into the mixer containing the diluted molasses. It is necessary that the temperature in this mixer should not rise above $30^{\circ} \mathrm{O}$. (86 F.). 
The lower the temperature the quicker the lime will combine with the sugar.

"The mixer consists of a large closed iron cylinder placed in a rertical position. Within this cylinder is a system of tubes arranged similarly to those in a pan of an ordinary double effect. Cold̉ water (below $15^{\circ}$ O., $59^{\circ}$ F.) cirenlates abont these tubes, entering below and discharging from above. The dilute molasses cireulates through and above this system of tubes; a helix, revolred by suitable machinery, keeps the mixt. ure in constant motion that it may be quickly cooled.

"The operations for the production of the tribasic lime saccharate are conducted as follows:

"A certain quantity of molasses is aceurately measured. Water is added to it until the density of the solution is $120 \mathrm{Brix}\left(6.6^{\circ} \mathrm{B}\right.$.), the percentage of sugar being from 7 to 8 . This solution is cooled down to $15^{\circ} \mathrm{C}(59 \circ \mathrm{F}$.$) ; small portions of the powdered lime are then added at$ intervals of about a minute. The temperature increases a little after each addition of lime. Before allling more lime it must be again reduced to $15^{\circ} \mathrm{C}$. This operation continues until lime has been added from ten to thirteen times, when the sugar is all precipitated. The workman determines this point by the density of a "proof" filtered from the mixture. The density of this filtrate should not be greater than $6 \circ$ to $62_{2}^{\circ}$ Brix $\left(3.5^{\circ}\right.$ B. $)$. The total quantity of lime added is 93.4 i)ounds lime per 100 pounds of sugar in the molasses. When this process was first invented muelı larger quantities of lime were employed, often as mueh as 150 pounds per 100 pounds of sugar. The chemist at Elsdorf informed me that 93.4 pounds is sufficient.

"The unwashed lime saccharate resembles a dirty milk of lime. After leaving the mixer it is pumped to the filter-presses. The filters are fitted for washing the saccharate in the press. The mother liquor, containing all the impurities of the molasses, is used as a fertilizer. The water for washing the saceharate is earefully measured, and the same quantity per press is always employed. The wash water is afterwards nsed to dilute the molasses. By this means losses due to the sliglit solubility of the saccharate are aroided.

"It is important that the pressure on the filter-presses should not exceed two and one-half atmospheres. An excess of pressure over this limit will cause the saccharate to cake in the presses and it will be impossible to wash it.

"The filter-cloths require washing every four or five days. The cloths from one press per day are replaced by clean ones.

"The co-efficient of purity of the saccharate, i.e., the pereentage of pure saccharate in the erude, ranges from 97.5 to 98.5 , and will avearge about 98.

"If one wishes to simply extract the sugar from the molasses, haring obtained the tribasic saccharate, it is only necessary to decompose it with hot water, remove the lime by precipitation and filtration, and 
evaporate the filtrate. Fut the greater number of establishments employing the Steflen substitntion process work it in comection with beet-sugir houses. In this case the saccharate of lime replaces the lime for slefecation.

"It is not sufficient to simply treat the saccharate with water to form a lime paste smitable for defecating. The objection is that the saccharate is in a gramular stateand is not readily acted upon by the carbonic acid. To produce a perfectly smooth milk of lime, free from grains, the saccharate is decomposed by lot juice. An average of 92 per cent. of the sugar contained in the molasses is extracted by this process.

\section{"EXPENSES FOR LAIBOR.}

"The extreme simplicity of this process is quite noticeable. There are $n 0$ operations requiring skilled labor asile from the control exer. cised by the chemist. There is not an operation that can not be performed by a common laborer.

"At Elstorf the workmen at the mixers receive one mark and a half per day (about 36 cents); at the filter-presses, one and a quarter marks (30 cents). These wages are about the average for the entire sugarhouse.

\section{"TREATMENT OF CANE MOLASSES BY STEFFEN'S PROCESS.}

"Shortly after the announcement of the successful working of the separation process on a large scale certain London refineries employed a chemical expert to examine the process and report to them. As a successful application of this process would be of great importance to our cane planters, I obtained a copy of this report, and shall give those portions not alreary included in my description.

"After speaking of the complete success of the Steffen process in the treatment of beet molasses, Mr. Gill, the expert mentioned above, says :

"Ilow far the same thing cau be said in regard to its application to the molasses obtained in the manufacture or refining of sugar from the cane depeuds on a variety of consilerations, of which the following are some of the most important:

" "First. Is the sugar separated as pure as that obtainerl from the beet molasses, and is any of the glucose (altered and uncrystallizable sugar), which is always present in large quantities, precipitated along with the true cane sugar, and theu again set free when the lime compound is decomposed by the carbonie acil, and if so how far the fact will interfere with the economy and utility of the process?

"The answers to these questions are not clear in the present state of the evidence. I an informed by Mr. Langen and his chemist that some glueose is precipitated, but that they do not know in liow large a proportion. This would therefore have to be determined by experiment. I may say with certainty that if all or most of the glucose be precipitated with the sugar, and then again sot free along with the sugar by the subsequent treatment with earbouic acid, that very littlo or no useful effeet witl be obtained, because glucose wheu present in solution with sugar greatly hinders, if it does not altogether prevent, the erystallization of an equal weight of the latter on uvaporation.

"That the evil indicated may attain large dimensions is shown hy the fact that 
second sirups ohtained in the mannfacture of Mauritius sugar contain, according to Dr. Icery, from 20 to $4: 3$ per cent. of glueose ont of 100 total sngars.

" "Second. Will the mother liquid drain away completely through the cloth of the filter-presses from the precipitated sngar lime when molasses obtained from cane juice in the usual rough mamer is the original naterial operated upon?

" Here again direct experience is practically wanting. In one experiment which I witnessed, and which was performed on a cane molasses of unknowu origin, but helieved to be from a refinery, the filtration proceeded without any difficulty. I should remark that solutions of orlinary raw cane sagar can not be filtered through a filter-press, since the gunmm matters cloke the pores of the cloth, and almost immediately.

"If the above two points can be settled in a favorahle manner then the process will be as great a success in a chenical and mochanical seuse as it is with beet molasses.'

"Mr. Gill then discusses the commercial conditions requisite for success. But as these conditions are so different in this country from those in London I shall not repeat them. In conclusion he says :

"I can not advise your clients to incur the expense of adopting this process until they have satisfed themselves by experiment that it is as applieable to the molasses of cane sugar as that of the beet.

" 'I may and that sufficiently extended experiments could be made on a laboratory scale at an expense which would not exceed, say, $\mathfrak{f} 40$, and which might be less.

“'To Messrs. Matheson \& Grant, "C. Haughton Gill. 32 Walbrook, London, E. C.'

* "Not having made any labolatory experiments on the treatment of cane molasses by Steffen's process, 1 can not adr anything to the above report.

"Estimate for the establishment of works for the treatment of 10,000 to 15,000 kilograms (22,000 to 33,000 pounds) of molasses per day.

1 reservoir for molasses, 318 enbie feet eapacity, fitted with valves........

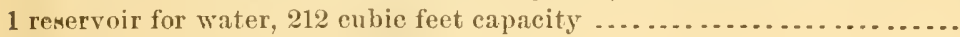

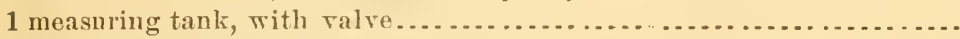

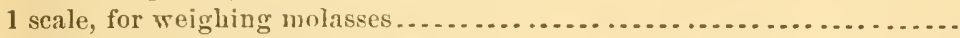

2 mixers, with connections, at $\$ 1,500$

2 antomatic neasuring apparatus for lime, at $\$ 162.50 \ldots \ldots . . . . . . . .$.

1 horizontal steam-pump, for the lime saccharate. Cy'linder, 12.8 inches diameter; jump, 7.9 inches diameter; stroke, 15.8 inches.............

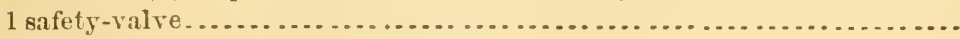

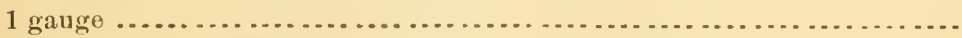

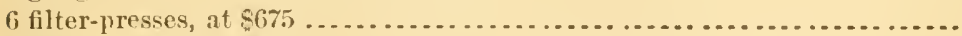
(i) iron fumels, at $\$ 43.75$.

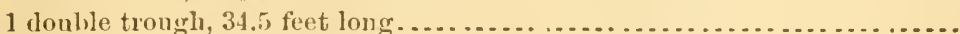

1 reservoir; capacity, 88.3 cubic feet (for wash water) ................

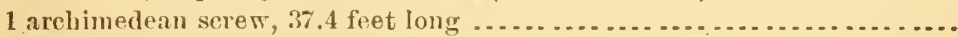

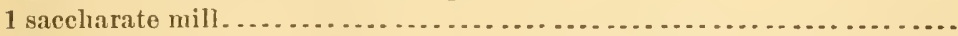

1 pump; 2 plungers, 5.9 inches diameter, stroke 7.9 inches, including trans-

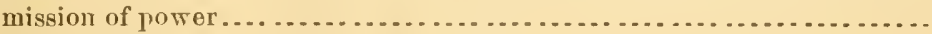

1 saccharate pump; 2 plungers, 3.9 inches diameter, stroke, 7.9 inches...

1 engine; cylinder, 13.8 inches diameter, stroke, 27.6 inches.

* Since this was written experiments have been successfully made in treating molasses with lime for the decomposition of the glucoses preparatory to the use of a saccharate process for the separation of the cane sugar. 


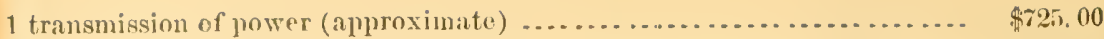

1 ore-ermsler, for lime ............................................ 553750

1 mill, to rriml the limo........................................ 1,212.50

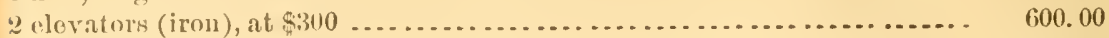

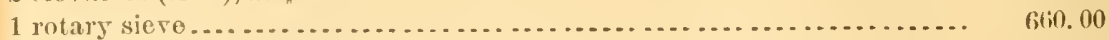

1 hopper, for powdered lime..................................... 225. 00

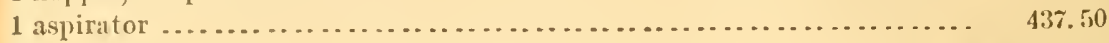

Total.......................................... 17, 155.00

"The ralue of the franc in the above estimates is taken at 20 cents.

"In adlition to the cost of the machinery a royalty must be paid, depending upon the size of the plant and the length of the working season.

"If the Steffen process is worked in eonnection with a sugar-house, the royalty is $\$ 7,500$ for works haviug a cilpacity to treat 22,000 poumds of molasses per day, or $\$ 10,000$ if 33,000 pounds are treated. To these sums $\$ 2,500$ and $\$ 3,750$, respectively, must be added, if the Steffen process is to be employed after the regular campaign of the sugar-house is finished.

"If the plant is to be employed the entire jear, only for the extraction of the sugar from molasses obtained by purchase, the royalty is $\$ 10,000$ for a daily capaenty of 22,000 pounds; $\$ 13,750$ for a daily capacity of 33,000 pounds. For larger plants, the royalty is fixed by special contract.

"This process has already been adopted by a number of German sugar-houses, and by eleven this season in Belgium. When I left France in October, the great central sugar-house at Cambrai was about to contract for the installation of the Steffen separation process.

"Plates Nos. 3, 4, 5, and 6 show the disposition of the machinery for working the Steffen process in connection with an ordinary sugar factory.

"Notw.-Mr. François Sachs, chemist of the Max le Docte Sugarhouse, Geml)loux, Belgium, has kindly giren me the results of his experiments last season with the Steffen process. He says:

"The separation process for the extraetion of the sugar from the molasses yields less sugar in actual practice when molasses alone is treated than was expeeted. In fact, it is necessary to add sugar in order to obtain a good crystallization.

"Taking 100 kilograms of molasses eontaining 50 per eent. sugar, we have added 24 kilograms of raw sugar (polarizing 89 to 90 degrees) with the following losses based on the weight of the molasses:

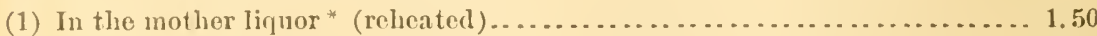

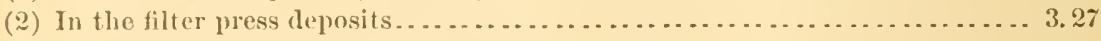

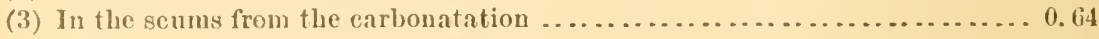

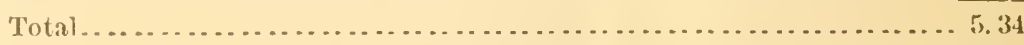

"Then 50 kilograms of sugar in the molasses, minus 5.34 loss, leaves 44.66 kilograms in the masse-enite. The masse-enite gave 52.52 per cent. first sugar, or 23.45 per cent. of second molasses. There then remained 24.12 per cent. of second molasses

* The mother liquor dissolyes a simall portion of the saccharate, which is reprecipitated on heating th: liquor, and is mostly recovered in the filter presses. 
Plate 3.

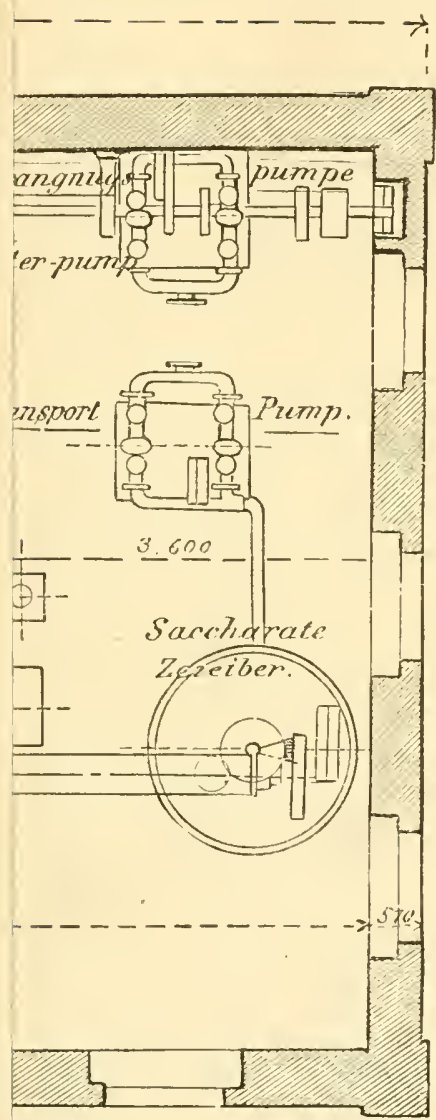



Plate 3.

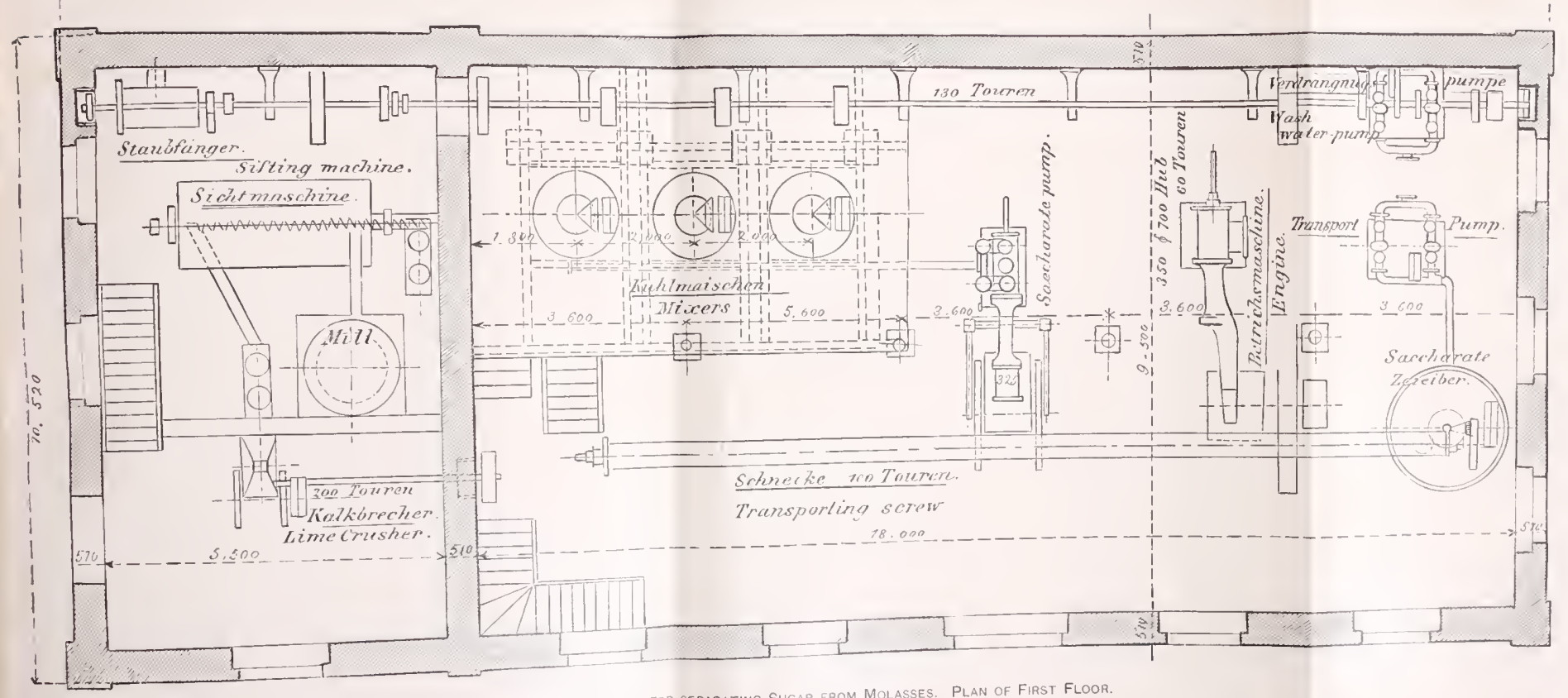

Steffen's process for separating sugar from Molasses. Plan of First Floor.

Face page : 
Plate 4.

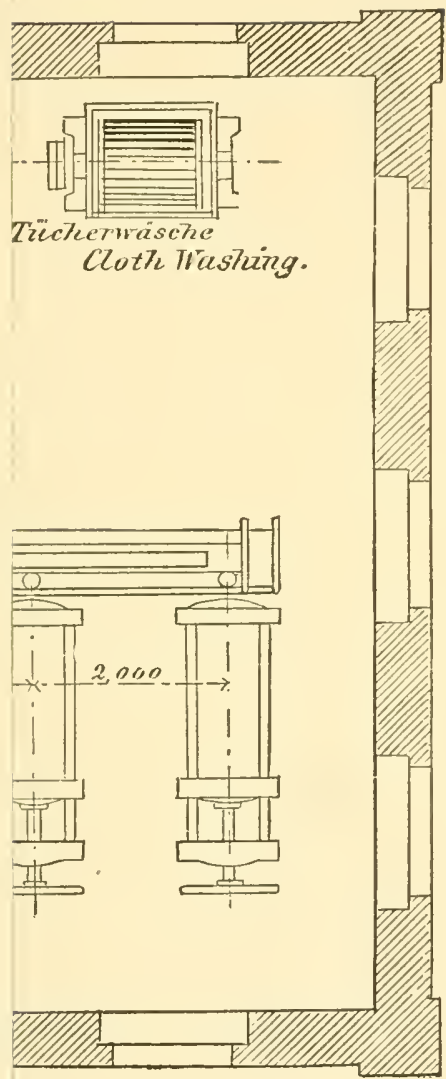





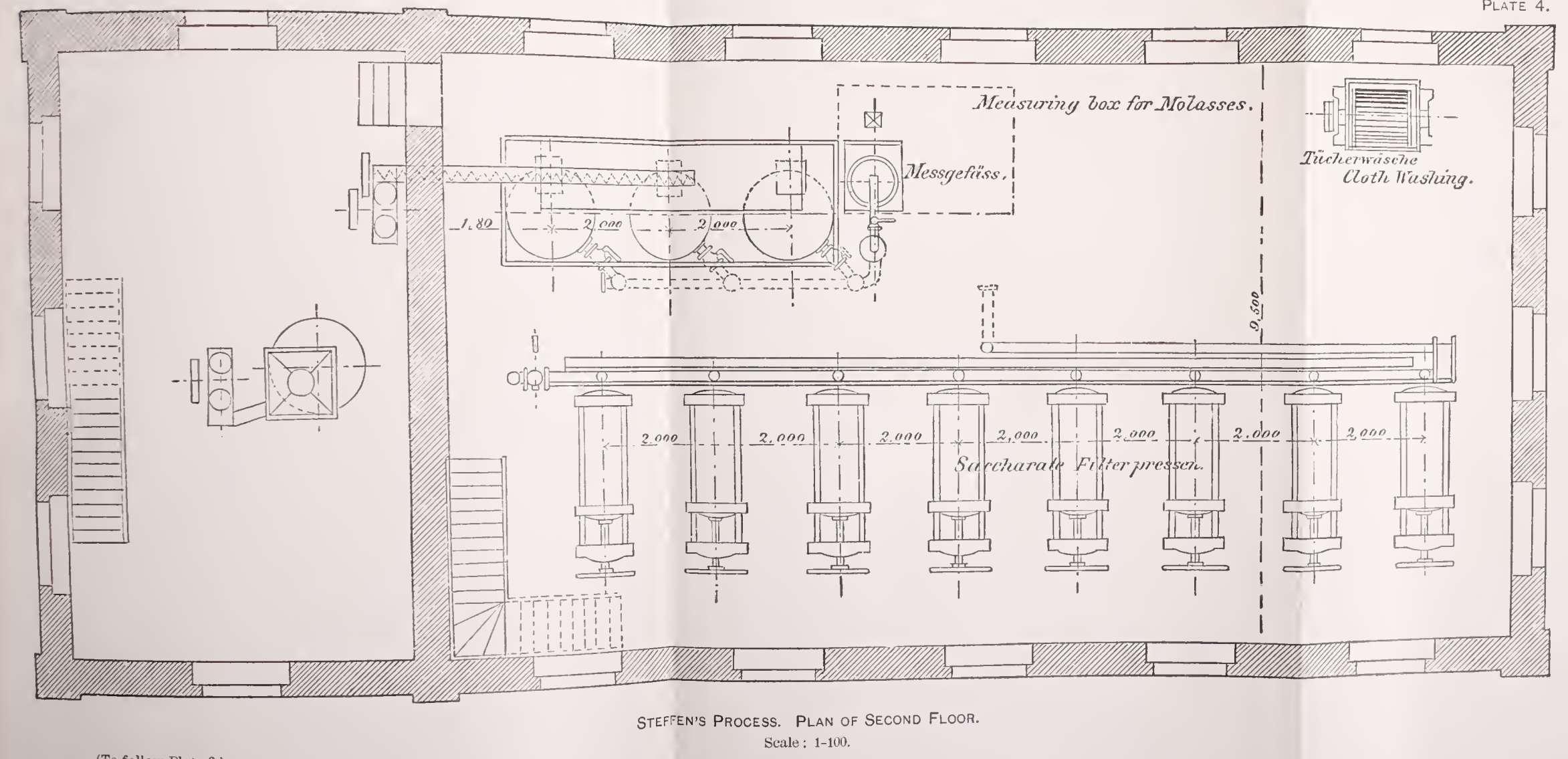

(To follow Plate 3.)

$$
\text { Scale: 1-100. }
$$


Plate 6.

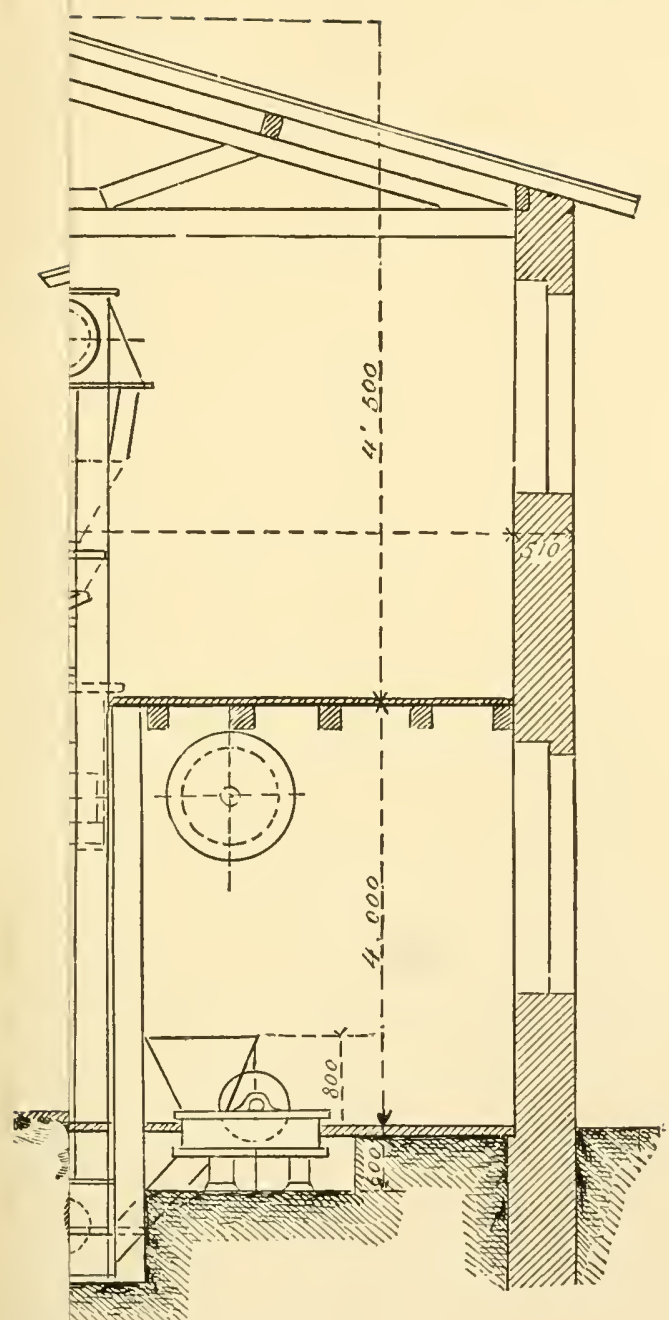

END VIEW.

(To 



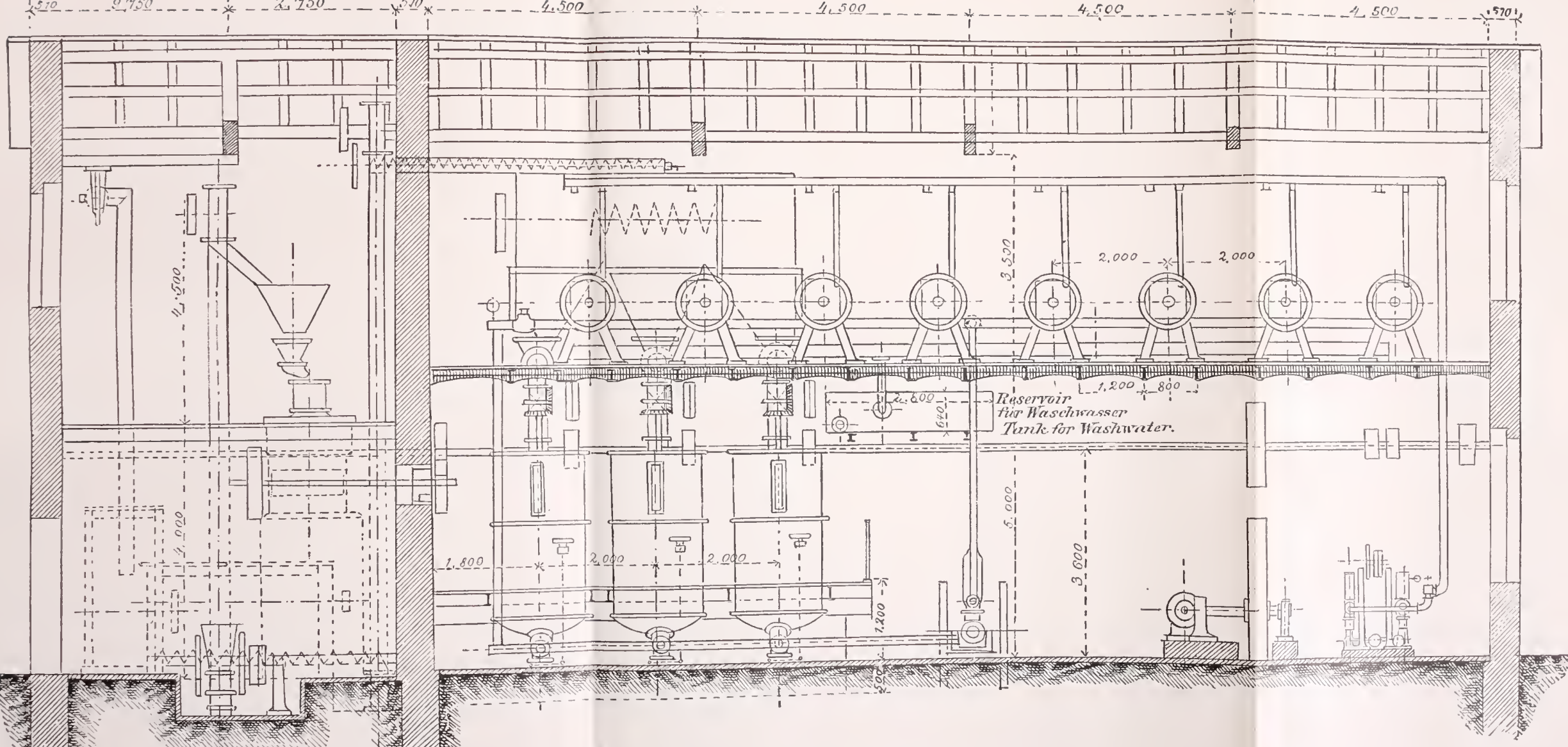

STEFFENS PROCESS, SIDE VIEW, SHOWING DISPOSITION OF MACHINERY.

(To follow Plate 4 ) 


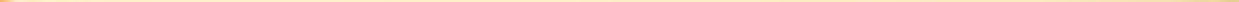



(the weight of raw sugar added not being taken into account). The second molasses yielded 25.52 per cent. sugar, or 6.03 per cent. of the molasses originally taken. The total amount of first acl second sugars extracted $\mathrm{j} \& 23.48$, plus (i. 03 , and equals 29.48 per cont. The proportion of third sugar has not yet been determined."

\section{REPORT ON THE TURKIEWITSCH METHODS OF DIFFUSION.}

Turkiewitsch has proverl that of all cireumstances which insure good desaccharification of the chips, as number of cells composing the battery, temperature, and time of maceration, the last is the most important. To increase this factor, he replaces the long batteries by short ones. For a battery of twelve cells he substitutes two of six cells each. This causes an increase in the amount of beets worked and a heavier and purer juice. It also reduces the suerose lost in the chips and the consump. tion of fuel to a minimum. Only slight changes in the connections and pipes are neeessary to arrive at the desired result. The battery is operated in the following manner:

(1) The chips are cut so fine that 100 grams repsesent a length of about 40 millimeters.*

(2) The water should be heated to 30 or $40^{\circ} \mathrm{R}$. and shonld enter the battery under a pressule of from 1 to $1 \frac{1}{4}$ atmospheres.

(3) The cells should be filled and emptied as rapidly as possible.

(4) The temperature shonld always be lower than it is in the old system, and should rary with the lind of beet and the rapidity of work. The last eell (i.e., the one just filled) is not heated and the juice passes from it to the measuring-tank at the same temperature at which it entered. Fire is lieated as soon as the required amount of juice has been drawn from 6 . The cells are to be heated as follows:

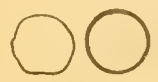

420

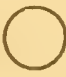

$57^{\circ}$

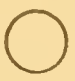

$60^{\circ} 500$ Ré́aumur.

(5) The heaters must not eontain any water while the cells are being emptied.

(6) The work must be so regulated that while Cell 1 Battery $I$ is being filled with chips, Cell 1 Battery II is emptied and washed. As soon as Cell 1 Battery I has been filled, juice is foreed into it from below anid Cell 1 Battery II filled with elips. When the latter has been filled, juice is forced into it and then in turn Cell 1 Battery I and Cell 1 Battery II are drawn off.

In actual practice the above method has been found to almost double the time of maceration.

\footnotetext{
* This corresponds to chips abont 2 millimeters wide and $1 \frac{1}{4}$ millimeters thick.
} 
In the following tables are some average analyses made at the beet house Raigovad while working according to the new system:

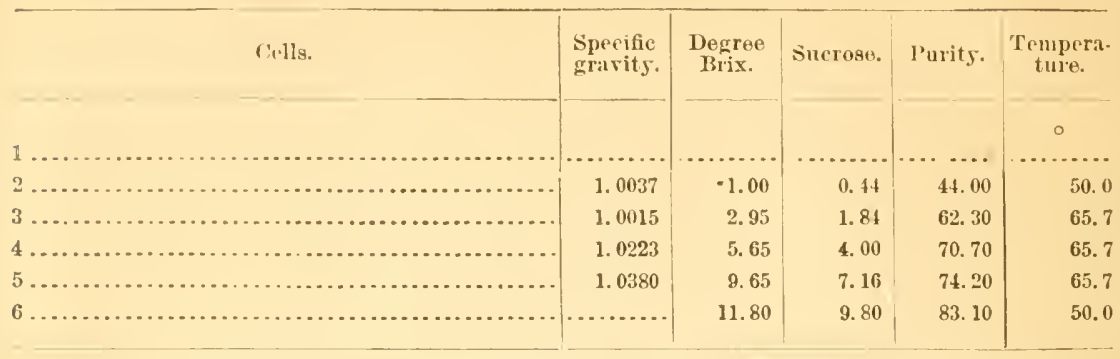

The purity of the normal beet juice was 80.60 . The following figures afford a comparison between the two systems:

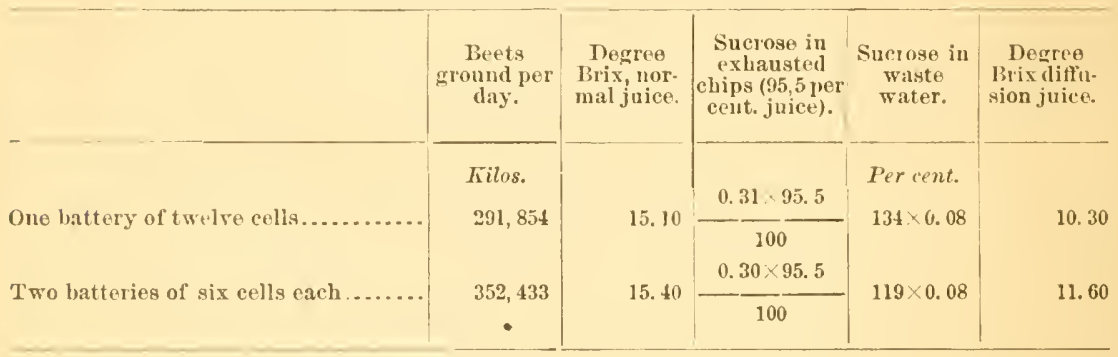

Seventy-five per cent. of milled bagasse were obtained. The waste water showed $0.2 \circ \mathrm{Brix}$; the juice from the exhausted chips $0.6^{\circ}$ The beets contained 95 per cent. juice.

The dilution in both methods is ealculated as follows:

A. Long battery.

$$
\begin{array}{r}
75 \times 0.6 \% \times 95.5 \%=0.429 \\
134 \times 0.2 \%=\frac{0.268}{0.697}
\end{array}
$$

$15.1 \times 0.95=14.34$

$$
-\overline{0.70} \text { 13.64 solids extracted. }
$$

13. $84 \times 100$ 10.3

13. Short battery.

$75 \times 0.60 \times 95.50 \%=0.499$

$119 \times 0.200=0.238$

$$
0.667
$$

$15.4 \times 0.95=14.60$

$$
-0.67
$$

$13.93 \times 100$ 
During the last season the beet house Mirowoka ran for five weeks accorling to the old and the remaining thirty-six days according to the new system. The following table makes the adrantages of the new system manifest :

\begin{tabular}{|c|c|c|c|c|c|c|c|c|c|c|c|c|c|}
\hline \multirow{2}{*}{ System. } & \multirow{2}{*}{ 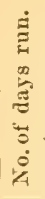 } & \multirow{2}{*}{ 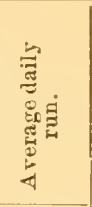 } & \multicolumn{3}{|c|}{ Normal juice. } & \multirow{2}{*}{ 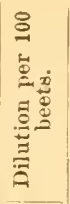 } & \multicolumn{3}{|c|}{ Diflusion juice. } & \multirow[b]{2}{*}{ 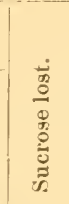 } & \multirow{2}{*}{ 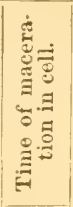 } & \multirow{2}{*}{ 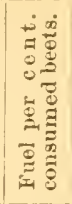 } & \multirow{2}{*}{ 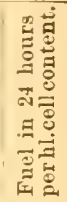 } \\
\hline & & & $\stackrel{\dot{A}}{\frac{1}{4}}$ & 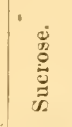 & $\stackrel{5}{\Xi}$ & & 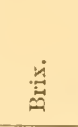 & 总 & $\stackrel{B}{\Xi}$ & & & & \\
\hline $\begin{array}{l}\text { ong battery } \\
\text { lort battery. }\end{array}$ & $\begin{array}{l}36 \\
86\end{array}$ & $\begin{array}{c}\text { Tilos. } \\
275,600 \\
324,300\end{array}$ & $\begin{array}{r}\text { Per ct. } \\
16.41 \\
15.61\end{array}$ & $\begin{array}{l}12.72 \\
12.00\end{array}$ & $\begin{array}{l}77.43 \\
76.85\end{array}$ & $\begin{array}{l}166 . \\
132.5\end{array}$ & $\begin{array}{r}\text { Perct. } \\
9.33 \\
11.06\end{array}$ & $\begin{array}{l}7.32 \\
8.71\end{array}$ & $\begin{array}{l}78.46 \\
78.89\end{array}$ & $\begin{array}{l}0.523 \\
0.499\end{array}$ & $\begin{array}{l}50 . \\
46.2\end{array}$ & $\begin{array}{l}\text { Perct. } \\
12.98 \\
11.82\end{array}$ & $\begin{array}{l}1338 \\
1504\end{array}$ \\
\hline
\end{tabular}

It becomes apparent that the above house has increased (1) the daily amount ground by $\mathbf{1 7 . 4}$ per cent., (2) the diffusion juice by 24.33 per cent., (?) and has lessened the (3) volume of juice by 32.6, (4) consumption of fuel by $\mathbf{1 . 1 6}$ per cent., (5) while the juice has a higher purity and (6) the loss of sucrose has been reduced. We can safely assume that the new system increases the daily capacity of the house by 10 per cent.*

\section{GENERAL PLAN OF SUGAR-HOUSE.}

For the information of the many persons who have written for general intelligence in regard to a beet-sugar house, Mr. G. L. Spencer has prepared at my request the following plan for such a building. (Plates $7,8,9$.

It would be unnecessary in this place to give the general working details of such a building, since those who propose to build such houses would desire to modify them in so many cases that such a general plan in detail would be undesirable. What is given, therefore, is merely for the purpose of illustrating the principles upon which a beet-sugar factory should be built and the general arrangement and proportion of its various parts:

\section{Ground floor. (Plate 7.)}

1. Warehous, for sugars.

2. Packing room for sugars.

3. Space for eight centritugals.

4. Centrifugal engine.

5. Hot room for low-grade sugars.

6. Elevator.

$\tau, 8,9$. Vacium pumps.

10. Carbonic-acid-gas pump.

11. Diffusion battery.

12. Hydranlic beet transporter.

13. Beet-washiug apparatus. 
14. Beot-elevator.

15. Driving-engrine for cutters, ote.

16. IBono-black filtors.

17. Room for treatment of bone-black proparatory to revivification.

18. Space for bono-black kiln.

19. Chimmey.

20. Boiler-houso and pump-room.

21. Lime-kilı.

22. Room for slaking lime.

Second floor. (Plate §.)

1. Space for sugar-bins.

2. Room for first sngars.

3. II rot room for second sugars, etc.

4. Elovator.

5. Carbonatation paus.

6. Triple effect.

7. Bone-black filters.

8. Diffusion battery.

9. Pulp-room.

10. Chutes for uso in removing pulps.

11. Beet elevator.

12. Space for filter presses.

13. Laboratory.

Third floor. (Plate 9.)

1. The vacum pans discharging into wagons, etc., in the hot room as indicatod by dotted lines from the pans.

The dotted lines (eontinnous with the main walls) indicato the loeation of the attics, which are high enough to accommodate projecting portions of the cutter and the pulp presses.

The general arrangement of a diffusion battery is shown in Plate 10, one of a sugar fitctory in Plate 11. These plates are taken from Bulletin No. 8, and are priuted from plates furnished by the Fives-Lille Company, No. 84 Rue Coumartiu, Paris, France.

\section{CosT.}

The cost of a beet-sugar factory depends on so many conditions that it will be impracticable to give anything more than a rough estimate of it. Much depends upon the character of the building itself, and this, for various reasons; should be made fire-proof, thus entailing the construetion of a building of considerable cost. In regard to both the building and machinery, the total cost will depend largely upon the capacity of the house; the cost, however, does not increase in the same ratio as the capacity. In other words, it may be stated that the cost of a beet-sugar factory capable of working 400 tous of beets per day would not be clouble the cost of one working 200 tons. A beet-sugar house based on an estimated capacity of 300 tons per day would probably be more in keepins with the character of the houses which are to be built 

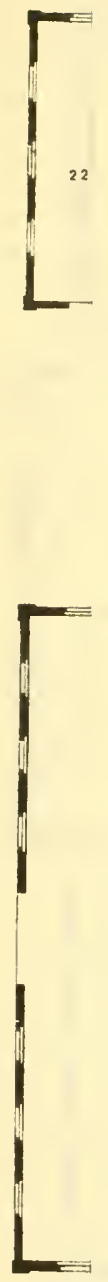



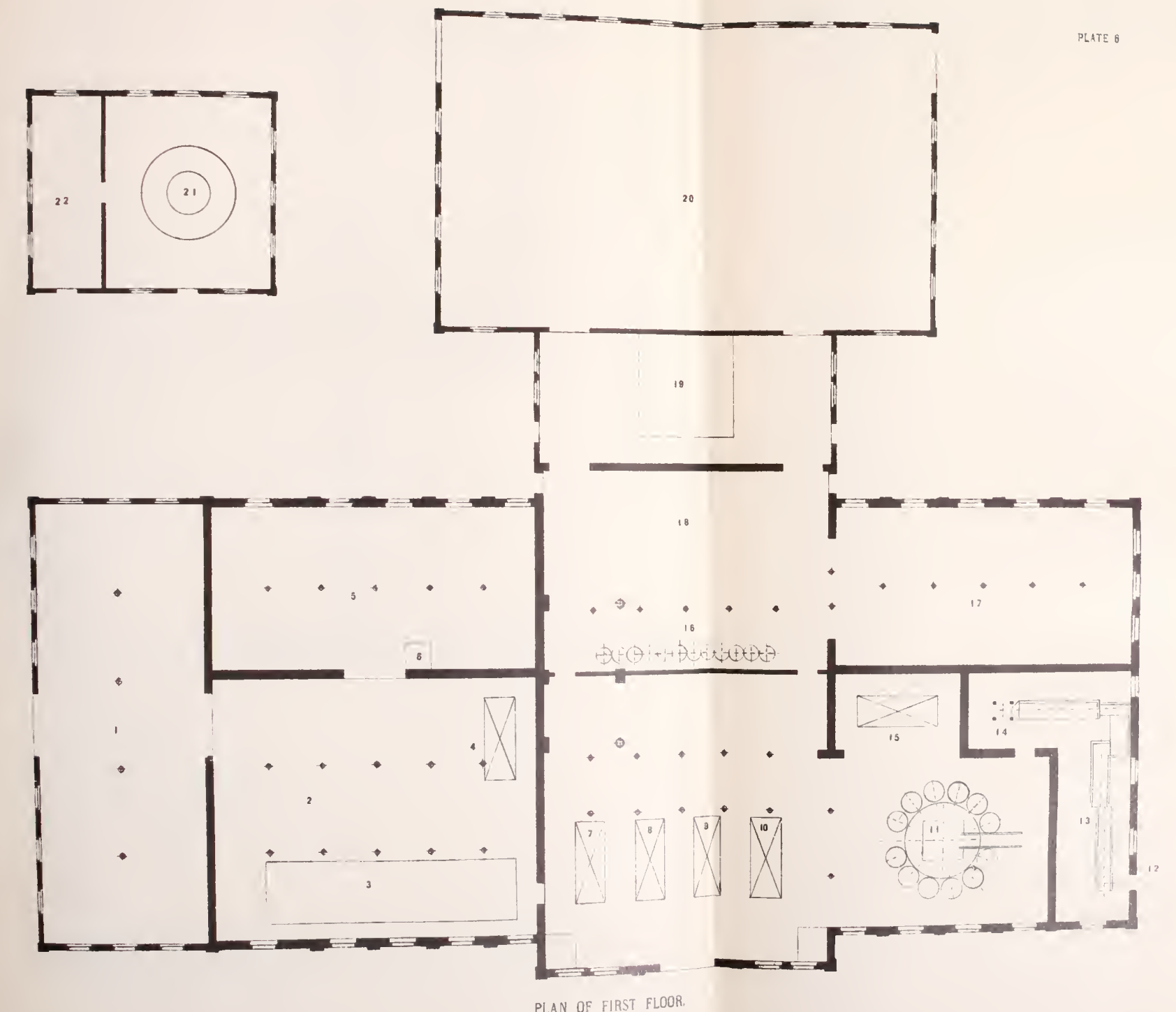




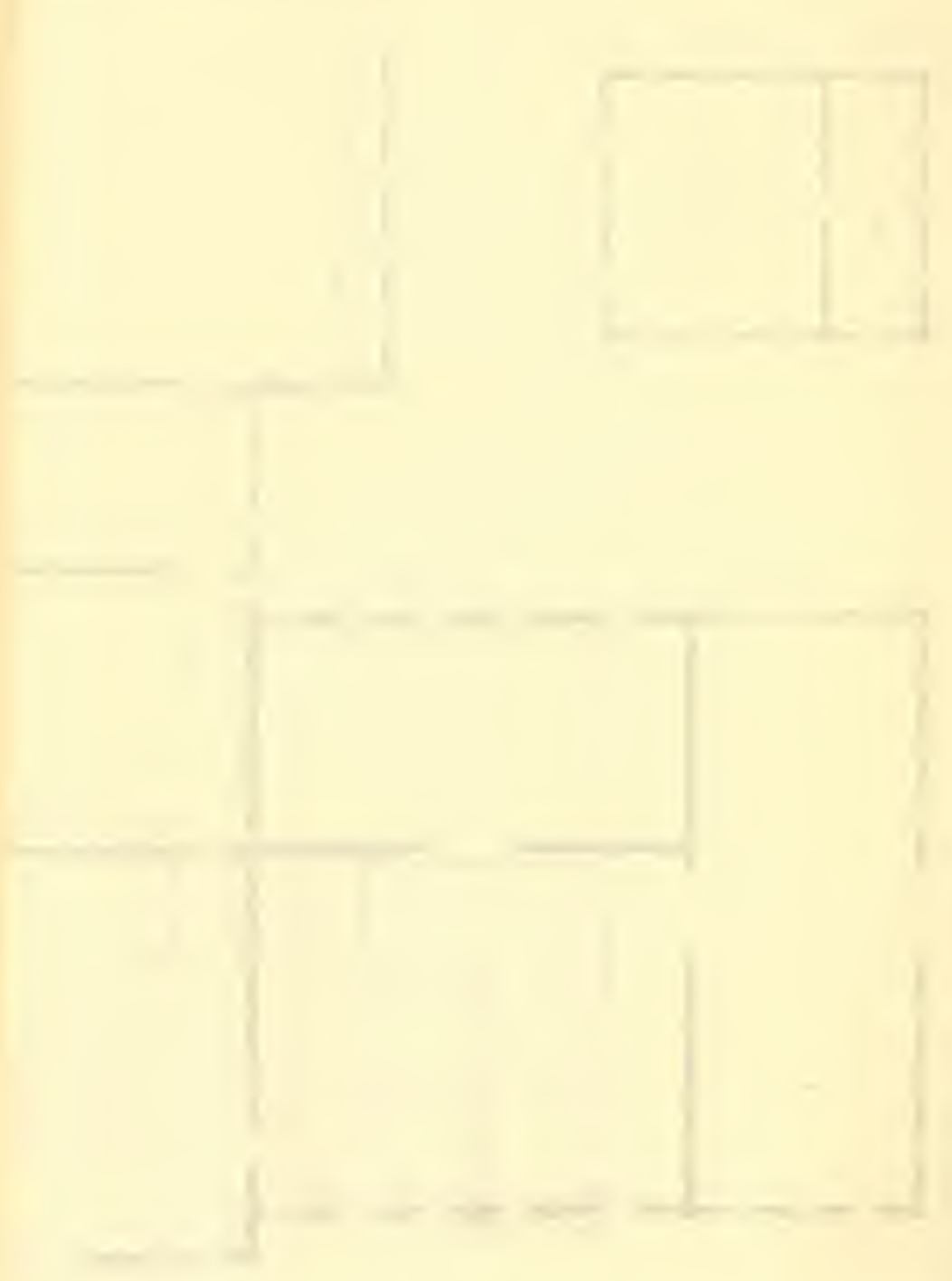




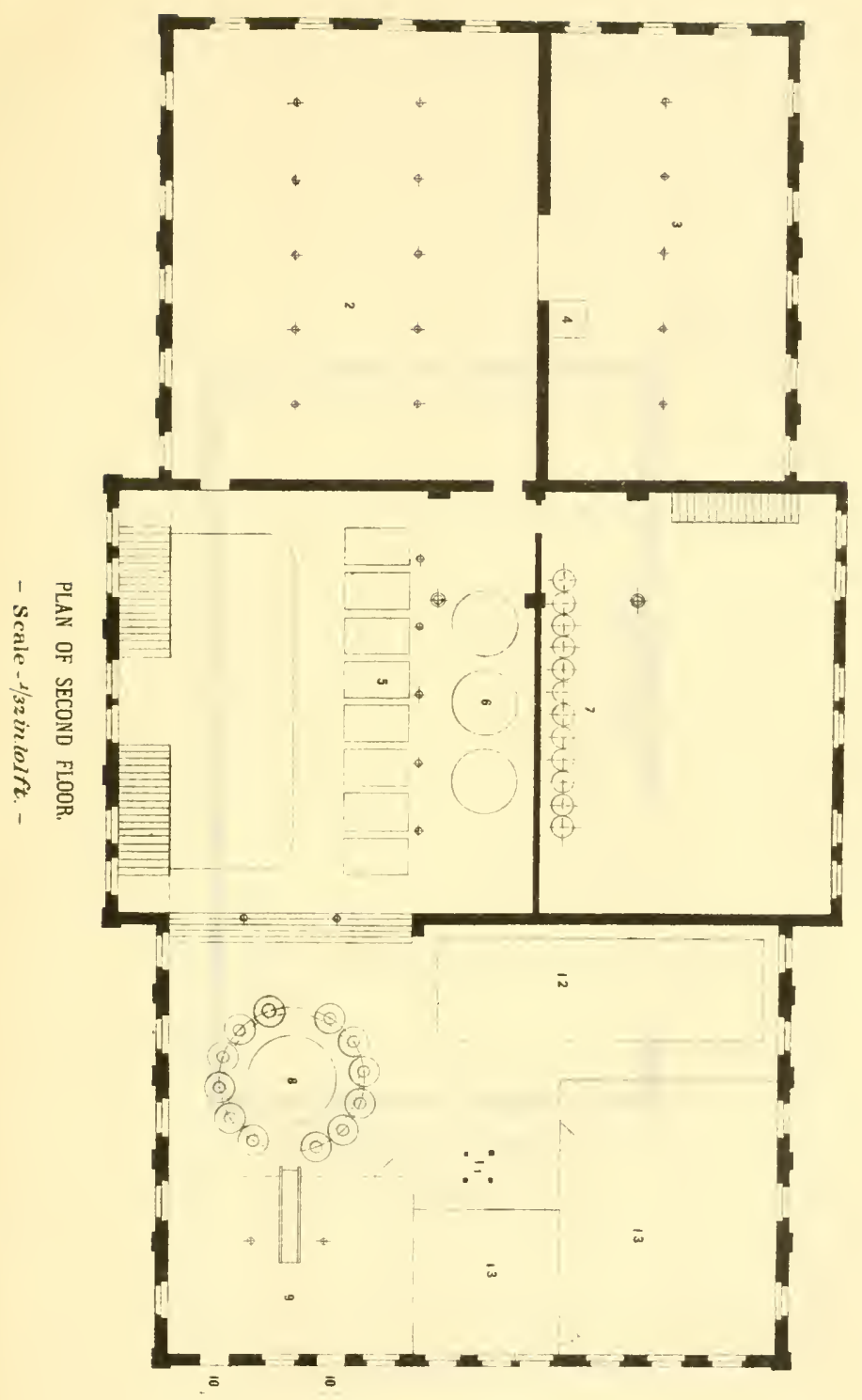

总 


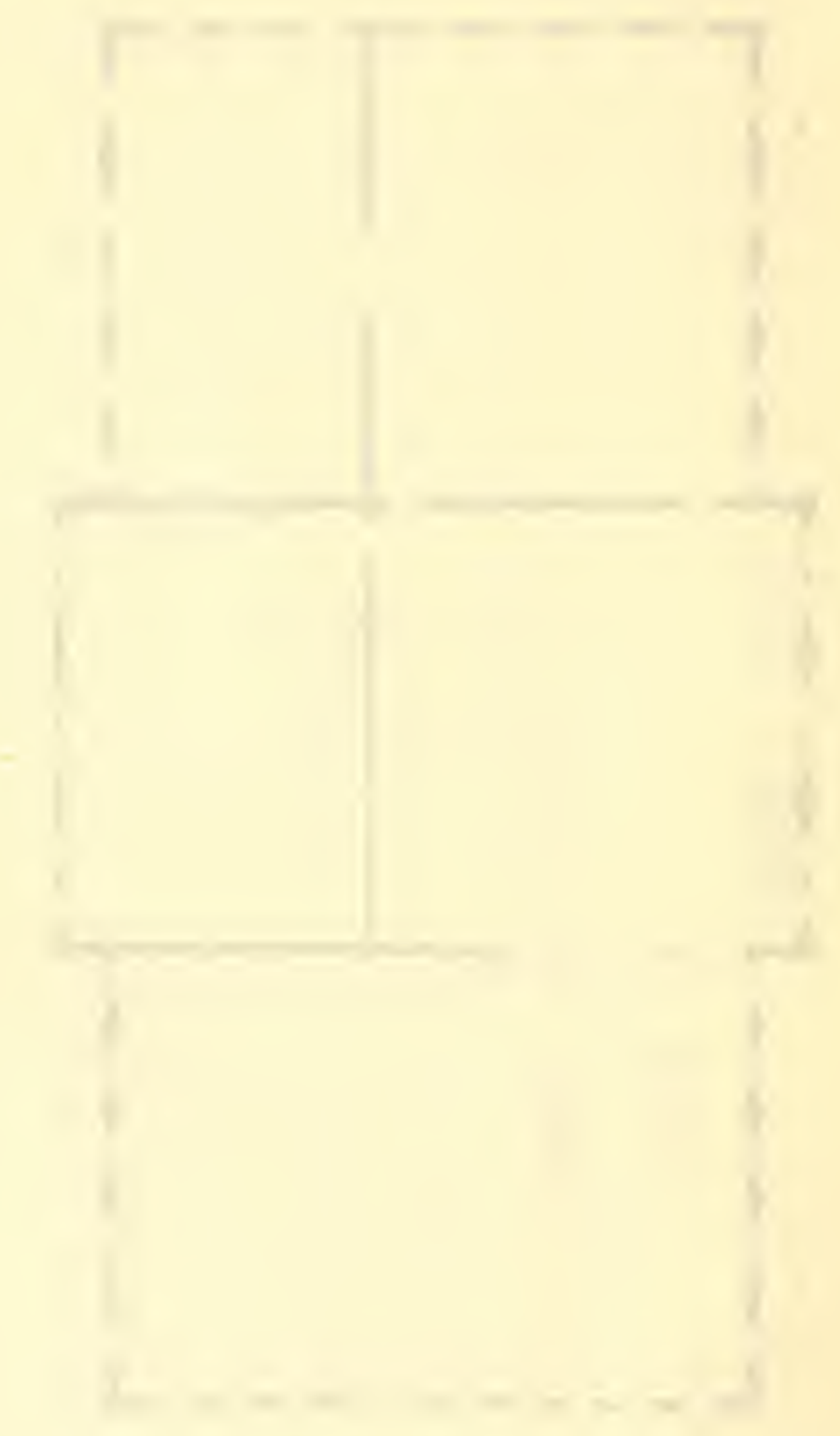


Plate 8.

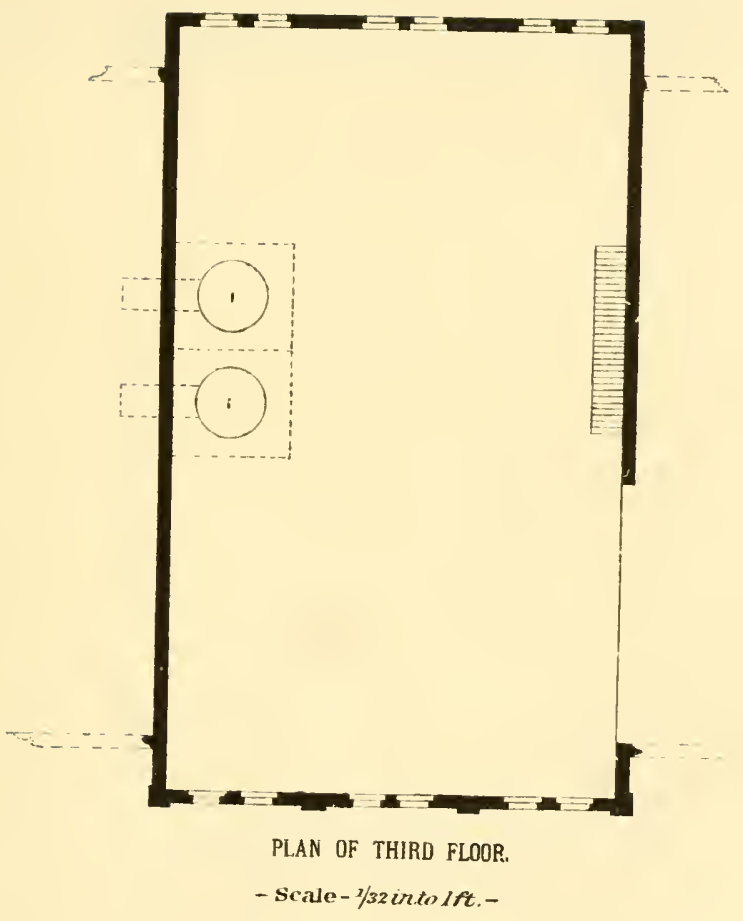



in this country for some time than any other. With a proper fire-proof building, and the best and latest machinery, such a factory would cost, ready for work, from $\$ 150,000$ to $\$ 200,000$. Factories, of course, can be built at a much less cost than this, but doubtless at the sacrifice of efficiency in some of its parts, so that true economy would adroeate the construction of a high-priced factory of the best workmauship and of the most approved modern style.

Local considerations may also affect the cost of a factory, as distance of transportation of the machinery, nearness of iron and machine works, cost of land, ete. The Department has received many letters from persous conveying the impression that they have an idlea that a beet-sugar factory can be built for a few thousand dollars, whereas it is seen from a general study of the problem itself that such a small outlay wonld be totally inadequate to secure a factory suitable for the work to be done. 



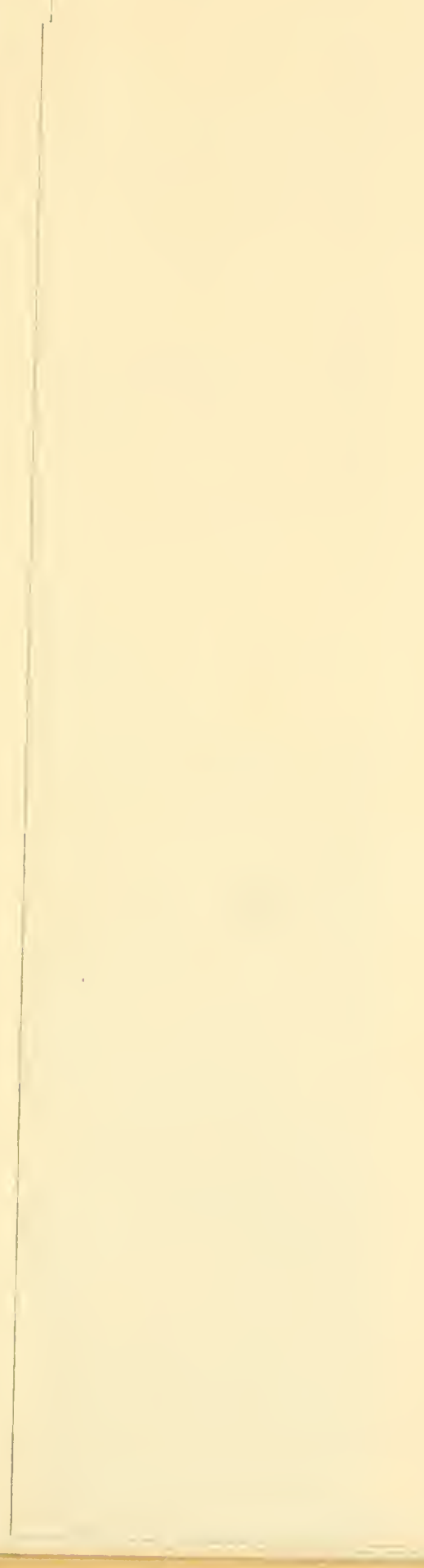





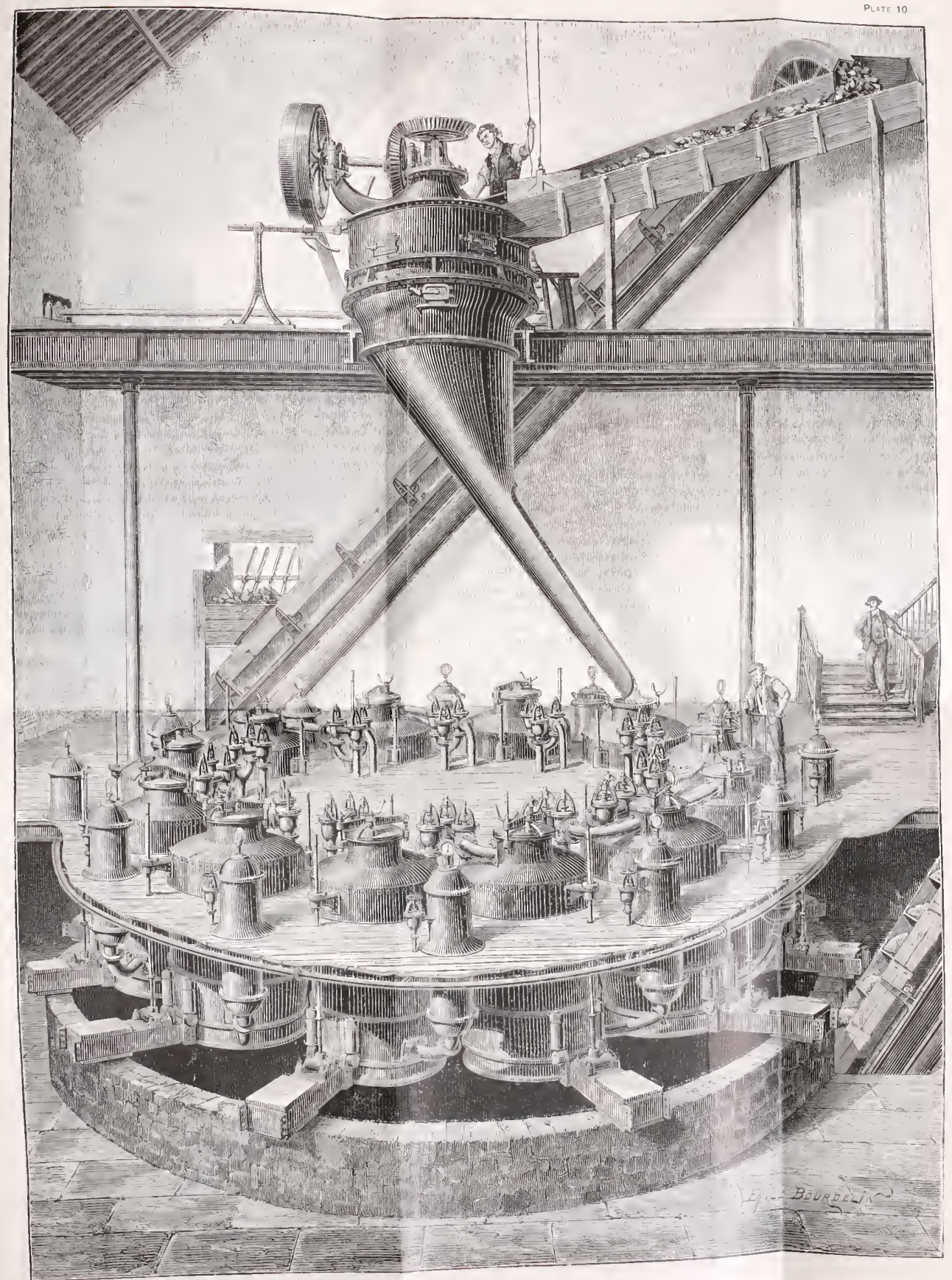






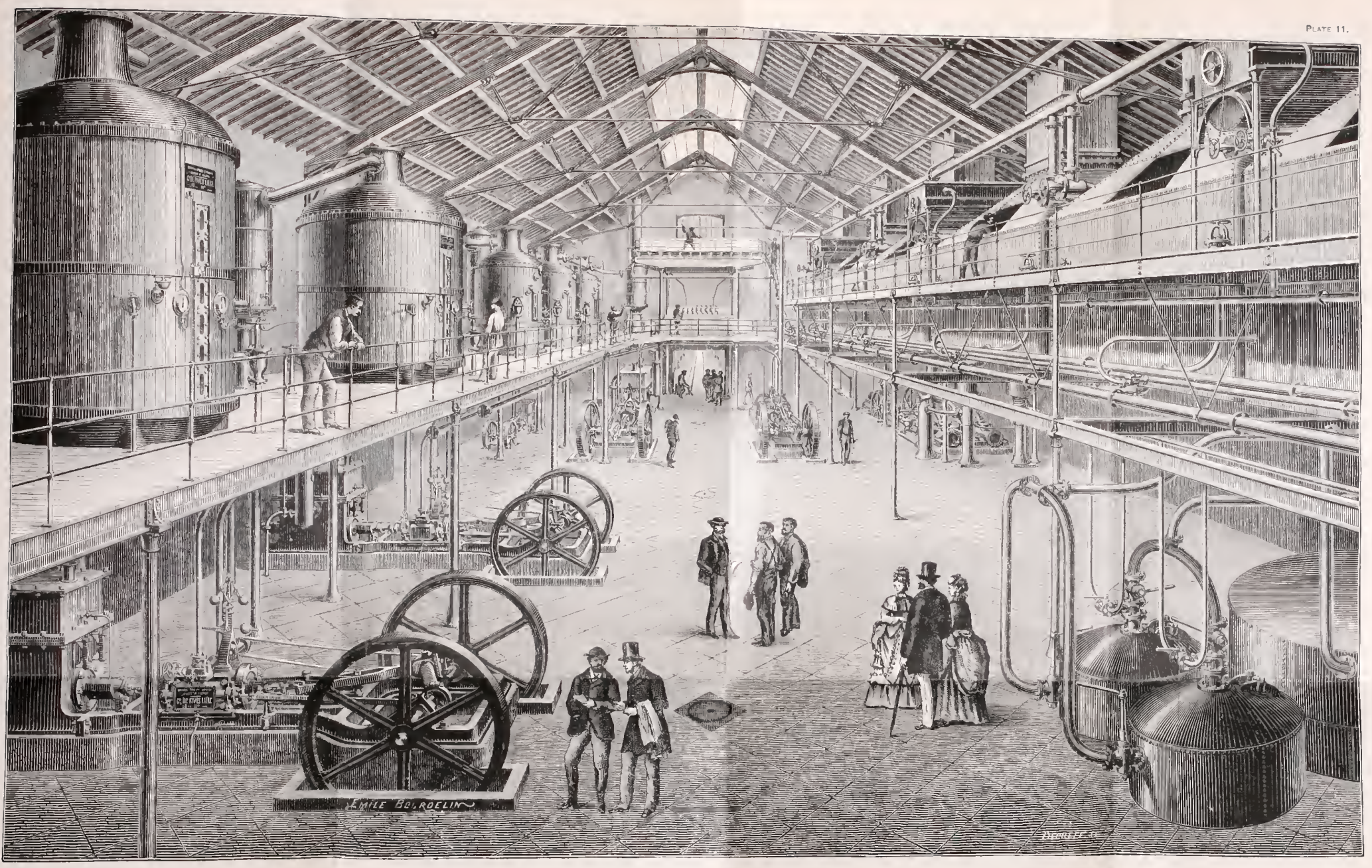





\section{INDEX.}

A.

Page.

Achard, letter of, in Moniteur ................................. 12

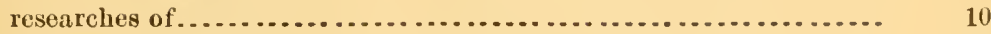

Acreagre in beet-seed culture ................................... 78

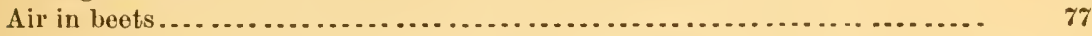

Alvarado, early history of the beet-sugar industry at . . . . . . . . . . . . $35-37$

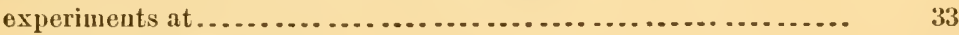

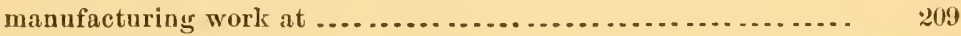

Area in the United States suitablo to sugar-beet culture............... 169, 177

of soil suitablo for culture of beets in California ................ 118

Ashes of beets, composition of ................................. 128

B.

Babrinsky, rules of, in regard to silos in Russia ..................... 101

Bajac harvester....................................... 94, 95

Barruel, method of extracting sugar of .........................

Becker, Dr. G. F., olsservations of ............................ 114, 115

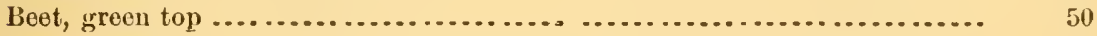

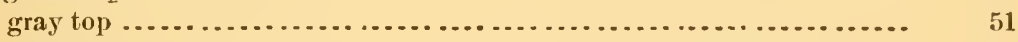

imperial ................................................. 49

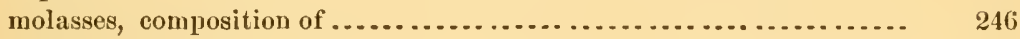

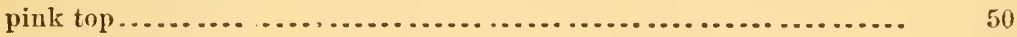

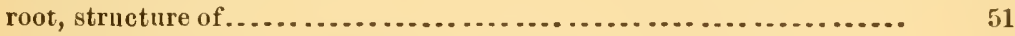

seed amelioration . . . . . . . . . . . . . . . . . . . .

nethod of Peligot and Leplay .................. 74

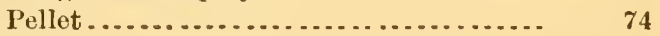

preparation of, for planting . ......................... 139, 140

preservation of ...................................... 46

production of, at Carlier ............................ $\quad 76$

sugar factory, establishment of, in Prussia ..................... 26

inclustry, extension of, il Germany ....................... 25

in Europe, total production of, during past four years......... 40

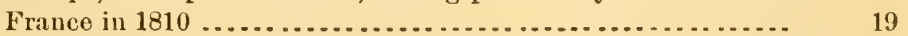

the Northwest, report of Mr. J. D. Fredericksen ......... . 44, 218

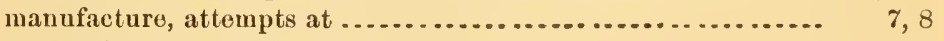

production of, in California, 1870, 1873................... 33

Vilmorin improved...................................... 51

White Silesian ......................................... 49

Beets, varicties of . ........................................

grown in France ............................... 47

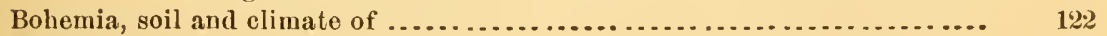

Brabant sugar-bect ............................................. 69,72

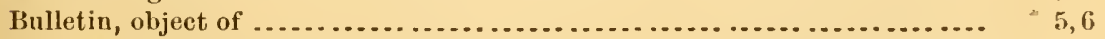

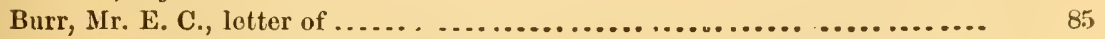

$25474-$ Bull. $27-17 \quad 257$ 
C.

Page.

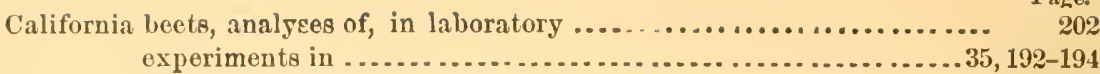

soils of, 'adapted to beet culture .......................... 107

southern, sugar-beet culture in .......................... 204

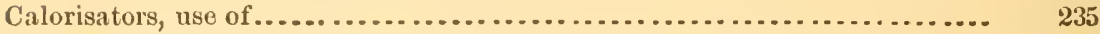

Camburgh sugar factory, description of.......................... 238

Canada, beet-sugar industry in ................................. 211

experiments in......................................... 34

factories in .................................................... 212

Cane and beet sugar, comparison of ............................ 40

statistics of production of ....................... 41

in Russia ................. 41

sugar, production of, in Java.............................. 41

Carbouation, process of....................................... 233

Cellars, preservation of beets in, according to Walkhoff............... 102

Champion and Pellet, olservations of ..........................47, 48, 52, 55

on the relation between the wcight of organic unatters and ash............................................

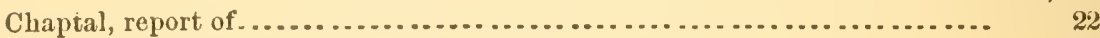

Chatsworth, Illinois, heet-sugar factory at........................ 37

experiments at............................... 32

Chemistry and physiology of the beet............................ 161-163

Child, Mr. David Lee, experiments of........................... 31

Chino Ranch, experiments at.................................. 207

Climate of California, description of ........................... 109, 110

Washington ...................................... 121

Continuous diffusion battery ................................... $\quad 229$

Corenwinder and Contamine, experiments of........................ 48

Crops preceding bects.......................................... 137

Cultivation, conditions of ........................................... 67

directions for ....................................... $\quad 144$

implements for................................... $80-85$

method of, used at Alvarado......................... 85,86

methods used in Bohemia............................. 87-92

D.

Decaisne, M., studies of, in structure of beet root.......................

Decombrecque, M., method of, in selecting seed.......................

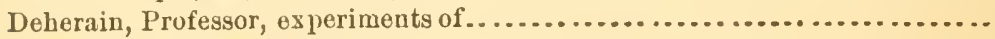

Delaware, experiments in .........................................

Demiatte, M., method of, in selecting "mothers "......................

Department of Agriculture, analyses of beets by ................... 210, 211

Development of the beet ........................................ 159-161

conditions of.............................. 137

Diffusion battery, arrangement of.............................. 228

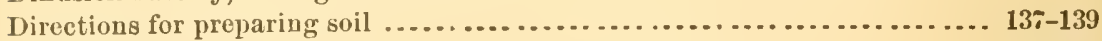

Distance between rows, influence of........................... 142, 143

of beets in row ..................................... 79,87

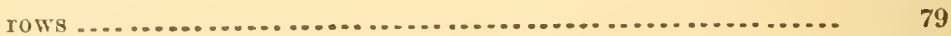

Drainage, importance of ........................................ 136

Dronyu de l'Huys, M., observations of, on the effect of nitrogen.......... 133

Dubrunfaut, observations of, on the cost of production................ 30

production of beet sced.............. $\quad 59$ 


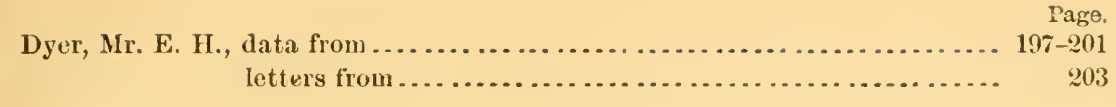

E.

Eckenbrecher and Maercker, studies of, of typical forms of beets ........ 163-168

England, beet-sugar industry in ............................... . 212, 213

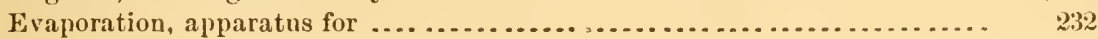

Extraction of the juices, apparatus for .......................... 227

F.

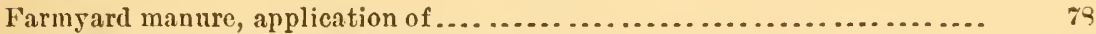

Fertilizers, best method of anplying............................ 136

Dr. Stammer's observations on ........................ 147, 148

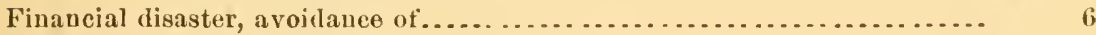

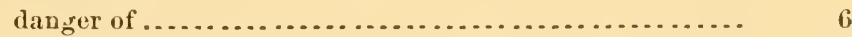

Fond du Lae, Wis., experiments at. .............................. 32

Frederieksen, Mr. J. D., report of, on beet sngar in the Northwest........ 213-219

G.

Georges, M., observations of, on the effeet of nitrogen ............... 133

Gill, Mr. C. Hanghton, report of, on Steffen's proeess................... . 248, 249

Girard, Prof. Aime, studies of, in beet development. .................. 159

H.

Harvest and preservation of beets........................... 99, 100

Harvesting beets.......................................... 93

apparatus for ...................................... 94

Henry, Prof. W. A., letter from, in regard to Chatsworth.............. 37

report of ................................... 178-181

Herzfeld, observations of, on nitrogenons manures..................... 151, 152

Hilgard, Prof. E. W., analyses of soils by ...................... 108, 109, 116-118

deseription of climate in Caiifornia hy ............ 109

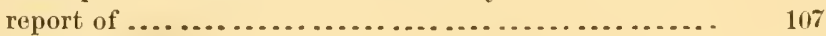

IHinze, Mr. Fred, experiments of ................................ 192

Howes, commercial agent, obsersations of, ou mannring in bohrmia ....... 154-158

report of ............................... 87

Huston, Prof. H. A., analyses by ............................. 178

I.

Imperial beet-sugar factories, establislıment of .................... 24

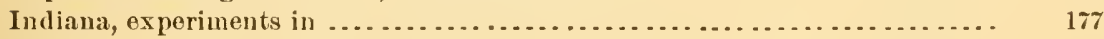

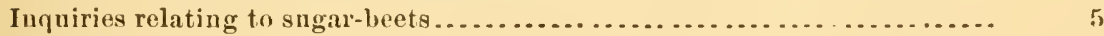

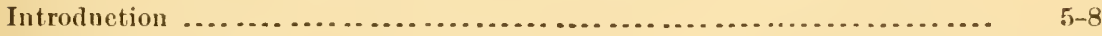

Iowa, experiments in .................................... 181

J.

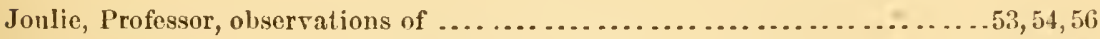

on effect of nitrogen .................. 132

Juice, treatment of ....................................... 233

K.

Kansas, experinents in ...................................... 190

Keilzie, Dr. R. C., analyses by ............................... 178 
Klein-Wanzleben sngar-boet................................ 69,71

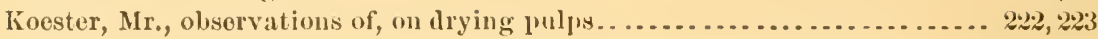

I.

Labor, cheapness of .....................................

Lawes and Gilbert, observations of, on the effect of fertilizers........... 134

Legrand, M., exhibition of, at the Paris Exposition .................. 75

Lemaire, systen of seleeting beets of............................ $\quad$ iz

M.

Maereker, Professor, experiments of, in feerling pulps ............... 224-226

olsservations of, on the cif'ect of nitrogen........... 133

Maine, experiments in .......................................... 34

Manufacture of sugar, ontline of .............................. 226, 227

Mąnures, influence of, on yielil and richness of sugar . . . . . . . . . . . . . 130, 131

Manuring, methods of, in Bohemia .............................. 154

Margraff, liseoveries of . . . . ................................ 9

Massachusetts, experiments in ................................... 34

Massecuite, treatment of ....................................... 240

McMurtrie, Dr. William, observations of, on soil and climate........... 124-128

special report of ......................... 9

Meeker, Mr. E., letter from .................................... 119-121

Meteorologieal conditions .................................... 169

Signal Service tables on................... 170-175

studies of Dr. William MeMurtrie on ......... 169-175, 176

Meyer \& Buettner, apparatus of, for dryiug sliced beets................. 213

Miehigan, experiments in ................................. 178

Mineral constituents remorci by erop . . . . . . . . . . . . . . . . . . . . . . . . . 128,129

Molasses, extriction of sugar flom ................................... 244

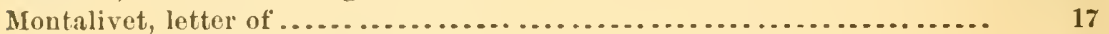

report of, in Moniteur. . . . . . .

Motbers, selection of .......................................... 43

by Dippe............................... 44,45

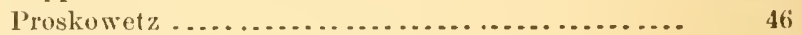

Rabbethge................................ 45

N.

Nadeau, Mr., experiments of.................................. 204-206

Napoleon I., deeree of . . . . . . . . . . . . . . . . . . . . . . . . . . . . . . . .

establishing beet-sugar faetories in schools......... 21

fall of, effect of, on beet-sugar industry ................. 28

Nebraska, experiments in ... . . . . . . . . . . . . . . . . . . . . . . . . . .. 183-185

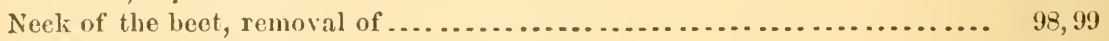

Now Jersey, experiments in ..................................... 34

Nieholson \& Lloyd. Professors, aualyses by .......................... 181

Nitrate of sola, fertilizing with............................... 152

Nitrogren as nitrates, effect of .................................. 132

Nitrogenous manures, influence of, on the quality of the beet ........... 151

O.

Oregon, sugar bcet in ........................................ 119

Organic matters and ash, relation of .............................. 134, 135

Oxuard, Mr. II. T., experiments of, at Grand Island, Nelor.............. 184 
Pagnonl, observations of, on the effects of nitrogen ..... Page.

Patrick, Prof. G. E., analyses by ................................. 182, 183

Peliet, M., observations of, on the influence of fertilizers............... 134

Per cent. sugar in sugar-beets.................................... ${ }^{10}$

Peret, M., continuons diffuser of. ............................... 229-232

Petermann, Dr. A., contribution of, to the chemistry and physiology of the beet............................... 161

observations of, on nitrate of soda................ 152-163

Phosphate slag, experiments with ............................... 152

Plowing, depth of ............................................. 78

Potash, best method of applying .............................. 149-151

Potassie and lime salts, action of.............................. 74

Prefatory note............................................... 3

Preservation of beets .......................................... 145

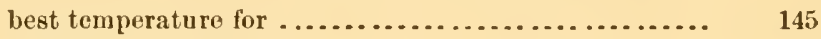

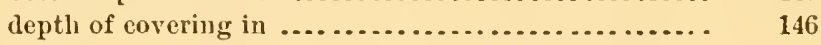

Production of seed ........................................... 41

Proskowetz, Dr. E. V., experiments of, with nitrogenons manures .......... 153

Pulps, drying of ........................................ 222, 223

feeding experiments with ............................... 224-226

preservation of ...................................... 221, 222

silos for.............................................. 220

nse and treatment of.................................. 220

R.

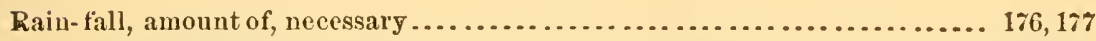

in California ........................................ 111-114

Reynolds, Mr. John P., letter from, in regard to Chatsworth, Ill ......... 38

S.

Saclis, Mr. Franeois, experiments of, on the Steffen process............. 250

Sagnier, M., olservations of ................................... 76

Sanborn, Mr. T. F., analyses by ............................... 191, 192

Saturation, process of ..................................... 233

Schack-Sommer, Dr., experiments of ........................... 212,213

School for manufacture of beet sugar, establishment of, in France........ 23

Seed, beet, production of ..................................... 41

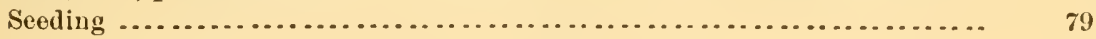

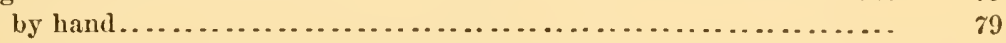

drill............................................. $\quad 79$

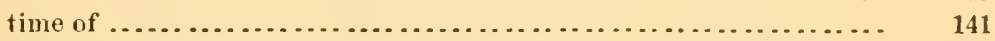

Separation process, ehemistry of ............................... 244

Shepard, Mr. James H., analyses hy........................... 190

Silos in cellars, illustrations of ................................. 103, $10_{4}$

Size and shape of beet, influence of ............................. 75

observations of Desprez upon ....................
Soaking seed, solution for...........................................

Soil and climate of Bohenia ................................. 123-124

character of, suitable for sugar-beets ......................... 105

chemical analyses of ............................... 108, 109, 116-118

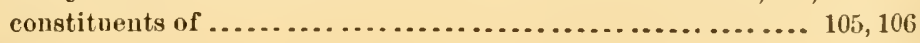

nitrogen in ............................................ 105 
Soil, olservatious of Stammer ou ............................. 106, 107

of Washington ...................................... 121

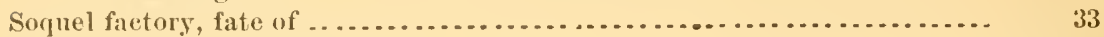

Sonth Dakota, experiments iu.................................... 185-189

Spencer, Mr. G. L., plans of, for a sugar factory ....................... 253, 254

report of, in Bulletin No. 5..................... 227-250

Stable manure, amount of, necessary ............................ 130

composition of ................................. 129

Stanmer, I)r. Karl, observations of, on fertilizers ................... 147

work of, on sugar-beet........................ 99

Statistics of the beet-sugar industry . . . . . . . . . . . . . . . . . . . . . . . 39

in Germany ..................... 39

Steffen process................................................. 248

Stoebritz slygar factory, description of ........................... 234

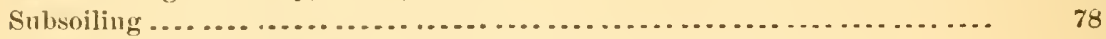

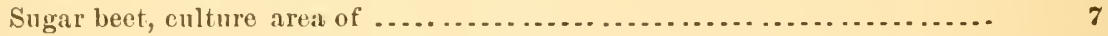

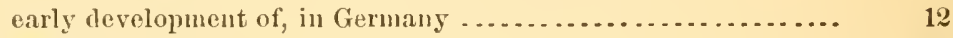

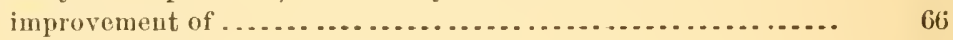

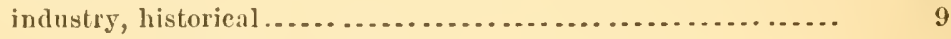

progress of, in America ....................... 31

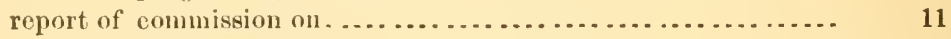

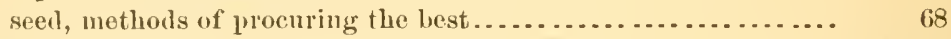

factory, $\operatorname{cost}$ of . . . . . . . . . . . . . . . . . . . . . . . . . . . . . . 254,255

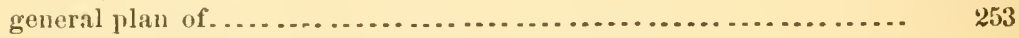

Summers, hot, in Kansas...................................

T.

Temperature and raiu-fall, relative importanee of. ...................

Turkiewitseh, diffusion hattery of . . . . . . . . . . . . . . . . . . . . . . . . 251-253

Typical forms of sugar beets ................................. 163

V.

Vilmorin-Andrieux \& Co., prodnetion of beet seed by.................

Vilmorin, M., early recommendations of ...........................

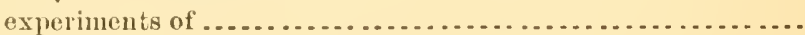

M. Heuri, deseription by, of varieties of beets in Franco.........

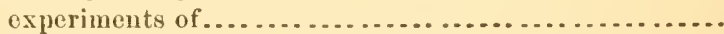

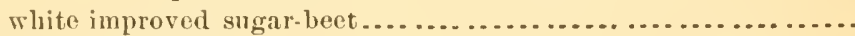

Violette, M., observations of . . . . . . . . . . . . . . . . . . . . . . . . . . .

\section{IV.}

Walkhoff, Professor, olservations of, on the prolnetion of beet seed .......

Ware, Mr. Lewis S., deseription of methods of harvesting, hy ............

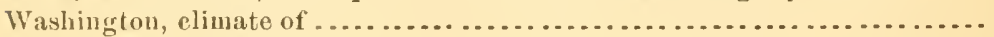

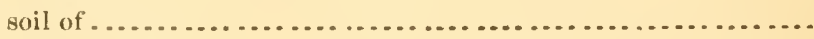

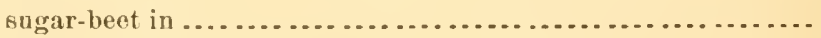

Watsonville, Cal., experiments at . . . . . . . . . . . . . . . . . . . . . . . . .

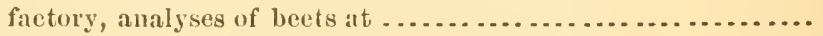

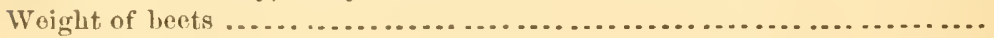

Wet autumu, influenee of . . . . . .

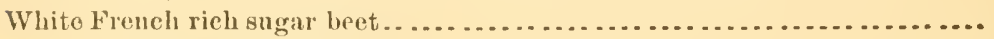

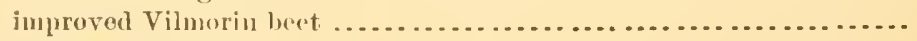

Wiscousin, experiments iu 








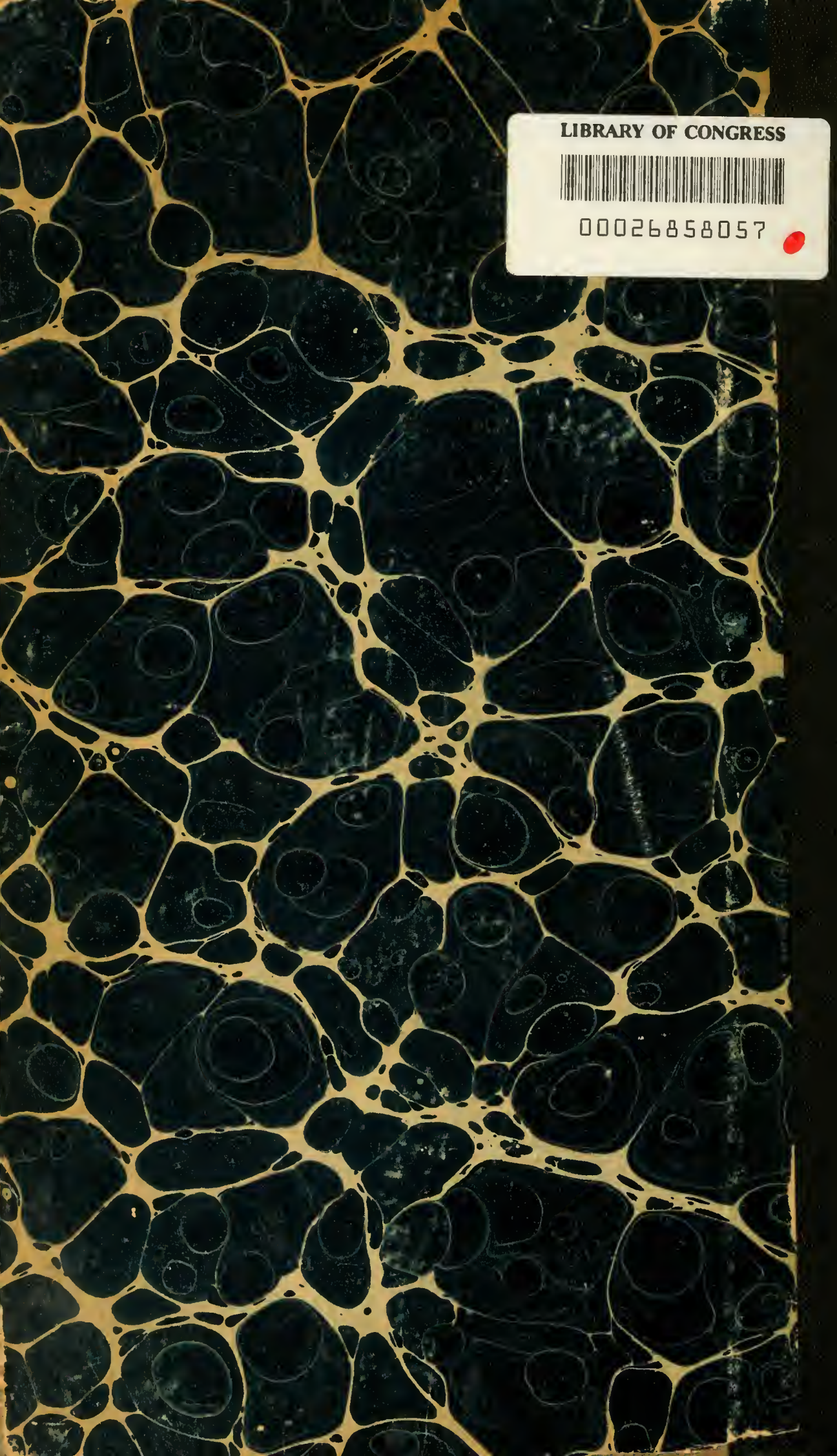

